COLUMBAA LIBRARIES OFFSTTE 


\section{QP915 At9 Conlumbia ôniversity

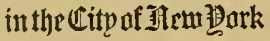 \\ College of 羽hysicians and surgeons \\ Yibrary}

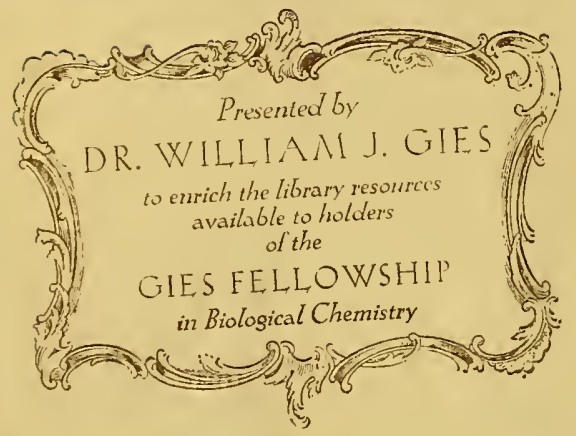





Digitized by the Internet Archive in 2010 with funding from

Open Knowledge Commons (for the Medical Heritage Library project) 
NATIONAL ACADEMY OF SCIENCES.

Volume VIII.

SIXTH IEIOIR.

\section{AN EXPERIMENTAL INQUIRY REGARDING THE NUTRITIVE VALUE OF ALCOHOL. \\ BY}

W. O. ATWATER AND F. G. BENEDICT.

Presented to the Academy hy JOHX $\therefore$. BILIIXGS. 


$$
\begin{aligned}
& \text { QP915 } \\
& A+9
\end{aligned}
$$




\section{CONTENTS.}

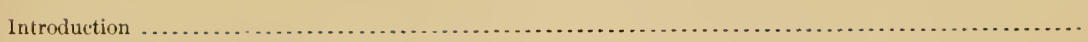

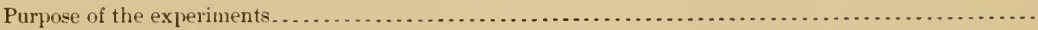

Questions actually studied . . . . . . . . .

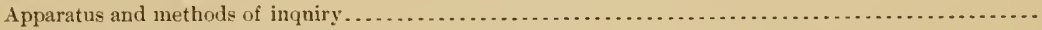

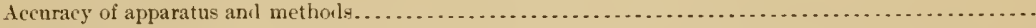

The experiments

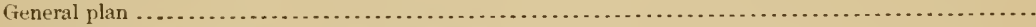

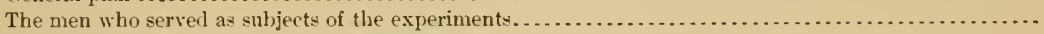

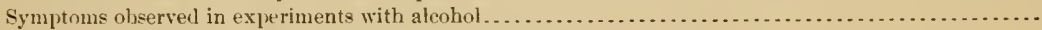

General description of individual metaholism experiments. . . . . . . . . . . . . . . . . . . . . . .

List of metabolism experiments with anıl withont alcohol and grouping for comparison .............

Group A. Rest experiments Nos. 9 and 10. Experiments with ordinary diet and with alcohol diet. -

Group B. Rest experiments Nos. 22 and 24. Experiments with orlinary sliet aml with alcoliol cliet..

Group C. Rest experiments Nos. 26 to 28 . Experiments with ordinary diet and with alcohol diet..

Group D. Work experiments Nos. 11 and 12. Experiments with ordinary diet and with alcohol

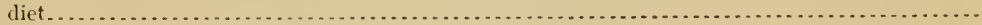

Group E. Work experiments Nos, 29 to 31. Experiments with ordinary diet and with alcohol diet..

Group F. Work experinents Nos. 32 to 34 . Experiments with ordinary diet and with alcohol diet..

Group G. Rest experiments Nos. 7,13 , and 14. Experiments with ordinary diet and with aleohol

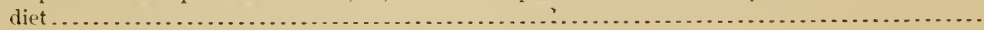

Gronp H. Rest experiments Nos. 5 and 15 to 17 . Experiments with ordinary diet and with aleohol

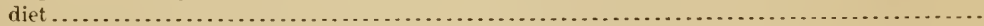

Group 1. Rest experiments Nos. 18 to 21. Experiments with ordinary diet and with alcohol diet..

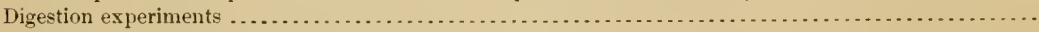

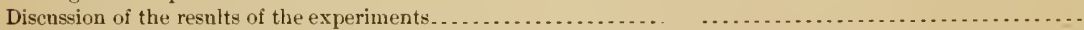

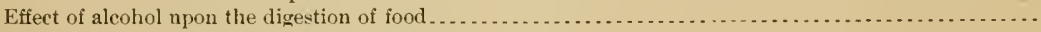

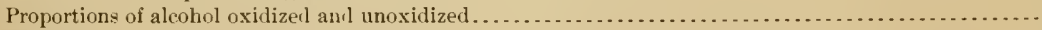

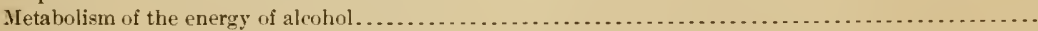

The protection of borly material by alcohol . . . . .

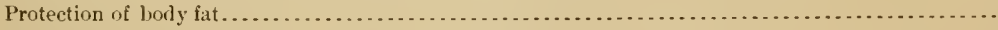

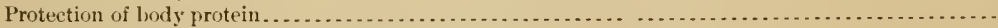

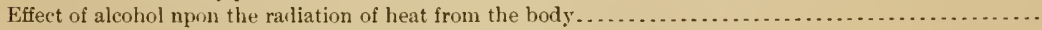

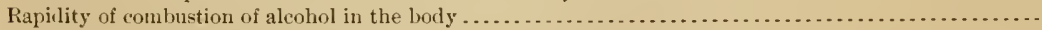

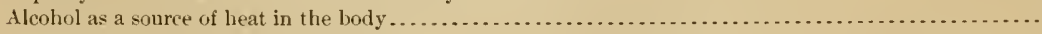

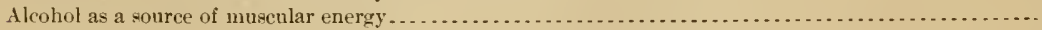

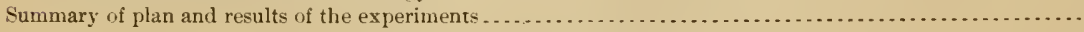

Page.

\section{APPENDIX.}

Data-Experimental methods

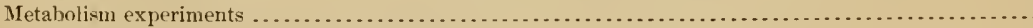

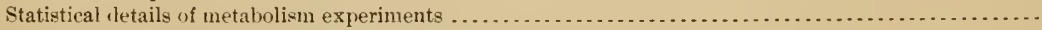

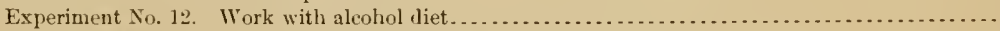

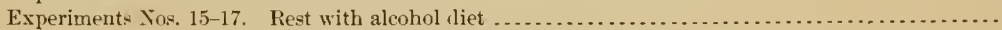

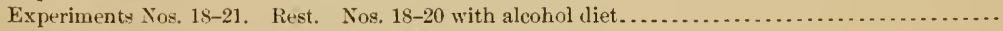

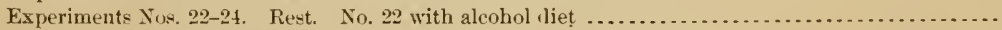

Experiments Nos. 26-28.

Experiments Nos. 29-31.

Experiments Nos. 32-34.

Rest. No. 27 with alcohol diet

Work. No. 30 with alcohol diet

Work. No. 33 with alcohol diet 
Statistical details of digestion experiments.

Details of digestion experiment-

No. 41

No. 42

No. 47

Yo. 48

No. 51

380

No. 52

.

No. 80

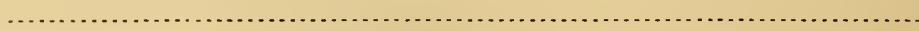

พัo. 81

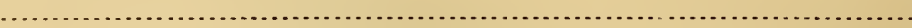

ก๊. 82

1.

No. 83

To. 84

\o. 151

No. 155

No. 159

$$
\begin{aligned}
& 3 \ldots \\
& 4 \ldots \\
& 1 \ldots \\
& 5 \ldots
\end{aligned}
$$

Tabular summaries of results of experiments

Income and outgo of nitrogen, and gain or loss of protein and fat

381

381

382

382

383

384

384

385

385

386

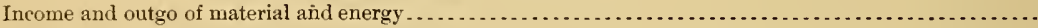

Proportions of alcohol oxidized and unoxidized $\ldots \ldots \ldots \ldots$

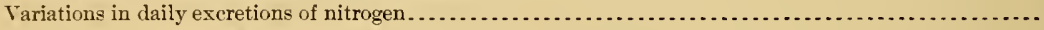

Availability of nutrients and energy 


\title{
AN EXPERIMENTAL INQUIRY REGARDING THE NUTRITIVE VALUE OF ALCOHOL.
}

\author{
BY W, O. ATWATER AND F. G. BENEDICT.
}

\section{INTRODUCTION.}

The present report gives the details of a number of metabolism experiments with men, in which the effects of diet with and without alcohol have been compared. ${ }^{a}$ The details of a number of digestion experiments, which form part of the same investigations, have also been included.

\section{PURPOSE OF THE EXPERIMENTS.}

The main purpose of the experiments has been to get light upon the effects of alcohol in the diet, with especial reference to the question of its nutritive value.

Food is used in the body to build and repair tissue and to furnish energy. Only the nitrogenous compounds (protein) of the food serve the first purpose; they also serve as a source of energy, but the main supply of energy is obtained from the fats and carbohydrates. The fuel ingredients may be burned at once or ma be stored for future usc.

Alcohol contains no nitrogen and therefore can not build or repair tissue; it is rather to be classed with the fats and carbohydrates, and if it has any food value, this must be as a fuel. It does not appear to be stored for any considerable time, but is disposed of soon after it is taken into the body.

Alcohol, however, differs from the protein, fats, and carbohydrates of food materials in that it may exest, and when taken in large enough doses does exert, an indirect action upon the brain and nerves and through them npon the nutritive and other processes to which the general term metabolism is applied. In this way its actual value may be either increased or dininished according as it aids or hinders digestion, or either accelerates or retards metabolism. We have then to consider not only its direet action as nutriment for the supply of energy, but also its indirect action upon the metabolism and ntilization of other food. In the experiments here

"The inquiry was undertaken at the instance of the Committee of Fifty for the Investigation of the Drink Problem. The experimental work was done in the chemical laboratory of Wesleyan University. A large slıare of the expense was borne by the committee of fifty although contributions were also received from the Elizabeth Thompson and Bache funds and from private individuals. The experiments were parallel with others of similar character, which are conducted under the auspices of the Enited States Department of Agriculture. These latter experiments form a part of a general inquiry regarding the food and nutrition of man, which is authorized by Congress and prosecuted in different parts of the United States. The special inquiry into the nutritive action of alcohol was made possible by the generosity of Wesleyan University, which offered to the committee of fifty the use of laboratory and other facilities that have been made available to the Department of Agriculture and the Storrs Experiment Station for nutrition inquiries.

The investigation has been pursued with the active cooperation of a number of gentlemen, including especially Mr. A. P. Bryant, under whose direction the computations of the results have been made, and Mr. A. W. Surth, Dr. O. F. Tower, and Dr. J. F. SNell, all of whom have been intimately associated with the elaboration of the apparatus and methods. Mr. Ssith and Dr. SNell served as subjects in several of the experiments reported beyond, though the subject of the larger number was Mr. F. Osterberg.

The details of the experiments without alcohol and of two of those with alcohol, Nos. 7 anil 10 , have been published in bulletins of the United States Department of Agrieulture as stated beyond. 
described the indirect action of alcohol has been studied only in so far as (1) through its influence upon the secretion of digestive juices or otherwise it has tended to increase or diminish the proportion of the other food digested, or (2) it has increased or decreased the metabolism of other food or body material.

The ulterior effects of alcohol do not come within the scope of this particular inquiry, which is limited to its use by the body as nutriment.

\section{THE QUESTIONS ACTUALLY STUDIED.}

It appears then that whatever value alcohol may have for nutriment must depend upon its ablity to serve as fuel for furnishing energy to the body. Accordingly the main question proposed for study is this: What is the ralue of aleohol for fuel and how does it compare in this respect with sugar, stareh, fats, and other nutrients of ordinary food materials? A collateral question is the effeet of alcohol upon the proportions of nutrients digested from the food with which it was taken.

Experimental researeh has shown sereral ways in which the ingredients of ordinary food and body material serve as fuel. They are oxidized in the body; in the oxidation, their potential energy becomes kinetic and is thus made useful to the body; part of this kinetic energy appear's as heat; another part appears as muscular work; in yielding energy by its own oxidation, food protects the material of the body and of other food from consumption. We have then to consider how alcohol compares with the ordinary fuel ingredients of the food in these ways.

It is clear that the main problem is that of the metabolism of energy in the body. Accordingly, while the experiments here described bear upon the use of alcohol in each of the ways just mentioned and upon collateral topies also, the fundamental question studied has been this: To what extent is the energy of alcohol transformed and utilized in the body like the energy of the nutrients, especially the fats and carbohydrates, of ordinary food materials?

In studying these questions we go down to one of the fundamental principles of material science. The plan of the whole inquiry is based upon the principle that the chemical and physical changes which take place in the body. and to which the general term metabolism is applied, occur in obedience to the laws of the eonservation of matter and energy. That the law of the conservation of matter applies within the living organism, no one would question. It might seem equally certain that the metabolism of energy within the body takes place in accordance with the law of the conservation of energy. In experiments with men in the respiration ealorimeter described beyond, the close agreement between the income and the outgo of energy in the body, uncler various conditions of work and rest, may be regarded as practically demonstrating that the law holds in the living organism. Such demonstration had, indeed, been approximated by earlier investigations, notably those of Rubner with dogs.

\section{APPARATUS AND METHODS OF INQUIRY.}

The experiments here described were made with a respiration ealorimeter especially devised for research of this kind. The apparatus serves to measure the materials received and given off by the body, including the products of respiration, and is thus a "respiration apparatus." It also serves to measure the heat given off by the body and hence is a form of calorimeter. To indicate this twofold purpose it is called a "respiration calorimeter." The apparatus and methods of its use have heen described elsewhere; ${ }^{\text {a }}$ a brief deseription will suffice here.

"In the following bulletins of the Office of Experiment Stations of the Uniter States Department of Agriculture: No. 44, Report of Preliminary Investigations on the Metabolism of Nitrogen and Carbon in the Human Organism with a Reppiration Calorimeter of Special Construction, by W. O. A Twster, Ph. D., C. D. Woons, B. S., and F. F. Benenict, Ph. D.; No. 63, ] Hescrijtion of a New Respiration Calorimeter and Experiments on the Conservation of linergy in the Iluman Borly, by W. O. Itwater, I'h. D., and F. B. Rosi, Ph. D., pp. 94; No. 69, Experiments on the Metabolism of Matter ant Finergy in the IJuman Body, ly W. O. Arwiten, Ph. D., and F. G. Benenct, Ph. D., with the

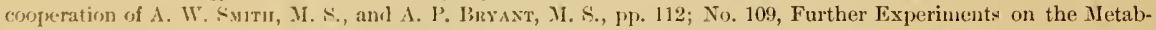
olism of Matter and linergy in the Iluman Body, by Wr. O. Atwaten, Ph. D., and F. G. Benedict, Ph. D., with the conperation of A. I'. BRraxt, M. S., A. W. Smitu, M. S., and J. F. Sxel, Ph. D. 
The chamber of the apparatus is so arranged that a man may spend a number of days in comparative eomfort within it. It is lighted by a window. and is furnished with a folding rbair, tahle, and bed, and. when the experiasent inrolres museular work, with a stationary bicrcle also. The ehamber is rentilateci by a measured eurrent of air. simples of which are taken for analy-is before it enters and after it leares the chamber. In this way the products of respiration are determined. Prorision is also made for weighing. sampling. and analyzing all the food and drink. and the solid and liquid excreta as well. Br conparing the chemical elements and compoundreceired by the body in food, drink. and inhaled air with those giren off in the solid, liquid, and gaseons forms by the intestines. kidneys, lungs, and skin, it is possible to strike a balance between the total income and the total ontgo of matter in the man's hody. This serves as the measure of the metabolism of uatter in the body.

In addition to this the metabolism of energy is also studied. To this end it is necessury to determine the potential energy of the food and drink taken into the body and of the solid and liquid excreta given off by the body, as well as the amounts of energy given off in the form of heat. external musular work. and otherwise. The measurements of the potential energy of the food and exereta are made with the homb calorimeter. ${ }^{a}$ The determination of the heat given off from the body is made by certain arrangements in connection with the respiration calorimeter. A current of water passing through a special coil of pipes suspended in the chamber alsorbs the beat that is generated within it. and by measuring the quantity of water that pasies through the coil and its rise in temperatme the amount of heat absolbed may be determined. To this is added the latent heat of the water vaporized within the chamber.

So delicate are the measurements of temperature that the obserrer sitting outside and recording the changes every two or four minutes inmediately detects a rise or tall of eren one one-hnndredth of a degree in the temperature of the inner copper wall or of the air inside the chamber. If the man inside rises to more about, the increase in the heat given off from his body with this muscular work show itself in a rise of temperature which is immediately detected.

In the work experiments the subject spends a certain portion of each day in nuscular exercise upon an apparatus arranged as an ergometer, hy which the amount of muscular work done may be measued. The ergometer consists of a stationary bieyele connected with a dyauno by which the power which the rider applies to the pedals, and which is not changed to heat by the friction of the machine, is converted into an electric current. which is passed through an electric lamp and is in turn ehanged to heat. The ergometer is arranged to measure the amount of muscular work done, in terms of heat, by determinations of the amount of energy converted into heat by friction and the amounts of electric current generated and rhanged to heat.

From the energy of food. drink, solid and liquid excretory products. and body material stored or lost the net income of energy nay be computed. The net ontgo is measured by the apparatus. By comparing these the balance of income and outgo of energy is found.

The data obtained as explained abore, taken in connection with what is known of the physiological processes that go on in the body, give more accurate information than ean be otherwise olstained regarding the ways in which the food is used in the body and the quantities of food ingredients that are needed to supply the demands of the hody for the rarious purposes of work and rest and the comparative untritive ralue of different food materials.

\section{ACCURACY OF APPARATUS AND METHODS.}

Two methods of testing the aceurac of the appuratus are employed. Bș one method known amounts of heat are generated electrically within the chamber, and the heat is measured by the apparatus. In this way its aceuracy as a calorimeter only is tested. By the second method known amounts of ethyl alcohol of known purity and composition are hurned completely within the ebamber. and the amounts of water, carbon dioxide, and heat rewulting from the conibustion of aleohol are determined by the apparatus. In this way it- accuracy hoth as a respiration apparatus and as a ealorimeter is tested. In the arerage of tive electrieal test the amount of heat

"For lescription of the bonh calorimeter see [. S. Dept. Agr., Ottice Expt. Stations, Bul. 21, pp. 120-126, and Storrs Conn. Experiment station Report, 1s97, p. 199. 
metsured by the calorimeter was 100.01 per cent of the amount generated by the electric current. The averages of the results obtained in seventeen alcohol tests are summarized in the following table:

Summary of results of tests in which alcohol was burned in the culorimeter.

Amount required.

Amount found

Ratio of amount found to amount required

$\begin{gathered}\text { Carbon } \\ \text { dioxide. }\end{gathered}$
Grams.
$19,239.8$
$19,206.9$
Per cent.

99.8

\begin{tabular}{|c|}
\hline Water. \\
\hline Grams. \\
$12,264.4$ \\
$12,379.1$ \\
Per cent. \\
a 100.9
\end{tabular}

Heat.

Calorics. $64,554.1$

$64,513.3$ Per cent.

"Aiter the completion of the later experiments a slight leak was found in the "valve box" through which the outgoinz air current passed on its way to and from the "freezers," and by which water, condensed on the ontside, may have entered. There is every reason to believe that the quantity of water actually found was thus made too large hy a fraction of 1 per cent. In the average of the first nine experiments the amonnt of water found was 100.6 per cent of that required. As an alcohol check test was generally made between each two metabolism experiments or series of experiments we have a means of knowing when the leak began to effect the results and the amount of the error introduced. See Bulletin 109 of the Office of Experiment Stations, above referred to.

The results thus indicate that the respiration calorimeter is an instrument of precision and that the determinations of carbon dioxide, water, and heat produced within the chamber of the respiration calorimeter are sufficiently accurate for experiments with the living subject.

\section{THE EXPERIMENTS.}

\section{GENERAL PLAN.}

For the subjects of the experiments men were selected who were in good health, had apparently normal digestion, and did not find the confinement in the chamber uncomfortable. A diet was chosen which provided materials as palatable and in as much variety as was consistent with convenient preparation, and with accurate sampling and analysis. The quantity and composition of the diet were generally such as to maintain the body nearly in nitrogen and carbon equilibrium under the conditions of the experiment, whether rf work or of rest. In 13 of the experiments the diet included alcohol.

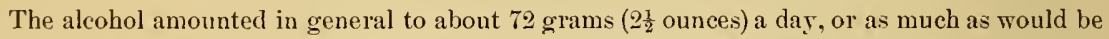
contained in a bottle of claret or 3 or $t$ glasses of whisky. In most cases pure (etbyl) alcohol, but in some whisky or brandy was used. It was mixed with either water or coffee, and was given in 6 small doses, 3 with meals and the rest at regular intervals between, in order to aroid as far as possible any effect upon the nerves. The alcohol supplied aot far from 500 calories of energy. In the experiments without external muscular work, the total energy of the diet was about 2,500 calories, so that the alcohol furnished one-fifth of the total energy. In the experiments in which the man was engaged in more or less active muscular work, the total energy of the food was larger, areraging abont 3,900 calories, so that the alcohol furnished between one-seventh and one-eighth of the total energy of the diet.

In order that the subject might become accustomed to the diet and reach approximate nitrogen equilibrium with it before the experiment proper began, a preliminary digestion experiment of at least 3 days immediately preceded the unetabolism experiment. Any change of diet found desirable or necessary was made during this period, and the preliminary experiment was continued until nitrogen equilibrium was supposed to be more or less nearly reached. In most cases the preliminary experiment continued 4 days. During this period the subject was, in general, engaged in his customary occupation, but conforned his muscular activity more or less to that of the coming experiment. Thus if it was to be a work experiment, he rode a bicycle or walked a considerable distance each day. If it was to be a rest experiment, he aroided all unnecessary exercise. For supper on the last day of this preliminary digestion experiment 
ahout . 3 of a gram of lampblack was taken in a gelatin capsule with the food, in order to mark the separation of the feces of the preliminary experiment from those of the metabolism experiment proper. The -ubject entered the chamber about $i$ oclock on the evening of the last day of the preliminary digrestion period and retired about $11 \mathrm{o}^{\circ}$ clock. At about $1 \mathrm{o}^{\circ}$. lock in the norning the heat measurements were begun.

The night cojourn in the chamber sufficed to get the temperature of the apparatus and its content - of carbonie acid and water into equilibrium. so that accurate measurements might begin at 7 oclock on the tirst morning of the experiment proper. In come cases the experiment continued only 4 days: in other cases the experimental period consisted of $b$ or strecesive days spent within the apparatns. the entire period being divided into 3 experiment $=$ of 2 or 3 dars each with changes in the diet as hereafter explained. The determination of carbon dioxide. water rapor, and heat were made in 6 -hour periods. so that complete data for an experiment showed the total amounts of these compounds given off from the body during the periods ending at 1 p. m.. T p.m.. 1 a. m.. and 7 a. m. of each day of the experiment. As noted beyond, the urine was also collected and its nitrogen content determined for corresponding periods.

The daily routine of the subject within the chamber was indicated hy a programme made up hefore the beginning of the experiment. A cops of the programme was furvished to the subject. who followed it with reasonahle closeness. and other copie-were posted in conrenient places outside the apparatus for the benefit of those who bad the experiments in charge.

Mnch care was necesarily taken in preparing the food materials selected for the diet and in taking samples for analrsis. With the exception of milk and alcohol. the proper quantity of each kind of food. either for each meal or for the whole day. was put up in glas jar- before the experiment legan: and materials which might spoil during the course of the experiment. such as bread and meat. were thoroughly -terilized.

Speeial arrangement- were made by which the mixed milk from a detinite number of select cows was supplied for each experiment. But eren with this precaution. the milk was not entirely uniform in composition from day to day.

The handling of the alcohol was much simpler. A quantity sufficient for sereral experiments was procured and analyzed, and the proper amounts mere drawn each day as needed.

As stated above. the separations of the feces for each experiment were made br means of lampblack. The total feces for each experiment were analyzed. and the average per day used in the computation - of results. It was assumed that when the food and exercise were so nearly uniform the undigested residues and metabolic products would not vary greatly from day to day, and such irregularities as might occur would hardls affect the arerage for an experiment.

The urine was collected in 6-hour periods. aud the amount. specific gravity. and nitrogen determined for each period. Aliquot portions of the urine of the h-hour periods were taken for preparation of a composite sample for the day. and in like manner aliquot portions of the composite sample of urine for each das mere taken for the preparation of a sample for the whole experiment or series of experiments. The nitrogen and heat of combustion were determined in the urine for each dar and in the composite for tie whole experiment. The carbon and hrdrogen were determined in the composite sample of urine for the whole experiment or series of experiments, and were dirided among the different dass in proportion to the amount of nitrogen."

\section{THE MEN WHO SERVED AS SUBJECTS OF THE EXPERIMENTS.}

Three different men. E. O.. A. W. S.. and .J. F. S., hare served a. subjects in these experiments. Each of these. when not sojourning in the apparatus. wa- engaged in work connected with the inrestigations. E. O. wan a general asi-tant in the chemical laboratory. a swede by birth. who had been a number of rears in this countrr: he was $32-33$ rears old. and weighed about 155 pounds. Since boyhood he had been accu-tomed to the moderate nse of alcoholic heverages. A. W. S. Was a physicist, a native of Sew England. 25 rear old. and weighed

"For further explanation, see L. S. Dept. Agr., Ofife Exp. Stations, Bul. 69, pp. 21 and 35. 
about 155 pounds. J. F. S. was a chemist. a Canadian by birth, 29 rears old, and reighed about 150 pounds. The last two had always been total abstainers. The subjects were weighed without clothingr.

\section{SYMPTOMS OBSERVED IN EXPERIMENTS WITH ALCOHOL.}

In deciding upon the daily amount of alcohol and its dirision into doses, the purpose ras to give the subjects as wuch as they conld well take without apparent nervous distnrbance. As above stated. the quantity of absolute alcohol, abont 72 grams per day. was divided into 6 nearly equal doses, of which 3 were taken with the meals and 3 between meals. It supplied about onefifth of the total energs of the diet in the rest experiments and about one-serenth in the rork experiments. On one or two oceasions J. F. S. experienced a slight tingling in the earsimmediately after drinking the alcohol. On one occasion E. O. complained of a slight feeling of dulliness. On one occasion A. W. S. thought he experienced a rery slight dizziness. Other'wise neither one was at any time aware of any especial effect of the alcohol upon the sensations in any way. With the exception of the tingling in the ears noticed by J. F. S., it is not certain that any of the symptoms referred to were due to the alcohol.

As regards the effect of alcohol upon the body temperature and pulse rate in these experiments there is little to be said. The only observations made were those by the subjects themselves and the dificulty of accurately determining one s own normal pulse rate is well known. The observations of temperature were made with a clinical thermometer in the mouth or axilla by the ustal method. which of 'course does not show the exact arerage internal temperature of the body. The data obtained with E. O. and A. W. S. were not sufficiently accurate and numerous to he decisive. The observations by J. F. S. were made at frequent intervals and with considerable care. The results imply a slightly decreased body temperature and increased pulse rate is the experiments with alcohol diet as compared with those with ordinary diet, but the differences are not large.

The data as observed are recorded in the tables in the appendix.

GENERAL DESCRIPTIONS OF INDIVIDUAL METABOLISM EXPERIMENTS.

The data of the experiments with alcohol are giren in detail in the appendix berond. The results are sllmmarized, and brief descriptions of the experiments are given on the following pages. The results of these experiments are here compared with those of similar experiments without alcohol. the details of which are published elsewhere, as indicated in Table 1 , which follows.

\section{LIST OF METABOLISM EXPERIMENTS WITH AND WITHOUT ALCOHOL, AND GROUPING} FOR COMPARISON.

Of the metabolism experiments with men in the respiration calorimeter, 13 had for one of their objects the study of the nutritive ralue of alcobol. The details of 11 of these are giren in the present report; those of 2 others hare been published elsewhere. These 13 experiments are compared with a like number made with the same men, but without alcohol in the diet. Table 1 gires a list of these 26 ; experiments, with grouping for comparison and references to publications in which the details may be found. 
T.1BLE 1.-List of the experiments, and grouping for comparison of results with and without alcohol.

\begin{tabular}{|c|c|c|c|c|c|c|c|c|c|c|}
\hline \multirow{2}{*}{ Group } & \multirow{2}{*}{\multicolumn{2}{|c|}{ No. }} & \multirow{2}{*}{ Date. } & \multirow{2}{*}{$\begin{array}{l}\text { Dura. } \\
\text { tion. }\end{array}$} & \multirow{2}{*}{ Subjeet. } & \multicolumn{2}{|c|}{$\begin{array}{l}\text { Nature of the experi- } \\
\text { ment. }\end{array}$} & \multirow{2}{*}{$\begin{array}{l}\text { Protein in } \\
\text { foorl. }\end{array}$} & \multirow{2}{*}{$\begin{array}{l}\text { Energy in } \\
\text { food. }\end{array}$} & \multirow{2}{*}{$\begin{array}{l}\text { Place of } \\
\text { publica- } \\
\text { tion of de- } \\
\text { tails. }\end{array}$} \\
\hline & & & & & & $\begin{array}{l}\text { Rest or } \\
\text { work. }\end{array}$ & $\begin{array}{l}\text { Ordinary or al- } \\
\text { eohol diet. }\end{array}$ & & & \\
\hline \multirow{8}{*}{ 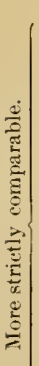 } & & $\begin{array}{r}9 \\
10\end{array}$ & $\begin{array}{l}\text { Jan. } 10-14,1898 . \\
\text { Feb. } 15-19,1898 .\end{array}$ & $\begin{array}{c}\text { Dayys. } \\
4 \\
4\end{array}$ & $\begin{array}{l}\mathrm{E}, \mathrm{O} . \\
\mathrm{N} \text {. do }\end{array}$ & $\begin{array}{l}\text { Rest... } \\
\text { Rest... }\end{array}$ & $\begin{array}{l}\text { Ordinary .. } \\
\text { Alcohol ... }\end{array}$ & $\begin{array}{r}\text { Groms. } \\
119 \\
123\end{array}$ & $\begin{array}{r}\text { Culoricks } \\
2,717 \\
2,709\end{array}$ & $\begin{array}{l}(a) \\
(a)\end{array}$ \\
\hline & & $\begin{array}{l}24 \\
22\end{array}$ & $\begin{array}{l}\text { Mar. 19-22, } 1899 . \\
\text { Mar. 13-16, } 1899 .\end{array}$ & $\begin{array}{l}3 \\
3\end{array}$ & $\begin{array}{l}\text {... ido } \\
\text {-...di lo }\end{array}$ & $\begin{array}{l}\text { Rest... } \\
\text { Rest... }\end{array}$ & $\begin{array}{l}\text { Ordinary .. } \\
\text { Aleohol ... }\end{array}$ & $\begin{array}{l}124 \\
124\end{array}$ & $\begin{array}{l}3,061 \\
3,044\end{array}$ & $\begin{array}{l}(b) \\
(0)\end{array}$ \\
\hline & & 26 & Feb. $14-17,1900$. & 3 & J.F.S & Rest... & Ordinary .. & 100 & 2,490 & $\left(b^{b}\right)$ \\
\hline & & 27 & Feb. $17-20,1900 \ldots \ldots \ldots \ldots \ldots$ & $\begin{array}{l}3 \\
3\end{array}$ & $\begin{array}{l}\text {...do } \\
\ldots . \text { do } \\
\ldots \text {. }\end{array}$ & $\begin{array}{l}\text { Rest... } \\
\text { Rest... }\end{array}$ & Alcohol ... & $\begin{array}{l}99 \\
95\end{array}$ & $\begin{array}{l}2,+89 \\
2,+91\end{array}$ & 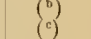 \\
\hline & & 11 & Mar. 22-26, 1898 & + & E. 0 & Work & Ordinary .. & 124 & 3,862 & (b) \\
\hline & & 12 & Apr. $12-16,1898$. & 4 & $\ldots . . d$ & Work & Alcohol ... & 121 & 3,891 & (c) \\
\hline & & 29 & Mar. $16-19,1900$ & 3 & J.F.S & Work & Ordinary . & 100 & 3,487 & (c) \\
\hline & & $\begin{array}{l}31 \\
30\end{array}$ & $\begin{array}{l}\text { Mar. } 22 \\
\text { Yar. } 19\end{array}$ & 3 & ....de & Work & $\ldots$ do & 100 & 3,495 & (b) \\
\hline \multirow{11}{*}{ 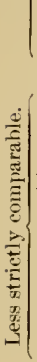 } & & 32 & Apr. $20-23,1900$. & 3 & .... do & Work . & Orlinary .. & 101 & 3,487 & $\left(\begin{array}{c}n \\
b\end{array}\right)$ \\
\hline & & $\begin{array}{l}3+ \\
33\end{array}$ & $\begin{array}{l}\text { Apr. } 26-29,1900 \ldots \\
\text { Apr. } 23-26,1900 \ldots\end{array}$ & $\begin{array}{l}3 \\
3\end{array}$ & $\begin{array}{l}\text { a.do } \\
\text {....do do }\end{array}$ & $\begin{array}{l}\text { Work : } \\
\text { Work }\end{array}$ & Alcohol ... & $\begin{array}{l}100 \\
100\end{array}$ & $\begin{array}{l}3,493 \\
3,486\end{array}$ & $\left(\begin{array}{l}b \\
c\end{array}\right.$ \\
\hline & & 13 & Nov. $8-11,1898$ & 3 & E. 0 & Rest... & Ordinary .. & 117 & 2,596 & (b) \\
\hline & & $1 \pm$ & Dec. $20-24,1 \mathrm{~s} 98$. & 4 & ....d & Rest... & $\ldots$ to & 94 & 2,513 & (b) \\
\hline & & 7 & June 8-12, 1897 . & $t$ & .... do & Rest... & Aleohol & 104 & $2,+62$ & (i) \\
\hline & & 5 & May & \pm & $\cdots \cdot$ & Rest... & Ordin & 119 & 2,655 & (a) \\
\hline & & $\begin{array}{l}15 \\
16\end{array}$ & $\begin{array}{l}\text { Jan. 16-18, } 1899 \text {. } \\
\text { Jan. 18-20, } 1899 \text {. }\end{array}$ & $\begin{array}{l}2 \\
2\end{array}$ & a.de & $\begin{array}{l}\text { Rest... } \\
\text { Rest... }\end{array}$ & Aleohol ... & 109 & $\begin{array}{l}2,653 \\
2,653\end{array}$ & $\left(\begin{array}{l}c \\
c\end{array}\right)$ \\
\hline & & 17 & Jan. $20-22,1899 \ldots$ & 2 & ....do & Rest. & .... do .. & 109 & 2,653 & (c) \\
\hline & & 21 & Feb. 12-15, 1899. & 3 & A. W.S & Rest... & Ordinary .. & 97 & 2,264 & (b) \\
\hline & & 18 & Feb. $6-8,1899 \ldots$ & $\frac{2}{2}$ & ....to do & Rest ... & Aleobol ... & 97 & 2,776 & (c) \\
\hline & & 20 & Feb. $10-12,1899$ & $\overline{2}$ & 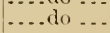 & Rest.. & ....do & 97 & 2,776 & (c) \\
\hline
\end{tabular}

${ }^{\mathrm{a}}$ U. S. Dept. Agr., Office Expt. Stations, Bul. 69, on "Experiments on the Metabolism of Hatter and Energy in the Human Body," by W. O. Atwater, F. G. Bexedict, and Associates.

${ }^{b}$ I. S. Dept. Agr., Oflice Expt. Stations, Bul. 109, on "Further Experiments on Metabolism of Matter and Energy, 1898-1900," by ATwATER, BeNeDict, and Associates.

The present memoir.

The experiments are divided into groups, each group including experiments with and withont aleohol, but made with the same subjeet. In some groups there are only two experiments, one with alcohol and one with ordinary diet; in others there are more than one experiment either with or without alcohol.

More and less strictly comparable experiments. - In the first $t \mathrm{groups}$, A to $\mathrm{F}$, inclusive, the experinents with and without alcohol were practieally duplieates in duration, museular activity, and amounts of protein and energy in the diet, the main difference being that a part of the fats and arbohydrates of the ordinary diet, enough to supply in general about 500 calories of energy, was replaced by the isodymanic amount of aleohol. In the 8 groups, G to I, which include a number of the earlier experiment, those with and without alcohol were not so nearly duplicates. In some instances the difference was unintentional, and was due to a difficulty in obtaining food materials of like composition at different times. In these eases it was not found pructicable to complete the analyses long enough in advance of the experiments to insure miformity of diet as regards amounts of protein and energy. Later, means were derised for putting up food materials in considerable quantities and preserving them by canning or cold storage, so that the amounts of protein and energy in the diet were made more nearly the same in experiments separated by longer or shorter intervals of time. Accordingly the experiments of groups $A$ to $\mathrm{F}$ are designated as more directly comparable and those of Groups $\mathrm{G}$ to I as less directly comparable. 
Order of arrungement of experiments with and without alcohol.-In these experiments two different orders of arrangement hare been obserred. By one plan the experiments with and without alcohol are separated by a longer or shorter interval, and in each case the experiment proper, during which the subject is in the respiration calorimeter, is preceded by a preliminary period during which he is outside the chamber but has the same or nearly the same diet and exercise. The experiments of Groups A, B, D, G, and No. 5 of Group $H$ belong to this class. Each of these experiments has continued in the majority of cases for $S$ dars, the first balf being deroted to the preliminary and the other half to the actual experimental period. In some instances, howerel, the preliminary period was only 3 days. One object of the preliminary period has been to bring the body as nearly into nitrogen equilibrium as practicable. The attempts to secure nitrogen equilibrium hy this means have not, on the whole, been successful, a circumstance to which more especial attention is called beyond.

$\mathrm{Br}$ the other plan the experiments with and without alcohol follow one another without interuption. thus making really successive periods of a single experiment, or successive experiments of a series. Each such series is preceded by a preliminary experiment, during which the man is not in the chamber, but receires, at least during the latter part of the period, the same diet as in the experiment proper. At the end of the preliminary period the man enters the chamber and remains there during the sereral periods of the experiments proper. The transitions from one diet to another are thus immediate. The experiments of Groups C, E, F, and $I$ and Nos. 15, 16. and 17 of Group $H$ were of this sort. Since, howerer, No. 15 was preceded by a preliminary period. and the onl 5 differences between Nos. 15, 16, and 17 were in the kind of alcoholic bererage-commercial alcohol, whisky, and brand -these might be considered one experiment of the first kind.

Each plan has its adrantages and disadrantages. A reason for this is found in the fact that alcohol in moderate quantities appears to have, with some persons, especially with those unaccustomed to its use, a special effect upon nitrogen metabolism. It seems probable that this is exercised through the nerrous system, that it may for a short time tend to increase the excretion of nitrogen, but that it is, in some cases at any rate, only temporary, and disappears after a few days when the permanent effect manifests itself. Accordingly, there is a disadvantage in the second plan, in which the alcohol experiment proper is not preceded by a preliminary period with alcohol diet, in that the persistent effect of the alcohol may not become manifest during the first days of its use in the experiment. Whether, when, or how much this factor may influence a gicen experiment it is difficult to say.

On the other hand, there is a disadrantage in the first plan in that, as the experiments with and without alcohol are not consecutive, the body mar, during the interval between them. become changed in its capacity or tendency to respond to the different diets. The second plan has the corresponding adrantage that differences in the observed results in two consecutive periods might be more clearly due to the diet and less influenced by changes in bodily condition; but here, again, we are dealing with uncertainties.

To some it might scem that the hest test of the effect of alcohol upon nitrogen metabolism would be found in experimenti on the first plan, while others would consider those on the second plan more trustworthy. To the writers it seems that experiments on both plans are desirable. Of course the most desirable plan of all would be to continue the experiments through periods long enough to make sure that the normal action of the alcohol appears, and to alternate the alcohol periods with periods without alcohol. This plan has been followed successfully in experiments upon the special question of the protection of protein by alcohol. as explained in the discussion of this subject heyond.

GROUP A. EXPEIIMEXTS NOS. 9 AND 10 . LEST EXPERIMENTS WTTH ORDINARY DIET AND WITH ALCOHOL DIET.

The 2 experiments in this group were planned to compare the effects of ordinary diet with those of alcohol diet when the sulject did as little mental and muscular work as practicable. The subject, E. O., was the same as in a number of other experiments. The amounts of nutrients 
and energy per day in the diet in both experiments were such as previous observation and experiment with the same subject bad indieated to be sutticient but not excessive. Fxperiment No. 10 was as exact a duplicate as possible of experiment No. 9, exeept that part of the fats and carbohydrates of the ordinary diet of No. 9 were taken out and were replaced in No. 10 by an amount of alcohol that was practically isodynamic with the fats and carbohydrates for which it was substituted, as explained below.

The preliminary digestion experiment preceding metabolism experiment No. 9 began with brenkfast January $6,189 \mathrm{~s}$, and continued $t$ days. During this preliminary period the subject was engaged in his usual ocenpation as laboratory janitor, save that he had as little muscular exercise as practicable. His diet was essentially the same as during the period of actual experiment in the alorimeter.

The subject antered the respiration chamber on the evening of Jannary 9 , and experiment No. 9 began at 7 a. m. on .January 10 and continued until 7 a. m. January 14 . During this period within the chamber his oceupation consisted of reading, writing, ete., but with very little muscular or mental actirity. 'The diet furnished 120 grams of protein and 2,717 calories of energy per day.

Between the close of experiment No. 9 and the beginning of No. 10 there was an interval of about 4 weeks, in which the subject was engaged in his usual oceupation as lahoratory assistant. The preliminary digestion period of No. 10 began with breakfast February 11, 1898, and continued 4 days. The subject bad as little muscular exereise as practicable aside from his regular ocempation. The diet during the preliminary period was practically the same as during the experiment proper.

The subject entered the respiration chamber in the crening of Fehruary 1t, and the experiment proper began at 7 a. m. Febroary 15 and continned 4 days. The diet of the experiment. which furnished 123 grams of protein and 2,709 calories of energy per day, differed from the diet of experiment No, 9 in that abont 37 grams of fat and 45 grams of carbohydrates, supplying 520 calories of energy, were taken out of the ordinary diet and were replaced by 80 grams of commercial alcohol with $\$ 0.6$ per cent or 72.5 grams of absolute alcohol, having a heat of combustion of 512 calories. Thus, the amount of alcohol was rery nearly isodynamie with the auounts of fats and carbohydrates which it replaced, and the total amounts of protein and energy were practically the same in the diets of both experiments.

The following table summarizes the results of these two experiments. Detailed data of the experiments will be found in Bulletin 69 of the Otfice of Experiment Stations of the United States Department of Agriculture.

TABLE 2.-Sitmmary of results of metabolism experiments No8. 9 and 10.

[Quantities per day.]

\begin{tabular}{|c|c|c|c|c|c|c|c|}
\hline & Protein. & Fat. & $\begin{array}{l}\text { Carbohy- } \\
\text { drates. }\end{array}$ & Alcohol. & Nitrogen. & Carbon. & Energy. \\
\hline Experiment No. 9. & Grams. & Grams. & Grams, & Grams. & Grams. & Grams, & alories. \\
\hline In total food & 119.6 & 69.0 & $3+1.8$ & ........ & 19.1 & 261.6 & 2,717 \\
\hline In available food . - & 111.7 & 64.9 & 329.7 & & 17.8 & 235.6 & $2,+26$ \\
\hline 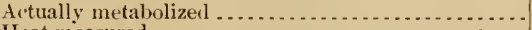 & 115.3 & 46. 7 & $(329.7)$ & .... & 18.4 & 223.6 & 2,277 \\
\hline 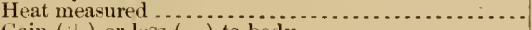 & $\ldots . . . .$. & $\ldots . . .$. & ........ & ........ & $\ldots . .$. & .......... & 2,309 \\
\hline $\begin{array}{l}\text { Gain }(+) \text { or loss }(-) \text { to body } \ldots \ldots \ldots \ldots . . . . . . \\
\text { E.rperiment No. } 10 .\end{array}$ & -3.6 & +18.2 & ...... & 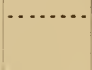 & -0.6 & +12.0 & +149 \\
\hline In total food. & 123.5 & 31.6 & 297.4 & 72.5 & 19.8 & 253.3 & 2,709 \\
\hline In available food ... & $11+.9$ & 27.9 & 288.4 & 71.4 & 18.4 & 227.5 & $2,+27$ \\
\hline 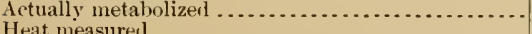 & 121.8 & 6.7 & $(288.4)$ & 71.4 & 19.5 & 214.9 & 2,268 \\
\hline 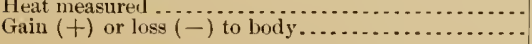 & -6.9 & +21.2 & (n) & (n........ & -1.1 & +12.6 & $\begin{array}{r}2,253 \\
+159\end{array}$ \\
\hline
\end{tabular}


GROUP 13. EXPERIMENTS NOS. 24 AND 22, WITII NO. 23 FOR COMPARISON. REST EXPERIMENTS WITII ORDINARY DIET AND WITH ALCOIIOL.

The experiments of this group are a series of 3 carried out with E. O. in March, 1599. The purpose was to comparc the effects of alcohol with those of sugar upon the metabolism of nitrogen and cspecially of carbon and energy, when the subject had little muscular or mental activity. During this series the subject remained in the calorimeter 9 days and 10 nights without intermission, and each experiment continued 3 days and nights. The plan of the experiments was to give the subject a diet consisting of a so-called basal ration which was the same in all 3 experiments, and a supplemental ration which was different in each experiment. The basal ration given was as large as the arerage of the rations that had been used in the previous experiments with the sume subject. It furnished 123 grams of protein and 2,535 calories of energy per day. The supplemental ration consisted of alcohol in experiment No. 22 and sugar in experiment No. $2 t$, each in quantity sufficient to furnish a little over 500 calories per day, as explained below. In experiment No. 23 the basal ration alone was given.

The preliminary digestion experiment continued $t$ days, beginning with breakfast on . March 9, the lampblack for the separation of the feces baving been taken with the supper the night before. During this preliminary period the subject was engaged in his usual occupation as laboratory assistant, but had as little muscular exereise as practicable. For 3 days of this preliminary experiment the subject lived on the basal ration alone. On the fourth day 79.2 grams of commercial ethyl alcohol, with 90.9 per cent or 72 grams of absolute alcohol, were added to the dict. The alcohol was taken by the subject in cotfee infusion, the total amount for the day being divided into 6 portions, one being taken at each meal and the other 3 portions between meals.

The subject entered the respiration chaniber on the evening of Mareh 12, and experiment No. 22 began at 7 o'clock in the morning of March 13 and continued until 7 a. m. March 16. During this experiment the diet consisted of the basal ration, supplemented each day by 72 grams of alcohol, is stated above. This amount of alcohol added 509 calories per day to the energy of the basal ration.

Experiment No. 23 began at 7 a. m. on March 16 and continued until 7 a. m. March 19 . The diet in this experiment consisted of the basal ration alone without the alcohol, but at the request of the subject with the addition of a small amount of horseradish to add flavor to the diet.

Experiment No. $2 t$ began at 7 a. M. March 19 and continued until 7 a. m. March 21. The diet in this experinent consisted of the basal ration and the horseradish, supplemented each day by $130 \mathrm{grams}$ of cane sugar in the form of rock candy. The daily ration of eandy was given to the subject each morning with breakfast, and he ate it as he felt disposed during the day. This amount of sugar added 515 calories per day to the energy of the basal ration, a similar amount to that added by the alcohol in experiment No. 22.

The following table summarizes the results of experiments Nos. 22 and 24 . The results of No. 23 are also included. although they are not strictly comparable with either 22 or 24 , because removal of the alcohol without replacement by any other material reduced the energy of the diet hy about 500 calories. Detailed data of No. 22 will be found in the Appendix, pp. 330 to 342. and those of Nos. 23 and $2 t$ will be found in Bulletin 109 of the Office of Experiment Stations. 


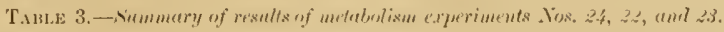

[(Juantities per thy.]

\begin{tabular}{|c|c|c|c|c|c|c|c|}
\hline & Protein. & Fat. & $\begin{array}{l}\text { Carboliy: } \\
\text { drates. }\end{array}$ & Aleohol. & Nitresen. & Curbon, & Energy. \\
\hline \multicolumn{8}{|l|}{ Earperiumb No. 24.} \\
\hline In total food & 123.6 & 68.8 & 408.13 & -......... & 19.8 & 299.7 & $3,(1+1)$ \\
\hline In availahle food & $115 . \pm$ & $6+.4$ & $\begin{array}{c}403.7 \\
(403,\end{array}$ & & $\begin{aligned} 18,5 \\
18,2\end{aligned}$ & 277.4 & 2,809 \\
\hline $\begin{array}{l}\text { Actually metaholiz } \\
\text { Ileat nieasturesl ... }\end{array}$ & 113.7 & & $( \pm 0.3 .1)$ & & & 250.9 & 2,272 \\
\hline Gain $(+)$ or loss $(-)$ to body.. & +1.7 & +59.7 & & & +0.3 & +46.5 & +571 \\
\hline \multicolumn{8}{|l|}{ Exproiment No. 2.3.} \\
\hline In total foorl & 123.6 & 68.8 & 278.6 & & 19.8 & 244.9 & 2,546 \\
\hline In availalsle foosl. & 116.6 & 65. 1 & 272.6 & & 18.7 & 234.6 & $2,+32$ \\
\hline Actually metaholizerl. & 118.2 & 56.2 & $(272.6)$ & & 19.0 & 228.5 & 2,216 \\
\hline 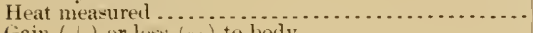 & & $\subset 0$ & & & 03 & & 2,176 \\
\hline Gain $(+)$ or luss $(-)$ to body $\ldots \ldots \ldots \ldots \ldots \ldots \ldots . . . . . . .$. & -1.6 & +8.9 & & & -0.3 & +6.1 & +75 \\
\hline \multicolumn{8}{|l|}{ Experimut Nis. 28} \\
\hline In total foor] & 123.2 & 68.8 & 276.1 & 72.0 & 19.8 & 279.8 & 3,044 \\
\hline & 116.2 & 65.1 & 270.1 & & 18.7 & 256.5 & $2,7 i 7$ \\
\hline $\begin{array}{l}\text { Actually metabolized ..... } \\
\text { Heat nieasured. }\end{array}$ & 114.8 & 2.4 & $(270.1)$ & 69.8 & 18.5 & 207.8 & 2,180 \\
\hline 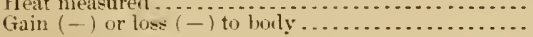 & +1.4 & +62.7 & &. & +0.2 & +48.7 & -597 \\
\hline
\end{tabular}

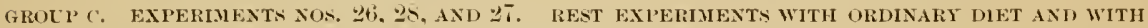
ALCOHOL, DIET.

The series of experiments forming this group was arried out with.J. F. S. in Februmy, 1900. The purpose of the experiments was to obtain data eoncerning the relative power of isolynamic quantities of aleohol, sugar, and butter to replace one another in the dict, when the subject was at rest. During this series the subject remained in the calorimeter !lays and 10 nights, and each experiment continued 3 davs and nights. The diet consisted of a basal ration furnisbing approximately 100 grams of protein and 1.982 ealories of energy per day, which was uniform in all 3 experiments, and a supplemental lation whieh was differed in the several experiment. heing butter in No. 26, aleohol in No. 27 , and sugar in No. 28, the amount of each used being sufficient to furnish ahont 500 ealories of energy.

The preliminary digestion experiment began with breakfast on February 10, and continued 4 days. During this preliminary period the diet consisted of the basal ration supplemented hy $63.5 \mathrm{gram}$ of lutter, furnishing ().1 of a gram of nitrogen and 50s calories of energy; thus making a total of 1 (n) grams of protein and 2,490 calories of energy in the daily diet.

The subjeet entered the respiration chamber on the evening of Fehrury 13, and experiment No. 26 began at 7 a. $m$. February 14, and eontinued 3 days. During this experiment the diet eomsisted of the basal ration supplemented by fat in the form of butter, as in the prehininary digestion experiment.

Experiment No. 27 began at 7 a. m. February 17 , and contimed 3 days. During this experiment the diet consisted of the hasal ration supplemented by 79.5 grams of commereial ethyl alcohol with 90.6 per cent or 72 grams of ahsolute alcohol supplying 509 calories of energy per day, so that during this experiment the daily diet furnished 99 grams of protein and 2,491 calories of energy. The aleohol was administered in sweetened water, and the mixture was eonsumed in 6 portions during the day, 3 with meals and 3 between meals.

Experiment No. 25 began at 7 a. m. February 20 , and continued 3 dars. The diet during this experiment eonsisted of the basal ration supplemented by 28 grams of sugar daily in the form of rock candy. The daily ration during this experiment thus furnished grams of protein and 2. $i s 9$ calories of energy. 'The total amount of roek candy for the day was supplied to the sulject with his loreakfast, and he ate it from time to time during the day aecording to his taste. 
The major portion of it was consumed at about the bours at which the alcohol bad been taken in the provist experiment.

The following table summinger the results of these 3 experiments. Detailed data of experiment No. 27 will be found in the Appendix, pages 342 to 353 , and those of experiments Nos. 26 and 24 in Bullotin 109 of the Oftice of Experiment Stations.

TABLE 4.-Summary of results of metabolism experiments Nos. 26, 2S, und 27.

[Quantities per day.]

\begin{tabular}{|c|c|c|c|c|c|c|c|}
\hline & Protcin. & Fat. & $\begin{array}{l}\text { Carbohy- } \\
\text { drates. }\end{array}$ & Aleohol. & Nitrogen. & Carbon, & Energy. \\
\hline Erperiment No. 26 . & & & & Grams. & & & \\
\hline In total food & 99.6 & 94.8 & $2+7.2$ & & 15.9 & 233.2 & 2,490 \\
\hline In available food. & 92.7 & 92.0 & $2 \pm 0.5$ & & 14.8 & 212.8 & 2,256 \\
\hline Actually metabolized . & 96.2 & 67.6 & $(240.5)$ & & 15.4 & 196.1 & $2,0+3$ \\
\hline $\begin{array}{l}\text { Heat meisured } \\
\text { Gain }(-) \text { or loss }(-) \text { to body....... }\end{array}$ & -3.5 & +24.4 & & & -0.6 & +16.7 & $\begin{array}{l}2,085 \\
+213\end{array}$ \\
\hline Experiment No. 28. & & & & & & & \\
\hline In total food .... & 98.6 & 40.3 & 375.2 & & 15.8 & 245.8 & 2,489 \\
\hline In available food. & 90.8 & 36.3 & 369.9 & & 14.6 & 224.9 & 2,249 \\
\hline Actually metabolized. & 95.3 & 14.5 & $(369.9)$ & & 15.3 & 210.7 & 2,067 \\
\hline Gain $(+)$ or loss $(-)$ to body..... & -4.5 & +21.8 & & & -0.7 & +14.2 & $\begin{array}{l}2,019 \\
+182\end{array}$ \\
\hline Arerage Nos. 26,28 . & & & & & & & \\
\hline In total food & 99.1 & 67.6 & 311.2 & & 15.9 & 239.5 & 2,490 \\
\hline In available food & 91.8 & 64.2 & 305.2 & & 14.7 & 218.8 & 2,253 \\
\hline Actually metabolized .............. & 95.8 & +1.1 & $(305.2)$ & & 15.3 & 203.4 & 2,055 \\
\hline 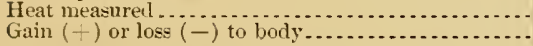 & -4.0 & +23.1 & & & -0.6 & +15.4 & $\begin{array}{r}2,082 \\
-198\end{array}$ \\
\hline Erperiment No. 27. & & & & & & & \\
\hline In total food ..... & 98.6 & 40.3 & 247.2 & 72.0 & 15.8 & 229.5 & 2,491 \\
\hline In available fool . & 91.6 & 38.2 & 240.1 & 71.1 & 14.7 & 208.9 & 2,264 \\
\hline Actually netabolized. & 97.6 & 20.0 & $(240.1)$ & 71.1 & 15.7 & 198.3 & 2,125 \\
\hline $\begin{array}{l}\text { Heat me:lised } \\
\text { Gain }(-) \text { or loss }(-) \text { to body.... }\end{array}$ & -6.0 & +18.2 & & & -1.0 & +10.6 & $\begin{array}{l}2,123 \\
+139\end{array}$ \\
\hline
\end{tabular}

GRG(') 1. EXI'ELIMENTS NOA. 11 AND 12. WORK EXPERIMENTS WITH ORDINARY DIET AND WITII ALCOHOL DIET.

The two experiments in this group were similar to those in Groul $\mathrm{A}$, except that those in Group A were rest experiments, while those in Group D were work experiments; that is, they were planned to compare the effects of ordinary diet and of alcohol diet when the subject was engaged in actire muscular work. The sulject, E. O., was the same in both groujs. The work in these experiments was performed on the bicycle ergometer descrihed on page 237.

The ordinary dist in experiment No. 11 funished 124 grams of protein and 3,862 calories of cneryy per day. The amomnt of protein was nearly the same as in No. 9, hut in order to supply: rnergy for musenlar work the amomut of energy in No. 11 was made to exceed considerably that in No. " by an inel'use in the amount of fats and carbohydrates in the diet.

The prelininary period of this experiment hegan with breakfast, Mareh 18, 1s!s, and rontinued t days. Inring this time the subject was engaged in his usual occupation, and took a comiderable amount of excreise and day walking or riding a bicycle. On the evening of Mareh 21 he entered the repiration chamber, and the experiment proper began at $7 \mathrm{a}$. 1 . March 22. and (entinued until 7 a. m. March 2 it.

Experiment No. 12 was intenderl to be as exact a duplicate as possible of experiment No. 11, exphpt that some of the sugar. starch, and fat was taken ont of the diet and replaced by an isorlynumic amount of alcohol. The alcohol diet of this experiment furnished 121 grams of

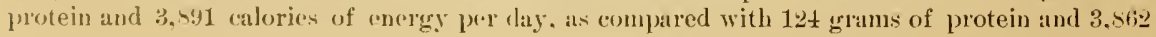


ealories of energy per day in the ordinary diet of experiment No. 11. In ronsideration of the diftienlties in planning and recrulating the diet so as to tumish exactly a definite ipuantity of protein or energy, the arreement of the two diets in regurd to anomnt of protein per day i- rely satisfactory.

In order to obtain a palatable diet in experiment No. 12. con-iderably more fat was furnished than in experiment No. 11. consequenty the carbohydrate- (sugar- and -tarebe-) had to he reduced more than would he required for their replacement by the amount of alcohol used. The fat waincreased by 30 grans. corre-ponding to about 2.55 calories of energy and the earbohydrat were decreased by 189 grams, corresponding to about 7 ul calories. In the place of the materials left out of the diet so gram of commercial aleohol. with !w.5 per eent or 72.4 gram- of pure ethyl alcohol, furnishing 512 calories of energy. were given each day. In this way the energy of the alcohol diet of experiment 1:- was made to agree rerg satisfactorily with that of the ordinary diet of experiment No. 11.

The preliminary period of this experiment hegan with breakfast on April s, 1san, and continned + days, during which the subject took considerable exercise in addition to his regular oecupation. The diet during the preliminary period was the same as during the metabolism experiment proper. The subject entered the chamber on the erening of April 11: metabolism experiment 广o. 12 began at 7 a. m. April 12 , and eontinued until 7 a. m. April 16 .

The following table summarizes the result of these 2 experiments. Detailed data of experiment No. 12 will be found in the Appendix. pages 291 to 305: those of No. 11 in Bulletin 109 of the Oftice of Experiment Stations:

$$
\text { TABLE 5. - Silmmary of results of metabolism experiments Wos. } 11 \text { aud } 12 .
$$

[Quantities per day.]

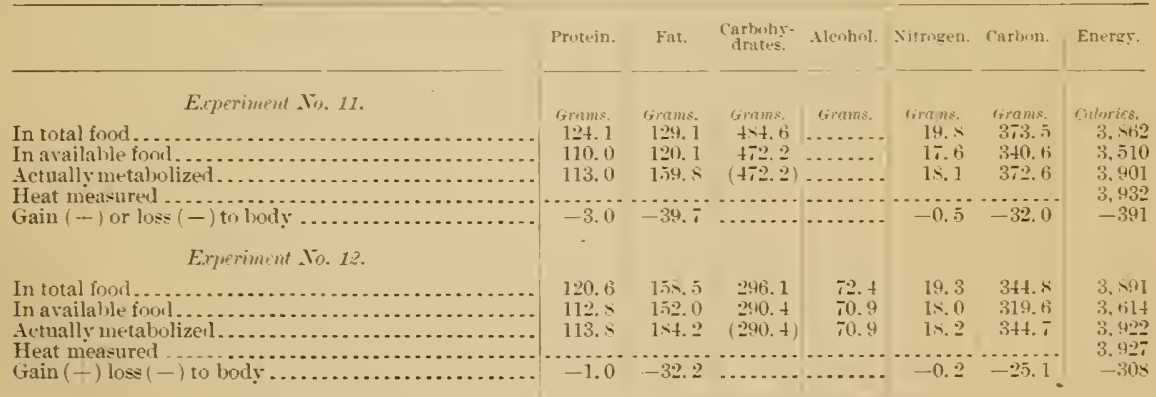

GROLP E. EXPERIMEXT- TO., 24. 31. AND 30. WORK EXPERIMEXTS WTTH ORDIXART MIET AXD WITII ALCOHOL DIET.

The series of experiments forming this group was (arried out in Mareh, 1sun. They were made with the same -ubjeet. J. F. S. as in Group ( and for the same purpose. namely, to study the relative replacing power of i-odynamic quantitie of alcohol. slugar. and fat. During this series the -ubject remained in the ealorimeter "t days and 11) night- without intermi-ion. and each experiment in the series continued 3 days and uights. The experiments in Group E ditfer from those in Group C. however, in that the subject worked for o hours each day upon the bicycle ergometer. described on page 237 . As in the previon - series of experiment-refered to, there waa basal ration which was the same and a supplemental ration which was different in each of the 3 experiments. The basal ration was planned to furnish approximately the same amount of protein as in the series in Group C. with the addition of about 1.1101 calories of energy per day in order to furnish the extra energy required for the performance of the extrmal musular work and the general increase of hodily aetirity. It furnished ahout 1 w grams of protein and from 2,244 to 2.95t calories of energy per day in the different experiments. 
The preliminary digestion experiment began with breaktast March 12, 1900, and continued t days. The diet dning this period cousisted of the basal ration supplemented by cane sugar, as in experiment No. 2⿺.

The subject entered the respiration chamber on the evening of March 15 , and experiment No. 29 began at 7 a. m. March 16 , and continued 3 days. During this experiment the diet comsisted of the basal ration supplemented by 128 grams of cane sugar furnishing 507 calories of energy per day, as in the preliminary digestion period; the whole diet furnishing daily 100 grams of protein and 3,487 calories of energy. The daily amount of sugar in the form of rock candy was supplied to the subject each morning at breakfast, and he ate it at intervals during the day according to his taste.

Experiment No. 30 began at 7 a. m. March 19, immediately at the close of experiment 29. The diet in this experiment consisted of the basal ration supplemented by 79.5 grams of commercial alcohol containing 90.6 per cent or 72 grams of pure ethyl alcohol in place of the sugar of experiment No. 29. The alcohol supplied 509 calories of energy, and the whole ration in this experiment furnished 99 grams of protein and 3,458 calories of energy per lay. The commercial alcohol used in this experiment was added each day to 795.5 grams of water sweetened with 25 grams of sugar from the basal ration. The total mixture, 900 grams, was divided into 6 portions which were taken with meals and between meals, as in other alcohol experiments.

Experiment No. 31 began at $7 \%$ m. on the morning of March 22, and continued 3 days. The diet in this experiment consisted of the basal ration supplemented by 63.5 grams of butter in place of the alcohol in the previous experiment. The butter furnished nearly 1 gram of protein and 511 calories of energy, so that the whole ration furnished 101 grams of protein and 3,495 calories of energy per day. The butter was consumed at meals with the rest of the diet.

The following table summarizes the results of these 3 experiments. Detailed data of experiment No. 30 will be found in the Appendix, pages 354 to 366 , and those of experiments Nos. 29 and 31 will be found in Bulletin 109 of the Uffice of Experiment Stations.

TABLE 6.-Summary of results of metabolism experiments Nos. 29, 31, and 30.

[Quantities per day.]

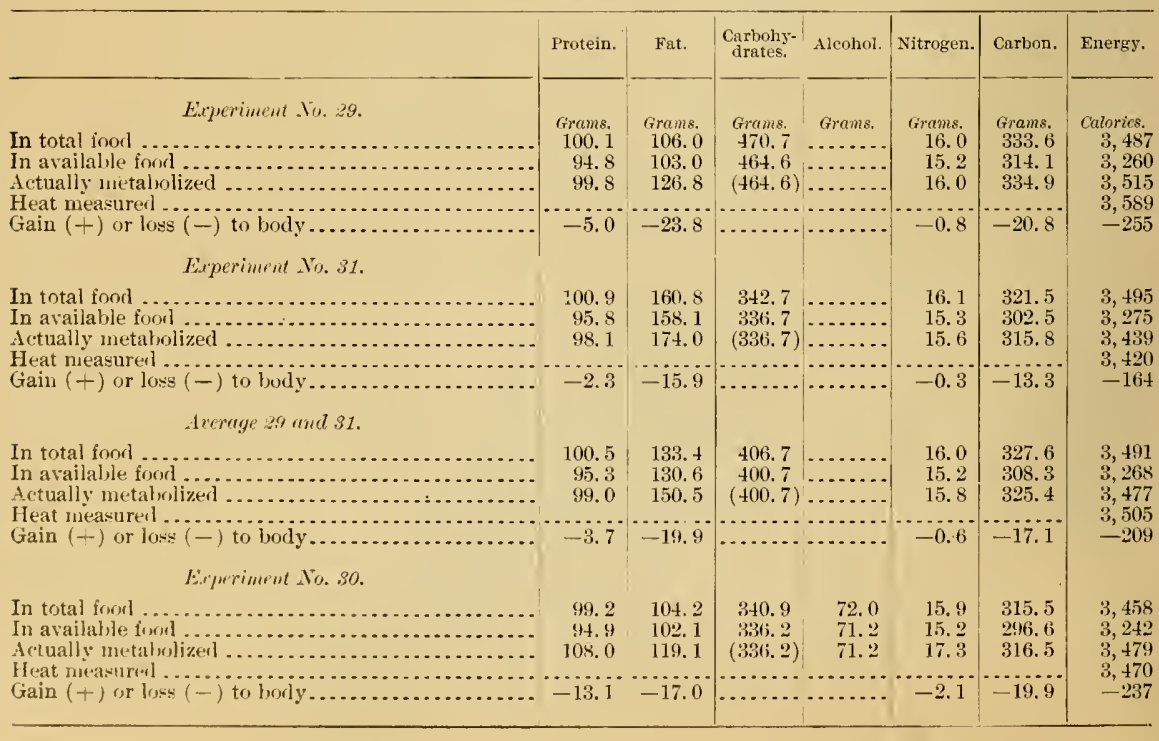




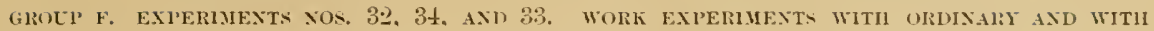
ALCOHOL DIET.

The series of experiments forming this group was made in April. 19m. The plan of the experments in this series was as nearly as powible a duplicate of that of the experiment-forming

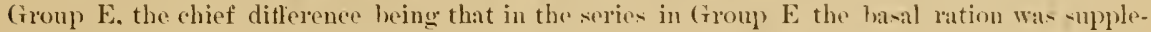
mented in the first experment by sugar, in the second by alcohol. and in the third by butter, whereas in the series in Gronp $\mathrm{F}$ the butter was used in the first experiment. alcohol in the second, and sugar in the third. Both series were work experiments in which the same -nljject. I. F. S.. spent s hours each day working on the bieycle ergometer. In earh series the snlject remained ancessive days within the calorimeter. and the whole inrestigation mas divided into 3 experiments of 3 days each, the different experiments being distinguished trom each other hy ehanges in the smpplemental ration. The hasal ration in this series furnished $101 \mathrm{grams}$ of protein and abont 2.976 calories of energy per day. The anount of energy in the hatal ration varied slightly in the successive experiments of the series. hecause of slight differences in the composition of the milk.

The preliminary digestion experiment began with breakfast April 16 and continued 4 dars. The diet consisted of the basal ration supplemented with fat in the form of hutter. as in experiment No. 32 .

The subject entered the respiration ehamber on the erening of April 14 and experiment No. 32 began at $\vec{i}$ a. m. April 2 () and continued 3 dars. The diet consisted of the basal ration supplemented by 63.5 grams of butter, furnishing 1 gram of protein and 510 ealories of energy. The butter was consmed at meals with the rest of the diet. The total diet in this experiment supplied 101 grams of protein and 3,456 ealories of energy per day.

Experiment Xo. 33 hegan at 7 a. m. April 23 and eontinued 3 days. The diet in this experiment consisted of the hasal ration, supplemented by $7: .5$ grams of commercial alcohol with $\$ 4.6$ per cent, or it gram of absolute alcohol. furnishing 50 s ealorie of energy. The commereial aleohol was added each day to 795.5 grams of water -weetened with 25 gram of sugar, making 900 grams of a mixture which was divided into six portions (see p. 29:2), the larger of which were taken at meals and the smaller between meals and before retiring. The total diet in this experiment furnished 100 grams of protein and 3.486 calories of energy per day.

Experiment No. 34 began at 7 a. m. April 26 and continned 3 days. The diet consisted of the lasal ration supplemented by $12 x$ gram of cane sugar, furnishing 507 ealories of energy. The daily amount of sugar was supplied to the subject each morning in the form of rock candr. which he ate at intervals during the day aceording to his taste. The total diet in this experiment furnished $100 \mathrm{gram}$ of protein and 3.493 calorie- of energy per day.

The following tahle summarizes the results of these 3 experiments. Detailed data of experiment No. 33 will be found in the Appendix. pager 366 to $3 \%$, and thove of experiments Nos. 32 and 34 in Bulletin 109 of the Office of Experiment Stations:

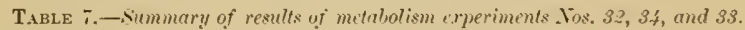

[Quantities per day.]

\begin{tabular}{|c|c|c|c|c|c|c|c|}
\hline & Protein. & Fat. & $\begin{array}{l}\text { Carbohs- } \\
\text { drates. }\end{array}$ & Alcohol. & Nitrogen. & Carbon. & Energy: \\
\hline Experiment No. 32. & & Grams. & & Grams. & & Grams. & \multirow{5}{*}{$\begin{array}{l}\text { Calories. } \\
3,4<7 \\
3,226 \\
3,5,3 \\
3,56.7 \\
-3 \pm 7\end{array}$} \\
\hline $\begin{array}{l}\text { In total food } \ldots \ldots \\
\text { In arailable fooi } \ldots \ldots\end{array}$ & $\begin{array}{r}100.5 \\
93.1\end{array}$ & $\begin{array}{l}151.6 \\
147.2\end{array}$ & $\begin{array}{l}353.9 \\
34.5\end{array}$ & - & $\begin{array}{l}16.1 \\
14.9\end{array}$ & $\begin{array}{l}320.0 \\
296.4\end{array}$ & \\
\hline Actually metabolized & 98.1 & 182.1 & $(34+.5)$ & & 15.7 & 325.6 & \\
\hline $\begin{array}{l}\text { Heat measured } \\
\text { Gain }(+) \text { or loss }(-) \text { to body }\end{array}$ & -5.0 & -34.9 & & & -0.8 & -29.2 & \\
\hline Erperiment Vo. 34. & & & & & & & \\
\hline In total lood ..... & 99.7 & 99.3 & 477.9 & ...... & 16.0 & 335.7 & 3,493 \\
\hline $\begin{array}{l}\text { In available fond -- } \\
\text { Actually metabolize }\end{array}$ & & & 40.1 & $\ldots$ & 14.8 & 312.5 & $\begin{array}{l}3.241 \\
3.629\end{array}$ \\
\hline Heat measured ... & & & $(+60.1)$ & & & & 3,587 \\
\hline Gain $(+)$ or loss $(-)$ to body.. & -11.9 & -35.0 & *. & & -1.9 & --32.9 & $-3 s s$ \\
\hline
\end{tabular}


TABLE 7. Siummary of results of melubolism experiments No.s. 32, 34, und 33-Continued.

\begin{tabular}{|c|c|c|c|c|c|c|c|}
\hline & Protein. & Fat, & $\begin{array}{l}\text { Carbohy- } \\
\text { drates. }\end{array}$ & Alcohol. & Nitrogen, & Carbon. & Energs: \\
\hline 1nerrege Tos. 32 and 34. & & & riten & Grams. & Gran & & \\
\hline In total food $\ldots \ldots \ldots \ldots \ldots$ & 100.1 & 125.5 & 415.9 & -......... & 16.0 & 327.8 & $3,+90$ \\
\hline 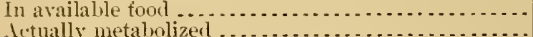 & $\begin{array}{r}92.8 \\
101.3\end{array}$ & $\begin{array}{l}120.8 \\
155.8\end{array}$ & $\left.\begin{array}{c}407.3 \\
(407.3)\end{array}\right)$ & (n....... & $\begin{array}{l}14.8 \\
16.2\end{array}$ & $\begin{array}{l}304.4 \\
335.5\end{array}$ & $\begin{array}{l}3,234 \\
3,601\end{array}$ \\
\hline Heat measured .. & 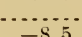 & 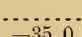 & ......... & . & ....... & ......... & 3,576 \\
\hline 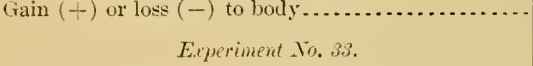 & -8.5 & -35.0 & $\ldots$ & & & & \\
\hline In total food & 99.7 & 99.3 & 355.0 & 72.0 & 16.0 & 319.6 & 3,486 \\
\hline In availabl & 92 & 95.0 & & 71.3 & 14.8 & & 3,227 \\
\hline 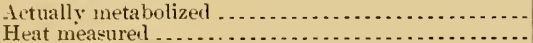 & 108.2 & 133.4 & $(3+6.9)$ & 71.3 & 17.3 & 333.3 & 3,669 \\
\hline Gain $(+)$ or loss $(-)$ to body & -15.8 & -38.4 & & & -2.5 & -37.6 & $\begin{array}{l}0,032 \\
-442\end{array}$ \\
\hline
\end{tabular}

GROLP G. EXPERIMENTS NOS. 13,14 , AND 7 . REST EXPERIMENTS WITH ORDINARY AND WITH ALCOHOL DIET.

While the 3 experiments in this group are all rest experiments and all with the same subject, E. O.. the ordinary experiments and the alcohol experiments were not planned to be exact duplicates of each other, and are therefore less exactly comparable than those in preceding groups. For the sake of comparison with the alcohol experiment, No. 7, however, 2 ordinary experiments, Nos. 13 and 14, were chosen in which the average of the amounts of protein and energy in the daily diet in the 2 experiments was practically the same as in the alcohol experiment. Since these experiments were made with the same subject and under conditions somewhat similar, the results may be compared in studying the effect of alcohol on metabolism.

Experiment No. 13 was intended to be as nearly as possible a duplicate of experiment No. 9. The ordinary diet in experiment No. 13 furnished 117 grams of protein and 2,596 calories of energy per day, which was 2 grams of protein and 121 calories of energy less than in No. 9. The preliminary period of No. 13 began with breakfast Norember 8,1898 , and contiuned 4 days, during which the subject had as little muscular exercise as practicable outside of his regnlar occupation as laboratory assistant. He entered the chamber on the evening of November 7 , and the experiment proper began at 7 a. m. November 8 . It was intended that the experiment hould continue $t$ days, but on the fourth day a leak occurred in the rentilating air pipe at such a point that the results for that day were destroyed; consequently the experiment is recorded as a 3 -day experiment. While this was a rest experinent in general character, the subject was not so yuiet throughout the experimental period as he had been in earlier and was in later similar experiments.

Experiment No. 14 was carried out under much the same conditions as No. 13, with the exception that in No. 14 the amount of protein in the diet was reduced from 117 to $9 \pm$ grams per dar. and the energy from 2,5\%6 to 2,513 calories per day. The preliminary digestion experiment began with Treakfast December 17,1895 , and continucd 3 days. The subject entered the apparatus on the erening of December 19, and the experiment proper began at 7. a. m. December 20 and continued $t$ days.

The arerage of the amounts of protein and tnergy in the daily diet of the 2 ordinary experiments. 13 and 14, was 105 grams of protein and 2,555 culories of energy.

The alcohol diet in experiment No. 7 furnished 104 grams of protein and 2,462 calories of energy per clay. The diet in this experiment included st grams of commereial alcohol, with 90.6 per cent, or T2.5 grams, of pure ethyl akohol, which furnished 512 calories of energy per day. The prelininary digestion experiment hegan with Jreakfast . Ine 4,1857 , and continned $t$ days. The subject entered the chamber on the evening of .Tune 7 , and the experiment proper began at 7 p. su. . Junn sind continued + days's. 
The following table summarizes the re-ult- of the-e experiments. Detailed data of experi-

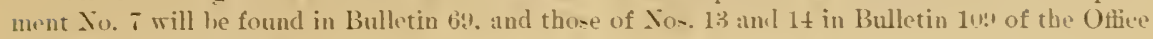
of Experiment Stations:

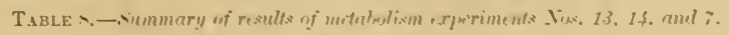

QQuantitie jer day:

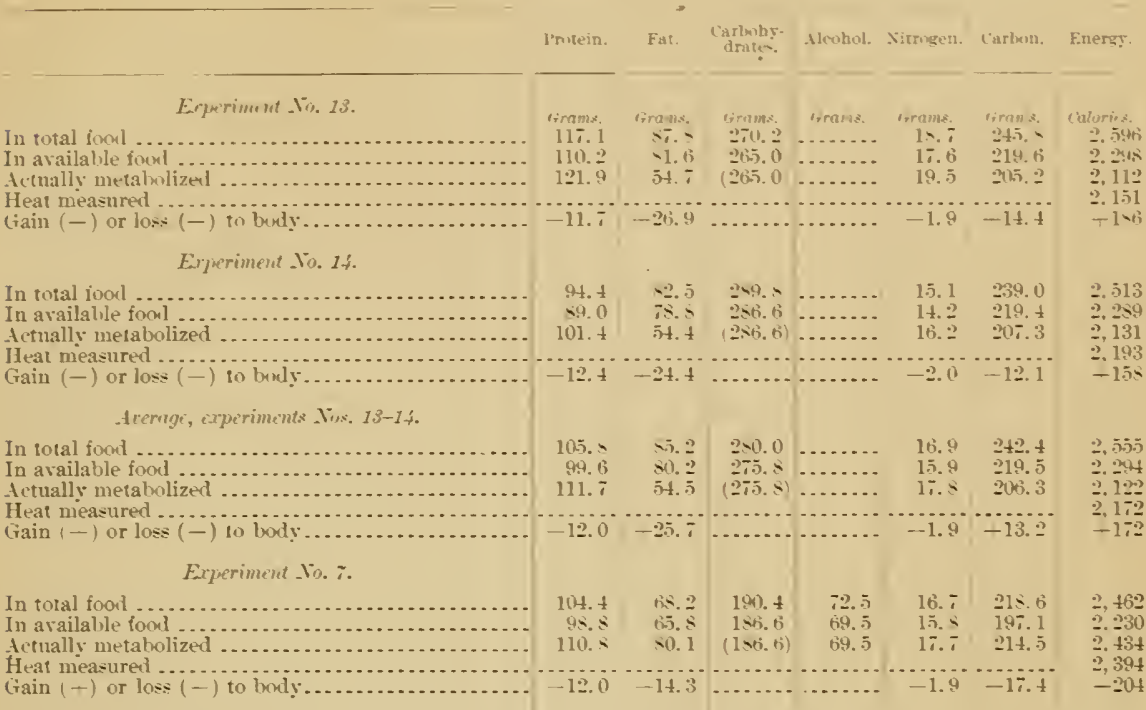

เiROTP H. EXPERIMEXTS YOS. 5. 15-1\%. REST EXPERIMENTS WITH ORDIXART DIET AND WITH ALCOHOL DIET.

The experiments in Group $\mathrm{H}$ were all rest experiments with the same subject. E. O. One purpose of the 3 experiments with alcohol diet (Nos. 15-1i) was to compare the effect of aleohol when taken in different forms. as commereial alcohol. whi-ky. or hrandy. The experiment with ordinarr diet (No. 5) has heen ehosen for comparison with the 3 experiment with alcohol diet for the reason that. while the amount of protein was somewhat larger in the former than in the latter. the amount of energy was practically the same in both diet.. The experiments in thi- group are less comparable than those in Group-G and I because of differences in the cireunntance- under which the experiments were made. Experiment Jo. 5 was the first of the serie- of metaboli-m experiment- in which the determination- of income and outgo of both motter and energr were made. The diet in this experiment wa- more raried than t that in solue of the later experiment-, and the method of sampling were not sitisfactory. which will account in part for the unusually widle discrepancies between the theoretical values for income and those actually found for outgo of energr. On the other hand. experiments No- 15-15 were made at a later period when the apparatus and the method of experimenting were much improred.

The preliminary period of experiment No. 5 began A pril 27.1507 . and continned a dars, in tead of 4 dars as usual. becanse unexpected cireumstances delared the starting of the experiment proper. The subject entered the ealorimeter at ahout " $0^{\circ}$ clock on the erening of May 3 and the experiment proper began at $i$ a. m. May $t$. and eontinued $t$ dars. The diet in this experiment furnished 119 gram of protein and 2.655 calorie- of energr per dar.

Each of the 3 experiment? Yos. 15-1\%. was of 2 dar duration. and one followed the other without intermission and without the subject learing the respiration chamber, so that in a way 
they constitute one long experiment. No attempt was made to obtain a separation of the feces for the different experiments. The usual separations, however, were made. the first between the preliminary digestion experiment and the beginning of metabolism experinent No. 15, and the second at the close of experiment No. 17. The diet in these experiments consisted of a hasal ration which was the same in all 3 experiments, supplemented by alcohol in the form of pure ethrl alcohol in experiment 50.15 . by alcohol in the form of whisky in experiment No. 16. and by aleobol in the form of hrandy in experiment No. 17. The total diet including the alcohol furnished 109 grams of protein and 2.653 calories of energy per day.

The preliminury digestion experiment began January 12, 1899, and continned $t$ days as usual. During this preliminary experiment the subject received the basal ration. and in addition to this 72.5 srams of absolute ethyl alcohol. which was administered daily in coffee infusion sweetened with to griums of sugar.

The subject entered the respiration chamber on the evening of Janury 15 and experiment 15 began at 7 a. m. January 16 . During this experiment he received the basal ration supplemented by 79.8 grams of 90.9 per cent commercial alcohol. or 72.5 grams of absolute ethyl alcohol. in 775.2 grams of cotfee infusion, the whole of which was sweetened with 45 grams of cane sugar. There was 900 grams of the mixture which sufficed for the whole day. This was taken at 6 intervals, the larger portions being consmmed with the meals and the smaller portions between meals and just before retiring.

Experiment No. 16 began at 7 a. m. January 18. and continued 2 days. The diet in this experiment consisted of the bisal ration supplemented by 158.3 grams of whiskr. with 45.8 per cent, or $72.5 \mathrm{grams}$, of absolute alcohol. This was mixed with $696.7 \mathrm{grams}$ of water sweetened with $5 t$ grams of sugar, and the whole divided into 6 doses and taken as before. The mixture was made with water rather than with coffee infusion, because it was thought the objection might he raised that the coffee might perhaps. to some extent, counteract the effect of the alcohol. The whisky, sllgar, and water were furnished to the subject. who mixed them at the usual hours within the apparatus. The amount of alcohol found in the air current was larger during this experiment than during the one preceding it, suggesting that some alcohol may hare been rolatilized as the whisky was ponled into the drinking cup and mixed with the water. The mixing was therefore done outside the apparatus in the next experiment. and the alcohol in the air current was again less than in No. 16.

Experiment No. 17 hegan at 7 a. m. January 20, and continued 2 days, during $w$ hich the subject receired the basal ration supplemented hy 143.8 grams of brandy, with $50 . t$ per cent, or 72.5 grams, of absolute alcobol, per day. This amount was added to 711.2 grams of water and 45 grams of sugar, making a total of 900 grams of the mixture, which was administered in 6 portions. als in the previous experiments.

The following table summarizes the results of these $t$ experiments. Detailed data of experiments Nos. 15-17 will be found in the Appendix, pages 305 to 317 ; those of No. 5 will be found in Bulletin 69 of the Office of Experiment Stations:

$$
\text { TABLE 9.-Simmary of results of metribolism experiments Nos. } 5 \text { and 15-1\%. }
$$

[Quantities frer day.]

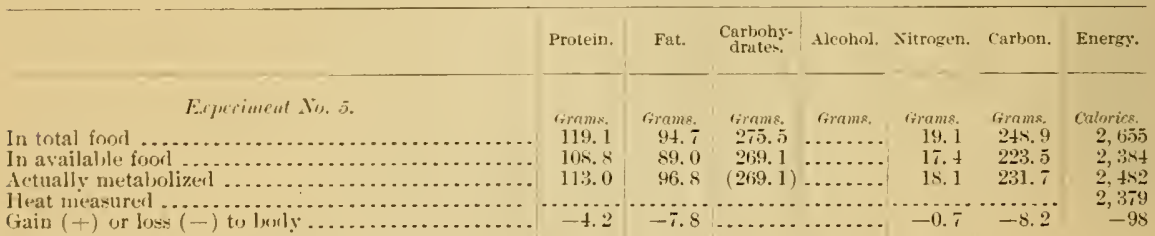

$$
\text { Eiguriumet Wo. } 1.5 .
$$




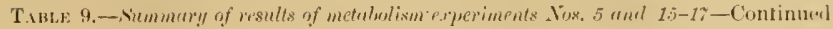

[Quantities per day.]

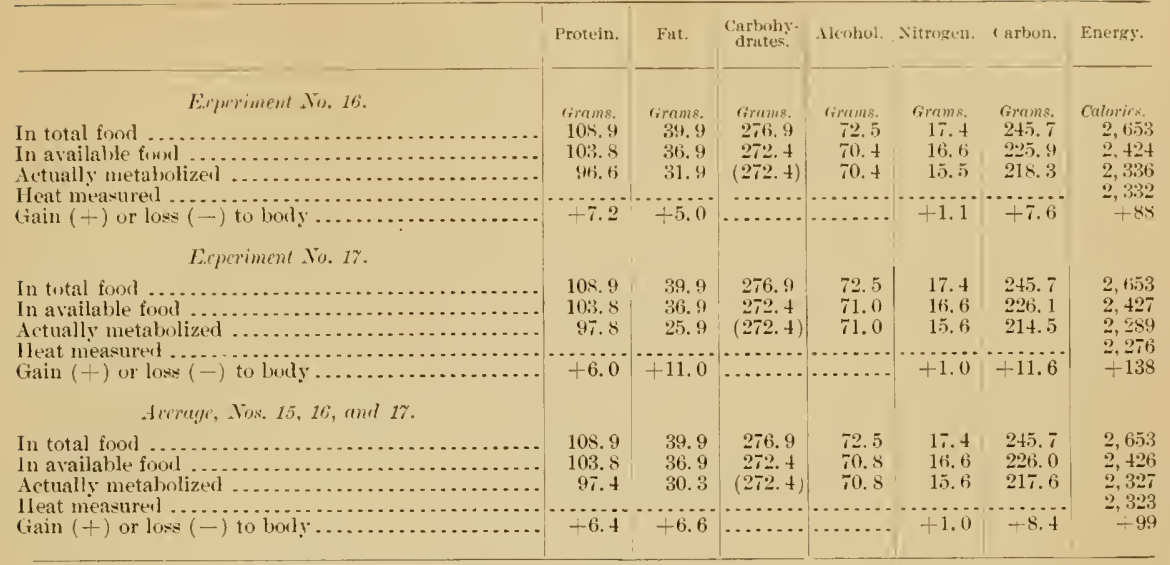

GROUP 1. EXPERIMETS NOS, 21 AXD 18-20. RENT EXPERIMENT WITH ORDINARY AND WTII ALCOHOL DIET.

The series of experiments comprising this group was carried ont in February, 1899. The purpose of the experiments with alcohol diet in this series was the same as that of experiments 15-17, namely, to determine whether there in any difference in the effect of alcohol when taken in different forms. Experiments Nos. 18-20 were somewhat similar in plan to Nos. 15-17, but were made with a different subject, A. W. S. The subject remaned in the calorimeter 9 day: without intermission. During the first 6 days of this period the 3 alcohol experinents, Nos. 15-20, were made, each of 2 days durtion, as in experiments 15-17. These were followed by one experiment, No. 21 , of 3 days, in which the diet contained $n$ alcohol.

As in the preceding series, the diet in experiments $18-21$ consisted of a basal ration which was the wame in all the experiments, and a supplemental ration which was different in each. This basal ration furnished $17 \mathrm{grams}$ of protein and 2,264 calories of energy per day. In experiments Nos. 1s-20 the basal ration was supplemented by commercial alcohol. whisky, and brandy, respectively, the quantity of each used being sufficient to furnisb 72.5 guams of alsolute alcohol per day, with a heat of combustion of 512 calories. The total diet in the alcohol experiments fun nished 97 grams of protein and 2,7\%6 alories of energy per day. In experiment No. 21 the alcohol was omitted, and the diet consisted of the basal ration alone.

The preliminary digestion experiment begar with breakfast February 2 , and continued 4 days. During this period the diet was the same as in experiment No. 1s, and eonsisted of the basal ration and the alcohol in the form of commercial spirits, which was administered in cotfee infusion, sweetened with sugar.

The subject entered the respiration ehamber on the evening of February 5, and experiment No. 18 hegan at 6 a. m. February 6 , and continued 2 dars. In this experiment the diet consisted of the baval ration. supplemented by 79.8 grams of commercial alcohol, with 10.9 per cent, or 72.5 grams, of absolute aleohol. The commercial spirits was mixed with 775.2 grams of cotfee infusion, sweetened with 45 grams of eane sugar. The whole mixture made gin grams. which was divided into 6 portions, the larger of which were taken with meals, and the smaller between meals and just before retiring.

Experiment No. 19 began at 7 a. m. February 8, and continnerl 2 days. The diet in thi. experiment consisted of the hasal ration, supplenjented ly 15.5.3 grams of whisky, with 45.8 per cent, or 72.5 grams, of absolute aleohol. The whisky was mixed with 6416.7 grams of water, 
sweetened with tj glams of eane sugar, the whole wixture forming 900 grams. which was administered as in experiment No. 18.

Experiment No. 20 began at $\tau$ a. m. February 10, and continued 2 days, during which the diet consisted of the basal ration, supplemented by $143.8 \mathrm{grams}$ of brandy, with 50.4 per cent, or'

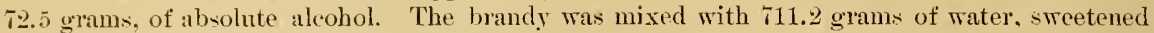
with t.5 grams of eane sugar. The whole mixture amounted to 900 grams. which was administered in 6 portions as in the previous experiments.

Experiment No. 21 began at 7 a. m. Februtry 12, and continned 3 days. The diet in this experiment consisted of the basal ration alone, without alcohol. The results of this experiment are here given in comparison with 3 alcohol experiments heatse it was a part of the sume series and followed the alcohol experiments without intermission and without the subject leaving the respiration chamber. The results are hardly comparable with those of the alcohol experiments, however, since by the omission of the alcohol from the diet the amount of energy per day was reduced nearly one-fifth, while the amounts of protein, fats, and carbohydrates remained the sime.

The following table summarizes the results of these $t$ experiments. Detailed data of experiments Nos. 18-20 may be found on pages 317 to 330 in the Appendix. Those of No. 21 may be found in Bulletin 109 of the Office of Experiment Stations.

TABLE 10.-Summary of results of metabolism experiments Nos. 18, 19, and 20 .

[Quantities per day.]

\begin{tabular}{|c|c|c|c|c|c|c|c|}
\hline & Protein. & Fat. & $\begin{array}{l}\text { Carbohy- } \\
\text { drates. }\end{array}$ & Alcohol. & Nitrogen. & Carbon. & Energy. \\
\hline \multicolumn{8}{|l|}{ Experiment No. 21 . } \\
\hline In total food .... & 9 & 72.4 & 250.1 & |....... & 15.5 & 215.2 & 2,264 \\
\hline 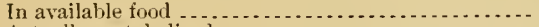 & 90.4 & 68.4 & 246.1 & .......... & 14.5 & 195.4 & 2,038 \\
\hline 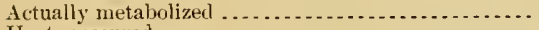 & 96.0 & 93.3 & $(246.1)$ & $\ldots . . .$. & 15.4 & 217.4 & 2,304 \\
\hline Heat measured $\ldots \ldots \ldots \ldots \ldots$ & $\ldots \ldots$ & $-2 j^{0}$ & 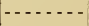 & $\cdots$ & ........... & 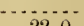 & 2,279 \\
\hline Gain $(+)$ or loss $(-)$ to body $\ldots \ldots \ldots \ldots \ldots . . . . . .$. & -5.6 & -24.9 & $\cdots$ & - & -0.9 & -22 & -266 \\
\hline \multicolumn{8}{|l|}{ Experiment No. 18.} \\
\hline$\ldots \ldots \ldots \ldots \ldots \ldots$ & 96.9 & 72.4 & 250.1 & 72.5 & 15.5 & 253.0 & 2,776 \\
\hline (n) & 90 & 68.4 & 246.1 & 69.5 & 14.4 & 232 & 2,532 \\
\hline Actually metalsolized $\quad \ldots \ldots \ldots \ldots$ & 102.6 & 43.3 & $(2+6.1)$ & 69.5 & 16.4 & 219.3 & 2,367 \\
\hline 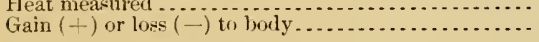 & -12.2 & +25.1 & $\cdots$ & & -2.0 & +12.7 & $\begin{aligned} 2,+\infty 0 \\
+168\end{aligned}$ \\
\hline \multicolumn{8}{|l|}{ E.rperiment Wo. 19.} \\
\hline In total foorl & 96.9 & 72.4 & 250.1 & 72.5 & 15.5 & 253.0 & 2,776 \\
\hline ailable food & 90.4 & 68.4 & $2+6.1$ & 69.9 & 14.5 & 23. & 2,550 \\
\hline Actually metabolizerl $\ldots \ldots \ldots \ldots \ldots \ldots \ldots$ & 90.4 & 33.3 & $(246.1)$ & 69.9 & 14.5 & 206.6 & $2,2=0$ \\
\hline 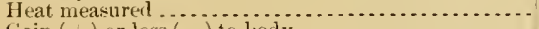 & ..... & $\cdots \cdots \cdots$ & $\mid \ldots . . .$. & $\cdots, \cdots$ & ...... & $\cdots$ & 2,279 \\
\hline 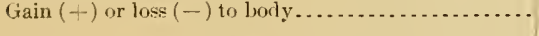 & & +35.1 & & & - & +26. & -330 \\
\hline \multicolumn{8}{|l|}{ Eiperiment Wo. $\approx 0}$. \\
\hline In $\mathrm{t}$ & 96.9 & 72.4 & 250.1 & 72.5 & 15.5 & 253.0 & 2,776 \\
\hline In & 90. & 68.4 & $2+6,1$ & 69.7 & 14.5 & 233.5 & 2,549 \\
\hline 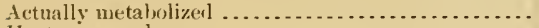 & 88.2 & 47.3 & $(246.1)$ & 69.7 & 14.1 & 216.2 & 2,339 \\
\hline 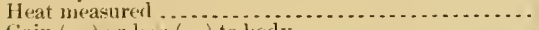 & & & -... & $\ldots$ & & & 2,303 \\
\hline 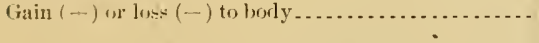 & +2.2 & +21.1 & $\cdots$ & $\cdots$ & +0.4 & $+17 .: 3$ & +210 \\
\hline Jermege of 18,19, and 20 & & & & & & & \\
\hline In $t$ & 96.9 & 72.4 & 250.1 & 72.5 & 15.5 & 253.0 & 2,776 \\
\hline In available form & $90 . \pm$ & tis. 4 & 246.1 & 69.7 & 14.5 & 293.0 & 2,544 \\
\hline Actually metalonlizerl .. & 93.7 & 41.3 & $(2+6.1)$ & 69.7 & 15.0 & 214.1 & 2,308 \\
\hline 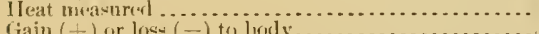 & $\cdots \cdots$ & $\cdots$ & $\ldots \ldots$ & $\ldots \ldots$ & - & .... & $\begin{array}{l}2,357 \\
-936\end{array}$ \\
\hline Gain $(+)$ or los & -3.3 & $\div 27.1$ & & & -0.5 & +18.9 & 236 \\
\hline
\end{tabular}




\section{DIGESTION EXPERIMENTS.}

The data of the motabolism experiments above described inelnde statistics of the amount: of nutrients consumed in the food and excreted in the feces. The difference between these amounts represents the so-tulled digestible or avalible nutrients. a The amount of exch nutrient thus male avialable divided by the amount in the eorresponding food is bere taken as the eoefticient of availahility.

Each metabolism experiment, therefore. includen a digention experiment: furthermore. each metabolism experiment or series of experiments was preceded hy a digestion experiment, generally of $t$ days duration. during which the subject was ontside the respiration calorimeter. but had the sume diet, and as nearly as convenient the same amount of mucular exercise. als in the metabolism experiment. We thus have for each metaholism experincnt or series of metabolism experiments two corresponding digestion experiments. While the chief object of the prcliminury experiment was to bring the boly into approximate nitrogen equilibrium, the results, as bearing upon the arailability of the food. are of importance.

The portions of protein, fat, carbohydrates, and asb not made avalable are eliminated in the feces. The mavalable alcohol is eliminated throngh the kidneys, lungs, and sin, and was determined in these experiments according to the method described beyond (p. 25.4$)$.

In what has been said about the arailability of the different nutrients in food no reference has been made to the arailability of the energy. While it is commonly beliered that all of the energy of the available fat and carbohydrates is atpable of tse by the body. all of the energy of the protein can not be so stilized. The nitrogen of the avilable protein is eliminated from the body in the form of urea, uric acid, and similar compounds. (arrying with them a certain amount of energy. From the result of a considerahle number of determinations of the ratio of the heat of combustion of urine to the arailable protein it has been found that for each gram of the latter. there is lost in the urine an areruge of 1.25 calories of energy. This amount must therefore be deducted from the energy of the arailable food in order to ohtain the arailable energy of the available protein. This is done hy multiplying the number of grams of the latter by 1.25. and deducting the product from the difference hetween the total energy in the food and that in the feces. The difference gives the amount of arailable energy, which, divided by the total energy in the food eonstmed. gives the coefficient of a vailability of the energy.

The proportions of the different mtrients digested and made arailable in any given case depend upon the diet and the individnal. So far as concerns the diet. the availability may vary with (1) the kinds. (2) the amounts of food materials. (3) the method of preparation. and $(4)$ the aceessories, including condiments. hevertges, etc., and with the rest, alcoholic beverages. The same diet mat be difterently digested by different individuals or by the same individual under different conditions of health. physieal activity. and nerrous-train.

The details of the digestion experiments with alcohol diet are griven in Tables CV to CXVIII of the Appendix.

Table 11 compares the arailability of food in diets with and without alcohol and the arailability of the same diet with the same person- outside and inside the reppiration chamber. In the tirst case the principal difference is that of diet, the alcohol being the chief factor: in the second case the differences are those of the phrsical and mental condition of the indiridual. The discussion of the effect of alcohol upon availability of the nutrients of the diet is given on pages 256 to 25.5. heyond.

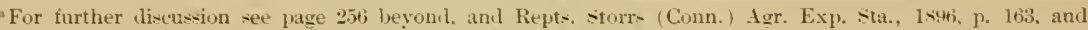
$1897, \mathrm{p}, 154$.

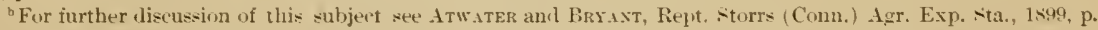
96. See al:o discussion by W. O. ATw.tTer in Bul. 49 of the [-. S. Dept. Ayr., (Iffice of Experiment stations, Proceedings of the Association of American Agricultural Colleges and Experiment station-, 1900, p. 112. 


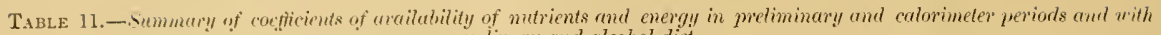
ordinury and alcohol diet.

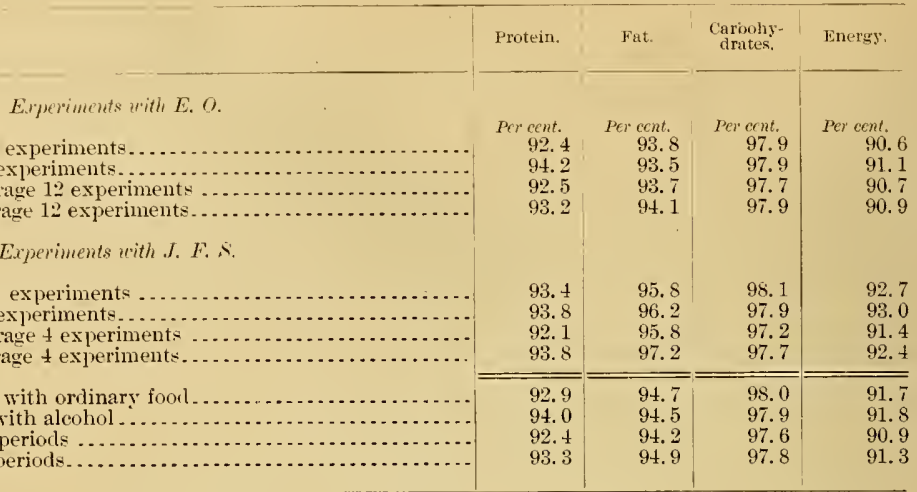

\section{DISCUSSION OF THE RESULTS OF THE EXPERIMENTS.}

The special purpose of the experiments summarized on the preceding pages, in so far as they have had to do with the nutritive action of alcohol, has been the study of the metabolism of the energy of alcohol and its consequent value for fuel as compared with isodynamic amounts of carbohydrates and fats. Incidentally, its effects upon digestion, the completeness of its oxidation, and its action in protecting body fat and protein from oxidation have also been observed. The more important results may be disenssed under the following topics:

1. Etfect of alcohol upon the digestion of food.

2. Proportions of alcohol oxidized and unoxidized.

3. Metabolism of the energy of alcohol.

4. Protection of body material by alcohol.

a, Protection of body fat.

b. Protection of body protein.

5. Effect of aleohol upon the radiation of heat from the body.

i. Alcohol as a source of heat in the body.

7. Alcohol as a source of museular energy.

\section{EFFECT OF ALCOHOL UPON THE DIGESTION OF FOOD.-DIGESTIBILITY VERSUS AVAIL- ABILITY OF NUTRIENTS.}

The term digestibility as applied to food has several meanings, which are not elearly distinguished in popular usage. It commonly refers to either the ease with which a given food material is cligested, or the time reruired for the process, or the extent to which the material "agrees" or " disagrees" with different persons, or its effects upon bodily comfort and health. Thene farctor's depend largely upon individual peculiarities, vary widely with different persons and with the chararter of the food, and are difticult to measure.

The term digestibility is also used to designate the quantity or proportion of the food or of each of it rlifferent ingredients-protein, fats, cubohydrates, and mineral matters-actually digested and absorbed in the passage of the food through the digestive tract. Only this latter factor of digretiluility is romsidered in these experiments. To determine what amount of eneh nutrient is antually digested it is necesiary to know the ruantity that is taken into the hody in food and the fuantity that has escaped digestion and is excreted in the feces. The latter cuantity is not easily determined, howerer, because the feces eontain, besides those portions of the food that have 


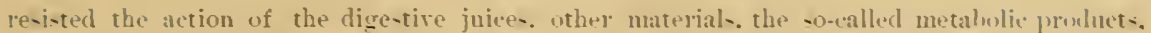
which are mainlr the re-idne- of the dige-tive juire- and which ale not eatsily -eparated from the undige-ted portion of the food. For thi-reat-on it i- diftienlt tu determine the actual dige-tibility of food or of it - reveral ingredient-.

The arailability of the food or of the -everal incredient- howerer. may he more accurately determined. By arailability i here meant the yuantity or proportion that can lue u-ed for the huilding and repair of ti-ne and the rielding of energy. The metabolic proluct-o although derired origrinally from the dige-ted food. are not uned for either huilding material or fuel, and hence are not arailable in the -ense in which the word $i$ - here employed. Ther may. therefore. he included with the nndige-ted re-idne of the food and the -mall quantitie- of inte-tinal epithelium and other materials which make up the re-t of the fece-s and the amounts of arailable nutrients mas he found hy -uhtracting from the total incredient- of the food the total corre-ponding ingredient-in the feces. These have often heen alled the dige-tible rather than the arailable nutrient.. but the distinction here made is yuite important.

The avilathility of the ingredients a-thu-determined iv n-ualls expre-sed by the percentage of the total amount of each in the food. Thi- percentagre is called the coefficient of avalability. In the following tahle. which is a mmary of a more detailed table given in the Appendix, the coethicients of arailability of the protein. fats. and carhohrdrates of the ordinary diet are compared with those of the alcohol diet. as atually found in the experiments. The arerage coefticient of arailability of the nutrient of ford a found in $4:$ pxperiments ${ }^{*}$ with healthy men with ordinary diet under varion condition, of work and rest are appended in the table for comparicon.

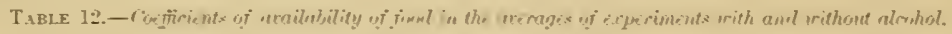

\begin{tabular}{|c|c|c|c|c|}
\hline \multirow{2}{*}{ Kind and number of experiments. } & \multicolumn{4}{|c|}{ Coetielents of a railability. } \\
\hline & Protein. & Fat. & $\begin{array}{l}\text { Carbooby- } \\
\text { drates: }\end{array}$ & Energs. \\
\hline 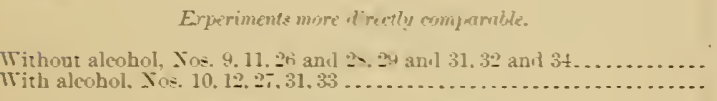 & $\begin{array}{l}\text { Fer } 20.7 .6 \\
43.7\end{array}$ & $\begin{array}{l}\text { Pre cent. } \\
94.9 \\
44.6\end{array}$ & $\begin{array}{l}\text { Per at. } \\
97.9 \\
97 . ?\end{array}$ & $\begin{array}{r}\text { Per cent. } \\
41.8 \\
4=1\end{array}$ \\
\hline Eaperiments lesolir.tly compuralde. & & & & \\
\hline 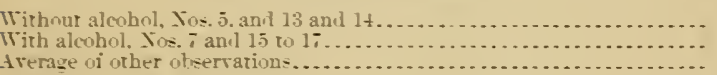 & $\begin{array}{l}92.6 \\
45.0 \\
43.0\end{array}$ & $\begin{array}{l}94.1 \\
4.4 \\
9.5 .0\end{array}$ & $\begin{array}{l}95.1 \\
97.3 \\
98.0\end{array}$ & $\begin{array}{r}40.3 \\
41.3 \\
=42.3\end{array}$ \\
\hline
\end{tabular}

* Arailability of enerys havel upon average proportions and amounts of nutrient- iound in dietaries of 3 s

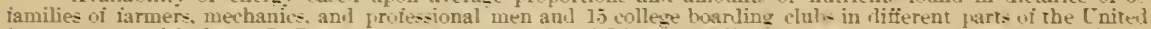

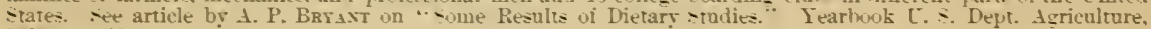
$1>4$. p. 439.

It thus appear - that the alcohol had little appreciable effect upon the arailability of the other ingredient of the diet: the coefficient of arailability of the vutrient: of the ordinary food were practicalls the same with and withont alcohol an part of the diet. The protein appears to have been slightly more arailable when the diet contained alcohol. The differencer. e-pecialls in the more coumparable experiment, are le- than might be found with different subjects ning the same ordinary fool, or with the -ame subject nsing the same food at different times and under different condition:.

The conclnsion from the results of these experiment- wonlu be to the effect that alcohol in moderate amount- tended to increase verr slightly the arailability of the nutrients of the diet, especially of the protein. In riew, howerer. of the fact that there are often marked differences in the arailabilits of the same diet with different person- and with the same person at different

see ATwدter and Bryst, Availability ant Fuel Value of Food Materials, Rept. stors (Conn.) Expt. Sta, 1399, p. 73. 
time-. eren this conclusion shonld he held with a degree of reserve. While it is statistically ralid for these experiments. the extent to which it would be true in general experience is by no means certain.

\section{PROPORTIONS OF ALCOHOL OXIDIZED AND UNOXIDIZED.}

The difference betreen the amonnt of alcohol taken into the body in food and the amount given off unoxidized by the kidney*, lung*, and skin is taken as the amount oxidized in the body. For the determination of the amounts not oxidized in the body quantitative examination was made of the sereral excretory products for the presence of alcohol. No similar examination of the fecer for alcohol was practicable: but. as it has heen found in other experiments ${ }^{a}$ that no alcohol was excreted throngh this chamel. even when considerable quantities were ingested, it was here assmed that the feces would contain no appreciable amount of the alcohol taken with the food.

The alcohol eliminated by the kidneys would. of course, be found in the urine; that giren off br the lungs and skin in the " drip" water collected from the surface of the system of cooling tubes. or it might pass out of the chamber as vapor in the air current and be condensed in the "freezers." in which a large part of the water is collected from the outgoing air, or it might eren pas throngh the freezers as rapor and be nltimately absorbed in concentrated sulphuric acid in an apparatus arranged for the purpose.

The determinations of the amounts of alcohol given off from the body unoxidized in experiment No. $\tau$ were made according to the method described by Bodü̈nder. ${ }^{b}$ This method, howerer. does not gire results sufficiently accurate when the amounts of alcohol are as small as were found in these experiments. In the latter experiments a modification ${ }^{\mathrm{c}}$ of this method was used, which has been shown to give very satisfactory results in the determination of extremely small quantities of alcohol.

The urine drip water, and freezer water were distilled sereral times in order to separate the alcohol and other volatile and readily oxidizable organic matters and to obtain them in a more concentrated form. The amount of organic matter (here designated as reducing material) in the distillates was then determined by the method mentioned above. The amount of reducing material in the air current was estimated by passing the ontgoing air through bulbs containing concentrated sulphuric acid. and determining the amount of redncing material in the acid. The total amount of reducing material thus cletermined in the rarions excretory products was calculated as alcohol.

Other inrestigators ${ }^{\mathrm{d}}$ hare fonnd eridence that such redncing materials are excreted by the hody when no alcohol was ingested. In several experiments in which alcohol did not form part of the diet. examinations of respiratory and excretory products were made the same as when alcohol was given. and reducing materials were found to be present. ${ }^{\circ}$ The arerage amount found in these experiments withont alcohol was, therefore, dedncted from the total amount determined in the experiments with alcohol and the difference taken as alcohol excreted, as show b below:

$$
\text { 17rohol ingested and exreterl mosidized. }
$$

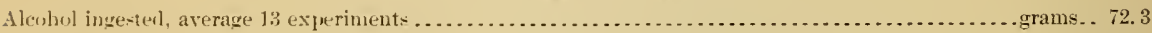
Reduring material in excretory product:

Then alrolw] was ingesterl, average 18 experiments . . . . . . . . . . . . . . 6

When no alwolol was ingesterl, average 6 experiments . . . . . . . . . .

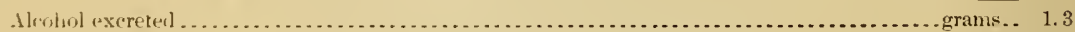

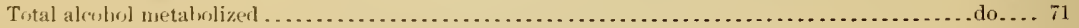

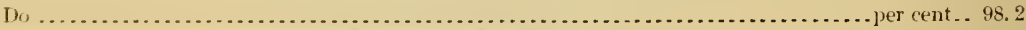

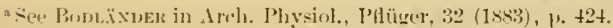

"Len: rit.

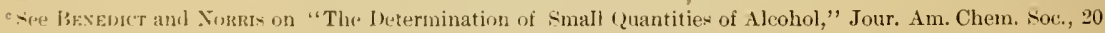
(1896). 1. 2:34.

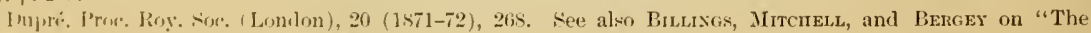
mompoition of expireil air and it. efiect upon animal life." Smithsonian Contributions to Knowledge, CXIX 
From Table CXXI in the Appendix it will ine oherved that the quatities of alcohol eliminated by the lungs, skin, and kidneys raried fiom o.7 to 2.7 grams, and areraged 1.3 grams per day. These puntities correspond to at range of from 1 per cent to 3.7 per cent and an arerage of 1.: per cent of the total amount of alcohol ingested. We consider, therefore, that in general when alcohol is taken in small doses not more than 2 per cent is given off unoxidized. and the result of the later experiments indirate that this figure is really too large. Accordingly. the coefticient of arailability of alcohol is taken as !s per cent.

Comparing this with the coefticients of ar:tilability of protein, fat, and carbohydrates in the diet with aleohol, as given in the Table 12,1 . 257. it appears that the coeffieient of availability of atcohol in these experiments was practically the same as that of the carbohydrates and larger than those of fats and protein of ordinary food. That is to say, it was found that 2 per cent or less of the total alcohol ingested in these experiments was given off unoxidized by the lungs and skin. while on the arerage about 2 per cent of the carbohydrates, 5 per cent of the fats and $z$ per cent of the protein of the ordinary diet appeared to be exereted moxidized.

The conclusion is that in these experiment the alcohol was more completely consumed than are the nutrients of ordinary mixed diet.

\section{METABOLISM OF THE ENERGY OF ALCOHOL.}

It was stated above that the experiments with men in the respiration calorimeter had shomn a very clowe agreement between the income and outgo of energy in the body, and that this was regarded an practically a demonstration that the law of the conservation of energy holds in the living organism. E T to April. 19o0, the results of 30 such experiments had heen oltained. These corered, all told, 93 days: they were made with 4 different subjects, under varions conditions of diet and oceupation. When the figures for individual days or for individual experiments are considered, there appears to he more or less disagreement between the figures for ineome and those of outgo energy, thongh the differences are inside the natural range of error in such phy wological experiment. When the results of all the experinents are areraged together, however. the differences counterbalance each other, and the daily income, 2,718 calories, is found to be practically identical with the daily outgo. 2.716 ealories. This agreement is in accordance with the law of the conservation of energy, and thus confirms the belief that this law governs the metalolism of energy in the liring organism.

In 13 of the 30 experiments referred to alcohol formed a part of the diet. The results of these experinent- compared with those without alcohol imply very clearly that the law of the conserration of energy hold as well with the diet containing alcohol as with the ordinary diet. This mar be seen from Table 13, which epitomizes the more detailed statistics given in Table CXX in the Appendix, and complares the arerages of the results of the rest and the work experiments in which alcohol formed part of the diet with those of similar experiments without alcohol. Both those experiment - that are strietly comparable and those less comparable, as explained on a precedmy page. are here included.

T.ABLE 13. - Witubulism of energy. Lierages of resulfs of experiments with orlinary and with alcohol, lint.

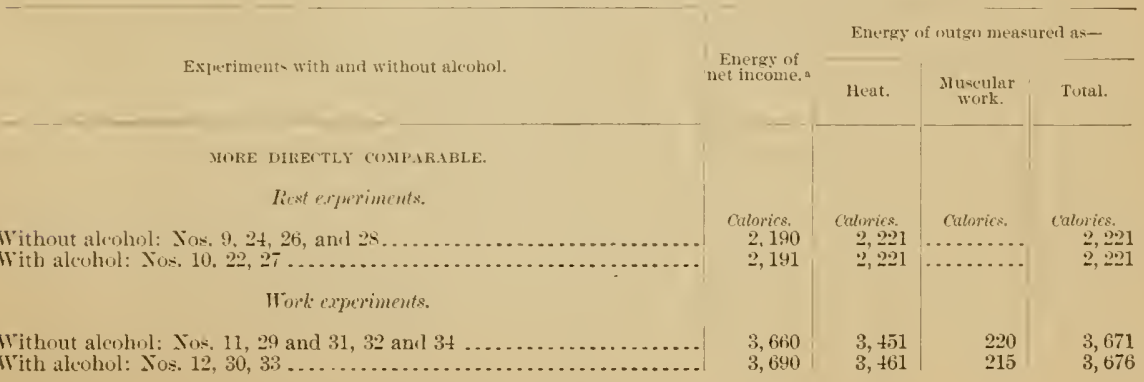


TABLE 13.-Metrlotism of energy. Arrages of results of experiments with ordinary and with alcohol diet-Continued.

Experiments with and without alcohol.

JURE DIRECTLY COMPARABLE-continued.

Lierage of rest and work experiments.

Without alcohol

TVith aleohol

LESS DIRECTLY COMPARABLE.

Rest experiments.

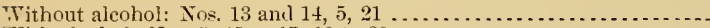

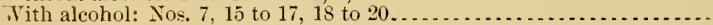

Aterage of all above experiments.

Without alcohol

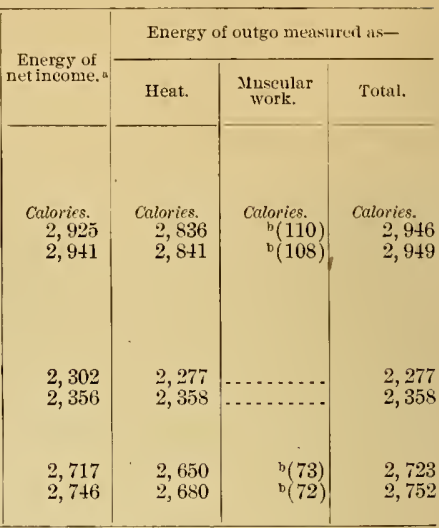

astimaterl energy of material actually oxidized in the body.

b In this average the muscular work of the work experiments is clistributed over both the work and the rest experiments, which is of course not strictly logical.

The energy of net income given in the table above represents the energy of the material actually oxidized in the body, as determined from the energy of the food, of the excretory products, and of the body material stored or lost. 'The energy of outgo is that given off' from the body in the form of heat and external muscular work, as measured by the apparatus. According to the law of the conservation of energy, the income and the ontgo must be equal. From the comparisons given in the table above it will be seen that, whether the diet did or did not contain alcohol, the outgo was sometimes greater and sometimes less than the income, but the difference in every case was far within the range of variation to be expected in physiological experiments of such nature as these, so that the results may be considered as showing practical agreement. If we counterbalance the variations by averaging the experiments in which alcohol formed part of the diet and those without alcohol, we get the following results:

Daily income and outgo of energy with and without alcohol.

Averase 13 experiments, withont alcoho

Diet.

\begin{tabular}{|c|c}
\hline $\begin{array}{c}\text { Euergy of ma- } \\
\text { terial oxidized } \\
\text { in the body. }\end{array}$ & $\begin{array}{c}\text { Energy given } \\
\text { off by the } \\
\text { body. }\end{array}$ \\
\hline Calorits. & Calories. \\
2,717 & 2,723 \\
2,746 & 2,752 \\
\end{tabular}

When the diet contained no alcohol, the energy of the proteids, fats, and earbohydrates burned in the body, averaging 2,717 calories per' day, was practically identical with the energy given off by the body in the form of heat, or heat and (the heat equivalent of) external muscular work, averaging 2,723 calories per day. When alcohol formed part of the diet the total energy of the proteids, fats, and carbohydrates burned in the body, added to the energy of the alcohol, averaged 2. Itf calories per day, and the energy given off as heat, or heat and external musenlar work. areraged 2.752 calories per day. The total kinetic energy of outgo is equal to the total potential energy of income, whether it be with ordinary diet alone, or with ordinary food and alcohol.

To thene result s there can be int one interpretation. The energy which was latent or potential in the alcohol wits wholly transformed in the body, was actually given off from the body, and was exactly recorered as heat or heat and muscular work. Otherwise, how did the body 
dispose of the energy of the alcohol, and from what other sonere did it get an exarty cuntal amount to replace it?

The comchusions, therefore, are:

1. The law of the concervation of energy obtained with the aleohol flict as with the orelinary diret.

2. The potential energy of the alcohol oxidized in the body was trastormed completely into kinetie energy, and appeared either as heat, or as muscular work, or both. To this extent, at any rate, it was used like the energy of the protein. fats, and carbohydrates of the foorl.

\section{THE PROTECTION OF BODY MATERIAL BY ALCOHOL.}

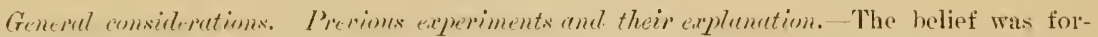
merly quite general that aleohol has a specific pharmacodynamie action in retarding the metalolism of body material, both fat and proteid. As much of the earlier experimenting implied that akohol in moderate quantities tends to "prevent wante" or " conserve the tissues," and its oxidation in the body was not understood, this effect was maturally attributed to its action as a drug. Later,. as the functions of the nonnitrogenous nutrients of food came to be better mnderstood, and the filct that alcohol is oxidized as they are in the body became fully established, the view has become common that its effect in retarding or protecting motabolism is to be explained hy al mutritive lather than a pharmacodynamie action-that, in other works, it tends, by its own oxidation, to prevent the oxilation of other materials. This latter function of alcohol, however, hasbren clenied on two wrounds:

1. The increased cireulation of the blood throngh the peripheral capillaries and the fall of body temperatme which follow the ingestion of alcohol have led to the theoretical inference that the energy supplied to the budy by the oxidation of the alcohol is lost by the extra radiation of heat it calises, so that it can not do the work of the fats and carbohydrates in protecting forel or hody material from ronsumption. This ground, howerer, is bard! tenable since, as shown beyond, the fall of body temperature with ordinary doses is rery small, and the amount of extra heat ladiated is only a fraction of that supplied by the alcohol.

2. The other ground for doubting the power of alcohol to protect body material from consumption is that of direet experiment. That it may protect fat is grenerally conceded, but there are a number of reliahle experiments on record in which the replacement of the earbohydrates and fats of a ration by alcohol has heen followed by an inereased elimination of nitrogen. This has been explained by the assumption that alcohol tends to inerease rather than diminish the "ataholism of protein in the body. On the other hand there is a considerable amount of experimental evidence to the effect that alcohol may and at times does selore as a protector of protein.

As explained in a review of the exprimenting upon this subject ${ }^{a}$ it seems to ths that the conflicting l'esults may be explained hy the hypothesis of two opposing tendencies of aleohol, the one phamatodymic and the other nutritive. This view makes the former a sperifie, and sometimes, if not always, temporary artion of alcohol, by which it inereases the eatabolism of protein, while the latter aetion is that resulting from its widation. Acording as the latter or the former action predominates the aleohol miy protect protein or fail to do so. In faror of this theory is the faret that it explains and larmonizes the results of previous experimenting and those of our. own experiment: also.

In considering the efleiency of alcohol for the protection of borly fat and protein it is important to distinguish between two questions. Does aleohol protect these materials at all? Is it equal in protecting power to the isodynamic amount of fats or of carbohydrates, or of a mixture of the two! The comparisons in these experiments are between nearly isodymamie amounts of aleohol and the other ingredients.

"Report of Physiological Subcommittee of Committee of Fifty for the Investigation of the Liquor Problem, Boston, Houghton, Iiftlin \& Co. (In press at the time of this writing.) See also a more letailed review of the subject by Rozemann. Der Einfluss des Alkohols auf den Eiweissstoffwechsel; Arch. f. d. ges. Physiol., Bil. S6, 1901,1 1 $307-503$.

Vol. -No. 6 
The evidence of the experiments here reported. - Although the present experiments were not planned for the study of these particular questions. they throw some light upon them. The details. in their bearing upon the protection or nonprotection of body protein and fat. are brought together in Table CXX in the appendix, and the arelage results are summarized in Table 14 herewith. which shows the anonnts of arailable protein and energy of the diet and the amount: of protein and fat gained or lost hy the body in the experiments with and withont alcohol.

TaBLE 14.-Comparison of gains and losses of protein and fat in experiments with and without alcohol.

Experiments comparud. $\mid \begin{gathered}\text { Serial numbers of } \\ \text { experiments. }\end{gathered}$

MORK DIRECTLY COMPARABLE.

$A$ and $\mathrm{B}$ :

E. O., rest-

Average, 2 experiments without alco- $9,24 \ldots \ldots \ldots \ldots \ldots . . . .$. hol.

D:

Arerage, 2 experiments with alcohol .. 10,22 ..............

E. O., work-

1 experiment without alcohol ........ $11 \ldots \ldots \ldots \ldots \ldots . . . .$. $A, B$, and $\mathrm{D}$ :

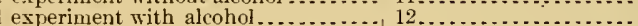

\begin{tabular}{|c|c|c|c|c|}
\hline \multirow{3}{*}{$\begin{array}{l}\text { Total } \\
\text { num- } \\
\text { ber of } \\
\text { days. }\end{array}$} & \multicolumn{4}{|c|}{ Average per day. } \\
\hline & \multicolumn{2}{|c|}{ Available food. } & \multicolumn{2}{|c|}{ Gain $(+)$ or loss $1-1$. } \\
\hline & Protein. & Energy. & Protein. & Fat. \\
\hline 7 & $\begin{array}{l}\text { Grams. } \\
114\end{array}$ & $\begin{array}{c}\text { Calorics. } \\
2,618\end{array}$ & $\begin{array}{l}\text { Grams. } \\
-1.0\end{array}$ & $\begin{array}{l}\text { Grams. } \\
\quad+39.0\end{array}$ \\
\hline 7 & 116 & 2,602 & -2.8 & +42.0 \\
\hline $\begin{array}{l}4 \\
4\end{array}$ & $\begin{array}{l}110 \\
113\end{array}$ & $\begin{array}{l}3,510 \\
3,614\end{array}$ & $\begin{array}{r}-3.0 \\
-1.0\end{array}$ & $\begin{array}{l}-39.7 \\
-32.2\end{array}$ \\
\hline 11 & 112 & 2,915 & -1.6 & +12.7 \\
\hline 11 & 115 & 2,939 & -2.2 & +17.2 \\
\hline 6 & 92 & 2,253 & -4.0 & +23.1 \\
\hline 3 & 92 & 2,264 & -6.0 & +18.2 \\
\hline 12 & 95 & 3,251 & -6.1 & $-2 \pi .5$ \\
\hline 6 & 94 & 3,235 & -14.5 & $-2 \pi .7$ \\
\hline 18 & 94 & 2,918 & -5.4 & -10.6 \\
\hline 9 & 93 & 2,911 & -11.6 & -12.4 \\
\hline 29 & 103 & 2,917 & -3.5 & -1.1 \\
\hline 20 & $10 t$ & 2,925 & -6.9 & $\rightarrow 2.4$ \\
\hline 14 & 100 & 2,239 & -7.3 & -2.3 \\
\hline 16 & 98 & 2,400 & -3.0 & -6.5 \\
\hline
\end{tabular}

AVERAGE OF ALL TIE ABOTE EXPERINEXTS.

A to I ( Froup III):

E. U., J. F. .., and A. W. S., rest and work-

Average, 13 experiments ( 3 with work) without alcohos.

Average, 13experiments (3 with work) with alenhol.

$(13,14),(26,28),(29,31)$, $(32,34), 5,9,11,21,24$. $7,(15,16,17),(18,19,20)$,
$(13,14), 5,21 \ldots \ldots \ldots$.

$7,(15,16,17),(18,19,20)$.

, 24, 11, (26, 25), $(29,31)$ $(32,34)$.

$10,22,12,27,30,33 \ldots \ldots$ 2

$(29,31),(32,34) \ldots \ldots$.

$(26,28),(29,31),(32,34)$.

$2 \pi, 30,33 \ldots \ldots \ldots \ldots$ A to F (croup I):

.

G, H, and I (Froup II):

Average, $4^{\mathrm{a}}$ experiments without alco-

"When tw, or more sinilar experiments are grouperl together, the group is counted as 1 experiment in rivaing the averagr. Fxperiments thus treated are put in parenthess in the kecont column; thus. (15 to 17 ).

Thr grouping in Table $1+$ is on the same basis as in the corresponding table- in the preceding pager and in the Appendix. 
When the fuet ralue of the diet is in excess of the needs of the body, the latter often, though not always, increases its store of material. Sometimes this increase is in the form of protein, sometimes fat, and sometimes both protein and fat. When the body requires energy in excess of that supplied hy the food. it will draw upon its previously accumulated store of fat or protein, or both, for fuel. Along with the gains and losses of protein and fat are changes in the carbohydrater (glyeogen), but the total quantity of these substances in the tiswes is relatively small. The present methods of experimenting do not suffice for accurate measurement of the changes of glycogen. and it is commonly left out of account in discussions such as that in which we are now engaged.

\section{PROTECTION OF BODY FAT.}

The figures for the individual experiments in Table CXX of the Appendix show in some cases a larger gain or smaller loss of fat without alcohol than with it; in other cases the results are reversed. When, however. the experiments are grouped together and the averages with and without alcohol are compared, it is clear that, except where the differences in fuel value of the dict were considerable. the differences of fat balunce are hardly large enough to be of consequence. Taking the experiments altogether, the figures of the tables, and especially those of Table 1t, show slight gains in fat both with and without alcohol, but the gain is slightly larger with the alcohol. Thus in Group I, in which the experiments are more directly comparable, the average gain in 9 experiments without alcohol is 1.1 grams, in 6 with alcohol 2.4 grams, making a difference in faror of the alcohol of 1.3 grams. In the less directly comparable experiments there is an average difference of 8.5 gram.., and in Gromp III with all the experiments there is an average of 3.9 grams in favor of the alcohol. It is also to be noted that in general the total energy of the rations with the alcohol average somewhat larger than in those without alcohol. The figures for differences just cited are brought out more clearly in Table 17, beyond, in the discussion of the utilization of energy in the experiments with and withont alcohol. The comparison as there made in detail shows on the whole an advantage of the ordinary diet over that with alcohol, though the difference is very small, indeed.

A direct indication of the fat-protecting porrer of alcohol is found in the series of experiments with E. O., Nos. 22, 23, 24. These were practically three successive periods of 3 dars each. In all there was a basal ration with 116 grams available protein and 2.240 calories of available energy. To this ration wa* added-in the first experiment, alcohol: in the second. nothing; in the third, sugar. The alcohol and sugar each furnished about 500 calories of energy. With the alcohol there was at daily gain of 133 grams of fat; with the basal ration this was reduced to 9 grams: with the sugar it rose again to 60 grams per day. With the sugar there was a gain of 1.7 and with the alcohol a gain of 1.4 grams, while with the basal ration alone there was a loss of 1.6 grams of protein. Learing this slight gain or loss of protein out of account the net gain of fat with the alcohol above that in the basal ration was 54 grams, which would make very nearly 50 calories. The net gain of fat with sugar was 51 grams. In this particular case, therefore. with isodynamic quantities of sugar and alcohol, the gain of fat was practically the same with hoth.

An even more striking illustration of the fat-protecting power of alcohol is tonnd in experiments Nos. 1S-21. with A. W. S. as summarized on page $32 y$ beyond. When alcohol was added to a basal ration of ordinary fool. the body gained fat at the rate of 21-35 grans per day; but when the giving of alcohol was stopped and the body had only the basal ration, it lost 25 grams of fat per day.

A clearer demonstration of the power of alcolsol to protect fat from consumption would he hardly possible than that given in the experiments with E. O. and $A$. W. S., just cited.

We thus have two kinds of tests of the power of alcohol as compared with that of isodynamic amounts of earbohydrates and fats of the food for the protection of body fat. In every individual case the protecting power of the alcohol is manifest. In some instances it is slightly inferior and in others it is slightly superior in this respect, and on the average it is just about equal to the nutrients which it replaced. 
-o fir as we are aware the-e are the only experiments in which the power of alcohol to protect fats has heen determined hy dirmet yuatitative tests. While there are numerous experianent on record which have seemed to inclicate that aleohol bas this power, we have found none

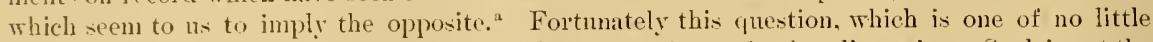
importance, thus seems to be so clearly settled as to require no further discussion. Such is not the case with the similar cuestion regarding the power of atcohol to protect protein from consumption.

\section{PROTECTION OF BODY PROTEIN.}

A- regards the protection of body protein by alcohol, the results of the experiments are rariable. hut on the whole the catabolism of protein, as measmred by the amount of nitrogen excreted by the kidneys. was slightly larger in the experiments with than in those without alcohol. In discusing the effeet of aleohol upon protein metabolism, we must consider the variations from day to day in the amount of nitrogen excreted in the urine when alcohol forms a part of the diet. and compare them with the variations in similar experiments in which alcohol is not included in the diet. The data of the daily eliminations of nitrogen by the clifferent subjects in experiment with and withont alcohol are summarized in Table CXXIII in the Appendix.

What especially concerns us here is the influence of the substitution of alcohol for a portion of the ordinary food upon the gain or loss of body protein. As this seems to depend largely apon the indiridual. it will be well to discuss the experiments with the three subjects separately.

Erperiments with E. O.-With this subject there was a marked tendency to exerete more nitrogen in the urine on either the day before or the day after he entered the respiration chamber. This tendency was as noticeable in the experiments without as in those with alcohol. This variation in nitrogen excretion is independent of either the character of the food or the actirity of the subject, and appeal's to be due to a psychic canse that is little understood. Since this rariation was often much larger than any which could be attributed to the alcohol, we hesitate to assign to the litter any definite and uniform effect mpon the metabolism of nitrogen.

It $i$ so be noted that there is no experiment with E. O. in which an alcohol diet immediately preceder or followed a diet furnishing the same amount of energy from orclinary food materials without alcohol. There are. however, a number of separate experiments which may be compared, as is done in Table 15.

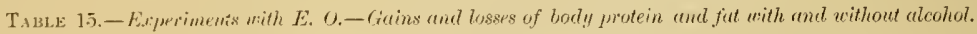

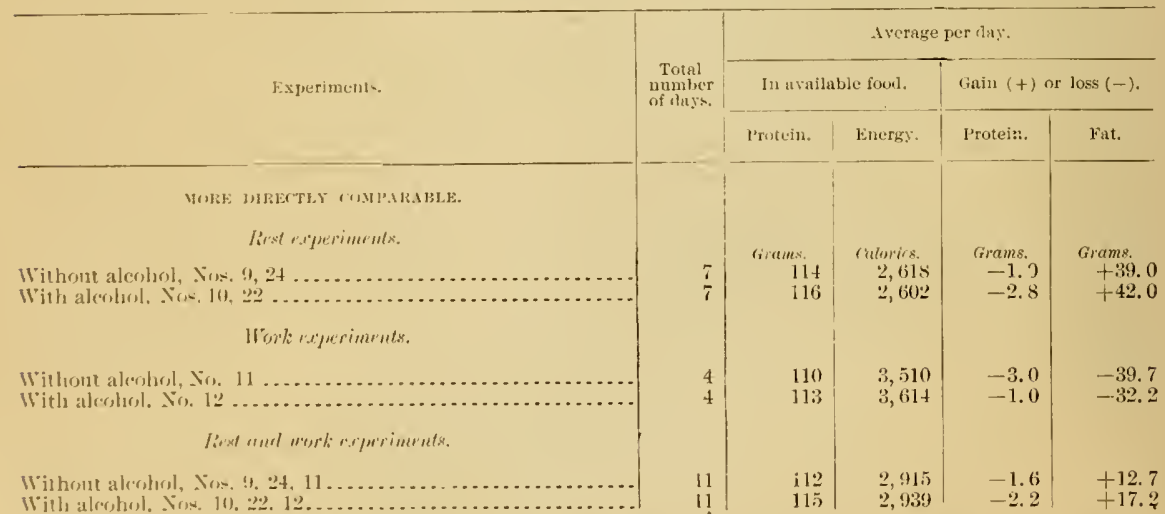

"Non resiew of exprinunt= on the effects of aleshol on the metabolism of carbon in the report of the Committee 


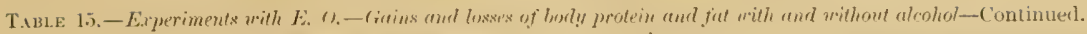

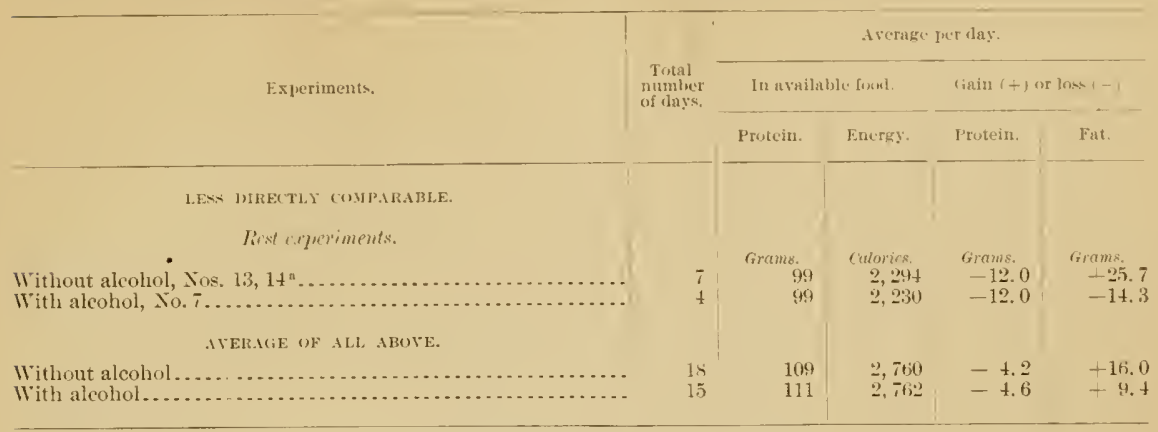

^Yos. 13 and 14 averaged as one experiment.

In the less directly comparable experiments Nos. 13 and 14 are grouped together ar one. since the arerage quantities of protein and energy are the same as in No. 7 . The details. however, show that while the puantities of energy in the rations were the same in botb. No. 13 had 110 and No. 14 only s9 grams of protein. Nerertheless the results as regards gain or losis of body material were amost identieal. In each there war a loss of 12 grams of protein and in No. 13 there was a gain of 27 grams and in No. 14 a gain of 24 grams of fat. The experiments were t11 days apart. We lay especial stress upon this cireumstance, becanse it illustraten the futility of drawing final conelusions from a singlo experiment. In ench of these cases the metabolism experiment was preceded by a period of 4 days with similar diet while the subject was ontside the ealorimeter, but in neither case was nitrogen equilibrium ohtained. Neither one of these experiments, therefore, could be taken as a ba-is for conclusion as to the quantity of protein required for either nitrogen equilibrium or constant elimination of nitrogen. A special reason for citing them here with No. 6 is that they were made with the same subject as the other experiments of the table.

The chief reliance is to be placed upon the more directly comparable experiments. In those in which the subjeet was at rest, the alcohol ration furnished 2 grams more protein and 16 less calories of energy per day than the nonalcohol ration. There was a larger loss of protein by 1.8 grams and a larger gain of fat by 3 grams with the alcohol. These ditferenees are all very small, but in so far as they go they imply that the alcohol was somewhat less effierent as a protector of protein than the fats and abohydrates which it replaced. In the work experiments the aleohol ration supplied 3 grams more of protein and 10.t calorifs more of energy than the other. With hoth there was a loss of protein, the amount being 3 grams per day without and 1 gram per day with aleohol; but since the aleohol ration furnished 3 grams of protein more than the other, there remains a deficit of 1 gram of protein per day against the aleohol ration as compared with that without alcohol, and that notwithstanding the larger fuel value of the diet. Here again the alcohol ration is slightly inferior in protein protecting power.

Taking the rest and work experiments together. the aleohol rations. with an arerage of 3 gram of protein and 24 calories of energy per day more than the nonaleohol lation, show a greater loss of protein by 0.6 gram per day. On the other hand there is a slightly larger arerage gain of fat with the alcohol.

If we reckon the less comparable experiments in the genelal average. we have 111 grams of protein with aleohol as against 104 grams without it. while the puantities of energy are the same in both rations. The arerage loss of protein is $1 . .4$ gram greater and the gain of fat 5.6 grams less with the alcohol: but of course much less stress is to be laid upon the less comparable experiments.

On the whole it is elear that in these experiments with this subject the aleohol was not as efficient as isodynamic quantities of fats and eabohydrates in protecting protein. Notwithstanding 
the energy of the alcohol was actually larger than that of the fats and carbohydrates which it replaced. it did not equal them in protecting power. The difference is the more striking because of the slightly larger arerage quantities of protein in the alcohol rations. On the other hand, the differences between the amounts of protein and energy in the alcohol as compared with the nonalcohol experiments are so slight as to imply only a slight inferiority of the alcohol in the protection of protein.

While the alcolol was not isodynamically equal to the carbohydrates and fats in protecting power, it would be going very far to deny that the experiments imply a positive protecting action. Not only were the differences in favor of the protecting power of the carbohydrates and fats as compared with the alcohol very suall, but the quantity of energy supplied by the alcohol was large. To claim that the alcohol has no protecting power would be to assume that the same reduction of fits and carbohydrates in the rations without any replacement by alcohol would have resulted in no greater differences in protein protection. This is in the highest degree improbable.

In this connection the results of experiments Nos. 22, 23. 24 above referred to are worthy of consideration. With the normal ration, plus alcohol, there was a gain of 1.4 grams of protein and 63 graus of fat per day; but when, in the period immediately following, the alcohol was removed, there was a loss of 1.6 grams of protein and a gain of only 9 grams of fat.

Experiments with A. W. S.-With this subject we have but one series of rest experiments. This consisted of a preliminary period of $t$ days, followed by four experimental periods, during which the subject was in the respiration chamber. Throughont the preliminary and experimental periods there was a uniform basal ration of ordinary food, supplying abont 90 grams of protein and 2.040 calories of energy. To this was added, in the preliminary period of $t$ days, commercial alcohol, furnishing about 500 calories of energy. The nitrogen in the urine during the successive dars was 12.2, 16, 19, 16.t grams; that is to say, there was a marked increase of protein catabolism during the whole period. The first three experiments proper were of 2 days each. In the first of these periods commercial alcohol, in the second whisky, and in the third brandy was added to the hasal rations, the quantities being sufficient to furnish the same amount, about 500 calories, of energs. The daily quantities of nitrogen in the urine were 17.t, 15.t, $14.7,14.2,13.8$, and 14.4 grams; that is to say, the rise in nitrogen excretion continued through the first day of the first period; thereafter it fell. During the fourth period of 3 days the basal ration was given without the alcohol. The nitrogen excretion was $14.5,16.2,15 . \pm$ grams, thus showing an increase again. The natural inference is that with this snbject, who had always been an abstainer, the rise in nitrogen excretion at first was due to the alcohol. The very erident fall after the fifth day implies that the action of alcohol in increasing the nitrogen was transitory, and that it had passed away at the end of the third period. The increase of nitrogen exeretion in the fourth period was apparently due to the reduction of the ration by the removal of the alcohol.

The arerage gains and losses of protein and fat for the separate periods may be tabulated as follows:

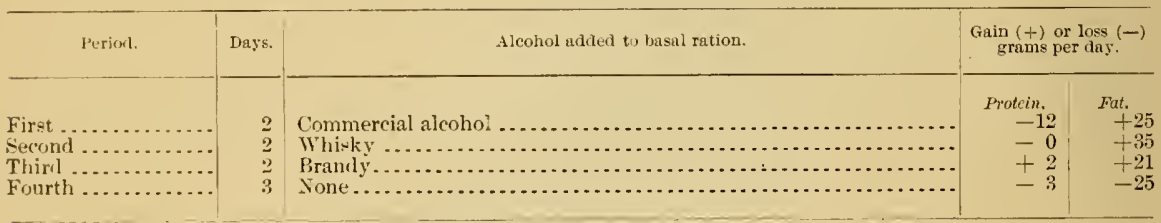

We thus have a gradual change from a loss of nitrogen to equilibrium and positive gain with the alcohol, and on its removal a positive loss. Writh the fat there is a constant gain with the alcohol and marked loss on its removal.

While it would he unwise to generalize from a single series of experiments, the indications here point clearly toward three conclusions: (1) The alcohol at first caused an increase of 
nitrogen metabolism and loss of body proteiu, but this effect was temporary: (2) thereatter the alcohol protected hody protein; (3) the alcohol protected fat throughont.

Eirjuriments with .I. F. S.- With the third subject there was opportunity to olserve the immediate eflect produced upon nitrogen metubolism by the substitution of alcobol for a part of the ordinary nutrients of the liet. Three series of experiments were made. Furb included three periods of 3 days each. In each series the subject recrived the same hainal ration throughout. but in addition thereto enough of either butter, sugn, or alcohol to furnish about 500 ("alories. In the first series the subject was at rest, and the order of addition was hutter, aleohol, sugatr. In the second series the subject was at work and received a larger diet, the order being sugar, alcohol. butter. The third series wis similar in all respects to the seeond exeept that the order was hutter, alcohol, sugar.

These experiments were thus better adapted than any of those previously discusiced to show the inmediate effeet of the substitntion of alcohol for other nutrients in the diet, and in each ease it will he seen that this substitution resulted in a loss (or an inereased loss) of hody protein, which loss eontinued through the 3 days of the alcohol period. The subject was unused to alcoholic beverages, and from what has already been said such a loss of protein during the first few days of the aleohol diet was to be expected from the results of other similar experiments. Whether this loss would have ceased on continuing the alcohol diet, as seems to have been the case with A. IV. S., the experiments do not show.

Experiments with J. F. s.-Giains and lusses of borly protein and fat with and without alcohol.

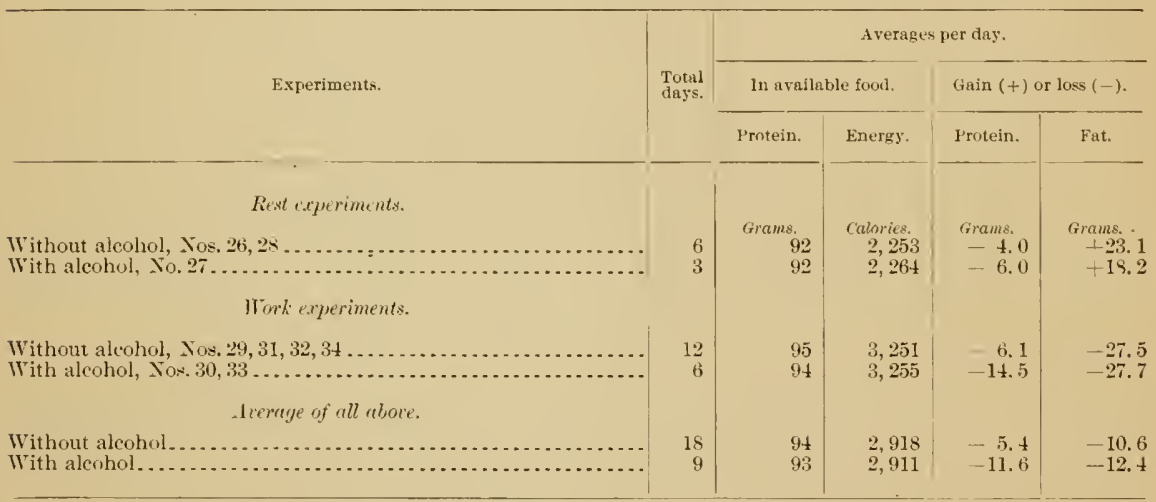

Thus all of the experiments with this subject would indicate elearly that for periods of 3 days the alcohol was inferior to either fat or earbohydrates as a protector of protein. It should be stated, also, that the loss of body protein with the aleohol was greater than the figures in the table would indieate, for the nitrogen elimination of the period preceding the alcohol was in each case slightly inereased by the entrauce of the subject into the respiration chamber, while that of the period following the alcohol is increased hy the lag in the exeretion of the extra nitrogen metabolized under the influenee of the aleohol. The lag would, of eourse, likewise prevent the effect of the alconol from becoming fully apparent in the first day of the alcohol period. Hence a better idea of the actual effect of the alcohol would probably be obtained by onitting from consideration the first day of each period. The average elimination of nitrogen thus beeomes, in the fore periods, 15.5 grams, in the alcohol periods, 17.1 grams, and in the after period, 15.5 grams per day, showing a difference in favor of the ordinary nutrients of 1.6 grams of nitrogen, or 10 grams of protein instead of 6.2 grams, as shown in the preceding table.

It is also noticeable that the loss of body protein under the influence of alcohol was larger with this subject when at work than when at rest. The difference is not great and may be 
simply accidental. It might. howerer. be interpreted as indicating that the subject morked to better advantage on the ordinary diet than on the diet of which a part was alcohol. This would accord with the conclusions drawn by Chanreau from experiments on dogs and by Parkes from extended observations on marching soldiers and workingmen."

Summary. - In interpreting these experiments tro things are to be considered. One is that the differences between the amount of nitrogen excreted with and without alcohol are generally very small. The other is that there is good ground for the belief that rith persons little accustomed to the use of alcohol it may have a tendency to increase nitrogen metabolism. which may counterart, to greater or lesi extent, the tendency to protect protein, though, with some persons at least, this action appenrs to be temporary. The results with the indiridual subjects may be briefly recapitulated as follows:

With E. O., who was accustomed to the nse of moderate quantities of alcoholic heverages. the protein protecting power of the alcohol was apparent, but seemed to be somewhat inferior to that of fats and carbohydrates.

With A. W. S., an abstainer, there was an increase of nitrogen excretion during the first days after the beginning of the alcohol diet, with a resulting loss of body protein, but this action ceased after 5 or 6 days, and thereafter the alcohol apparently protected protein. though the experiments do not show how its efficiency in this respect compared with that of the carbohydrates and fats.

With .J. F. S.. who was also an abstainer, there was, in each case, an increase of nitrogen excretion and loss of body protein during the 3 -day periods in which the alcohol replaced fat or sugar. There was thus a unarked inferiority of alcohol in protecting porrer. The result is similar to that observed with $\mathrm{A}$. W. S. during the first days with alcohol, but the experiments do not show what the effect of continuing the alcohol diet would have heen, and they are, therefore, not decisive.

Taking the results of all the experiments together, it may be said that-

1. They offer no evidence to imply that alcohol can not protect protein. though they imply in some cases it may, at least for a time, fail to do so.

2. On the other hand, they give rery marked indications of its protein protecting power.

3. They imply clearly that in this respect it was in some cases nearly or quite equal and in others decidedly inferior to the isodynamic amounts of carbohydrates and fats which it replaced.

Other erperiments upon the protection of protein by alcolol. - It is clear that the experiments ahore described are not conclusive regarding the action of alcohol in protecting protein from consumption. They were not planned for the study of this subject. To make the results decisive the alcohol periods should be long enough to eliminate the more or less temporary action of alcohol as a drug: the arailable energy of the ration of the nonalcohol periods should equal in some cases the total available energy of the alcohol ration. while in other cases it should equal only that of the ordinary food of the alcoiol ration, and finally, the experiments should be reperted with different persons and under different conditions. These faets we did not fully understund when the experiments were legun, nor would it have been practicable with the means at our disposial to make such experiments with men in the respiration calorimeter as would be nended tor the comprehensive study of the question. Experiments of from trenty to thirty consecutir days sem necessary for the most satisfactory results. For a man to spend so long a time in the respiration chamber of onl' apparatus would be, to say the least, rely tedious, and the cost of such rxjeriments, in lalkor and money, would have exceeded our available resources. Fortumately, the rasults ohtained by a number of other investigators. while our experiments were being marli and since. have done mueh to elarify the sitnation as regards the effects of alcohol upon portein motaholism.

rempt. rentl. Acarl. d. Sic. Par. 132, 11, 6.5 and 110.

I'rue, liog. Sis, 20 (1871-72), 402, and monograph "On the iscue of a spirit ration sluring the Ashantee canpagn, $187 t, "$ ele. London, 1875. 
Referring to the above-naumed review of the -nbject, and enperially to that of liowemann for detail- and references to the origrinal menoir. it will -uflice here to smmarize the re-ults. It aprear that:

1. A large number of arty experiment- have bought contlicting lesult.. some implying the protection of protein hy alcohol: others the oppo-ite. Of the former class those of Mogrilianski are of expecial interost. Of the latter those of Miura. made under the direction of Van Soorden, and those of shmidt and of Shome-eitfen. under the direction of Rosemann. have been much guted. The general plan of experimenting followed ly these three inrestigntors consisted in giving the sulject an ordinary diet for a time and ol-erving the nitrogen lalance. Thereafter. during a period of fonl to six days. alcohol wa- used. In Miuras case the alcohol was sub-tituted for carlwhydrates in a diet which had been aderuate for maintaining nitrogen equilintinm: hut with the alcuhol the exeretion of nitrogen increased and the hody lost nitrogen. With schmidt. alcohol was added to a diet with which nitrogen equilibrium had heen maintained: the aleobol did not diminish the cxretion of the nitrogen and the equilibrim continued. With sehoenereiften. alcohol wa- added to an inadequate diet with which there was loss of nitrogen: the low contimed with the alcohol.

The-e experiment- have fumished the chief basis for the contention that alcohol can not protect protein. In Miun's case the increase of nitrogen excretion with the alcohol was as large. and. indeed, in one in-tance rery slightly larger, than when the carhohydrate- were removed and no alcohol wa- uned in their place. Minla, and after him Rosenamn and others.inferred that alcohol was mahle to protect protein fom disintegration. and went so far as to ascribe to it a positive disintegrating action and to apply to it the term " proteid poison."

2. Veumann. in 1s:4!. made experiment on a similar plan, save that the alcohol period was coutinued for sixteen days. during which part of the fat of the normal diet was replaced by alcohol. He found that during the trist four days of the alcohol period there wan no evidence of protein protection: the nitrogen excretion was increased and was at large as during another greriod when the ordinary ration was redueed and no alcohol wa ned in it- place. Thereafter the nitrogen excretion diminished. and during the remaining twelve day of the alcohol period it was the same as with the normal ration. When the aleohol was remored and nothing substituted the exeretion of nitrogen inereased as before. Seumum conclucles that in his own case the failure of the alcohol to protect protein at first was probably due to a specific though temporary action by which it tended to increase the disintegration of protein so that the tentency to protein protection mas comteracted. Later this special action disappeared and the protecting action came into full play.

Jemmann - interpretation of hi- experiment s wa = questioned by Rosemann. who has heen a most rigorons opponent of the theory that alcohol can protect protein. and a keen critic of the experiments which bare seemed to faror this riew. He mantained the disintegrating. but questioned the protecting action of the alcohol. alleging defects in the plans of fenmanns experiments. Yemann. without replying. repeated his experiment - in such way as to meet Rosemann's oljections. and found concluvive evidence of the protecting powel of the alcohol. these later results being publi-hed early in 14ro. In 1901, Chotzen, working under the direction of Rosenfeld, and in 1:+11. Clopatt, each published result - of inquirien which agreed with Temman's. Meantime Rosemann made seremal series of experiment - of his own, the outcome of which, to his surplise. cleary demonstrated the protecting poter of alcohol, and contined the views maintained by Seuman. He has taken the pain to prepare an exten-ive smumary of the experimenting in thi- field. ' in which be assent- fully to the interpretation placed ly Xeumann. Rosenfeld. Chotzen. and Clopatt upon their experiments: believes that the protection of protein is shown by other experiment - as those of Mogilian-ki: considers it fully demomstrated by his own experiments: and

sisemann interprets $t$ wo of our experiments. Fos. $T$ and 10 , the only ones then published. as not showing the prolection of protein: an interpretation trom which we should not diseent. since Jo. T was exceptional. and two experiments coukl harny suffice for the establishment of the principle.

I see pate 26 il. 
comes to the definite conclusion that alcohol has a twofold influence upon the metabolism of protein, as previously suggested by Neumann. He is inclined to believe, with Neumann, that the disintegrating action is most apt to occur with persons little accustomed to the use of alcohol, and is of short duration, while in its action as a protector of protein it is analogous to the carbohydrates and fats, its influence being due to the utilization of its energy by the body. According to this view, the results obtained by Miura and others, in whose experiments the alcohol periods continued only from four to six days, are explained by the disintegrating action of the alcohol, which counteracted the protecting action, so that the resultant effect was an apparent failure of the alcohol to protect protein. With Neumann the alcohol periods continued after this disintegrating action ceased, and showed the more permanent protecting influence. The fact that in a number of the experiments the protecting influence was manifested from the start is explained by the absence or only partial action of the disintegrating tendency.

We hare, then, a clearly defined theory regarding the influence of alcohol upon proteid metabolisin. This theory assumes two different kinds of action of alcohol. In the one it is a direct protector of protein, and serves the body as food; in the other it tends to disintegrate protein, and acts as a drug. The belief in the first action follows as a corollary from the oxidation of alcohol in the body and the transformation of its energy. In undergoing these changes alcohol is similar to sugar, starch, and fat, which, by their own oxidation and consequent supply of energy to the body are able to protect the constituents of the food and of the body, including protein, from oxidation. That alcohol may and does protect protein is abundantly demonstrated by the experiments above cited.

The disintegrating influence of alcohol upon protein is less definitely proven. The theory is little more than a convenient hypothesis for explaining the failure of alcohol, under some circumstances, to protect protein. It is the only satisfactory hypothesis which has thus far been suggested. It is all the easier to accept because of the considerations that the breaking up of protein compounds in the body seems to be influenced, in some unexplained way or ways. by the nervous system, and this latter in turn is influenced by alcohol. In our own experiments, for instance, the excretion of nitrogen is apparently affected at times by the mental condition of the subject.

In large enough doses alcohol has a paralyzing effect, and may thus reduce general metabolism to a minimum and cause coma or even death. There is no proof that it can not, on the other hand. increase proteid metabolism.

The positive proof of the disintegrating action of alcohol upon protein is limited in amount. The experimental demonstration must be sought in eases in which more protein is broken down with alcohol than without it, the ration of ordinary food being otherwise the same in both cases. We have been able to find only three cases on record in which the amount of protein thus broken down with alcohol apparently exceeded by more than $0.1 \mathrm{gram}$ of nitrogen per day the amount broken down withont alcohol. They are discnssed in the review rbove referred to. The first was in one of Miura's experiments, in which the excess with alcohol amounted to 0.5 gram of nitrogen (3.2 grams of protein) per day during an alcohol period of four days. The second was in one of Neumann's experiments, in which the excess during the first foul days of an alcohol period of ten days was $0.9 \mathrm{gram}$ of nitrogen per day. During the remaining six days of the same period the nitrogen exeretion was less by 1.5 grams per day than in the corresponding period without alcohol. The third was in an experiment by Clopatt. During the first six days of an alcohol period of twelve days the nitrogen exeretion exceeled that of a eorresponding period without alcohol by 2 grams per day. During the remaining six days of the ame alcohol period the nitrogen excretion was less by 1.4 grams per day than it was without alcohol.

It secms to the writer's that in view of the nuavoidable irregularities in the nitrogen balance in such experimenting these data are insufficient to demonstrate the disintegrating action of alcohol, but. taken in connection with the need of an explanation for the oecasional failure of aleohol to protect protein, they make the theory plausible. 
Sources of uncertainty in this hind of experimenting.-One point wnich has hardly receited the attention it deserves in discussions of this kind is the uncertainty of the nitrogen balance in any given case as a measure of the atual influence of a given condition upon nitrogen metabolism. This has been emphasized elsewhere in the present memoir (nee pp. 39:3 and 39t). Diflerences which look large in a table of figures are often fitr inside the unaroidable variations in actual experimenting.

Even when the differences are significant the interpretation may be erroneous. A striking illustration of the danger of such error is found in the enrrent discussion of the question we are now considcring. For a number of years past writcrs upon this sulject have insisted most positively that alcohol, instead of being a protector of protein, is a protein poison. This theory is based almost wholly upon the experiments of Miura, Schmidt, and Schoeneseiffen. The experiments of Neumann, Rosenfeld-Chotzen, Clopatt, and Rosemam, not to speak of others, including our own, have shown that this theory was wrong and have given ns a very plausible hypothesis to explain why it was wrong.

We can not insist too strongly upon the danger of drawing positive conclusions from figures for nitrogen balanee as a measure of protein protection by either alcohol or sugar or starch or fat. Certainty comes ouly with careful planning and execntion and manifold repetition of experiments.

Incidentally, it is to be noted that the excretion of nitrogen in the urine is not necessarily an exact measure of the amount of proteid broken down in short periods, since the time between the disintegration of the protein and the appearance of the nitrogen in the urine, the so-eallect nitrogen lag, varies widely. The longer the experimental period the less the error from this souree.

Finally, there is the unsettled question as to how much of the protein metabolized is that of food and how mueh comes from organized tissue.

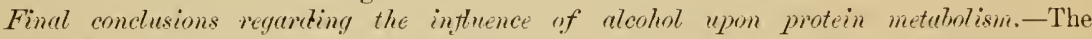
experiments and eonsiderations above cited seem to us to warrant the following couelusions:

1. The power of aleohol to protect the protein of food or body tissue, or both, from consumption is elearly demonstrated. Its aetion in this respect appears to he similar to that of the carbohydrates and fats; that is to say, in its oxidation it yiclds cnergy needed by the hody, and thus sares other substanees from oxidation. In this way aleohol serves the body an food. Just how moderate quantitics of alcohol compare with isodynamic amounts of sugar, starch, and fat in the power to protect protein from catabolism is not yet settled. Apparently it is in some cases equal, in other's inferior, to these substances. It is by no means certain that the fats and carbohydrates are always equal to each other in this power.

2. Alcohol appears also to exert at times a special action as a drug. In large quantities it is positively toxie, and may retard or even prevent metabolism in general and proteid metaholism in particular. In small doses it seems at times to have an opposite influence, tending to inerease the disintegration of protein. This aetion, though not eonclusirely demonstrated, is rery probable. It otters a satisfactory explanation for the oceasional failure of alcohol to protect protein, the assumption heing that the two tendencies counteract each other. The only justification for ealling alcohol a proteid poison is found in this disintegrating tendeney. This pharmaeodynamie action of aleohol appear's to he temporary and most apt to oecur with people little aceustomed to its use. The circumstances under whieh such action occurs can not now be fully defined.

Influence of coffece upon protein metalotism in these experiments.-In some of these experiments alcohol was administered with coffee, in other with water. It might be thonght that the presence of the coffee would interfere with the action of the alcohol. ${ }^{a}$ The figures give no support for this view, as is shown in the following tabular statement.

a See Woolbury and Egbert, A Physiologic Consideration of the Food Value of Alcohol, Jour. Am. Med. Assc, Mar. 31, 1900. 
Elimination of nitrogen in presence and rabsence of colfice.

[Quantities per day.]

\begin{tabular}{|c|c|c|c|c|c|}
\hline \multirow[b]{2}{*}{ Find and number oi experimente. } & \multirow[b]{2}{*}{ Days. } & \multicolumn{4}{|c|}{ Sitrogen. } \\
\hline & & In food. & In feces. & In urine. & $\begin{array}{l}\text { Gain }(+) \\
\text { or loss }(-) \\
\text { to body. }\end{array}$ \\
\hline $\begin{array}{l}\text { I. With coffee: } \\
\text { Arerage t experiments with alcohol }[10,12,18,22] \ldots \\
\text { Arerage t experiments without alcohol }[9,11,21,24]\end{array}$ & $\cdot 13$ & $\begin{array}{r}\text { Grams. } \\
18.6 \\
18.6\end{array}$ & $\begin{array}{l}\text { Grams. } \\
1.2 \\
1.5\end{array}$ & $\begin{array}{l}\text { Grams } \\
18.2 \\
17.5\end{array}$ & $\begin{array}{l}\text { frams. } \\
\quad-0.8 \\
-0.4\end{array}$ \\
\hline Increase $(+)$ or decrease $(-)$ with alcohol. & ..... & 0 & -0.3 & +0.7 & -0.4 \\
\hline 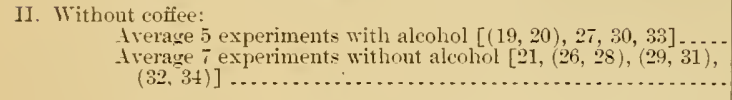 & $\begin{array}{l}13 \\
21\end{array}$ & $\begin{array}{l}15.8 \\
15.9\end{array}$ & $\begin{array}{l}1.0 \\
1.0\end{array}$ & $\begin{array}{l}16.1 \\
15.7\end{array}$ & $\begin{array}{l}-1.3 \\
-0.8\end{array}$ \\
\hline $\begin{array}{l}\text { Increase }\{(+) \text { or lecrease }(-) \text { with alcohol } \ldots . . . . . . \\
\text { Increase }(-) \text { or decrease }(-) \text { in presence of coffee.. }\end{array}$ & . & $\begin{array}{r}-0.1 \\
+0.1\end{array}$ & $\begin{array}{r}0 \\
-0.3\end{array}$ & $\begin{array}{r}-0.4 \\
+0.3\end{array}$ & $\begin{array}{l}-0.5 \\
+0.1\end{array}$ \\
\hline $\begin{array}{l}\text { III. Direct conparison, alcohol with and without coffee: } \\
\text { Experiments } 15,17,18 \text {, alcolol given with coffee.... } \\
\text { Experiments } 16,19,20 \text {, alcohol given without coffee }\end{array}$ & $\begin{array}{l}6 \\
6\end{array}$ & $\begin{array}{l}16.5 \\
16.5\end{array}$ & $\begin{array}{l}0.9 \\
1.0\end{array}$ & $\begin{array}{l}16.0 \\
14.9\end{array}$ & $\begin{array}{l}-0.4 \\
+0.6\end{array}$ \\
\hline Increase $(+)$ or decrease $(-)$ in presence of coffee.. & $-\ldots$ & 0 & -0.1 & +1.1 & -1.0 \\
\hline
\end{tabular}

This table comprises all of the experiments that are directly comparable. The experiments in which the alcohol was given with coffee are averaged together and compared with the corresponding nonalcohol experiments, and the figures in the third line of eategory I show the effects of alcohol in presence of coffee. Under II a similar comparison is made of the experiments in which no coffee was given, the third line of figures here showing the effeets of alcohol when taken alone. Br subtracting the third line of figures under II from the corresponding figures under I we obtain ralues which may be taken als showing the influence of the coffee. A more direct comparison of results with and without coffee is given under III. but the number of experiments compared is necessarily smaller, and therefore individual rariations have relatively much greater weight. While the differences which could be attributed to the coffee are probahly within the limits of experimental error, it would seem that if there is any effeet it is to inerease rather than to retard proteid metabolism.

\section{EFFECT OF ALCOHOL UPON THE RADIATION OF HEAT FROM THE BODY.}

A current theory maintains that although alcohol sipplies heat to the body it also increases the radiation of heat from the hody, so that much or all the energy it supplies is wasted.

This theory is based upon two kinds of evidence, which are well attested and make it rery. plausible. One is the distension of the blood ressels which cause the flush of the skin when almohol is taken. The other is the lowering of the temperature of the body after the ingestion of alcohol. which is shown by many of experiments and is explained by the loss of heat.

Some writers even go so far as to clain that the extra heat radiation due to the distension of the peripheral resisels is greater than the heat supply from the oxidation of the alcohol. According to this view. alcohol. instead of being a source of energy, is a cause of its loss to the hody.

The difficulty with the theory is the exaggeration of the influence of small quantities of alcohol in increa-ing heat radiation. While the temperature of the body has been found to fall considerally after' the ingention of large domes of alcohol, and especially under exposure to great cold, the eflect of ordinary doses is slight and often impereptible.

In the experimints here described the determinations of borly temperature were made with an ordinary relinical thermometer in the mouth and axilla, as elsewbere stated. This method. 


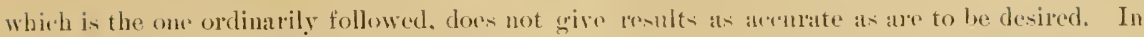
some of the earlior experiments, expecially with E. (). the observations are of doubtrul value. Stepi have loen taken in this laboratory to drevise a thermometer and method of ofrervation

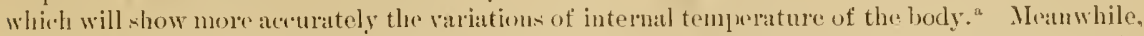

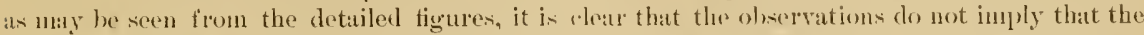
lonlily tempritures with and without alcohol ware greatly diflerent. This agrees with the results of other olservations."

The alcohol used in these experiments was equivalent to alunt ity grams of absolute alcohol per day taken in 6 doses. This is about the amount contuined in an ordinary bottle of wins with

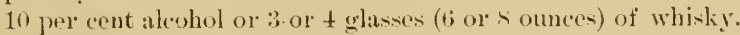

If we use our own observations and the others junt roferved to as a basis. it would seem that the fall of body temperature produced by such amounts of alcohol might ordinarily range from nothing to one-half of a degree centigrade. The heat which the borly of an average man would have to lose in order to reduce the temperature one-half of a clegree wight be ronghly calculated as follow:

We may take the weight of the body of the arelage man at 148 pounds, or fit kilon. 'The specitic heat of the hody is not exactly known, but may be extimated at 0.43 . On this base a fall of temperature of one-half of a degree centigrade wonld correspond to $\frac{1}{2}(67 \times 11.83)$, or ahout

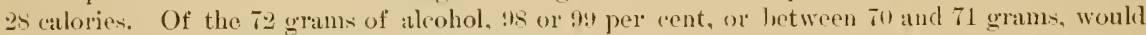
be burned in the body, and would yedd at 7.1 calories per gram ahout 5em) (atories of heat. By this estimate, if the 72 grams of alcohol were taken in one dose and catued a lowering of the hody temperature by one-half of a degree. the 28 ealories of heat wasted in the extra radiation due to the alcohol would be one-eighteenth the amount supplied ly its combustion.

This method of calculating the amount of heat which the body must lose in order to produce "given fall of temperature is hardly correct. It wouk be so if we hat to do only with a fixed amount of heat at the ontset and i fixed amount of loss. But, as a matter of fact, the body is constuntly gaining heat from the oxidation of material from within and constantly losing not unly by outward radiation, but in other was, as in the exhalation of air and water, vapor in respiration, in the excretions of the kidneys and intestine, and in the evaporation of water from the skin. The actual temperature depends upon the income and ontgo of heat. The income depends upon the material oxidized in the body. The ontgo is regulated to a greater or less extent by processes which are not fully understood, but in which the nerrous system is the iuportant ageney.

Enprimentul inquiries.-Neanwhile we may consider the experimental evidence hearing directly upon the question of the radiation of heat with and without alcohol.

In a series of experiments by Reichert with dogs the effect of alcohol on the radiation of lreat was tested." The experimental periods were however, only 5 or t; hour's each, and there was no complote comparison of the effeets of different diets. The rate of hat radiation and the change of budy temperature were carefully ohserved. The results implied a probable but at most very small increase of heat radiation as the result of administering alcohol.

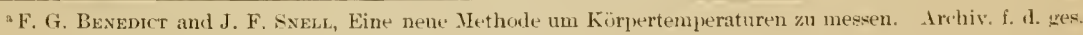
Phymiologie so, p. 492 (1901).

"The results of the most reliable observations are well summarized ly Pewnes (A.hater's Physiology, I, k20) in the following statements:

"Varicus olservers lave found that alcohol taken in ordinary quantities as a beverage causes a slight clepression, generally less than half a degree, in the temperature of healthy men. On the other hand, poisonons doses may cause a fall of $5^{\circ}$ or $6^{\circ}$-in fact, many of the lowest temperatures recorder in man have heen observed in drunken

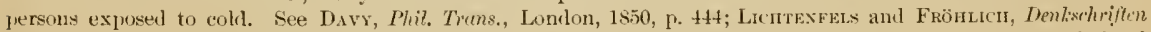

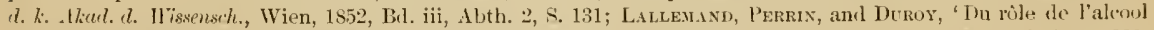
et des anesthésiques dans l'organisme' Paris, 1860; ()gLe, N. George's IIosp. Rop., London, 186ti, vol. i, P. 233;

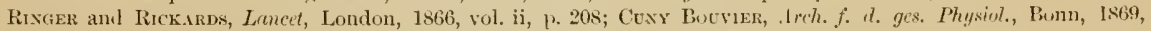
Bd. ii, S. 370; Goprrix, 'De l'aleool, son action physiologique, ses applieations thérapentiques,' 1864; Wreken.rvG,

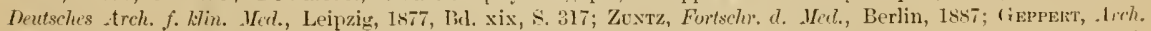
f. expre. Path. u. Phamakot., Leipzig, Bil. xxii, 36; PAnkes and Wollowicz, Pror. Roy. Sor. Londom, 1si0, vol. xvili, p. 362 , found that alcohol in ordinary quantities had no effect on the temperature of a healthy man."

Therapeutic Gazette, February, 1s:\$0. 
The experiments with men in the respiration calorimeter here deseribed give extended data regarding both the consumption of fuel and the radiation of heat. The details are summarized in Table CXX in the appendix. The final outcome is simple and may be illustrated by two cases, (iroups $A$ and D. In each there were two experiments, practically alike, save that one was with ordinary diet and the other with a diet in which part of the fats and carbohydrates were replaced by alcohol as above described. In Group $\mathrm{A}$ the subject was at rest, i. e., doing no external muscular work. The potential energy of the material burned in the body and the amounts of heat giren off in calories were practically the same, as is shown by the figures herewith. The differences in the results without and with alcohol are entirely within the limits of ordinary rariation:

Compurison of energy of materiul metabolized and heat given off per duy in rest experiments with and without alcohol.

\begin{tabular}{|c|c|c|}
\hline Diet. & $\begin{array}{l}\text { Energy of ma- } \\
\text { terial burned. }\end{array}$ & $\begin{array}{l}\text { Energy given } \\
\text { off by the body } \\
\text { as heat. }\end{array}$ \\
\hline $\begin{array}{l}\text { Without alcohol, experiment No. } 9 \ldots \ldots \ldots \\
\text { With alcohol, experiment No. } 10 \ldots \ldots\end{array}$ & $\begin{array}{l}\text { Calories. } \\
2,277 \\
2,268\end{array}$ & $\begin{array}{l}\text { Calories. } \\
2,309 \\
2,283\end{array}$ \\
\hline
\end{tabular}

If the alcohol had caused increased radiation of heat, more heat would have been given off from the body and more fuel would hare been required, and naturally more would have been burned in the alcohol experiment than in the other. Such, however, was not the case.

In the experiments of Group B the man was engaged for eight hours a day in active muscular work, driving a stationary bicycle. The amount of work was such that he burned enough fuel to yield in all 3,900 calories, and, as the food did not supply enough, he used up some of his store of body fat. The results of such experimenting imply that when the body has not enough food for its support and is forced to draw upon its reserve capital, it uses the materials economically. The energy given off from the body was in two forms - heat and extemal work. This work was practically the same in both experiments and is reckoned with the heat in the energy given off.

Comparison of energy of material metubotized and heat given off per day in work experiments with and without alcoliol.

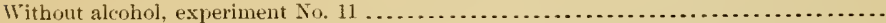

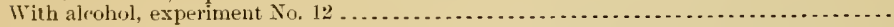

\begin{tabular}{c|c}
$\begin{array}{c}\text { Energy of } \\
\text { material } \\
\text { burned. }\end{array}$ & $\begin{array}{c}\text { Energygiven } \\
\text { off by the } \\
\text { body as heat } \\
\text { and muscular } \\
\text { work. }\end{array}$ \\
\hline & $\begin{array}{c}\text { Calories. } \\
3,901\end{array}$ \\
3,932 & 3,922 \\
3,927
\end{tabular}

Here again there was slightly more fuel burned per day with alcohol than without, though the difference was small, while the amount of heat given off was practically the same in the one case it: the other. So fir as the disposal of the energy is concerned, the figures imply that alcohol was used as economically as the fat, sugar, and starch which it replaced, and that it caused no increased radiation of heat.

We have, all told, 13 experinents with alcohol, corering 36 days. For purposes of comparison these hare been groupec, as already explained (p. 241), with 13 experiments without akcohol, covering 43 dars.

The sulject in 5 of these groups, E. O., was a man who hal been long accustomed to the moderate use of alcoholic herrages. The subjects in the other four groups, A. W. S. and I. F. S., wele two men who latd always heen total abstainers.

The results are summurized in the table herewith, which is condensed from Table CXX of the appendix. The first column gires the figures for energy for material actually oxidized. The figrue- in the second colum show the relation between the averages of experiments with alcohol 
and those without alcohol, the latter heing taken as a basis (100 per cent). The corresponding values for total and proportional energy measured as heat in the two chases of experiments are shown in the last two columns of the table. Thus, in the average of all the experiments without alcohol the energy of the material actually oxidized was 2,717 calories. In the arerage of all the experiments with alcohol it was 2,746 calories. The latter was 101.1 per cent of the former. ${ }^{n}$

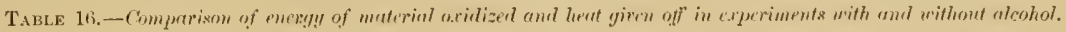

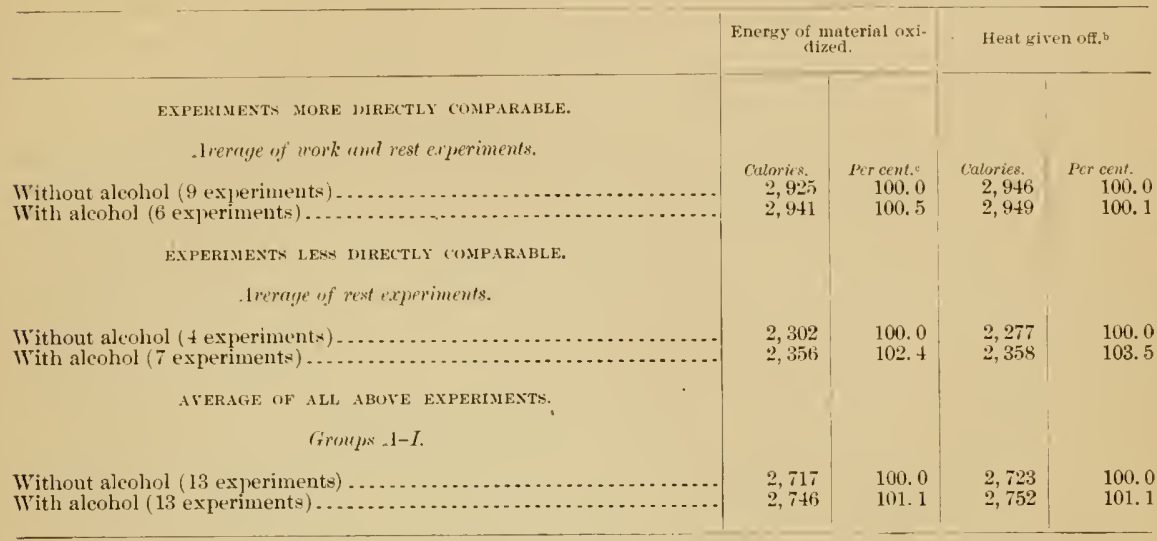

There was slightly more fuel burned and more heat given off from the bodies of the men when they had aleohol in their diet than when they had the same amomnt of protein and energy in a diet withont alcohol, but with conditions otherwise similar. The differences, however, were very small; in the more directly comparable experiments the excess of fuel burned with the alcohol diet, as measured in calories, was only five parts and that of heat given off only one part in 1.000 . In the less directly comparable experiments the differences were larger, but still small.

The quantities of total food were grenerally below rather than above the reqnirements of the body, especially in the work experiments, as may be seen from Table CXX of the Appendix. The general results of experiment imply that nnder sueb circumstances the body makes economieal use of it.s food and its reserve supply of material. The fact, therefore, that under these conditions. the oxidation of material and radiation of heat were so nearly the same with the rations with and withont alcohol add still greater force to the comparison.

The conclusion is that in these experiments, with three different wen at rest and at work, when 72 grams of alcohol per day taken in six doses and furnishing 500 ealories of energy replaced the isodynamic amounts of fats and carbohydrates, the alcohol cansed no considerable increase in the amount of heat radiated from the body.

If the alcohol in these experiments had all been taken at one dose, it might have eaused the eutaneous ressels to dilate, stimulated the sweat glands (?), and increased the circulation, and thus increased the heat radiation. If there had leen enough to cause the ordinary symptoms of intoxication, and especially if it had sufficed to induce the comatose condition for which the expression "dead drunk" is used, and if the men had at the sime time been exposed to serere

A difference so small as this is well inside the range of mavoidable error in single experinents. It is only where a large number of such experiments are averaged that differences of one or two parts in one hundred could probably be regarded as significaut.

"Including heat equiralent of external muwcular work in the work experiments.

- Of amount oxidizet without aleohol. 
cold. the production of heat in the hody might have heen retarded. and the radiation increased no an to lowr the hody temperature by several degrees.

\section{RAPIDITY OF COMBUSTION OF ALCOHOL IN THE BODY.}

There is a popular impression that alcohol is burned in the body much more rapidy than ordiuary food, and that in consequence not only is the enejoy resulting from itsoxidation wasted. but clerangements of bodily functions may result from the rapid eombustion of the alcohol. The exact grounds for the belief or uature of the supposed disturbances we have not seen distinctly stater. Terertheless. as the impression prevails to some extent, at least among physicians and phrsiologists. it seems to demand consideration.

Leaving ont of account the unsettled question as to how soon after the ingestion of the alcohol its oxiclation begins, the main problem is the rate of oxidation. If it is especially rapid, either one of two results may follow. The oxidation of other materials may go on as usual, in which case the total production of arbon dioxid and heat will be abnornally large: or the oxidation of other substances may be diminished so as to compensate for more or less of the oxidation of the alcobol, in which case the rate of production of carbon dioxid and heat may be little. if any. larger than without the alcohol. The natmal test will be found in the measurement of these rates of production. So far as we are aware no adequate tests of this character have thus far been made.

In examining the literature of the snbject we have not succeeded in finding any experimental proof that the rate of elimination of carbon dioxid or heat from the body is materially increased or decreased by moderate quantities of alcohol. Satisfactory tests would involve the measurement by short periods, as, for instance, hour by hour. Our own experiments were not planned for this purpose, and the measurements were made generally in six-hour periods. There was nothing in the observations to imply that the rate of production of either carbon dioxid or heat was materially increaser either immediately after the ingestion of the alcohol or later.

Part of the heat given off from the body is carried away in water vapor given off from the lung- and skin, but the larger portion finds its way to the water current, by which it is carried out of the chamber. The rate of flow of this current and its rise of temperature in pasing through the chamber thus measure the rate of evolution of heat from the hody other than that carried away by water rapor.

The observations of rate of flow and rise in temperature are made every few minutes, and thus show the rate of evolution of the larger portion of the heat.

We have taken the pains to caleulate the evolution of heat for bourly periods for three series of experiments, in which the alcohol diet and ordinary diet were compared, riz, Nos. 22-24. 26-2s, 2!-31. The calculations, however, have been limited to the night periods between $7 \mathrm{p} . \mathrm{m}$. and 7 a. m., because the erolution of hoth carbon dioxid and heat is much more regular by night than by dar, and any disturbance, such as might be caused by the rapid oxidation of alcohol. would be more easily detected in comparing the figures for the experiments with and without alcohol during the night periods.

The results of these comparisons are negative. There are practically no more irregularities or indications of disturbance in the alcohol than in the nonalcobol experiments. There is nothing in the figures which seems to us to indicate any appreciable tendency towarl increase of heat production during the first, second, or third hour after the ingestion of the alcohol. The figures are, indeed, so destitute of such indications as to hardly warrant their printing.

We are therefore led to the conchsion that in these experiments either the alcohol was not suddenly or rapidly oxidized, or if there was such rapid oxidation, there was a corresponding decrease in the oxidation of carbohydrates, fats, or protein.

It is interesting to note that this conclusion acrords with the other ob-ervations. viz. those of the total heat production and the economy of the use of energy in the rations with or without alcohol. All of these imply that the alcohol. wabohydrates, and fats simply replaced one another as sonees of energy: that an either was oxidized the others were proportionately spared. 


\section{ALCOHOL AS A SOURCE OF HEAT IN THE BODY.}

In the rest experiments the heat griven ofl trom the boly was equivalent to the total potential energy of the materials oxidized. This was as true in the experiments in which aleohol made part of the diet an in those with ordinary food exelusively. The aloolus must therefore have contributed its full quota of heat as truly as did the starch or fat. and all it- potential energy was (onverted into heat within the body.

In the work experiments the same principle applies. and it follows that unless all the potential energy of the aleohol was conrerted diretly into that of external museular work part must have been converted into heat within the body. But the total energy of external muscular work was at most the equiralent of gol) calorie-, while the energy of the alcohol was about 5in. Even if all the external work was done at the expense of the alcohol. there would remain 2.20 calorie: which must have been transtormed into beat within the body. But it is extremely improbahle that the alcohol -upplied all and the ordinary food none of the energy of external work. In so far. therefore, as the latter ame from the ordinary food. more than 200 of the 5 m ealories of the alcohol mu-t have reached the form of heat within the body.

Wo have to do here with the question: Of the total energy which wa- potential in the alcohol and was made kinetic by its oxidation. how much was transformed directly into heat and how much wa- tirst changed to the energr of nu-cular and other bodily work. interual and external. and was aftermark tran-formed into heat? This inrolves two fundamental problems. One is the still unsettled physiological question as to whether the production of muscular energy in general is or is not a direct transformation of potential into mechanical energy. The other is the more specific question as to whether the energy of alcohol is like that of the ordinary nutrients of food in it- transformation into muscular energy. Both will be referred to beyond in the dimcusion of alcohol as a source of muschlar cnergy. Meanwhile it is -ife to say that:

1. Unless all the potential energy of the alcohol was transformed directy into the energy of internal work in the rest experiment $o r$ into that of internal and external work in the work experiments. a supposition that seems highly improbable, part munt have been tansformed directly into heat in the hody.

2. Whether the potential energy was first transformed into museralar energy or not. the whole in the rest experiments and part at any rate in the work experiments reached the form of heat within the body.

The conclusion is that in all these experiments alcohol wan a source of heat for the hody.

\section{ALCOHOL AS A SOURCE OF MUSCULAR ENERGY.}

frimml crmsiderutions. - The fuestion whether or not the energy of alcohol is used for muscular work is not yet definitely answered. The experiments thus far made do not provide means for tracing the energy of the alcohol through the changes it undergoes in the body, and finding how much of it becomes muscular energy. Nor is it easy to derise such experiments. The difficulty is that the potential energy of the alcohol is transformed along with that of other materials oxidized. and there is no known way of separating the kinetic energy which comes from the alcohol from that which is supplied by the arbohydraten or fats or protein. While there is no evidence of any ditfierences between the energy from the sereral sources. the absolute proof that no sich differences exist is not ret at band.

Back of this is the nrore fundamental question as to how museular energy is produced. Concerning this two theories are held. One is that part of the potential energy of the food and body material oxidized is eonverted directy into the meehanieal enery axerted by the muscle. The other is that the contraction of the muscle. by which it work is done. is due to heat. According to this view, practically all of the potential eneror in first transformed into heat and a part afterwards appears as musealar energs. If the recond view is correct. it is bard to see how the heat derived from the oxidation of the alcohol should he in any way lifferent from

Vol. - No. ti- $t$ 
the rest of the heat. If the muscular energy is the first product of the transformation of potential energy, it is conceivable that there might be some attribute of alcohol which wonld prevent its potential energy from being changed into mechanical energy. But there is nothing in the results of experiment to imply any such difference between alcohol on the one hand. and sugar. starch, or fat on the other. The ease regarding the transformation of energy is like that just referred to regarding the use of the energy after it is transformed. There is no evidence of any difference between aleohol and other nutrients in either respect. but there is no proof that the ditference does not exist.

The most satisfactory method of study of this question as to whether alcohol can be a source of the mechanical energy exerted by the muscles is by measuring the amounts of ditferent substances metabolized and the amounts of muscular work done. and thus getting light upon the comparative efficiency of the sereral substances as parts of a diet for muscular work.

If the experiment could be made with lean meat and alcohol in such a way that the body could obtain no other fuel than alcohol and protein, and the energs of the internal and external muscular work shonld be found to exceed that of the protein. it would be clear that the rest of the muscular energy must come from the alcohol. But as yet we have no means for measuring the internal work. and it would probably be difficult to find a man who conld do much external work dar after day ou such a diet without drawing upon the store of material in his body.

For the present, therefore, we are limited to experiments in which other fuel is burned with the alcohol, and our conclusions must depend upon measurements of (1) the energy supplied by each kind of fuel. (2) the energy given off from the body, and (3) the amount of muscular work performed.

Here again we meet a difficulty, namely, that of measuring the musular work. We have to do with two kinds of work, external and internal. The extermal work is that which is performed outside of the body, as, for instance, the power which a man riding a bicycle applies to the pedals. This is capable of quite aceurate measurement. Such measurements were made in the experiments here described. By internal work is meant that of circulation, respiration, digestion, ete. Thus a not inconsiderable amount of energy must be used for the muscular contractions of the heart by which the blood is pumped out through the arteries and back from the veins. It is held by some physiologists that a large portion of the total energy supplied by the food is used for this internal plysiological work. At present no exact method is known for measuring the internal work of the body. It is transformed into heat before it leares the body and in the experiments with the respiration calorimeter it is collected and measured as part of the total heat given off. But this total heat includes also the heat which was produced in the body and not used for muscular work, and no way has yet been found to distinguish between the heat which has and that which has not been used. and to measure the two quantities of heat separately.

We know from measurements of the external muscular work that it represents at most a fraction, and generally a small fraction of the total energy transormed. It may be that in the case of a man doing a large amount of muscular lahor this external work added to the interual work would account for the larger part of the total energy transformed in the bodr.

The measurements of income of energy from the oxidation of ordinary nutrients and alcohol and of outgo of energy in the different forms of heat and external muscular work therefore do not answre the specific question as to how much of the energy provided ly the alcohol is used for either internal or external musular work. or both.

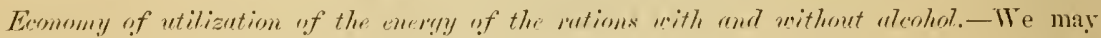
nerertheless get some light on the fuestion by putting it in another way : Is the total energy of the ration used as economically when part of it is supplied by alcohol as when the whole connes from ordinary fool? 'The question may be approached in two ways, (1) by considering the differences in the amounts of araibhle mergy in the diets with and without allohol. and comparing these with the energy in the hody protein and fat gained or lost in the two cases. and (2:) by 
comparing the energy of material aetually oxidized in parallel experiments with and withont alcohol. The prineiptes here involved may be explained as follows:

The energy neded and used by the burly. - The body rexuires and uses a certain amount of energy. This amount is larger when the man is at work and smaller when he is at rest. The larger the amount of enerery used, the more material will be metabolized to furnish it. If the avalable nutrients of the food exceed the amounts metabolized, the excess will be stored in the hody. Assuming the store of carbohydrates to remain constant, the body will gain protein or fat or both. Translating this last statement from terms of material to terms of energy, if the available energy of the food exceeds the energy metabolized, the amount of energy in the borly will be increased by the storage of energy in protein or fut. On the other band, if the available energy of the food does not supply the demand, the lack will be made up by drafts upon hody protein or fat. We thus have two measures of the energy used by the hody. One is the gain or loss of hody protein and fit with a given amomnt of arnilable energy in the food. The other is the total energy metabolized whether it be more or less than the available energy of the food.

Eirmmy of utitizution of energy. . We have distinguished between the energy needed and that actully metabolized. If the body uses the energy economically it does not metabolize more than it needs. But it cloes not always make the most economical use of either material or energy. If it has more food than it needs, it may use this wastefully. Part of the excess of material, at times perhaps the whole, may be stored for future use, hut often more or less of the excess is simply consumed and the energy wasted. On the other band, if the food only equals the demand, and especially if it falls short and body material has to be drawn upon, the body will probably make economical nse of the energy of both food and body material. This was the case in the experiments now under diseussion. When the men were at rest the food supplied but little more, and when they were at work it supplied less, than was actually needed. In these experiments, therefore, the two measures just referred to, namely, the energy of body material gained or lost and the total energy metabolized, show how much the body uses when the energy is economically ntilized.

To state the ease in another way, either the energy of material gained or lost with the given diet, or the energy of the total material oxidized, gives a measure of the energy actually employed for economical nse. These quantities can be expressed in calories.

Comparative ecomomy of energy of ditferent materials. - This hrings ns to the question at issue. Is the cnergy of alcohol equil, superior, or inferior in value to that of carbohydrates or fits or other nutrients of ordinary food as part of a diet for rest or for muscular work? Will a calorie of energy from alcohol go as far, farther, or not as far as a calorie from sugar, starch, fat, or protein in meeting the actual needs of the hody? The answer is to be sought in the experiments in which a diet of ordinary food is compared with a diet containing alcohol, the total availahle protein and energy of the food and the other conditions being the same in both experiments. The test will be found in the gains or losses of body protein and fat, and in the total energy metabolized in the two experiments. Any differences in either of these factors, to wit, (1) gains or losses of body material, or (2) energy metabolized, provided they are outside the limits of experimental error, must he attributed to the diet; that is to say, the alcohol in the diet. If the body gains or loses the same amount of material, or if it metabolizes the same amount of energy with both diets, a culorie of energy from one is equal to a ealorie of energy from the other, and as a source of energy the alcohol is equal to the isodynumic amomnt of the carbohydrates or fats which it replaces. If the gain of material is less or the loss more, or if the total energy metabolized is larger with the alcohol. the latter is inferior as at source of energy, and vice versi.

Eriperimentul results. - Table 17 shows the differences between the available energy of the food in experiments with and without alcohol and the corresponding differences between the energy of body material gained or lost in the same experiments. The tigures in the fourth and sixth columns are computed from those in the third and fifth, respectively, nsing the factor 5.65 for the energy of one gram of protein, and $9.5 \pm$ for that of one gram of fat. 
TABLE 17.-Compurison of gaius and losses of holy protein and fat, and trunsformation of energy in experimets with and rithom alcohol.

[Quantitics per day.]

\begin{tabular}{|c|c|c|c|c|c|c|c|}
\hline \multirow[b]{2}{*}{ Groups, kind, and number of experiments. } & \multicolumn{2}{|c|}{ Arailable in food. } & \multicolumn{4}{|c|}{ Gain $(+)$ or loss $(-)$ in body material. } & \multirow{2}{*}{$\begin{array}{c}\text { (b) } \\
\text { Energy } \\
\text { of } \\
\text { material } \\
\text { oxidized. } \\
b \rightarrow(d+f) .\end{array}$} \\
\hline & $\begin{array}{l}\text { (a) } \\
\text { Protein. }\end{array}$ & $\begin{array}{c}\text { (b) } \\
\text { Energy. }\end{array}$ & $\begin{array}{l}\text { (c) } \\
\text { Protein. }\end{array}$ & $\begin{array}{l}(d) \\
\text { Energy } \\
\text { of } \\
\text { protein. } \\
c \times 5.65\end{array}$ & Fat. & $\begin{array}{l}(f) \\
\text { Energy. } \\
\text { of fat: } \\
e \times 9.54\end{array}$ & \\
\hline 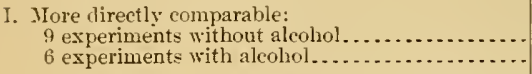 & $\begin{array}{r}\text { Frame. } \\
103 \\
104\end{array}$ & $\begin{array}{l}\text { Crulories. } \\
2,917 \\
2,925\end{array}$ & $\begin{array}{l}\text { Grams. } \\
-3.5 \\
-6.9\end{array}$ & $\begin{array}{r}\text { Calorics. } \\
-19 \\
-39\end{array}$ & $\begin{array}{l}\text { Grams. } \\
+\quad 1.1 \\
+\quad 2.4\end{array}$ & $\begin{array}{l}\text { Calorics. } \\
+\quad 11 \\
+\quad 23\end{array}$ & $\begin{array}{l}\text { Calories, } \\
\qquad \overrightarrow{2}, 925 \\
2,941\end{array}$ \\
\hline Increase $(+)$ or decrease $(-)$ with alcolıol... & +1 & +8 & -3.4 & -20 & +1.3 & +12 & +16 \\
\hline 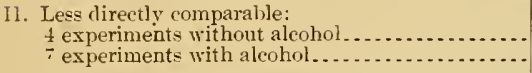 & $\begin{array}{r}100 \\
98\end{array}$ & $\begin{array}{l}2,239 \\
2,400\end{array}$ & $\begin{array}{r}-7.3 \\
-.3 .0\end{array}$ & $\begin{array}{l}-41 \\
-17\end{array}$ & $\begin{array}{l}-2.8 \\
+6.5\end{array}$ & $\begin{array}{l}-22 \\
+61\end{array}$ & $\begin{array}{l}2,302 \\
2,356\end{array}$ \\
\hline Increase $(+)$ or decrease $(-)$ with alcohol.... & -2 & +161 & +4.3 & +24 & +8.8 & +83 & +54 \\
\hline 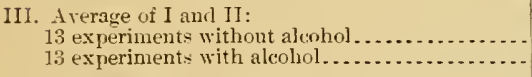 & $\begin{array}{l}102 \\
102\end{array}$ & $\begin{array}{l}2,691 \\
2,750\end{array}$ & $\begin{array}{l}-4.8 \\
-7.1\end{array}$ & $\begin{array}{l}-25 \\
-40\end{array}$ & $\begin{array}{r}.1 \\
+3.8\end{array}$ & $\begin{array}{r}1 \\
+36\end{array}$ & $\begin{array}{l}2,717 \\
2,746\end{array}$ \\
\hline Increase $(+)$ or decrease $(-)$ with alcohol.... & 0 & +59 & -2.3 & -15 & +3.9 & +37 & -33 \\
\hline $\begin{array}{l}\text { Work and rest experiments of Group } \mathrm{J} \text { : } \\
\text { Work experiments compared- } \\
5 \text { experiments without alcolol ...... } \\
3 \text { experiments with alcohol........ }\end{array}$ & $\begin{array}{l}100 \\
100\end{array}$ & $\begin{array}{l}3,337 \\
3,361\end{array}$ & $\begin{array}{l}-5.1 \\
-10.0\end{array}$ & $\begin{array}{l}-27 \\
-56\end{array}$ & $\begin{array}{l}-31.5 \\
-29.2\end{array}$ & $\begin{array}{l}-301 \\
-278\end{array}$ & $\begin{array}{l}3,660 \\
3,690\end{array}$ \\
\hline Increase $(+)$ or decrease $(-)$ witl alcohol... & 0 & +24 & -4.9 & -29 & +2.3 & +23 & +30 \\
\hline 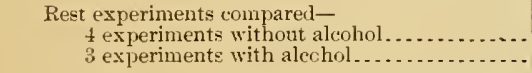 & $\begin{array}{l}106 \\
108\end{array}$ & $\begin{array}{l}2,496 \\
2,489\end{array}$ & $\begin{array}{r}-2.0 \\
-3.8\end{array}$ & $\begin{array}{l}-11 \\
-21\end{array}$ & $\begin{array}{r}+33.7 \\
+34.1\end{array}$ & $\begin{array}{l}+317 \\
+319\end{array}$ & $\begin{array}{l}2,190 \\
2,191\end{array}$ \\
\hline Increase $(+)$ or decrease $(-)$ with alcoliol .... & +2 & -7 & -1.8 & -10 & +.4 & +2 & $\div 1$ \\
\hline
\end{tabular}

The bold-face figures in the last line of each group in the columns for protein and fat give the gain or loss of material and energy in the alcohol experiments as compared with those without alcohol. The plus sign indicates greater gain and the minus sign greater loss with the alcohol than without it.

So far as the available (digestible) nutrients of the food are concerned, the quantities of protein are about the same and the quantities of energy slightly larger with alcohol than without it. Wut with the body material, on the other hand, there was generally a little larger loss of protein and a little larger gain or smaller loss of fat in the experiments with alcohol.

The figures in the last column represent the energy of material actually oxidized; that is, the total energy metaholized in the two elasses of experiments. The full-face figures show by the + sigr: the exces of energy metaholized with the alcohol diet. The values are found by deducting the algebraic sum of the calories of energy gained or lost in protein and fat from the total available energy of the food as indicated by the letters and formule in the column headings. Thus in the first group we have an excess of $+S-(-20+12)=16$ calories of total energy metabolized in the alcohol as compared with the nonalcohol experiments. The same result is found hy compuring the total quantities of energy metabolized, nimely, 2,925 without and $2,9 \pm 1$ with alcohol. The variations in the amounts of body material gained or lost and in the amount of energy metalolized in the two classes of experiments ma be due to either of three canses:

1. Such experimental erroris as irregularities in the daily absorption of the food from the alimentary canal, or variations in the amounts of carbohydrates in the body which are here an-med to be constant from morning to morning, or from experiment to experiment, ol small errors in the estimates of gains or losses of protein and fat from the gains or losses of nitrogen 
and carbou. The-e errors are birdly avoidable, but on the whole they appear to counterlatance one another $-o$ that their ettert i- eliminated in the averages of at considerable number of experinnt-.

2. Difference in the atctivity of the subjects in the two clasesof expeliments. Then differ(nee- are not easy to aroid. The man in the ehamber may make more mu-cular effort on one day than on another in taking dom his hed in the morning and in setting it up at night. or he mily more about more in caring for the food and excretory product-and weighing himelf and $t e$ absorbers. In the work experiments there nuy be differences in the external mu-cular work de-pite the best efforts to make the amount constant from day to dar. These differencr- in musenlar activity. though small. may affect the metabolism of matter and eneroy.

3. The energy furnished by the alcohol mas not be ar efficient, calorie for calorie, in meeting the demands of the hody as the energy from the materials which it replaces. It in hardly to be supposed that the experimental errors in categorie- (1) and ( $(2)$ will be consideralule. It is still less probable that they will be so concentrated in either the alcohol or nonalcohol experiments as to mat rially affect the areruge results. If. therefore, the differences between the figures for the experiments of the two clawes are large and reasonably con-tant, it would seem fair to attribute them to differences in the actual ralue of the aleohol as compared with isodynamic amounts of fats and earbohrdrates.

The tigure- of Table 17 show difference to the disadvantacre of the alcolol. The differences are, horrever, minly within the range of experimental error. ${ }^{\text {a }}$

In the more directly comparable experiments (Group I) the conditions with and without alcohol were closely similar. In Group II there were not inconsiderable differences hetween the amount - of protein and energy in the diet. in the number of subjects. in the number of experiments. and in the amounts of muscular exercise. These differences do not, in our judgment. destroy the value of the comparisons in Group II, though they do make the ditferences in result les- decisive. The result - of Group II are, therefore, valuable as contirming those of Group I.

Gains and loss of broly material us indicative of the relative effectiveness of alcohol.-The

differences in the gain or loses of protein and fat in the experiments with alcohol as compared with the other are slightly to the disadrantage of the al ohol. They thus imply that. calorie for calorie, the energy furni-hed to the body by the alcohol was less effective than that furnished by the carbohrdrates and fats. These differences ma be due to experimental error. but even if they are wholly charged to the alcohol they make it only slightly inferior to the nutrient: which it replace-. The inferiority is found only in the work experinents; in the rest experiments there is practically no difference between the alcohol and the ordinary nutrients in effectiveness.

Amounts of energy metabolized as indicative of the relative effectiveness of alcohol. - The results here are similar to those found in the comparison of gains or losies of material. This is to be expected, since the two measares are really different expressions of the same fundamental fact. In the rest experiments the results with and without alcohol are practically identical. The inferiority of the alcohol is limited to the work experiments.

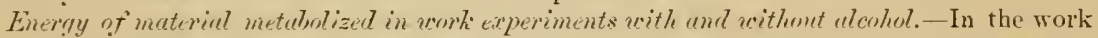
experiments more material was oxidized than the food supplied, and the defieiency was made up br drafts upon the previously accumulated store of body protein and fat. Under these circumstances the boly may be supposed to use the energy economically so as to make the draft s upon

"The differences between the results with and without alcohol are in all cases small. Considering them from the orlinary mathematical standpoint, they are, of course, noticeable; but in such physiological experimenting as this the unavoidahle errors of individual experiments are consilerable, and it is only when a large number of such experiments are averagerl that differences of one or two parts in one liunilred could properly be regarded as significant. Indeed, in this whole discussion there is danger of being misled by the figures in the tables nnless one constantly recalls the lact that the range of unavolable variation is wide. When, however, the averages of large numbers of experiments show a constant difference on one sile or the other, it may be permissible to use such differences for conchsions and generalizations. On the whole, it night seem that in these experiments the results were sufficiently numerous to imply a slight inieriority of the alcohol in respect to the economy of the 11 se of energy: but this inierence rests upon the rather questionable assumption of the absolute equality of all conditions other than the presence or absence of alcohol in the diet. 
its capital as small as practicable. It would therefore seem that the amounts of material oxidized in the experiments with the two kinds of diet would give a somewhat eritical test of the power of the body to utilize the energy of alcohol, either directly for muscular work or indirectly to silve the energy of other materials for that work. $W \mathrm{c}$ may, then, determine the relative efficiency of the alcohol in supplying energy in these experiments by comparing the amounts of energy in material oxidized. If the amounts are the same with and withont alcohol the inference is that the energy of the alcohol was utilized as effectively. so far as simply the economy of energy is concerned, as that of the fats and carbohydrates: but if more energy is metabolized with the alcohol we must conclude that it is inferior as a source of energy in a diet for muscular work. Tre may take, for instance, the pair of experiments Nos. 11 and 12, in which the man was at hard work. (See Table CXX, p. 390.) His body used, in No. 11, with ordinary diet, 3,901 calories of energy per day. The food digested and absorbed from the diet supplied 3,510 calories, and the body burned enough of its previously accumulated material, protein and fat, to supply the lacking 391 calories.

In the corresponding alcohol experiment, No. 12, enough of the fats, sugar, and starch of the previons diet to furnish about 500 calories of energy was taken out and replaced by sufficient alcohol to furnish approximately the same amount, 500 calories. It happened that the total energy in the alcohol ration was abont 30 calories the larger. Furthermore, the availability of the food proved to be slightly larger, so that the whole available energy of the alcohol ration was $3,61 t$ calories. The amount of work done and the other conditions were practically the same as in the previous experiment. The hody transformed 3,922 calories and in order to do so drew enough from its own store to furnish 308 calories.

According to these figures the body burned a trifle more material in the alcohol experiments than in the others-enough to furnish 3,922 instead of 3,901 calories of energy. But the alcohol diet furnished, with the alcohol, a somewhat larger amount of total energy, and furthermore a somewhat larger proportion of the nutrients of the ordinary food was digested, so that the body had $10+$ calories more of a vailable energy. The fact that it drew 83 calories less from its previously stored material in this experiment than in No. 11 indicates that it used its energy economically. In each of these two cases the daily amount of external muscular work measured was equivalent to not far from 200 calories. In the first experiment all of this came from ordinary food. It may be that in the second experiment likewise it all came from the reduced supply of the ordinary food, and that none of the energy actually transformed into muscular work came from the alcohol. There is, however, no reason to suppose that the body made any distinction betreen the energy from the alcohol and that from the other fuel, and even if it did so it made just as good use of the energy of the alcohol to meet its other needs as it did of the energy of the ordinary nutrients.

The test of the comparative economy of the two diets so far as concerns the supply of energy is found in the amount of energy of material oxidized. This was 20 calories, or about 0.6 per cent the larger in the alcohol diet. This is far inside the limit of experimental error. Indeed, the quantity of energy given off from the body as measured by the respiration calorimeter was 5 calorjes larger with the ordinary than with the alcohol diet. (See Table CXX of the Appendix.) Of course such differences have practically no significance in physiological experimenting.

The results of the experiments in their bearing upon the subject are summarized herewith:

Serage amounts of energy in material oxidized.

[Calories per day.]

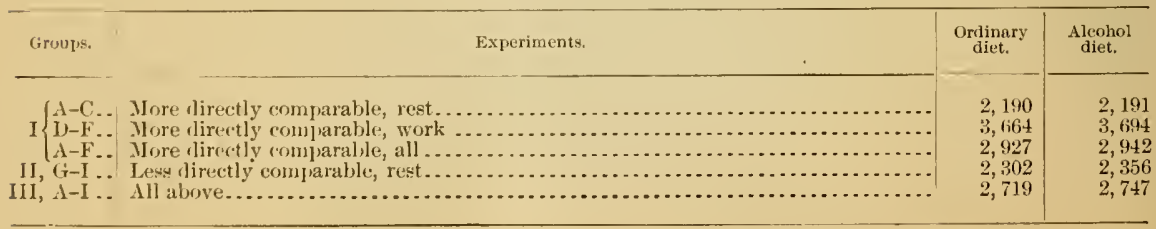




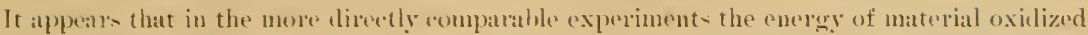

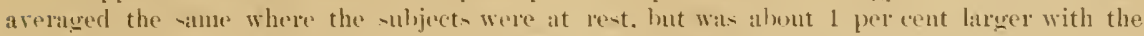
aleohul when they wre at work. In the lex- direetly comparable experiments, in all of which

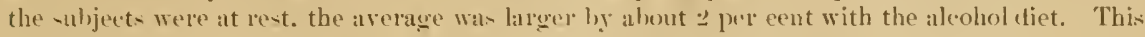
is perhaps no more than was to be expected with the slight ditlerences in the conditions of the experiments.

In this methed of comparion by anount-of material and enerer oxidized, as in the previous method, the differences were too smill to be taken into aceount in individual experiments. but appearing an they do in the average of a mumber of experiments they are not without significance. The com lusion i- that the enery of the alcohol diet was slightly less eenomically weel than that of the ordinary diet. especially in the work experiments. This implies that the energy of the aleohol itself was les. peomonically utilized than that of the fats and carbohydrates. Int the ditfereness are io surall at to be of little or no practical eonsequence.

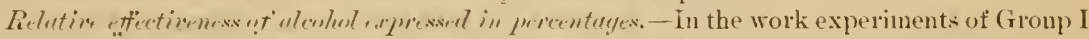
3.ritit calories" were metabolized with the ordinary. and 3.694 with the alcohol ration. The relative costs of mantainiug the boty with the two rations were thus $3.664: 3.694=101): 110$.

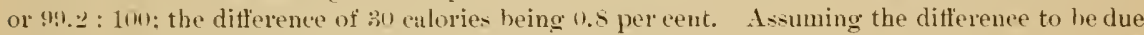
wholly to the inferiority of the alcohol ration. its effeetivenes. ealorie for calorie. would he y9.2 per cent of that of the ordinary ration, so tar as the energy is concerned.

The aleohol supplied 511 calories of energy. of which the so ealories would represent ti per cent. If we charge the deficit wholly to the alcolwol. the latter would be, calorie for calorie. i per cent less effeetive than the fats and arbohydates it replaced. In other words, the effectiveness of the alcohol as a soure of nergy in the ration for nuscular work in this cuse would be 94 per cent of that of the isodynumic amounts of earbohydrates and fats.

Caleulated in these ways the etfectiveness of the aleohol ration as compared with the ordinary ration. and that of the alcohol as compared with earbohydrates and fats in the experiments of Groups I-III. would be as follow: :

Perrentage uf ifiectiveness of energy.

Experiments.
tirulw.

smmmum. The conditions and results of these experiments and the inferences here drawn from them reatrding alcohol as a soure of museular euergy may be hriefly summarized:

1. We hare here experiments with ordinary diet enpared with other experiments in which the conditions were similar except that carbohydrates and fats sufficient to supply jur ealories of energy of the 2.20 -3.6no ealories in the daty ration were replaced by the isodynamie amount (about $i z$ grams) of alcohol, the latter being taken in six doses. The conditions of work and rest were rery nearly the same in the eorresponding experiments, with and witlout alcohol.

2. The amounts of material and energy trunstormed in the experiments with aleohol were very nearly the same as in the corresponding ones without aleohol. Where the ration was insitfieient to meet the needs of the body, and it had to draw upon its store of fiat and protein to supply the lacking energy. the drafts were pratically the same with the ordinary as with the alcobol diet. so far as concerns the energy of the body material dram upon.

3. The utilization of the energy of the whole ration was slightly less eeononical with the alcohol than with the ordinary diet, especially when the subjects were at hard musular work. 
but the difference in filror of the ordinary food was very small indeed, hardly enough to be of pratetical consequence. From this it follows that the energy of the alcohol was utilized very nearly or yuite as well as that of the other fuel ingredients which it replaced.

i. That the alcohol contributed its share of energy for muscular work is a matural hypothesis and rery probahle, but not absolutely proven. The hypothesis that the energy of the alcohol was not so nsed, is not called for as an explanation of any fact observed in these experiments.

It should not be forgotten that the desirahility of alcohol as part of a diet for muscular work is not decided by the narrower questions here discussed. There is a rery essential difference between the transformation of the potential energy of alcohol into the mechanical energy of muscular work and the advantage or disadvantage of alcohol in the diet of people engaged in muscular labor. Even with the small doses in these experiments there rere indications that the subjects worked to slightly better advantage with the ordinary rations than with the alcohol. The results of practical test on a large seale elsewhere coincide with those of general observation in implying that the use of any considerable quantity of alcoholic beverages as part of the diet for muscular labor is generally of donbtful value and often positively injurious." Aside from the question of the power of alcohol to protect protein and fat and supply energy to the body for varions useful purposes, there are the far weightier considerations of the general effect of alcohol upon the muscular and especially the nervous system and upon health and welfare. Upon these most serious hygienic, economical, and ethical problems the experiments here reported throw no special light.

"For a summary of results of experiments upon various phases of this subject by different investigators, see article by Prof. J. H. ABeL in the Report of the Physiological Subeommittee of the Committee of Fifty for the Investigation of the Drink Problem. (See page 261 of this memoir.) 


\section{SLMYATY OF PLAN AND RE-LLTS UF TIIF EXPERIMFNTS.}

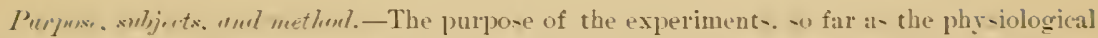
action of alcohol is concerned. was primarily to get light upon the way- by which it-potential energr is tran-formed and utilized in the hody, hut attention ma-al-o gireu to the effect-of alcohol upon the dige-tion of the food taken with it, the proportion of alcohol that rere uxidized and e-caped oxidation, and it-effect- upon the metaholi-m of carhon and nitrogen and the gain and loss of fat and protein in the body.

The subject- were three roung. healthy, active men who were ordinarily engaged in rather light work: one wa- a lahoratory awi-tant. one a phy-ici-t. and one a chemi-t in the chemical lahoratory of Wesleran Enirer-ity, where the experiment- were made. The firs. E. O.. a Swede by hirth. had been aceustomed from hi- routh to drink -mall yuantities of alcoholic beverage: : the other two. A. W. S. and .J. F. S.. had alway - been ah-tainer-

The re-ult of experiment- with ordinary diet were compared with thowe of experiments in which part of the fats and carbohrdiate of the ordinary food were replaced br the isodrnamic

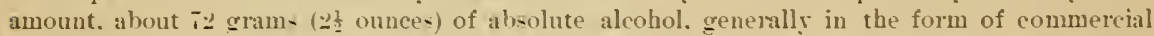
alcohol, though in one experiment brandr and in another whiskr wa- used. The amount of alcohol ma- about as much a- would be supplied in a bottle of claret. or bs ounces of whisky, or 5 ounces of hrandy,

The ordinary diet consi-ted of meat, milk. hread, cereal-, butter, -ugar. and the like, with. in some case-. cotfee. The quantitie- were -uch a- had been found to be sufficient, or nearls so. for meeting the demand of the hodr under the conditions of the experiments, whether of rest or muscnlar work. The method, of preparation were such as to make the food palatable to the subject.

During the metaboli-m experiment- proper the subjects mere in the chamber of the respiration calorimeter, where ther remained during period-rarring from $t$ to 9 dars. The sojourn wa- made comfortable and the conditions seemed to he normal. Each metabolism experiment or series of experiments in the respiration chamber was preceded br a period during which the subject had es-entially the same diet and nearly the same amount of muscular exercise outside the chamber. In these preliminary experiments the amounts. composition. and heats of combustion of the food. feces. and urine were determined. In the metabolism experiments the determinations include besides these the water and carbon dioxide of the incoming and ontgoing air current hy which the chamber was rentilated, the heat given off from the hodr. and. in the work experiments. the heat equivalent of the muscular work done. In the alcohol experiments the determinations were made of the small amounts of alcohol excreted br the kidners. lungs. and skin.

Accordingly the data of the metabolism experiments show the income aud outgo of the bodr as expresed in terms of (a) nitrogen, carbon, and hrdrogen: (b) water, protein, fats, carbohrdrates, and mineral matter: (c) potential energy of food and unoxidized excreta. and (d) kinetic energy of heat given off from the body and external muscular work performed. The accuracy of the apparatus and method were a--ured by burning alcohol within the chamber measuring the amount- of carbon dioxide. water. and heat produced. Such te:t- were made generally bettreen each two experiments or experimental serien. Taking the theoretical amounts at $1(0)$, the arerage amounts found were carbon dioxid. 49.6: water. 101.6; heat, 99.9.

In the so-called "rest" experiment- the subject had no more muscular exercise than was involved in dressing and undressing. weighing himself, arranging his folding bed. chair, and tahle. 
and cariny for the food and solid and liquid excreta. His diversion was found m reading. writing. and occusional converstion by telephone with persons ontside. In the "work" experiment- the sulject engaged in the active muscular exercise of riding a stationary bicycle for eight hours or thereahouts per day. The wheel of the bicyele was belted to a dynamo conneeted with an clectric lamp. so that the muscular porer which was applied to the pedals was converted partly into heat by friction but mainly into electrical energy and then into heat. The apparatus Was calihrated so as to serre as an ergoneter for measuring the external muscular work.

In interpreting the results in their bearing upon the physiological action of alcohol. it should be particularly noted that the whole amount of alcohol ingested per day was small and that furthermore it was taken in 6 doses, 3 with meals and 3 betreen meals. The object of the experiments was to tudy the action of alcohol under conditions calculated to secnre the minimum of influence upon the nerrous system. With such small doses, the equiralent of a glass of wine each. and thus distributed, two of the subjects were able to detect practieally no seusible effect of the alcohol, while the third, J. F. S., felt nothing more than at times a slight " tingling" in the ears. There was in some cases an apparent though slight quickening of pulse rate, but practically no lowering of body temperature was observed. In such freedom from nerrous disturbance it wis believed that the normal nutritire action would be best observed.

There is the more reason for emphasizing this last point, because in the majority of the published experiments with men and animals for the study of the effects of alcohol the quantities of the latter have been much larger. Doses of 1 to $1 \frac{1}{2}$ grams per kilogram of body have commonly been considered small, and those of 2 to 3 grams per kilogram have been common and generall taken on an empty stomach. Often the amonnts hare been such as to cause the symptoms of drunkenness. In our experiments, on the other hand, the whole amount per day was oniy about 1 gram per kilogram body weight; the indiridual doses were only about one-sixth of a gram per kilogram. and half of them were taken with meals. This fact doubtless accounts for a not inconsiderable share of the differeuce between the results of our experiments and those found by a number of other investigators.

While the quantities of aleohol were small, the energy sufficed to make about one-fifth of the total energy of the diet in the "rest," and one-seventh of the total energy of the diet in the "rork" experiments.

It is to be especially noted that these experiments were not made to test the effects of alcohol upon muscular or nerrous actirity or power, nor do they lead to any conclusions regarding the effects of alcohol when taken habitually or in large quantities.

The otwerned results.-The results, as shown by the statistics of the experiments, may be briefly stated as follows:

1. The quantities of alcohol eliminated by the lungs, skin, and kidneys raried from 0.7 to 2.7 crams. and averaged 1.3 grams per day (see p. 25s). This corresponds to an areragc of 1.9 per cent of the whole alcuhol ingested. Accordingly orer 95 per cent of the ingested alcohol was oxidized in the body. There is. howerer, reason to believe that 99 per cent would more nearly represent the proportion actually oxidized.

$\therefore$. The experiments give clata for comparing the availability and fael value of alcohol with those of the nutrients of ordinary food. The word "availability " as here applied to the ordinary nutrients. expresses the proportion which is digested and made arailable for the building and repair of tisise and the yiclding of energy. This proportion is the difference between the total amomnt and that excreted by the intestine. In like manner the avalable alcohol would be the difference between the totul amount ingested and the amount excreted by the lungs, skin, and kidneys. practically none being excreted by the intestine. The available energy of the ordinart mutrients is the total energr (heat of oxidation) less that of the material unoxidized. For fats. carlolydrates. and alcotiol it is the heat of oxidation of the total arailable material. For the protein it is the same. less the heat of oxidation of the unoxidized residue excreted ly the kidney $\%$. The available energy is taken as the measure of the fuel value. The following table compares the coefficient of arailability and the fuel values of the protein. fats, and carbohrdrates of ordinary 
diet. a found by a considerable number of experiments." with those of the alcohol as shown ly the experiment- here reported.

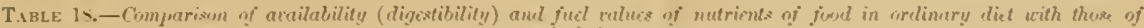
rilculorl.

\begin{tabular}{|c|c|c|c|c|c|c|c|}
\hline & \multirow{3}{*}{$\begin{array}{l}\text { Heat oi } \\
\text { combustion } \\
\text { per gram. }\end{array}$} & \multicolumn{2}{|c|}{$\begin{array}{l}\text { Cuefficieuts of availabil- } \\
\text { ity- }\end{array}$} & \multicolumn{4}{|c|}{ Fuel vulues. } \\
\hline & & \multirow{2}{*}{ of waterial. } & \multirow{2}{*}{ wi eneryy. } & \multicolumn{2}{|c|}{$\begin{array}{l}\text { Referterl to arailable ma- } \\
\text { terial. }\end{array}$} & \multicolumn{2}{|c|}{$\begin{array}{l}\text { Referred to total mate- } \\
\text { rial. }\end{array}$} \\
\hline & & & & Per gram. & Per pouna. & Per sram. & Per pound. \\
\hline 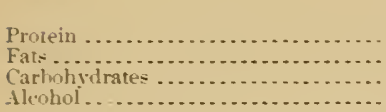 & $\begin{array}{l}\text { Calorics. } \\
5.05 \\
9.40 \\
+.10 \\
7.07\end{array}$ & $\begin{array}{r}\text { Per cent. } \\
42 \\
95 \\
47 \\
94\end{array}$ & $\begin{array}{r}\text { Per cent. } \\
70 \\
9.5 \\
97 \\
95\end{array}$ & 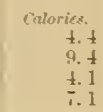 & 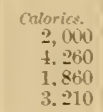 & $\begin{array}{r}\text { Culorics. } \\
\quad \text { 4. } 0 \\
\quad .9 \\
\text { 4. } 0 \\
6.9\end{array}$ & 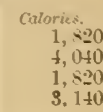 \\
\hline
\end{tabular}

The isodrnamic ralues of alcohol, earhohrdrates, and fats are thus in the ratios of $1.9 .9: 4: 8.9$. and 1 gram of alcohol would be isodrnamic with 1.73 grams carbohydrate or 0. Ts gram of fats of ordinar food materials.

3. The proportion - of food and of the sereral kinds of nutrients digested and macle arailable fol" use in the bodr were practically the same in the experiments with and those without alcohol in the diet. The only difference worthy of mention was in the proportions of protein made arailable. These were rerv slightly larger with the alcohol. but the difference was too small to be of practical consequence. In all the experiments. both those with and those without alcohol, the result - agree verr closels with those commonly found in digestion of food in ordinary mixed diet hr healthr men.

4. The potential energy of the alcohol was transformed in to kinetic energy in the body as completely as that of the ordinars nutrients. The income and outgo of energs were equal in the experiments without alcohol: the same was true in the experiments with alcohol. In all the experiments the body obeyed the law of conservation of energy.

5. With the exception of the energy of the external muscular work in the work experiments. all of the energs of the food. including that of the alcohol. left the body as heat. and must therefore hare been transformed into heat within the body. Part of this total energy must hare heen used for the internal mechanical (muscular) work: the energy thus used was therefore transformed into beat before learing the hodr.

6. The radiation of heat from the body was rery slightly greater with the alcohol diet than with the ordinary diet. but the difference was extremely small-enough to make only about 1 per cent of the whole energy metaholized and not orer 5 per cent of the energr of the alcohol.

i. The efficiency of alcohol in the protection of body fat from consmption was very erident. The Iosses of fat were no larger and the gains no smaller with the alcohol diet than with the corresponding diet without alcohol. In this respect there was no indication of any considerable difference betreen the alcohol and the nearly isodrnamic amounts of fats and carbohrdrates which it replaced. This mas the case in all the experiments.

S. The efficiency of the aleohol in protecting body protein was evident. but it was not fully equal in this respect to the isodynamic amounts of the ordinar nutrients. The results, howerer, were not the same with the different subjects. With E. O.. who had been acustomed to use alcoholic bererages, the differenees betreen the alcohol diet and the ordiuary diet in their apparent effect upon nitrogen metabolism were small. The figures shomed a slightls larger output of nitrogen with the alcohol. but the differences were not large enough to be of especial significance. With A. W. S.. who was unaceustomed to alcohol, its use in the place of other

see discussion of this subject by W. O. A TwATER and A. P. BRrivt in the Report of the storrs (Conn.) Exprerment Station for $18 \% 9$, irom which the figures ior ordinary nutrients in the table are taken. 
nutrients resulted. at first, in an increased excretion of nitrogen in the mine and inferentially a greater catabolism of protein, but after 5 or 6 days the ontput of nitrogen fell to what seemed to be the amount with ordinary diet, and when the alcobol was remored and diet thus reduced there was an increase in the output. These results implied that the alcohol at first failed to protect protein but was afterwards able to do so. There was, however, but one series of experiments with this subject. With J. F.S. also an abstainer, the alcohol periods covered only 3 days, during which there was in each case an increased nitrogen catabolism. On the whole these experiments accord with the belief that with some persons, especially those who are not accustomed to the use of alcohol. it may fail to protect protein: but this action is temporary and the more permanent influence is to protect protein.

9. That a part of the potential energy of the alcohol was transformed into the kinetic energy of muscular work these experiments do not prore, though they make it highly probable. They imply that, so far as the utilization of the total energy of the diet was concerned. there was a slight adrantage in economy in faror of the ordinary as compared with the alcohol diet, especially when the subjects were at hard muscular work. but the difference was inside the limits of experimental error and too small to be of practical consequence. On the average it was less than 1 per cent of the total energy and hardly reached 5 per cent of the energy of the alcohol. From this it follows that the energy of the alcohol was utilized nearly if not quite as well as that of the fats. sugar, and starch which it replaced.

10. We repeat that there is a very essential difference between the trausformation of the potential energy of alcohol into the kinetic energy of heat, or of either internal or external muscular work, and the usefulness or harmfulness of alcohol as a part of ordinary diet. Regarding this latter question the experiments bring no more eridence than they do regarding the influence of alcohol upon the nervous system or its general effect upon health and welfare. 


\section{APPENDIX.}

The detail of the experiment-dercribed above are set forth in the folloming pages, and include:

1. Kind of experimental data and methods for obtaining them.

2. Statistical details of metaholism experiments with alcohol.

3. Statistical cletails of digestion experiments with alcohol.

t. Tabular summaries.

A list of the experiment., with grouping for comparison. mar be found in Table 1 , on page 241 of the first part of this report. As there explained, the metabolism experiments here described in detail were made with aleohol as a part of the diet. They are compared with similar experiments without alcohol. which have been described in detail elsewhere. Each metabolism experiment or series of metabolism experiments with or without alcohol not only included a dige-tion experiment, but was alio preceded by such an experiment. The data of these digestion experiments are also given beyond. The experiments without alcohol and two of those with alcohol have been described $i$ detail elsewhere. In reveral instances the results are here summarized with the details of the aleohol experiments.

\section{DATA.-FXPFRIMENTAL METIODS.}

\section{METABOLISM EXPERIMENTS.}

The larger part of the statisties of the metabolism experiments have to do with the ineome and outgo of material and energy.

Eriprimentul dutn of incrome. - These inclucle statisties of the kinds. amounts. composition. and potential energy of food and drink. the volume of the ventilating current of air entering the chamber and the amount of carbon dioxide and water in that air. The food for each experiment was selected before the experiment began and the desired amounts for different meals were placed in suitable jars, as deseribed on page 239. Such of the analytieal determinations as were necessary for the control of the diet. in order to insure the desired amount of protein and energy. were made previons to the beginning of the experiment.

Erperimentril duta of metgr.-These include statisties of the amount. componition. and heat of combustion of the unoxidized materials of feces and urine, the puantity of earbon dioxid and water in the air learing the chamber. and the total energy given off by the body in the form of heat and external museular work.

Alpumetus and genemel methorls "f' inprisy. - The respiration "alorimeter and method of its use have been deseribed in detail in publications referred to on page $23 t^{a}$. The methods of analy-is of food. feces, and wine were, in the main, those adopted by the Association of Ofticial Agricultural Chemists." but with certain modifications which lave been developed in this labolatory. ${ }^{c}$ The heats of combustion were determined by nse of the bomb calorimeter. ${ }^{d}$

Bulletins $44,63,69$, and 109 of the Othce of Experiment stations of the $\mathrm{C}$. . . Jept. Agr.

'See Bulletin 46 , revised, of the Division of Chemistry, U. \&. Dept. Agr.

see L. s. Dept. Agr., Office uf Experiment Stations, Bul. 4, p. 22; Bul. 69, p. Is, and Report of storrs (Conn.) Expt. Sta., 1591, p. 47 . The methods for the determination of carbon and hyilrogen in use in this laboratory are deseribed in detail by F. (․ Bexedset in Elementary Organic Analysis, The Chemical Publishing Co, on page 51 wi which the apparatus is pictured.

dThe bomb calorimeter and accessory apparatus used have heen described lw $W$. $U$. ATw ATER and associates in Bulletin 21 of the Office of Experiment stations of the L. $\therefore$. Dept. Agr., 1. 123, and in the Reports of the kitorrs (Conn.) Expt. Sta., 1s94, p. 133, and 159i, p. 199. 
Further descriptions of experimental methods are given in connection with the descriptions of experiment 12, beyond.

Cimposition of fool materials and feces. - The figures for the analyses of the food materials and feces of the alcoholic experiments here described are giren in Tables I and II.

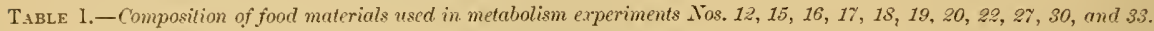

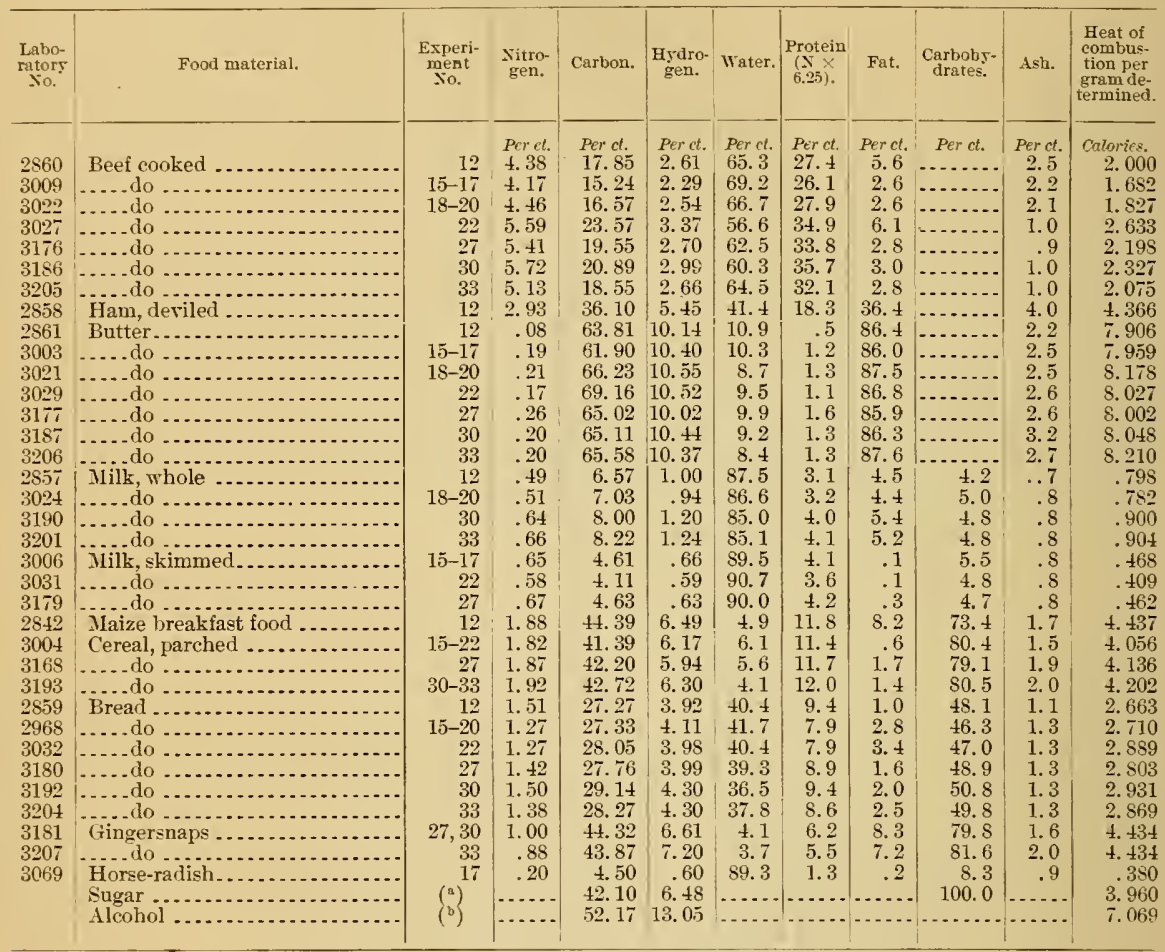

C Esed in all the experiments.

"As pure ethyl alcohol.

TABLE II.-Comprosition of feces in metabolism experiments Nos, 12, 15, 16, 17, 18, 19, 20, 22, 27, 30 , and 83 .

\begin{tabular}{|c|c|c|c|c|c|c|c|c|c|c|c|}
\hline $\begin{array}{l}\text { Labo- } \\
\text { ratory } \\
\text { Sio. }\end{array}$ & & $\begin{array}{c}\text { Experi- } \\
\text { ment } \\
\text { No. }\end{array}$ & $\begin{array}{l}\text { Yitro- } \\
\text { gen. }\end{array}$ & Carbon. & $\begin{array}{c}\text { Hydro } \\
\text { gen. }\end{array}$ & Water. & $\begin{array}{c}\text { Protein } \\
\left(\mathrm{X}^{2} \times\right. \\
6.25) .\end{array}$ & Fat. & $\begin{array}{l}\text { Carbohy- } \\
\text { drates. }\end{array}$ & Ash. & $\begin{array}{l}\text { Heat of } \\
\text { combus- } \\
\text { tion per } \\
\text { gram de- } \\
\text { terminer. }\end{array}$ \\
\hline $\begin{array}{l}2863 \\
3008 \\
3033 \\
3035 \\
3184 \\
3196 \\
3210\end{array}$ & 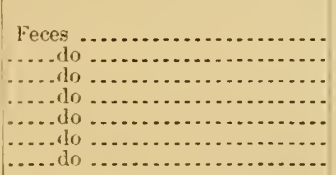 & $\begin{array}{r}12 \\
15-17 \\
18-20 \\
22 \\
27 \\
30 \\
33\end{array}$ & $\begin{array}{l}\text { Per rt. } \\
1.35 \\
1.57 \\
1.62 \\
1.59 \\
1.53 \\
1.43 \\
1.37\end{array}$ & $\begin{array}{l}\text { Prert. } \\
13.05 \\
14.85 \\
14.03 \\
14.41 \\
12.26 \\
13.53 \\
13.22\end{array}$ & $\begin{array}{l}\text { Fcret. } \\
1.85 \\
2.07 \\
1.94 \\
2.07 \\
1.10 \\
1.89 \\
1.92\end{array}$ & $\begin{array}{l}\text { Perct. } \\
74.1 \\
6.3 \\
72.6 \\
69.3 \\
69.5 \\
71.2 \\
71.0\end{array}$ & $\begin{array}{r}\text { Perd. } \\
8.4 \\
9.5 \\
10.1 \\
9.9 \\
9.6 \\
8.9 \\
8.5\end{array}$ & \begin{tabular}{r|} 
Perct. \\
7.0 \\
5.6 \\
6.3 \\
5.2 \\
2.9 \\
4.5 \\
5.0
\end{tabular} & \begin{tabular}{r|} 
Perct. \\
6.1 \\
8.6 \\
6.3 \\
8.5 \\
9.7 \\
9.8 \\
9.4
\end{tabular} & $\begin{array}{c}\text { Perct. } \\
4.4 \\
7.7 \\
4.7 \\
7.1 \\
8.3 \\
5.6 \\
6.1\end{array}$ & $\begin{array}{r}\text { Calaries. } \\
1.473 \\
1.675 \\
1.571 \\
1.610 \\
1.335 \\
1.487 \\
1.452\end{array}$ \\
\hline
\end{tabular}




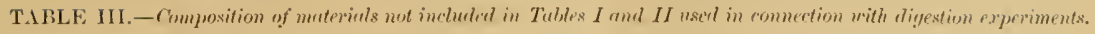

\begin{tabular}{|c|c|c|c|c|c|c|c|c|c|}
\hline $\begin{array}{l}\text { Labur- } \\
\text { atory" } \\
\text { No, }\end{array}$ & Material. & $\begin{array}{l}\text { Digestion } \\
\text { expriment } \\
\text { No. }\end{array}$ & Nitrogen. & Water. & Protein. & Fat. & $\begin{array}{l}\text { Carbohy- } \\
\text { ilrates. }\end{array}$ & Ash. & $\begin{array}{l}\text { Heat of } \\
\text { combuntion } \\
\text { lergram. } \\
\text { (deter- } \\
\text { minedl.) }\end{array}$ \\
\hline $2 \$ 45$ & Milk & 47 & $\begin{array}{l}\text { Per ernt. } \\
0.50\end{array}$ & $\begin{array}{r}\text { Per cent. } \\
90.48\end{array}$ & $\begin{array}{l}\text { Perent. } \\
\text { 3. } 13\end{array}$ & $\begin{array}{l}\text { Per cent. } \\
\quad 0.10\end{array}$ & $\begin{array}{l}\text { Per cent. } \\
\quad 5.52\end{array}$ & $\begin{array}{r}\text { Pererut. } \\
0.77\end{array}$ & $\begin{array}{l}\text { Fituries. } \\
\qquad 0^{2}\end{array}$ \\
\hline $28+6$ & ... do ...... & $4 \mathrm{~s}$ & .53 & 90.36 & 3. 31 & .11 & 5.45 & .77 & 414 \\
\hline 2856 & ...do. & 51 & .53 & 85.88 & 3. 31 & 5.00 & 5.07 & .74 & 865 \\
\hline 3005 & ....do & $\$ 0$ & .64 & 80.44 & $3.9 \mathrm{~s}$ & .06 & 5. 136 & Sitj & 467 \\
\hline 2809 & Fecer .............. & +1 & 1. 89 & 71. 44 & 11.79 & 5.38 & 6.133 & 4. 76 & 1,564 \\
\hline 2810 & ... do ............. & 42 & 1. 81 & 70.96 & 11.30 & 4.95 & 7.183 & 5. 16 & 1,530 \\
\hline $28+7$ & ... do .............. & 47 & 1. 48 & 73.37 & 9. 28 & 3. .44 & $9.0 \times$ & 4. 43 & $1,34 ! 4$ \\
\hline $28+6$ & . . do . . . . & $4 \mathrm{~S}$ & 1.57 & 71.01 & 9.83 & 4. 15 & 10. 21 & 4. 50 & $1,+45$ \\
\hline $2 \times 62$ & $\ldots$... do .. & 51 & $1 .+7$ & 70.32 & 9.20 & 7.56 & 7.42 & 5. 50 & 1,598 \\
\hline 3007 & ... do .. & 80 & 1. 68 & 62.69 & 10.53 & T. 17 & 12.03 & 7.58 & $2,06 \mathrm{~s}$ \\
\hline $303 t$ & .... do .. & 83 & 1.75 & 68.75 & 10.93 & 5.68 & 7. 60 & 7. 04 & 1. $56 \mathrm{~s}$ \\
\hline
\end{tabular}

Comprasition of coffie infusiom.-Coffee infusion was prepared by pouring boiling water orer ground coffee and straining the infusion thus obtained. The nitrogen was determined in this infusion and found to amount to ahout 0.004 grams per liter-quantities too small to be taken into account. The coffee infusion is therefore reckoned simply as so much water.

\section{STATISTICAL DETAILS OF METABOLISM EXPERIMENTS.}

The details of the methols of condueting the experiments and of computing the results. as well as the statistital tahles in which these results are presented, will be adrantageously given in connection with the description of one of the experiments. For this purpose we select No. 12. which is the first in consecutive order of those here described in detail.

EXPERIMENT NO. 12-WORK WIT11 ALCOIIOL DIET.

Subject.-E. O., laboratory assistant, 31 years of age and weighing, without clothing, about 71 kilograms (157 pounds).

Dceupution dering experiment. - Work 8 hours a day upon a stationary hiegele belted to a

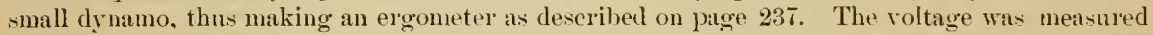
and the current passed through resistance within the apparatus and thus transformed into heat and measured with the heat given off by the subject. Previous calibration showed the anount of work done in driving the bicyele.

Durutiom.-Preliminary period $t$ days, beginning with breakfast April s, 1s:ts, and experiment proper $t$ days, beginning at 7 a. m. April 12 and endiug at 7 a. m. April 16 . The subject entered the respiration chamber on the evening of April 11 and thus spent 5 nights and 4 days within the ealorineter.

Diet.-Ordinary food furnishing 121 grams of protein and 3,379 ealories of energy, and in addition 72.4 grams of alcohol furnishing 512 ealories of energy, making the total energy of the cliet 3,851 calories. The alcohol was added to a sweetened coffee infusion. It was taken in if doses, 3 with the meals and the other 3 hetween meals and just before retiring. The cotfee infusion was prepared in the usual manner, eare being taken to keep that given to the subject free from particles of coffee. To 630 grams of infusion were added 50 grams of sugar and so grams of commercial ethyl alcohol containing 90.63 per eent absolute alcohol. The so grams of commercial alcohol thus contained 72.4 grams of absolute alcohol and 7.5 grams water. The diet was practically the same during both the preliminary digestion experiment and the metaholism experiment proper. The kinds and amount of different food materials taken at each meal and the amounts of coffee infusion and water consumed at different times during the day are shown herewith. 
Diet in metabolism experiment No. 12.

FOOD.

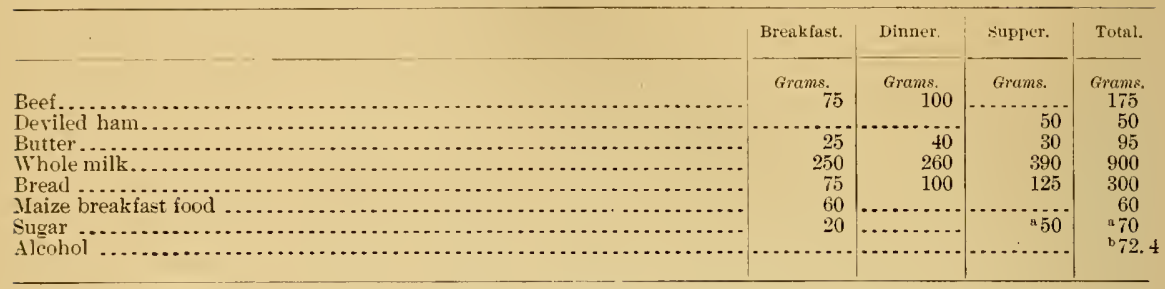

DRINK.

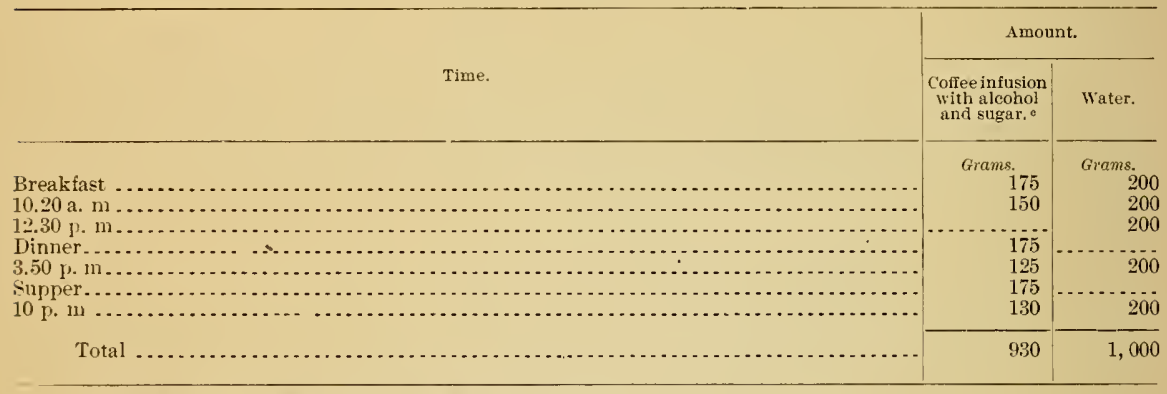

Including 50 grams used in coffee infusion and alcohol.

bdderl to coffee infusion and taken as indicated below.

" Harle by adcling 80 grams of 90.5 per cent commercial alcohol and 50 grams sugar to 800 grams coffee infusion. The mixture then contained 807.5 grams water, 72.4 grams absolute alcohol and 50 grams sugar.

Daily routine.-In order to make the conditions of the experiment on the different days as nearly uniform as practicable a daily programme was drawn up and one copy was given to the subject within the respiration chamber while other's were posted outside for the use of those carrying on the details of the experiment. The routine in experime. It No. 12 was as follows:

Intily program- Sotabolism experiment No. 12.

7.00 a.m...... Rire, paso urine, collect drip, weigh absorlers, weigh self stripped and iressed.

7. 55 a. m. ..... . Breakfast, llrink 200 grams water.

8.20ia. m...... Bergin work.

$10.20 \mathrm{a} . \mathrm{m} . . . .$. Rest 10 minutes, 1 rink alcohol, drink 200 grams water.

10.30 a. m...... Be.gin work.

12.30 p.m...... . Stop work, lrink 200 grams water.

1.00 r. m...... l'as urine, (wollect rlrip, weigh absorly-

$1.15 \mathrm{I}, \mathrm{m} \ldots . . \mathrm{E}$ Dinner.
1.50 p. 1n ...... Begin work.

3.50 p. $1 \mathrm{~m} . . . .$. Stop work, rest 10 minutes, trink alcohol, drink 200 grams water.

4.00 p. in ..... Begin work.

6.00 p. 1 ...... Stop work.

6.30 p.m...... Supper, change underclothes, weigh self stripperl and tressed.

7.00 p. m..... Pass urine, (wllert drip, weigh absorbers.

10.00 1. 111 . . . . . Take cover off food aperture, drink 200 grams water, retire.

1.00 a. $11 . . .$. Pass urine.

The subject weighed himself, with and without clothing, at ahout $\tau$ a. m. and 7 p. m. each day of the experiment. He olserved his pulse rate, after intervals of rest, and took his body temperature from time to time by means of a registered itinical thermometer. The body temperatures wore measured sul, limgur. We do not think that great reliance an be placed upon observations for aitber pulie rate or temperature when made hy the subject upon bimself under surh conditions.

A hygrometer inside the hamber was observed two or three tims each day in order to give data concerning the anount of watel vapor within the calorimeter, but the figures ale not used in the final romputations of results. 
These -tatistics noted by the subject within the calorimeter are recorded in al diary, together with any other information which he thinks may be of value in interpreting the rexults of the experiment.

The main facts in the diary of experiment No. 12 are shown in Table IV.

Table $\mathrm{V}$ recapitulates the record of work done on the ergometer. It is much less than would be required to propel a bieycle the number of miles indicated by the cyclometer.

TABLE IV. - Summery of diary-Metabolism experiment Fo. 12.

\begin{tabular}{|c|c|c|c|c|c|c|}
\hline \multirow{2}{*}{ Date mi time. } & \multicolumn{2}{|c|}{ Weight of subject. } & \multirow{2}{*}{$\begin{array}{l}\text { Pulse rate } \\
\text { per } \\
\text { minute. }\end{array}$} & \multirow{2}{*}{$\begin{array}{l}\text { Tempera- } \\
\text { ture. }\end{array}$} & \multicolumn{2}{|c|}{ Hygrometer. } \\
\hline & $\begin{array}{l}\text { Withont } \\
\text { clothex. }\end{array}$ & $\begin{array}{l}\text { With } \\
\text { elothes. }\end{array}$ & & & Dry bulb. & Wet bulb. \\
\hline 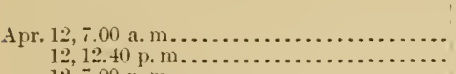 & $\begin{array}{l}\text { Kilograms. } \\
70.92\end{array}$ & $\begin{array}{r}\text { Kilograms. } \\
75.09 \\
. .2 . . .\end{array}$ & $\begin{array}{l}64 \\
68\end{array}$ & $\begin{array}{l}\text { F. } \\
48.4 \\
98.8\end{array}$ & $\begin{array}{l}\circ \mathrm{C} . \\
21.5 \\
21.5\end{array}$ & $\begin{array}{l}{ }^{\circ} C . \\
16.4 \\
18.6\end{array}$ \\
\hline $12,7.00$ p. m $\ldots \ldots \ldots \ldots$ & $\because 1$ & 75.38 & & 98,3 & $\because 3$ & 180 \\
\hline $\begin{array}{l}12,9.45 \\
13,7.00 \mathrm{a}, \mathrm{m} \ldots \ldots \ldots \ldots \ldots \ldots \ldots \ldots \ldots \ldots\end{array}$ & 典.09 & 74.82 & $\dddot{17}$ & $\begin{array}{l}98.3 \\
96.1\end{array}$ & 21.5 & 17.4 \\
\hline $13,12.40 \mathrm{p}, \mathrm{m} \ldots \ldots \ldots \ldots \ldots \ldots \ldots \ldots$ & $\because \cdots$ & 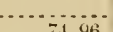 & $6 s$ & 98.8 & 21.5 & 18.8 \\
\hline 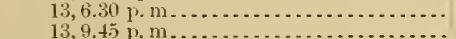 & 71.40 & $\begin{array}{l}74.96 \\
\ldots . . .\end{array}$ & $\because i$ & 98.4 & 21.5 & 18.0 \\
\hline 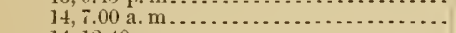 & 70.56 & 74.19 & 58 & 97.0 & 21.4 & 17.0 \\
\hline 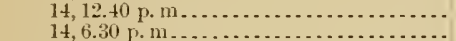 & 70.98 & 74.50 & 70 & $\begin{array}{c}49.0 \\
\ldots \ldots\end{array}$ & $\begin{array}{l}21.4 \\
\ldots . . .\end{array}$ & 18.8 \\
\hline $14,9.45$ p. m. & & & 73 & 98.5 & 21.5 & 17.8 \\
\hline $15,7.00$ a.m. & 70.47 & 73.98 & 57 & 97.2 & 21.3 & 16.8 \\
\hline $15,12.40$ p. m. . . . . . . . . . . . . & & & 72 & 97.0 & 21.7 & 19.0 \\
\hline $15,7.00 \mathrm{p}, \mathrm{m} \ldots \ldots \ldots$ & 71.12 & & & 900 & 915 & $\cdots \cdots$ \\
\hline $10,9,4) \mathrm{p}, \mathrm{m} \ldots$ & 70.31 & 73.98 & 60 & 96.4 & $\begin{aligned} 21.5 \\
22.0\end{aligned}$ & $\begin{array}{l}16.8 \\
18.4\end{array}$ \\
\hline
\end{tabular}

TABLE V.-Fecord of work alome-Metabolism experiment Wo. 12.

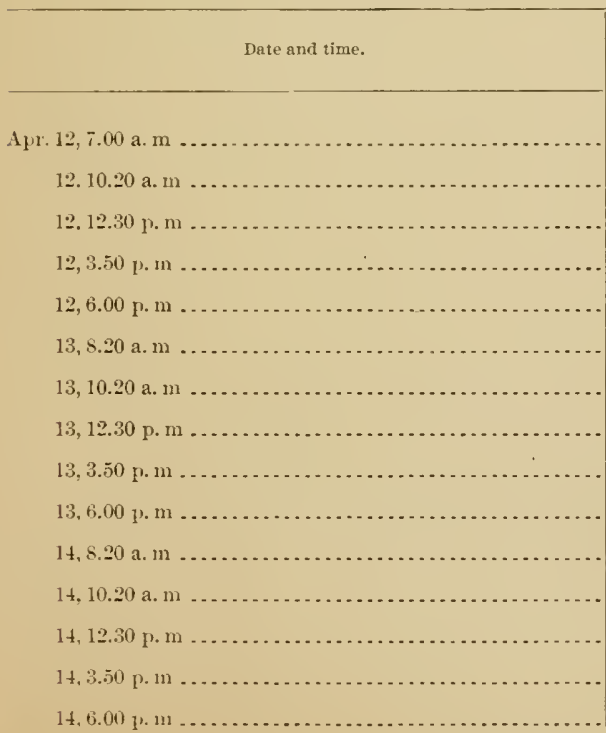

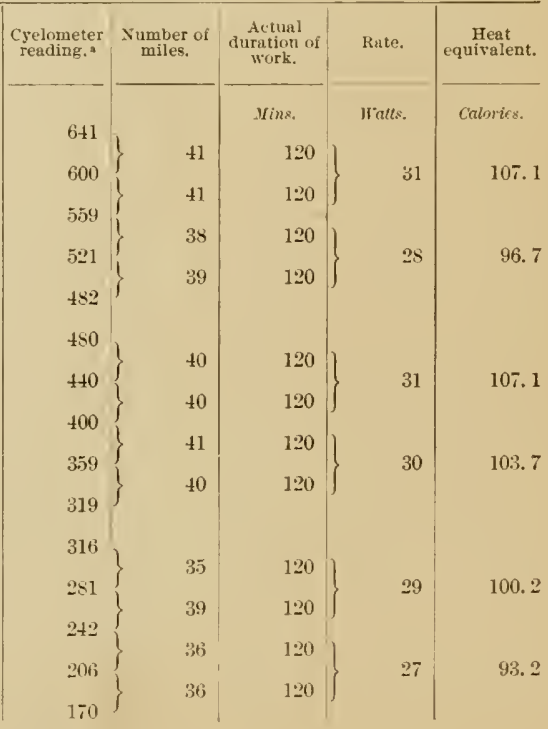

Vol. s-No. 6-5

"The cyclometer was reversed. 
Table T.-Record of work done-Metabolism experiment No. 12-Continued.

\begin{tabular}{|c|c|c|c|c|}
\hline $\begin{array}{l}\text { Cyclometer } \\
\text { reading.a }\end{array}$ & $\begin{array}{c}\text { Number of } \\
\text { miles. }\end{array}$ & $\begin{array}{l}\text { Aetual } \\
\text { duration of } \\
\text { work. }\end{array}$ & Rate. & $\begin{array}{c}\text { Heat } \\
\text { equivalent. }\end{array}$ \\
\hline \multirow{2}{*}{$\begin{array}{l}168 \\
132\end{array}$} & & Mins. & Watts. & Calories. \\
\hline & 36 & 120 & 30 & 103.7 \\
\hline 93 & כני & 120 & & \\
\hline 57 & & & \multirow[t]{2}{*}{26} & \multirow[t]{2}{*}{89.3} \\
\hline 34 & & & & \\
\hline & 600 & 1,920 & & 801.0 \\
\hline
\end{tabular}

${ }^{a}$ The cyclometer was reversed.

Food and excreta.-The weight, composition, and heat of combustion of the food and feces in this experiment are shown in Tables VI and VII. The weights of the different elements and compounds are computed by use of the values for percentage composition of the different materials as shown in Tables I and II:

TABLE VI.- Weight, composition, and heat of combustion of foods-Metabolism experiment No. 12.

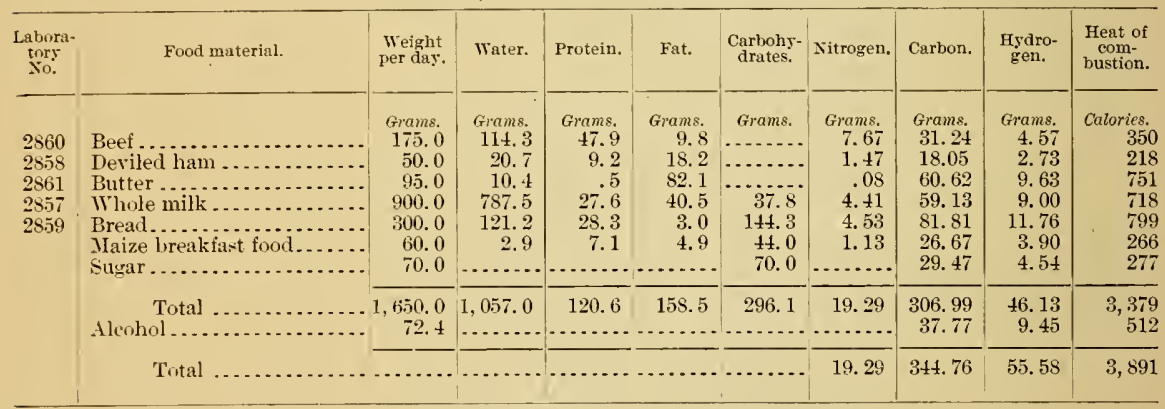

T.ABLE VII. - Weight, composition, and heat of combustion of feces-Metabolism experiment No. 12.

\begin{tabular}{|c|c|c|c|c|c|c|c|c|c|c|}
\hline $\begin{array}{l}\text { Labrora- } \\
\text { tory } \\
\text { No. }\end{array}$ & & Weight. & Water. & Protein. & Fat. & $\begin{array}{l}\text { Carbohy- } \\
\text { drates. }\end{array}$ & Nitrogen. & Carbon. & $\begin{array}{l}\text { Hydro- } \\
\text { gen. }\end{array}$ & $\begin{array}{l}\text { Heat of } \\
\text { com- } \\
\text { bustion. }\end{array}$ \\
\hline 28152 & $\begin{array}{l}\text { Total, four days .......... } \\
\text { Average per lay . . . . . . . . }\end{array}$ & $\begin{array}{r}\text { frotms. } \\
370.0 \\
92.5\end{array}$ & $\begin{array}{r}\text { Grams. } \\
27 \pm .2 \\
6.8 .6\end{array}$ & $\begin{array}{r}\text { Grams. } \\
31.1 \\
7.8\end{array}$ & $\begin{array}{r}\text { Grams. } \\
25.9 \\
6.5\end{array}$ & $\begin{array}{r}\text { Grams. } \\
22.6 \\
5.7\end{array}$ & $\begin{array}{r}\text { Grams. } \\
5.00 \\
1.25\end{array}$ & $\begin{array}{l}\text { Grams. } \\
48.29 \\
12.07\end{array}$ & $\begin{array}{r}\text { Grams. } \\
6.85 \\
1.71\end{array}$ & $\begin{array}{r}\text { Calories. } \\
5+5 \\
136\end{array}$ \\
\hline
\end{tabular}

The separation between the feces from the food consumed during the experiment and those from the food consumed before and after were made by means of charcoal, as described on page 239. Intsmuch as separations made in this way are at the best not as satisfactory as might be desired, no attempt was made to determine the excreta from the food on different days of the exprriment. It is assumed that, when the food and exercise are so nearly uniform, the undigested residues and metabolic products would not vary a great deal from day to dity. Even if there were irregularities from day to day they would hardly be large enongh to affect very greatly the arerage for the wholo experinent.

The amount, specific gravity. and nitrogen of the urine for the different 6-hour periods during the experiment are shown in 'lable VIII. and the carhon, hydrogen, water, and energy of 
the daily urine in Table IX. The urine was also collected during the preliminary period of $t$ dars and during 1:2 hours following the experiment. Aliquot portions (from one-half to twothird-) in these b-hour period- were taken for the preparation of a compo-ite sample of the urine for the day, and in like manner aliquot portions (about one-eighth of the total weight of urine) of the composite sample of the urine for 24 hours were taken for the preparation of a composite sample for the whole period of the experiment. The nitrogen was determined in the urine for each dar and in the composite for $t$ dars of the experiment. The quantities of nitrogen eliminated each dar. as determined from the 6 -hour periods and from the composite sample for the dar. do not alwars agree exactly. Such discrepancies may be due in part to small errors in the sampling of the compo-ites, in part to errors in the amount of urine measured out for analrsis. and in part to errors in the analrses. Samples mere measured out for analyses in a calibrated 5 -c. e. pipette, and it is possible that differences in the amount delirered from time to time might introduce slight errors in the results. It is assumed. where discrepancies exist, that the values obtained from the 6-hour periods are the more accurate. and these latter are consequently used in the estimation of the nitrogen balance.

It is difficult to eraporate urine to drrness withont more or less decomposition of urea to ammonium carbonate. and consequent loss of energy. Accordingly. no attempt was made to determine the solid matter in the urine of individual dars. but a portion of the composite sample for the experiment was dried according to the manner described on page 239 and the residue used for the determination of carbon. hrdrogen. and heat of combustion. The heat of combustion is also determined in the composite samples of the fresh urine each dar, as explained abore. The precautions taken to aroid error through loss of nitrogen, carbon, and energy during the process of drring of the urine hare been described in the publication referred to on page 239 .

The nitrogen is determined in the fresh urine from day to dar. but in order to obtain an approximate measure of the amount of carbon and hydrogen in the urine on the successire days of the experiment some computations are necessary. In making these computations it is assumed that the ratio of nitrogen to carbon. hrdrogen or water-free substance will be the same for each indiridual dar as for the $t$ dars. Thus, the amount of nitrogen in the urine of the first dar of the experiment wa 17.62 grams. and that for the whole experiment 71.56 grams. The carbon for the whole experiment was found br actual determinations to he $49.15 \mathrm{grams}$. The computations for the amount of carbon in the urine for the first day would then he als folloms: $71.96: 49.15:: 16.62: x(=12.05)$. This method of estimating the carbon and hrdrogen in the urine on the different day is manifestly more accurate than would be the case if the total quantity of carbon and hydrogen in the urine for the experiment were dirided br the number of dars, as is done in estimating the dail excretion through the feces. We know that the quantitie of nitrogen and carbon in the urine vary from day to day. and hare an accurate measure of the rariation of the nitrogen, and. -ince the rariation in the nitrogen must insolve rariations in the amount of carton united with this nitrogen in the form of urea and allied compound, it does not seem inappropriate to take the rariation- in the nitrogen as a measure of the corresponding rariations in the earbon. Of conrse there may be rarring quantities of non-nitrogenons compounds in the nrine from day to dar, which would render the above method of estimation more or less inacenrate. It is probable. howerer. that the rariations in nitrogen gire the fairest measure of the rariations in carbon and hydrogen. As a matter of fact. it has been found that the heat of combustion raries in clove relation to the nitrogen. Of course. the result-for the experiment as a whole are not affected bs the subdirisions of the amounts for the indiridual dars. 


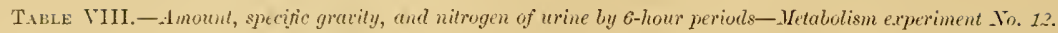

\begin{tabular}{|c|c|c|c|c|c|}
\hline Date. & J'eriod. & Amount. & $\begin{array}{l}\text { Speeifie } \\
\text { gravity. }\end{array}$ & \multicolumn{2}{|c|}{ Xitrogen. } \\
\hline \multirow[t]{2}{*}{$\begin{array}{c}1898 . \\
\text { Apr. } 12-13 . . . . .\end{array}$} & \multirow{2}{*}{ 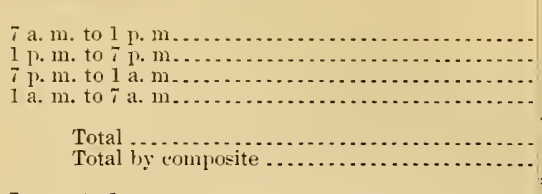 } & $\begin{array}{r}\text { Grams. } \\
309.4 \\
349.0 \\
247.6 \\
187.0\end{array}$ & $\begin{array}{l}1.026 \\
1.030 \\
1.027 \\
1.030\end{array}$ & $\begin{array}{r}\text { Per cent. } \\
1.18 \\
1.51 \\
1.90 \\
2.14\end{array}$ & $\begin{array}{r}\text { Grams. } \\
\text { 3. } 64 \\
5.28 \\
4.70 \\
4.00\end{array}$ \\
\hline & & $\begin{array}{l}1,093.0 \\
1,093.0\end{array}$ & 1.028 & 1.64 & $\begin{array}{r}17.62 \\
\ldots \ldots . . .\end{array}$ \\
\hline \multirow[t]{2}{*}{$13-14 \ldots \ldots$} & \multirow{2}{*}{ 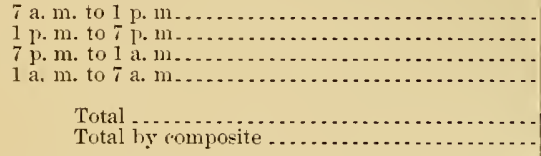 } & $\begin{array}{l}316.7 \\
455.4 \\
276.4 \\
286.0\end{array}$ & $\begin{array}{r}1.025 \\
1.029 \\
1.027 \\
1.028\end{array}$ & $\begin{array}{l}1.40 \\
1.29 \\
1.84 \\
2.00\end{array}$ & $\begin{array}{l}4.42 \\
5.89 \\
5.07 \\
5.73\end{array}$ \\
\hline & & $\begin{array}{l}1,334.5 \\
1,334.5\end{array}$ & 1.028 & 1.59 & $\begin{array}{r}21.11 \\
\ldots . . .\end{array}$ \\
\hline \multirow[t]{2}{*}{$14-15 \ldots .}$. & \multirow{2}{*}{ 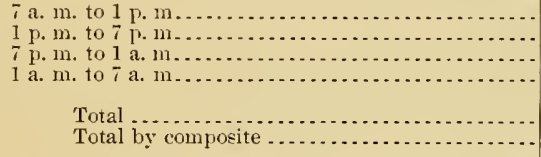 } & $\begin{array}{l}243.6 \\
386.3 \\
285.4 \\
154.3\end{array}$ & $\begin{array}{l}1.024 \\
1.024 \\
1.025 \\
1.030\end{array}$ & $\begin{array}{l}1.14 \\
1.24 \\
1.72 \\
2.06\end{array}$ & $\begin{array}{l}2.78 \\
4.78 \\
4.91 \\
3.18\end{array}$ \\
\hline & & $\begin{array}{l}1,069.6 \\
1,069.6\end{array}$ & 1.025 & 1.48 & \begin{tabular}{r}
15.65 \\
\hdashline..- \\
\end{tabular} \\
\hline \multirow[t]{3}{*}{$15-16}$. & \multirow{3}{*}{ 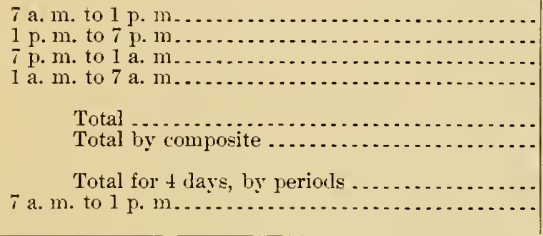 } & $\begin{array}{l}320.5 \\
326.0 \\
333.3 \\
160.3\end{array}$ & $\begin{array}{l}1.024 \\
1.026 \\
1.028 \\
1.028\end{array}$ & $\begin{array}{l}1.39 \\
1.32 \\
1.65 \\
2.02\end{array}$ & $\begin{array}{l}4.45 \\
4.30 \\
5.49 \\
3.24\end{array}$ \\
\hline & & $\begin{array}{l}1,140.1 \\
1,140.1\end{array}$ & 1.026 & 1.51 & $\begin{array}{r}17.48 \\
\ldots . . .\end{array}$ \\
\hline & & $\begin{array}{r}4,637.2 \\
325.8\end{array}$ & -- & .73 & $\begin{array}{r}7] .86 \\
2.38\end{array}$ \\
\hline
\end{tabular}

TABLE 1X.-Daily elimination of carbon, hydrogen, water, and energy in urine-Metalolism experiment No. 12.

\begin{tabular}{|c|c|c|c|c|c|c|c|c|c|c|}
\hline \multirow{2}{*}{\multicolumn{2}{|c|}{ Date. }} & \multirow{2}{*}{ Amount. } & \multirow{2}{*}{\multicolumn{2}{|c|}{ Carbon. }} & \multirow{2}{*}{\multicolumn{2}{|c|}{ Hydrogen. }} & \multirow{2}{*}{\multicolumn{2}{|c|}{ Water. }} & \multicolumn{2}{|c|}{ Heat of eombustion. } \\
\hline & & & & & & & & & Per gram, & Total. \\
\hline $\begin{array}{r}\text { Apr. } 12 \text { to } 13 . \\
13 \text { to } 14 . \\
14 \text { to } 15 . \\
15 \text { to } 16 .\end{array}$ & 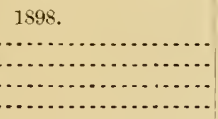 & $\begin{array}{c}\text { Grams. } \\
1,093.0 \\
1,334.5 \\
1,069.6 \\
1,140.1\end{array}$ & \begin{tabular}{l} 
Perct. \\
\hdashline$\cdots$ \\
\hdashline$\cdots$ \\
\hdashline$\cdots$ \\
\end{tabular} & $\begin{array}{l}\text { Grams. } \\
12.05 \\
14.44 \\
10.70 \\
11.96\end{array}$ & 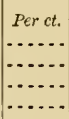 & $\begin{array}{r}\text { Grams. } \\
3.30 \\
3.95 \\
2.93 \\
3.27\end{array}$ & \begin{tabular}{|l} 
Per et. \\
\hdashline... \\
\hdashline \\
\hdashline... \\
\hdashline \\
\hdashline... \\
\end{tabular} & $\begin{array}{r}\text { Grams. } \\
1,025.9 \\
1,254.1 \\
1,010.0 \\
1,073.6\end{array}$ & $\begin{array}{r}\text { Calories. } \\
0.112 \\
.108 \\
.115 \\
.114\end{array}$ & $\begin{array}{r}\text { Calorieg. } \\
123 \\
145 \\
123 \\
130\end{array}$ \\
\hline Total. & 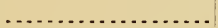 & $4,637.2$ & 1.06 & 49.15 & 29 & 13.45 & 94.1 & $4,363.6$ & $(.112)$ & a 521 \\
\hline
\end{tabular}

"The heat of eombustion of the urine was determined in the composite sample for each day and in the total composite for four days. The total heat of combustion of the urine for the experiment, as determined in the latter sample, was 0.112 calorie per gram, or a total of 519 calories.

Carbon dioxid and water of respiration and perspiration.-The determinations of carbon dioxid and water in the rentilating air current in this experiment are shown in Tables XI and $\mathrm{XI}$, which follow. Table $\mathrm{X}$ gives the total anounts of earbon dioxid and of water in the air of the chamber at the close of each period and the gain or loss during the period. Differences in the amounts in the chamber at the beginning and end of a given period -.. "residual "amounts, as they are here termed-indicate whether the rentilating air curent has remored more or less carbon dioxid and water than was actually exhaled by the subject during the corresponding period. For instance, if a change from rest to work is made during a given period, the quantities of carbon dioxid and water given off will be increased, and the air remaining in the chamber at the end of the period will contain a larger amount of these products than was present in the air of the chamber at the loggimning. This inerease must be added to the amount actually 
found in the rentilating air current in order to obtain the actual amount exhluled during the interval. On the other hand when the transition i- made from a period of con-iderable actirity to one of re-t. there is a cradual diminution of the puntity of re-ishal carlon dioxid and water in the air of the chamber. Thi- rexidual earlon disxid i- carried out in the rentilating ail current during the period. hut was actually given off during some preeding period. The total amount measued mu-t. therefor. le diminished by the difference in the puantities of pesidual carlon clioxicl at the hegriming and end of the period. Furthermore. with the increased water content of the air consefuent upon increased museular work, the amount of water accumulated by condensation upon the water srstem or ".alsorber." mar be gradually increaned. Indeed, the amount of water thus condened in perious of active work in apt to be so large that a portion gradually drip from the trough or shield- beneath the water system into the " drip Hasks" suspended at the end of the shields. This water is called " drip. $\therefore$ The weight of the mater srstem or absorbers also increase- through the conden-ation of moi-ture which does not run off into the drip. On the other hand. with the change from work to rest. the reight of the ab-orbers dininishes beeause of eraporation of some of the moisture condensed thereon during the prerious period.

In order to determine the actuat amount of earbon dioxid and water vapor in the air of the chamber at the elose of each period. samples of the air are drawn and the quantitie of carbon dioxid and water determined. At the same time the ab-orbers are reighed and the drip collected. The data thus obtained. shown in Table X. sere for correcting the amounts of carbon dioxid and water found in the rentilating air current, as - hown in Tables XI and XII beyond.

In experiment No. 12 drip wa- not meighed at the end of each period. but was poured intoa bottle and the total anount for each -t hour parsed out at the clowe of the day and weighed. We have, therefore. no measure of the amount of drip in the ditferent periods. It is altogether improbable that the amount was uniform from period to period. but in lack of any indication as to how it should be subdivided, the amounts have been apportioned equally among the four periods of the day. While this may introduce some error in individual period- it does not affeet the aceurney of the figures for the whole dar.

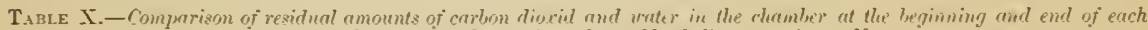

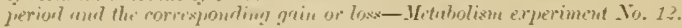

\begin{tabular}{|c|c|c|c|c|c|c|c|c|}
\hline \multirow[b]{2}{*}{ Inate. } & \multirow[b]{2}{*}{ End of perionl. } & \multicolumn{2}{|c|}{ Carbon dioxid. } & \multicolumn{5}{|c|}{ Water. } \\
\hline & & $\begin{array}{l}\text { Total } \\
\text { amount in } \\
\text { chamber. }\end{array}$ & $\begin{array}{l}\text { Gain }(+) \\
\text { or loss } \\
(-) \text { over } \\
\text { preceding } \\
\text { period. }\end{array}$ & $\begin{array}{l}\text { Total } \\
\text { amolint of } \\
\text { valor re- } \\
\text { maining } \\
\text { in cham- } \\
\text { ber. }\end{array}$ & $\begin{array}{l}\text { Gain }+ \text { + } \\
\text { or lows } \\
\text { 1-) nser } \\
\text { preceding } \\
\text { leriod. }\end{array}$ & $\begin{array}{l}\text { Change in } \\
\text { weight of } \\
\text { abwirber. } \\
\text { Gain }(+) \\
\text { or lo-s } \\
1-1 .\end{array}$ & $\begin{array}{l}\text { Drip from } \\
\text { absiorbers. }\end{array}$ & $\begin{array}{l}\text { Total } \\
\text { amount } \\
\text { gained } \\
\text { (t) or } \\
\text { lost } 1-7 \\
\text { during } \\
\text { period. }\end{array}$ \\
\hline \multirow[t]{2}{*}{$\begin{array}{l}\text { 149s. } \\
\text { Apr. } 12-13 . .\end{array}$} & 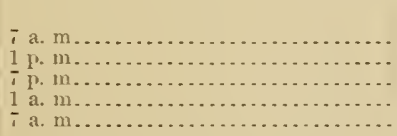 & $\begin{array}{r}\text { Grams } \\
24.3 \\
93.6 \\
71.5 \\
31.4 \\
30.5\end{array}$ & $\begin{array}{l}\text { Grems. } \\
-1,4.3 \\
-2.1 \\
-40.1 \\
-\quad .1\end{array}$ & $\begin{array}{l}\text { Gram.s. } \\
40.7 \\
55.4 \\
57.6 \\
56.6 \\
51.2\end{array}$ & $\begin{array}{l}\text { Gram: } \\
-17.5 \\
-\quad .0 \\
-1.0 \\
-5.4\end{array}$ & \begin{tabular}{c} 
Grams \\
\hdashline 246 \\
$-16 t$ \\
-34 \\
-34
\end{tabular} & $\begin{array}{l}\text { Grams. } \\
191.5 \\
191.6 \\
191.6 \\
191.6\end{array}$ & $\begin{array}{r}\text { Grrms. } \\
49.3 .2 \\
24.8 \\
156.0 \\
152.2\end{array}$ \\
\hline & Tutal ........... & - . . . & -1.2 & .......... & +10.5 & -52 & 766.3 & 528.8 \\
\hline \multirow[t]{2}{*}{$13-14 .}$. & 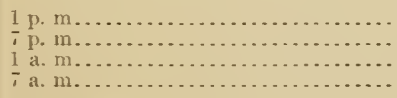 & $\begin{array}{l}99.5 \\
79.0 \\
31.4 \\
26.9\end{array}$ & $\begin{array}{l}-69.0 \\
-20.5 \\
-47.3 \\
-4.8\end{array}$ & $\begin{array}{l}61.9 \\
64.9 \\
57.6 \\
51.5\end{array}$ & $\begin{array}{r}-10.7 \\
+3.0 \\
-\quad 5.3 \\
-5.5\end{array}$ & $\begin{array}{l}-112 \\
-\quad 9 \\
-\quad 25 \\
-25\end{array}$ & $\begin{array}{l}298.0 \\
298.0 \\
297.9 \\
297.9\end{array}$ & $\begin{array}{l}420.7 \\
292.0 \\
265.6 \\
26 \% .1\end{array}$ \\
\hline & Tutal... & .......... & -3.6 & $\ldots \ldots$ & -.6 & +53 & $1,191 . \mathrm{s}$ & 1. 245.4 \\
\hline \multirow[t]{2}{*}{$1+-15 .}$. & 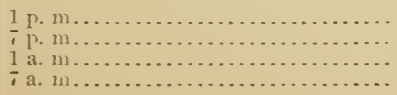 & $\begin{array}{l}5 \times .2 \\
74.4 \\
25.1 \\
27.1\end{array}$ & $\begin{array}{l}-61.3 \\
-13.8 \\
-40.3 \\
-2.0\end{array}$ & $\begin{array}{l}60.2 \\
63 . \overline{8} \\
56.0 \\
50.7\end{array}$ & $\begin{array}{l}+8.4 \\
-3.6 \\
-\quad 7.8 \\
-5.3\end{array}$ & $\begin{array}{ll}- & 7 \\
- & 11 \\
- & 1 \\
- & 81\end{array}$ & $\begin{array}{l}251.3 \\
251.3 \\
251.2 \\
251.2\end{array}$ & $\begin{array}{l}336.7 \\
265.5 \\
162.4 \\
164.9\end{array}$ \\
\hline & Total ..... & . . . . & 1.2 & $\ldots .$. & -1.1 & - it & $1,005.0$ & 929.9 \\
\hline
\end{tabular}




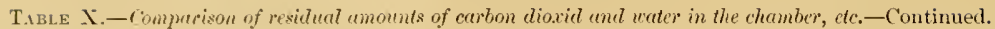

\begin{tabular}{|c|c|c|c|c|c|c|c|c|}
\hline \multirow[b]{2}{*}{ Date. } & \multirow[b]{2}{*}{ End of period. } & \multicolumn{2}{|c|}{ Carbon dioxid. } & \multicolumn{5}{|c|}{ Water. } \\
\hline & & $\begin{array}{c}\text { Total } \\
\text { amount in } \\
\text { chamber. }\end{array}$ & $\begin{array}{l}\text { Gain (+) } \\
\text { or loss } \\
(-) \text { over } \\
\text { preceding } \\
\text { period. }\end{array}$ & $\begin{array}{c}\text { Total } \\
\text { amount of } \\
\text { vapor re- } \\
\text { maining } \\
\text { in cham- } \\
\text { ber. }\end{array}$ & $\begin{array}{l}\text { Gain }(+) \\
\text { or loss } \\
(-) \text { over } \\
\text { preceding } \\
\text { period. }\end{array}$ & $\begin{array}{l}\text { Change in } \\
\text { weight of } \\
\text { absorbers. } \\
\text { Gain }(+) \\
\text { or loss } \\
(-) \text {. }\end{array}$ & $\begin{array}{l}\text { Drip from } \\
\text { absorbers. }\end{array}$ & $\begin{array}{l}\text { Total } \\
\text { amount } \\
\text { gained } \\
(+) \text { or } \\
\text { lost }(-) \\
\text { during } \\
\text { period. }\end{array}$ \\
\hline \multirow[t]{3}{*}{$\begin{array}{l}1540 . \\
15-16 . .\end{array}$} & \multirow{3}{*}{ 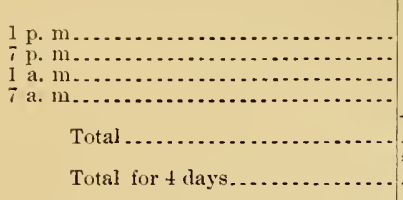 } & $\begin{array}{r}\text { Grams. } \\
81.5 \\
32.1 \\
30.2 \\
27.4\end{array}$ & $\begin{array}{r}\text { Grams. } \\
+54.4 \\
-49.4 \\
-1.9 \\
-2.8\end{array}$ & $\begin{array}{c}\text { Grams. } \\
61.1 \\
61.4 \\
54.3 \\
50.6\end{array}$ & $\begin{array}{l}\text { Grams. } \\
+10.4 \\
+\quad .3 \\
-7.1 \\
-\quad 3.7\end{array}$ & $\begin{array}{r}\text { Grams. } \\
+110 \\
+106 \\
-36 \\
-36\end{array}$ & $\begin{array}{c}\text { Grams. } \\
233.0 \\
233.0 \\
232.9 \\
232.9\end{array}$ & $\begin{array}{r}\text { Grams. } \\
353.4 \\
339.3 \\
189.8 \\
193.2\end{array}$ \\
\hline & & ……. & +.3 & ........ & -.1 & +144 & 931.8 & $1,075.7$ \\
\hline & & 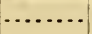 & -1.9 & $\ldots \ldots \ldots$ & +9.9 & +175 & $3,894.9$ & $4,079.8$ \\
\hline
\end{tabular}

The determinations of carbon dioxid in the ventilating air current in this experiment are given in detail in Table XI. This table shows the total ventilation in liters during each 6-hour period, and the quantity of carbon dioxid in the incoming air and in the ontgoing air. The difference between the carbon dioxid in the incoming and outgoing air, corrected for changes in the amount of residual carbon dioxid, gives the amount actually exhaled by the subject. Threeelevenths of this amount is taken as the quantity of carbon.

The letter's in the columu headings of these tables serve to indicate how the quantities in the different columns are obtained.

TABI,E XI.-Record of carbon dioxid in ventiluting air current-Metabolism experiment .No. 1\%.

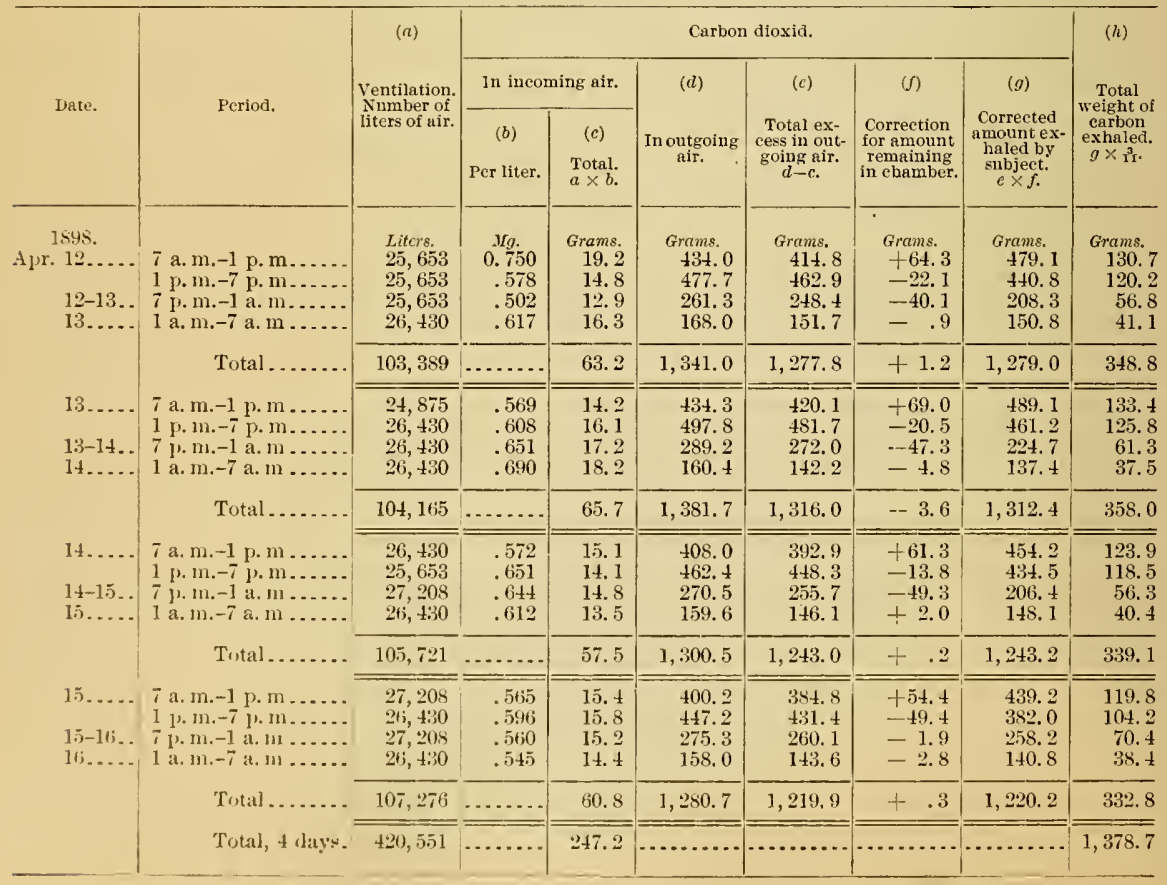


The quantity of water exhaled hy the subjest in the ditferent periods of the experiment ale shown in Table XIl. Unlike the earbon dioxid, the major portion of the water exhaled is condensed either within the chamber as drip, upon the surface of the ahsorbers, or in the "freczer" cans, which are immersed in a brine tank eooled to about - $20 \mathrm{C}$., and through which the ventilating air enrent passes. Table XII shows the amonnt of water in the ingoing air, the amount in the outgoing air not condensed in the freezers, and the correction for water remaning in the chamber. The final columm of the table shows the total water of respiration and perspiration during the different periods of this experiment.

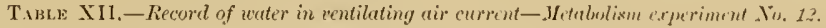

\begin{tabular}{|c|c|c|c|c|c|c|c|c|c|c|}
\hline \multirow[b]{2}{*}{ Date. } & \multirow[b]{2}{*}{ Period. } & \multirow{2}{*}{ 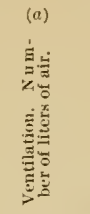 } & \multicolumn{2}{|c|}{$\begin{array}{l}\text { Water in incoming } \\
\text { air. }\end{array}$} & \multicolumn{3}{|c|}{ Water in outguing air. } & \multirow{2}{*}{ 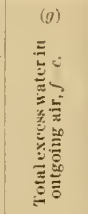 } & \multirow{2}{*}{ 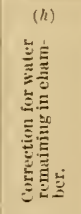 } & \multirow{2}{*}{ 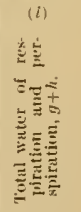 } \\
\hline & & & 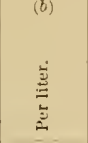 & 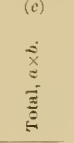 & $\begin{array}{l}(d) \\
1 \\
= \\
\end{array}$ & 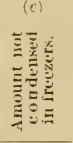 & $\begin{array}{l}(f) \\
\pm \\
= \\
\Xi \\
\Xi \\
E\end{array}$ & & & \\
\hline \multirow[t]{2}{*}{$\begin{array}{c}1898 . \\
\text { Apr. } 12-13 . .\end{array}$} & \multirow{2}{*}{ 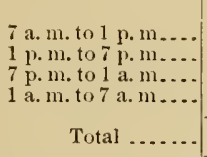 } & $\begin{array}{l}\text { Litcrs. } \\
25,653 \\
25,653 \\
25,653 \\
26,430\end{array}$ & $\begin{array}{r}19 s \\
1.025 \\
.884 \\
.507 \\
.821\end{array}$ & $\begin{array}{l}\text { frams. } \\
26.3 \\
22.7 \\
20.7 \\
21.7\end{array}$ & $\begin{array}{l}\text { frams. } \\
250.6 \\
290.6 \\
279.0 \\
254.5\end{array}$ & $\begin{array}{l}\text { Grams. } \\
64.3 \\
45.7 \\
42.6 \\
36.2\end{array}$ & $\begin{array}{l}\text { Grams. } \\
314.4 \\
336.5 \\
321.6 \\
290.7\end{array}$ & $\begin{array}{l}\text { Grams. } \\
288.6 \\
313.8 \\
300.9 \\
269.0\end{array}$ & $\begin{array}{r}\text { Grams. } \\
495.2 \\
24.8 \\
156.6 \\
152.2\end{array}$ & $\begin{array}{l}\text { Grims. } \\
783.8 \\
3.58 .6 \\
457.5 \\
421.2\end{array}$ \\
\hline & & 103,389 & ..... & 91.4 & $1,074.9$ & 188.8 & $1,263.7$ & $1,172.3$ & 825.8 & $2,001.1$ \\
\hline \multirow[t]{2}{*}{$13-14 \ldots$} & \multirow{2}{*}{$\begin{array}{l}7 \text { a.m. to } 1 \text { p. m... } \\
1 \text { p. m. to } 7 \text { p.m.... } \\
7 \text { p. m. to } 1 \text { a. m.... } \\
1 \text { a.m. to } 7 \text { a. m... } \\
\quad \text { Total ....... }\end{array}$} & $\begin{array}{l}24,875 \\
26,430 \\
26,430 \\
26,430\end{array}$ & $\begin{array}{l}.973 \\
.844 \\
.867 \\
.829\end{array}$ & $\begin{array}{l}24.2 \\
22.3 \\
22.9 \\
21.9\end{array}$ & $\begin{array}{l}281.1 \\
319.1 \\
295.0 \\
265.3\end{array}$ & $\begin{array}{l}41.3 \\
39.0 \\
42.4 \\
34.7\end{array}$ & $\begin{array}{l}32.4 \\
358.1 \\
337.4 \\
300.0\end{array}$ & $\begin{array}{l}298.2 \\
335.8 \\
314.5 \\
278.1\end{array}$ & $\begin{array}{l}420.7 \\
292.0 \\
265.6 \\
267.1\end{array}$ & $\begin{array}{l}718.9 \\
627.8 \\
580.1 \\
545.2\end{array}$ \\
\hline & & 104,165 & $\ldots \ldots \ldots$ & 91.3 & $1,160.5$ & 157.4 & $1,317.9$ & $1,226.6$ & $1,245.4$ & $2,472.0$ \\
\hline \multirow[t]{2}{*}{$14-15 \ldots$} & \multirow{5}{*}{ 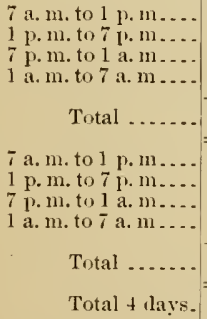 } & $\begin{array}{l}26,430 \\
25,653 \\
27,208 \\
26,430\end{array}$ & $\begin{array}{l}.974 \\
.864 \\
.788 \\
.811\end{array}$ & $\begin{array}{l}25.7 \\
22.2 \\
21.4 \\
21.4\end{array}$ & $\begin{array}{l}283.3 \\
301.0 \\
284.1 \\
262.6\end{array}$ & $\begin{array}{l}43.8 \\
40.6 \\
39.1 \\
35.8\end{array}$ & $\begin{array}{l}327.1 \\
341.6 \\
323.2 \\
298.4\end{array}$ & $\begin{array}{l}301.4 \\
319.4 \\
301.8 \\
277.0\end{array}$ & $\begin{array}{l}336.7 \\
265.9 \\
162.4 \\
164.9\end{array}$ & $\begin{array}{l}638.1 \\
585.3 \\
464.2 \\
441.9\end{array}$ \\
\hline & & 105,721 & $\mid \begin{array}{lll}\cdots & \ldots & \ldots\end{array}$ & 90.7 & $1,131.0$ & 159.3 & $1,290.3$ & $1,199.6$ & 929.9 & $2,129.5$ \\
\hline \multirow[t]{3}{*}{$15-16 \ldots$} & & $\begin{array}{l}27,208 \\
26,430 \\
27,208 \\
26,430\end{array}$ & $\begin{array}{l}.953 \\
.905 \\
.803 \\
.767\end{array}$ & $\begin{array}{l}25.9 \\
23.9 \\
21.8 \\
20.3\end{array}$ & $\begin{array}{l}290.2 \\
306.5 \\
289.2 \\
261.1\end{array}$ & $\begin{array}{l}43.3 \\
43.9 \\
59.1 \\
35.1\end{array}$ & $\begin{array}{l}333.5 \\
350.4 \\
348.3 \\
296.2\end{array}$ & $\begin{array}{l}307.6 \\
326.5 \\
326.5 \\
275.9\end{array}$ & $\begin{array}{l}353.4 \\
339.3 \\
189.8 \\
193.2\end{array}$ & $\begin{array}{l}661.0 \\
66.5 .8 \\
516.3 \\
469.1\end{array}$ \\
\hline & & 107,276 & $\ldots \ldots \ldots$ & 91.9 & $1,1 \pm 7.0$ & 181.4 & $1,328.4$ & $1,236.5$ & $1,075.7$ & $2,312,2$ \\
\hline & & 420,551 & . & 365.3 & $4,513.4$ & 686.9 & $5,200.3$ & $4,835.0$ & $4,079.8$ & $8,914.8$ \\
\hline
\end{tabular}

Ileat measurements. - The details of the measurements of heat given off by the subject during the experiment are too extensive to be given here. Those for each hour of the day and night, as recorded, till a page of a notebook sheet 22 by 29 ('m. For a detailed description of the applianees for determining the amount of heat carried out by the water enrent and for aroiding gain or loss of heat from the apparatus except where it can be determined, reference may be made to an earlier publication on this subject. ${ }^{a}$ As has alleady heen explained (see p. 237), the larger part of the heat given off hy the subject is arvied away in the water current, whowe temperature as it enter's and leaves the apparatus is determined at intervals of from 2 to $t$ minntes, and whose quantity is measured in eylinders holding 10 liters each. The arerage difference in temperature between the ineoming and ontgoing water multiplied hy the mumber of kilograms of water which has passed through the chamber gives the number of calories of heat remored during the time. Since, however, the specitic heat of water raries at different temperatures, it 
is our custom to reduce all these measurements of heat to the calorie at $20^{\circ} \mathrm{C}$. To this end it is necessary to multiply the number of ealories of heat remored in the water current at the mean difference of temperature betreen the incoming and outgoing current by the mean specific heat of water for that range. The product gires the corrected heat mensured in terms of calories at

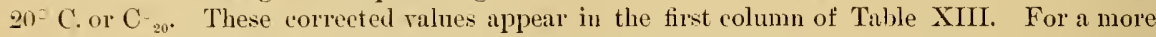
detailed discrission of this subject see page 55 of Bulletin 63 , above referred to.

The heat measured in terms of $\mathrm{C}{ }_{20}$ does not represent all of the heat giren off by the subject during a giren period, but must be corrected for changes in temperature of the calorineter and for the heat introdnced or remored by urticles of food and drink taken into or remored from the chamber. and for the heat required to raporize the excess of water given off in the outgoing as compared with the incoming air current; i. e.. latent heat of vaporization of water giren off from the lungs and skin.

The temperatures of the inner walls of the calorimeter are obserred at the beginning and end of each period. If these walls are warmer at the end than at the beginning of the period, some heat has been absorbed. If they are cooler, some heat has been added to the air of the chamber. For a rise in temperatnre of $1^{2} \mathrm{C}$. it has been found that the walls absorb 60 calories of heat, and vice rersa, in cooling $1^{\circ}$ they gire up 60 calories of heat. The changes of temperature are, however, kept so nearly constant as to vary rarely more than a tenth of a degree between the beginning and end of any period.

The temperature of the drink is taken immediately before it is passed into the chamber, and corrections are made for heat introduced by the hot coffee, or required to bring the cold water to the temperature of the chamber. The temperature of the food is brought as nearly as possible to that of the chamber before being sent in to the subject, so that little or no heat is added to or remored from the apparatus in this way. The corrections for temperature of food and drink and the dishes containing them are shown in column $d$ of Table XIII.

From the best data arailable it appears that 0.592 calorie of heat is required for the raporization of one gram of water at the temperature of $\mathrm{C}_{20}^{\circ}$. Water which condenses on the absorbers and is removed as drip gives up this latent heat of raporization within the chamber and it is measured by the water current. The water which passes out from the chamber in the form of rapor in the ventilating air current carries ont, however, a considerable quantity of latent heat. The amount of water raporized is found by taking the algebraic difference between the total excess of water in the outgoing air, as shown in colmmn $g$ of Tabie XII, and the gain or loss of water vapor in the air of the chamber, as shown in the fourth column of Table $\mathrm{X}$. The amount of water thus raporized multiplied by 0.592 , the heat of raporization of $1 \mathrm{gram}$, gires the total heat remored by the raporization of water within the chamber.

The heat carried away in the water current, as measured in terms of $\mathrm{C}_{2 n}^{\circ}$, corrected for change in temperature of calorimeter and for temperature of food and drink introduced into the chamber, added to the amount removed in the water rapor, gives the total heat determined, as shown in colninn y of Table XIII.

TABLE XIII. - Summary of falorimetric measurements-Metabolism experiment No. 12.

\begin{tabular}{|c|c|c|c|c|c|c|c|c|}
\hline Date. & Perioul. & $\begin{array}{c}\text { (a) } \\
\text { Hent } \\
\text { measured } \\
\text { in terms } \\
\text { of } \mathrm{C}^{\circ} \mathrm{g} \text {. }\end{array}$ & $\begin{array}{l}\text { Change } \\
\text { of tempera. } \\
\text { ture of } \\
\text { calorimeter. }\end{array}$ & \begin{tabular}{|c|}
$(c)$ \\
\\
Capacity \\
correction \\
of ealorim- \\
cter \\
$b \times 60$.
\end{tabular} & $\begin{array}{l}(d) \\
\text { Correction } \\
\text { due to } \\
\text { tempera- } \\
\text { ture of } \\
\text { fond and } \\
\text { dishes. }\end{array}$ & $\begin{array}{c}(e) \\
\text { Water va. } \\
\text { porized } \\
\text { equals to- } \\
\text { tal amonnt } \\
\text { exhaled } \\
\text { less } \\
\text { amount } \\
\text { conderised } \\
\text { in ehamber. }\end{array}$ & $\begin{array}{l}\text { Heat used } \\
\text { in vapor- } \\
\text { ization of } \\
\text { water } \\
\epsilon \times 0.592\end{array}$ & $\begin{array}{l}\text { Total heat } \\
\text { deter- } \\
\text { mined } \\
a+c+a+f .\end{array}$ \\
\hline $\begin{array}{c}\text { lkes: } \\
\text { Apr, } \quad 12-13 .\end{array}$ & 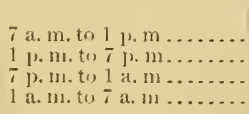 & $\begin{array}{r}\text { Crtwics. } \\
1,204.6 \\
1,236.9 \\
4 ! 16.3 \\
314.5\end{array}$ & $\begin{array}{r}\text { Degrecs, } \\
+05 \\
+05 \\
-05 \\
-10\end{array}$ & $\begin{array}{r}\text { Calorics. } \\
+3.0 \\
+3.0 \\
+3.0 \\
-13.0\end{array}$ & $\left\{\begin{array}{r}\text { Calorics. } \\
\quad 3.3 \\
+8.0 \\
\ldots \ldots\end{array}\right.$ & $\begin{array}{l}\text { Grams. } \\
301 \text {. } 3 \\
313.0 \\
299.9 \\
263.6\end{array}$ & $\begin{array}{r}\text { ralorise. } \\
181.3 \\
185.3 \\
177.6 \\
156.0\end{array}$ & $\begin{array}{r}\text { Calorirs, } \\
1,35.6 \\
1,433.2 \\
670.9 \\
464.5\end{array}$ \\
\hline & Total............ & $3,252.3$ & -05 & -3.0 & +4.7 & $1,182.8$ & 700.2 & $3,954.2$ \\
\hline
\end{tabular}




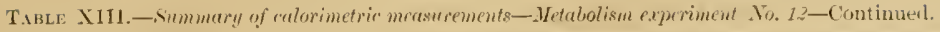

\begin{tabular}{|c|c|c|c|c|c|c|c|c|}
\hline & & (a) & (b) & (c) & (d) & $(1)$ & $(f)$ & (g) \\
\hline Date. & Perion. & $\begin{array}{l}\text { Heat } \\
\text { measured } \\
\text { in terms } \\
\text { of }(1000\end{array}$ & $\begin{array}{c}\text { Change } \\
\text { of tempiera- } \\
\text { ture of } \\
\text { (alorimeter. }\end{array}$ & $\begin{array}{l}\text { Capacity } \\
\text { rorrection } \\
\text { of calorim- } \\
\text { etter } \\
b>60 .\end{array}$ & $\begin{array}{l}\text { Correction } \\
\text { dne to } \\
\text { tempera- } \\
\text { ture of } \\
\text { fond and } \\
\text { dishes. }\end{array}$ & 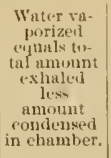 & $\begin{array}{l}\text { Hent used } \\
\text { in rapor- } \\
\text { ization of } \\
\text { water } \\
\text { exi. } 0.592 .\end{array}$ & $\begin{array}{l}\text { Tolal heat } \\
\text { deter- } \\
\text { nuined } \\
a+c+d+f\end{array}$ \\
\hline \multirow[t]{2}{*}{$\begin{array}{c}1598 \\
\text { Apr. } \quad 13-14 .\end{array}$} & \multirow{2}{*}{ 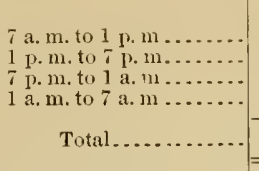 } & $\begin{array}{r}\text { Calovies. } \\
1,254.3 \\
1,265.3 \\
555.3 \\
279.6\end{array}$ & 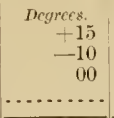 & $\begin{array}{r}\text { Calorics. } \\
+\quad 9.0 \\
-6.0 \\
.0 \\
. . . . . \\
\end{array}$ & 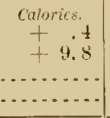 & $\begin{array}{l}\text { Grams. } \\
30 \times .9 \\
335.8 \\
307.2 \\
272.3\end{array}$ & $\begin{array}{l}\text { Calories. } \\
182.9 \\
200.6 \\
141.8 \\
161.2\end{array}$ & $\begin{array}{l}\text { Calorirs. } \\
\begin{array}{r}1, \pm 46.6 \\
1, \pm 69.7 \\
737.1 \\
+40.8\end{array}\end{array}$ \\
\hline & & $3,35+.5$ & +05 & +3.0 & +10.2 & $1,2: 7.2$ & 726.5 & $4,094.2$ \\
\hline \multirow[t]{2}{*}{$1+-15$} & 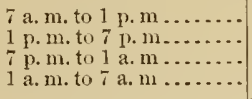 & $\begin{array}{r}1,163.6 \\
1,159.0 \\
510.4 \\
302.2\end{array}$ & $\begin{array}{l}-08 \\
-05 \\
+05 \\
+05\end{array}$ & $\begin{array}{l}-4.8 \\
-3.0 \\
+\quad 4.8 \\
+\quad 3.0\end{array}$ & $\begin{array}{r}-1.9 \\
+9.2 \\
\ldots . . . \\
\ldots . . .\end{array}$ & $\begin{array}{l}304.8 \\
323.0 \\
294.0 \\
271.7\end{array}$ & $\begin{array}{l}183.4 \\
191.2 \\
174.0 \\
160.9\end{array}$ & $\begin{array}{l}1,340.3 \\
1,356.4 \\
659.2 \\
466.1\end{array}$ \\
\hline & Total. & $3,135.2$ & n......... & ......... & +7.3 & $1,198.5$ & 709.5 & $3,852.0$ \\
\hline \multirow[t]{2}{*}{$15-16$} & 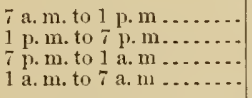 & $\begin{array}{r}1,124.9 \\
1,104.2 \\
536.5 \\
246.5\end{array}$ & $\begin{array}{c}+20 \\
-10 \\
\cdots+0 . \cdots \\
-0.05\end{array}$ & $\begin{array}{r}+12.0 \\
-6.0 \\
-3.0\end{array}$ & 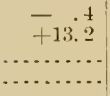 & $\begin{array}{l}318.0 \\
226.8 \\
419.4 \\
272.2\end{array}$ & $\begin{array}{l}188.2 \\
134.3 \\
248.3 \\
161.1\end{array}$ & $\begin{array}{r}1,324.7 \\
1,245.7 \\
784.8 \\
454.6\end{array}$ \\
\hline & Total... & $3,062.1$ & -0.5 & +3.0 & +12.8 & $1,236.4$ & 731.9 & $3,809.8$ \\
\hline
\end{tabular}

Elimination of unoxidized alcohol.-The urine, freezer water, and air current were tested for alcohol or products of incomplete oxidation of alcohol by the method referred to on page 258 above. The results obtained in this experiment are shown in Table XIV. It will be observed that 95 per cent of the alcohol taken with the food was apparently oxidized in the body. Inasmuch, however, as it has since been found ${ }^{\text {a }}$ that even when alcohol forms no part of the diet there is a considerable amount of organic material in the mine, drip water, and rentilating air current which is eapable of redueing the chromie acid employed, it is probable that the actual elimination of unoxidized or incompletely oxidized alcohol is considerably smaller than is indicated by the figures in the table.

TABLE XIV.-Alcohol ingested and exereted-Metabolism experiment No. 12.

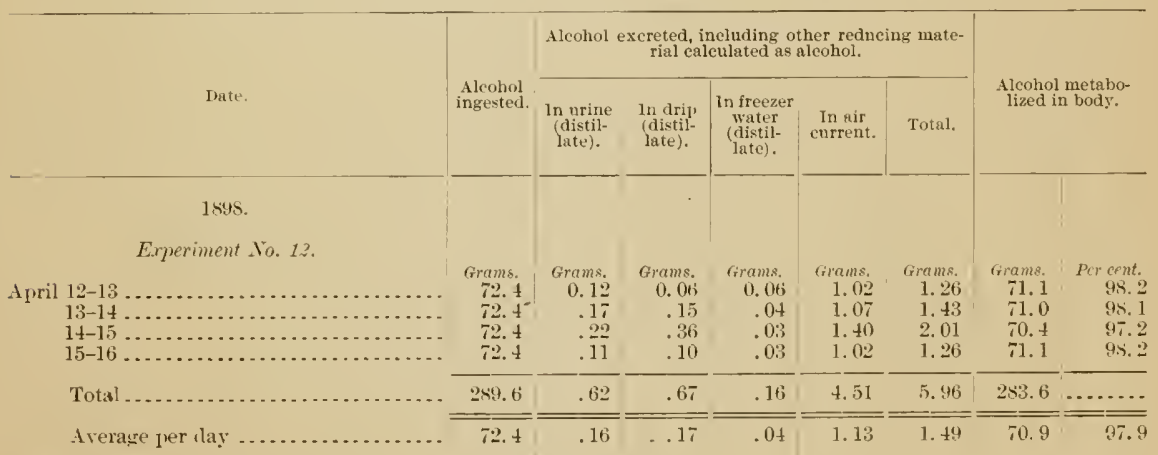


The experimental data recorded in detail in the preceding tables can be summarized in "deriver" tables showing the balance of income and ontgo of matter and energy, the amounts of materials excreted under different conditions and at different times of the das, and other points of interest.

Vitrogen und carbon buturee.-The daily income and outgo of nitrogen and carbon in this experiment are summarized in Table XV. The quantities of nitrogen and of carbon in the food, feces, and urine are derived respectively from Tables VI-VIII, the quantity of carbon in the respiratory prodncts from Table XI, and the alcohol eliminated from Table XIV.

Vitregenons materials and mater of perspiration collected in clothing. - It will be noticed that the figures in column $c$ of Table XV, nitrogen in urine, differ slightly from those given in Table VIII. The subject changed his underclothing each night. The gain in weight of the underclothes from the time they were sent into the chamber until they were sent out was taken as water absorbed, and the amount thus removed is added to that in column $e$ of Table XVI, "Water in respiratory products." The underelothes taken out were extracted with distilled water, which was afterwards evaporated nearly to dryness, the residue made up to a given volume, and the nitrogen determined by the Kjeldahl method. The nitrogen thus given off amounted, in this experiment, to $0.96 \mathrm{gram}$ for the 4 days. This amount has been divided equally between the different days of the experiment and added to the amount of nitrogen in the urine. The sums are given in column of the following table:

TABLE XV.- Income aml outgo of nitrogen and carbon-Metabolism experiment No. 12.

\begin{tabular}{|c|c|c|c|c|c|c|c|c|c|c|}
\hline \multirow[b]{3}{*}{ Date and period. } & \multicolumn{4}{|c|}{ sitrogen. } & \multicolumn{6}{|c|}{ Curbon. } \\
\hline & $(\alpha)$ & $(b)$ & (c) & (d) & (e) & $(f)$ & $(g)$ & (h) & $(i)$ & $(k)$ \\
\hline & In food. & $\begin{array}{c}\text { Is } \\
\text { feces. }\end{array}$ & $\underset{\text { urine. }}{\text { In }}$ & $\begin{array}{c}\text { Gain } \\
(+) \text { or } \\
\text { loss }(-) \\
a-(b+ \\
c) .\end{array}$ & In food. & $\begin{array}{c}\text { In } \\
\text { feces. }\end{array}$ & $\begin{array}{l}\text { In } \\
\text { urine. }\end{array}$ & $\begin{array}{l}\text { In re- } \\
\text { spira- } \\
\text { tory } \\
\text { prod- } \\
\text { uets. }\end{array}$ & $\begin{array}{l}\text { In al- } \\
\text { cohol } \\
\text { elimi- } \\
\text { nated. }\end{array}$ & $\begin{array}{c}\text { Gain } \\
(+) \text { or } \\
\text { loss }(-) \\
c-(j+ \\
g+h+i)\end{array}$ \\
\hline 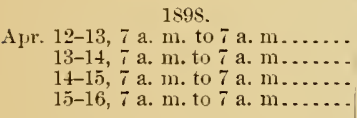 & $\begin{array}{l}\text { frams, } \\
19.3 \\
19.3 \\
19.3 \\
19.3\end{array}$ & $\begin{array}{r}\text { Grams. } \\
1.3 \\
1.2 \\
1.3 \\
1.2\end{array}$ & $\begin{array}{l}\text { Grams. } \\
17.9 \\
21.3 \\
15.9 \\
17.7\end{array}$ & $\begin{array}{l}\text { Grams. } \\
+0.1 \\
+3.2 \\
+2.1 \\
+\quad .4\end{array}$ & $\begin{array}{l}\text { Grams. } \\
344.7 \\
344.8 \\
344.7 \\
344.8\end{array}$ & $\begin{array}{r}\text { Grams. } \\
12.1 \\
12.1 \\
12.1 \\
12.1\end{array}$ & $\begin{array}{l}\text { Grams, } \\
12.1 \\
14.4 \\
10.7 \\
12.0\end{array}$ & $\begin{array}{l}\text { Grams. } \\
3 \pm 8.8 \\
358.6 \\
339.1 \\
332.8\end{array}$ & $\begin{array}{r}\text { Grams. } \\
0.7 \\
.7 \\
1.0 \\
.7\end{array}$ & $\begin{array}{l}\text { Grams. } \\
-29.0 \\
-40.4 \\
-18.2 \\
-12.8\end{array}$ \\
\hline Total - & 77.2 & 5.0 & 72.8 & -.6 & $1,379.0$ & 48.4 & 49.2 & $1,378.7$ & 3.1 & -100.4 \\
\hline Arelage yer day ........... & 19.3 & 1.3 & 18.2 & -.2 & $3 \pm 4.8$ & 12.1 & 12.3 & $3+4.7$ & .8 & -25.1 \\
\hline
\end{tabular}

a Ineinding nitrogen of verspiration. The nitrogen thus giren off amounted to 0.96 gram for the four days, and ha been divided equally between the different days of the experiment and added to the amount of nitrogen in the urine.

IIydrogen bulunce.-The income and outgo of hydrogen and water upon the different days of this experiment are shown in Table XVI. The figures are collated from the previous tables. The values for water of respiration and perspiration have been increased by the amount absorbed $\mathrm{hy}$ the underelothing on each day, and therefore differ from the eorresponding values as found in the last column of Table XII. The water thus absorbed by the underelothing and removed from the apparatus amounted to $63,10,12.3$, and 7 grams, respectively, on the successive days of the experiment. The apparent loss of water is shown in column $f$ of the table. The quantities in this column are always negative, since the water given off in the respiratory products is derived not only from the water taken into the srstem with food and drink but also from the oxidation of bydrogen and organic compounds. When, therefore, we consider the ineome and outgo of water, the body is appatrently losing becaune of the oxidation of hydrogen within the body to form water. The figmres of column, $f$. therefore, represent water apparently but not actually lost from the hody. The fuantities in columns $\%, 7$, and $i$ of Table XVI represent the amounts of hydrogen in organic combination in the food, feces, and urine, and the values in column $l$ show the apparent gains of hydrogen. The puantities in this column are always positive, owing to the 
fact that the most of the hydrogen in organic combination in the fool is eliminated, not in organic combination in the teces and urine, but in the form of water in the urine or respiratory products. In other words, the figures iu column $l$ apparently represent hydrogen gained by the body in organie compounds, but for the most part actually represent hydrogen given off as water. The total gain or loss of hydrogen for the experiment is calculated by adding together the hydrogen apparenty lost as water, column $f$, and the hydrogen in organic combination apparently gained, colum 7. This total gain or loss of hydrogen is shown in column $n$. There was in this experiment a gain of hydrogen on the first day and a loss on the three following days, making an average loss for the experiment of 20.8 grams per day.

It should he silil, howerer, that the determinations of water and consequently of hydrogen are less satisfactory than those of nitrogen, carbon and energy.

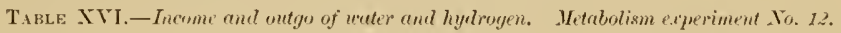

\begin{tabular}{|c|c|c|c|c|c|c|c|c|c|c|c|c|c|}
\hline \multirow{3}{*}{ Date and period. } & \multicolumn{6}{|c|}{ Water. } & \multicolumn{7}{|c|}{ Hydrogen. } \\
\hline & (a) & (b) & (c) & $(d)$ & (c) & $(f)$ & $(g)$ & (h) & (i) & $(k)$ & (l) & $(m)$ & $(n)$ \\
\hline & $\begin{array}{l}\text { In } \\
\text { forot. }\end{array}$ & $\underset{\text { drink. }}{\text { In }}$ & $\underset{\text { feces. }}{\ln }$ & $\underset{\text { nrine. }}{\ln }$ & $\begin{array}{c}\text { In re- } \\
\text { spiratory } \\
\text { lrod- } \\
\text { uets. }\end{array}$ & $\begin{array}{l}\text { Appar- } \\
\text { ent loss } \\
(a+b-(c \\
+d+c)\end{array}$ & $\begin{array}{c}\text { In } \\
\text { food. }\end{array}$ & $\underset{\text { feces. }}{\text { In }}$ & $\underset{\text { urine. }}{\ln }$ & $\begin{array}{l}\text { In al- } \\
\text { eohol } \\
\text { elimi- } \\
\text { nated. }\end{array}$ & $\begin{array}{l}\text { Appar- } \\
\text { ent gain } \\
g-(h+i \\
+k)\end{array}$ & $\begin{array}{l}\text { Loss } \\
\text { from } \\
\text { water } \\
f \div 9 \text {. }\end{array}$ & $\begin{array}{c}\text { Total } \\
\text { gain }+ \\
\text { orloss- } \\
l+m .\end{array}$ \\
\hline \multirow{7}{*}{ 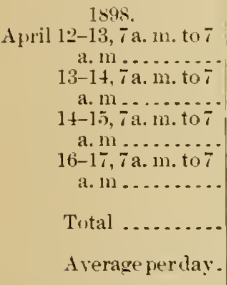 } & frrams. & froms. & Grams. & Groms. & firams. & & & Grams. & & Grems. & & & \\
\hline & 1,057 & $1,807.6$ & 68.5 & $1,025.9$ & $92,007.4$ & 237.2 & 55.6 & 1.7 & 3. 3 & 0.2 & 50.4 & 26.4 & $4+24.0$ \\
\hline & $1,0.57$ & $1,807.6$ & 68.6 & $1,254.1$ & $2,473.0$ & 931.1 & 55. 6 & 1. 7 & 4.0 & .2 & 49. 7 & 103.4 & $1-53.7$ \\
\hline & & $1,807.6$ & & $1,010.0$ & $92,141.8$ & 355.7 & 55.6 & 1. $i$ & 2.9 & .2 & 50.8 & 39.5 & $5+11.3$ \\
\hline & 1,057 & $1,807.6$ & 68.6 & $1,073.6$ & $62,319.2$ & 596.8 & 55.6 & 1.7 & 3.3 & .2 & 50.4 & 66.3 & -15.9 \\
\hline & 4,208 & $7,230.4$ & 274.2 & $4,363.6$ & $68,9+1.4$ & $2,120.8$ & 222.4 & 6.8 & 13.5 & .8 & 201.3 & $235.6^{3}$ & -34.3 \\
\hline & 1,057 & $1,807.6$ & 68.6 & $1,090.9$ & $92,235.3$ & 530.2 & $5 \overline{5} .6$ & 1. 7 & 3.4 & .2 & 50.3 & 58.9 & -8.6 \\
\hline
\end{tabular}

Extimuted greins and loxses of body protein and fiut.-From the data summarized in Tables XV and XVI we may compute the gain or loss of protein, fat, and water on the successive days of the experiment. These computations are shown in Table XVIl. If nitrogen is gained or lost, a corresponding gain or loss of protein is assumed. Protein compounds are here assumed to contain on the average 16 per cent of nitrogen, 53 per cent of carbon, and 7 per cent of hydrogen. Accordingly, the gain or loss of protein is computed by multiplying the gain or loss of nitrogen by 6.25 , and is shown in column 7 . Whatever protein is gained or lost must, by the above assumption, contain 53 per cent of carbon and 7 per cent of hydrogen. The amounts of earbon and hydrogeu in the protein gained or lost in the successive days of this experiment, as thms computed, are shown in columns $d$ ind $h$. The algebraic difference between the total carbon gained or lost and that in the protein gained or lost gives the amount of carbon gained or lost in other compounds, namely, fat, glycogen, etc. It is probable that the amount of glycogen in the body at the time of rising, 7 a. m., does not differ greatly from day to day, and the assumption is here made that all of the gain or losis of carbon abore that in the protein gained or lost comes from change in the anount of body fat. It is assumed that arelage body fat contains 76.5 per cent carbon ${ }^{\text {a }}$ and the amount of fat gained or lost is consequently computed by diriding the ralues in colunm e by .765, as is shown in column $f$. Axsmming, as before, that there has been no change in the body content of glyeogen, the algebraic difference between the total hydrogen gained or lost and that in the protein and fat gained or lost is assumed to represent the hydrogen gained or lost in the form of water.

" Determinations of the perentage of carbon in boily fat male in this laboratory by F. G. BExEDICT and E. Osterbert in 1900, publisherl in vol. 4 of the American Journal of Physiology, page 74 , average 76.08 per cent. The value 0.761 was therefore used instearl of 0.765 in computations of fat gainerl or lost in later experiments, leeginning witl No. 26 . 
These latter values are shown in column $k$ of the table. The corresponding amounts of water are shown in columen 7 .

So far from claiming that these assumptions and the calculations based upon them are correct, we are per-uaded that they must he nore or less erroneous; but until deterninations can be made of the income and outgo of oxygen, we can hardly be warranted in making other assumptions than those stated abore. It is our present belief that the largest errors are in the figures for water. The experimental data are recorded in such detail in prerious tables that modifications in the method of computing the nitrogen, carbon, and bydrogen balance, and the gain or loss of body material can he made at any time shorld results of later research indicate that such modifications were desirable.

TABLE XVII.-Gain or loss of protein $(\mathrm{N} \times 6.25)$, fat, and water. Setabolism experiment No. 12.

\begin{tabular}{|c|c|c|c|c|c|c|c|c|c|c|c|}
\hline Date and period. & $\begin{array}{l}\text { Nitrogen } \\
\text { gained } \\
(+) \text { or } \\
\text { lost }(-) \text {. }\end{array}$ & $\begin{array}{l}\text { Protein } \\
\text { gained } \\
(+) \text { or } \\
\text { lost }\left(\frac{-}{a}\right) \\
a \times 6.25 \text {. }\end{array}$ & $\begin{array}{l}\text { Total } \\
\text { earbon } \\
\text { gained } \\
(+) \text { or } \\
\text { lost }(-) \text {. }\end{array}$ & $\begin{array}{c}(d) \\
\\
\text { Carbon } \\
\text { in pro- } \\
\text { tein } \\
\text { gained } \\
(+) \text { or } \\
\text { lost }\left(-\frac{1}{2}\right) \\
b \times .53 .\end{array}$ & $\begin{array}{c}(e) \\
\\
\text { Carbon } \\
\text { in fat, } \\
\text { ete., } \\
\text { gained } \\
(+) \text { or } \\
\text { lost }(-) \\
c-d .\end{array}$ & $\begin{array}{c}\text { Fat } \\
\text { gained } \\
(+) \text { or } \\
\text { lost }(-\overrightarrow{-}) \\
e \div .765 \text {. }\end{array}$ & $\begin{array}{c}(g) \\
\\
\text { Total } \\
\text { hydro- } \\
\text { gen } \\
\text { gained } \\
(+) \text { or } \\
\text { lost }(-) .\end{array}$ & $\begin{array}{l}(h) \\
\text { Hydro- } \\
\text { gen } \\
\text { in pro- } \\
\text { tein } \\
\text { gained } \\
(+) \text { or } \\
\text { lost }(-) \\
b \times .07 .\end{array}$ & $\begin{array}{c}\text { Hydro- } \\
\text { gen } \\
\text { in fat } \\
\text { gained } \\
(+) \text { or } \\
\text { lost }(-) \\
f \times .118 .\end{array}$ & $\left\{\begin{array}{l}(k) \\
\text { Hydro- } \\
\text { gen in } \\
\text { water, } \\
\text { ete., } \\
\text { gained } \\
(+) \text { or } \\
\text { Jost } \\
(-) g- \\
(h+i) .\end{array}\right.$ & $\begin{array}{c}\text { Water } \\
\text { gained } \\
(+) \text { or } \\
\text { lost }(-) \\
k \times 9 .\end{array}$ \\
\hline \multirow{3}{*}{$\begin{array}{l}1898 . \\
\text { April } 12-13,7 \text { a.m. to } 7 \text { a.m. } \\
13-14,7 \text { a.m. to } 7 \text { a.m. } \\
14-15,7 \text { a.m. to } 7 \text { a. } . \\
16-17,7 \text { a. m. to } 7 \text { a. m. } \\
\text { Total............... } \\
\text { Arerage per day .... }\end{array}$} & $\begin{array}{l}\text { Grams. } \\
+0.1 \\
-3.2 \\
+2.1 \\
+.4\end{array}$ & $\begin{array}{r}\text { Grams. } \\
+\quad 0.6 \\
-20.0 \\
+13.1 \\
+\quad 2.5\end{array}$ & $\begin{array}{r}\text { Grams. } \\
-\quad 29.0 \\
-40.4 \\
-18.2 \\
-12.8\end{array}$ & $\begin{array}{r}\text { Grams. } \\
+\quad 0.3 \\
-10.6 \\
+\quad 7.0 \\
+\quad 1.3\end{array}$ & $\begin{array}{r}\text { Grams. } \\
-29.3 \\
-29.8 \\
-25.2 \\
-14.1\end{array}$ & $\begin{array}{r}\text { Grams. } \\
-38.3 \\
-39.0 \\
-32.9 \\
-18.4\end{array}$ & $\begin{array}{r}\text { Grams. } \\
+24.0 \\
-53.7 \\
+11.3 \\
-15.9\end{array}$ & $\begin{array}{r}\text { Grams. } \\
0.0 \\
-1.4 \\
+\quad .9 \\
+\quad .2\end{array}$ & $\begin{array}{r}\text { Grams. } \\
-4.5 \\
-4.6 \\
-3.9 \\
-2.2\end{array}$ & $\begin{array}{r}\text { Grams. } \\
+28.5 \\
-47.7 \\
+14.3 \\
-13.9\end{array}$ & $\begin{array}{r}\text { Grams. } \\
+256.5 \\
-429.3 \\
+128.7 \\
-125.1\end{array}$ \\
\hline & -.6 & -3.8 & -100.4 & -2.0 & -98.4 & -128.6 & -34.3 & -.3 & -15.2 & -18.8 & -169 \\
\hline & -.2 & -1.0 & -25.1 & -.5 & -24.6 & -32.2 & -8.6 & -.1 & -3.8 & -4.7 & -12 \\
\hline
\end{tabular}

Balance of energy. - The income and outgo of energy are shown in Table XVIII. The figures for heats of combustion of food and unoxidized materials of feces and urine are taken from Tables VI. ViI, and VIII, respectively. The ralues in column $d$, heat of combustion of alcohol eliminated, are derived from the corresponding values in the fifth column of Table XIV by multiplying the total alcohol unoxidized, as there given, by the heat of combustion per gram, 7.067 calories. As explained on page 258 , small quantities of organic matter in the rentilating air current were reckoned as alcohol, hence the figures in column $d$ somewhat orerstate the heat of combustion of the alcohol giren off unoxidized. The values in column e are obtained by multiplying the number of grams of protein gained or lost by the heat of combustion of one gram of protein, which is taken as 5.65 calories. The estimated heat of combustion of fat gained or lost, as shown in colnmu $f$, is computed for the different days from the corresponding ralues in Table XVII upon the supposition that each gram of fat has a heat of combustion of 9.5 ("ulories, ${ }^{a}$ which has been found to be not far from the arerage for one gram of rarious aninal fats. The estimates of column $g$ are the heat of combustion of the food eaten less the algebraic sum of the heats of combustion of food, feces. and body material gained or lost. To put it in another may, they are the heats of combustion of the food eaten and of body material lost less the heats of combustion of feces. urine. and body material stored. They may be said to represent the net income of energy to the body. The net outgo is measured directly by the apparatus, and is shown in columin / of Table XVIII. The net income averages in this experiment 5 calories per disy len than the net outgo. On different days of the experinent the net outgo varied from 25 calorim below to :

Determinations of the heat wi combustion of human losly fat wate in this laboratory by F. G. Bexenct and

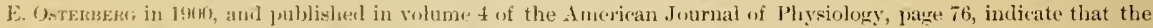

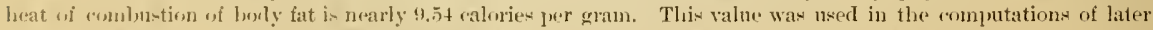

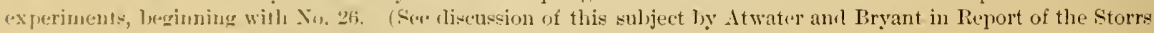
(Com, I Fixperiment Station for lsy!, p. 93.) 


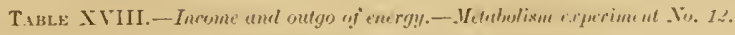

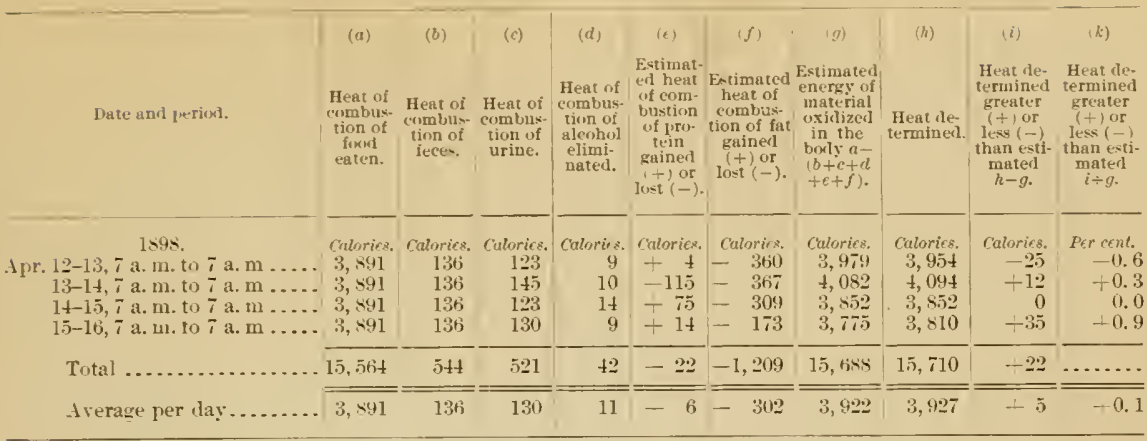

EXPERIMENT YOS. 1.̃-17-REST. WITH ALCOHOL. DIET.

Subject.-E. O., who was the subject of No. 12. His weight without chothing was about $i 1$ kilograms (1ว6 ponnds).

Occupation during experiment.-Reading, writing, ete, with as little mental and muscular actirity as was compatible with comfort.

Dicration.-Preliminary period $t$ days, beginning with breaktast January 12, 1599. The series of experiments Yos. 15-17 began at 7 a. m., January 16 , and ended at $\tau$ a. m., January 22. The whole period was thus 6 days, of which 2 days were giren to each experiment. The subject entered the respiration chamber on the evening of January 15 . The total time spent in the chamber was thus 7 nights and 6 days.

Diet.-Ordinary food furnishing, per day, 109 grams of protein and $2,1+1$ calories of energy, and in addition $72.5 \mathrm{grams}$ of absolute alcohol, furnishing 512 calories of energy, making the total energs of the diet 2,653 calories. The alcohol was taken in 6 doses, 3 with the meals and the other 3 between meals and just before retiring.

In experiment No. 15 commercial ethyl alcohol was added to a sweetened cotfee infusion, as in experiment No. 12. To 775.2 grams of coffee infusion were added 45 grams of sugar and 79.8 grans of 90.9 per cent commercial ethyl alcohol, making a total of 901) grams of the mixture, containing 752.5 grams of water.

In experiment No. 16 whisky containing 45.5 per cent ethyl aleohol by weight was nsed. Instead of adding the whisky to the coffee infusion it was taken with sugar in water. The whisks and sugar were added to the water by the subject within the calorimeter, in the proportion of 155.3 grams whisky, 45 grams sugar, and 696.7 grams water, making a total of 900 grams, containing 782.5 grams of water and 72.5 grams absolute alcohol, as in experiment No. 15 . An apparent increase in the alcohol found in the ventilating air current during experiment No. 16 led us to beliere that some alcohol might be eraporated during the admixture of whisky and water in the apparatus, and in the following experiments the mixture of alcohol with cotfee or water was prepared outside, as had been done in all cases previous to Yo. 16 .

In experiment No. 17 the alcohol was administered in the form of brandy, containing 50.4 per cent alcohol by weight. To 711.2 grams of water were added 45 grams of silgar and 143.5 grams of brandy, thus furnishing the same amount of water and alcohol as in the previous experiments. The alcohol in the whisky and brandy was determined by the urual method of distillation and determination of the specific grarity of the distillate. ${ }^{a}$

see Iethods of Analysis, [. . . Dept. Agr., Division of Chemistry, Bulletin 4 (h (revised), p. 5i. 
Diet in metabolism experiments . Tos. 15-1\%.

FOOD.

Beef

Butter.......

Bread

Parched cereal

Sugar

\begin{tabular}{|c|c|c|c|}
\hline Breakfast. & Dinner. & Supper. & Total. \\
\hline Grams. & Grams. & Grams. & Grams. \\
\hline 55 & 105 & & 160 \\
\hline 7 & 10 & 13 & 30 \\
\hline 300 & 260 & 390 & 950 \\
\hline 55 & 100 & 155 & 310 \\
\hline 30 & ........ & $\ldots . .$. & 30 \\
\hline 12 & ......... & 45 & 57 \\
\hline
\end{tabular}

${ }^{2}$ Used in coffee infusion and alcohol.

DRINK.

\begin{tabular}{|c|c|c|c|c|c|c|}
\hline Time. & $\begin{array}{l}\text { Coffee infu- } \\
\text { sion, sugar, } \\
\text { and aleo- } \\
\text { hol.a }\end{array}$ & Water. & $\begin{array}{l}\text { Water, } \\
\text { sugar, and } \\
\text { whisky." }\end{array}$ & Water. & $\begin{array}{c}\text { Coffee infu- } \\
\text { sion, sugar, } \\
\text { and } \\
\text { brandy.a }\end{array}$ & Water. \\
\hline Breakfast . . . . . . . . . . . . . . . . . . . . . . . & $\begin{array}{r}\text { Grams. } \\
300\end{array}$ & $\begin{array}{c}\text { Grams. } \\
. . .\end{array}$ & $\begin{array}{r}\text { Grams. } \\
300\end{array}$ & $\begin{array}{c}\text { Grams. } \\
. . .2 .\end{array}$ & $\begin{array}{l}\text { Grams. } \\
300\end{array}$ & Grams. \\
\hline 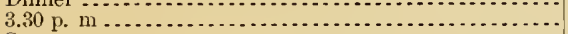 & & 200 & & 200 & & 200 \\
\hline Supper & 300 & 200 & 300 & $\cdots+\cdots$ & 300 & $\cdots 0$ \\
\hline 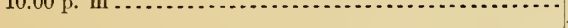 & . & 200 & 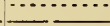 & 200 & & \\
\hline Total ........ & ${ }^{\text {a }} 900$ & 600 & " 900 & 600 & a 900 & 600 \\
\hline
\end{tabular}

${ }^{a}$ Contains 72.5 grams absolute alcohol and 45 grams sugar.

Daily routine.-The general routine of the experiment was as follows:

Daily programme-Metabolism experiments Nos. 15-17.

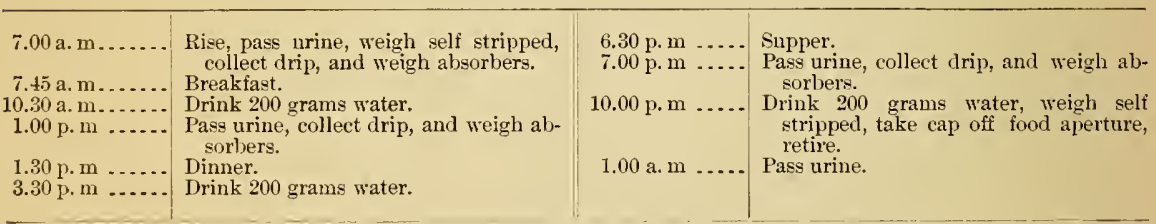

The main facts recorded in the diary kept by the subject during the experiment are shown in Table XIX:

TAnLE IIX.-Summary of diary-Metabolism erperiments Vus. 15-17.

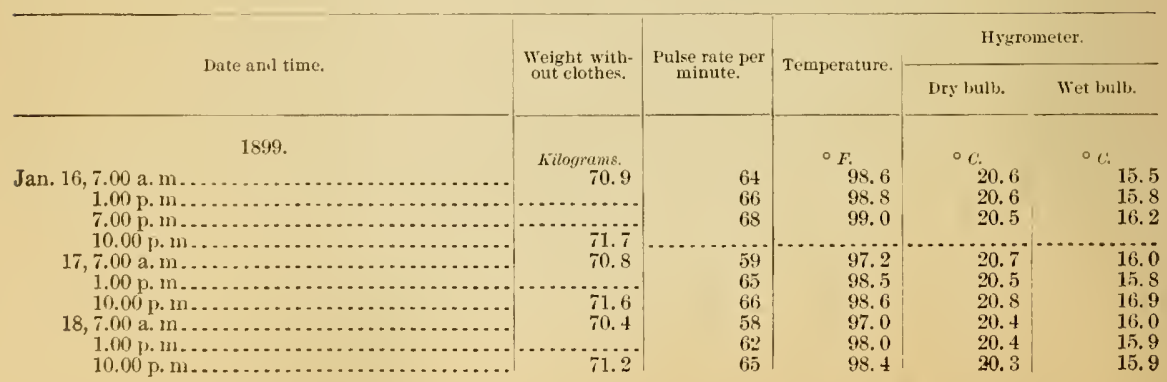




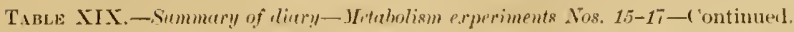

\begin{tabular}{|c|c|c|c|c|c|}
\hline \multirow{2}{*}{ Ihate and time. } & \multirow{2}{*}{$\begin{array}{l}\text { Weight with- } \\
\text { out clotleses. }\end{array}$} & \multirow{2}{*}{$\begin{array}{l}\text { Pulse rate per } \\
\text { nainute. }\end{array}$} & \multirow{2}{*}{ Temperature. } & \multicolumn{2}{|c|}{ Hygrometer. } \\
\hline & & & & Dry inltb. & Wet bulb. \\
\hline 1899. & Killogray & & & & \\
\hline $19,7.00$ a.m..... & 70.3 & 59 & 97.2 & 20.6 & 15.8 \\
\hline 1.00 p.m..... & ....... & 68 & 98.6 & 20.5 & 16.0 \\
\hline $3.30 \mathrm{p.m}$. & & 68 & & 20.5 & 16. 8 \\
\hline $7.00 \mathrm{p} . \mathrm{m} .$. & & 68 & 98.9 & 20.5 & 16.0 \\
\hline 10.00 p. m... & 71.2 & 69 & 98.0 & 20.7 & 16.6 \\
\hline $20,7.00$ a. m... & 70.3 & 55 & 96.8 & 20.7 & 16.0 \\
\hline $10.40 \mathrm{a} . \mathrm{m}$. & & & & 20.5 & 15.9 \\
\hline $1.00 \mathrm{p.m} .$. & & 60 & 97.8 & 20.4 & 15.6 \\
\hline 7.00 p. $\mathrm{m} .$. & & $6 s$ & 98.6 & 20.4 & 16.0 \\
\hline $10.00 \mathrm{p} . \mathrm{m} .$. & ii. 1 & 70 & 99.0 & 20.4 & 16.7 \\
\hline $21,7.00 \mathrm{a} . \mathrm{m} . . .6$. & 70.2 & 60 & 98.0 & 20.6 & 15.9 \\
\hline 9.50 a. $\mathrm{m}$. & & & & 20.7 & 16.1 \\
\hline $1.00 \mathrm{p} . \mathrm{m}$. & ...... & it & 98.3 & 20.7 & 15.8 \\
\hline 7.00 p.m. & (n.... & 67 & 98.3 & 20.4 & 15.8 \\
\hline $10.00 \mathrm{p} . \mathrm{m} . \mathrm{cos}$ & 70.9 & 71 & 98.5 & 20.6 & 16.4 \\
\hline $22,7.00$ a. m............ & 70.1 & 60 & 97.8 & 20.5 & 16.0 \\
\hline
\end{tabular}

Detuiled stutistics of income and outyn.--The weight, composition, and heat of combustion of food, feces, and urine are shown in Tables XX to XXIII. The gross income of nitrogen, earbon, hydrogen, and energy in the food and drink did not vary from day to day, and the outgo of each in the feces was assumed to be uniform in all the 6 days of the 3 experiments. Inasmuch as the diet was identical in the different experiments, with the exception of the substitution of whisky and brandy for the commereial ethyl ateohol, this assumption regarding the feces is probably within the limits of experimental error. The elimination of nitrogen in the urine was quite constant during the 6 days within the respiration chamber. During the 4 days of the preliminary period it amounted to $11.7,16,13.4$, and 10.4 grams, respectively. The urine of the daily composite samples decomposed before the heat of combustion could be determined. The heat of combustion of the urine for each day has therefore heen eompited from that of the composite sample of the 6 dars, according to the method employed for computing the carbon and hydrogen on the different individual days from the total carbon and hydrogen climinated in the mine during the experiment.

TABLE XX.-Weight, composition, and hert of combustion of foods-Wetalulism experiments Nos. 15-1\%.

\begin{tabular}{|c|c|c|c|c|c|c|c|c|c|c|}
\hline $\begin{array}{l}\text { Labora- } \\
\text { tory } \\
\text { No. }\end{array}$ & Foюd material. & $\begin{array}{l}\text { Weight } \\
\text { per day. }\end{array}$ & Water. & Protein. & Fat. & $\begin{array}{l}\text { Carnohy- } \\
\text { drates. }\end{array}$ & $\begin{array}{l}\text { Nitro- } \\
\text { gen. }\end{array}$ & Carbon. & $\begin{array}{l}\text { Hydro- } \\
\text { gen. }\end{array}$ & $\begin{array}{c}\text { Heat of } \\
\text { eombous- } \\
\text { ticus. }\end{array}$ \\
\hline $\begin{array}{l}3009 \\
3008 \\
3006 \\
2968 \\
3004\end{array}$ & $\begin{array}{l}\text { Beef } \\
\text { Butter } \\
\text { Milk, skimmed... } \\
\text { Brearl ............ } \\
\text { Cereal, parched... } \\
\text { Sugar .............. }\end{array}$ & $\begin{array}{l}\text { Grams. } \\
160 \\
30 \\
950 \\
310 \\
30 \\
57\end{array}$ & $\begin{array}{r}\text { Grams. } \\
110.7 \\
3.1 \\
850.3 \\
129.3 \\
1.8 \\
1.8 .\end{array}$ & $\begin{array}{r}\text { Frams. } \\
41.7 \\
.4 \\
38.9 \\
24.5 \\
3.4 \\
\ldots . . . .\end{array}$ & $\begin{array}{r}\text { Grams. } \\
4.2 \\
25.8 \\
1.0 \\
8.7 \\
.2 \\
\ldots . . .\end{array}$ & \begin{tabular}{r} 
crams. \\
\hdashline$\ldots . .$. \\
\hdashline 2.3 \\
$1+3.5$ \\
24.1 \\
57.0
\end{tabular} & $\begin{array}{r}\text { Grams. } \\
6.67 \\
.06 \\
6.18 \\
3.94 \\
.55 \\
.6 .\end{array}$ & $\begin{array}{l}\text { Grans. } \\
24.38 \\
18.57 \\
43.79 \\
84.72 \\
12.42 \\
24.00\end{array}$ & $\begin{array}{r}\text { Grams. } \\
3.66 \\
3.12 \\
6.27 \\
12.74 \\
1.55 \\
3.69\end{array}$ & $\begin{array}{l}\text { Colorics. } \\
269 \\
239 \\
+55 \\
840 \\
122 \\
226\end{array}$ \\
\hline \multirow{2}{*}{3004} & 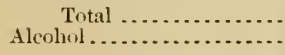 & 1,5377 & $\begin{array}{l}1,095.2 \\
\ldots \ldots \ldots\end{array}$ & $\begin{array}{r}108.9 \\
\hdashline . . .6\end{array}$ & $\begin{array}{r}39.9 \\
\cdots \cdots\end{array}$ & $\begin{aligned} 276.9 \\
\cdots \cdots\end{aligned}$ & $\begin{array}{l}17 .+0 \\
\cdots\end{array}$ & $\begin{array}{r}207.88 \\
37.82\end{array}$ & $\begin{array}{r}31.33 \\
9.46\end{array}$ & $\begin{array}{r}2,1+1 \\
512\end{array}$ \\
\hline & Total & & & & & & 17. 40 & 245.70 & 40.79 & 2,653 \\
\hline
\end{tabular}

TABLE XX1.- Weight, composition, and hert of combustion of feces-1Ietutuolism experiments los. 15-1\%.

\begin{tabular}{|c|c|c|c|c|c|c|c|c|c|c|}
\hline $\begin{array}{c}\text { Labora- } \\
\text { tory } \\
\text { No. }\end{array}$ & & Weight. & Water. & Protein. & Fat. & $\begin{array}{l}\text { Carbohy- } \\
\text { drates, }\end{array}$ & $\begin{array}{l}\text { Nitro- } \\
\text { gen. }\end{array}$ & Carbon. & $\begin{array}{l}\text { Hỹro- } \\
\text { gen. }\end{array}$ & $\begin{array}{l}\text { Heat of } \\
\text { combus- } \\
\text { tion. }\end{array}$ \\
\hline 3008 & $\begin{array}{l}\text { Total for } 6 \text { days............. } \\
\text { Average per day . . . . . . . . }\end{array}$ & $\begin{array}{r}\text { Grams. } \\
315.5 \\
52.6\end{array}$ & $\begin{array}{r}\text { Grames. } \\
215.5 \\
35.9\end{array}$ & $\begin{array}{r}\text { Groms. } \\
30.9 \\
5.1\end{array}$ & $\begin{array}{r}\text { Grams } \\
17.7 \\
3.0\end{array}$ & $\begin{array}{l}\text { Grams. } \\
\quad 27.1 \\
\quad 1.5\end{array}$ & $\begin{array}{r}\text { Trams. } \\
+.95 \\
.82\end{array}$ & $\begin{array}{r}\text { Grams. } \\
46.85 \\
7.81\end{array}$ & $\begin{array}{l}\text { Groms } \\
6.58 \\
1.09\end{array}$ & $\begin{array}{r}\text { Calurice } \\
528 \\
88\end{array}$ \\
\hline
\end{tabular}


TABLE XXII.-Amount, sperifie gravity, and nitrogen of urine by six-hour periods-Metabolism experiments Nos. 15-17.

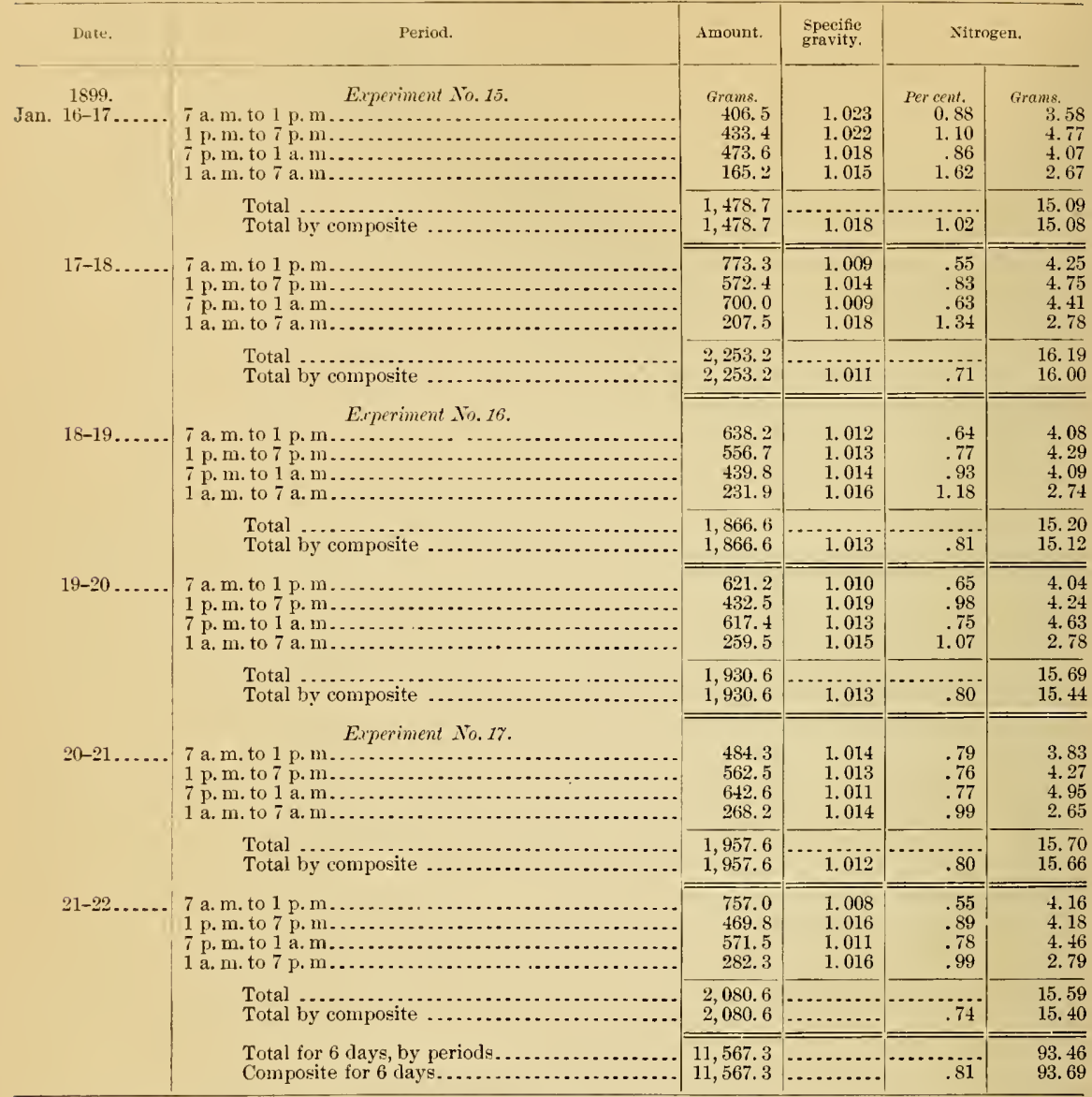

TABLE XXI1I.-Daily elimination of carbon, hydrogen, water, and energy in urine-Metabolism experiments Nos. 15-17.

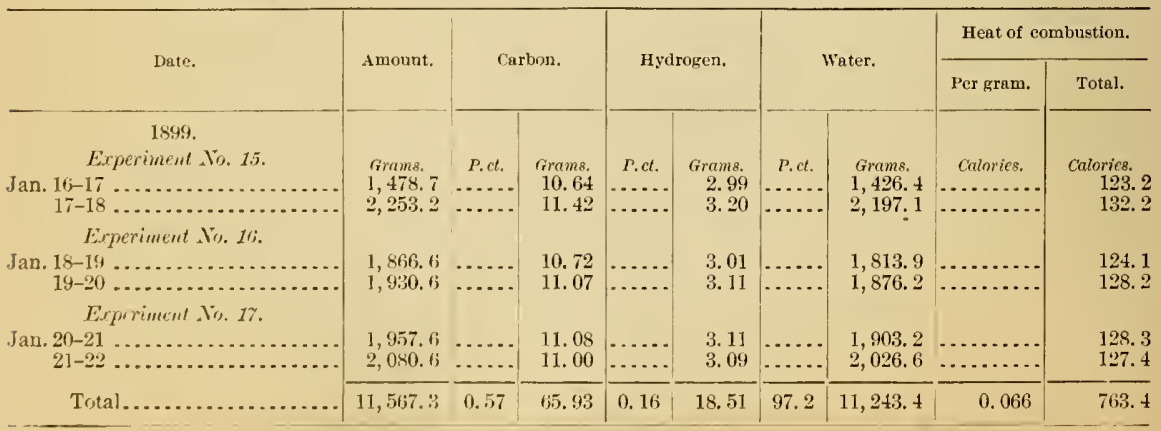


There was but very little change in the weight of the absorbing system inside the apparatus during the experiment, and the drip trom the system was very slight, so that little correction has to be made for variations in the weight of the absorbers. The details of the determinations of carbon dioxid and water are as follows:

TABLE XXIV.-Comparison of residual amounts of carbon dioxid and water in the chamber at the beginning and end of

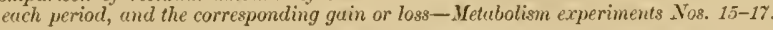

\begin{tabular}{|c|c|c|c|c|c|c|c|c|}
\hline \multirow[b]{2}{*}{ Date. } & \multirow[b]{2}{*}{ End of period. } & \multicolumn{2}{|c|}{ Carbon dioxid. } & \multicolumn{5}{|c|}{ Water. } \\
\hline & & $\begin{array}{c}\text { Total } \\
\text { amount } \\
\text { in cham- } \\
\text { ber. }\end{array}$ & $\begin{array}{l}\text { Gain }(+) \\
\text { or loss } \\
(-) \text { over } \\
\text { preced- } \\
\text { ing } \\
\text { period. }\end{array}$ & $\begin{array}{c}\text { Total } \\
\text { amount } \\
\text { of vapor } \\
\text { remain- } \\
\text { ing in } \\
\text { cha.n- } \\
\text { ber. }\end{array}$ & $\begin{array}{l}\text { Gain }(+) \\
\text { or loss } \\
(-) \text { over } \\
\text { preced- } \\
\text { ing } \\
\text { period. }\end{array}$ & $\begin{array}{c}\text { Change } \\
\text { in } \\
\text { weight } \\
\text { of ab- } \\
\text { sorbers. } \\
\text { Gain (t+) } \\
\text { or loss } \\
(-) \text {. }\end{array}$ & $\begin{array}{l}\text { Drip } \\
\text { from } \\
\text { absorb- } \\
\text { ers. }\end{array}$ & $\begin{array}{l}\text { Total } \\
\text { amount } \\
\text { gained } \\
(+) \text { or } \\
\text { lost }(-) \\
\text { during } \\
\text { the } \\
\text { period. }\end{array}$ \\
\hline \multirow[t]{3}{*}{ Jan. } & \multirow{3}{*}{ 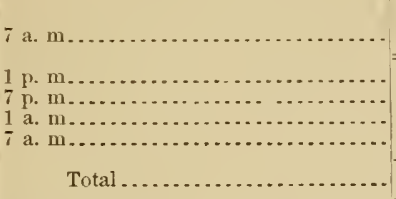 } & $\begin{array}{r}\text { Grams. } \\
31.4\end{array}$ & $\begin{array}{l}\text { Grams. } \\
+1.0\end{array}$ & $\begin{array}{r}\text { Grams. } \\
32.9\end{array}$ & $\begin{array}{r}\text { frams. } \\
\quad+0.5\end{array}$ & $\begin{array}{l}\text { Grams. } \\
. . . . . .\end{array}$ & $\begin{array}{c}\text { Grams. } \\
\text { Gen }\end{array}$ & $\begin{array}{l}\text { Grams. } \\
\text {. }\end{array}$ \\
\hline & & $\begin{array}{l}37.5 \\
39.1 \\
25.2 \\
26.4\end{array}$ & $\begin{array}{l}+6.1 \\
+1.6 \\
-13.9 \\
+\quad 1.2\end{array}$ & $\begin{array}{l}38.8 \\
41.4 \\
47.3 \\
38.6\end{array}$ & $\begin{array}{r}+5.9 \\
+2.6 \\
+5.9 \\
-8.7\end{array}$ & $\begin{array}{l}+5 \\
+8 \\
+1 \\
+1\end{array}$ & $\begin{array}{l}3 \\
3 \\
3 \\
3\end{array}$ & $\begin{array}{r}+13.9 \\
-\quad 2.4 \\
+\quad 9.9 \\
-4.7\end{array}$ \\
\hline & & ......... & -5.0 & $\ldots \ldots \ldots$ & +5.7 & -1 & 12 & +16.7 \\
\hline \multirow[t]{2}{*}{$17-18$} & 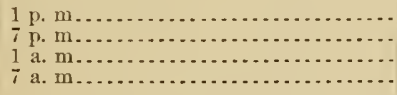 & $\begin{array}{l}33.3 \\
40.5 \\
27.4 \\
31.2\end{array}$ & $\begin{array}{l}+6.9 \\
+7.2 \\
-13.1 \\
+\quad 3.8\end{array}$ & $\begin{array}{l}40.1 \\
41.7 \\
49.1 \\
43.2\end{array}$ & $\begin{array}{r}+1.5 \\
+1.6 \\
+7.4 \\
-5.9\end{array}$ & $\begin{array}{r}-13 \\
-\quad 3 \\
+\quad 5 \\
+5\end{array}$ & $\begin{array}{l}3 \\
3 \\
3 \\
3\end{array}$ & $\begin{array}{r}-8.5 \\
+\quad 1.6 \\
+15.4 \\
+\quad 2.1\end{array}$ \\
\hline & Total & •...... & +4.8 & $\ldots \ldots \ldots$ & +4.6 & -6 & 12 & +10.6 \\
\hline \multirow[t]{2}{*}{$18-19$} & 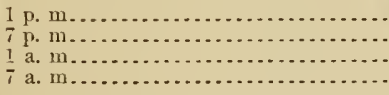 & $\begin{array}{l}35.2 \\
40.7 \\
28.4 \\
25.5\end{array}$ & $\begin{array}{r}+4.0 \\
+5.5 \\
-12.3 \\
-2.9\end{array}$ & $\begin{array}{l}42.1 \\
47.1 \\
45.8 \\
39.4\end{array}$ & $\begin{array}{l}-1.1 \\
+5.0 \\
-1.3 \\
-6.4\end{array}$ & $\begin{array}{l}+4 \\
+5 \\
-3 \\
-2\end{array}$ & $\begin{array}{l}3 \\
3 \\
3 \\
3\end{array}$ & $\begin{array}{r}+5.9 \\
+13.0 \\
-\quad 1.3 \\
-5.4\end{array}$ \\
\hline & Total & $\ldots \ldots$ & -5.7 & $\ldots \ldots$ & -3.8 & +4 & 12 & +12.2 \\
\hline \multirow[t]{2}{*}{$19-20$} & 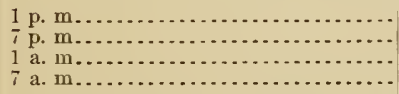 & $\begin{array}{l}42.1 \\
44.1 \\
29.5 \\
27.7\end{array}$ & $\begin{array}{r}+16.6 \\
+2.0 \\
-14.6 \\
-1.8\end{array}$ & $\begin{array}{l}41.6 \\
45.0 \\
46.2 \\
41.3\end{array}$ & $\begin{array}{l}+2.2 \\
+3.4 \\
+1.2 \\
-4.9\end{array}$ & $\begin{array}{r}+11 \\
+14 \\
+8 \\
-8\end{array}$ & $\begin{array}{l}3 \\
3 \\
3 \\
3\end{array}$ & $\begin{array}{r}+16.2 \\
+20.4 \\
-3.8 \\
-9.9\end{array}$ \\
\hline & Total .. & n. & +2.2 & ....... & +1.9 & +9 & 12 & +22.9 \\
\hline \multirow[t]{2}{*}{$20-21$} & 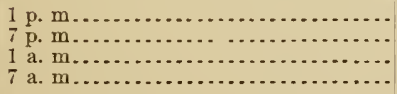 & $\begin{array}{l}38.9 \\
38.4 \\
29.3 \\
27.7\end{array}$ & $\begin{array}{l}+11.2 \\
-\quad .5 \\
-9.1 \\
-1.6\end{array}$ & $\begin{array}{l}39.2 \\
42.5 \\
48.6 \\
40.1\end{array}$ & $\begin{array}{l}-2.1 \\
+3.3 \\
+6.1 \\
-8.5\end{array}$ & $\begin{array}{r}-9 \\
+17 \\
-11 \\
-11\end{array}$ & $\begin{array}{r}3 \\
3 \\
3 \\
3\end{array}$ & $\begin{array}{r}-8.1 \\
+23.3 \\
-1.9 \\
-16.5\end{array}$ \\
\hline & Total & ....... & $\ldots$ & ......... & -1.2 & -14 & 12 & -3.2 \\
\hline \multirow[t]{3}{*}{$21-22$} & \multirow{3}{*}{ 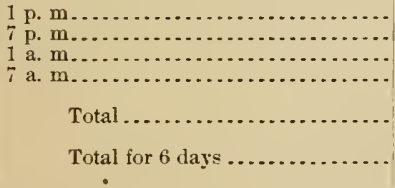 } & $\begin{array}{l}38.3 \\
38.9 \\
26.2 \\
30.1\end{array}$ & $\begin{array}{l}+10.6 \\
+\quad .6 \\
+12.7 \\
+\quad 3.9\end{array}$ & $\begin{array}{l}40.1 \\
42.2 \\
42.9 \\
38.4\end{array}$ & $\begin{array}{r}+2.1 \\
+\quad .7 \\
-4.5\end{array}$ & $\begin{array}{l}+11 \\
+14 \\
-19 \\
-19\end{array}$ & $\begin{array}{l}3 \\
3 \\
3 \\
3\end{array}$ & $\begin{array}{r}+14.0 \\
+19.1 \\
-15.3 \\
-20.5\end{array}$ \\
\hline & & 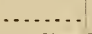 & +2.4 & $\ldots$ & -1.7 & -13 & 12 & -2.7 \\
\hline & & ....... & -1.3 & ... & +5.5 & -21 & 72 & +56.5 \\
\hline
\end{tabular}

Vol. 8-No. $6-6$ 
TaBLE XXV.-Record of carbon dioxid in ventilating air current-Metabolism experiments Nos. 15-1\%.

\begin{tabular}{|c|c|c|c|c|c|c|c|c|c|}
\hline \multirow{3}{*}{ Date. } & \multirow{3}{*}{ Period. } & \multirow{3}{*}{$\begin{array}{l}\text { Ventilation. } \\
\text { Number of } \\
\text { liters of air. }\end{array}$} & \multicolumn{6}{|c|}{ Carbon dioxid. } & \multirow{3}{*}{$\begin{array}{l}\text { (h) } \\
\text { Total } \\
\text { weight of } \\
\text { carbon } \\
\text { exhaled, } \\
g \times \text { Ir. }\end{array}$} \\
\hline & & & \multicolumn{2}{|c|}{ In incoming air. } & \multirow{2}{*}{$\begin{array}{c}\text { (d) } \\
\text { In ontgo- } \\
\text { ing air. }\end{array}$} & \multirow{2}{*}{\begin{tabular}{|c|}
$(e)$ \\
Total \\
excess in \\
outgoing \\
air, \\
$d-c$.
\end{tabular}} & \multirow{2}{*}{$\begin{array}{l}(f) \\
\text { correc- } \\
\text { tion for } \\
\text { amount } \\
\text { remain- } \\
\text { ing in } \\
\text { chamber. }\end{array}$} & \multirow{2}{*}{$\begin{array}{c}(g) \\
\text { Corrected } \\
\text { amount } \\
\text { exhaled } \\
\text { by subjeet, } \\
c+f .\end{array}$} & \\
\hline & & & $\begin{array}{c}(b) \\
\text { Perliter. }\end{array}$ & $\begin{array}{c}(c) \\
\text { Total, } \\
a \times b .\end{array}$ & & & & & \\
\hline \multirow[t]{2}{*}{$\begin{array}{l}1899 . \\
\text { Jan. } \quad 16-17\end{array}$} & \multirow{2}{*}{ 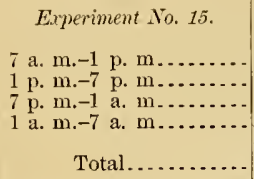 } & $\begin{array}{l}\text { Litcrs. } \\
26,341 \\
27,012 \\
28,184 \\
27,549\end{array}$ & $\begin{array}{l}.3 g \\
0.621 \\
.551 \\
.555 \\
.589\end{array}$ & $\begin{array}{r}\text { Grams. } \\
16.4 \\
14.9 \\
15.6 \\
16.2\end{array}$ & $\begin{array}{l}\text { Grams. } \\
243.5 \\
248.4 \\
228.4 \\
157.4\end{array}$ & $\begin{array}{l}\text { Grams. } \\
227.1 \\
233.5 \\
212.8 \\
141.2\end{array}$ & $\begin{array}{l}\text { Grams. } \\
+6.1 \\
+1.6 \\
+13.9 \\
+1.2\end{array}$ & $\begin{array}{l}\text { Grams. } \\
233.2 \\
235.1 \\
198.9 \\
142.4\end{array}$ & $\begin{array}{r}\text { Grams. } \\
63.6 \\
64.2 \\
54.2 \\
38.8\end{array}$ \\
\hline & & 109,086 & ....... & 63.1 & 877.7 & 814.6 & -5.0 & .809 .6 & 220.8 \\
\hline \multirow[t]{2}{*}{$17-18$} & \multirow{2}{*}{ 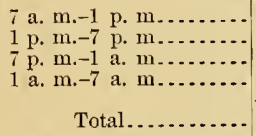 } & $\begin{array}{l}26,862 \\
27,308 \\
27,663 \\
28,241\end{array}$ & $\begin{array}{l}.615 \\
.718 \\
.568 \\
.720\end{array}$ & $\begin{array}{l}16.5 \\
19.6 \\
15.7 \\
20.3 \\
\end{array}$ & $\begin{array}{l}222.8 \\
240.9 \\
242.8 \\
164.7 \\
\end{array}$ & $\begin{array}{l}206.3 \\
221.3 \\
227.1 \\
144.4\end{array}$ & $\begin{array}{r}+6.9 \\
+7.2 \\
-13.1 \\
+\quad 3.8 \\
\end{array}$ & $\begin{array}{l}213.2 \\
228.5 \\
214.0 \\
148.2\end{array}$ & $\begin{array}{l}58.2 \\
62.3 \\
58.4 \\
40.4\end{array}$ \\
\hline & & 110,074 & & 72.1 & 871.2 & 799.1 & +4.8 & 803.9 & 219.3 \\
\hline \multirow[t]{2}{*}{ 18-19 } & $\begin{array}{l}\text { Experiment No. } 16 . \\
7 \text { a. m.-1 p. m...... } \\
1 \text { p. m.-7 p. m...... } \\
7 \text { p. m.-1 a. m..... } \\
1 \text { a. m. }-7 \text { a. m...... }\end{array}$ & $\begin{array}{l}26,544 \\
27,013 \\
28,510 \\
27,813\end{array}$ & $\begin{array}{l}.652 \\
.666 \\
.513 \\
.551 \\
\end{array}$ & $\begin{array}{l}17.3 \\
18.0 \\
14.6 \\
15.3 \\
\end{array}$ & $\begin{array}{l}232.1 \\
233.1 \\
241.9 \\
160.7 \\
\end{array}$ & $\begin{array}{l}214.8 \\
215.1 \\
227.3 \\
145.4\end{array}$ & $\begin{array}{r}+4.0 \\
+5.5 \\
-12.3 \\
-2.9 \\
\end{array}$ & $\begin{array}{l}218.8 \\
220.6 \\
215.0 \\
142.5\end{array}$ & $\begin{array}{l}59.6 \\
60.2 \\
58.6 \\
38.9 \\
\end{array}$ \\
\hline & Total. & 109,880 & ...... & 65.2 & 867.8 & 802.6 & -5.7 & 796.9 & 217.3 \\
\hline \multirow[t]{2}{*}{$19-20$} & 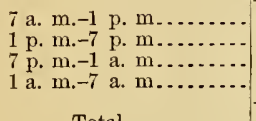 & $\begin{array}{l}24,950 \\
22,648 \\
27,492 \\
26,818 \\
\end{array}$ & $\begin{array}{l}.560 \\
.607 \\
.632 \\
.663 \\
\end{array}$ & $\begin{array}{l}14.0 \\
13.7 \\
17.4 \\
17.8\end{array}$ & $\begin{array}{l}223.4 \\
249.2 \\
237.5 \\
154.7\end{array}$ & $\begin{array}{l}209.4 \\
235.5 \\
220.1 \\
136.9\end{array}$ & $\begin{array}{l}+16.6 \\
+2.0 \\
-14.6 \\
-1.8\end{array}$ & $\begin{array}{l}226.0 \\
237.5 \\
205.5 \\
135.1\end{array}$ & $\begin{array}{l}61.6 \\
64.7 \\
56.1 \\
36.9\end{array}$ \\
\hline & Total. & 101,908 & N....... & 62.9 & 864.8 & 801.9 & +2.2 & 804.1 & 219.3 \\
\hline \multirow[t]{2}{*}{$20-21$} & $\begin{array}{l}\text { Experiment No. } 1 \text {. } \\
7 \text { a. m. }-1 \text { p. m..... } \\
1 \text { p. m. }-7 \text { p. m.... } \\
7 \text { p. m. }-1 \text { a. m.... } \\
1 \text { a. m. }-7 \text { a. m.... }\end{array}$ & $\begin{array}{l}25,502 \\
26,811 \\
27,935 \\
28,699\end{array}$ & $\begin{array}{l}.703 \\
.657 \\
.568 \\
.611 \\
\end{array}$ & $\begin{array}{l}17.9 \\
17.6 \\
15.9 \\
17.5 \\
\end{array}$ & $\begin{array}{l}218.0 \\
242.6 \\
217.8 \\
170.4 \\
\end{array}$ & $\begin{array}{l}200.1 \\
225.0 \\
201.9 \\
152.9\end{array}$ & $\begin{array}{l}+11.2 \\
-\quad .5 \\
-9.1 \\
-1.6\end{array}$ & $\begin{array}{l}211.3 \\
224.5 \\
192.8 \\
151.3\end{array}$ & $\begin{array}{l}57.6 \\
61.3 \\
52.6 \\
41.2 \\
\end{array}$ \\
\hline & Total. & 108,947 & 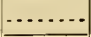 & 68.9 & 848.8 & 779.9 & $\ldots$ & 779.9 & 212.7 \\
\hline \multirow[t]{3}{*}{$21-22$} & 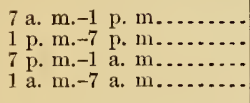 & $\begin{array}{l}25,958 \\
26,321 \\
27,920 \\
27,829\end{array}$ & $\begin{array}{l}.634 \\
.565 \\
.554 \\
.632 \\
\end{array}$ & $\begin{array}{l}16.5 \\
14.9 \\
15.5 \\
17.6\end{array}$ & $\begin{array}{l}222.2 \\
243.5 \\
229.2 \\
160.4\end{array}$ & $\begin{array}{l}205.7 \\
228.6 \\
213.7 \\
142.8\end{array}$ & $\begin{array}{l}+10.6 \\
+\quad .6 \\
+12.7 \\
+\quad 3.9\end{array}$ & $\begin{array}{l}216.3 \\
229.2 \\
201.0 \\
146.7\end{array}$ & $\begin{array}{l}59.0 \\
62.5 \\
54.8 \\
40.0\end{array}$ \\
\hline & Total.. & 108,028 & $\cdots$ & 64.5 & 855.3 & 790.8 & +2.4 & 793.2 & 216.3 \\
\hline & Total, 6 days..... & 647,923 & .......... & 396.7 & $5,185.6$ & $4,788.9$ & -1.3 & $4,787,6$ & $1,305.7$ \\
\hline
\end{tabular}


TABLE XXVI. - Record of werer in rentilating air current-. Wetabolism experiments. Jus. 15-12.

\begin{tabular}{|c|c|c|c|c|c|c|c|c|c|c|}
\hline \multirow[b]{2}{*}{ Date. } & \multirow[b]{2}{*}{ Period. } & \multirow{2}{*}{$\begin{array}{l}n \\
\text { Ventila- } \\
\text { tion. Yum- } \\
\text { ber fiters } \\
\text { of air. }\end{array}$} & \multicolumn{2}{|c|}{$\begin{array}{l}\text { Water in incoming } \\
\text { air. }\end{array}$} & \multicolumn{3}{|c|}{ Watet in outgoing air. } & \multirow[b]{2}{*}{$\begin{array}{l}\text { Total ex- } \\
\text { cens water } \\
\text { in outzo- } \\
\text { ing air, } \\
j-c \text {. }\end{array}$} & \multirow{2}{*}{$\begin{array}{l}\text { h } \\
\text { Correc- } \\
\text { tion for } \\
\text { water re- } \\
\text { maining } \\
\text { in cham- } \\
\text { ber. }\end{array}$} & \multirow{2}{*}{$\begin{array}{l}(i) \\
\text { Total } \\
\text { mater of } \\
\text { respirs- } \\
\text { tiun and } \\
\text { perspira- } \\
\text { tion, } g+h \text {. }\end{array}$} \\
\hline & & & $\begin{array}{l}\text { b } \\
\text { Per } \\
\text { liter. }\end{array}$ & $\begin{array}{c}c \\
\text { Tutal. } \\
a \times b .\end{array}$ & $\begin{array}{l}d \\
\text { Amount } \\
\text { condensed } \\
\text { in fretzers. }\end{array}$ & $\begin{array}{l}\text { te } \\
\text { Amount } \\
\text { nest con- } \\
\text { dented in } \\
\text { ineezer. }\end{array}$ & $\begin{array}{c}\mid f \\
\text { Total. } \\
d+e .\end{array}$ & & & \\
\hline \multirow[t]{2}{*}{$\begin{array}{c}1899 \\
\text { Jan. } 16-17\end{array}$} & \multirow{2}{*}{ 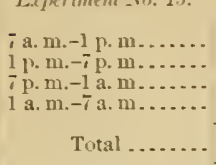 } & $\begin{array}{l}\text { Liters. } \\
26,341 \\
27,012 \\
28,1<4 \\
27,549\end{array}$ & $\begin{array}{l}y,-5 \\
0.573 \\
.846 \\
\times 51\end{array}$ & $\begin{array}{l}\text { Grams. } \\
23.1 \\
23.6 \\
25.2 \\
23.4\end{array}$ & $\begin{array}{l}\text { Grans. } \\
176.3 \\
19.5 \\
225.1 \\
21+.1\end{array}$ & $\begin{array}{l}\text { Grams. } \\
42.7 \\
40.3 \\
50.7 \\
41.5\end{array}$ & $\begin{array}{l}\text { Grams. } \\
219.0 \\
235.5 \\
275.8 \\
255.9\end{array}$ & $\begin{array}{l}\text { Grams. } \\
195.9 \\
215.2 \\
250.6 \\
23: .5\end{array}$ & $\begin{array}{r}\text { Grams. } \\
-13.9 \\
-\quad 2.4 \\
-9.9 \\
-4.7\end{array}$ & $\begin{array}{l}\text { (rnums. } \\
20.9 .5 \\
212.5 \\
260.5 \\
227.5\end{array}$ \\
\hline & & $109,0 \times 6$ & 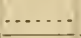 & 95.3 & $\$ 1+.0$ & 175.5 & 949.5 & 894.2 & -16.7 & 910.9 \\
\hline \multirow[t]{2}{*}{$17-15$} & \multirow{2}{*}{ 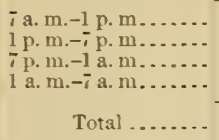 } & $\begin{array}{l}26 . \times 62 \\
27.304 \\
27,663 \\
28.241\end{array}$ & $\begin{array}{l}920 \\
.979 \\
.914 \\
595\end{array}$ & $\begin{array}{l}24.7 \\
26.7 \\
25.3 \\
25.3\end{array}$ & $\begin{array}{l}140.9 \\
204.6 \\
248.3 \\
241.7\end{array}$ & $\begin{array}{l}40.0 \\
34.6 \\
45.9 \\
41.5\end{array}$ & $\begin{array}{l}237.5 \\
243.2 \\
294.2 \\
2 \$ 3.2\end{array}$ & $\begin{array}{l}212 . x \\
216.5 \\
26-9 \\
25-.9\end{array}$ & $\begin{array}{r}-8.5 \\
-1.6 \\
-1.5 .4 \\
-\quad 2.1\end{array}$ & $\begin{array}{l}204.3 \\
215.1 \\
284.3 \\
260.0\end{array}$ \\
\hline & & 110.074 & .... & 102.0 & 891.5 & $166^{\circ} .6^{\circ}$ & $1.95 \mathrm{~s} .1$ & 956.1 & -10.6 & 9636.7 \\
\hline \multirow[t]{2}{*}{$15-19$} & \multirow{2}{*}{ 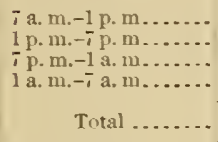 } & $\begin{array}{l}26,514 \\
27,013 \\
25,510 \\
27,813\end{array}$ & $\begin{array}{l}.999 \\
.897 \\
.805 \\
.761\end{array}$ & $\begin{array}{l}26.5 \\
24.2 \\
22.9 \\
21.2\end{array}$ & $\begin{array}{l}209.7 \\
214.0 \\
230.4 \\
217.0\end{array}$ & $\begin{array}{l}39.3 \\
39.6 \\
41.1 \\
39.6\end{array}$ & $\begin{array}{l}249.0 \\
252.6 \\
271.5 \\
256.6\end{array}$ & $\begin{array}{l}2.27 .5 \\
2-29.4 \\
240.6 \\
235.4\end{array}$ & $\begin{array}{l}-5.9 \\
-13.0 \\
-1.3 \\
-5.4\end{array}$ & $\begin{array}{l}2.28 .4 \\
241.4 \\
247.3 \\
230.0\end{array}$ \\
\hline & & 109.350 & ........ & 94.5 & .1 & 15.6 & $1,029.7$ & 934.9 & -12.2 & 947.1 \\
\hline \multirow[t]{2}{*}{$19-20$} & \multirow{2}{*}{ 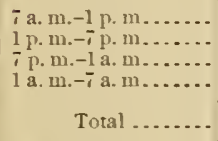 } & $\begin{array}{l}24,950 \\
22.645 \\
27,492 \\
26,818\end{array}$ & $\begin{array}{l}-254 \\
.723 \\
.818 \\
.786\end{array}$ & $\begin{array}{l}19.6 \\
17.7 \\
22.5 \\
21.1\end{array}$ & $\begin{array}{l}145.7 \\
157.6 \\
219.7 \\
217.2\end{array}$ & $\begin{array}{l}33.2 \\
32.0 \\
+2.2 \\
37.0\end{array}$ & $\begin{array}{l}214.9 \\
219.6 \\
261.9 \\
254.2\end{array}$ & $\begin{array}{l}199.3 \\
201.9 \\
239.4 \\
233.1\end{array}$ & $\begin{array}{r}-16.2 \\
-20.4 \\
-3.8 \\
-9.9\end{array}$ & $\begin{array}{l}-15.5 \\
222.3 \\
235.6 \\
223.2\end{array}$ \\
\hline & & 101,905 & $\ldots \ldots$ & 80.9 & 810.2 & 144.4 & 954.6 & 873.7 & -20.9 & 896.6 \\
\hline \multirow[t]{2}{*}{$20-21$} & \multirow{3}{*}{ 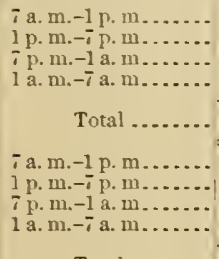 } & $\begin{array}{l}25,502 \\
26,811 \\
2-935 \\
25,699\end{array}$ & $\begin{array}{r}.53 \\
9.53 \\
.840 \\
.795\end{array}$ & $\begin{array}{l}21.7 \\
25.5 \\
23.5 \\
22.9\end{array}$ & $\begin{array}{l}186.5 \\
205.6 \\
215.1 \\
239.2\end{array}$ & $\begin{array}{l}36.3 \\
39.6 \\
41.4 \\
40.7\end{array}$ & $\begin{array}{l}322.8 \\
245.2 \\
262.5 \\
269.9\end{array}$ & $\begin{array}{l}201.1 \\
219.7 \\
239.0 \\
247.0\end{array}$ & $\begin{array}{l}-\quad .1 \\
-23.3 \\
-1.9 \\
-16.5\end{array}$ & $\begin{array}{l}193.0 \\
243.0 \\
237.1 \\
230.5\end{array}$ \\
\hline & & $108,94 \pi$ & ........ & 93.6 & 839.4 & 161.0 & $1,000.4$ & 906.5 & -3.2 & 903.6 \\
\hline \multirow[t]{3}{*}{$21-22$} & & $\begin{array}{l}25.958 \\
26,321 \\
27,920 \\
27,829\end{array}$ & $\begin{array}{l}.930 \\
.939 \\
.935 \\
.924\end{array}$ & $\begin{array}{l}25.4 \\
24.7 \\
26.1 \\
25.7\end{array}$ & $\begin{array}{l}192.0 \\
205.2 \\
223.4 \\
206.7\end{array}$ & $\begin{array}{l}37.5 \\
39.0 \\
41.7 \\
38.5\end{array}$ & $\begin{array}{l}229.5 \\
244.2 \\
26.5 .1 \\
245.2\end{array}$ & $\begin{array}{l}204.1 \\
219.5 \\
239.0 \\
219.5\end{array}$ & $\begin{array}{l}-14.0 \\
+19.1 \\
-15.3 \\
-20.5\end{array}$ & $\begin{array}{l}215.1 \\
235.6 \\
223.7 \\
199.0\end{array}$ \\
\hline & Total . & 105,025 & ........ & 101.9 & 827.3 & 156. 7 & 984.0 & $8 \times 2.1$ & -2.7 & 8.9 .4 \\
\hline & Total, 6 dars. & 647,923 & ....... & 535.5 & 5.053 .5 & 962.5 & $6,016.3$ & $5,47.5$ & -56.5 & 5.504 .3 \\
\hline
\end{tabular}


Table XXVII summarizes the results of the calorimetric measurements during this experiment.

Table XXVII.-Summary of calorimetric measurement-Metabolism cxperiments _Nos. 15-1\%.

\begin{tabular}{|c|c|c|c|c|c|c|c|c|}
\hline Date. & Period. & $\begin{array}{c}\langle a\rangle \\
\\
\text { Heat } \\
\text { measured } \\
\text { in } \\
\text { terms of } \\
\text { Co. }\end{array}$ & $\begin{array}{l}\text { Change } \\
\text { of tem- } \\
\text { perature } \\
\text { of calo- } \\
\text { rimeter. }\end{array}$ & $\begin{array}{c}(c) \\
\\
\text { Capacity } \\
\text { eorrec- } \\
\text { tion of } \\
\text { calorim- } \\
\text { eter, } \\
b \times 60 .\end{array}$ & $\begin{array}{c}(d) \\
\\
\text { Correc- } \\
\text { tion due } \\
\text { to tem- } \\
\text { pera- } \\
\text { ture of } \\
\text { food and } \\
\text { dishes. }\end{array}$ & $\begin{array}{c}(e) \\
\text { Water } \\
\text { raporized, } \\
\text { equals } \\
\text { tottl } \\
\text { amount } \\
\text { exhaled } \\
\text { less } \\
\text { amount } \\
\text { condensed } \\
\text { in } \\
\text { chamber. }\end{array}$ & 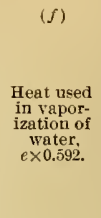 & $\begin{array}{c}\text { Total heat } \\
\text { determined, } \\
a+c+d \\
+f .\end{array}$ \\
\hline $\begin{array}{l}1899 . \\
\text { Jan. } 16-18\end{array}$ & 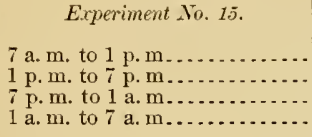 & $\begin{array}{l}\text { Calories. } \\
557.1 \\
543.8 \\
473.6 \\
269.1\end{array}$ & $\begin{array}{l}\text { Degress. } \\
-0.03 \\
+.02 \\
+.0 . \\
+.01\end{array}$ & $\begin{array}{c}\text { Calories. } \\
-1.80 \\
+1.20 \\
\cdots+.60 \\
+. .60\end{array}$ & \begin{tabular}{c} 
Calories. \\
$+\quad 5.2$ \\
$+\quad .3$ \\
\hdashline$\ldots .$. \\
\end{tabular} & $\begin{array}{l}\text { Grams. } \\
201.8 \\
217.8 \\
256.5 \\
223.8\end{array}$ & $\begin{aligned} \text { Calorice. } \\
119.5 \\
128.9 \\
151.9 \\
132.5\end{aligned}$ & $\begin{array}{l}\text { Calories. } \\
680.0 \\
674.2 \\
625.5 \\
402.2\end{array}$ \\
\hline & Total. & $1,843.6$ & .00 & .00 & +5.5 & 899.9 & 532.8 & $2,381.9$ \\
\hline $17-18$ & $\begin{array}{l}7 \text { a. m. to } 1 \text { p. m... } \\
1 \text { p. } m \text {. to } 7 \text { p. m.. } \\
7 \text { p. m. to } 1 \text { a. } m . . \\
1 \text { a. m. to } 7 \text { a. m.. }\end{array}$ & $\begin{array}{l}488.5 \\
516.8 \\
490.0 \\
274.8\end{array}$ & \begin{tabular}{|}
-.01 \\
-.01 \\
\hdashline-.03 \\
\end{tabular} & \begin{tabular}{|}
-.60 \\
-.60 \\
-1.80 \\
\end{tabular} & $\begin{array}{r}+2.2 \\
+4.7 \\
+\end{array}$ & $\begin{array}{l}214.3 \\
218.1 \\
276.3 \\
252.0\end{array}$ & $\begin{array}{l}126.9 \\
129.1 \\
163.6 \\
149.2\end{array}$ & $\begin{array}{l}617.0 \\
650.0 \\
653.6 \\
422.2 \\
\end{array}$ \\
\hline & Total... & $1,770.1$ & -.05 & -3.00 & $\begin{array}{r}+6.9 \\
\end{array}$ & 960.7 & 568.8 & $2,342.8$ \\
\hline 18-19 & 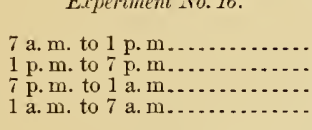 & $\begin{array}{l}531.7 \\
484.1 \\
461.9 \\
282.0\end{array}$ & $\begin{array}{r}+.02 \\
+.01 \\
+.01 \\
-.05 \\
\end{array}$ & $\begin{array}{r}+1.20 \\
+.60 \\
+\quad .60 \\
-3.00\end{array}$ & $\begin{array}{l}+.2 \\
-2.5 \\
\ldots \ldots . . \\
\ldots \ldots . .\end{array}$ & $\begin{array}{l}221.4 \\
233.4 \\
277.3 \\
229.0\end{array}$ & $\begin{array}{l}131.1 \\
138.2 \\
146.4 \\
135.6\end{array}$ & $\begin{array}{l}664.2 \\
620.4 \\
608.9 \\
414.6\end{array}$ \\
\hline & Total & $1,759.7$ & -.01 & -.60 & -2.3 & 931.1 & 551.3 & $2,308.1$ \\
\hline $19-20$ & 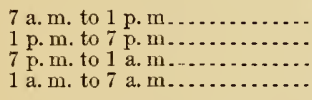 & $\begin{array}{l}549.6 \\
553.3 \\
437.4 \\
286.7\end{array}$ & $\begin{array}{r}+.02 \\
+.01 \\
+.10 \\
-.09\end{array}$ & $\begin{array}{l}+1.20 \\
+.60 \\
+6.00 \\
-5.40\end{array}$ & $\begin{array}{l}+\quad .9 \\
+7.8 \\
\ldots \ldots . . . \\
\ldots \ldots . .\end{array}$ & $\begin{array}{l}201.5 \\
205.3 \\
240.6 \\
228.2\end{array}$ & $\begin{array}{l}119.3 \\
121.5 \\
142.4 \\
135.1\end{array}$ & $\begin{array}{l}671.0 \\
683.2 \\
585.8 \\
416.4\end{array}$ \\
\hline & Total.... & $1,827.0$ & +.04 & $\begin{array}{r}+2.40 \\
\end{array}$ & +8.7 & 875.6 & 518.3 & $2,356.4$ \\
\hline $20-21$ & $\begin{array}{l}\text { Experiment No. } 17 . \\
7 \text { a.m. to } 1 \text { p. m......... } \\
1 \text { p. m. to } 7 \text { p. m........ } \\
7 \text { p. m, to } 1 \text { a. m........ } \\
1 \text { a. m. to } 7 \text { a. m........ }\end{array}$ & $\begin{array}{l}465.8 \\
490.2 \\
467.7 \\
286.7\end{array}$ & $\begin{array}{r}-.02 \\
+.04 \\
+.04 \\
+.03\end{array}$ & $\begin{array}{l}-1.20 \\
+2.40 \\
-2.40 \\
+1.80\end{array}$ & $\begin{array}{l}-\quad .2 \\
+1.2 \\
\cdots \\
\cdots\end{array}$ & $\begin{array}{l}199.0 \\
223.0 \\
235.1 \\
238.5\end{array}$ & $\begin{array}{l}117.8 \\
132.0 \\
145.1 \\
141.2\end{array}$ & $\begin{array}{l}582.2 \\
625.8 \\
610.4 \\
429.7\end{array}$ \\
\hline \multirow{4}{*}{$21-22$} & Total. & $1,710.4$ & +.01 & +.60 & +1.0 & 905.6 & 536.1 & $2,248.1$ \\
\hline & $\begin{array}{l}7 \text { a.m. to } 1 \text { p. m....... } \\
1 \text { p. m. to } 7 \text { p. m........ } \\
7 \text { p.m. to } 1 \text { a.m........ } \\
1 \text { a.m. to } 7 \text { a.m....... }\end{array}$ & $\begin{array}{l}506.0 \\
528.2 \\
456.6 \\
295.4\end{array}$ & $\begin{array}{l}-.02 \\
-.01 \\
+.02 \\
-.01\end{array}$ & $\begin{array}{l}-1.20 \\
-.60 \\
+1.20 \\
-.60\end{array}$ & 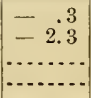 & $\begin{array}{l}204.1 \\
221.6 \\
239.7 \\
215.0\end{array}$ & $\begin{array}{l}120.8 \\
131.2 \\
141.9 \\
127.3\end{array}$ & $\begin{array}{l}625.3 \\
656.5 \\
599.7 \\
422.1\end{array}$ \\
\hline & Total. & $1,786.2$ & -.02 & -1.20 & -2.6 & 880.4 & 521.2 & $2,303.6$ \\
\hline & Total for 6 days. & $10,697.0$ & $\cdots$ & -1.80 & +17.2 & $5,453.3$ & $3,228.5$ & $\overline{13,940.9}$ \\
\hline
\end{tabular}


MEMOIRS OF THE NATIONAL ACADEMY OF SCIENCES.

313

Elimination of unoxidized alcohol. -As has been explained on page 258 there may be a considerable amount of reducing matter in the ventilating air current when alcohol does not form a part of the diet. The determinations of the quantity of reducing matter in the air current during these experiments were made in the manner previously described, and the amounts are all reckoned as alcohol, although it is not believed that this is the ease. It seems probable that the increased elimination of reducing matter in the air current on the 2 days of experiment No. 16 is due to the mixing of the whisky and water within the chamber by the subject, as already mentioned. According to the figures in Table XXVIII the subject actually metabolized 97.9 per cent of the alcohol in the diet during experiment No. 15, 96.6 per cent in experiment No. 16, and 97.9 per cent in experiment No. 17 .

TABLE XXVIII. -Alcohol ingested and excreted-Mftabolism experiments Nos. 15-17.

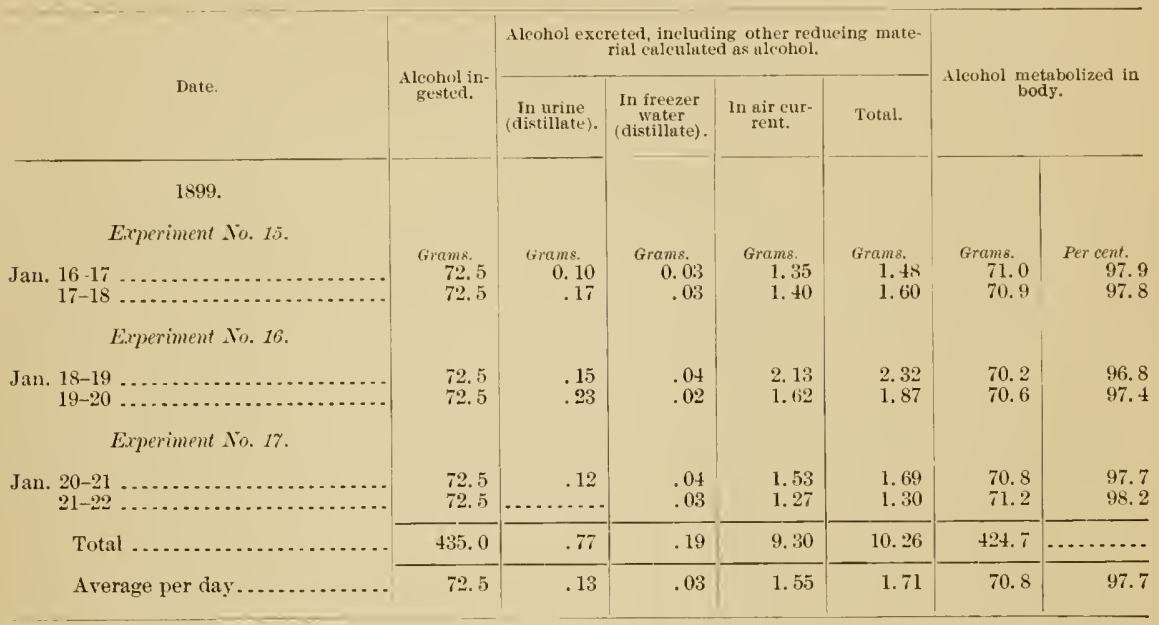


Balunce of income and outgo of mutter and energy.-The income and outgo of nitrogen, carbon, hydrogen, and energy in these experiments are shown in Tables XXIX to XXXII. It will be noticed that the snbject was nearly in nitrogen and carbon equilibrium. The amount of water consumed was $1,382.5$ grams, 600 of which were contained in drinking water and 782.5 in coffee infusion or water with which the alcohol was mixed. The agreement between the estimated energy of materials oxidized in the body and the heat actually determined in these experiments was very close, the variations being so small as to lie far within the limit of experimental error.

TABLE XXIX. - Income and outgo of nitrogen and carbon-Metabolism experiments Nos. 15-17.

\begin{tabular}{|c|c|c|c|c|c|c|c|c|c|c|}
\hline \multirow[b]{2}{*}{ Date and period. } & \multicolumn{4}{|c|}{ Nitrogen. } & \multicolumn{6}{|c|}{ Carbon. } \\
\hline & $\begin{array}{l}(a) \\
\text { In } \\
\text { food. }\end{array}$ & $\begin{array}{c}(b) \\
\text { In } \\
\text { feces. }\end{array}$ & $\begin{array}{c}\text { (c) } \\
\text { In } \\
\text { urine. }\end{array}$ & $\begin{array}{c}(d) \\
\text { Gain } \\
(+) \text { or } \\
\text { loss } \\
(-) \\
a- \\
(b+c)\end{array}$ & $\begin{array}{l}(e) \\
\text { In } \\
\text { food. }\end{array}$ & $\begin{array}{c}(j) \\
\text { In } \\
\text { feces. }\end{array}$ & $\begin{array}{c}(g) \\
\text { In } \\
\text { urine. }\end{array}$ & $\begin{array}{c}(h) \\
\begin{array}{c}\text { In respira- } \\
\text { tory prod- } \\
\text { uets. }\end{array}\end{array}$ & $\begin{array}{l}\text { (i) } \\
\text { In al- } \\
\text { cohol } \\
\text { elimi- } \\
\text { nated. }\end{array}$ & $\begin{array}{l}(k) \\
\text { Gain } \\
(+) \text { or } \\
\text { loss } \\
(-) e- \\
(f+g+ \\
h+i)\end{array}$ \\
\hline $\begin{array}{c}1899 . \\
\text { Erperiment No. } 15 . \\
\text { Jan. 16-17,7 a. m. to } 7 \text { a. m..... } \\
17-18,7 \text { a. m. to } 7 \text { a. m.... }\end{array}$ & $\begin{array}{l}\text { Gms. } \\
17.4 \\
17.4\end{array}$ & $\begin{array}{r}G m s . \\
0.8 \\
.8\end{array}$ & $\begin{array}{l}G m s . \\
15.1 \\
16.2\end{array}$ & $\begin{array}{r}G m s . \\
+1.5 \\
+\quad .4\end{array}$ & $\begin{array}{l}\text { Gms. } \\
245.7 \\
245.7\end{array}$ & $\begin{array}{r}\text { Gms. } \\
7.8 \\
7.8\end{array}$ & $\begin{array}{l}\text { Gms. } \\
10.6 \\
11.4\end{array}$ & $\begin{array}{l}G m s . \\
220.8 \\
219.3\end{array}$ & $\begin{array}{r}G m s . \\
0.8 \\
.8\end{array}$ & $\begin{array}{l}\text { Gms. } \\
+5.7 \\
+\quad 6.4\end{array}$ \\
\hline $\begin{array}{l}\text { Total for } 2 \text { days } \ldots \ldots \ldots \ldots \ldots \ldots \ldots \ldots \\
\text { Average per day } \ldots \ldots \ldots \ldots \ldots \ldots\end{array}$ & $\begin{array}{l}34.8 \\
17.4 \\
\end{array}$ & $\begin{array}{r}1.6 \\
.8 \\
\end{array}$ & $\begin{array}{l}31.3 \\
\mathbf{1 5 . 6} \\
\end{array}$ & $\begin{array}{r}+1.9 \\
+1.0 \\
\end{array}$ & $\begin{array}{l}491.4 \\
245.7 \\
\end{array}$ & $\begin{array}{r}15.6 \\
7.8 \\
\end{array}$ & $\begin{array}{l}22.0 \\
11.0\end{array}$ & $\begin{array}{l}440.1 \\
220.0\end{array}$ & $\begin{array}{r}1.6 \\
.8 \\
\end{array}$ & $\begin{array}{l}+12.1 \\
+6.1 \\
\end{array}$ \\
\hline Experiment No. 16. & & & & & & & & & & \\
\hline $\begin{array}{r}\text { Jan. } 18-19,7 \text { a. m. to } 7 \text { a. m..................... } \\
\quad 19-20,7 \text { a.m. to } 7 \text { a.m }\end{array}$ & $\begin{array}{l}17.4 \\
17.4\end{array}$ & $\begin{array}{l}.8 \\
.8 \\
\end{array}$ & $\begin{array}{l}15.2 \\
15.7\end{array}$ & $\begin{array}{r}+1.4 \\
+\quad .9 \\
\end{array}$ & $\begin{array}{l}245.7 \\
245.7\end{array}$ & $\begin{array}{l}7.8 \\
7.8 \\
\end{array}$ & $\begin{array}{l}10.7 \\
11.1\end{array}$ & $\begin{array}{l}217.3 \\
219.3\end{array}$ & $\begin{array}{l}1.2 \\
1.0 \\
\end{array}$ & $\begin{array}{l}+8.7 \\
+6.5 \\
\end{array}$ \\
\hline 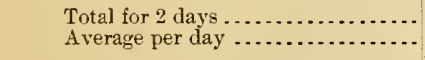 & $\begin{array}{l}34.8 \\
17.4 \\
\end{array}$ & $\begin{array}{r}1.6 \\
.8 \\
\end{array}$ & $\begin{array}{l}30.9 \\
15.5 \\
\end{array}$ & $\begin{array}{r}+2.3 \\
+1.1 \\
\end{array}$ & $\begin{array}{l}491.4 \\
245.7 \\
\end{array}$ & $\begin{array}{r}15.6 \\
7.8 \\
\end{array}$ & $\begin{array}{l}21.8 \\
10.9 \\
\end{array}$ & $\begin{array}{l}436.6 \\
213.3 \\
\end{array}$ & $\begin{array}{l}2.2 \\
1.1 \\
\end{array}$ & $\begin{array}{r}+15.2 \\
+7.6 \\
\end{array}$ \\
\hline $\begin{array}{r}\text { Experi rent No. } 1 \% . \\
\text { Jan. } 20-21,7 \text { a.m. to } 7 \text { a. m.... } \\
21-22,7 \text { a. m. to } 7 \text { a. m.... }\end{array}$ & $\begin{array}{l}17.4 \\
17.4 \\
\end{array}$ & $\begin{array}{r}.8 \\
.8 \\
\end{array}$ & $\begin{array}{l}15.7 \\
15.6 \\
\end{array}$ & $\begin{array}{r}+.9 \\
+1.0 \\
\end{array}$ & $\begin{array}{l}245.7 \\
245.7 \\
\end{array}$ & $\begin{array}{l}7.8 \\
7.8 \\
\end{array}$ & $\begin{array}{l}11.1 \\
11.0 \\
\end{array}$ & $\begin{array}{l}212.7 \\
216.3 \\
\end{array}$ & $\begin{array}{l}.9 \\
.7 \\
\end{array}$ & $\begin{array}{r}+13.2 \\
+9.9 \\
\end{array}$ \\
\hline $\begin{array}{l}\text { Total for } 2 \text { days } \ldots \ldots \ldots \ldots \ldots \ldots \\
\text { Average per day } \ldots \ldots \ldots\end{array}$ & $\begin{array}{l}34.8 \\
17.4 \\
\end{array}$ & $\begin{array}{r}1.6 \\
.8 \\
\end{array}$ & $\begin{array}{l}31.3 \\
15.6\end{array}$ & $\begin{array}{r}+1.9 \\
+1.0 \\
\end{array}$ & $\begin{array}{l}491.4 \\
245.7\end{array}$ & $\begin{array}{r}15.6 \\
7.8\end{array}$ & $\begin{array}{l}22.1 \\
11.0\end{array}$ & $\begin{array}{l}429.0 \\
214.5\end{array}$ & $\begin{array}{r}1.6 \\
.8\end{array}$ & $\begin{array}{r}+23.1 \\
+11.6 \\
\end{array}$ \\
\hline $\begin{array}{l}\text { Total for } 6 \text { days } \ldots \ldots \ldots \ldots \ldots \ldots \\
\text { Average per day } \ldots \ldots \ldots \ldots \ldots \ldots\end{array}$ & $\begin{array}{r}104.4 \\
17.4\end{array}$ & $\begin{array}{r}4.8 \\
.8\end{array}$ & $\begin{array}{l}93.5 \\
15.6\end{array}$ & $\begin{array}{r}+6.1 \\
+1.0\end{array}$ & $\begin{array}{r}1,474.2 \\
245.7\end{array}$ & $\begin{array}{r}46.8 \\
7.8\end{array}$ & $\begin{array}{l}65.9 \\
11.0\end{array}$ & $\begin{array}{r}1,305.7 \\
217.6\end{array}$ & $\begin{array}{r}5.4 \\
.9\end{array}$ & $\begin{array}{r}+50.4 \\
+8.4\end{array}$ \\
\hline
\end{tabular}


TABLE XXX.-Income and outgo of urter ruml hydrogm-Metabolism experiments . Dos. 15-17.

Date and periorl.

1899.

Experiment Nis. 1.5

Jan. $16-17, \bar{i}$ a. m. to $\bar{i}$ a. m

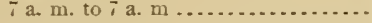

Total for 2 days . . . . . . . . . . . . . . . . . . .

Average per day

\section{Experiment No. 16.}

Jan. 1s-19, 7 a. m. to 7 a. m ..................

19-20, $\bar{i}$ a. m. to $\bar{i}$ a. $m$

Total for 2 days

Average per day

\section{Experiment No. 17 .}

Jan. $20-21, \tau$ a. m. to $\bar{z}$ a. m .................. $21-22,7$ a. m. to 7 a. m.....................

Total for 2 days

Average per day

Total for 6 days

Average per day

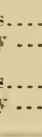

.......

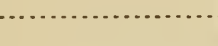

.

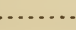

\footnotetext{
(1)
}

Date and period.

Jan. 16-17, 7 a. m. to 7 a. $m . . . . . . . . . . .$.

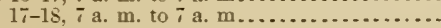

Total for ? days.

Arerage per day

Experiment So. 16.

Jan. 18-19, т a. m. to 7 a. m...................

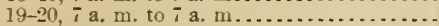

Total for 2 days .....................

Arerage per day

\section{Experiment Wo. $1 \%$.}

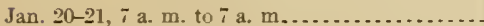

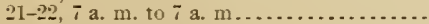

Total for 2 days

Average per day.

Total for 6 days

ircrage per day.
Water.

In foot. $\mid$ In alrink.

\begin{tabular}{l|l} 
Grams. & Gramk. \\
$1,095.2$ & $1,3 \times 2.5$ \\
$1,095.2$ & $1,3 \times 2.5$ \\
\hline $2,190.4$ & $\frac{2,765.0}{1,382.5}$ \\
\hline $1,095.2$ & $1,73.5$ \\
\hline
\end{tabular}

(c)

(d)

(e)

In respir-
atory
losparent $a+b-$ $\begin{array}{cc}\text { atory } & \text { loss } a+b- \\ \text { products. } & (c+d+e) \text {. }\end{array}$

$(c+d+e)$.

\begin{tabular}{|c|c|c|c|c|c|c|}
\hline $\begin{array}{l}1,095.2 \\
1,095.2\end{array}$ & $\begin{array}{l}1,382.5 \\
1,382.5\end{array}$ & $\begin{array}{l}35.9 \\
35.9\end{array}$ & $\begin{array}{l}1,813.9 \\
1,876.2\end{array}$ & $\begin{array}{l}947.1 \\
896.6\end{array}$ & - & $\begin{array}{l}319.2 \\
331.0\end{array}$ \\
\hline $\begin{array}{l}2,190.4 \\
1.095 .2\end{array}$ & $\begin{array}{l}2,765.0 \\
1,382.5\end{array}$ & $\begin{array}{l}71.8 \\
35.9\end{array}$ & $\begin{array}{l}3,690.1 \\
1,845.0\end{array}$ & $\begin{array}{r}1.843 .7 \\
921.9\end{array}$ & - & $\begin{array}{l}650.2 \\
325.1\end{array}$ \\
\hline
\end{tabular}

\begin{tabular}{|c|c|c|c|c|c|}
\hline $\begin{array}{l}1,095.2 \\
1,095.2\end{array}$ & $\begin{array}{l}1,382.5 \\
1,382.5\end{array}$ & $\begin{array}{l}35.9 \\
35.9\end{array}$ & $\begin{array}{l}1,903.2 \\
2,026.6\end{array}$ & $\begin{array}{l}903.6 \\
879.4\end{array}$ & $\begin{array}{r}365.0 \\
-\quad 464.2 \\
\end{array}$ \\
\hline $\begin{array}{l}2,190.4 \\
1,095.2\end{array}$ & $\begin{array}{l}2,765.0 \\
1,352.5\end{array}$ & $\begin{array}{l}71.8 \\
35.9\end{array}$ & $\begin{array}{l}3,929.8 \\
1,964.9\end{array}$ & $\begin{array}{r}\text { 1, } 783.0 \\
891.5\end{array}$ & $\begin{array}{r}829.2 \\
-\quad 414.6\end{array}$ \\
\hline $\begin{array}{l}6,571.2 \\
1.095 .2\end{array}$ & $\begin{array}{l}8,295.0 \\
1,352.5\end{array}$ & $\begin{array}{r}215.4 \\
35.9\end{array}$ & $\begin{array}{r}11,243.4 \\
1,573.9\end{array}$ & $\begin{array}{r}5,504.3 \\
917.4\end{array}$ & $\begin{array}{r}-2.096 .9 \\
-\quad 349.5\end{array}$ \\
\hline
\end{tabular}

Hyddrogen.

\begin{tabular}{|c|c|c|c|c|c|c|}
\hline In fourd. & In feces. & In urine. & $\begin{array}{c}\text { (k) } \\
\text { In alco- } \\
\text { hol elim- } \\
\text { insted. }\end{array}$ & $\begin{array}{c}\text { (l) } \\
\text { Apporent } \\
\text { gain } g- \\
(h+i+k)\end{array}$ & $\begin{array}{c}\quad(m) \\
\text { Loss from } \\
\text { water } f \div 9 \text {. }\end{array}$ & $\begin{array}{c}(n) \\
\text { Total } \\
\text { gain }(+) \\
\text { nr } \\
\begin{array}{c}\text { loss }(-) \\
l+m .\end{array}\end{array}$ \\
\hline $\begin{array}{r}\text { Grrms. } \\
40.8 \\
40.8\end{array}$ & $\begin{array}{r}\text { Grams. } \\
1.1 \\
1.1\end{array}$ & $\begin{array}{r}\text { rrams. } \\
3.0 \\
3.2\end{array}$ & $\begin{array}{r}\text { Grams. } \\
0.2 \\
.2\end{array}$ & $\begin{array}{l}\text { Grams. } \\
+36.5 \\
+36.3\end{array}$ & $\begin{array}{l}\text { Grams. } \\
+\quad 11.6 \\
-50.2\end{array}$ & $\begin{array}{l}\text { Grams. } \\
+48.1 \\
-43.9\end{array}$ \\
\hline $\begin{array}{l}81.6 \\
40.8\end{array}$ & $\begin{array}{l}2.2 \\
1.1\end{array}$ & $\begin{array}{l}6.2 \\
3.1\end{array}$ & $\begin{array}{l}.4 \\
.2\end{array}$ & $\begin{array}{r}+72.8 \\
+\quad 36.4\end{array}$ & $\begin{array}{r}-68.6 \\
-34.3\end{array}$ & $\begin{array}{r}+4.2 \\
+\quad 2.1\end{array}$ \\
\hline $\begin{array}{l}40.8 \\
40.8\end{array}$ & $\begin{array}{l}1.1 \\
1.1\end{array}$ & $\begin{array}{l}3.0 \\
3.1\end{array}$ & $\begin{array}{l}.3 \\
.2\end{array}$ & $\begin{array}{r}+36.4 \\
+\quad 36.4\end{array}$ & $\begin{array}{l}-35.5 \\
-36.8\end{array}$ & $\begin{array}{r}+\quad .9 \\
-\quad . \pm\end{array}$ \\
\hline $\begin{array}{l}81.6 \\
40.8\end{array}$ & $\begin{array}{l}2.2 \\
1.1\end{array}$ & $\begin{array}{l}6.1 \\
3.1\end{array}$ & $\begin{array}{l}.5 \\
.2\end{array}$ & $\begin{array}{l}+72.8 \\
+\quad 36.4\end{array}$ & $\begin{array}{r}72.3 \\
-\quad 36.1\end{array}$ & $\begin{array}{r}+\quad .5 \\
+\quad .3\end{array}$ \\
\hline $\begin{array}{l}40.5 \\
40.5\end{array}$ & $\begin{array}{l}1.1 \\
1.1\end{array}$ & $\begin{array}{l}3.1 \\
3.1\end{array}$ & .2 & $\begin{array}{r}+36.4 \\
+\quad 36.4\end{array}$ & $\begin{array}{l}-40.5 \\
-51.6\end{array}$ & $\begin{array}{r}4.1 \\
-15.2\end{array}$ \\
\hline $\begin{array}{l}81.6 \\
40.8\end{array}$ & 2. 2 & $\begin{array}{l}6.2 \\
3.1\end{array}$ & $\begin{array}{r}4 \\
.2\end{array}$ & $\begin{array}{r}+2.8 \\
+\quad 36.4\end{array}$ & $\begin{array}{l}-92.1 \\
-46.1\end{array}$ & $\begin{array}{r}-19.3 \\
-9.7\end{array}$ \\
\hline $\begin{array}{r}244.8 \\
40.8\end{array}$ & $\begin{array}{l}6.6 \\
1.1\end{array}$ & $\begin{array}{r}18.5 \\
3.1\end{array}$ & $\begin{array}{r}1.3 \\
.2\end{array}$ & $\begin{array}{l}+218.4 \\
-\quad 36.4\end{array}$ & $\begin{array}{l}-233.0 \\
-38.8\end{array}$ & $\begin{array}{r}-14.6 \\
-2.4\end{array}$ \\
\hline
\end{tabular}


Table XXXI.-Guin or loss of protein $(N \times 6.25)$, fut, and water-Metabolism experiments Nos. 15-17.

\begin{tabular}{|c|c|c|c|c|c|c|}
\hline Date and period. & $\begin{array}{l}\text { (a) } \\
\text { Nitringen } \\
\text { gained } \\
(+) \\
\text { or lost } \\
(-)) .\end{array}$ & $\begin{array}{c}(b) \\
\text { Protein } \\
\text { gained } \\
(+) \\
\text { or loot } \\
\left(-\frac{1}{6}\right) \\
a \times 6.25 .\end{array}$ & $\begin{array}{c}(c) \\
\\
\text { Total } \\
\text { carbon } \\
\text { gained } \\
(+) \\
\text { or lost } \\
(-) \text {. }\end{array}$ & $\begin{array}{c}(d) \\
\text { Carbon } \\
\text { in pro- } \\
\text { tein } \\
\text { gained } \\
(+) \\
\text { or lost } \\
(-) \\
b \times 0.53 .\end{array}$ & $\begin{array}{c}(e) \\
\text { Carbon } \\
\text { in fat, } \\
\text { etec. } \\
\text { gained } \\
(+) \\
\text { or lost } \\
(-) \\
e-d .\end{array}$ & $\begin{array}{c}(f) \\
\text { Fat } \\
\text { gained } \\
(+) \\
\text { or lost } \\
(-) \\
e \div 0.765 .\end{array}$ \\
\hline 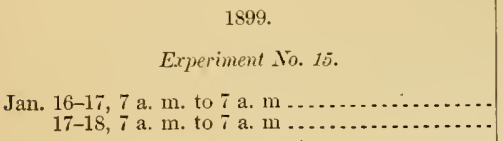 & $\begin{array}{l}\text { Grams. } \\
+1.5 \\
+.4\end{array}$ & $\begin{array}{l}\text { Grams. } \\
+9.4 \\
+\quad 2.5\end{array}$ & $\begin{array}{l}\text { Grams. } \\
+5.7 \\
+\quad 6.4\end{array}$ & $\begin{array}{l}\text { Grams. } \\
+5.0 \\
+1.3\end{array}$ & $\begin{array}{l}\text { Grams. } \\
+\quad 0.7 \\
+\quad 5.1\end{array}$ & $\begin{array}{l}\text { Grams. } \\
\quad+0.9 \\
+\quad 6.7\end{array}$ \\
\hline $\begin{array}{l}\text { Total for } 2 \text { days } \ldots \ldots \ldots \ldots \\
\text { Average per day } \ldots \ldots \ldots \ldots\end{array}$ & $\begin{array}{r}+1.9 \\
+1.0 \\
\end{array}$ & $\begin{array}{r}+11.9 \\
+\quad 6.0 \\
\end{array}$ & $\begin{array}{r}+12.1 \\
+6.1 \\
\end{array}$ & $\begin{array}{r}+6.3 \\
\dashv-3.2 \\
\end{array}$ & $\begin{array}{l}+5.8 \\
+\quad 2.9 \\
\end{array}$ & $\begin{array}{l}+7.6 \\
+\quad 3.8 \\
\end{array}$ \\
\hline $\begin{array}{c}\text { Experiment } \text { Wo. } 16 . \\
\text { Jan. } 18-19,7 \text { a. m. to } 7 \text { a. } \mathrm{m} \ldots \ldots \ldots \ldots \ldots \ldots \ldots \\
19-20,7 \text { a. m. to } 7 \text { a. } \mathrm{m} \ldots \ldots \ldots \ldots \ldots\end{array}$ & $\begin{array}{l}+1.4 \\
+\quad .9\end{array}$ & $\begin{array}{l}+8.7 \\
+5.6 \\
\end{array}$ & $\begin{array}{r}+8.7 \\
+6.5 \\
\end{array}$ & $\begin{array}{l}+4.6 \\
+3.0 \\
\end{array}$ & $\begin{array}{l}+4.1 \\
+\quad 3.5\end{array}$ & $\begin{array}{l}+5.3 \\
+\quad 4.6\end{array}$ \\
\hline $\begin{array}{l}\text { Total for } 2 \text { days } \ldots \ldots \ldots \ldots \\
\text { Average per day } \ldots \ldots \ldots \ldots \ldots \ldots\end{array}$ & $\begin{array}{r}+2.3 \\
+1.1 \\
\end{array}$ & $\begin{array}{r}+14.3 \\
+\quad 7.2 \\
\end{array}$ & $\begin{array}{r}+15.2 \\
+\quad 7.6 \\
\end{array}$ & $\begin{array}{l}+7.6 \\
+3.8 \\
\end{array}$ & $\begin{array}{r}+7.6 \\
+3.8 \\
\end{array}$ & $\begin{array}{r}+9.9 \\
+5.0 \\
\end{array}$ \\
\hline $\begin{array}{c}\text { Experiment Кo. } 1 \% \\
\text { Jan. } 20-21,7 \text { a. m. to } 7 \text { a. } \mathrm{m} \ldots \ldots \ldots \ldots \ldots \ldots \ldots \\
21-22,7 \text { a. m. to } 7 \text { a. } \mathrm{m} \ldots \ldots \ldots \ldots \ldots\end{array}$ & $\begin{array}{l}+.9 \\
+1.0 \\
\end{array}$ & $\begin{array}{l}+5.6 \\
+6.3\end{array}$ & $\begin{array}{r}+13.2 \\
+\quad 9.9 \\
\end{array}$ & $\begin{array}{l}+3.0 \\
+\quad 3.3 \\
\end{array}$ & $\begin{array}{r}+10.2 \\
+\quad 6.6 \\
\end{array}$ & $\begin{array}{l}+13.4 \\
+8.6\end{array}$ \\
\hline $\begin{array}{l}\text { Total for } 2 \text { days } \ldots \ldots \ldots \ldots \ldots \\
\text { Average per day } \ldots \ldots \ldots \ldots\end{array}$ & $\begin{array}{l}+1.9 \\
+1.0 \\
\end{array}$ & $\begin{array}{r}+11.9 \\
+6.0 \\
\end{array}$ & $\begin{array}{l}+23.1 \\
+11.6 \\
\end{array}$ & $\begin{array}{l}+6.3 \\
+3.2 \\
\end{array}$ & $\begin{array}{l}+16.8 \\
+8.4 \\
\end{array}$ & $\begin{array}{l}+22.0 \\
+11.0 \\
\end{array}$ \\
\hline $\begin{array}{l}\text { Total for } 6 \text { days } \ldots \ldots \ldots \\
\text { Average per day } \ldots \ldots \ldots\end{array}$ & $\begin{array}{l}+6.1 \\
+1.0\end{array}$ & $\begin{array}{r}+38.1 \\
+\quad 6.3\end{array}$ & $\begin{array}{r}+50.4 \\
+8.4\end{array}$ & $\begin{array}{r}+20.2 \\
+\quad 3.4\end{array}$ & $\begin{array}{r}+30.2 \\
+\quad 5.0\end{array}$ & $\begin{array}{l}+39.5 \\
+\quad 6.6\end{array}$ \\
\hline
\end{tabular}

\begin{tabular}{|c|c|c|c|c|c|}
\hline Date and period. & $\begin{array}{l}(g) \\
\text { Total hydrogen } \\
\text { gained }(+) \text { or } \\
\text { lost }(-) \text {. }\end{array}$ & $\begin{array}{c}(h) \\
\text { Hydrogen in } \\
\text { protein gained } \\
(+) \text { or lost }(-) \\
b \times 0.07\end{array}$ & $\begin{array}{c}(i) \\
\text { Hydrogen in } \\
\text { fat gained (+) } \\
\text { or lost }(-) \\
f \times 0.12 .\end{array}$ & $\begin{array}{c}(k) \\
\text { Hydrogen in } \\
\text { water, etc., } \\
\text { gained }(\leftarrow) \text { or } \\
\text { lost }(-) \\
g-(h+i) \text {. }\end{array}$ & $\begin{array}{l}(l) \\
\text { Water gained } \\
(+) \text { or lost }(-) \\
k \times 9 .\end{array}$ \\
\hline 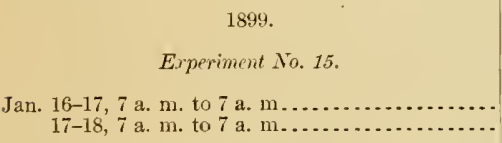 & $\begin{array}{l}\text { Grams. } \\
\quad+48.1 \\
\quad-43.9\end{array}$ & $\begin{array}{l}\text { Grams. } \\
+0.6 \\
+.2\end{array}$ & $\begin{array}{l}\text { Grams. } \\
\quad+0.1 \\
+\quad .8\end{array}$ & $\begin{array}{r}\text { Grams. } \\
+47.4 \\
-41.9\end{array}$ & $\begin{array}{r}\text { Grams. } \\
+426 \\
-404\end{array}$ \\
\hline $\begin{array}{l}\text { Total for } 2 \text { days } \ldots \ldots \ldots \ldots \ldots \\
\text { Average per day } \ldots \ldots \ldots \ldots\end{array}$ & $\begin{array}{l}+4.2 \\
+\quad 2.1 \\
\end{array}$ & $\begin{array}{r}+.8 \\
+.4\end{array}$ & $\begin{array}{r}+.9 \\
+\quad .5\end{array}$ & $\begin{array}{l}+2.5 \\
+\quad 1.3\end{array}$ & $\begin{array}{l}+22 \\
+11 \\
\end{array}$ \\
\hline 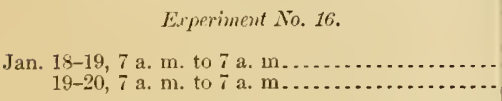 & $\begin{array}{l}\therefore \\
-\quad .9 \\
\end{array}$ & $\begin{array}{l}+.6 \\
+.4\end{array}$ & $\begin{array}{l}+.6 \\
+.6\end{array}$ & -1.3 & $\begin{array}{r}-3 \\
-12\end{array}$ \\
\hline $\begin{array}{l}\text { Total for } 2 \text { days } \ldots \ldots \ldots \ldots \ldots \\
\text { Average per day } \ldots \ldots \ldots \ldots \ldots \ldots\end{array}$ & $\begin{array}{r}+\quad .5 \\
+\quad .3\end{array}$ & $\begin{array}{r}+1.0 \\
+\quad .5\end{array}$ & $\begin{array}{l}+1.2 \\
+\quad .6\end{array}$ & $\begin{array}{r}-1.7 \\
-\quad .8\end{array}$ & $\begin{array}{r}-15 \\
-7\end{array}$ \\
\hline 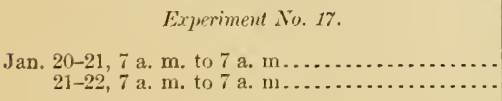 & $\begin{array}{r}4.1 \\
-15.2\end{array}$ & $\begin{array}{r}+.4 \\
+\quad .4\end{array}$ & $\begin{array}{l}+1.6 \\
+1.0\end{array}$ & $\begin{array}{l}-6.1 \\
-16.6\end{array}$ & $\begin{array}{r}-55 \\
-149\end{array}$ \\
\hline 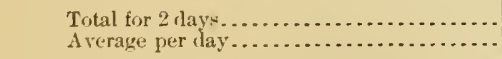 & $\begin{array}{l}-19.3 \\
-9.7\end{array}$ & $\begin{array}{l}+.8 \\
+.4\end{array}$ & $\begin{array}{r}+2.6 \\
+1.3\end{array}$ & $\begin{array}{l}-22.7 \\
-11.4\end{array}$ & $\begin{array}{l}-204 \\
-102\end{array}$ \\
\hline 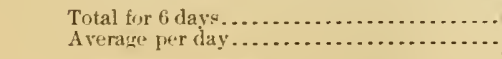 & $\begin{array}{r}-14.6 \\
-2.4\end{array}$ & $\begin{array}{r}+2.6 \\
+\quad .4\end{array}$ & $\begin{array}{r}+4.7 \\
+\quad .8\end{array}$ & $\begin{array}{r}-21.9 \\
--3.6\end{array}$ & $\begin{array}{r}-197 \\
-33\end{array}$ \\
\hline
\end{tabular}


T.1вLE XXX11.-Income and outgo of energy-Metabolism experiments Sus. $15-17$.

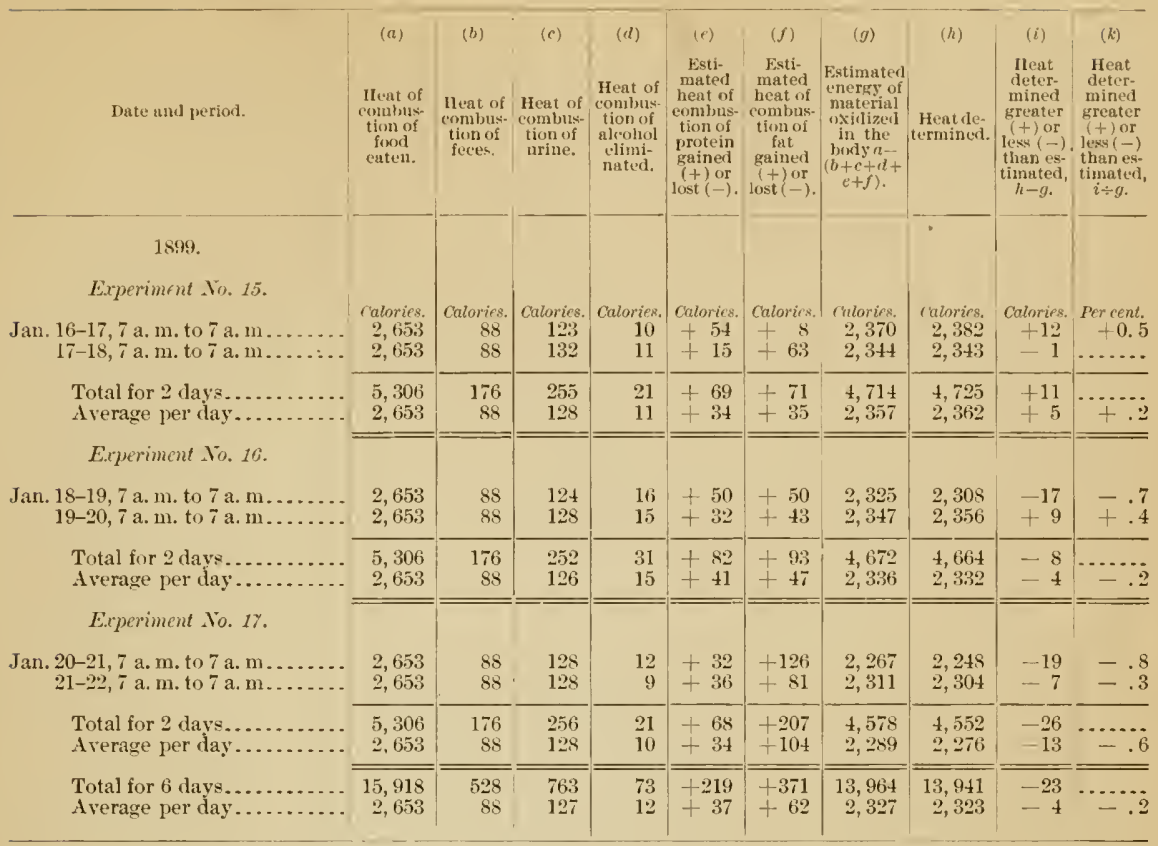

EXPERIMENTS NOS. 1S-21.-REST. NOS. 1S-20 WITH ALCOHOL 1)ET.

Sulject.-A. W. S., a plysicist, who was associated with these investigutions. He was 2j years of age and areraged about 70 kilograms ( 154 pounds) in weight.

Occupation during experiment.-Reading, writing, etc., with as little mental and muscular activity as practicahle.

Duration.-The preliminary period began with breakfast, February 2, 1899, and continued 4 days. On the evening of the fourth day the subject entered the calorimeter, and experiment No. 18, the fist of the series, commenced at 7 oclock the following morning, February 6 , and continued 2 days. It was followed hy Nos. 19 and 20 of 2 days each. A fourth experiment, elsewhere described, ${ }^{8}$ No. 21 , in which the alcohol was onitted from the diet. followed No. 20 immediately and continued 3 days. The subject thus spent 10 nights and 9 days in the chumber.

Dict.-Ordinary food furnishing 97 grams of protein and $2,26+$ calories of energy per day, in addition to $72.5 \mathrm{grams}$ of absolute aleohol furnishing 512 calories of energy; making the total energy of the diet 2,776 calories per day. In experiment No. 18 the alcohol was furuished in ordinary commercial alcohol, in experment No. 19 in whisky, and in experiment No. 20 in brandy. The plan of the experiment was thus practically the same as that of the previous series of experiments. Nos. 15-17. The alcohol was taken as usual in 6 doses, 3 with the meals and the other 3 between meals and upon retiring.

In experiment No. 18, 755.2 grams of coffee infusion were sweetened with 45 grams of sugar, and 79.8 grams of 90.5 per cent commercial alcohol were then added. In experiment No. $19,158.3$ grams of whisky containing 45.8 per cent alcohol by weight was added to 6966.7 
grams of water, sweetened with 45 grams of sugar. In experiment No. 20, 143.8 grams of brandy containing 50.4 per cent alcohol by weight was added to 711.2 grams of water, sweetened with 45 grams of sugar. It will be noticed that the cotfee infusion was used only in the first of the series of experiments. The reason for use of the coffee infusion was to cover up the taste of the commercial ethyl alcohol, which was somewhat obnoxious to the subject.

The kinds and quantities of food served at each meal and the quantity of drink at different periods were as follows:

Diet in metabolism experiments $\mathrm{N}_{0}$. 18-21.

FOOD.

\begin{tabular}{|c|c|c|c|c|}
\hline & Breakiast. & Dinner. & Supper. & Total. \\
\hline Beet. ... & Grams. & $\begin{array}{c}\text { Grams. } \\
105\end{array}$ & Grams. & $\begin{array}{l}\text { Grams. } \\
160\end{array}$ \\
\hline 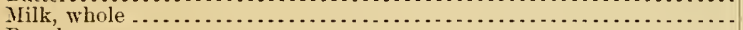 & 250 & 175 & 325 & 750 \\
\hline Bread & 55 & 100 & 155 & 310 \\
\hline 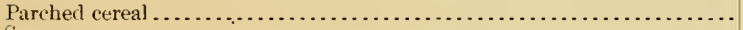 & 30 & ........... & ............ & 30 \\
\hline
\end{tabular}

"Used with the coffee infusion or water and alcohol in experiments 18-20.

DRINK.

\begin{tabular}{|c|c|c|c|c|c|c|c|c|}
\hline \multirow{2}{*}{ · } & \multirow[b]{2}{*}{ Time. } & \multicolumn{2}{|c|}{ Experiment 18.} & \multicolumn{2}{|c|}{ Experiment 19.} & \multicolumn{2}{|c|}{ Experiment 20.} & \multirow{2}{*}{$\begin{array}{c}\begin{array}{c}\text { Experiment } \\
21 .\end{array} \\
\text { Water. }\end{array}$} \\
\hline & & $\begin{array}{l}\text { Alcohol and } \\
\text { sweetened } \\
\text { coffee in- } \\
\text { fusion." }\end{array}$ & Water. & $\begin{array}{l}\text { Whisky } \\
\text { and } \\
\text { sweetened } \\
\text { water." }\end{array}$ & Water. & $\begin{array}{c}\text { Brandy } \\
\text { and } \\
\text { sweetened } \\
\text { water. }\end{array}$ & Water. & \\
\hline \multicolumn{2}{|c|}{$\begin{array}{r}\text { Breakfast } \ldots \ldots \\
10 \text { a. } \mathrm{m} . \\
\end{array}$} & $\begin{array}{l}\text { Grams. } \\
300\end{array}$ & Grams. & $\begin{array}{l}\text { Grams. } \\
300\end{array}$ & Groms. & $\begin{array}{l}\text { Grams. } \\
300\end{array}$ & Grams. & $\begin{array}{r}\text { Grams. } \\
300\end{array}$ \\
\hline \multirow{2}{*}{\multicolumn{2}{|c|}{$\begin{array}{r}\text { Dinner. } \quad 3.30 \text { p. m } \ldots \ldots \\
\end{array}$}} & 300 & ........ & 300 & $\ldots .$. & 300 & & 300 \\
\hline & & $\ldots$ & 200 & & 200 & - & 200 & 200 \\
\hline \multirow{2}{*}{\multicolumn{2}{|c|}{ 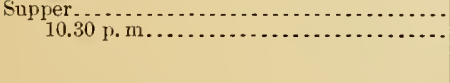 }} & 300 & 200 & 300 & 200 & 300 & 200 & $\begin{array}{l}300 \\
200\end{array}$ \\
\hline & & s 900 & 600 & a 900 & 600 & 8900 & 600 & 1,500 \\
\hline
\end{tabular}

${ }^{a}$ Contained 72.5 grams alcohol and 45 grams sugar.

Drity routine.-The general plan of the experiment was practically the same as in the previous experiments, and is shown in the following schedule:

Duily programme-Mctabolism experiments Nos. 18-20.

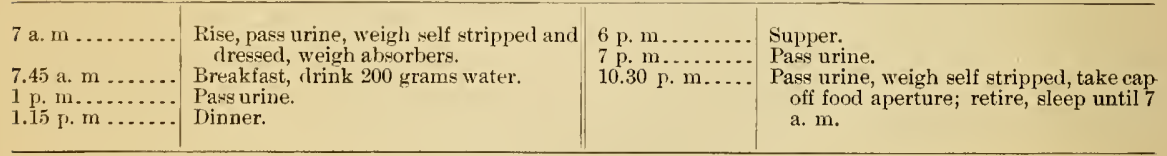


The statisties of the diary kept by the subject are summarized in Table XXXIII.

T.ABLE XXXIII.-Sinmmary of dian-Yetubolism experiments Wos. 18-20.

\begin{tabular}{|c|c|c|c|c|c|}
\hline \multirow[b]{2}{*}{ Date and time. } & \multirow{2}{*}{$\begin{array}{l}\text { Weight with- } \\
\text { out elothes. }\end{array}$} & \multirow{2}{*}{$\begin{array}{l}\text { Pulse rute per } \\
\text { minute. }\end{array}$} & \multirow{2}{*}{ Temperature. } & \multicolumn{2}{|c|}{ llygrometer. } \\
\hline & & & & Dry bulb. & Wet bulb. \\
\hline 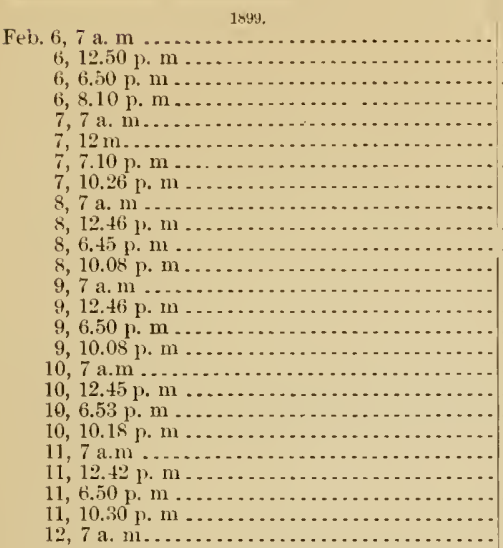 & 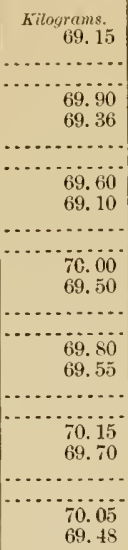 & 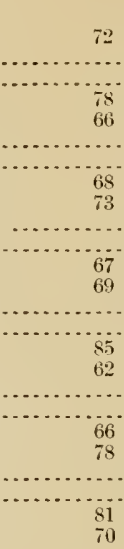 & 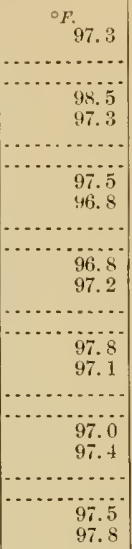 & $\begin{array}{l}{ }^{\circ} C . \\
19.60 \\
19.80 \\
19.80 \\
\cdots . . . \\
19.90 \\
19.60 \\
19.80 \\
19.60 \\
20.00 \\
19.80 \\
19.75 \\
19.60 \\
20.00 \\
19.70 \\
19.70 \\
19.70 \\
19.70 \\
19.65 \\
19.75 \\
19.80 \\
19.80 \\
19.70 \\
19.70 \\
19.70 \\
19.80\end{array}$ & $\begin{array}{r}{ }^{\circ} C . \\
14.80 \\
15.95 \\
15.40 \\
\cdots . .2 \\
15.60 \\
15.20 \\
15.80 \\
15.60 \\
15.10 \\
15.45 \\
15.20 \\
14.80 \\
15.00 \\
15.00 \\
14.80 \\
15.40 \\
15.00 \\
14.95 \\
15.05 \\
15.30 \\
14.90 \\
15.40 \\
14.85 \\
15.00 \\
15.15\end{array}$ \\
\hline
\end{tabular}

Detailed statistics of income and migo.-The usual statistics of income and outgo of matter and energy are shown in Tables XXXIV to XLVI, which follow. The diet was the same during the series of experiments Nos. 18-20, except in the form of alcohol taken. It supplied 97 grams of protein and 2,776 calories of energy per day. In experiment No. 21, which immediately followed, the diet was the same, with the exception that no alcohol was administered, so that the total energy of the food was only 2,264 calories.

No separation of the feces was obtained between the beginning of the preliminary period and the end of experiment No. 21, in which the subject had what may be called the basal ration without the alcohol. It was necessary, therefore, to assume a uniform amount of feces from the fool from day to day. While this may introduce a slight error in the results of the 3 experiments with alcohol, Nos. 18-20, such error ean hardly be large enough to affect seriously the computed results of the experiments.

T.1BLE XXX1V.- Weight, composition, and heat of combustion of fnods-Wetabolism erperiments 2 Tos. $18-21$.

\begin{tabular}{|c|c|c|c|c|c|c|c|c|c|c|}
\hline $\begin{array}{l}\text { Labora- } \\
\text { tory } \\
\text { No. }\end{array}$ & Food material. & $\begin{array}{l}\text { Weight } \\
\text { per day. }\end{array}$ & Water. & Protein. & Fat. & $\begin{array}{l}\text { Carbohy- } \\
\text { dratec. }\end{array}$ & Nitrogen. & Carbon. & $\begin{array}{c}\text { Hydro- } \\
\text { gen. }\end{array}$ & $\begin{array}{l}\text { Heat of } \\
\text { com- } \\
\text { bustion. }\end{array}$ \\
\hline $\begin{array}{l}3022 \\
3020 \\
3024 \\
2968 \\
3004\end{array}$ & 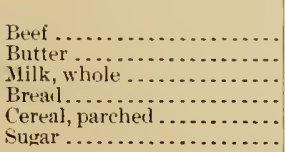 & $\begin{array}{r}\text { Grams. } \\
160 \\
30 \\
750 \\
310 \\
30 \\
45\end{array}$ & $\begin{array}{r}\text { Crams. } \\
106.7 \\
2.6 \\
6+9.5 \\
129.3 \\
1.8\end{array}$ & $\begin{array}{r}\text { Grams. } \\
44.6 \\
.4 \\
24.0 \\
24.5 \\
3.4 \\
\ldots . .\end{array}$ & $\begin{array}{r}\text { Grams. } \\
4.2 \\
26.3 \\
33.0 \\
8.7 \\
.2 \\
. . . .\end{array}$ & $\begin{array}{r}\text { Grams. } \\
. . . \\
37.5 \\
143.5 \\
24.1 \\
+5.0\end{array}$ & $\begin{array}{r}\text { Grams } \\
7.14 \\
.06 \\
3.83 \\
3.94 \\
.55 \\
. . . .\end{array}$ & $\begin{array}{l}\text { Grams. } \\
26.51 \\
19.87 \\
52.72 \\
84.72 \\
12.42 \\
18.95\end{array}$ & $\begin{array}{r}\text { frams. } \\
\text { 4. } 06 \\
3.16 \\
7.05 \\
12.74 \\
1.85 \\
2.92\end{array}$ & $\begin{array}{r}\text { Calorics. } \\
292 \\
245 \\
587 \\
840 \\
122 \\
178\end{array}$ \\
\hline & $\begin{array}{r}\text { Total Feb. } 12 \text { to } 14 \ldots \\
\text { Alcohol ....................... }\end{array}$ & $\begin{array}{r}1,325 \\
72.5\end{array}$ & $\begin{array}{c}8 \times 9.9 \\
\ldots . . .\end{array}$ & $\begin{array}{r}96.9 \\
\ldots .\end{array}$ & $\begin{array}{r}72.4 \\
. . . .\end{array}$ & $\begin{array}{c}250.1 \\
\ldots . . .\end{array}$ & $\begin{array}{c}15.52 \\
-\ldots .\end{array}$ & $\begin{array}{r}215.19 \\
37.82\end{array}$ & $\begin{array}{r}31.78 \\
9.46\end{array}$ & $2, \frac{264}{512}$ \\
\hline & Total Feb. 6 to $12 \ldots$. & & & & & & 15.52 & 253.01 & 41.24 & 2,776 \\
\hline
\end{tabular}


TaBLe XXXVt.-Weight, composition, and heut of combustion of feces-Metabolism experiments Nos. $18-21$.

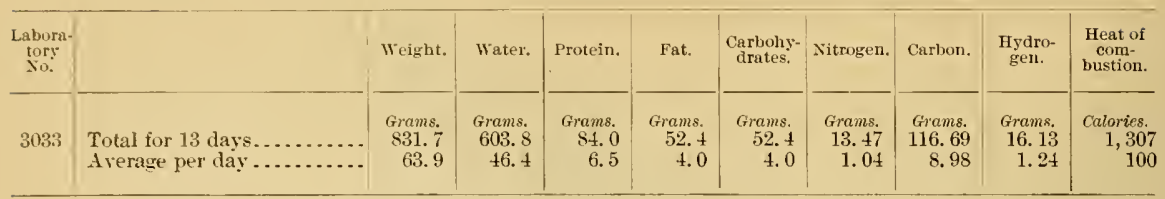

In these inrestigations the elimination of nitrogen in the urine on the first day inside the apparatus has frequently been larger than that of the preceding and following days. Sometimes this increase occurs 1 or 2 days before the subject enters the respiration chamber. On the $t$ days of the preliminary period preceding this series of experiments the nitrogen in the urine amounted to $12.2,16,19$ and 16.4 grams, respectively On the first day of experinent No. 18 the nitrogen in the urine amonnted to 17.4 grams, but it dropped to 15.4 grams on the second day, and raried between 13.9 and 14.7 on subsequent dass. In experiment No. 21, when the energy of the diet was reduced, the excretion of nitrogen again increased. The elimination of nitrogen with and without alcohol has been already referred to.

Table XXXVI gires the detailed statisties of the quantity of urine and its nitrogen content in the successive 6-hour periods of this series of experiments. The statisties for experiment No. 21, in which no alcohol was given, show the total quantity of urine and nitrogen for the individual days, but not for individual periods. These daily amounts are given for the sake of comparison with those of experiments $18-20$.

TABLE XXXVI._Imount, specific gravity, and nitrogen of urine by 6-hour periods-Metabolism experiments Nos. 18-20. ${ }^{\mathrm{a}}$

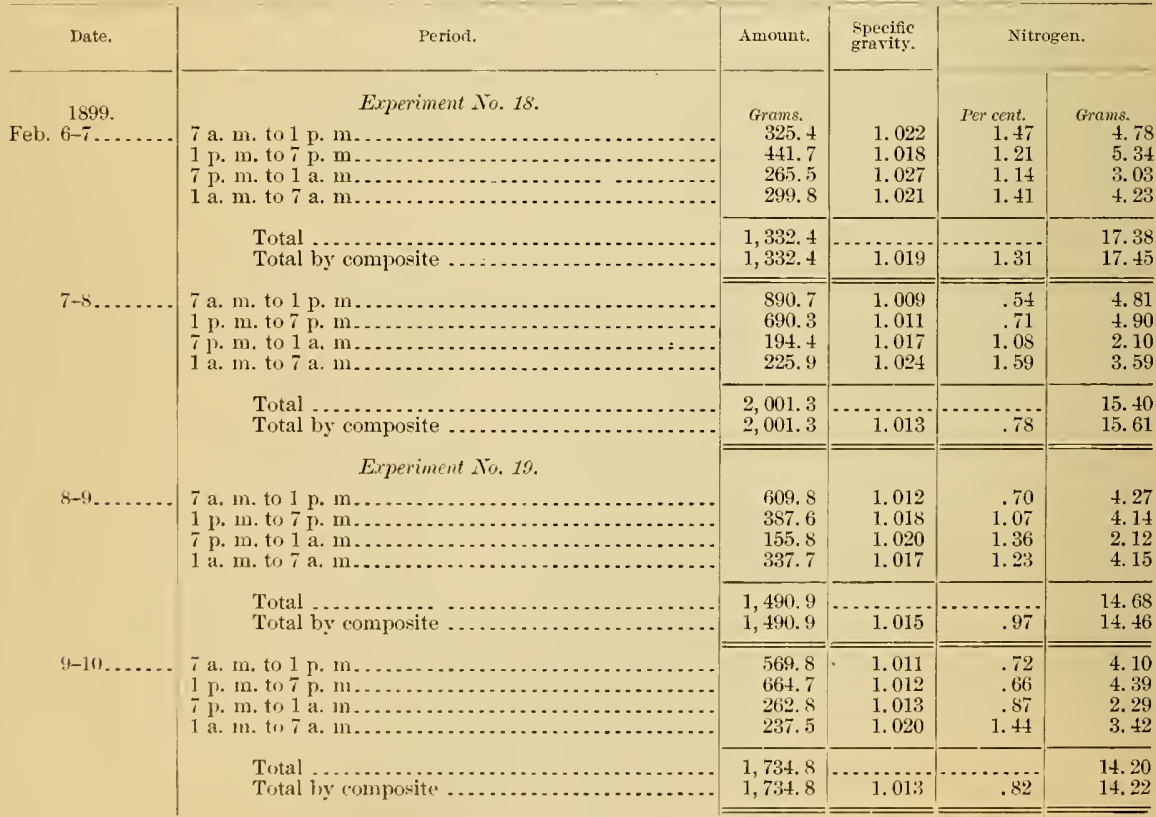

"No. 21 incinderl for emparison. 
TABLE XXXVI.-Amount, specitic guvit!, end nitrogen of urine by ti-hour priods, ate.-Continued.

\begin{tabular}{|c|c|c|c|c|c|}
\hline Date. & Peries. & Imount & $\begin{array}{l}\text { Specitic } \\
\text { gravity. }\end{array}$ & Nit & \\
\hline \multirow[t]{2}{*}{$\begin{array}{l}1899 . \\
10-11\end{array}$} & \multirow{2}{*}{ 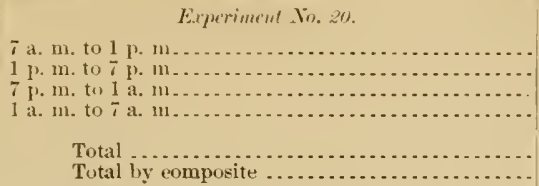 } & $\begin{array}{l}\text { rrams. } \\
715.1 \\
445.1 \\
270.9 \\
265.6\end{array}$ & $\begin{array}{l}1.008 \\
1.016 \\
1.012 \\
1.021\end{array}$ & $\begin{array}{r}\text { Percent. } \\
0.50 \\
.87 \\
.78 \\
1.49\end{array}$ & $\begin{array}{r}\text { Grams. } \\
3.93 \\
3.87 \\
2.11 \\
3.96\end{array}$ \\
\hline & & $\begin{array}{l}1,696.7 \\
1,696.7\end{array}$ & 1.013 & .82 & $\begin{array}{l}13.87 \\
13.91\end{array}$ \\
\hline \multirow[t]{2}{*}{$11-12 \ldots .}$. & \multirow{4}{*}{ 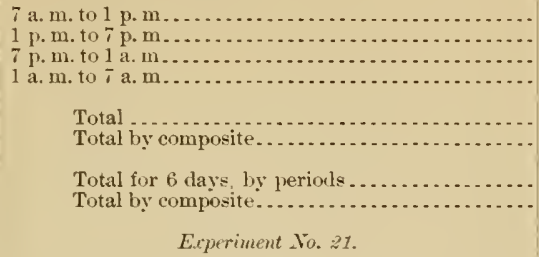 } & $\begin{array}{l}611.1 \\
703.7 \\
360.8 \\
264.5\end{array}$ & $\begin{array}{l}1.011 \\
1.011 \\
1.012 \\
1.020\end{array}$ & $\begin{array}{r}.66 \\
.63 \\
.70 \\
1.29\end{array}$ & $\begin{array}{l}4.03 \\
4.43 \\
2.52 \\
3.41\end{array}$ \\
\hline & & $\begin{array}{l}1,9+0.1 \\
1,940.1\end{array}$ & 1.013 & .73 & $\begin{array}{l}14.39 \\
14.16\end{array}$ \\
\hline \multirow[t]{2}{*}{$6-11 \ldots \ldots$} & & $\begin{array}{l}10,196.2 \\
10,196.2\end{array}$ & 1.0135 & .88 & $\begin{array}{l}89.92 \\
89.69\end{array}$ \\
\hline & & & & & \\
\hline $\begin{array}{l}12-13 \ldots \ldots \\
13-14 \ldots \ldots \\
1+15 \ldots \ldots\end{array}$ & 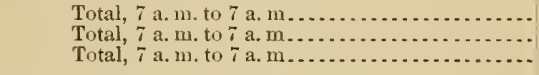 & $\begin{array}{l}1,680.9 \\
1,748.1 \\
1,965.3\end{array}$ & & & $\begin{array}{l}14.50 \\
16.15 \\
15.44\end{array}$ \\
\hline $12,13,14 \ldots$ & Total for 3 days . . . . . . . . . . & $5,394.3$ & & & 46. 09 \\
\hline
\end{tabular}

T. вLE XXXV11.-Daily eliminution of carbon, hydrogen, water, and energy in urine-Metabolism experiments . Nos. $18-20 .^{\mathrm{A}}$

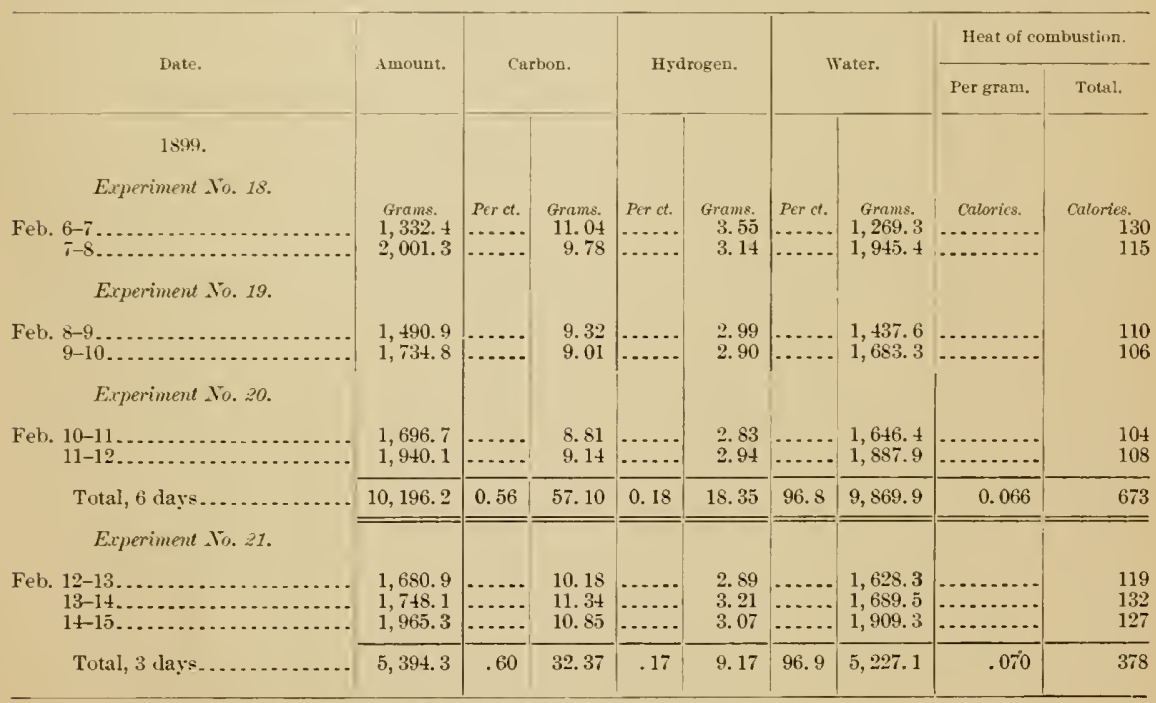

To. 21 summarized for comparison. 
The details of the measurements of carbon dioxid and water in the rentilating air current are shown in Tables XXXVIII to XL, which follow. The total amounts of carbon dioxid and water eliminated each day in Experiment No. 21 are also added for comparison.

TABLE XXXVIII.-Comparison of residual amounts of carbon dioxid and water in the chamber at the begimning and end of euch period, and the corresponding gain or loss-Metabolism experiments Nos. 18-20.

\begin{tabular}{|c|c|c|c|c|c|c|c|}
\hline \multirow[b]{2}{*}{ Date. } & \multirow[b]{2}{*}{ End of period. } & \multicolumn{2}{|c|}{ Carbon dioxid. } & \multicolumn{4}{|c|}{ Water. } \\
\hline & & $\begin{array}{c}\text { Total } \\
\text { amount } \\
\text { in } \\
\text { chamber }\end{array}$ & $\begin{array}{c}\text { Gain }(+) \\
\text { or } \\
\text { loss }(-) \\
\text { over pre- } \\
\text { ceding } \\
\text { period. }\end{array}$ & $\begin{array}{l}\text { Total } \\
\text { amount } \\
\text { of vapor } \\
\text { remain- } \\
\text { ing in } \\
\text { chamber. }\end{array}$ & $\begin{array}{l}\text { Gain }(+) \\
\text { or } \\
\text { loss }(-) \\
\text { over pre- } \\
\text { eeding } \\
\text { period. }\end{array}$ & $\begin{array}{c}\text { Change } \\
\text { in } \\
\text { weight } \\
\text { of ab- } \\
\text { sorbers. } \\
\text { Gain (+) } \\
\text { or } \\
\text { loss (-). }\end{array}$ & $\begin{array}{c}\text { Total } \\
\text { amount } \\
\text { gained } \\
\text { ( +) or } \\
\text { lost (- } \\
\text { during } \\
\text { the } \\
\text { period. }\end{array}$ \\
\hline \multirow{6}{*}{ Feb. ${ }^{1899 .} 6-\bar{\tau}$} & \multirow{6}{*}{ 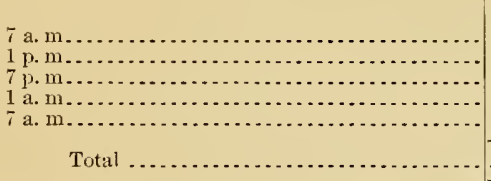 } & \multirow{4}{*}{$\begin{array}{c}\text { Grams. } \\
29 \\
42.6 \\
41.3 \\
37.2 \\
31.5\end{array}$} & Grams. & \multirow{4}{*}{$\begin{array}{r}\text { Grams. } \\
35.0 \\
46.4 \\
42.1 \\
46.2 \\
39.3\end{array}$} & Grams. & \multirow{4}{*}{\begin{tabular}{r} 
Grams. \\
\hdashline$\quad 2$ \\
+2 \\
+1 \\
+1
\end{tabular}} & Grams. \\
\hline & & & +13.6 & & +11.4 & & +13.4 \\
\hline & & & -1.3 & & -4.3 & & -2.3 \\
\hline & & & $\begin{array}{l}-4.1 \\
-5.7\end{array}$ & & $\begin{array}{r}+4.1 \\
-6.9\end{array}$ & & $\begin{array}{l}+5.1 \\
-5.9\end{array}$ \\
\hline & & & & & & & \\
\hline & & ...... & +2.5 & ....... & +4.3 & +6 & +10.3 \\
\hline \multirow[t]{4}{*}{$7-8$} & 1 p.m. & 39.6 & +8.1 & 40.8 & +1.5 & -1 & \\
\hline & 7 p.m... & 31.3 & -8.3 & $\begin{array}{l}44.5 \\
41.0\end{array}$ & $\begin{array}{l}+3.7 \\
-3.5\end{array}$ & $=1$ & $\begin{array}{r}+2.7 \\
+\quad 4\end{array}$ \\
\hline & $\begin{array}{l}1 \\
7 \\
\text { a. } m \ldots \ldots\end{array}$ & $\begin{array}{l}30.1 \\
26.4\end{array}$ & $\begin{array}{l}-1.2 \\
-3.7\end{array}$ & $\begin{array}{l}41.0 \\
35.6\end{array}$ & $\begin{array}{l}-3.5 \\
-5.4\end{array}$ & $\begin{array}{l}-1 \\
-1\end{array}$ & $\begin{array}{l}-4.5 \\
-6.4\end{array}$ \\
\hline & Total & & -5.1 & $\ldots, \ldots$ & -3.7 & -4 & -7.7 \\
\hline \multirow[t]{5}{*}{$8-9$} & 1 p. m.. & 39.2 & +12.8 & 41.8 & +6.2 & +2 & +8.2 \\
\hline & $7 \mathrm{p.m}$. & 38.9 & -.3 & 41.1 & -.7 & +2 & $\begin{array}{l}+1.3 \\
\end{array}$ \\
\hline & 1 a. $\mathrm{m}_{*}$ & 26.8 & -12.1 & 38.0 & -3.1 & +1 & -2.1 \\
\hline & 7 a.m.. & 26.3 & -.5 & 33.6 & -4.4 & +1 & -3.4 \\
\hline & Total & ..... & -.1 & $\cdots .$. & -2.0 & +6 & +4.0 \\
\hline \multirow[t]{4}{*}{$9-10$} & 1 p.m.. & 37.5 & +11.2 & 39.3 & +5.7 & -1 & +4.7 \\
\hline & 7 p. $\mathrm{xr}$ & 40.1 & +2.6 & 38.2 & -1.1 & -1 & $\div 2.1$ \\
\hline & 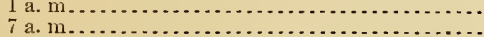 & $\begin{array}{l}30.3 \\
29.9\end{array}$ & $\begin{array}{l}-9.8 \\
-0.4\end{array}$ & $\begin{array}{l}39.7 \\
36.4\end{array}$ & $\begin{array}{l}+1.5 \\
-3.3\end{array}$ & $\begin{array}{l}-1 \\
-2\end{array}$ & $\begin{array}{l} \pm .5 \\
-5.3\end{array}$ \\
\hline & Total . & ....... & +3.6 & $\ldots$ & +2.8 & -5 & -2.2 \\
\hline \multirow{5}{*}{$10-11$} & 1 p.r & 37.5 & +7.6 & 39.1 & +2.7 & +3 & +5.7 \\
\hline & $70 m$ & 42.8 & $\begin{array}{l}+5.3 \\
+5\end{array}$ & 40.9 & +1.8 & +2 & +3.8 \\
\hline & 1 a. m.. & 30.4 & -12.4 & 39.3 & -1.6 & +2 & +.4 \\
\hline & 7 a. & 35.5 & +5.1 & 36.1 & -3.2 & +2 & -1.2 \\
\hline & Total & …. & +5.6 & $\ldots$ & -.3 & +9 & +8.7 \\
\hline \multirow[t]{5}{*}{$11-12$} & $1 \mathrm{p}, \mathrm{m} \ldots \ldots$ & 40.8 & +5.3 & 43.5 & +7.4 & & +7.4 \\
\hline & & 42.8 & +2.0 & 39.3 & -4.2 & ....... & -4.2 \\
\hline & 1 a. m. & 30.9 & -11.9 & 41.6 & +2.3 & (....... & +2.3 \\
\hline & 7 a. m... & 32.7 & +1.8 & 38.1 & -3.5 & & -3.5 \\
\hline & Total . & & -2.8 & $\ldots$ & +2.0 & $\cdots$ & +2.0 \\
\hline
\end{tabular}




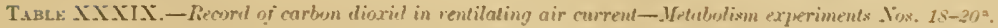

\begin{tabular}{|c|c|c|c|c|c|c|c|c|c|}
\hline \multirow[b]{3}{*}{ Date. } & \multirow[b]{3}{*}{ Period. } & \multirow{3}{*}{$\begin{array}{l}\text { la } \\
\text { Ventila- } \\
\text { tion. } \\
\text { sumber of } \\
\text { liten of } \\
\text { air. }\end{array}$} & \multicolumn{6}{|c|}{ rartoun dioxial. } & \multirow{3}{*}{$\begin{array}{l}\text { h } \\
\text { Total } \\
\text { weight of } \\
\text { Carbon } \\
\text { exhaled, } \\
\text { g×rt. }\end{array}$} \\
\hline & & & \multicolumn{2}{|c|}{ In inemming air. } & \multirow{2}{*}{$\begin{array}{l}\text { it } \\
\text { In outso- } \\
\text { ing air. }\end{array}$} & \multirow[b]{2}{*}{$\begin{array}{l}\text { Total } \\
\text { exces in } \\
\text { outgoing } \\
\text { air. } \\
d \rightarrow c\end{array}$} & \multirow{2}{*}{$\begin{array}{l}f \\
\text { correc- } \\
\text { tion } \\
\text { for } \\
\text { amount } \\
\text { remain- } \\
\text { ing in } \\
\text { chamber. }\end{array}$} & \multirow{2}{*}{$\begin{array}{l}\text { Cor- } \\
\text { rected } \\
\text { amount } \\
\text { exhaled } \\
\text { by sub- } \\
\text { ject. } \\
\epsilon \rightarrow f \text {. }\end{array}$} & \\
\hline & & & $\begin{array}{l}\text { Pet } \\
\text { liter. }\end{array}$ & $\begin{array}{l}\text { Total, } \\
a \times b \text {. }\end{array}$ & & & & & \\
\hline \multirow[t]{2}{*}{ Feb. 1899.} & \multirow{2}{*}{ 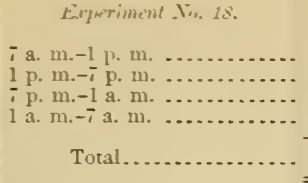 } & $\begin{array}{l}\text { Liters. } \\
26,069 \\
25,745 \\
26,362 \\
27,245\end{array}$ & $\begin{array}{r}3 / 9 \\
0.569 \\
.511 \\
.566 \\
.570\end{array}$ & $\begin{array}{l}\text { Grami. } \\
14.8 \\
13.2 \\
14.9 \\
15.5\end{array}$ & $\begin{array}{l}\text { Frms. } \\
25+9 \\
232.7 \\
230 . x \\
160.3\end{array}$ & $\begin{array}{l}\text { Grams. } \\
2 \pm 0.1 \\
219.5 \\
215.9 \\
114.8\end{array}$ & $\begin{array}{l}\text { Grame. } \\
-13.6^{2} \\
-1.3 \\
-\quad+.1 \\
-5.7\end{array}$ & $\begin{array}{l}\text { errams. } \\
253.1 \\
215.2 \\
211.8 \\
139.1\end{array}$ & 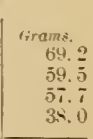 \\
\hline & & 105,421 & $\ldots$ & 58.1 & 875.7 & 820.3 & - 2.5 & 522.3 & 224.4 \\
\hline \multirow[t]{2}{*}{$i-i$} & \multirow{4}{*}{ 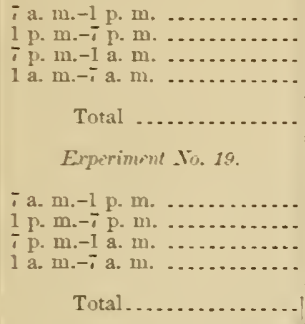 } & $\begin{array}{l}25,795 \\
25,908 \\
26,924 \\
25,1=2 \\
\end{array}$ & $\begin{array}{l}.5 .5 \\
.531 \\
.554 \\
.576 \\
\end{array}$ & $\begin{array}{l}14.8 \\
13.5 \\
14.9 \\
15.6\end{array}$ & $\begin{array}{l}239.6 \\
236.7 \\
210.6 \\
15-.1\end{array}$ & $\begin{array}{l}224.5 \\
223.0 \\
201.7 \\
1+1.5\end{array}$ & $\begin{array}{l}+8.1 \\
-3.3 \\
-1.2 \\
-3.7 \\
\end{array}$ & $\begin{array}{l}232.9 \\
214.7 \\
200.5 \\
137.8\end{array}$ & $\begin{array}{r}63.5 \\
5.6 \\
54.7 \\
37.5\end{array}$ \\
\hline & & $105,7+9$ & ........... & 59.0 & 850.0 & 791.0 & -5.1 & 78.9 .9 & 214.3 \\
\hline \multirow[t]{2}{*}{ co } & & $\begin{array}{l}26,792 \\
26,010 \\
27,593 \\
27,999\end{array}$ & $\begin{array}{l}.562 \\
.616 \\
.554 \\
.552\end{array}$ & $\begin{array}{l}15.1 \\
16.0 \\
15.3 \\
15.5\end{array}$ & $\begin{array}{l}203.9 \\
204.0 \\
210.7 \\
159.4\end{array}$ & $\begin{array}{l}20 \times .8 \\
205.0 \\
195.4 \\
143.9\end{array}$ & $\begin{array}{l}-12.8 \\
-\quad .3 \\
-12.1 \\
-\quad .5\end{array}$ & $\begin{array}{l}221.6 \\
207.7 \\
183.3 \\
143.4\end{array}$ & $\begin{array}{l}60.5 \\
56.6 \\
50.0 \\
39.1\end{array}$ \\
\hline & & $105.394^{\circ}$ & .... & 61 & 815.0 & 756.1 & -.1 & 756.0 & 206.2 \\
\hline \multirow[t]{3}{*}{$9-10$} & \multirow{3}{*}{ 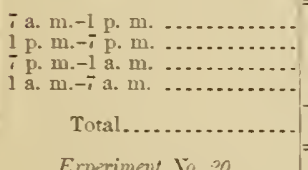 } & $\begin{array}{l}26,358 \\
26,150 \\
27,647 \\
26,015\end{array}$ & $\begin{array}{l}.554 \\
.5 \% \\
.5 .9 \\
.550\end{array}$ & $\begin{array}{l}14.6 \\
15.1 \\
16.0 \\
15.4\end{array}$ & $\begin{array}{l}223.9 \\
211.0 \\
3=25.7 \\
156.1\end{array}$ & $\begin{array}{l}209.3 \\
195.9 \\
209.7 \\
140.7\end{array}$ & $\begin{array}{r}-11.2 \\
+2.6 \\
-9.8 \\
-\quad .4\end{array}$ & $\begin{array}{l}220.5 \\
194.5 \\
199.9 \\
140.3\end{array}$ & $\begin{array}{l}60.2 \\
54.1 \\
54.5 \\
38.3\end{array}$ \\
\hline & & 105,200 & $\cdots$ & 61.1 & $\$ 16.7$ & 755.6 & +3.6 & 759.2 & $20 \pi .1$ \\
\hline & & & & & & & & & \\
\hline \multirow[t]{2}{*}{$10-11$} & \multirow{2}{*}{ 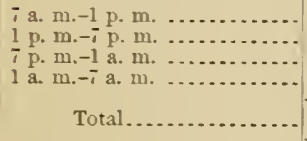 } & $\begin{array}{l}25,750 \\
26.228 \\
27.422 \\
28,046\end{array}$ & $\begin{array}{l}.561 \\
.6014 \\
.575 \\
.562 \\
\end{array}$ & $\begin{array}{l}14.4 \\
16.0 \\
15.5 \\
15.7\end{array}$ & $\begin{array}{l}203.5 \\
217.6 \\
2-27.0 \\
173.0\end{array}$ & $\begin{array}{l}209.4 \\
201.6 \\
211.2 \\
15 \div .3\end{array}$ & $\begin{array}{r}+7.6 \\
+5.3 \\
-12.4 \\
+5.1\end{array}$ & $\begin{array}{l}217.0 \\
206.9 \\
192.8 \\
162.4\end{array}$ & $\begin{array}{l}59.2 \\
56.4 \\
54.2 \\
44.3\end{array}$ \\
\hline & & $10 \overline{7}, 446^{2}$ & . & 61.9 & $8+1.4$ & 7.9 .5 & -5.6 & $7 \$ 5.1$ & 214.1 \\
\hline \multirow[t]{2}{*}{$11-12$} & \multirow{3}{*}{ 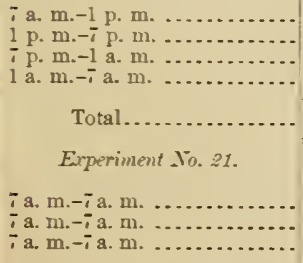 } & $\begin{array}{l}26,132 \\
26,157 \\
27,966 \\
28,443\end{array}$ & $\begin{array}{l}.595 \\
.600 \\
.562 \\
.573\end{array}$ & $\begin{array}{l}15.6 \\
15.7 \\
15.7 \\
16.3\end{array}$ & $\begin{array}{l}240.8 \\
20.2 .3 \\
235.4 \\
165.0\end{array}$ & $\begin{array}{l}225.2 \\
206.6 \\
219.7 \\
151.7\end{array}$ & $\begin{array}{r}+5.3 \\
+2.0 \\
-11.9 \\
+1.8\end{array}$ & $\begin{array}{l}230.5 \\
20.5 \\
207.5 \\
153.5\end{array}$ & $\begin{array}{l}62.8 \\
56.9 \\
56.7 \\
41.9\end{array}$ \\
\hline & & $10 \$ .695$ & ......... & 63.3 & 866.5 & 803.2 & -2.5 & 800.4 & 218.3 \\
\hline $\begin{array}{l}12-13 \\
13-14 \\
14-15\end{array}$ & & $\begin{array}{l}109,063 \\
109,164 \\
107,9=2\end{array}$ & & $\begin{array}{r}62.7 \\
125.3 \\
65.2\end{array}$ & $\begin{array}{l}\$ 5 \% .1 \\
913.9 \\
834.2\end{array}$ & $\begin{array}{l}-94.4 \\
-55.6 \\
819.0\end{array}$ & $\begin{array}{l}-5.3 \\
+\quad 1.3 \\
-3.0\end{array}$ & $\begin{array}{l}-\$ 9.1 \\
-56.9 \\
\$ 16.0\end{array}$ & $\begin{array}{l}215.2 \\
214.6 \\
22.5\end{array}$ \\
\hline
\end{tabular}

\section{To. 21 included for comparison.} periods.

Sample lost; carbon dioxid assumed to be the same in amount as the average in preceding and following 
T.BLE XLL.-Record of wuter in ventiluting uir current-Netabolism experiments Nos 18-20. a

\begin{tabular}{|c|c|c|c|c|c|c|c|c|c|c|}
\hline \multirow[b]{2}{*}{ Date. } & \multirow[b]{2}{*}{ Period. } & \multirow[b]{2}{*}{$\begin{array}{l}\text { Ventila- } \\
\text { tion. } \\
\text { Number of } \\
\text { Jiters of } \\
\text { air. }\end{array}$} & \multicolumn{2}{|c|}{$\begin{array}{l}\text { Water in incom- } \\
\text { ing air. }\end{array}$} & \multicolumn{3}{|c|}{ Water in outgoing air. } & \multirow[b]{2}{*}{$\begin{array}{l}\text { Total ex- } \\
\text { eess water } \\
\text { in ontgo- } \\
\text { ing air, } \\
f-c \text {. }\end{array}$} & \multirow{2}{*}{$\begin{array}{l}\text { (hi) } \\
\text { Correc- } \\
\text { tion for } \\
\text { water re- } \\
\text { maining } \\
\text { in cham- } \\
\text { ber. }\end{array}$} & \multirow{2}{*}{$\begin{array}{l}(i) \\
\text { Totaì } \\
\text { water of } \\
\text { respira- } \\
\text { tion and } \\
\text { perspira- } \\
\text { tion, } \\
g+h .\end{array}$} \\
\hline & & & $\begin{array}{c}(b) \\
\text { Per liter. }\end{array}$ & $\begin{array}{c}(c) \\
\text { Total, } \\
a \times b\end{array}$ & $\begin{array}{c}(d) \\
\text { Amount } \\
\text { con- } \\
\text { densed in } \\
\text { freezcrs. }\end{array}$ & $\begin{array}{c}\langle e\rangle \\
\text { Amount } \\
\text { not eon- } \\
\text { densed in } \\
\text { freezers. }\end{array}$ & $\begin{array}{c}(f) \\
\text { Total, } \\
d+e\end{array}$ & & & \\
\hline \multirow[t]{4}{*}{ b. $\quad 699$} & \multirow{2}{*}{ 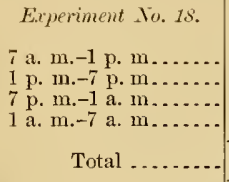 } & $\begin{array}{l}\text { Liters. } \\
26,069 \\
25,745 \\
26,362 \\
27,245\end{array}$ & $\begin{array}{c}. M g \\
0.825 \\
.769 \\
.799 \\
.812\end{array}$ & $\begin{array}{r}\text { Grams. } \\
21.5 \\
19.8 \\
21.1 \\
22.1\end{array}$ & $\begin{array}{l}\text { Grams. } \\
200.5 \\
201.8 \\
210.5 \\
196.9\end{array}$ & $\begin{array}{r}\text { Groms. } \\
45.0 \\
37.4 \\
41.2 \\
37.3\end{array}$ & $\begin{array}{l}\text { Grams. } \\
245.5 \\
239.2 \\
251.7 \\
234.2\end{array}$ & $\begin{array}{l}\text { Grams. } \\
224.0 \\
219.4 \\
230.6 \\
212.1\end{array}$ & $\begin{array}{l}\text { Grams. } \\
+13.4 \\
-2.3 \\
+5.1 \\
-5.9\end{array}$ & $\begin{array}{l}\text { Grams. } \\
237.4 \\
217.1 \\
235.7 \\
206.2\end{array}$ \\
\hline & & 105.421 & ........ & 84.5 & 809.7 & 160.9 & 970.6 & 886.1 & +10.3 & 896.4 \\
\hline & $\begin{array}{l}7 \text { a. m. }-1 \text { p. m. } \\
1 \text { p. m.-7 p. m. } \\
7 \text { p. m.-1 a. m. } \\
1 \text { a. m. }-7 \text { a. m. }\end{array}$ & $\begin{array}{l}25,795 \\
25,908 \\
26,924 \\
27,122 \\
\end{array}$ & $\begin{array}{l}.825 \\
.820 \\
.790 \\
.797\end{array}$ & $\begin{array}{l}21.3 \\
21.2 \\
21.3 \\
21.6 \\
\end{array}$ & $\begin{array}{l}192.2 \\
212.0 \\
213.0 \\
193.8\end{array}$ & $\begin{array}{l}38.1 \\
37.2 \\
40.2 \\
37.9\end{array}$ & & $\begin{array}{l}209.0 \\
228.0 \\
231.9 \\
210.1\end{array}$ & $\begin{array}{r}+.5 \\
+2.7 \\
-4.5 \\
-6.4 \\
\end{array}$ & $\begin{array}{l}209.5 \\
230.7 \\
227.4 \\
203.7 \\
\end{array}$ \\
\hline & Total & $105,7+9$ & . & 85.4 & 811.0 & 153.4 & 964.4 & 879.0 & -7.7 & 871.3 \\
\hline \multirow[t]{2}{*}{$8-9$} & $\begin{array}{l}\text { Experiment No. } 19 . \\
7 \text { a. m.-1 p. m.... } \\
1 \text { p. m. }-7 \text { p. m.... } \\
7 \text { p. m. }-1 \text { a. m..... } \\
1 \text { a. m. }-7 \text { a. m.... }\end{array}$ & $\begin{array}{l}26,792 \\
26,010 \\
27,593 \\
27,999\end{array}$ & $\begin{array}{l}.812 \\
.811 \\
.775 \\
.719\end{array}$ & $\begin{array}{l}21.8 \\
21.1 \\
21.4 \\
20.1\end{array}$ & $\begin{array}{l}195.3 \\
195.1 \\
191.6 \\
184.4\end{array}$ & $\begin{array}{l}38.2 \\
36.1 \\
41.8 \\
40.0\end{array}$ & $\begin{array}{l}233.5 \\
231.2 \\
233.4 \\
224.4\end{array}$ & $\begin{array}{l}211.7 \\
210.1 \\
212.0 \\
204.3\end{array}$ & $\begin{array}{r}+8.2 \\
+1.3 \\
+2.1 \\
-3.4\end{array}$ & $\begin{array}{l}219.9 \\
211.4 \\
209.9 \\
200.9\end{array}$ \\
\hline & Total ... & 108,394 & ....... & 84.4 & 766.4 & 156.1 & 922.5 & 838.1 & +4.0 & 842.1 \\
\hline \multirow[t]{2}{*}{$9-10$} & $\begin{array}{l}7 \text { a. m. }-1 \text { p. m. } \\
1 \text { p. m.-7 p. m. } \\
7 \text { p. m.-1 a. m. } \\
1 \text { a. m. }-7 \text { a. } m . .\end{array}$ & $\begin{array}{l}26,388 \\
26,150 \\
27,647 \\
28,015\end{array}$ & $\begin{array}{l}.738 \\
.747 \\
.758 \\
.685 \\
\end{array}$ & $\begin{array}{l}19.5 \\
19.5 \\
20.9 \\
19.2 \\
\end{array}$ & $\begin{array}{l}184.3 \\
173.6 \\
192.4 \\
185.7\end{array}$ & $\begin{array}{l}35.8 \\
34.6 \\
44.7 \\
35.5 \\
\end{array}$ & & & $\begin{array}{r}+4.7 \\
-2.1 \\
+\quad .5 \\
-5.3\end{array}$ & $\begin{array}{l}205.3 \\
186.6 \\
216.7 \\
196.7 \\
\end{array}$ \\
\hline & Tota & 108,200 & & 79.1 & 736.0 & 150.6 & 886.6 & 807.5 & -2.2 & 805.3 \\
\hline \multirow[t]{2}{*}{$10-11$} & $\begin{array}{l}\text { Experiment No. } 20 . \\
7 \text { a. m. }-1 \text { p. m..... } \\
1 \text { p. m. }-7 \text { p. m..... } \\
7 \text { p. m.-1 a. m..... } \\
1 \text { a. m.-7 a. m..... }\end{array}$ & $\begin{array}{l}25,750 \\
26,228 \\
27,422 \\
28,046 \\
\end{array}$ & $\begin{array}{l}.697 \\
.703 \\
.645 \\
.555 \\
\end{array}$ & $\begin{array}{l}17.9 \\
18.4 \\
17.7 \\
15.5 \\
\end{array}$ & $\begin{array}{l}178.6 \\
194.6 \\
195.6 \\
179.3 \\
\end{array}$ & & & & $\begin{array}{r}+5.7 \\
+\quad 3.8 \\
+\quad .4 \\
-1.2 \\
\end{array}$ & $\begin{array}{l}201.3 \\
215.4 \\
221.0 \\
198.6 \\
\end{array}$ \\
\hline & Total & 107,446 & 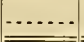 & 69.5 & $7+8.1$ & 149.0 & 897.1 & 827.6 & $\begin{array}{r}+8.7 \\
\end{array}$ & 836.3 \\
\hline \multirow[t]{2}{*}{$11-12$} & $\begin{array}{l}7 \text { a. } m .-1 \text { p. } m . \ldots \\
1 \text { p. } m .-7 \text { p. m...... } \\
7 \text { p. m. }-1 \text { a. m....... } \\
1 \text { a. } m .-7 \text { a. } m . . .\end{array}$ & $\begin{array}{l}26,132 \\
26,157 \\
27,966 \\
28,443\end{array}$ & $\begin{array}{l}.559 \\
.645 \\
.697 \\
.723\end{array}$ & $\begin{array}{l}14.6 \\
16.9 \\
19.5 \\
20.6\end{array}$ & & & & $\begin{array}{l}212.4 \\
207.3 \\
219.9 \\
206.0\end{array}$ & $\begin{array}{r}+7.4 \\
+4.2 \\
+2.3 \\
-3.5 \\
\end{array}$ & $\begin{array}{l}219.8 \\
203.1 \\
222.2 \\
202.5 \\
\end{array}$ \\
\hline & Tote & 108,698 & $\cdots$ & 71.6 & 762.6 & 154.6 & 917.2 & 845.6 & +2.0 & 847.6 \\
\hline $\begin{array}{l}12-13 \\
13-14 \\
14-15\end{array}$ & 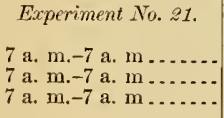 & $\begin{array}{l}109,063 \\
109,064 \\
107,982\end{array}$ & $\cdots$ & $\begin{array}{l}81.1 \\
84.9 \\
84.3\end{array}$ & $\begin{array}{l}755.4 \\
795.9 \\
833.5\end{array}$ & $\begin{array}{l}150.1 \\
149.4 \\
146.7\end{array}$ & $\begin{array}{l}905.5 \\
945.3 \\
980.2\end{array}$ & $\begin{array}{l}824.4 \\
860.4 \\
895.9\end{array}$ & $\begin{array}{r}-3.1 \\
-2.0 \\
+1.7\end{array}$ & $\begin{array}{l}821.3 \\
858.4 \\
897.6\end{array}$ \\
\hline
\end{tabular}

${ }^{3}$ No. 21 included for comparison. 
The calorimetric measurements tor experiments $18-20$ ale given in detail, and those for experiment 21 summarized, in Table XLI.

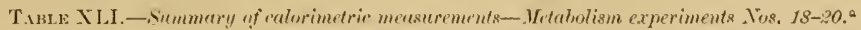

\begin{tabular}{|c|c|c|c|c|c|c|c|c|}
\hline Date. & Period. & $\begin{array}{l}\text { Heat meas- } \\
\text { urul in } \\
\text { terms of } \\
\text { ('O }{ }_{20} \text {. }\end{array}$ & $\begin{array}{l}\text { Change } \\
\text { of tem- } \\
\text { pernture } \\
\text { of ealo- } \\
\text { rineter. }\end{array}$ & $\begin{array}{l}\text { Capacity } \\
\text { correction } \\
\text { of calorim- } \\
\text { cter, } b \times 60 .\end{array}$ & $\begin{array}{l}\text { (d) } \\
\text { Correction } \\
\text { due to tem- } \\
\text { perature } \\
\text { of foril and } \\
\text { dishes. }\end{array}$ & $\begin{array}{c}\langle f\rangle \\
\text { Water } \\
\text { vaporized } \\
\text { equals } \\
\text { total } \\
\text { amount ex- } \\
\text { lusled, less } \\
\text { amount } \\
\text { condensed } \\
\text { in chamber. }\end{array}$ & $\begin{array}{c}(f) \\
\text { lieat used } \\
\text { in vapori- } \\
\text { zation of } \\
\text { Water, } \\
e: 0.592 .\end{array}$ & $\begin{array}{l}\text { Total heat } \\
\text { deter- } \\
\text { mined, } a+ \\
c+d+t\end{array}$ \\
\hline Feb. ${ }^{\text {Is99. }}$ & 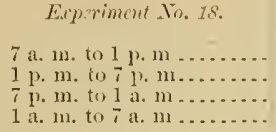 & $\begin{array}{l}\text { ralorics. } \\
713.7 \\
502.7 \\
491.0 \\
308.5\end{array}$ & $\begin{array}{l}\text { Degrees. } \\
+0.05 \\
-.02 \\
-.05\end{array}$ & $\begin{array}{l}\text { calorits. } \\
+5.40 \\
-1.20 \\
-3.00\end{array}$ & $\begin{array}{r}\text { Culurins. } \\
+\quad 5.5 \\
+\quad 8.5 \\
\ldots . . .\end{array}$ & $\begin{array}{l}\text { Frams. } \\
235.4 \\
215.1 \\
234.7 \\
205.2\end{array}$ & $\begin{array}{l}\text { Calorics. } \\
139.4 \\
127.3 \\
139.0 \\
121.5\end{array}$ & $\begin{array}{l}\text { Calories. } \\
\text { 855. } 6 \\
663.9 \\
628.8 \\
427.0\end{array}$ \\
\hline & Total............ & $2,035.9$ & +.02 & +1.20 & +14.0 & \$90. 4 & 527.2 & $2,578,3$ \\
\hline $7-8$ & 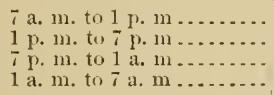 & $\begin{array}{l}549.4 \\
525.6 \\
475.1 \\
262.9\end{array}$ & $\begin{array}{l}+.05 \\
+.03 \\
+.14 \\
+\quad .25\end{array}$ & $\begin{array}{r}+\quad 3.00 \\
+\quad 1.80 \\
+\quad 8.40 \\
-15.00\end{array}$ & $\begin{array}{r}+\quad 8.2 \\
+9.3 \\
\ldots \ldots \\
\ldots .\end{array}$ & $\begin{array}{l}210.5 \\
231.7 \\
228.4 \\
204.7\end{array}$ & $\begin{array}{l}124.6 \\
137.2 \\
135.2 \\
121.2\end{array}$ & $\begin{array}{l}735.2 \\
673.9 \\
618.7 \\
369.1\end{array}$ \\
\hline & Total............. & $1, \mathbf{A}+3 . .0$ & -.03 & -1.80 & +17.5 & 575.3 & 518.2 & $2,396.9$ \\
\hline $8-9$ & 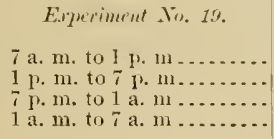 & $\begin{array}{l}540.0 \\
+97.2 \\
+32.3 \\
296.4\end{array}$ & $\begin{array}{r}+.11 \\
+.01 \\
-.03 \\
+.03\end{array}$ & $\begin{array}{l}+6.60 \\
+\quad .60 \\
+\quad 1.80 \\
+1.80\end{array}$ & $\begin{array}{r}+5.1 \\
+7.5 \\
\ldots \ldots \ldots \\
\ldots \ldots \ldots\end{array}$ & $\begin{array}{l}217.9 \\
209.4 \\
208.9 \\
199.9\end{array}$ & $\begin{array}{l}129.0 \\
124.0 \\
123.7 \\
118.3\end{array}$ & $\begin{array}{l}680.7 \\
629.3 \\
554.2 \\
+16.5\end{array}$ \\
\hline & Total ............... & $1,765.9$ & +.12 & +7.20 & +12.6 & 836.1 & 495.0 & $2,280.7$ \\
\hline $9-10$ & 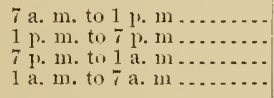 & $\begin{array}{l}528.4 \\
+46.3 \\
470.3 \\
335.3\end{array}$ & $\begin{array}{r}+.04 \\
-.05 \\
+.06 \\
-.02\end{array}$ & $\begin{array}{l}+2.40 \\
-\quad 3.00 \\
+\quad 3.60 \\
-1.20\end{array}$ & 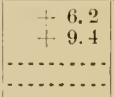 & $\begin{array}{l}206.3 \\
187.6 \\
217.7 \\
195.7\end{array}$ & $\begin{array}{l}122.1 \\
111.1 \\
128.9 \\
117.6\end{array}$ & $\begin{array}{l}659.1 \\
563.8 \\
602.8 \\
451.7\end{array}$ \\
\hline & Total............... & $1,780.3$ & +.03 & +1.80 & +15.6 & 810.3 & 479.7 & $2,277.4$ \\
\hline $10-11$ & 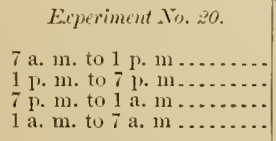 & $\begin{array}{l}522.9 \\
483.4 \\
477.7 \\
310.0\end{array}$ & $\begin{array}{r}+.01 \\
+.02 \\
-.03 \\
\ldots \ldots .\end{array}$ & $\begin{array}{l}+.60 \\
+1.20 \\
-1.80 \\
\end{array}$ & $\begin{array}{r}+6.1 \\
+7.8 \\
\ldots \ldots \\
\ldots \ldots\end{array}$ & $\begin{array}{l}198.3 \\
213.4 \\
219.0 \\
196.6\end{array}$ & $\begin{array}{l}117.4 \\
126.3 \\
129.6 \\
116.4\end{array}$ & $\begin{array}{l}647.0 \\
618.7 \\
605.5 \\
426.4\end{array}$ \\
\hline & Total..... & $1,794.0$ & 0.0 & 0.0 & +13.9 & 827.3 & 459.7 & $2,297.6$ \\
\hline $11-12$ & 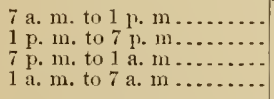 & $\begin{array}{l}549.1 \\
461.1 \\
460.2 \\
312.9\end{array}$ & $\begin{array}{r}+.01 \\
-.02 \\
+.06 \\
-.04\end{array}$ & $\begin{array}{l}+\quad .60 \\
-1.20 \\
+\quad 3.60 \\
-2.40\end{array}$ & $\begin{array}{r}+11.9 \\
+10.4 \\
\cdots \ldots \ldots \\
\cdots+\ldots .\end{array}$ & $\begin{array}{l}219.8 \\
203.1 \\
222.2 \\
202.5\end{array}$ & $\begin{array}{l}130.0 \\
120.3 \\
131.6 \\
119.9\end{array}$ & $\begin{array}{l}691.6 \\
590.6 \\
59.5 .4 \\
430.4\end{array}$ \\
\hline & Total........ & $1,783.3$ & +.01 & +.60 & +22.3 & $84 \overline{7.6}$ & 501.8 & $\overline{2,308,0}$ \\
\hline $\begin{array}{l}12-13 \\
13-14 \\
14-15\end{array}$ & 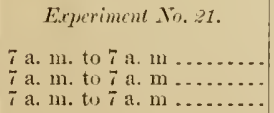 & $\begin{array}{l}1,718.4 \\
1,737.4 \\
1,801.5\end{array}$ & $\begin{array}{r}-.02 \\
+.02 \\
+\quad .03\end{array}$ & $\begin{array}{l}-1.20 \\
-1.20 \\
+1.80\end{array}$ & $\begin{array}{r}+22.4 \\
+16.9 \\
+13.8\end{array}$ & $\begin{array}{l}821.3 \\
860.4 \\
896.6\end{array}$ & $\begin{array}{l}486.2 \\
509.4 \\
530.8\end{array}$ & $\begin{array}{l}2,226.2 \\
2,262.5 \\
2,347.9\end{array}$ \\
\hline
\end{tabular}

"Fo. 21 included for comparison.

The determinations of redueing material in the ventilating air eurent were made according to the method followed in the preceding experiments (see 1. 25s). The analytical data are shown in Table XLII. It will be noticed that the amount of reducing material, reckoned as 
alcohol, found in the air current on the first day of the series of experiments, February $6-\pi$, is considerably larger than on the 3 days following. This may be due in part to the fact that the subject had taken with him into the chamber an atomizer containing an alcoholic solution of encalyptol, of which reagent, however, only a very small amount was used on the first day, and none thereafter. It will also be observed that the amount of reducing material in the air current during the 3 days of experiment No. 21, in which alcohol did not form a part of the diet, was considerable. Attention has already been called to the fact that what is reckoned as alcohol in the air current consists to a greater or less degree of reducing matter ordinarily present in the respired air, whether the subject consumed alcohol or not. Later experiments indicate that this amount of reducing material may be equivalent to as much as 0.4 of a gram of alcohol per day (see experiments 26,28 , and 30 beyond). That the amount of alcohol and other reducing material should be so large during the 3 days of experiment No. 21 is rather surprising. During the 4 days of the preliminary period and the 6 days of experiments Nos. 18-20, 725 grams of absolnte alcohol had been taken. It way be that there was a certain lag in the elimination of alcohol not oxidized by the body. That there could be any large amount of alcohol remaining in the body seems altogether improbable, both from physiological considerations and from the results of experiments which have been made concerning the amount of alcohol which may be found in the tissues of the body. If there were a lag in the elimination, we do not know how long it wonld continue. In later experiments, Nos. 22, 27, and 33, no snch lag was observed. The figures for reducing material in the alcohol on the 3 days of experiment No. 21 are not as trustworthy as those of the previous days, owing to certain analytical irregularities. The figures in column 5 of Table XLII show the total exeretion of alcohol on the arbitrary assumption that one-half the average amount of reducing material found in experiment No. 21 was actually alcohol. While it is believed that these amounts represent more than the actual elimination of alcohol, they have been used in the computations of the income and outgo of carbon and energy in the following tables:

TABLe XLII.-Alcohol ingested and excreted-Metabolism experiments Nos. 18-20."

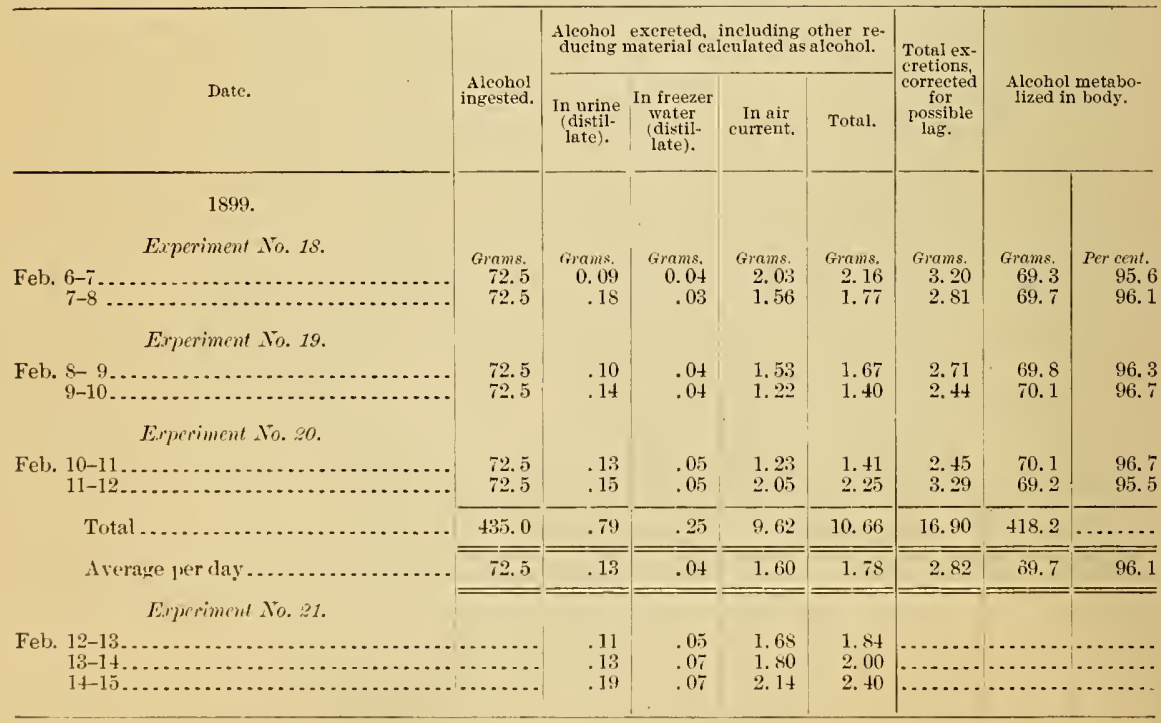


Balance of income and outgont matter and emergy: The income and ontgo of nitrogen, carbon, hydrogen. and energy in these experiments are shown in Tables XLIII to XLVI.

T.ABLE XLIII. - Income and outgo of nitrogen and carbon--Velubalism experiments . Tos. 18-20."

\begin{tabular}{|c|c|c|c|c|c|c|c|c|c|c|}
\hline \multirow[b]{2}{*}{ Date and period. } & \multicolumn{4}{|c|}{ Xitrogen. } & \multicolumn{6}{|c|}{ Carbon. } \\
\hline & In foot. & $\underset{\text { In }}{\text { In }}$ & $\mid \begin{array}{c}\text { (c) } \\
\text { ln } \\
\text { urine. }\end{array}$ & $\begin{array}{c}(d) \\
\text { Gain } \\
(+1 \\
\text { or loss } \\
\left(-\frac{1}{b}\right) \\
a-(b+c)\end{array}$ & In food. & $\underset{\text { In }}{(j)}$ & $\begin{array}{l}\text { (g) } \\
\text { urinc. } \\
\text { urinc. }\end{array}$ & $\begin{array}{l}(h) \\
\text { In respi- } \\
\text { ralory } \\
\text { products. }\end{array}$ & $\begin{array}{c}(i) \\
\text { In alco- } \\
\text { hol } \\
\text { elimi- } \\
\text { nated. }\end{array}$ & $\begin{array}{l}(k) \\
\text { Gain } \\
(+) \\
\text { or loss } \\
(-), \\
-(f+g+ \\
h+i)\end{array}$ \\
\hline 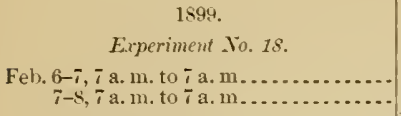 & $\begin{array}{c}\text { Grams. } \\
15.5 \\
15.5\end{array}$ & $\begin{array}{r}\text { Grams. } \\
1.0 \\
1.1 \\
\end{array}$ & $\begin{array}{c}\text { Grams. } \\
17.4 \\
15.4\end{array}$ & $\begin{array}{l}\text { Grame. } \\
-2.9 \\
-1.0\end{array}$ & $\begin{array}{l}\text { Grame. } \\
253.0 \\
253.0\end{array}$ & $\begin{array}{r}\text { Grames. } \\
9.0 \\
9.0\end{array}$ & $\begin{array}{r}\text { Grams. } \\
11.0 \\
9.8\end{array}$ & $\begin{array}{l}\text { Grams. } \\
2 \div 24.4 \\
214.3\end{array}$ & $\begin{array}{r}\text { Grams. } \\
1.7 \\
1.4\end{array}$ & $\begin{array}{l}\text { Grams. } \\
+\quad 6.9 \\
+18.5\end{array}$ \\
\hline 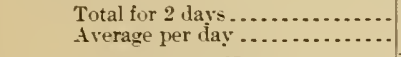 & $\begin{array}{l}31.0 \\
15.5 \\
\end{array}$ & $\begin{array}{l}2.1 \\
1.1 \\
\end{array}$ & $\begin{array}{l}32.8 \\
16.4 \\
\end{array}$ & $\begin{array}{r}-3.9 \\
-2.0 \\
\end{array}$ & & $\begin{array}{r}18.0 \\
9.0 \\
\end{array}$ & $\begin{array}{l}20.8 \\
10.4 \\
\end{array}$ & $\begin{array}{l}438 . \overrightarrow{1} \\
219.3 \\
\end{array}$ & $\begin{array}{l}3.1 \\
1.6 \\
\end{array}$ & $\begin{array}{l}+25 . \pm \\
+12.7 \\
\end{array}$ \\
\hline 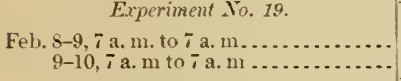 & $\begin{array}{l}15.5 \\
15.5\end{array}$ & $\begin{array}{l}1.0 \\
1.1\end{array}$ & $\begin{array}{l}14.7 \\
14.2 \\
\end{array}$ & $-\frac{2}{2}$ & $\begin{array}{l}253.0 \\
253.0 \\
\end{array}$ & $\begin{array}{l}9.0 \\
9.0 \\
\end{array}$ & $\begin{array}{l}9.3 \\
9.0\end{array}$ & $\frac{206.2}{20 \%} \cdot 1$ & $\begin{array}{l}1.4 \\
1.3 \\
\end{array}$ & $\begin{array}{l}+27.1 \\
+26.6 \\
\end{array}$ \\
\hline $\begin{array}{l}\text { Total for } 2 \text { days } \ldots \ldots \ldots \ldots \ldots \ldots . \\
\text { Arerage per day } \ldots \ldots \ldots \ldots \ldots \ldots\end{array}$ & $\begin{array}{l}31.0 \\
15.5\end{array}$ & $\begin{array}{l}2.1 \\
1.0\end{array}$ & $\begin{array}{l}28.9 \\
14.5\end{array}$ & $\ldots$. & $\begin{array}{l}506.0 \\
253.0\end{array}$ & $\begin{array}{r}15.0 \\
9.0\end{array}$ & $\begin{array}{r}18.3 \\
9.2\end{array}$ & $\begin{array}{l}+13.3 \\
206.6\end{array}$ & $\begin{array}{l}2.7 \\
1.3\end{array}$ & $\begin{array}{l}+53.7 \\
+26.9\end{array}$ \\
\hline 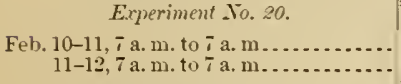 & $\begin{array}{l}15.5 \\
15.5\end{array}$ & $\begin{array}{l}1.0 \\
1.1\end{array}$ & $\begin{array}{l}13.8 \\
14.4\end{array}$ & +.7 & $\begin{array}{l}253.0 \\
253.0 \\
\end{array}$ & $\begin{array}{l}9.0 \\
9.0 \\
\end{array}$ & $\begin{array}{l}8.8 \\
9.2\end{array}$ & $\begin{array}{l}214.1 \\
218.3 \\
\end{array}$ & $\begin{array}{l}1.3 \\
1.7\end{array}$ & $\begin{array}{r}+19.8 \\
+14.8 \\
\end{array}$ \\
\hline $\begin{array}{l}\text { Total for } 2 \text { days } \ldots \ldots \ldots \ldots \ldots \\
\text { Average per day ................ }\end{array}$ & $\begin{array}{l}31.0 \\
15.5 \\
\end{array}$ & $\begin{array}{l}2.1 \\
1.0\end{array}$ & $\begin{array}{l}28.2 \\
14.1\end{array}$ & $\begin{array}{r}+.7 \\
+.4 \\
\end{array}$ & $\begin{array}{l}506.0 \\
253.0\end{array}$ & $\begin{array}{r}18.0 \\
9.0\end{array}$ & $\begin{array}{r}18.0 \\
9.0\end{array}$ & $\begin{array}{l}432.4 \\
216.2 \\
\end{array}$ & $\begin{array}{l}3.0 \\
1.5\end{array}$ & $\begin{array}{r}+34.6 \\
+17.3 \\
\end{array}$ \\
\hline $\begin{array}{l}\text { Euperiments . Tos. } 18-20 \text {. } \\
\text { Average per day ......... }\end{array}$ & 15.5 & 1.0 & 15.0 & -.5 & 253.0 & 9.0 & 9.5 & 214.1 & 1.5 & +18.9 \\
\hline 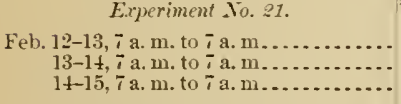 & $\begin{array}{l}15.5 \\
15.5 \\
15.5\end{array}$ & $\begin{array}{l}1.0 \\
1.1 \\
1.0\end{array}$ & $\begin{array}{l}14.5 \\
16.2 \\
15.4\end{array}$ & $\begin{array}{r}-1.8 \\
-.9\end{array}$ & $\begin{array}{l}215.2 \\
215.2 \\
215.2\end{array}$ & $\begin{array}{l}9.0 \\
9.0 \\
9.0\end{array}$ & $\begin{array}{l}10.2 \\
11.3 \\
10.9\end{array}$ & $\begin{array}{l}215.2 \\
21 \pm .6 \\
22.2 .5\end{array}$ & $\mid \begin{array}{c}\cdots \\
\ldots \\
\cdots\end{array}$ & $\begin{array}{r}-19.2 \\
-19.7 \\
-21.2\end{array}$ \\
\hline $\begin{array}{l}\text { Total for } 3 \text { days ............... } \\
\text { Average per day . . . . . . . . . . }\end{array}$ & $\begin{array}{l}46.5 \\
15.5\end{array}$ & $\begin{array}{l}3.1 \\
1.0\end{array}$ & $\begin{array}{l}46.1 \\
15.4\end{array}$ & $\begin{array}{l}-2.7 \\
-.9\end{array}$ & $\begin{array}{l}645.6 \\
215.2\end{array}$ & $\begin{array}{r}2 \pi .0 \\
9.0\end{array}$ & $\begin{array}{l}32.4 \\
10.8\end{array}$ & $\begin{array}{l}652.3 \\
217.4\end{array}$ & & $\begin{array}{l}-66.1 \\
-22.0\end{array}$ \\
\hline
\end{tabular}

Vo. 21 ineluded for comparison.

TABLE XLIV. - Income and outgo of water and hydrogen-Metubolism exjeriments Wos. 18-21."

\begin{tabular}{|c|c|c|c|c|c|c|}
\hline \multirow[b]{2}{*}{ Date and period. } & \multicolumn{6}{|c|}{ Water. } \\
\hline & $\begin{array}{c}\text { (a) } \\
\text { In food. }\end{array}$ & $\begin{array}{c}(b) \\
\text { In drink, }\end{array}$ & $\begin{array}{c}\text { (c) } \\
\text { In feces. }\end{array}$ & $\begin{array}{c}\text { (d) } \\
\text { In urine. }\end{array}$ & $\begin{array}{l}(e) \\
\text { In respira- } \\
\text { tory prod- } \\
\text { uets. }\end{array}$ & $\begin{array}{c}(j) \\
\text { Apparent } \\
\text { loss } a+b-b \\
(c+d+e) .\end{array}$ \\
\hline 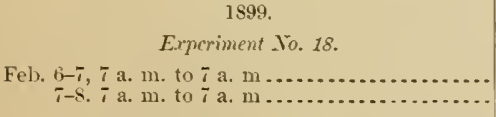 & $\begin{array}{l}\text { Grams. } \\
889.9 \\
8 \times 9.9\end{array}$ & $\begin{array}{l}\text { Grams. } \\
1,398.2 \\
1,384.8\end{array}$ & $\begin{array}{l}\text { Grams. } \\
\quad 46 . \pm \\
46 . \frac{1}{4}\end{array}$ & $\begin{array}{l}\text { Grams. } \\
1,269.3 \\
1,945.4\end{array}$ & $\begin{array}{l}\text { Grams. } \\
896.4 \\
8.1 .3\end{array}$ & $\begin{array}{r}\text { Grams. } \\
+\quad 76.0 \\
+\quad 5 \$ 5 . t\end{array}$ \\
\hline $\begin{array}{l}\text { Total for } 2 \text { days } \ldots \ldots \ldots \ldots \ldots \ldots \ldots \ldots \ldots \\
\text { Average per day } \ldots \ldots \ldots \ldots\end{array}$ & $\begin{array}{r}1,779.8 \\
859.9\end{array}$ & $\begin{array}{l}2,783.0 \\
1,391.5\end{array}$ & $\begin{array}{l}92.5 \\
46.4\end{array}$ & $\begin{array}{l}3,214.7 \\
1.607 .3\end{array}$ & $1,767.7$ & $\begin{array}{l}-\quad 512 . t \\
-\quad 256.2\end{array}$ \\
\hline 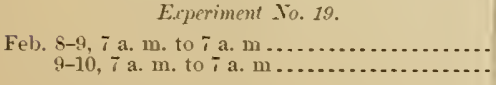 & $\begin{array}{l}889.9 \\
889.9\end{array}$ & $\begin{array}{l}1,3 \$ 4.3 \\
1,383.8\end{array}$ & $\begin{array}{l}46.4 \\
46.4\end{array}$ & $\begin{array}{l}1,43 \pi .6 \\
1,6 \times 3.3\end{array}$ & $\begin{array}{l}8+2.1 \\
805.3\end{array}$ & $\begin{array}{r}51.9 \\
-\quad 261.3\end{array}$ \\
\hline $\begin{array}{l}\text { Total for } 2 \text { days } \ldots \ldots \ldots \ldots \ldots \ldots \ldots \ldots \\
\text { Average per day } \ldots \ldots \ldots \ldots \ldots \ldots \ldots \ldots \ldots\end{array}$ & $\begin{array}{r}1,779.8 \\
859.9\end{array}$ & $\begin{array}{l}2,768.1 \\
1,384.1\end{array}$ & $\begin{array}{l}92.5 \\
46.4\end{array}$ & $\begin{array}{l}3,120.9 \\
1,560.5\end{array}$ & $\begin{array}{l}1.647 . \frac{4}{2} \\
823.7\end{array}$ & $\begin{array}{l}-313.2 \\
-\quad 156.6\end{array}$ \\
\hline
\end{tabular}

To. 21 included for comparison.

buring the 9 days of these experiments 28.5 grams water was evaporated irom the hygrometer, or an arerage of 3.2 grams per day, which is here added to the drink. 
TABLE XLIV. - Income and outgo of water and hydrogen-Metabolism experiments .Tos. 18-21 ${ }^{a}$.-Continued.

\begin{tabular}{|c|c|c|c|c|c|c|}
\hline \multirow[b]{2}{*}{ Date and period. } & \multicolumn{6}{|c|}{ Water. } \\
\hline & $\begin{array}{c}(a) \\
\text { In food. }\end{array}$ & $\begin{array}{c}\text { (b) } \\
\text { In drink. }\end{array}$ & $\begin{array}{c}\text { (c) } \\
\text { In feces. }\end{array}$ & $\begin{array}{c}\text { (d) } \\
\text { In urine. }\end{array}$ & $\begin{array}{l}(e) \\
\text { In respira- } \\
\text { lory prod- } \\
\text { uets, }\end{array}$ & $\begin{array}{c}(f) \\
\text { Apparent } \\
\text { loss } a+b- \\
(c+d+e) .\end{array}$ \\
\hline 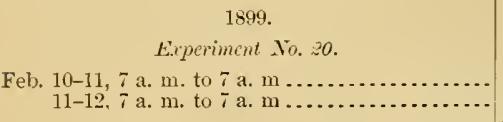 & $\begin{array}{r}\text { Grams. } \\
889.9 \\
889.9\end{array}$ & $\begin{array}{l}\text { Grams. } \\
1,384.1 \\
1,385.2\end{array}$ & $\begin{array}{l}\text { Grams. } \\
46.4 \\
46.4\end{array}$ & $\begin{array}{l}\text { Grams. } \\
1,646.4 \\
1,887.9\end{array}$ & $\begin{array}{l}\text { Grams. } \\
836.3 \\
847.6\end{array}$ & $\begin{array}{r}\text { Grams. } \\
-\quad 255.1 \\
-\quad 506.8\end{array}$ \\
\hline $\begin{array}{l}\text { Total for } 2 \text { days } \\
\text { Arerage per day } \ldots \ldots\end{array}$ & $\begin{array}{r}1,779.8 \\
889.9\end{array}$ & $\begin{array}{l}2,769.3 \\
1,384.7\end{array}$ & $\begin{array}{l}92.8 \\
46.4\end{array}$ & $\begin{array}{l}3,531.3 \\
1,767.2 \\
\end{array}$ & $\begin{array}{r}1,683.9 \\
842.0\end{array}$ & $\begin{array}{r}761.9 \\
-\quad 381.0 \\
\end{array}$ \\
\hline Average per day (experiments 18-20).. & 889.9 & $1,386.7$ & 46.4 & $1,645.0$ & 849.8 & -264.6 \\
\hline 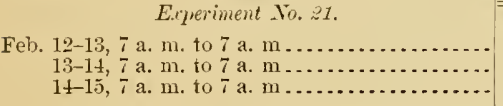 & $\begin{array}{l}889.9 \\
889.9 \\
889.9\end{array}$ & $\begin{array}{l}1,385.4 \\
1,383.8 \\
1,384.9\end{array}$ & $\begin{array}{l}46.4 \\
46.4 \\
46.4\end{array}$ & $\begin{array}{l}1,628.3 \\
1,689.5 \\
1,909.3\end{array}$ & $\begin{array}{l}821.3 \\
858.4 \\
897.6\end{array}$ & $\begin{array}{l}-\quad 220.7 \\
-\quad 320.6 \\
-\quad 578.5\end{array}$ \\
\hline $\begin{array}{l}\text { Total for } 3 \text { days } \ldots \ldots \ldots \ldots \ldots \ldots \ldots \ldots \ldots \\
\text { Average per day } \ldots \ldots \ldots \ldots \ldots \ldots \ldots \ldots\end{array}$ & $\begin{array}{r}2,669.7 \\
889.9\end{array}$ & $\begin{array}{l}4,154.1 \\
1,384.7\end{array}$ & $\begin{array}{r}139.2 \\
46.4\end{array}$ & $\begin{array}{l}5,227.1 \\
1,7 \pm 2.4\end{array}$ & $\begin{array}{r}2,577.3 \\
859.1\end{array}$ & $\begin{array}{r}-1,119.8 \\
-\quad 373.3\end{array}$ \\
\hline
\end{tabular}

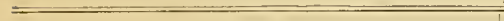

Date and period.

\section{9.}

Experiment No. 18.

Feb. $6-7,7$ a. m. to 7 a. $\mathrm{m}$......................

$7-8,7$ a. m. to 7 a. $m \ldots \ldots \ldots \ldots$

Total for 2 days

Tremage 2 days . . . . . . . . . . . . . . . . . . . .

\section{Experiment No. 19.}

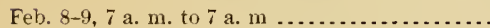

$9-10,7$ a.m. to 7 a. $m \ldots \ldots \ldots \ldots \ldots \ldots . . . .$.

Total for 2 days

Average per day

\section{Erperiment Yo. 20.}

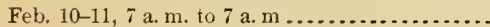

$11-12,7$ a.m. to 7 a. $m \ldots \ldots \ldots \ldots \ldots . .$.

Total for 2 days

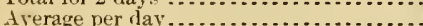

Average per day (experiments 18-20).

$$
\text { Errperiment No. } 21 .
$$

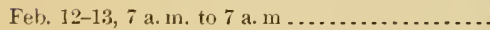

$13-14,7$ a.m. to 7 a.m $\ldots \ldots \ldots \ldots \ldots \ldots . . . .$.

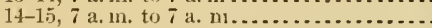

Trtal for 3 rlay.....................

Average per flay .......................

\begin{tabular}{|c|c|c|c|c|c|c|}
\hline $\begin{array}{c}(g) \\
\text { In food. }\end{array}$ & $\begin{array}{c}(h) \\
\text { In feces. }\end{array}$ & $\begin{array}{c}\text { (i) } \\
\text { In urine. }\end{array}$ & $\begin{array}{c}(k) \\
\text { In alcohol } \\
\text { eliminated. }\end{array}$ & $\begin{array}{c}(l) \\
\begin{array}{c}\text { Apparent } \\
\text { gain } g-(h+ \\
i+k) .\end{array}\end{array}$ & $\begin{array}{c}(m) \\
\begin{array}{c}\text { Loss from } \\
\text { water } \\
f \div 9 .\end{array}\end{array}$ & $\begin{array}{c}(n) \\
\text { Total } \\
\text { gain }(+) \\
\text { or loss } \\
(-) l+m .\end{array}$ \\
\hline $\begin{array}{r}\text { Grams. } \\
\quad+1.2 \\
\quad 11.3\end{array}$ & $\begin{array}{r}\text { Grams. } \\
1.2 \\
1.3\end{array}$ & $\begin{array}{r}\text { Grams. } \\
3.6 \\
3.1\end{array}$ & $\begin{array}{r}\text { Grams. } \\
0.4 \\
.4\end{array}$ & $\begin{array}{l}\text { Grams. } \\
+36.0 \\
+36.5\end{array}$ & $\begin{array}{r}\text { Grams. } \\
+\quad 8.5 \\
-\quad 65.4\end{array}$ & $\begin{array}{l}\text { Grams. } \\
+44.5 \\
-28.9\end{array}$ \\
\hline $\begin{array}{l}82.5 \\
41.3\end{array}$ & $\begin{array}{l}2.5 \\
1.3\end{array}$ & $\begin{array}{l}6.7 \\
3.3 \\
\end{array}$ & $\begin{array}{l}.8 \\
.4 \\
\end{array}$ & $\begin{array}{r}+72.5 \\
+36.3 \\
\end{array}$ & $\begin{array}{r}56.9 \\
-\quad 28.5 \\
\end{array}$ & $\begin{array}{r}+15.6 \\
+\quad 7.8 \\
\end{array}$ \\
\hline $\begin{array}{l}41.2 \\
41.3\end{array}$ & $\begin{array}{l}1.2 \\
1.3\end{array}$ & $\begin{array}{l}3.0 \\
2.9\end{array}$ & $\begin{array}{l}.4 \\
.3\end{array}$ & $\begin{array}{r}+36.6 \\
+36.8\end{array}$ & $\begin{array}{r}5.8 \\
-29.0\end{array}$ & $\begin{array}{r}+30.8 \\
+\quad 7.8\end{array}$ \\
\hline $\begin{array}{l}82.5 \\
41.3 \\
\end{array}$ & $\begin{array}{l}2.5 \\
1.3\end{array}$ & $\begin{array}{l}5.9 \\
3.0 \\
\end{array}$ & $\begin{array}{l}.7 \\
.3\end{array}$ & $\begin{array}{r}+73.4 \\
+36.7 \\
\end{array}$ & $\begin{array}{r}-34.8 \\
-\quad 17.4 \\
\end{array}$ & $\begin{array}{l}+38.6 \\
+19.3\end{array}$ \\
\hline $\begin{array}{l}41.2 \\
41.3\end{array}$ & $\begin{array}{l}1.2 \\
1.3\end{array}$ & $\begin{array}{l}2.8 \\
2.9\end{array}$ & $\begin{array}{l}.3 \\
.4\end{array}$ & $\begin{array}{r}+36.9 \\
+36.7\end{array}$ & $\begin{array}{r}28.4 \\
-\quad 56.3\end{array}$ & $\begin{array}{r}+8.5 \\
-19.6\end{array}$ \\
\hline $\begin{array}{l}82.5 \\
41.3\end{array}$ & $\begin{array}{l}2.5 \\
1.2\end{array}$ & $\begin{array}{l}5.7 \\
2.9\end{array}$ & $\begin{array}{l}.7 \\
.4\end{array}$ & $\begin{array}{r}+73.6 \\
+36.8\end{array}$ & $\begin{array}{l}-84.7 \\
-42.4\end{array}$ & $\begin{array}{r}-11.1 \\
-5.6\end{array}$ \\
\hline 41.3 & 1.3 & 3.0 & .4 & +36.6 & -29.4 & +7.2 \\
\hline $\begin{array}{l}31.8 \\
31.8 \\
31.8\end{array}$ & $\begin{array}{l}1.2 \\
1.3 \\
1.2\end{array}$ & $\begin{array}{l}2.9 \\
3.2 \\
3.1\end{array}$ & & $\begin{array}{r}+27.7 \\
+27.3 \\
+27.5\end{array}$ & $\begin{array}{l}24.5 \\
-35.6 \\
-64.3\end{array}$ & $\begin{array}{r}+3.2 \\
-8.3 \\
-36.8\end{array}$ \\
\hline $\begin{array}{l}95.4 \\
31.8\end{array}$ & $\begin{array}{l}3.7 \\
1.2\end{array}$ & $\begin{array}{l}9.2 \\
3.1\end{array}$ & ............ & $\begin{array}{r}+82.5 \\
+27.5\end{array}$ & $\begin{array}{r}-124.4 \\
-\quad 11.5\end{array}$ & $\begin{array}{r}-41.9 \\
-14.0\end{array}$ \\
\hline
\end{tabular}

"No. 21 inchuded for comprarison.

During the ! days of these experiments 28.5 grams water was evaporated from the hygrometer, or an average of 3.2 grans per lay, which is leere alled to the lrink. 


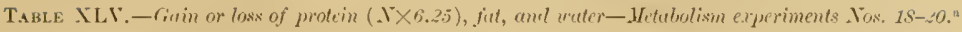

\author{
Thate and perion. \\ 1 1.54. \\ Experiment No. 18 .
}

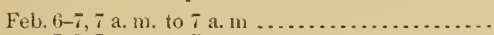

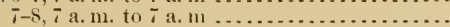

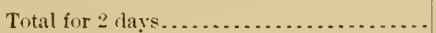
Average per day.

\section{Eipreriment So. 19}

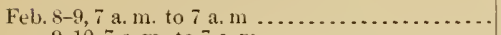
$9-10,7$ a.m. to 7 a.

Total for 2 dave.

Average per day

$$
\text { Experiment } \mathrm{No}, 20 .
$$

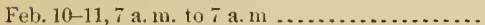

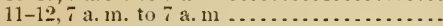

Total for 2 days......................

Average per day .....................

Average per day (experimentw 18-20) .... Erperiment . 21.

Feb. $12-13, \tau$ a. $m$. to 7 a. $m$.................

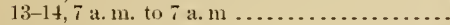

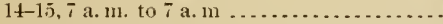

Total for 3 days. . . . . . . . . . . . . . . . . Average per day ......................

Date and perion.

\section{1 s.9.}

Experiment No. 18.

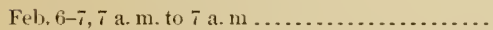
$7-8,7$ a. m. to 7 a. $m \ldots \ldots \ldots \ldots \ldots \ldots$

Total for 2 day

Average per lay

$$
\text { Experiment Wo. 19. }
$$

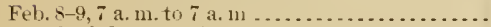

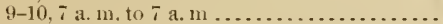

Total for 2 days. A rerace per day

$$
\text { Experiment No. } 20 .
$$

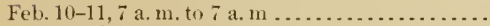

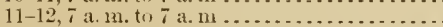

Total for 2 days .................... Average per flay ....................

Arerage per day (experiments $18-20$ ) ....

$$
\text { Erperiment So. } 21 \text {. }
$$

Fel, $12-13,7$ a. m. to 7 a. $m$..................

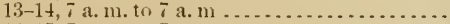

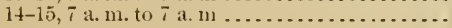

Total for 3 days

Arerage per day

(a)
Nitrugen
gar lost $(+)$
-

Gran

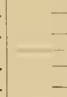

$\begin{array}{r}-2.9 \\ -1.0 \\ -3.9 \\ -2.0 \\ \hline\end{array}$

$\begin{array}{r}\hline-.2 \\ +.2 \\ 0 \\ 0 \\ \hline\end{array}$

\section{$+.7$ \\ .

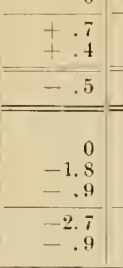

(g)

Total hydrogen
gained $(+)$ or

\begin{tabular}{|c|c|c|c|c|}
\hline (b) & (c) & (d) & $(r)$ & $(f)$ \\
\hline $\begin{array}{l}\text { Protein } \\
\text { ained }(+) \\
r \text { list }(-) \\
a: 6.25 .\end{array}$ & $\begin{array}{l}\text { Total carbon } \\
\text { gaincd }(t) \\
\text { or lost }(-) \text {. }\end{array}$ & $\begin{array}{c}\text { Carbon in } \\
\text { protein } \\
\text { gained ( }) \\
\text { or low }(-) \\
b \times 0.53 \text {. }\end{array}$ & $\begin{array}{c}\text { Parbon in } \\
\text { fut, ete. } \\
\text { guine+d }(+) \\
\text { or lost }(-) \\
c-d \text {. }\end{array}$ & $\begin{array}{c}\text { Fut gained } \\
\begin{array}{c}+1 \text { or lost } \\
(-)\end{array} \\
6 \div 0.765 .\end{array}$ \\
\hline
\end{tabular}
gained $(+)$
lost $(-)$.

$\longrightarrow$

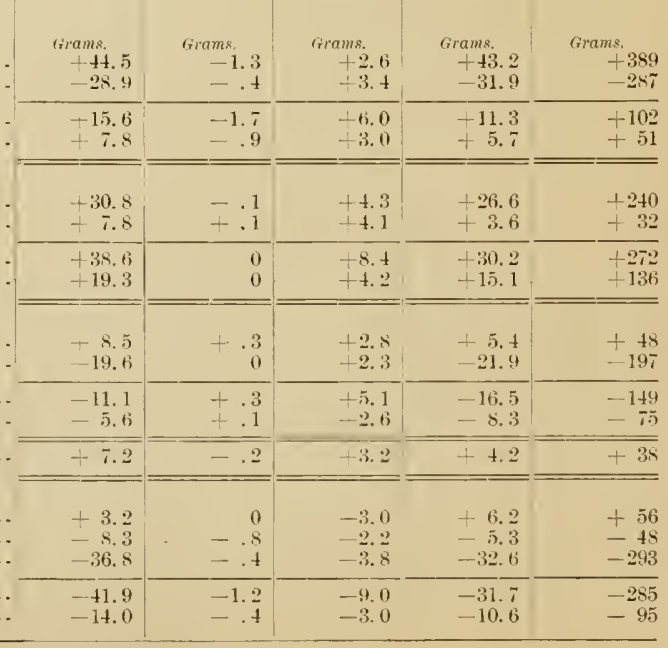


TABLE XLV1.-Income and outgo of energy-Metabolism experiments Nos. 18-20."

\begin{tabular}{|c|c|c|c|c|c|c|c|c|c|c|}
\hline Date and period. & 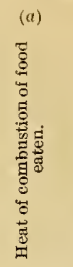 & 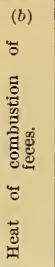 & 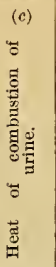 & 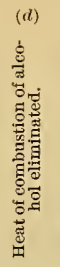 & 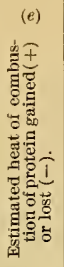 & 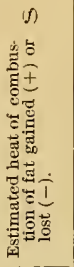 & 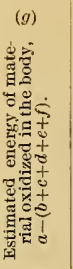 & 这 & 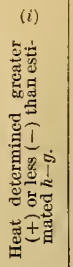 & 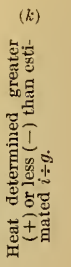 \\
\hline $\begin{array}{c}1899 . \\
\text { Experiment No. } 18 . \\
\text { Feb. } 6-7,7 \text { a. m. to } 7 \text { a. m.... } \\
7-8,7 \text { a. m. to } 7 \text { a. m... }\end{array}$ & $\begin{array}{c}\text { Calo- } \\
\text { rics. } \\
2,776 \\
2,776\end{array}$ & $\begin{array}{c}\text { Calo- } \\
\text { ries. } \\
100 \\
100\end{array}$ & $\begin{array}{c}\text { Calo- } \\
\text { ries. } \\
130 \\
115\end{array}$ & $\begin{array}{r}\text { Calo- } \\
\text { ries. } \\
23 \\
20\end{array}$ & $\begin{array}{c}\text { Caio- } \\
\text { ries. } \\
-104 \\
-36\end{array}$ & $\begin{array}{l}\text { Calo- } \\
\text { ries. } \\
+203 \\
+268\end{array}$ & $\begin{array}{l}\text { Calo- } \\
\text { ries. } \\
2,424 \\
2,309\end{array}$ & $\begin{array}{c}\text { Calo- } \\
\text { riess } \\
2,578 \\
2,397\end{array}$ & $\begin{array}{c}\text { Calo- } \\
\text { ries. } \\
+154 \\
+88\end{array}$ & $\begin{array}{c}\text { Per } \\
\text { cent. } \\
+6.4 \\
+3.8\end{array}$ \\
\hline $\begin{array}{l}\text { Total for } 2 \text { days....... } \\
\text { Average per day ...... }\end{array}$ & $\begin{array}{l}5,552 \\
2,776\end{array}$ & $\begin{array}{l}200 \\
100\end{array}$ & $\begin{array}{l}245 \\
123\end{array}$ & $\begin{array}{l}43 \\
21\end{array}$ & $\begin{array}{r}-140 \\
-70\end{array}$ & $\begin{array}{r}+471 \\
+235\end{array}$ & $\begin{array}{l}4,733 \\
2,367\end{array}$ & $\begin{array}{l}4,975 \\
2,488\end{array}$ & $\begin{array}{l}+242 \\
+121\end{array}$ & +5.1 \\
\hline $\begin{array}{l}\text { Experiment No. } 19 . \\
\text { Feb. } 8-9,7 \text { a. m. to } 7 \text { a. m... } \\
9-10,7 \text { a. m. to } 7 \text { a. m.. }\end{array}$ & $\begin{array}{l}2,776 \\
2,776\end{array}$ & $\begin{array}{l}100 \\
100\end{array}$ & $\begin{array}{l}110 \\
106\end{array}$ & $\begin{array}{l}19 \\
17\end{array}$ & $\begin{array}{l}7 \\
+\quad 7 \\
\end{array}$ & $\begin{array}{l}+341 \\
+319\end{array}$ & $\begin{array}{l}2,213 \\
2,227\end{array}$ & $\begin{array}{l}2,281 \\
2,277\end{array}$ & $\begin{array}{l}+68 \\
+50\end{array}$ & $\begin{array}{l}+3.1 \\
+2.2 \\
\end{array}$ \\
\hline $\begin{array}{l}\text { Total for } 2 \text { days. } \\
\text { Average per day...... }\end{array}$ & $\begin{array}{l}5,552 \\
2,776\end{array}$ & $\begin{array}{l}200 \\
100\end{array}$ & $\begin{array}{l}216 \\
108\end{array}$ & $\begin{array}{l}36 \\
18\end{array}$ & $\begin{array}{l}0 \\
0\end{array}$ & $\begin{array}{l}+660 \\
+330\end{array}$ & $\begin{array}{l}4,440 \\
2,220\end{array}$ & $\begin{array}{l}4,558 \\
2,279\end{array}$ & $\begin{array}{l}+118 \\
+59\end{array}$ & +2.7 \\
\hline $\begin{array}{l}\text { Experiment No. } 20 . \\
\text { Feb. } 10-11,7 \text { a. m. to } 7 \text { a. } \mathrm{m} . \ldots \ldots \ldots \\
11-12,7 \text { a. m. to } 7 \text { a. } \mathrm{m} . \ldots . . .\end{array}$ & $\begin{array}{l}2,776 \\
2,776\end{array}$ & $\begin{array}{l}100 \\
100\end{array}$ & $\begin{array}{l}104 \\
108\end{array}$ & $\begin{array}{l}18 \\
23\end{array}$ & $\begin{array}{r}25 \\
0 \\
\end{array}$ & $\begin{array}{l}+215 \\
+181\end{array}$ & $\begin{array}{l}2,314 \\
2,364\end{array}$ & $\begin{array}{l}2,298 \\
2,308\end{array}$ & $\begin{array}{l}-16 \\
-56\end{array}$ & $\begin{array}{l}-.7 \\
-2.4\end{array}$ \\
\hline $\begin{array}{l}\text { Total for } 2 \text { days } \\
\text { Average per day } \ldots \ldots\end{array}$ & $\begin{array}{l}5,552 \\
2,776\end{array}$ & $\begin{array}{l}200 \\
100\end{array}$ & $\begin{array}{l}212 \\
106\end{array}$ & $\begin{array}{l}41 \\
21\end{array}$ & $\begin{array}{l}+25 \\
+12\end{array}$ & $\begin{array}{l}+396 \\
+198\end{array}$ & $\begin{array}{l}4,678 \\
2,339\end{array}$ & $\begin{array}{l}4,606 \\
2,303\end{array}$ & $\begin{array}{l}-72 \\
-36\end{array}$ & -1.5 \\
\hline $\begin{array}{r}\text { Average per day (experiments } \\
18-20)\end{array}$ & 2,776 & 100 & 112 & 20 & -19 & +255 & 2,308 & 2,356 & +48 & +2.1 \\
\hline $\begin{array}{l}\text { Experiment No. } 21 . \\
\text { Feb. } 12-13,7 \text { a. m. to } 7 \text { a. } \mathrm{m} \ldots \ldots \ldots \\
13-14,7 \text { a. m. to } 7 \text { a. } \mathrm{m} . \ldots \ldots \\
14-15,7 \text { a. m. to } 7 \text { a. } \mathrm{m} . \ldots\end{array}$ & $\begin{array}{l}2,264 \\
2,264 \\
2,264\end{array}$ & $\begin{array}{l}100 \\
100 \\
100\end{array}$ & $\begin{array}{l}119 \\
132 \\
127\end{array}$ & $\cdots$ & $\begin{array}{r}0 \\
-\quad 65 \\
-32\end{array}$ & $\begin{array}{l}-236 \\
-168 \\
-297\end{array}$ & $\begin{array}{l}2,281 \\
2,265 \\
2,366\end{array}$ & $\begin{array}{l}2,226 \\
2,263 \\
2,348\end{array}$ & $\begin{array}{r}-55 \\
-\quad 2 \\
-18\end{array}$ & $\begin{array}{r}-2.4 \\
-. .1 \\
-.7\end{array}$ \\
\hline $\begin{array}{l}\text { Total for } 3 \text { days } \\
\text { Average per day }\end{array}$ & $\begin{array}{l}6,792 \\
2,264\end{array}$ & $\begin{array}{l}300 \\
100\end{array}$ & $\begin{array}{l}378 \\
126\end{array}$ & & $\begin{array}{l}-97 \\
-32\end{array}$ & $\begin{array}{l}-701 \\
-234\end{array}$ & $\begin{array}{l}6,912 \\
2,304\end{array}$ & $\begin{array}{l}6,837 \\
2,279\end{array}$ & $\begin{array}{l}-75 \\
-25\end{array}$ & -1.1 \\
\hline
\end{tabular}

${ }^{\mathrm{n}}$ No. 21 included for comparison.

EXPERIMENTS NOS. 22-2t-REST. NO. 22 WITH ALCOHOL DIET.

Sulject.-E. O., who served as the subjeet of experiments Nos. 12, 15-17, and 18-20, described above. His weight was about 72.5 kilograms (160 pounds).

Occupation during experiment.-Reading, writing, etc., with as little mental and muscular activity as possible.

Durution.-The preliminary period of 4 days hegan with breakfast, March 9, 1899, and the sulject entered the respiration chamber on the evening of Mareh 12; experinent No. 22 beginning at 7 'clock on the morning of March 13 and continuing 3 days. This experiment was the first of a series of three (Nos. 22-24), each continuing 3 days; the subjeet, therefore, remained in the respiration chamber 10 nights and 9 days, the series of experiments ending on the morning of Mareh 22.

Diet.-One especial object of the experiments of this series was to study the relative replacing power of aleohol and sugar in the diet. The litter consisted of what mily be called a basal ration of ordinary food to which was added a supplementary ration of either sugar or alcohol. 


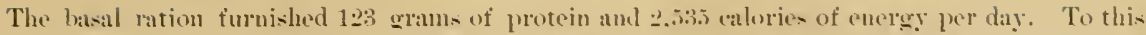

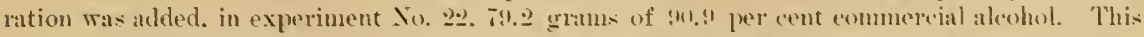

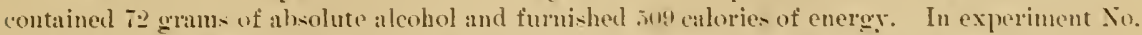
23 the suhject had 30 grams of horse-ladish, furnishing 11 alories of energy per day. and in experiment $\mathrm{No}, 24.30$ grams of bormeradi-h, furnishing 11 calories of energy, and 130 grams of

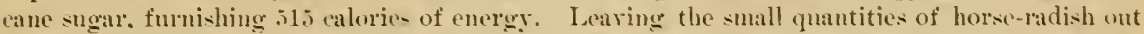
of account, the eliet of experiment 2.2 supplied the basal ration plus aleohol. Xo. 2.3 the hasal ration alone. and $\mathrm{So}_{0} . \pm t$ the basil ration plus an amount of sugar isodynamic with the aleohol of No. 2.2. In experinent No. 2.22 the alcohol was taken in the usual if doses. 3 with and 3 hetween meals and upon retiring. It was prepared hy adding 79.2 grams of 40.9 per cent alcohol to 780.8 grams of cotfee infusion sweetened with $f_{11}$ grams of sugur. This mixture thus contained iD grams of absolute alcohol. to grams of sugar. and iss grams of water. The kinds and quantities of food served at each meal and the guantities of drink at different periods were as follows:

Diet in metalustisme experiments Ius. 23-34.

FOOD-B.ASAL R.ATIOX.

\begin{tabular}{|c|c|c|c|c|}
\hline & Breakfast. & Dinner. & supper. & Total. \\
\hline Beef. & Grams. & Grams. & Grams. & Grams. \\
\hline 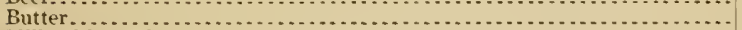 & 15 & 20 & 20 & 55 \\
\hline 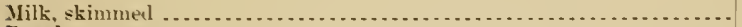 & 350 & 390 & 390 & 1,130 \\
\hline 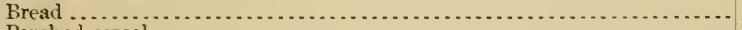 & $5 \overline{5}$ & 100 & 155 & 310 \\
\hline 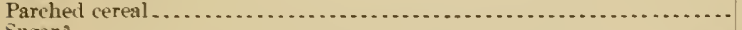 & 45 & (n............. &... & 45 \\
\hline 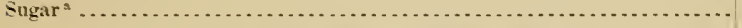 & 40 & & & 40 \\
\hline
\end{tabular}

" Lsed with the coffee infusion aml aleohol in experimem 50.22.

FOOD-SLPPLEMEXTAL RATIOX.

Last day of preliminary perionl and during metabolism experiment Xo. 20.2:

Coffee infusion . . . . . . . . . . . . .

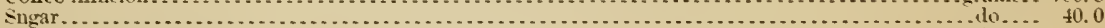

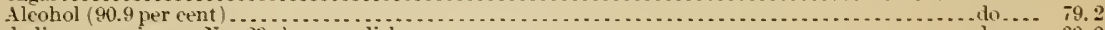

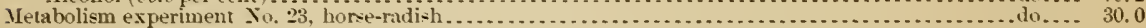

Metabolism experiment No. 2t:

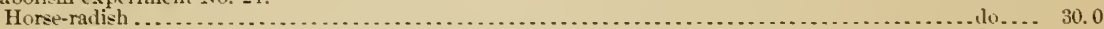

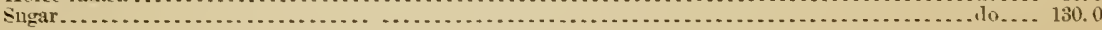

IR1Xk.

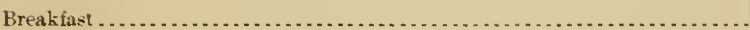

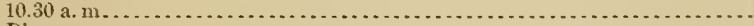

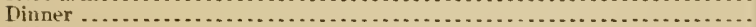

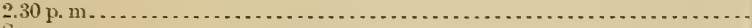

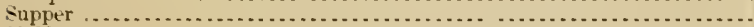

11.00 p. m.

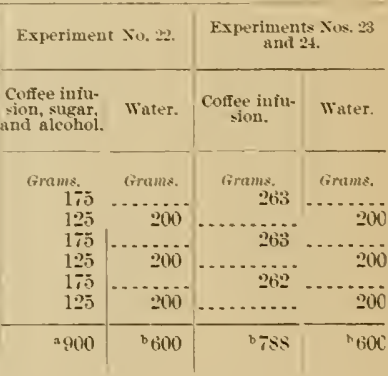

a Contains 72 grams absolute alcohol and to grams sugar.

The subject did not always lrink the full sehedule allowance of coffee and of water. The actual amount of water consumed each day is shown in the second column of Table LYIII. 
Daily routine.-The general routine of the experiment is indicated by the following schednle:

Duily progrum-.Metabolism coperiments Wos. 22-24. 7.00 a. m ...... Rise, pass urine, weigh self, weigh

7. 45 a. m ...... Breakfast.

10.30 a. m...... Urink 200 grams water.

$1.00 \mathrm{p} . \mathrm{m}$........ Pass urine.

1.30 p. m...... Dinner.
3.30 p. m . . . . D . Drink 200 grams water.

6.30 p. $\mathrm{m}$...... Supper.

7.00 p. m...... Pass nrine.

$11.00 \mathrm{P} . \mathrm{m}$.... D Drink 200 grams water, take cap off food aperture, retire.

Table XLVII summarizes the more important statistics in the diary kept by the subject during the series of experiments.

TABLE XLVII.-Summary of Ainry-Wetabolism experiments _Tos. 23-24.

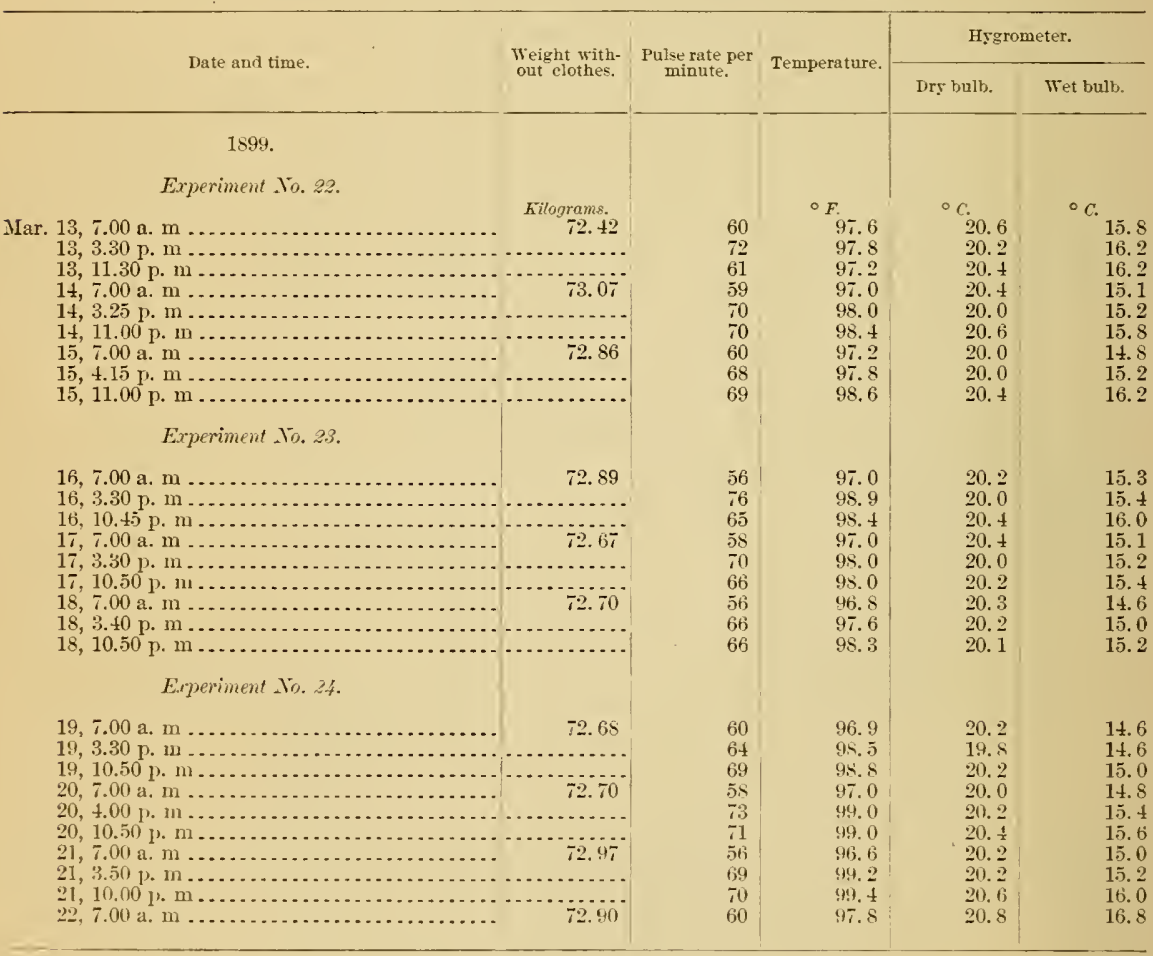


Detailed stutisties of incme and outyo. - The quantitie- of nutrients in the lawal ration and the quantities in the supplemental ration in the different experiments of this series are shown in Table XLVIII. No attempt wa made in this experiment to obtain a siparation of the feces between experiments 22 and 23 . since it was beliered the amount of such excretion during the alcohol experiment wonld not differ materially from the amount in the following experiment in which alcohol was not used but in which the diet was otherwise the same, with the exception of the small amount of horse-radish. It is our experience that too frequent separation of the feces renders the line of demareation less aecurate. The separation of the feces was, howerer. made between experiments 23 and 24 . The data of amount and composition of the fecer of the two experiments are given in Table XLIX.

TaBle XLV11I.- Weight, composition, and heat of rombustion of foods-Metabolism experiments Nos. 22-24.

\begin{tabular}{|c|c|c|c|c|c|c|c|c|c|c|}
\hline $\begin{array}{c}\text { Labora- } \\
\text { tory } \\
\text { So. }\end{array}$ & Food material. & $\begin{array}{l}\text { Weight } \\
\text { per day. }\end{array}$ & Water. & Protein. & Fat. & $\begin{array}{l}\text { Carbohy- } \\
\text { drates. }\end{array}$ & Nitrogen. & Carbon. & $\begin{array}{c}\text { Hydro- } \\
\text { gen, }\end{array}$ & $\begin{array}{c}\text { Heat of } \\
\text { combus- } \\
\text { tion. }\end{array}$ \\
\hline $\begin{array}{l}3027 \\
3029 \\
3031 \\
3032 \\
3004\end{array}$ & 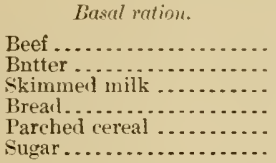 & $\begin{array}{r}\text { Grams. } \\
150 \\
55 \\
1,130 \\
310 \\
45 \\
40\end{array}$ & $\begin{array}{r}\text { Grams. } \\
84.9 \\
5.2 \\
1,025.0 \\
125.2 \\
2.7\end{array}$ & $\begin{array}{r}\text { Grams. } \\
52.3 \\
.6 \\
40.7 \\
24.5 \\
5.1 \\
\end{array}$ & $\begin{array}{r}\text { Grams. } \\
9.2 \\
47.7 \\
1.1 \\
10.5 \\
.3 \\
-. . .\end{array}$ & $\begin{array}{r}\text { Grams. } \\
70.2 . \\
54.2 \\
36.2 \\
40.0\end{array}$ & $\begin{array}{r}\text { Grams. } \\
8.38 \\
.09 \\
6.55 \\
3.94 \\
.82 \\
.6 .\end{array}$ & $\begin{array}{l}\text { Grams. } \\
35.35 \\
38.03 \\
46.44 \\
86.95 \\
18.63 \\
16.84\end{array}$ & $\begin{array}{l}\text { Grams } \\
5.05 \\
5.79 \\
6.67 \\
12.34 \\
2.78 \\
2.59\end{array}$ & $\begin{array}{r}\text { Calorieg. } \\
395 \\
+11 \\
+62 \\
896 \\
183 \\
158\end{array}$ \\
\hline & & $\ldots$ & $1,243.0$ & 123.2 & 68.8 & 276.1 & 19. 78 & 242.24 & 35. 22 & 2,535 \\
\hline & $\begin{array}{l}\text { Sipplemental ration. } \\
\text { ExPERIMENT No. } 22 . \\
\text { Alcohol................. }\end{array}$ & 72 & & & & & & 37.56 & 9.39 & 509 \\
\hline & Total ration per day. & ..... & $1,243.0$ & 123.2 & 68.8 & 276.1 & 19.78 & 279.80 & 44.61 & 3,044 \\
\hline \multirow[t]{2}{*}{3069} & 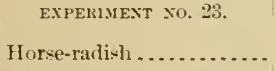 & 30 & 26.8 & .4 & . & 2.5 & .06 & 2. 70 & .18 & 11 \\
\hline & Total ration per day - & ...... & $1,269.8$ & 123.6 & 68.8 & 278.6 & 19.84 & 244.94 & 35.40 & 2,546 \\
\hline \multirow[t]{2}{*}{3069} & $\begin{array}{l}\text { Horse-radish } \ldots \ldots \ldots \ldots . \\
\text { Rock candy . . . . . . . . . }\end{array}$ & $\begin{array}{r}30 \\
130\end{array}$ & $\begin{array}{l}26.8 \\
\ldots \ldots\end{array}$ & .4 & & $\begin{array}{r}2.5 \\
130.0\end{array}$ & $\begin{array}{c}.06 \\
. . .\end{array}$ & $\begin{array}{r}2.70 \\
54.72\end{array}$ & $\begin{array}{r}.18 \\
8.42\end{array}$ & 511 \\
\hline & Total ration per lay. & $\ldots$ & $1,269.8$ & 123.6 & 68.8 & 408.6 & 19.84 & 299.66 & 43.82 & 3.061 \\
\hline
\end{tabular}

TABLE NLIX.-Weight, romposition, and heat of combustion of feces-Metabolism erperiments .1os. 2.2-24.

\begin{tabular}{|c|c|c|c|c|c|c|c|c|c|c|}
\hline $\begin{array}{l}\text { Labora- } \\
\text { tors } \\
\text { So. }\end{array}$ & & Weight. & Water. & Protein. & Fat. & $\begin{array}{l}\text { Carbohy- } \\
\text { drates:- }\end{array}$ & Sitrugen. & Carbon. & $\begin{array}{c}\text { Hydro- } \\
\text { gen. }\end{array}$ & $\begin{array}{c}\text { Heat of } \\
\text { combusus- } \\
\text { tion. }\end{array}$ \\
\hline $\begin{array}{l}3035 \\
3036\end{array}$ & $\begin{array}{l}\text { Total, experiments } 22 \text { to } 23 . \\
\text { Average per day . } \\
\text { Total, experiment } 24 . . . . \\
\text { Average per day........ }\end{array}$ & $\begin{array}{r}\text { Grams. } \\
425.7 \\
70.9 \\
270.0 \\
90.0\end{array}$ & $\begin{array}{r}\text { Grams. } \\
29 \overline{5} .0 \\
49.2 \\
204.4 \\
68.1\end{array}$ & $\begin{array}{r}\text { Grams. } \\
+2.1 \\
7.0 \\
24.5 \\
8.2\end{array}$ & \begin{tabular}{l} 
Grame. \\
20.1 \\
\hdashline .7 \\
13.2 \\
4.4
\end{tabular} & $\begin{array}{r}\text { Grams. } \\
36.2 \\
6.0 \\
14.6 \\
4.9\end{array}$ & $\begin{array}{r}\text { Grams } \\
6.71 \\
1.13 \\
3.91 \\
1.30\end{array}$ & $\begin{array}{l}\text { Grams. } \\
61 .+7 \\
10.25 \\
31.43 \\
10.48\end{array}$ & $\begin{array}{l}\text { Grams: } \\
8.81 \\
1.47 \\
4.46 \\
1.49\end{array}$ & $\begin{array}{r}\text { Culorits. } \\
6 s .5 \\
114 \\
347 \\
i 16\end{array}$ \\
\hline
\end{tabular}


The following table gives the data for the amount and composition of the urine. In prerions experiments the urine was collected in 6-hour interrals throughout the day. Inasmuch. however, as the subject at times found it difficult to get to sleep again after emptying the bladder at 1 o'clock in the morning, the urine was collected at 11 p. m.. immediately before retiring. instead of $1 \mathrm{a} . \mathrm{m}$., as in the previous experiment. The day is thus subdivided into two periods of 6 hour's, one of $t$, and one of 8 hour's.

During the first 3 days of the preliminary digestion period, the subject eliminated 17.3, 11.8, and 14.6 grams, respectively, of nitrogen in the urine. During these days alcohol did not form a part of the diet. On the third day of the preliminary period, which was the first day upon which alcohol was added to the diet, the elimination of nitrogen in the urine amounted to 13.7 grams. It will be noticed that after the subject entered the apparatus the amount of nitrogen in the urine was larger in amount, but remained quite uniform throughout the whole series of experiments. As has preriously been remarked, it is not infrequently the case that an increased elimination of nitrogeu takes place when the subject enters the respiration chamber. This may account for the increase in the present case. Another explanation of the increase would be to assume that it was caused by the presence of alcohol in the diet. It is noticeable, however, that it did not take place until the subject entered the calorimeter, a day after alcohol was added to the diet, and that it continued throughout the 9 days of the sojourn in the respiration chamber, during but 3 of which alcohol was a part of the diet. The urine was not collected after the close of the experiments.

TABLE L.-Amount, specific gravity, and nitrogen of urine, by 6-hour periods-Melabolism experiments Nos. 22-24.

\begin{tabular}{|c|c|c|c|c|c|}
\hline Date. & Period. & Amount. & $\begin{array}{l}\text { Specific } \\
\text { gravity. }\end{array}$ & \multicolumn{2}{|c|}{ Xitrogen. } \\
\hline \multirow[t]{2}{*}{$\begin{array}{c}1899 . \\
\text { Mar. } 13-14 . .\end{array}$} & 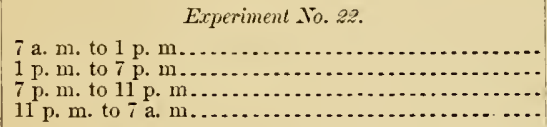 & $\begin{array}{l}\text { Grame. } \\
356.6 \\
377.6 \\
268.5 \\
356.7\end{array}$ & $\begin{array}{l}1.022 \\
1.024 \\
1.021 \\
1.018\end{array}$ & $\begin{array}{l}\text { Per cent. } \\
1.27 \\
1.38 \\
1.51 \\
1.36\end{array}$ & $\begin{array}{r}\text { Grams. } \\
4.53 \\
5.21 \\
4.05 \\
4.85\end{array}$ \\
\hline & $\begin{array}{l}\text { Total } \ldots \ldots \ldots \\
\text { Total by composite } \ldots\end{array}$ & $1,359.4$ & 1.019 & 1.40 & $\begin{array}{l}\text { 18. } 64 \\
19.04\end{array}$ \\
\hline \multirow[t]{2}{*}{$1+-15 \ldots \ldots$} & 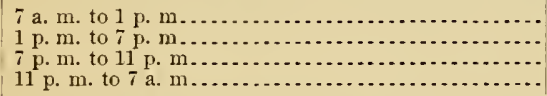 & $\begin{array}{l}671.6 \\
776.8 \\
617.5 \\
310.8\end{array}$ & $\begin{array}{l}1.009 \\
1.007 \\
1.007 \\
1018\end{array}$ & $\begin{array}{r}.62 \\
.52 \\
.99 \\
1.45\end{array}$ & $\begin{array}{l}4.16 \\
4.04 \\
6.11 \\
4.51\end{array}$ \\
\hline & $\begin{array}{l}\text { Total } \ldots \ldots \ldots \ldots \\
\text { Total by composite } \ldots \ldots\end{array}$ & $2,376.7$ & 1.011 & .80 & $\begin{array}{l}18.82 \\
19.01\end{array}$ \\
\hline \multirow[t]{2}{*}{$15-16 \ldots \ldots$} & 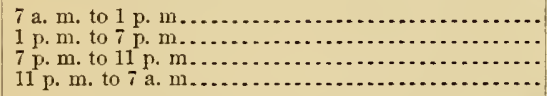 & $\begin{array}{l}514.9 \\
629.9 \\
493.2 \\
633.5\end{array}$ & $\begin{array}{l}1.009 \\
1.007 \\
1.018 \\
1.012\end{array}$ & $\begin{array}{r}.68 \\
.48 \\
.96 \\
1.04\end{array}$ & $\begin{array}{l}3.50 \\
3.02 \\
4.73 \\
6.59\end{array}$ \\
\hline & $\begin{array}{l}\text { Total } \ldots \ldots \ldots \ldots \\
\text { Total by composite } . \ldots .\end{array}$ & $2,271.5$ & 1.012 & .80 & $\begin{array}{l}17.84 \\
18.17\end{array}$ \\
\hline $\begin{array}{l}16-17 \ldots \ldots \\
17-18 \ldots \ldots \\
18-19 \ldots \ldots\end{array}$ & 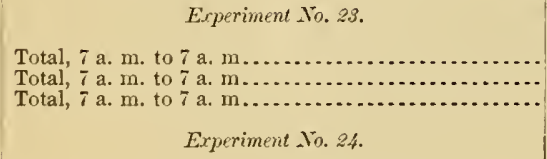 & $\begin{array}{l}2,299.1 \\
2,280.0 \\
1,996.2\end{array}$ & $\begin{array}{l}1.012 \\
1.013\end{array}$ & & $\begin{array}{l}18.80 \\
19.61 \\
18.47\end{array}$ \\
\hline $\begin{array}{l}19-20 \ldots \\
20-21 \ldots \\
21-22 \ldots\end{array}$ & 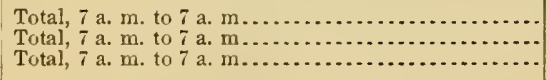 & $\begin{array}{l}2,225.5 \\
1,870.9 \\
1,861.5\end{array}$ & $\begin{array}{l}1.014 \\
1.013 \\
1.014\end{array}$ & & $\begin{array}{l}19.45 \\
18.07 \\
17.26\end{array}$ \\
\hline
\end{tabular}


TABLE LI.-Daily elimination of carbon, hydrogen, water, and encrgy in urine-Metabolism experiments Nos. 22-24.

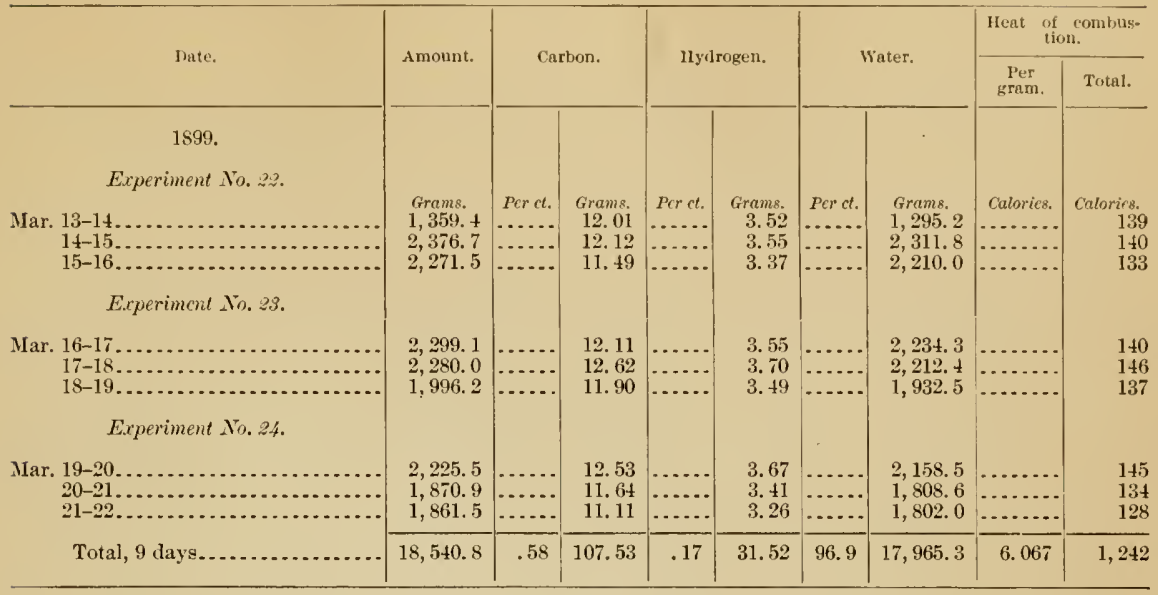

The results of the determinations of carbon dioxid and water in the ventilating air current are given in Tables LII-LIV. These statistics are given in detail for the first 3 days of the series and are summarized by days for the following 6 days, in order to serve as a basis of comparison of the results with and without alcohol as a part of the diet.

TABLE LII.-Comparison of residual umounts of carbon dioxid and water in the chamber at the beginning and end of each period, and the corresponding gain or loss-Metabolism experiment No. $_{22}$.

\begin{tabular}{|c|c|c|c|c|c|c|}
\hline \multirow[b]{2}{*}{ Date. } & \multirow[b]{2}{*}{ End of period. } & \multicolumn{2}{|c|}{ Carbon dioxid. } & \multicolumn{3}{|c|}{ Water. } \\
\hline & & $\begin{array}{l}\text { Total amount } \\
\text { in chamber. }\end{array}$ & $\begin{array}{l}\text { Gain }(t+) \text { or } \\
\text { loss }(-) \text { over } \\
\text { preceding pe- } \\
\text { riod. }\end{array}$ & $\begin{array}{l}\text { Total amonnt } \\
\text { of vapor re- } \\
\text { maining in } \\
\text { ebamber. }\end{array}$ & $\begin{array}{l}\text { Gain }(+) \text { or } \\
\text { loss }(-) \text { over } \\
\text { preceding pe- } \\
\text { riod. }\end{array}$ & $\begin{array}{l}\text { Total amonnt } \\
\text { gained }(+) \text { or } \\
\text { lost }(-\rightarrow \text { during } \\
\text { the period. }\end{array}$ \\
\hline $\begin{array}{r}1899 . \\
\text { Mar. } 13\end{array}$ & 7 a. $\mathrm{m}$. & $\begin{array}{l}\text { Grams. } \\
28.6\end{array}$ & $\begin{array}{l}\text { Grams. } \\
\text {. }\end{array}$ & $\begin{array}{l}\text { Grams. } \\
38.6\end{array}$ & $\begin{array}{l}\text { Grams. } \\
\text {....... }\end{array}$ & $\begin{array}{l}\text { Grams. } \\
\end{array}$ \\
\hline \multirow[t]{2}{*}{$13-14$} & 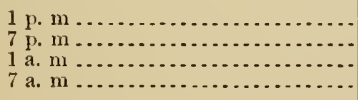 & $\begin{array}{l}36.4 \\
37.7 \\
27.1 \\
26.2\end{array}$ & $\begin{array}{r}+7.8 \\
+\quad 1.3 \\
-10.6 \\
-\quad .9\end{array}$ & $\begin{array}{l}47.4 \\
47.0 \\
45.7 \\
42.4\end{array}$ & $\begin{array}{l}+8.8 \\
-.4 \\
-1.3 \\
-3.3\end{array}$ & $\begin{array}{l}+8.8 \\
-.4 \\
-i .3 \\
-3.3\end{array}$ \\
\hline & Total & ............. & -2.4 & …... & +3.8 & +3.8 \\
\hline \multirow[t]{2}{*}{$14-15$} & 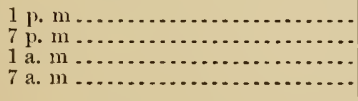 & $\begin{array}{l}39.3 \\
37.6 \\
28.7 \\
24.6\end{array}$ & $\begin{array}{l}+13.1 \\
-1.7 \\
-8.9 \\
-4.1 \\
\end{array}$ & $\begin{array}{l}41.9 \\
40.6 \\
42.5 \\
36.0 \\
\end{array}$ & $\begin{array}{l}-.5 \\
-1.3 \\
+1.9 \\
-6.5\end{array}$ & $\begin{array}{r}-.5 \\
-1.3 \\
+1.9 \\
-6.5 \\
\end{array}$ \\
\hline & Total ..... & ......... & -1.6 & ....... & -6.4 & -6.4 \\
\hline \multirow[t]{2}{*}{$15-16$} & 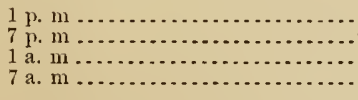 & $\begin{array}{l}36.8 \\
41.9 \\
30.2 \\
24.5\end{array}$ & $\begin{array}{r}+12.2 \\
+5.1 \\
-11.7 \\
-5.7\end{array}$ & $\begin{array}{l}38.6 \\
+1.5 \\
42.3 \\
35.2 \\
\end{array}$ & $\begin{array}{r}+2.6 \\
+2.9 \\
+\quad .8 \\
-7.1\end{array}$ & $\begin{array}{r}+2.6 \\
+2.9 \\
+.8 \\
-7.1 \\
\end{array}$ \\
\hline & Total & ... &.$- \mathrm{I}$ & & -.8 & -.8 \\
\hline
\end{tabular}

${ }^{\mathrm{B}}$ In these experiments there was no change in weight of absorbers and there was no drip. 

MEMOIRS OF THE NATIONAL ACADEMY OF SCIEACES.

TABLE LII1. - Pecond of curlon dioxid in ventilating air crirent-Metabolism experiments Tos. 22-234.

1899.

Iar. $13-14$

$14-15$

7 a. m. to 1 p. m...........

i p. m. to 1 a. m..............

l a. m. to $i$ a. m...........

$$
\text { Total. }
$$

15-16 $7 \mathrm{a}, \mathrm{m}$, to 1 p. $\mathrm{m}$

1 p. m. to $T$ p. m...........

7 p. m. to 1 a. $m . . . . . . . .$.

1 a. 1 . to t a. m..........

Total

Experiment To. 23.

$16-17$

$18-19$

i a. m. to $\tau$ a. m...........

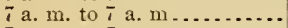

T a. m. to $T$ a. m..........

Experiment No. 24.

$19-20$

20-?1

$21-22$ t a. 'm. to $t$ a. $m$...........

7 a. m. to 7 a. $m$..........

i a. m. to $\vec{i}$ a. m ...........

\begin{tabular}{|c|c|c|c|c|c|c|c|}
\hline \multirow{3}{*}{$\begin{array}{l}\text { Ventilation. } \\
\text { Xumber of } \\
\text { liters of air. }\end{array}$} & \multicolumn{6}{|c|}{ Carbon dioxid. } & \multirow{3}{*}{$\begin{array}{c}(h) \\
\\
\text { Total } \\
\text { weight of } \\
\text { carbon } \\
\text { exhaled } \\
g \times y_{11}^{3} \text {. }\end{array}$} \\
\hline & \multicolumn{2}{|c|}{ In incoming air. } & \multirow{2}{*}{$\begin{array}{l}\text { (d) } \\
\text { In witgo- } \\
\text { ing air. }\end{array}$} & \multirow{2}{*}{$\begin{array}{c}(e) \\
\text { Total } \\
\text { excessin } \\
\text { outgoing } \\
\text { air } d-c .\end{array}$} & \multirow{2}{*}{$\begin{array}{c}(f) \\
\text { Corlec- } \\
\text { tion for } \\
\text { amonnt } \\
\text { remain- } \\
\text { ing in } \\
\text { chamber. }\end{array}$} & \multirow{2}{*}{$\begin{array}{l}\text { (g) } \\
\text { Corrected } \\
\text { amonnt } \\
\text { exhaled } \\
\text { by subject } \\
e+f .\end{array}$} & \\
\hline & $\begin{array}{c}\text { (b) } \\
\text { Per liter. }\end{array}$ & $\begin{array}{c}(c) \\
\text { Total } \\
a \times b .\end{array}$ & & & & & \\
\hline $\begin{array}{l}\text { Liters. } \\
26,085 \\
26,212 \\
27,942 \\
27,945\end{array}$ & $\begin{array}{r}.1 g . \\
0.610 \\
.587 \\
.574 \\
.591\end{array}$ & $\begin{array}{r}\text { Grams. } \\
15.9 \\
15.4 \\
16.0 \\
16.5\end{array}$ & $\begin{array}{l}\text { Grams. } \\
241.5 \\
226.0 \\
209.3 \\
156.7\end{array}$ & $\begin{array}{l}\text { Grams. } \\
225.6 \\
210.6 \\
193.3 \\
1+0.2\end{array}$ & $\begin{array}{r}\text { Grams. } \\
+\quad 7.8 \\
+\quad 1.3 \\
-10.6 \\
-\quad .9\end{array}$ & $\begin{array}{l}\text { Grams. } \\
233.4 \\
211.9 \\
182.7 \\
139.3\end{array}$ & $\begin{array}{r}\text { Grams. } \\
63.6 \\
5 \% .8 \\
49.8 \\
38.0\end{array}$ \\
\hline $108,18 t$ & ...... & 63.8 & 833.5 & 769.7 & -2.4 & 767.3 & 209.2 \\
\hline $\begin{array}{l}26,606 \\
27,595 \\
27,873 \\
27,604\end{array}$ & $\begin{array}{l}.588 \\
.569 \\
.563 \\
.57\end{array}$ & $\begin{array}{l}15.6 \\
15.7 \\
15.7 \\
15.9\end{array}$ & $\begin{array}{l}228.6 \\
221.4 \\
212.8 \\
149.5\end{array}$ & $\begin{array}{l}213.0 \\
205.7 \\
197.1 \\
133.6\end{array}$ & $\begin{array}{l}+13.1 \\
-1.7 \\
-8.9 \\
-4.1\end{array}$ & $\begin{array}{l}226.1 \\
204.0 \\
188.2 \\
129.5\end{array}$ & $\begin{array}{l}61.7 \\
55.6 \\
51.3 \\
35.3\end{array}$ \\
\hline 109,675 & - & 62.9 & $\mathrm{~S} 12.3$ & 749.4 & -1.6 & $74 \pi .8$ & 203.9 \\
\hline $\begin{array}{l}26,590 \\
26,841 \\
28,013 \\
29,057\end{array}$ & $\begin{array}{l}.564 \\
.576 \\
.582 \\
.576\end{array}$ & $\begin{array}{l}15.0 \\
15.5 \\
16.3 \\
16.7\end{array}$ & $\begin{array}{l}219.5 \\
230.1 \\
229.2 \\
156.3\end{array}$ & $\begin{array}{l}204.5 \\
214.6 \\
212.9 \\
139.6\end{array}$ & $\begin{array}{r}+12.2 \\
+5.1 \\
-11.7 \\
-5.7\end{array}$ & $\begin{array}{l}216.7 \\
219.7 \\
201 . \frac{7}{9} \\
133.9\end{array}$ & $\begin{array}{l}59.1 \\
59.9 \\
54.9 \\
36.5\end{array}$ \\
\hline 110,501 & & 63.5 & 835.1 & $\pi 1.6$ & -.1 & $\pi 1.5$ & 210.4 \\
\hline $\begin{array}{l}106,553 \\
110,227 \\
107,982\end{array}$ & & $\begin{array}{l}6 S .6 \\
63.3 \\
61.3\end{array}$ & $\begin{array}{l}865.4 \\
846.9 \\
860.3\end{array}$ & $\begin{array}{r}796.8 \\
783.6 \\
799.0\end{array}$ & $\begin{array}{r}\frac{1}{1} \\
-\quad .2 \\
+1.4\end{array}$ & $\begin{array}{l}797.5 \\
783.4 \\
800.4\end{array}$ & $\begin{array}{l}217.5 \\
213.6 \\
218.2\end{array}$ \\
\hline $\begin{array}{l}110,6 \pm 1 \\
108,528 \\
107,299\end{array}$ & & $\begin{array}{l}67.2 \\
61.9 \\
6 \% 2.5\end{array}$ & $\begin{array}{l}887.2 \\
904.8 \\
935.7\end{array}$ & $\begin{array}{l}820.0 \\
842.9 \\
873.2\end{array}$ & $\begin{array}{r}+1.4 \\
-3 . \frac{1}{1} \\
+6.3\end{array}$ & $\begin{array}{l}821.4 \\
839.2 \\
879.5\end{array}$ & $\begin{array}{l}224.0 \\
228.8 \\
239.8\end{array}$ \\
\hline
\end{tabular}


TABLE LIV.-Record of ureter in rentiluting wir current-Whabolism fxperiments. Nus. 2.2-24.

\begin{tabular}{|c|c|c|c|c|c|c|c|c|c|c|}
\hline \multirow[b]{2}{*}{ Date. } & \multirow[b]{2}{*}{ Period. } & \multirow[b]{2}{*}{$\begin{array}{l}\text { Ventila- } \\
\text { tion. Num- } \\
\text { ber of liters } \\
\text { of air. }\end{array}$} & \multicolumn{2}{|c|}{$\begin{array}{l}\text { Waterin intom- } \\
\text { ing air. }\end{array}$} & \multicolumn{3}{|c|}{ Water in outgring air. } & \multirow[b]{2}{*}{$\begin{array}{c}\text { Total ex- } \\
\text { cess water } \\
\text { in outgo- } \\
\text { jng air } \\
f-c \text {. }\end{array}$} & \multirow[b]{2}{*}{$\begin{array}{l}\text { Corree- } \\
\text { tion for } \\
\text { water re- } \\
\text { maining } \\
\text { in eham } \\
\text { ber. }\end{array}$} & \multirow{2}{*}{$\begin{array}{l}\text { (i) } \\
\text { Tota] } \\
\text { waterol } \\
\text { respira- } \\
\text { tion and } \\
\text { perspira- } \\
\text { tion } \\
g+h \text {. }\end{array}$} \\
\hline & & & $\begin{array}{c}\text { (b) } \\
\text { Per } \\
\text { liter. }\end{array}$ & $\begin{array}{l}\text { Total } \\
a \times b\end{array}$ & $\begin{array}{c}(r) \\
\text { Imonnt } \\
\text { etml- } \\
\text { densed in } \\
\text { freezers. }\end{array}$ & $\begin{array}{c}(c) \\
\text { Amount } \\
\text { not cons- } \\
\text { densed in } \\
\text { freezers. }\end{array}$ & $\begin{array}{l}(f) \\
\text { Total } \\
d+e\end{array}$ & & & \\
\hline \multirow[t]{2}{*}{$\begin{array}{l}\text { 1s9y. } \\
\text { Mar. } 13-14\end{array}$} & \multirow{2}{*}{ 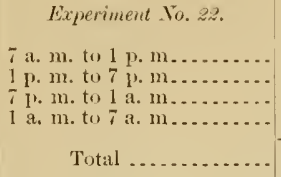 } & $\begin{array}{l}\text { Liters. } \\
26,085 \\
26,212 \\
27,942 \\
27,945\end{array}$ & $\begin{array}{l}1 y_{6 j} \\
.1416 \\
882 \\
.827 \\
.782\end{array}$ & $\begin{array}{l}\text { Grrms. } \\
24.7 \\
23.1 \\
23.1 \\
21.9\end{array}$ & $\begin{array}{l}\text { frrams. } \\
207.2 \\
325.3 \\
235,6 \\
237.1\end{array}$ & $\begin{array}{l}\text { Gams. } \\
45.7 \\
40.0 \\
43.7 \\
39.0\end{array}$ & $\begin{array}{l}\text { frums. } \\
252.4 \\
26.5 .3 \\
279.3 \\
276.1\end{array}$ & $\begin{array}{l}\text { firtms. } \\
225.2 \\
242.2 \\
256.2 \\
254.2\end{array}$ & $\begin{array}{l}\text { Grams. } \\
+8.8 \\
-\quad .4 \\
-1.3 \\
-3.3\end{array}$ & $\begin{array}{l}\text { Grums. } \\
237.0 \\
241.8 \\
254.9 \\
250.9\end{array}$ \\
\hline & & 108, Ist & $\ldots$. & 92.8 & 905.2 & $168 . t$ & $1,0 \div 3.6$ & 980.8 & +3.8 & 984. \\
\hline \multirow[t]{2}{*}{$14-15$} & \multirow{2}{*}{ 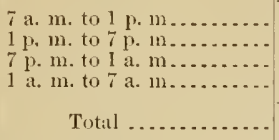 } & $\begin{array}{l}26,606 \\
27,595 \\
27,873 \\
27,604\end{array}$ & $\begin{array}{l}.78 \frac{1}{2} \\
.766 \\
.745 \\
.773\end{array}$ & $\begin{array}{l}20.8 \\
21.2 \\
20.8 \\
21.3\end{array}$ & $\begin{array}{l}203.0 \\
197.9 \\
203.9 \\
194.0\end{array}$ & $\begin{array}{l}40.1 \\
37.4 \\
39.9 \\
36.4\end{array}$ & $\begin{array}{l}243.1 \\
235.3 \\
243.8 \\
230.4\end{array}$ & $\begin{array}{l}22.2 .3 \\
214.1 \\
223.0 \\
209.1\end{array}$ & $\begin{array}{l}-0.5 \\
-1.3 \\
+1.9 \\
-6.5\end{array}$ & $\begin{array}{l}221.8 \\
212.8 \\
224.9 \\
202.6\end{array}$ \\
\hline & & 109,678 & $\cdots$ & S4. 1 & 798.8 & 153.8 & 952.13 & 868.5 & -6.4 & 862. \\
\hline \multirow[t]{2}{*}{$15-16$} & \multirow{4}{*}{ 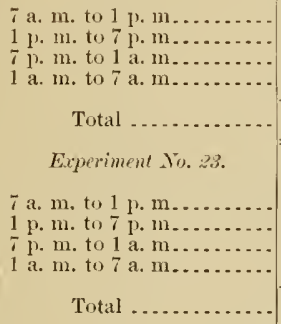 } & $\begin{array}{l}26,590 \\
26,8+1 \\
28,013 \\
29,057\end{array}$ & $\begin{array}{l}.803 \\
.789 \\
.889 \\
.820\end{array}$ & $\begin{array}{l}21.4 \\
21.2 \\
22.1 \\
23.8\end{array}$ & $\begin{array}{l}179.1 \\
192.3 \\
218.5 \\
202.1\end{array}$ & $\begin{array}{l}39.3 \\
36.0 \\
42.2 \\
38.6\end{array}$ & $\begin{array}{l}218.4 \\
228.3 \\
260.7 \\
240.7\end{array}$ & $\begin{array}{l}197.0 \\
207.1 \\
238.6 \\
216.9\end{array}$ & $\begin{array}{r}+2.6 \\
+2.9 \\
+\quad .8 \\
-7.1\end{array}$ & $\begin{array}{l}194.6 \\
210.0 \\
234.4 \\
209.8\end{array}$ \\
\hline & & 110,501 & & 88.5 & 792.0 & 156.1 & 948.1 & 859.6 & -.8 & 85 \\
\hline \multirow[t]{2}{*}{$16-17$} & & $\begin{array}{l}24,857 \\
26,329 \\
27,749 \\
27,618\end{array}$ & $\begin{array}{l}.830 \\
.787 \\
.719 \\
.730\end{array}$ & $\begin{array}{l}20.6 \\
20.7 \\
20.0 \\
20.2\end{array}$ & $\begin{array}{l}180.1 \\
193.5 \\
2332.4 \\
208.4\end{array}$ & $\begin{array}{l}35.5 \\
35.5 \\
12.3 \\
35.6\end{array}$ & $\begin{array}{l}215.6 \\
229.0 \\
274.7 \\
244.0\end{array}$ & $\begin{array}{l}195.0 \\
208.3 \\
254.7 \\
223.8\end{array}$ & $\begin{array}{r}+5.3 \\
+\quad 2.7 \\
+\quad 2.4 \\
-\quad 7.9\end{array}$ & $\begin{array}{l}200.3 \\
211.0 \\
257.1 \\
215.9\end{array}$ \\
\hline & & 106,553 & $\ldots \ldots$ & 81.5 & 814.7 & 148.9 & 963.3 & 881.8 & +2.5 & 88 \\
\hline $17-18$ & \multirow{3}{*}{$\begin{array}{l}7 \text { a. m. to } 7 \text { a. m......... } \\
7 \text { a. m. to } 7 \text { a. m........ } \\
\quad \text { Experiment No. } 24 . \\
7 \text { a. m. to } 7 \text { a. m......... }=\end{array}$} & 110,227 & & 79.3 & 762.1 & 151.9 & 914.0 & 834.7 & -4.2 & 830.5 \\
\hline $18-19$ & & 107,982 & ...... & 83.3 & $7 \overline{70.5}$ & 148.8 & 889.3 & 806.0 & $\overline{+1.0}$ & 807.0 \\
\hline $19-20$ & & $110,6+1$ & & 85.5 & 808.2 & 152.3 & 960.5 & 875.0 & +4.4 & 879.4 \\
\hline $20-21$ & 7 a. m. to 7 a. $m \ldots$ & 108,528 & $\cdots$ & 77.2 & $\overline{814.9}$ & 143.5 & 958.4 & 881.2 & -2.2 & $8 \% 9.0$ \\
\hline \multirow[t]{2}{*}{$21-2 \cdot 2$} & \multirow{2}{*}{$\begin{array}{l}7 \text { a. m. to } 7 \text { a. m.......... } \\
\text { Total for } 9 \text { days.... }\end{array}$} & 107,299 & $\ldots$ & 76.5 & 886.5 & 142.2 & $1,028.7$ & 952.2 & +10.1 & 962.3 \\
\hline & & 979,593 & . . . . . & 748.7 & $7,32 \cdot 6$ & $1,36.5 .9$ & $8,688.5$ & $7,939.8$ & +8.2 & $7,948.0$ \\
\hline
\end{tabular}


The summary of the calorimetric measurements during this series of experiments is shown in Table LV. The results of experiments Nos. 23 and 24 are summarized by days, and those for experiment No. 22, in which alcohol formed a part of the diet, are summarized by 6 -hour periods.

TABLE LT.-Summary of calorimetric measurements-Metabolism experiments Nos. 22-24.

\begin{tabular}{|c|c|c|c|c|c|c|c|c|}
\hline Date. & Period. & $\begin{array}{c}\text { (a) } \\
\text { Heat } \\
\text { measured } \\
\text { in terms } \\
\text { of } \mathrm{C}_{2 n} \text {. }\end{array}$ & $\begin{array}{c}(b) \\
\text { Change } \\
\text { of tem- } \\
\text { perature } \\
\text { of ealo- } \\
\text { rimeter. }\end{array}$ & $\begin{array}{c}(c) \\
\\
\text { Capacity } \\
\text { correction } \\
\text { of ealo- } \\
\text { rimeter } \\
b \times 60 .\end{array}$ & $\begin{array}{c}(d) \\
\text { Correction } \\
\text { due to } \\
\text { tempera- } \\
\text { ture of } \\
\text { food and } \\
\text { dishes. }\end{array}$ & $\begin{array}{c}(\epsilon) \\
\text { Water vapor- } \\
\text { ized equals } \\
\text { total } \\
\text { amount } \\
\text { exhaled less } \\
\text { amount } \\
\text { condensed } \\
\text { in eham- } \\
\text { ber. }\end{array}$ & 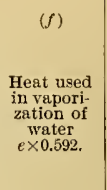 & $\begin{array}{l}(g) \\
\begin{array}{l}\text { Total heat } \\
\text { deter- } \\
\text { mined } \\
(a+c+d \\
+f) .\end{array}\end{array}$ \\
\hline \multirow[t]{2}{*}{$\begin{array}{c}1899 . \\
\text { Mar. } 13-14\end{array}$} & 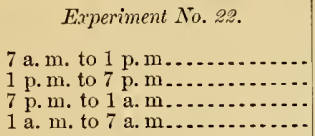 & \begin{tabular}{|c|} 
Calories. \\
547.4 \\
486.1 \\
+13.4 \\
280.6
\end{tabular} & \begin{tabular}{l} 
Degrees. \\
\hdashline-0.03 \\
+.02 \\
+.07
\end{tabular} & $\begin{array}{l}\text { Calories. } \\
+1.80 \\
+1.20 \\
+\quad 4.20\end{array}$ & $\begin{array}{c}\text { Calories. } \\
-1.1 \\
+3.2 \\
\end{array}$ & $\begin{array}{c}\text { Grams. } \\
237.0 \\
241.8 \\
254.9 \\
250.9\end{array}$ & $\begin{array}{r}\text { Calories. } \\
140.3 \\
143.2 \\
150.9 \\
148.5\end{array}$ & $\begin{array}{r}\text { Calories. } \\
686.6 \\
630.7 \\
565.5 \\
433.3\end{array}$ \\
\hline & Total. & $1,727.5$ & +.06 & +3.60 & +2.1 & 984.6 & 582.9 & $2,316.1$ \\
\hline \multirow[t]{2}{*}{ 14-15 } & $\begin{array}{l}7 \text { a.m. to } 1 \text { p. m.. } \\
1 \text { p.m. to } 7 \text { p. m.. } \\
7 \text { p.m. to } 1 \text { a. m.. } \\
1 \text { a.m. to } 7 \text { a. m.. }\end{array}$ & $\begin{array}{l}504.1 \\
488.7 \\
427.7 \\
267.7\end{array}$ & $\begin{array}{r}-.06 \\
-.03 \\
+.01 \\
+.04\end{array}$ & $\begin{array}{r}-3.60 \\
-\quad 1.80 \\
+\quad .60 \\
+\quad 2.40\end{array}$ & $\begin{array}{r}0.6 \\
+4.5 \\
\\
\end{array}$ & $\begin{array}{l}221.8 \\
212.8 \\
224.9 \\
202.6\end{array}$ & $\begin{array}{l}131.3 \\
126.0 \\
133.1 \\
120.0\end{array}$ & $\begin{array}{l}631.2 \\
617.4 \\
561.4 \\
390.1\end{array}$ \\
\hline & Total... & $1,688.2$ & -.04 & -2.40 & +3.9 & 862.1 & 510.4 & $2,200.1$ \\
\hline \multirow[t]{3}{*}{$15-16$} & $\begin{array}{l}7 \text { a.m. to } 1 \text { p. } m . . \\
1 \text { p. m. to } 7 \text { p. m.. } \\
7 \text { p.m. to } 1 \text { a. } m . . \\
1 \text { a.m. to } 7 \text { a. m.. }\end{array}$ & $\begin{array}{l}475.2 \\
518.3 \\
454.3 \\
310.8\end{array}$ & $\begin{array}{l}+.03 \\
-.05 \\
-.01 \\
-.015\end{array}$ & $\begin{array}{l}+1.80 \\
-3.00 \\
-\quad .60 \\
-9.00\end{array}$ & $\begin{array}{r}-1.8 \\
+5.4 \\
\ldots . . . \\
\end{array}$ & $\begin{array}{l}199.6 \\
210.0 \\
239.4 \\
209.8\end{array}$ & $\begin{array}{l}118.2 \\
124.3 \\
141.7 \\
124.2\end{array}$ & $\begin{array}{l}593.4 \\
645.0 \\
595.4 \\
426.0\end{array}$ \\
\hline & Total. & $1,758.6$ & -.18 & -10.80 & +3.6 & 858.8 & 508.4 & $2,259.8$ \\
\hline & $\begin{array}{l}\text { Experiment No.23. } \\
7 \text { a.m. to } 7 \text { a.m......... }\end{array}$ & $1,711.0$ & +.14 & +8.40 & -41.4 & 884.3 & 523.5 & $2,201.5$ \\
\hline $17-18$ & 7 a.m. to 7 a.m. & $1,700.3$ & +.01 & +.60 & -47.3 & 830.5 & 491.6 & $2,145.2$ \\
\hline $18-19$ & 7 a.m. to 7 a.m......... & $1,750: 4$ & -.06 & -3.60 & -44.1 & 807.0 & 477.8 & $2,180.5$ \\
\hline $19-20$ & $\begin{array}{l}\text { Experiment No. } 24 . \\
7 \text { a.m. to } 7 \text { a. } \mathrm{m} \text {......... }\end{array}$ & $1,737.8$ & +.09 & +5.40 & -48.4 & 879.4 & 520.6 & $2,215.4$ \\
\hline $20-21$ & 7 a.m. to 7 a. m.. & $1,752.7$ & -.07 & -4.20 & -46.1 & 879.0 & 520.3 & $2,222.7$ \\
\hline $21-22$ & $\tau$ a.m. to $\tau$ a.m... & $1,851.5$ & +.04 & +2.40 & -44.6 & $\overline{962.3}$ & 569.7 & $2,379.0$ \\
\hline
\end{tabular}

The determinations of alcohol in urine and freezer water, and of reducing material reckoned as alcohol in the ventilating air eurrent, were made in the usual manuer. The results are shown in Table LVI. It will be noticed that there was a considerable anount of reducing material in the air and urine on diys in which aleohol did not form a part of the diet, equivalent on an arerage to 0.37 of a gram of aleohol per day. It is of course possible that this reducing material may have been alcohol that had been retained in the system and was slowly eliminated. This, however, seems improbable, especially in view of the fact that the results are no larger than hare been found in later experiment s in the ventilating air current when alcohol had not formed a part of the diet for it long period. To be strictly atcurate, the total amounts of alcohol excreted on the different days of experiment No. 22 should be reduced by a certain amount representing the arerage excretion of reducing material not aleohol. lnasmuch, however, as this was a matter still under investigation no such correction was made in this experiment, and the results were computed on the supposition that all the reducing material in the air current was alcohol, although from later investigations it seems rquite certain that this is wrong. The error, however, would probably not exceed 0.3 or 0.4 of a gram of alcohol, corresponding to 2 or 3 calories of energy per day. 
TABLE LYI.-Alcohol ingested und exerefer-Metabolism experiment 1o. 22.

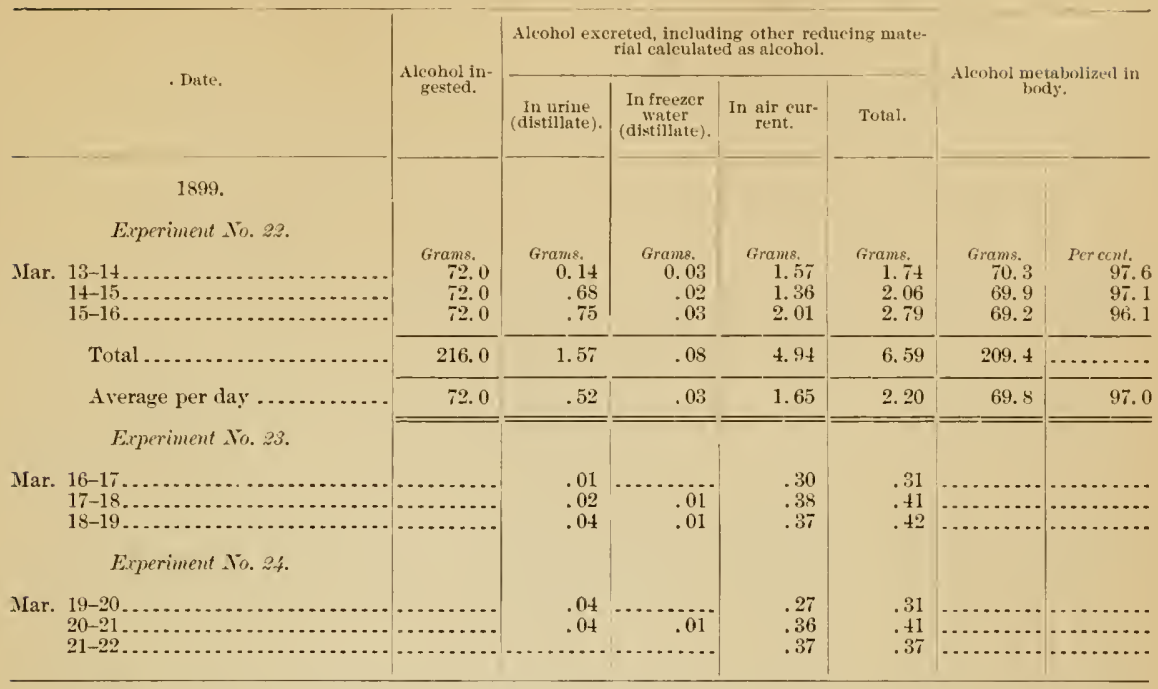

Balence of income and outgo of matter and energy.-The usual summary of the income and outgo of nitrogen, carbon, hydrogen, and energy may he found in Table LVII.

TabLe LV11.-Income and outgo of nitrogen and carlon-Metabolism experiments. Yos. 22-24.

\begin{tabular}{|c|c|c|c|c|c|c|c|c|c|c|}
\hline \multirow[b]{2}{*}{ Date and period. } & \multicolumn{4}{|c|}{ Nitrogen. } & \multicolumn{6}{|c|}{ Carbon. } \\
\hline & $\begin{array}{c}\text { (a) } \\
\underset{\text { In }}{\text { In }} \\
\text { food. }\end{array}$ & $\begin{array}{c}\text { (b) } \\
\text { In } \\
\text { feces. }\end{array}$ & $\mid \begin{array}{c}(c) \\
\text { In } \\
\text { urine. }\end{array}$ & $\begin{array}{c}(d) \\
\text { Gain }(+) \\
\text { or } \operatorname{loss}^{(-)} a- \\
(b+c)\end{array}$ & $\begin{array}{c}(e) \\
\text { In food. }\end{array}$ & $\begin{array}{c}(f) \\
\text { In } \\
\text { feces. }\end{array}$ & $\begin{array}{c}(g) \\
\text { In } \\
\text { urine. }\end{array}$ & $\begin{array}{c}(h) \\
\begin{array}{l}\text { In respir- } \\
\text { atory } \\
\text { products. }\end{array}\end{array}$ & $\begin{array}{l}\text { (i) } \\
\text { In al- } \\
\text { cohol } \\
\text { elimi- } \\
\text { nated. }\end{array}$ & $\begin{array}{c}(k) \\
\text { Gain }(+) \\
\text { or loss } \\
(-) \in- \\
(f+q+h \\
+i) .\end{array}$ \\
\hline $\begin{array}{c}1899 . \\
\text { Experiment No. } 22 . \\
\text { Mlar. } 13-14, \bar{i} \text { a.m. to } 7 \text { a.m..... } \\
14-15,7 \text { a.m. to } 7 \text { a. m.... } \\
15-16,7 \text { a.m. to } 7 \text { a.m.... }\end{array}$ & \begin{tabular}{|l|} 
Grams. \\
19.8 \\
19.8 \\
19.8
\end{tabular} & $\begin{array}{r}\text { Grams. } \\
1.1 \\
1.2 \\
1.1\end{array}$ & $\mid \begin{array}{l}\text { Groms. } \\
18.7 \\
18.8 \\
17.8\end{array}$ & $\begin{array}{c}\text { Grams. } \\
-\ldots .2 \\
+\quad .9\end{array}$ & $\begin{array}{l}\text { Grams. } \\
279.8 \\
279.8 \\
279.8\end{array}$ & \begin{tabular}{|l|} 
Grams. \\
10.3 \\
10.2 \\
10.3
\end{tabular} & $\begin{array}{l}\text { Grams. } \\
12.0 \\
12.1 \\
11.5\end{array}$ & \begin{tabular}{c|} 
Grams. \\
209.2 \\
203.9 \\
210.4
\end{tabular} & \begin{tabular}{r|} 
Grams. \\
0.9 \\
1.1 \\
1.5
\end{tabular} & $\begin{array}{l}\text { Grams. } \\
+47.4 \\
+52.5 \\
+\quad+6.1\end{array}$ \\
\hline $\begin{array}{l}\text { Total for } 3 \text { day's } . . . . \\
\text { Average per day ..... }\end{array}$ & $\begin{array}{l}59.4 \\
19.8 \\
\end{array}$ & $\begin{array}{l}3.4 \\
1.1\end{array}$ & $\begin{array}{l}55.3 \\
18.5 \\
\end{array}$ & $\begin{array}{r}+.7 \\
+.2 \\
\end{array}$ & $\begin{array}{l}839.4 \\
579.8 \\
\end{array}$ & $\begin{array}{l}30.8 \\
10.3 \\
\end{array}$ & $\begin{array}{l}35.6 \\
11.8 \\
\end{array}$ & $\begin{array}{l}623.5 \\
207.8 \\
\end{array}$ & $\begin{array}{l}3.5 \\
1.2 \\
\end{array}$ & $\begin{array}{r}+146.0 \\
+\quad 45.7 \\
\end{array}$ \\
\hline $\begin{array}{l}\text { Experiment No. } 23 . \\
\text { Mar. } 16-1 \tau, 7 \text { a.m. to } 7 \text { a. m..... } \\
17-18,7 \text { a. m. to } 7 \text { a. m..... } \\
18-19,7 \text { a. m. to } 7 \text { a.m.... }\end{array}$ & $\begin{array}{l}19.8 \\
19.9 \\
19.8\end{array}$ & $\begin{array}{l}1.1 \\
1.2 \\
1.1\end{array}$ & $\begin{array}{l}18.8 \\
19.6 \\
18.5\end{array}$ & $\begin{array}{l}-.1 \\
-.9 \\
+.2\end{array}$ & $\begin{array}{l}2+4.9 \\
245.0 \\
244.9\end{array}$ & $\begin{array}{l}10.2 \\
10.3 \\
10.2\end{array}$ & $\begin{array}{l}12.1 \\
12.6 \\
11.9\end{array}$ & $\begin{array}{l}217.5 \\
213.6 \\
218.2\end{array}$ & ……. & $\begin{array}{r}+\quad 5.1 \\
+\quad 8.5 \\
+\quad 4.6\end{array}$ \\
\hline $\begin{array}{l}\text { Total for } 3 \text { days ...... } \\
\text { Average per ilay ...... }\end{array}$ & $\begin{array}{l}59.5 \\
19.8 \\
\end{array}$ & $\begin{array}{l}3.4 \\
1.1\end{array}$ & $\begin{array}{l}56.9 \\
19.0 \\
\end{array}$ & $\begin{array}{l}-.8 \\
-.3 \\
\end{array}$ & $\begin{array}{l}734.8 \\
244.9 \\
\end{array}$ & $\begin{array}{l}30.7 \\
10.2\end{array}$ & \begin{tabular}{|l|}
36.6 \\
12.2 \\
\end{tabular} & $\begin{array}{l}6+9.3 \\
216.4 \\
\end{array}$ & & $\begin{array}{r}+18.2 \\
+\quad 6.1 \\
\end{array}$ \\
\hline $\begin{array}{l}\text { Experiment No. } 24 . \\
\text { Mlar. } 19-20,7 \text { a. m. to } 7 \text { a.m.. } \\
20-21,7 \text { a. m. to } 7 \text { a.m.. } \\
21-22,7 \text { a. m. to } 7 \text { a. m.. }\end{array}$ & $\begin{array}{l}19.8 \\
19.9 \\
19.8\end{array}$ & $\begin{array}{l}1.3 \\
1.3 \\
1.3\end{array}$ & $\begin{array}{l}19.4 \\
18.1 \\
17.3\end{array}$ & $\begin{array}{l}-.9 \\
+.5 \\
+1.2\end{array}$ & $\begin{array}{l}299.7 \\
294.6 \\
299.7\end{array}$ & $\begin{array}{l}10.5 \\
10.5 \\
10.5\end{array}$ & $\begin{array}{l}12.5 \\
11.7 \\
11.1\end{array}$ & $\begin{array}{l}224.0 \\
228.8 \\
239.8\end{array}$ & & $\begin{array}{r}+52.7 \\
+48.6 \\
+38.3\end{array}$ \\
\hline $\begin{array}{l}\text { Total for } 3 \text { days ... } \\
\text { Average per dlay ... }\end{array}$ & $\begin{array}{l}59.5 \\
19.8\end{array}$ & $\begin{array}{l}3.9 \\
1.3\end{array}$ & $\begin{array}{l}54.8 \\
18.2\end{array}$ & $\begin{array}{l}+.8 \\
+.3\end{array}$ & $\begin{array}{l}899.0 \\
299.7\end{array}$ & $\begin{array}{l}31.5 \\
10.5\end{array}$ & $\begin{array}{l}35.3 \\
11.8\end{array}$ & $\begin{array}{l}692.6 \\
230.9\end{array}$ & & $\begin{array}{l}+139.6 \\
+\quad 46.5\end{array}$ \\
\hline
\end{tabular}


TaBle LVIII.-Income uml untyo of water und hydrogen-Wetrbolism experiments . Tos. 2:-24.

\begin{tabular}{|c|c|c|c|c|c|c|}
\hline \multirow[b]{2}{*}{ Date and periot. } & \multicolumn{6}{|c|}{ Water. } \\
\hline & $\begin{array}{c}(a) \\
\text { In food. }\end{array}$ & $\begin{array}{c}\text { (b) } \\
\text { In drink. }\end{array}$ & In feces. & $\begin{array}{c}\text { (d) } \\
\text { In urine. }\end{array}$ & $\begin{array}{l}(e) \\
\text { In respir- } \\
\text { atory prod- } \\
\text { uets. }\end{array}$ & $\begin{array}{l}(f) \\
\text { Apparent } \\
\text { loss } \\
a+b- \\
(c+d+e)\end{array}$ \\
\hline 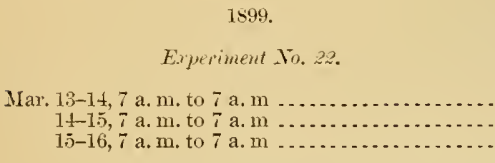 & $\begin{array}{c}\text { Grams. } \\
1,243.0 \\
1,243.0 \\
1,243.0\end{array}$ & $\begin{array}{l}\text { Grains. } \\
1,387.8 \\
1,388.0 \\
1,387.7\end{array}$ & $\begin{array}{r}\text { Grams. } \\
49.2 \\
49.2 \\
49.2\end{array}$ & $\begin{array}{c}\text { Grams. } \\
1,295.2 \\
2,311.8 \\
2,210.0\end{array}$ & $\begin{array}{l}\text { Grams. } \\
984.6 \\
862.1 \\
858.8\end{array}$ & $\begin{array}{r}\text { Grams. } \\
+\quad 301.8 \\
-\quad 592.1 \\
-\quad 487.3\end{array}$ \\
\hline $\begin{array}{l}\text { Total for } 3 \text { days } \ldots \ldots \ldots \\
\text { Arerage per day } \ldots \ldots\end{array}$ & $\begin{array}{l}3,729.0 \\
1,243.0\end{array}$ & $\begin{array}{l}4,163.5 \\
1,387.8\end{array}$ & $\begin{array}{r}1+7.6 \\
49.2 \\
\end{array}$ & $\begin{array}{l}5,817.0 \\
1,939.0\end{array}$ & $\begin{array}{r}2,705.5 \\
901.8 \\
\end{array}$ & $\begin{array}{r}-777.6 \\
-\quad 259.2 \\
\end{array}$ \\
\hline 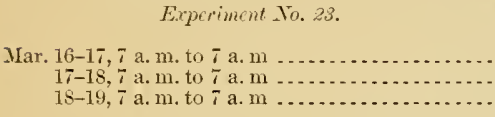 & $\begin{array}{l}1,269.8 \\
1,269.8 \\
1,269.8\end{array}$ & $\begin{array}{l}1,362.8 \\
1,379.2 \\
1,378.0\end{array}$ & $\begin{array}{l}49.2 \\
49.2 \\
49.2\end{array}$ & $\begin{array}{l}2,234.3 \\
2,212.4 \\
1,932.5\end{array}$ & $\begin{array}{l}884.3 \\
830.5 \\
807.0\end{array}$ & $\begin{array}{l}535.2 \\
-\quad 443.1 \\
-\quad 140.9\end{array}$ \\
\hline 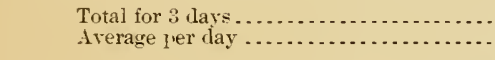 & $\begin{array}{l}3,809.4 \\
1,269.8 \\
\end{array}$ & $\begin{array}{l}4,120.0 \\
1,373.3 \\
\end{array}$ & $\begin{array}{r}147.6 \\
49.2 \\
\end{array}$ & $\begin{array}{l}6,379.2 \\
2,126.4 \\
\end{array}$ & $\begin{array}{r}2,521.8 \\
840.6 \\
\end{array}$ & $\begin{array}{l}-1,119.2 \\
-\quad 373.1 \\
\end{array}$ \\
\hline 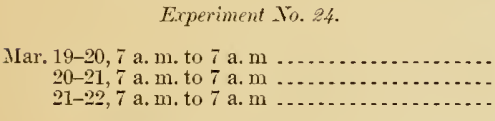 & $\begin{array}{l}1,269.8 \\
1,269.8 \\
1,269.8\end{array}$ & $\begin{array}{l}1,376.0 \\
1,382.4 \\
1,373.4\end{array}$ & $\begin{array}{l}68.1 \\
68.1 \\
68.1 \\
\end{array}$ & $\begin{array}{l}2,158.5 \\
1,808.6 \\
1,802.0\end{array}$ & $\begin{array}{l}879.4 \\
879.0 \\
962.3\end{array}$ & $\begin{array}{r}-\quad 460.2 \\
-\quad 103.5 \\
-\quad 189.2 \\
\end{array}$ \\
\hline $\begin{array}{l}\text { Total for } 3 \text { days } \ldots \ldots \ldots \\
\text { Average per day } \ldots \ldots \ldots\end{array}$ & $\begin{array}{l}3,809.4 \\
1,269.8\end{array}$ & $\begin{array}{l}4,131.8 \\
1,377.3\end{array}$ & $\begin{array}{r}204.3 \\
68.1\end{array}$ & $\begin{array}{l}5,769.1 \\
1,923.0\end{array}$ & $\begin{array}{r}2,720.7 \\
906.9\end{array}$ & $\begin{array}{l}-\quad 752.9 \\
-\quad 250.9\end{array}$ \\
\hline
\end{tabular}

\begin{tabular}{|c|c|c|c|c|c|c|c|}
\hline \multirow[b]{2}{*}{ Date and period. } & \multicolumn{7}{|c|}{ Hydrogen. } \\
\hline & $\begin{array}{c}(g) \\
\text { In food. }\end{array}$ & $\begin{array}{c}(h) \\
\text { In feces. }\end{array}$ & (i) & $\begin{array}{c}(k) \\
\text { In alcohol } \\
\text { elimi- } \\
\text { nated. }\end{array}$ & $\begin{array}{c}(l) \\
\text { Apparent } \\
\text { gain } g- \\
(h+i+k) \text {. }\end{array}$ & $\begin{array}{l}\quad(m) \\
\text { Loss from } \\
\text { water } \\
(f \div 9) \text {. }\end{array}$ & $\begin{array}{c}(n) \\
\text { Total } \\
\text { gain }(+) \\
\text { or loss } \\
(-) l+m .\end{array}$ \\
\hline 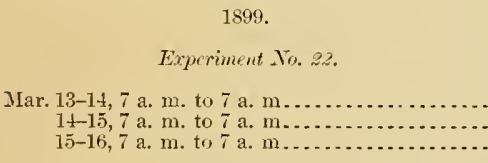 & $\begin{array}{r}\text { Grams. } \\
44.6 \\
44.6 \\
44.6\end{array}$ & $\begin{array}{r}\text { Grams. } \\
1.4 \\
1.5 \\
1.4\end{array}$ & $\begin{array}{r}\text { Grams. } \\
3.5 \\
3.5 \\
3.4\end{array}$ & $\begin{array}{r}\text { Grams. } \\
0.2 \\
.3 \\
.4\end{array}$ & $\begin{array}{l}\text { Grams. } \\
+\quad 39.5 \\
+\quad 39.3 \\
+\quad 39.4\end{array}$ & $\begin{array}{l}\text { Grams. } \\
+\quad 33.5 \\
-\quad 65.8 \\
-\quad 54.1\end{array}$ & $\begin{array}{l}\text { Grams. } \\
+73.0 \\
-26.5 \\
-14.7\end{array}$ \\
\hline $\begin{array}{l}\text { Total for } 3 \text { days } \ldots \ldots \ldots \\
\text { Average per lay } \ldots \ldots \ldots\end{array}$ & $\begin{array}{r}133.8 \\
44.6\end{array}$ & $\begin{array}{l}4.3 \\
1.4\end{array}$ & $\begin{array}{r}10.4 \\
3.5\end{array}$ & .9 & $\begin{array}{r}+118.2 \\
+\quad 39.4\end{array}$ & $\begin{array}{l}-86.4 \\
-28.8\end{array}$ & $\begin{array}{l}+31.8 \\
+10.6\end{array}$ \\
\hline Experiment No. 23. & & & & & & & \\
\hline 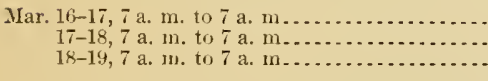 & $\begin{array}{l}35.4 \\
35.4 \\
35.4\end{array}$ & $\begin{array}{l}1.5 \\
1.4 \\
1.5\end{array}$ & $\begin{array}{l}3.5 \\
3.7 \\
3.5\end{array}$ & $\mid$ & $\begin{array}{r}+304 \\
+\quad 30.3 \\
+\quad 30.4\end{array}$ & $\begin{array}{l}-59.5 \\
-\quad 49.2 \\
-\quad 15.7\end{array}$ & $\begin{array}{r}-29.1 \\
-18.9 \\
+14.7\end{array}$ \\
\hline $\begin{array}{l}\text { Total for } 3 \text { days } \ldots \ldots \ldots \ldots \\
\text { Average jer day } \ldots . . .\end{array}$ & $\begin{array}{r}106.2 \\
35.4\end{array}$ & $\begin{array}{l}4.4 \\
1.5\end{array}$ & $\begin{array}{r}10.7 \\
3.5\end{array}$ & (n...... & $\begin{array}{r}+91.1 \\
+\quad 30.4 \\
\end{array}$ & $\begin{array}{l}-124.4 \\
-41.5\end{array}$ & $\begin{array}{l}-33.3 \\
-11.1 \\
\end{array}$ \\
\hline 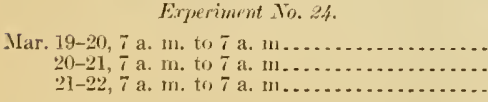 & $\begin{array}{l}43.8 \\
43.8 \\
43.8\end{array}$ & $\begin{array}{l}1.5 \\
1.5 \\
1.5\end{array}$ & $\begin{array}{l}3.7 \\
3.4 \\
3.3\end{array}$ & (n) & $\begin{array}{r}38.6 \\
+\quad 38.9 \\
+\quad 39.0\end{array}$ & $\begin{array}{r}-51.1 \\
-11.5 \\
-21.0\end{array}$ & $\begin{array}{r}-12.5 \\
+27.4 \\
+18.0\end{array}$ \\
\hline 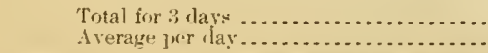 & $\begin{array}{r}131.4 \\
4.3 .8\end{array}$ & $\begin{array}{l}4.5 \\
1.5\end{array}$ & $\begin{array}{r}10.4 \\
3.5\end{array}$ & . & $\begin{array}{r}116.5 \\
+\quad 38.8\end{array}$ & $\begin{array}{r}83.6 \\
-\quad 27.9\end{array}$ & $\begin{array}{r}+32.9 \\
-10.9\end{array}$ \\
\hline
\end{tabular}




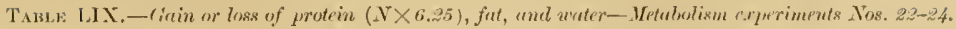

Inte sucl perionl.
1899.
Expreriment Wo. 22.

Mar. 13-14, 7 a. m. to 7 a. m..................

$14-15,7$ a. 11 , to 7 a. $m \ldots \ldots \ldots \ldots \ldots . . . . . .$.

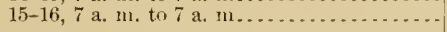

Total for 3 days. . . . . . . . . . . . . . . . . . .

Average per day.

\section{Experimem To. 28.}

Mar. 16-17, 7 a. m. to 7 a. m................. $17-18,7$ a. m. to 7 a. $m \ldots \ldots \ldots \ldots \ldots$ $18-19,7$ a, 3u. to 7 a. $m \ldots \ldots \ldots \ldots \ldots$

Total for: 3 lays.

Average per day.

\section{Experincut No. 24.}

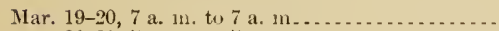

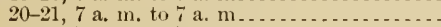

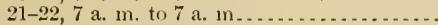

Total for 3 days Average per lay.

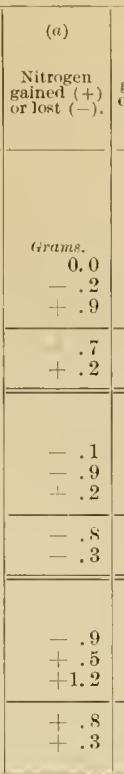

$\overline{\overline{20}}$

Date and period.

1899,

Experiment No. 22.

Mar. $13-14,7$ a.m, to 7 a. $m$

$14-15,7$ a $m$, to 7 a. $m$.

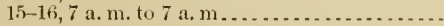

Total for 3 rlays... . . . . . . . . . . . . . . Average jer day

Erperiment Vo. 23.

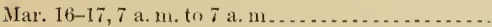
$17-18,7$ a.m. to 7 a. 1 . . . . . . . . . . . . . .

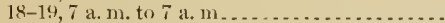

Total for 3 days.

Average per day.

\section{Erperiment 10.24 .}

Mar, $19-20,7$ a. m. to 7 a. $m$ 20-2I, 7 a.m. to 7 a.m $21-22,7$ a. m. to 7 a. $m$

Total for 3 ilays.

Average per lay. (b)

(c)

Protein Total cargained $(+)$ bon gained or lost $(-), \quad(+)$ or los

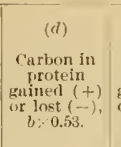

(e)

(e)

farbon in

fat, ete., Fat gained Gatined $(+)(+)$ or lost a.6.25. $(-)$

$b \div 0,5$

or lost $(-)$

$(-), e \div 0.765$.

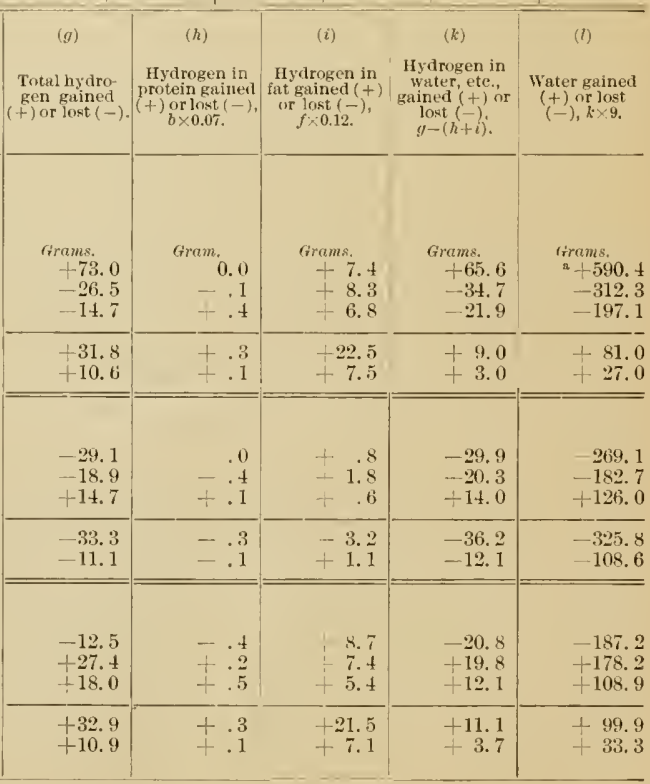

"Compare weight of urine eliminated on this day with that on succeeding days. 
TABLE LX.- Income and outgo of cnergy-Metabolism experiments Nos. 22-24.

\begin{tabular}{|c|c|c|c|c|c|c|c|c|c|c|}
\hline Dute and period. & $\begin{array}{l}(a) \\
\text { Heat of } \\
\text { combus- } \\
\text { tion of } \\
\text { food } \\
\text { eaten. }\end{array}$ & $\begin{array}{l}\text { (b) } \\
\text { Heat of } \\
\text { combus- } \\
\text { tion of } \\
\text { feces. }\end{array}$ & $\begin{array}{c}\text { (c) } \\
\text { Heat of } \\
\text { combus- } \\
\text { tion of } \\
\text { urine. }\end{array}$ & $\begin{array}{l}(d) \\
\text { Heat of } \\
\text { combus- } \\
\text { tion of } \\
\text { alcohol } \\
\text { eliminat- } \\
\text { ed. }\end{array}$ & $\begin{array}{c}(c) \\
\text { Estimated } \\
\text { heat of } \\
\text { conibus- } \\
\text { tion of } \\
\text { protein } \\
\text { gained } \\
(+) \text { or lost } \\
(-)\end{array}$ & $\begin{array}{l}(f) \\
\text { Estimated } \\
\text { hent of } \\
\text { eombus- } \\
\text { tion of fat } \\
\text { gained } \\
(+) \text { or lost } \\
(-)\end{array}$ & $\begin{array}{c}(g) \\
\text { Estimated } \\
\text { energy of } \\
\text { material } \\
\text { oxidized } \\
\text { in the } \\
\text { bodye } a-(b \\
+c+d+c \\
+f)\end{array}$ & $\begin{array}{l}\text { Heat de- } \\
\text { termined. }\end{array}$ & $\begin{array}{c}(i) \\
\text { Heat de- } \\
\text { termined } \\
\text { greater } \\
(+) \text { or less } \\
(-\rightarrow) \text { than } \\
\text { estimated } \\
n-g .\end{array}$ & $\mid \begin{array}{c}(k) \\
\text { Heat de- } \\
\text { termined } \\
\text { greater } \\
(+) \text { or less } \\
(-) \text { than } \\
\text { estimated } \\
i \div 0 .\end{array}$ \\
\hline $\begin{array}{c}1899 . \\
\text { Experiment No. } 22 \text {. } \\
\text { Mar. } 13-14,7 \text { a.m. to } 7 \text { a. m. } \\
14-15,7 \text { a.m. to } 7 \text { a. m. } \\
15-16,7 \text { a.m. to } 7 \text { a. m. }\end{array}$ & $\begin{array}{l}\text { Calories. } \\
3,044 \\
3,044 \\
3,044\end{array}$ & $\begin{array}{r}\text { Calonies. } \\
114 \\
114 \\
114\end{array}$ & $\begin{array}{r}\text { Calories. } \\
139 \\
140 \\
133\end{array}$ & $\begin{array}{r}\text { Calories. } \\
12 \\
14 \\
20\end{array}$ & $\begin{array}{r}\text { Calorics. } \\
0 \\
-8 \\
+32\end{array}$ & $\begin{array}{r}\text { Calonies. } \\
+\quad 583 \\
+\quad 653 \\
+\quad 531\end{array}$ & $\begin{array}{c}\text { Calories. } \\
2,196 \\
2,131 \\
2,214\end{array}$ & $\begin{array}{r}\text { Calorics. } \\
2,316 \\
2,200 \\
2,260\end{array}$ & $\begin{array}{l}\text { Calories. } \\
+120 \\
+69 \\
+\quad 46\end{array}$ & $\begin{array}{l}\text { Per cent. } \\
\quad+5.5 \\
+3.2 \\
+2.1\end{array}$ \\
\hline $\begin{array}{l}\text { Total for } 3 \text { days..... } \\
\text { Average per day.... }\end{array}$ & $\begin{array}{l}9,132 \\
3,044 \\
\end{array}$ & $\begin{array}{l}3 \pm 2 \\
114\end{array}$ & $\begin{array}{l}412 \\
138 \\
\end{array}$ & $\begin{array}{l}46 \\
15 \\
\end{array}$ & $\begin{array}{l}+24 \\
+8 \\
\end{array}$ & $\begin{array}{r}+1,767 \\
+\quad 589 \\
\end{array}$ & $\begin{array}{l}6,541 \\
2,180 \\
\end{array}$ & $\begin{array}{l}6,776 \\
2,258 \\
\end{array}$ & $\begin{array}{r}+235 \\
+78 \\
\end{array}$ & +3.6 \\
\hline $\begin{array}{l}\text { Experiment } \text { To. } 23 . \\
\text { Mar. } 16-17,7 \text { a.m. to } 7 \text { a.m. } \\
17-18,7 \text { a.m. to } 7 \text { a. m. } \\
18-19,7 \text { a.m. to } 7 \text { a.m. }\end{array}$ & $\begin{array}{l}2,546 \\
2,546 \\
2,546\end{array}$ & $\begin{array}{l}114 \\
114 \\
114\end{array}$ & $\begin{array}{l}140 \\
146 \\
137\end{array}$ & & $\begin{array}{r}-4 \\
-32 \\
+\quad 8\end{array}$ & $\begin{array}{rr}+ & 63 \\
+ & 141 \\
+\quad 48\end{array}$ & $\begin{array}{l}2,233 \\
2,177 \\
2,239\end{array}$ & $\begin{array}{l}2,202 \\
2,145 \\
2,181\end{array}$ & $\begin{array}{l}-31 \\
-32 \\
-58 \\
\end{array}$ & $\begin{array}{l}-1.4 \\
-1.5 \\
-2.6 \\
\end{array}$ \\
\hline $\begin{array}{l}\text { Total for } 3 \text { days.... } \\
\text { Average per day.... }\end{array}$ & $\begin{array}{l}7,638 \\
2,546 \\
\end{array}$ & $\begin{array}{l}342 \\
114 \\
\end{array}$ & $\begin{array}{l}423 \\
141 \\
\end{array}$ & (n...... & $\begin{array}{r}-28 \\
-9 \\
\end{array}$ & $\begin{array}{r}+\quad 252 \\
+\quad 84 \\
\end{array}$ & $\begin{array}{l}6,6+9 \\
2,216 \\
\end{array}$ & $\begin{array}{l}6,528 \\
2,176 \\
\end{array}$ & $\begin{array}{r}-121 \\
-40 \\
\end{array}$ & -1.8 \\
\hline $\begin{array}{l}\text { Experiment No. } 24 . \\
\text { Mar. } 19-20,7 \text { a. m. to } 7 \text { a.m. } \\
20-21,7 \text { a. m. to } 7 \text { a.m. } \\
21-22,7 \text { a.m. to } 7 \text { a.m. }\end{array}$ & $\begin{array}{l}3,061 \\
3,061 \\
3,061\end{array}$ & $\begin{array}{l}116 \\
116 \\
116\end{array}$ & $\begin{array}{l}145 \\
134 \\
128\end{array}$ & 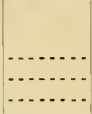 & $\begin{array}{r}-32 \\
+18 \\
+43\end{array}$ & $\begin{array}{r}+\quad 684 \\
+\quad 579 \\
+\quad 421\end{array}$ & $\begin{array}{l}2,148 \\
2,214 \\
2,353\end{array}$ & $\begin{array}{l}2,215 \\
2,223 \\
2,379\end{array}$ & $\begin{array}{r}+67 \\
+\quad 9 \\
+\quad 26\end{array}$ & $\begin{array}{l}+3.1 \\
+.4 \\
+1.1\end{array}$ \\
\hline $\begin{array}{l}\text { Total for } 3 \text { days..... } \\
\text { Average per day... }\end{array}$ & $\begin{array}{l}9,183 \\
3,061\end{array}$ & $\begin{array}{l}348 \\
116\end{array}$ & $\begin{array}{l}407 \\
136\end{array}$ & ......... & $\begin{array}{l}+29 \\
+10\end{array}$ & $\begin{array}{r}+1,684 \\
+\quad 561\end{array}$ & $\begin{array}{l}6,715 \\
2,238\end{array}$ & $\begin{array}{l}6,817 \\
2,272\end{array}$ & $\begin{array}{r}+102 \\
+34\end{array}$ & +1.5 \\
\hline
\end{tabular}

EXPERYHENTS NOS. 26 -28-REST. NO. 27 WITH ALCOHOL DIET.

Subject.-J. F. S., a chenist, 29 years of age. His weight with underclothing was about 64 kilograms (1+1 pounds).

Occupation during exprement.-Reading, writing, and miscellaneons observations within the apparatus, with as little muscular activity as was practicable.

Duration.-This experiment was the second of a series of 3 experiments, each continuing 3 days. The series was preceded by a preliminary period of $t$ days, beginning with breakfast February 10, 1900. The subject entered the calorimeter on the erening of February 13 . The first experiment of the series, No. 26 , began at 7 a. m. February 14; the second, No. 27 , at 7 a. $m$. February 17, and the third, No. 28, at 7 a. m. February 20 . The whole period of the metabolism experiments was thus 9 days.

Dirt.- A basal ration of ordinary food furnisbed 19 grams of protein and 1,982 ealories of energy per day. To this was added in experiment No. 26, 63.5 grams of butter, furnishing 1 gram of protein and 508 calories of energy; in experiment No. 27, 79.5 grams of 90.6 per cent alcohol, furnishing 509 calories of energy, and in No. 28, 128 grams of cane sugar, furnishing 507 ealories of energy per day. The protein and energy was thus practieally the same in each of the 3 experments of this series. In experiment No. 27 the 79.5 grams of commercial alcohol, eontaning 7.2 grams absolute alcohol, was added to 792.5 grams of water sweetened with 15 grams of sugar. The alcohol was taken in 6 doses, as indicated in the following schedule. The kinds and quantities of food in the hasal lation, as served for each meal, the character and amount of the supplemental ration in the different experiments, and the quantity of drink consumed at different periods of the day were as follows: 
Ihiet in metabolism experiments Nos. 2tj-2S.

FOOD-BASAL, R.ATION.

\begin{tabular}{|c|c|c|c|c|}
\hline & Brenk fust. & binner. & supter. & Total. \\
\hline 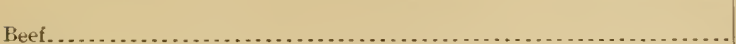 & $\begin{array}{r}\text { Grams. } \\
35.5\end{array}$ & $\begin{array}{l}\text { Grams. } \\
50\end{array}$ & $\begin{array}{l}\text { Grams. } \\
. . . . . .\end{array}$ & $\begin{array}{r}\text { Girnms. } \\
85.5\end{array}$ \\
\hline Butter & 10 & 12 & 8 & 30 \\
\hline Milk & 300 & 400 & 300 & 1,000 \\
\hline 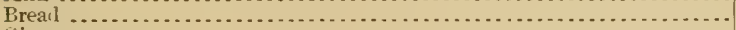 & 50 & 100 & 50 & 200 \\
\hline Ginger snaps ${ }^{2}$ & .......... & 30 & 30 & 60 \\
\hline 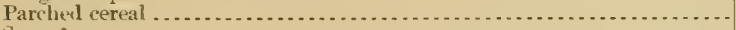 & 25 & .... & 25 & 50 \\
\hline Sugar"..... & 15 & & & 15 \\
\hline
\end{tabular}

ased in alcohol and water in experiment No. 27.

FOOD-GLPPLEMENTAL RATIOX.

Experiment No. 26. -63.5 grams butter were added to basal ration.

Experimmt $10.2 \%-72$ grams absolute alcohol were added to basal ration.

Erperiment . To. 28.-128 grams sugar were added to basal ration.

DRINK.

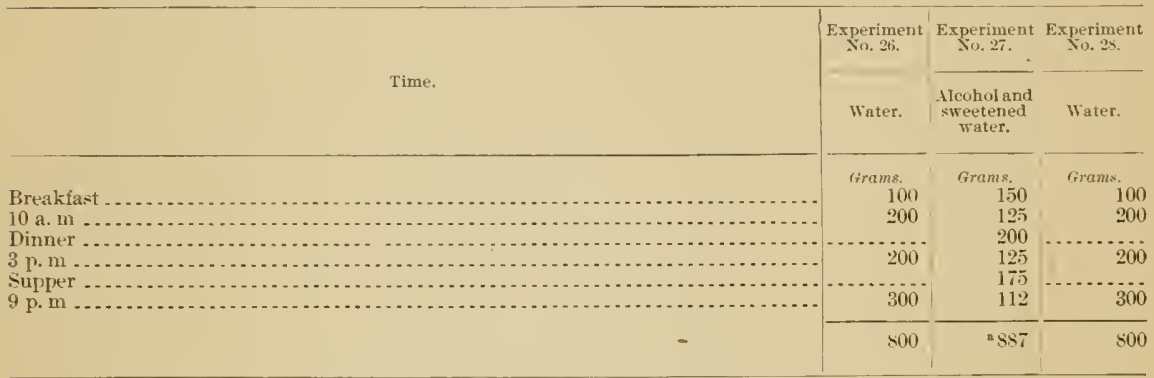

- Contains 72 grams absolute alcohol and 15 grams sugar.

Inaily routine.-The general rontine of the experiment was as follows:

Duily proyranme-Metubolism experiments Nox. 26-28.

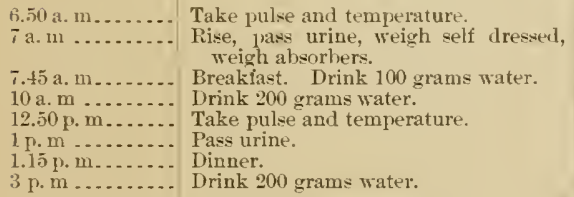

6.50 a. m....... Take pulse and temperature.

a. In ... Rise, jass urine, weigh self dressed,

Breakfast. Drink 100 grams water.

10 a. m ........ Drink 200 grams water.

$12.50 \mathrm{p} . \mathrm{m} . . . .$. . Take pulse and temperature

$1.15 \mathrm{p} . \mathrm{m}-\ldots$ Dinner.

p. m......... Drink 200 grams water.

Table LXI sumuarizes the most important statisties in the diary kept ly the subjeet. The subject weighed himself with clothing twice each day. The reasons for not removing all the elothing in weighing were two: It was desirable to avoid the muscular work involred in dressing and undressing: it has also been found that the sudden increase of radiation of heat from the skin when the clothing is removed causes a decided rise in the temperature inside the chamber, and thus disturbs the aceuracy of the heat measurements to some extent. There was extremely little muscular exereise and no sensible perspiration. Hence the differences in weight from time to time must represent rery nearly the changes in body weight. The determinations of pulse rate were made, of course, by the subject himself, when either sitting or reclining. after sereral minutes rest. The measurement at 6.50 a. m. however, was made before rising from bed. 
The temperature was determined by a mercury thermometer placed in the axilla. As has already been stated, it was found that the thermometer reached as high a point in 10 minutes as in 15 or 20 minntes. The most of the temperatures, therefore, were made after the thermometer had been in place about 10 minutes. It was our belief at the outset that the body temperatures as thus taken are not perfectly accurate, and this belief has been confirmed by observations with an electrical rectal thermometer, since derised for continuous and accurate observations of interual body temperature. ${ }^{a}$ While these axillary determinations of body temperature are not entirely accurate, the later observations with the electrical thermometer lead us to believe that the daily curves for the two are nearly parallel.

In previons experiments an hygrometer had been placed in the chamber, and readings with dry and wet bulb were taken at freqnent intervals. Inasmuch, however, as these readings were not used in the computations of results, and it is desirable in rest experiments to avoid all unnecessary exertion, even that of rising and reading the hygrometer, these observations were not made in the experiments of 1900 .

TABLe LXI.-Summary of the diary-Metabolism experiments Nos. $26-28$.

\begin{tabular}{|c|c|c|c|c|c|c|c|}
\hline Date and time. & $\begin{array}{l}\text { Weight with } \\
\text { clothes. }\end{array}$ & $\begin{array}{l}\text { Pulse rate } \\
\text { per } \\
\text { minute. }\end{array}$ & $\begin{array}{l}\text { Temper- } \\
\text { ature. }\end{array}$ & Date and time. & $\begin{array}{l}\text { Weight with } \\
\text { clothes. }\end{array}$ & $\begin{array}{c}\text { Pulse rate } \\
\text { per } \\
\text { minute. }\end{array}$ & $\begin{array}{l}\text { Temper- } \\
\text { ature. }\end{array}$ \\
\hline 1900. & & & & 1900-Continued & & & \\
\hline Experiment No. 26 . & & & & Experiment No. 26 - C't'd. & & & ${ }^{\circ} F$. \\
\hline $\begin{aligned} & \text { Feb. } 14,7 \text { a.m....... } \\
& 8.36 \mathrm{a} . \mathrm{m} . .\end{aligned}$ & 0 & $\begin{array}{l}68 \\
78\end{array}$ & $\begin{array}{l}97.8 \\
98.3\end{array}$ & $\begin{array}{r}\text { Feb. } 15,10.15 \text { p. m....... } \\
10.20 \text { p. m...... }\end{array}$ & 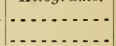 & 70 & 97.5 \\
\hline $10.27 \mathrm{a} . \mathrm{m}$ & & 67 & 98.1 & Feb. $16,6.55$ a.m. ....... & & 71 & $\begin{array}{l}91.5 \\
\cdots . . .\end{array}$ \\
\hline 12.27 p.m. & & 64 & & 7 a.m...... & 01 & & 98.1 \\
\hline $12.33 \mathrm{p} . \mathrm{m}$ & & & 97.8 & 8.32 a.m... & & 82 & \\
\hline $\begin{array}{l}12.53 \mathrm{p} . \mathrm{n} \\
1 \text { p. } \mathrm{m} . .\end{array}$ & & 61 & 979 & $\begin{array}{l}8.4 \\
9.3\end{array}$ & & 79 & 98.3 \\
\hline 2.27 p. m. & & 77 & $\begin{array}{l}97.9 \\
98.5\end{array}$ & 9.37 a.m & & 10 & $98 . \overline{2}$ \\
\hline 3.4 & & & 98.5 & 10.3 & & 76 & 98.3 \\
\hline $4.30 \mathrm{p} . \mathrm{m}$. & & 72 & 98.5 & 11. & & 72 & 98,2 \\
\hline $\begin{array}{l}5.30 \text { p.m } \\
5.45 \text { p. }\end{array}$ & & & 98.7 & $12.27 \mathrm{p} . \mathrm{m}$. & & 70 & 98.2 \\
\hline $6.17 \mathrm{p.m}$ & 64.88 & . & 80.1 & 12.3 & & & 98.1 \\
\hline $8.13 \mathrm{p}, \mathrm{m}$ & & & 97.6 & $12.58 \mathrm{P} . \mathrm{m}$ & & 71 & \\
\hline & & 64 & 97. & & & & 98.2 \\
\hline $9.29 \mathrm{p} . \mathrm{m}$ & $\cdots$ & 64 & 97.7 & 2.0 & & $\begin{array}{r}80 \\
79\end{array}$ & 98.22 \\
\hline $\begin{array}{l}10.15 \mathrm{p} . \mathrm{m} . . \\
\text { Feb. } 15,6.50 \mathrm{a} . \mathrm{m} \ldots\end{array}$ & $\ldots$ & 69 & 99.1 & $\begin{array}{l}2.30 \text { p. m... } \\
3.35 \text { p. } \mathrm{m}_{. .}\end{array}$ & & 81 & $\begin{array}{l}98.2 \\
98.3\end{array}$ \\
\hline 7 a.m................. & 64.18 & . & 5... & 4.05 p. m.. & & & 98.2 \\
\hline 7.34 a.m... & & 78 & 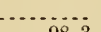 & 4.27 p. m. & & 79 & \\
\hline & & 82 & $\begin{array}{l}98.3 \\
98.5\end{array}$ & & & 75 & $\begin{array}{l}98.2 \\
98.5\end{array}$ \\
\hline $\begin{array}{l}8.33 \text { a. } \mathrm{m} \ldots \\
9.28 \text { a. } \mathrm{m} . .\end{array}$ & & 80 & 98. & $\begin{array}{l}5.30 \text { p. m.. } \\
5.43 \text { p. m.. }\end{array}$ & & & 98.7 \\
\hline $9.30 \mathrm{a}$ & & & 98.3 & $6.32 \mathrm{p} . \mathrm{m}$ & & 80 & \\
\hline$\cdots$ & $\cdots$ & 71 & 98 & $\begin{array}{l}6.4 \\
7 \mathrm{p}\end{array}$ & 6473 & & $\begin{array}{l}98.4 \\
98.5\end{array}$ \\
\hline $\begin{array}{l}10.46 \text { a. m.. } \\
11.30 \text { a.m.. }\end{array}$ & & 70 & $\begin{array}{l}98.3 \\
98.1\end{array}$ & 7. p.m p..... & & 75 & 90.0 \\
\hline $12.31 \mathrm{I}$ & & 68 & & 7.40 & & . & 98.0 \\
\hline $12.37 \mathrm{~F}$ & & & 98.4 & $7.50 \mathrm{p.} \mathrm{I}$ & & & 98.3 \\
\hline $\begin{array}{l}12.54 \\
1.11\end{array}$ & & 68 & 98.2 & $\begin{array}{l}8.26 \mathrm{I} \\
8.30 \mathrm{l}\end{array}$ & & 71 & 97.8 \\
\hline $1.59 \mathrm{j} \cdot \mathrm{n}$ & & 75 & 98.2 & $9.30 \mathrm{p} . \mathrm{m}$. & & 68 & 97.8 \\
\hline p. $\mathrm{m}$ - & & 81 & 98.5 & 10.19 p. m & $\cdots$ & 65 & 071 \\
\hline p. m. & & 76 & 98.2 & $10.22 \mathrm{p} \cdot \mathrm{m}$. & & & 97.1 \\
\hline $\begin{array}{l}4.28 \mathrm{p} \cdot \mathrm{m} . . \\
4.30 \mathrm{p} . \mathrm{m} .\end{array}$ & & 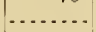 & 98.1 & Experiment No. $2 \%$. & & & \\
\hline $5.30 \mathrm{p} . \mathrm{m}$ & & & 98.0 & Feb $176559 \mathrm{~m}$ & & & \\
\hline 5.49 [1. 11 & (n.... & $\begin{array}{l}69 \\
69\end{array}$ & & $\begin{array}{r}\text { Feb. } 17,6.55 \text { a. } \mathrm{m} . \\
7 \text { a. } \mathrm{m} . . .\end{array}$ & 6407 & 69 & $\cdots \cdot$ \\
\hline $\begin{array}{l}6.30 \mathrm{p} \cdot \mathrm{m} . \\
6.55 \mathrm{p} \cdot \mathrm{m} .\end{array}$ & 64.87 & 68 & 98. & 7.31 a.m... & (........ & 82 & \\
\hline $7.30 \mathrm{p} \cdot \mathrm{n}$ & - & 75 & 98. & $7.35 \mathrm{a} . \mathrm{m} .$. & & & 97.8 \\
\hline p. n & $\cdots$ & 67 & 97.6 & a. m... & & 89 & \\
\hline $8.541,1 \mathrm{n} \ldots$ & ... & 70 & 97.5 & $\begin{array}{l}8.38 \text { a. m... } \\
9.32 \text { a. } \mathrm{m...}\end{array}$ & & 98 & $\begin{array}{l}97.9 \\
98.1\end{array}$ \\
\hline 9. & .... & 67 & & $10.29 \mathrm{am}$ & & 97 & 8.1 \\
\hline 1.3. p.m.. & 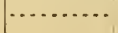 & $\cdots$ & 97.4 & $\begin{array}{l}10.30 \mathrm{a} . \mathrm{m} \\
11.30 \mathrm{a} . \mathrm{m}\end{array}$ & & $\because$ & 98.3 \\
\hline 9.51 p.m.. & $\cdots$ & & 97.6 & 11.30 a. $\mathrm{m} .$. & & 87 & 97.9 \\
\hline
\end{tabular}


T.nm.e LXI. - Summary of th' diary-Metabolism experiments Nos. 26-28-Continued.

\begin{tabular}{|c|c|c|c|}
\hline Date and time. & $\begin{array}{l}\text { Weight with } \\
\text { elothes. }\end{array}$ & $\begin{array}{c}\text { Pulse rate } \\
\text { jer } \\
\text { minute. }\end{array}$ & $\begin{array}{l}\text { Temper- } \\
\text { ature: }\end{array}$ \\
\hline 1900-Continuerl. & & & \\
\hline Experiment No. $2 \gamma-C$ - t'd. & & & \\
\hline Feh. $17,12.30$ p. $\mathrm{m}_{\ldots} \ldots \ldots$ & Kilngrams. & 80 & ${ }^{\circ} \mathrm{F} \cdot \mathrm{9} .8$ \\
\hline I p. $11, \ldots . .$. & . & 77 & 97.8 \\
\hline $11 \ldots . . .6$ & ( & 80 & \\
\hline 1.49 p. $111 . . . .$. & ........... & $\ldots$ & 98.0 \\
\hline ........ & (............ & ... & 98.1 \\
\hline 1....... & & & 97.9 \\
\hline 1....... & ( . . n & 90 & \\
\hline ........ & (............ & & 97.8 \\
\hline - $\ldots \ldots$ & $-\ldots \ldots \ldots$ & 91 & \\
\hline $\begin{array}{l}3 \text { p. m........... } \\
3.27 \text { p. } 1 . . . . . . .\end{array}$ & ( & & 97.9 \\
\hline $\begin{array}{l}3.27 \mathrm{p.m.......} \\
3.30 \mathrm{pm} . \mathrm{m.......}\end{array}$ & ( & $\begin{array}{c}96 \\
\ldots .\end{array}$ & \\
\hline $\begin{array}{l}3.30 \mathrm{p}, \mathrm{m} \ldots \ldots . \\
4.27 \mathrm{p} . \mathrm{m} . . .\end{array}$ & (n) & & AS. 1 \\
\hline $4.30 \mathrm{p}, 11 . .2$. & (1) & & …...... \\
\hline $111 . . . \ldots$ & & 83 & 48.1 \\
\hline m....... & $\cdots$ & 83 & \\
\hline $11 \ldots \ldots . . .$. & ... & & 98.1 \\
\hline 1......... & $\ldots$ & 84 & \\
\hline ........... & $\cdots$ & .... & 97.7 \\
\hline ......... & $\cdots$ & & 98.1 \\
\hline $\begin{array}{l}6.58 \mathrm{p}, \mathrm{m} \ldots . . . . \\
7 \text { p. m........... }\end{array}$ & 64.55 & 87 & 98.0 \\
\hline $11 \ldots . .$. & (........... & 90 & \\
\hline 1....... & ......... & & \\
\hline m ........ & ............ & $8+$ & \\
\hline 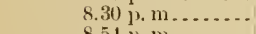 & $\ldots$ & ... & $97 . \overline{5}$ \\
\hline$\ldots \ldots \ldots$ & $\cdots$ & 83 & \\
\hline$\cdots$ & $\cdots$ & & 97.5 \\
\hline ........ & (1) & 79 & \\
\hline (......... & ( & -.... & 97.3 \\
\hline n....... & & & 97.3 \\
\hline (..... & $\cdots$ & 73 & \\
\hline p. & (n) & +72 & 97.1 \\
\hline .......... & 63.75 & & 98.1 \\
\hline $\mathrm{m} \ldots . .$. & $\ldots$ & 82 & \\
\hline $\mathrm{m} \ldots .$. & $\ldots$ & $\cdots$ & 97.9 \\
\hline ...... & $\cdots$ & 90 & 98.2 \\
\hline . . . . & $\cdots$ & 96 & 95.4 \\
\hline $112 \ldots . . .$. & $\cdots$ & 90 & \\
\hline III. . . & - & & \\
\hline m... & $\cdots$ & & 97.8 \\
\hline $\begin{array}{ll}m . . \\
m \ldots\end{array}$ & & 75 & 98.1 \\
\hline m....... & ( & 75 & ; \\
\hline 12 & (1) & & \\
\hline 1. & - $\ldots \ldots \ldots$ & $\begin{array}{l}75 \\
83\end{array}$ & 98.3 \\
\hline 11......... & $\cdots$ & & (....... \\
\hline 1. $111 . . .$. & .......... & 90 & \\
\hline n. m... & $\cdots$ & & $\ddot{9}$ \\
\hline p. m.. & ......... & 90 & \\
\hline m. & . . . . . & & 98.4 \\
\hline 1.. & . & 90 & 98.3 \\
\hline 1. $\mathrm{mI}_{-}$ & ...... & 78 & \\
\hline p. 111. & - & & 98.3 \\
\hline m... & 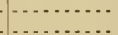 & 80 & \\
\hline 6. & - & & 48.1 \\
\hline$m \ldots$ & , & il & 0 \\
\hline 7 & 64.37 & & 98.0 \\
\hline & ......... & 87 & 97.7 \\
\hline 1. $111 . . . .$. & . . . . . & 80 & 97.7 \\
\hline 1. $111 \ldots . .$. & $\ldots \ldots \ldots$ & 72 & 97.4 \\
\hline in ......... & .......... & $\ldots .$. & 97.4 \\
\hline 1. ni....... & & & 97.2 \\
\hline p. m.. & & Ti & \\
\hline, 7 & . . . . . . & 75 & \$S. 1 \\
\hline & $\cdots$ & 85 & 97.8 \\
\hline a. $\mathrm{m}$. & (-... & 90 & 98.0 \\
\hline 9.30 a. m. & ( $\ldots \ldots \ldots \ldots$ & 96 & 98.2 \\
\hline
\end{tabular}

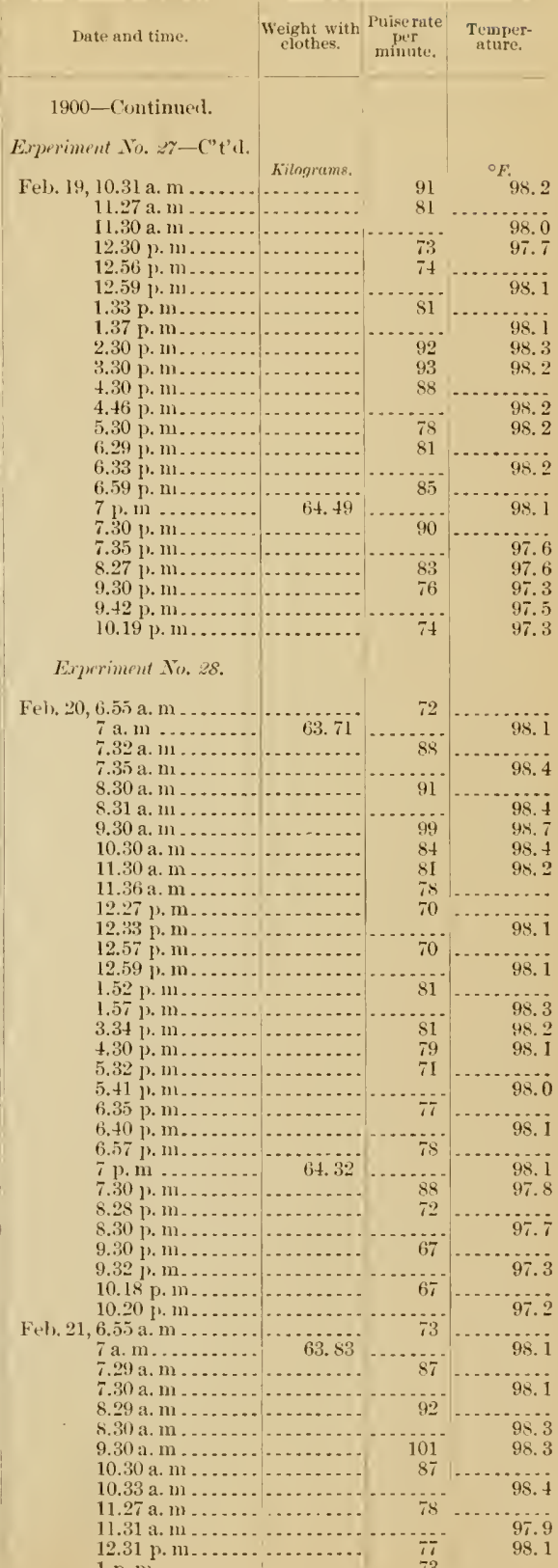


Tarle LX1. -Simmary of the diany-Metubolism experiments Nos. 26-2S-Continued.

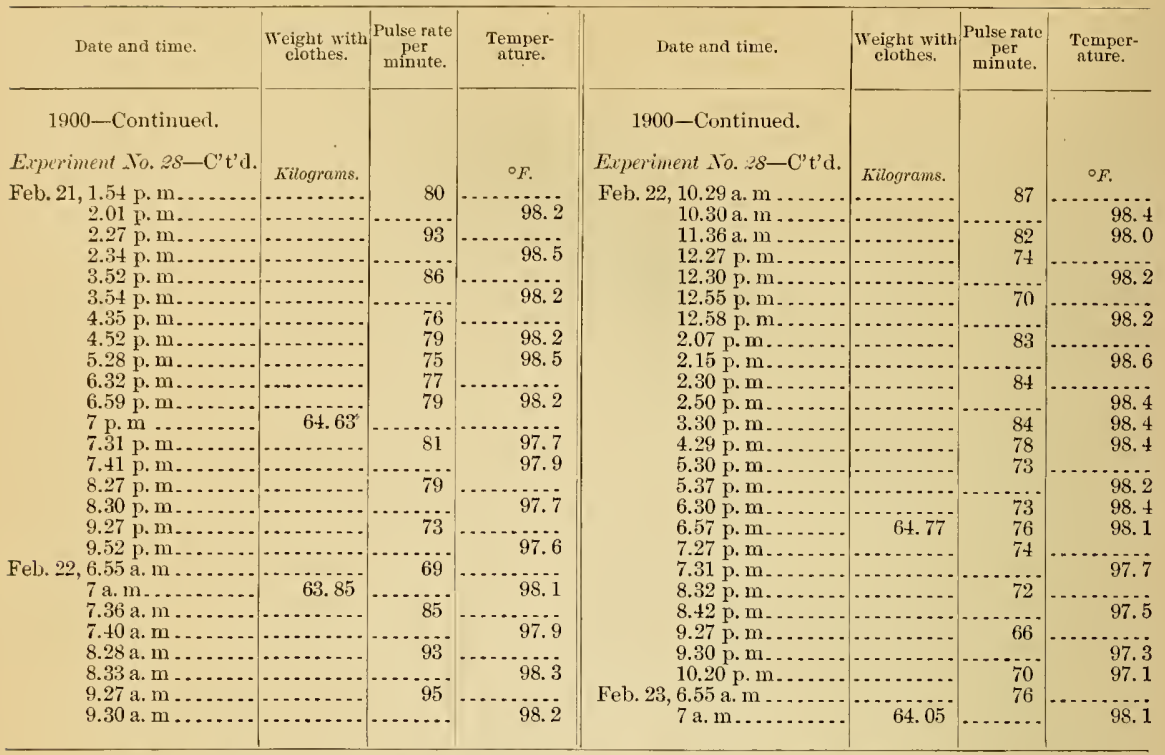

Detuiled statistics of income and outgo.-The quantities of nutrients in the basal ration, which was the same in all 3 experiments, and the quantities in the supplemental ration in the different experiments of this series are shown in Table LXII. The feces were determined for each experiment in order to obtain data concerning the relative digestibility of the food with the different supplemental rations.

TABLE LX1I.-Weight, composition, and heat of combustion of foods-Metabolism experiments Nos. 26-2S.

\begin{tabular}{|c|c|c|c|c|c|c|c|c|c|c|}
\hline $\begin{array}{l}\text { Labora- } \\
\text { tory } \\
\text { No. }\end{array}$ & Food material. & $\begin{array}{l}\text { Weight } \\
\text { per day. }\end{array}$ & Water. & Protein. & Fat. & $\begin{array}{l}\text { Carbo- } \\
\text { hydrates. }\end{array}$ & $\begin{array}{l}\text { Nitro- } \\
\text { gen. }\end{array}$ & Carbon. & $\begin{array}{l}\text { Hydro- } \\
\text { gen. }\end{array}$ & $\begin{array}{l}\text { Heat of } \\
\text { combus- } \\
\text { tion. }\end{array}$ \\
\hline $\begin{array}{l}3176 \\
3177 \\
3179 \\
3180 \\
3181 \\
3168 \\
\end{array}$ & 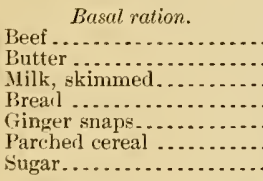 & $\begin{array}{r}\text { Grams. } \\
85.0 \\
30.0 \\
1,000.0 \\
200.0 \\
60.0 \\
50.0 \\
15.0\end{array}$ & $\begin{array}{r}\text { Grams. } \\
53.1 \\
3.0 \\
900.0 \\
78.6 \\
2.5 \\
2.8 \\
\ldots . . .\end{array}$ & $\begin{array}{r}\text { Grams. } \\
28.7 \\
.5 \\
42.0 \\
17.8 \\
3.7 \\
5.9\end{array}$ & $\begin{array}{r}\text { Grams. } \\
2.4 \\
25.8 \\
3.0 \\
3.2 \\
5.0 \\
.9 \\
. . .\end{array}$ & \begin{tabular}{r} 
Grams. \\
\hdashline$\cdots . .$. \\
17.0 \\
97.8 \\
47.9 \\
39.5 \\
15.0
\end{tabular} & $\begin{array}{r}\text { Grams. } \\
4.60 \\
.08 \\
6.70 \\
2.84 \\
.60 \\
.94 \\
. . .\end{array}$ & $\begin{array}{r}\text { Grams. } \\
16.62 \\
19.51 \\
46.30 \\
55.52 \\
26.59 \\
21.10 \\
6.31\end{array}$ & $\begin{array}{r}\text { Arrams. } \\
2.30 \\
3.01 \\
6.30 \\
7.98 \\
3.97 \\
2.97 \\
.97\end{array}$ & $\begin{array}{r}\text { Calories. } \\
187 \\
240 \\
462 \\
561 \\
266 \\
207 \\
59\end{array}$ \\
\hline \multirow{7}{*}{3168} & Total for $\mathbf{1}$ day .. & $1,440.0$ & $1,040.0$ & 98.6 & 40.3 & 247.2 & 15. 76 & 191.95 & 27.50 & 1,982 \\
\hline & $\begin{array}{l}\text { Supplemental ration. } \\
\text { Exserrinexr No. } 26 . \\
\text { Butter................ }\end{array}$ & 63.5 & 6.3 & 1.0 & 54.5 & & .16 & 41.29 & 6.36 & 508 \\
\hline & Total for 1 day.. & $1,503.5$ & $1,046.3$ & 99.6 & 94.8 & 247.2 & 15.92 & 233.24 & 33.86 & 2,490 \\
\hline & Alcohol............... & 72.0 & & & & & & 37.56 & 9.39 & 509 \\
\hline & Total for 1 day... & $1,512.0$ & $1,040.0$ & 98.6 & 40.3 & 247.2 & 15.76 & 229.51 & 36.89 & 2,491 \\
\hline & Sugar ................... & 128.0 & & & & 128.0 & & 53.88 & 8.29 & 507 \\
\hline & Total for 1 day .... & $1,568.0$ & $1,040.0$ & 98.6 & 40.3 & 375.2 & 15.76 & 245.83 & 35.79 & 2,489 \\
\hline
\end{tabular}




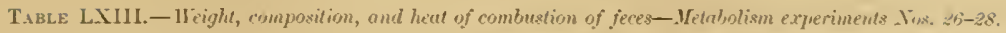

\begin{tabular}{|c|c|c|c|c|c|c|c|c|c|c|}
\hline $\begin{array}{l}\text { Labors- } \\
\text { tort: } \\
\text { xio. }\end{array}$ & & Weight. & Water. & Protein. & Fat. & $\begin{array}{l}\text { Carbur } \\
\text { hydrates. }\end{array}$ & $\begin{array}{l}\text { Nitro- } \\
\text { gen. }\end{array}$ & Carbon. & $\underset{\text { gen.- }}{\text { Hydro- }}$ & $\begin{array}{l}\text { Heat of } \\
\text { combus- } \\
\text { tion. }\end{array}$ \\
\hline \multirow[t]{2}{*}{$31 \cdots 3$} & $\begin{array}{l}\text { Erperiment Li. } z^{t} \text {. } \\
\text { Feces for } 3 \text { days ...... }\end{array}$ & $\begin{array}{l}\operatorname{limave} \\
2-36.5\end{array}$ & $\begin{array}{l}\text { Prramis. } \\
\text { jil.n }\end{array}$ & $\begin{array}{l}\operatorname{linamz} \\
20.6\end{array}$ & (irams, & $\begin{array}{l}\operatorname{Grame} \\
20.1\end{array}$ & $\begin{array}{l}\text { tirums. } \\
3.26\end{array}$ & $\begin{array}{l}\text { firmmes } \\
2 \rightarrow, 33\end{array}$ & $\begin{array}{l}\text { tiramis: } \\
3 .+1\end{array}$ & $\begin{array}{r}\text { falorices } \\
317\end{array}$ \\
\hline & Arerage per lay. & $\therefore s$ & 5.0 & 6.9 & 2. & 6.7 & 1.09 & 4.44 & 1.14 & 106 \\
\hline 314 & $\begin{array}{l}\text { Experiment lo. } 2 . \\
\text { Feces ior } 3 \text { days ...... }\end{array}$ & 218.9 & 152.1 & 21.0 & 6. 3 & 21.2 & 3. 35 & 26.84 & 2. 41 & 29.2 \\
\hline \multirow{3}{*}{3155} & Ireraue per day. & 73.0 & 50.7 & 7.0 & 2.1 & 7.1 & 1.12 & 8.45 & .80 & 97 \\
\hline & $\begin{array}{l}\text { Erperiment Lic. } 28 . \\
\text { Feces for } 3 \text { day } . . . . .\end{array}$ & 219.9 & 155.2 & 23.3 & $1: 1$ & 16. 1 & $3.7 t$ & 29.93 & 4.02 & 335 \\
\hline & Arerage per lay.. & 73.3 & $51 . \bar{T}$ & i.s & 4.0 & 5.3 & 1. 25 & 9.95 & 1. 34 & 112 \\
\hline
\end{tabular}

The urine was collected and the nitrogen determined in the usual b-hour periods each day. No attempt was made to dry composite samples of the urine for each experiment for the determinations of carbon and hrdrogen, but aliquot portions were taken from each day's urine for the preparation of a $9 \mathrm{~d}$ al $\mathrm{s}^{\circ}$ composite simple, which should represent the urine for the total series of experiments. The heat of combustion of the composite sample for cach day were, horrerer. determined. Statistics of the urine for experiment No. 27 are given in detail. by ti-hour periods, and those of experiments Nos. 26 and 2s, in which alcohol did not form a part of the diet. are summarized br dars. for comparison.

TABLE LXIV.-Amount, epecific gravily, and nitrogen of urine, hyl 6-hour periods-Melaholism experiments . Vos. $26-23$.

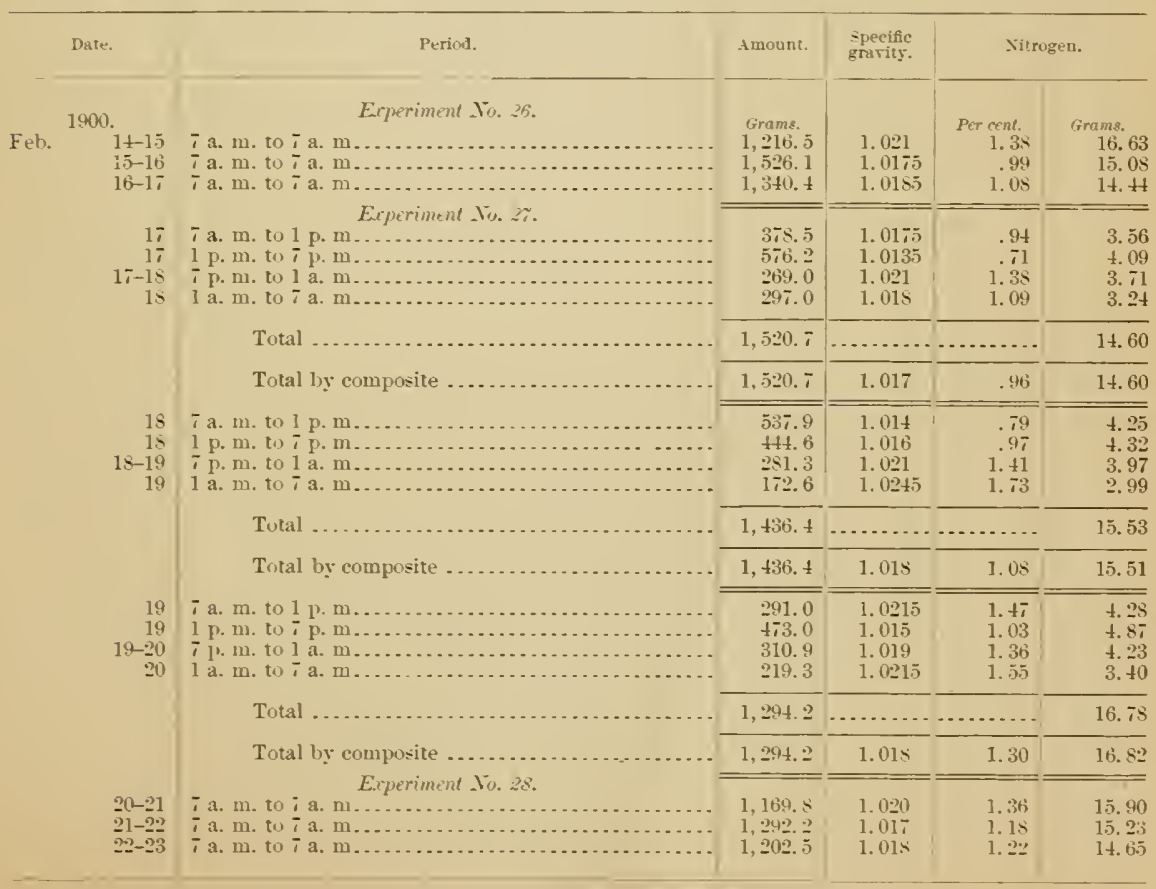


TABLE LXV.-Daily elimination of curbon, hydrogen, and wuter in the urine-Metabolism experiments Nos. 26-28.

\begin{tabular}{|c|c|c|c|c|c|c|c|c|c|}
\hline \multirow[b]{2}{*}{ Date. } & \multirow{2}{*}{ Amount. } & \multirow{2}{*}{\multicolumn{2}{|c|}{ Carbon. }} & \multirow{2}{*}{\multicolumn{2}{|c|}{ Hydrogen. }} & \multirow{2}{*}{\multicolumn{2}{|c|}{ Water. }} & \multicolumn{2}{|c|}{ Heat of eombustion. } \\
\hline & & & & & & & & Per gram. & Total. \\
\hline \multirow[t]{2}{*}{ 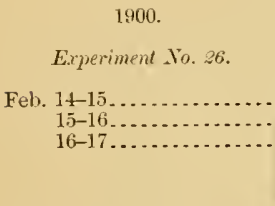 } & $\begin{array}{l}\text { Grams. } \\
1,216.5 \\
1,526.1 \\
1,340.4\end{array}$ & $\begin{array}{c}\text { Per cent. } \\
\ldots . . . \\
\ldots \ldots \\
\ldots \ldots\end{array}$ & $\begin{array}{c}\text { Grams. } \\
11.93 \\
10.82 \\
10.36\end{array}$ & \begin{tabular}{c} 
Per cent. \\
$\ldots$ \\
\hdashline$\ldots$ \\
$\cdots$
\end{tabular} & $\begin{array}{r}\text { Grams. } \\
2.87 \\
2.61 \\
2.50\end{array}$ & \begin{tabular}{c} 
Per cent. \\
$\ldots \ldots$ \\
\hdashline$\ldots$ \\
$\ldots$
\end{tabular} & $\begin{array}{c}\text { Grams. } \\
1,157.3 \\
1,472.4 \\
1,289.0\end{array}$ & $\begin{array}{r}\text { Calories. } \\
0.103 \\
.082 \\
.101\end{array}$ & $\begin{array}{r}\text { Calories. } \\
125 \\
125 \\
135\end{array}$ \\
\hline & $4,083.0$ & ...... & 33.11 & -. & 7.98 & ....... & $3,918.7$ & ......... & 385 \\
\hline 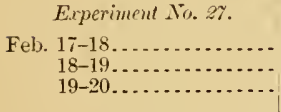 & $\begin{array}{l}1,520.7 \\
1,436.4 \\
1,294.2\end{array}$ & $\begin{array}{l}\cdots \\
\cdots \\
\cdots\end{array}$ & $\begin{array}{l}10.47 \\
11.14 \\
12.04\end{array}$ & $\begin{array}{l}-- \\
\cdots \\
\cdots\end{array}$ & $\begin{array}{l}2.52 \\
2.69 \\
2.90 \\
\end{array}$ & $\mid \begin{array}{l}\ldots \ldots \\
\ldots \ldots \ldots\end{array}$ & $\begin{array}{l}1,468.7 \\
1,381.1 \\
1,234.5\end{array}$ & $\begin{array}{l}.073 \\
.084 \\
.108\end{array}$ & $\begin{array}{l}111 \\
121 \\
140\end{array}$ \\
\hline & $4,251.3$ & -........ & 33.65 & $\ldots \ldots$ & 8.11 & ........ & $4,084.3$ & $\ldots \ldots \ldots$ & 372 \\
\hline 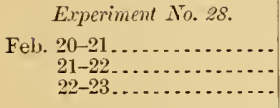 & $\begin{array}{l}1,169.8 \\
1,292.2 \\
1,202.5\end{array}$ & $\mid$\begin{tabular}{c}
$\ldots$ \\
\hdashline$\ldots \ldots$ \\
\hdashline$\ldots \ldots$ \\
$\cdots$
\end{tabular} & $\begin{array}{l}11.40 \\
10.92 \\
10.51\end{array}$ & $\cdots$ & $\begin{array}{l}2.75 \\
2.63 \\
2.53\end{array}$ & $\begin{array}{l}\ldots \\
\ldots \\
\cdots\end{array}$ & $\begin{array}{l}1,113.2 \\
1,238.0 \\
1,150.3\end{array}$ & $\begin{array}{l}.102 \\
.103 \\
.110\end{array}$ & $\begin{array}{l}119 \\
133 \\
132\end{array}$ \\
\hline & $3,664.5$ & ......... & 32.83 & . . . . . & 7.91 & ........ & $3,501.5$ & $\cdots$ & 384 \\
\hline Total, 9 days....... & $11,998.8$ & .83 & 99.59 & .20 & 24.00 & 95.88 & $11,504.5$ & .095 & $1,1 \pm 1$ \\
\hline
\end{tabular}

Tables LXVI-LXVIII show the quantities of carbon dioxid and water found in the ventilating: air current in this series of experiments. These statistics are given in detail for the 3 days of experiment No. 27 , in which alcohol formed a part of the diet, and are summarized by days for experiments Nos. 26 and 28.

TABLE LXYI.-Comparison of residual amounts of carbon dioxid and water in the chamber at the beginning and end of each period, and the corresponding gain or loss-Metabolism experiment $\mathrm{No} .2 \%$.

\begin{tabular}{|c|c|c|c|c|c|c|c|}
\hline \multirow{2}{*}{\multicolumn{2}{|c|}{ Date. }} & \multirow[b]{2}{*}{ End of period. } & \multicolumn{2}{|c|}{ Carbon dioxid. } & \multicolumn{3}{|c|}{ Water." } \\
\hline & & & $\begin{array}{l}\text { Total } \\
\text { amount in } \\
\text { chamber. }\end{array}$ & $\begin{array}{l}\text { Grin }(+) \text { or } \\
\text { loss }(-) \text { over } \\
\text { preeeding } \\
\text { period. }\end{array}$ & $\begin{array}{c}\text { Total amount } \\
\text { of vapor re- } \\
\text { maining in } \\
\text { ehamber. }\end{array}$ & $\begin{array}{c}\text { Gain }(+) \text { or } \\
\text { loss }(-) \text { over } \\
\text { preeeding } \\
\text { period. }\end{array}$ & $\begin{array}{l}\text { Total amount } \\
\text { gained }(+) \text { or } \\
\text { lost }(-) \text { during } \\
\text { the period. }\end{array}$ \\
\hline \multirow{6}{*}{ Feb. } & \multirow{2}{*}{$\begin{array}{l}17 \\
17 \\
17 \\
18 \\
18\end{array}$} & \multirow{2}{*}{ 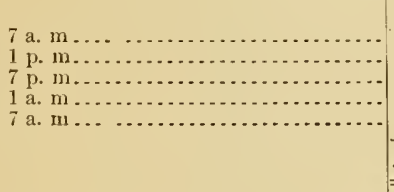 } & Grams. & Grans. & Grams. & Grams. & Grams. \\
\hline & & & …..... & +4.0 & 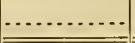 & +1.9 & $\begin{array}{r}+1.9 \\
\end{array}$ \\
\hline & \multirow[t]{2}{*}{$\begin{array}{l}18 \\
18 \\
19 \\
19\end{array}$} & \multirow[t]{2}{*}{ 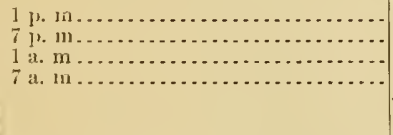 } & $\begin{array}{l}31.0 \\
36.5 \\
24.1 \\
25.3\end{array}$ & $\begin{array}{r}+4.0 \\
+5.5 \\
-12.4 \\
+\quad 1.2 \\
\end{array}$ & $\begin{array}{l}37.2 \\
37.8 \\
35.3 \\
31.0\end{array}$ & $\begin{array}{r}+3.9 \\
+0.6 \\
-2.5 \\
-4.3 \\
\end{array}$ & $\begin{array}{l}+3.9 \\
+0.6 \\
-2.5 \\
-4.3 \\
\end{array}$ \\
\hline & & & n......... & -1.7 & ................ & -2.3 & $\begin{array}{r}-2.3 \\
\end{array}$ \\
\hline & \multirow[t]{3}{*}{$\begin{array}{l}19 \\
19 \\
20 \\
20\end{array}$} & \multirow[t]{3}{*}{ 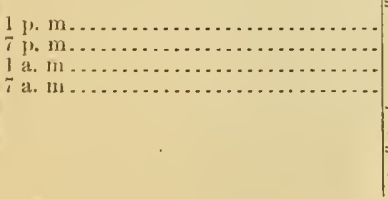 } & $\begin{array}{l}31.0 \\
39.1 \\
23.0 \\
26.4\end{array}$ & $\begin{array}{r}+5.7 \\
+8.1 \\
-16.1 \\
+\quad 3.4 \\
\end{array}$ & $\begin{array}{l}37.1 \\
39.0 \\
35.5 \\
32.9\end{array}$ & $\begin{array}{l}+6.1 \\
+1.9 \\
-3.5 \\
-2.6 \\
\end{array}$ & $\begin{array}{l}+6.1 \\
+1.9 \\
-3.5 \\
-2.6 \\
\end{array}$ \\
\hline & & & $\ldots \ldots \ldots$ & +1.1 & $\begin{array}{lll}\cdots & \ldots \\
\end{array}$ & +1.9 & $\begin{array}{r}+1.9 \\
\end{array}$ \\
\hline & & & ( & +3.4 & ..... & +1.5 & $\ldots .$. \\
\hline
\end{tabular}

"There wa no change in weight of absorber and no drip in this experiment. 


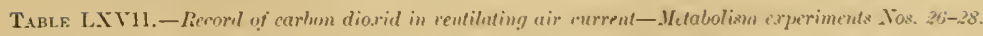

\begin{tabular}{|c|c|c|c|c|c|c|c|c|c|}
\hline \multirow{3}{*}{ Date. } & \multirow{3}{*}{ Period. } & \multirow[b]{3}{*}{$\begin{array}{l}\text { Ventilation. } \\
\text { Sumber of } \\
\text { liter of air. }\end{array}$} & \multicolumn{6}{|c|}{ Carbon dioxid. } & \multirow{3}{*}{$\begin{array}{c}\text { Total } \\
\text { weight of } \\
\text { carbon } \\
\text { exhaled, } \\
g \times \text { tt }\end{array}$} \\
\hline & & & \multicolumn{2}{|c|}{ In ineoming air. } & \multirow{2}{*}{$\begin{array}{l}\text { (d) } \\
\text { In outgo- } \\
\text { ing nir. }\end{array}$} & \multirow{2}{*}{$\begin{array}{c}(\epsilon) \\
\text { Total ex- } \\
\text { eesin in } \\
\text { outgoing } \\
\text { air, } \\
d-c \text {. }\end{array}$} & \multirow{2}{*}{$\begin{array}{l}(f) \\
\text { Corree- } \\
\text { tion for } \\
\text { amount } \\
\text { remain- } \\
\text { ing in } \\
\text { ebamber. }\end{array}$} & \multirow{2}{*}{$\begin{array}{l}(g) \\
\text { Correeted } \\
\text { amount } \\
\text { exhaled } \\
\text { br sub- } \\
\text { ject, } \\
f+f .\end{array}$} & \\
\hline & & & $\begin{array}{c}\text { (b) } \\
\text { Per liter. }\end{array}$ & $\begin{array}{l}\text { (c) } \\
\text { Total, } \\
a \times b\end{array}$ & & & & & \\
\hline $\begin{array}{l}1900 . \\
\text { Feb. } 1 \pm-15 \\
15-16 \\
16-17\end{array}$ & 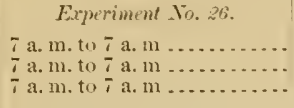 & $\begin{array}{l}\text { Liters. } \\
116,602 \\
118,158 \\
119,712\end{array}$ & 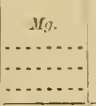 & $\begin{array}{l}\text { Grams. } \\
64.7 \\
65.7 \\
67.7\end{array}$ & $\begin{array}{l}\text { Grams. } \\
776.3 \\
795.9 \\
782.0\end{array}$ & $\begin{array}{l}\text { Grams. } \\
711.6 \\
730.2 \\
714.3 \\
\end{array}$ & $\begin{array}{l}\text { Grams } \\
+\quad 3.1 \\
-2.7 \\
+\quad 0.4 \\
\end{array}$ & $\begin{array}{l}\text { Grams. } \\
714.7 \\
727.5 \\
714.7\end{array}$ & $\begin{array}{r}\text { Grams. } \\
194.9 \\
145.4 \\
194.9 \\
\end{array}$ \\
\hline $\begin{array}{r}17 \\
17 \\
17-18 \\
18\end{array}$ & 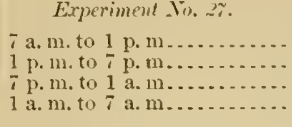 & $\begin{array}{l}29,5+0 \\
27,207 \\
24,5+0 \\
24,762\end{array}$ & $\begin{array}{r}0.567 \\
.610 \\
.561 \\
.554 \\
\end{array}$ & $\begin{array}{l}16.8 \\
16.6 \\
16.6 \\
15.9 \\
\end{array}$ & $\begin{array}{l}217.6 \\
215.5 \\
206.3 \\
146.2 \\
\end{array}$ & $\begin{array}{l}200.8 \\
198.9 \\
189.7 \\
130.3\end{array}$ & $\begin{array}{r}+10.1 \\
+\quad 4.7 \\
-14.2 \\
+\quad 3.4 \\
\end{array}$ & $\begin{array}{l}210.9 \\
203.6 \\
175.5 \\
133.7\end{array}$ & $\begin{array}{l}57.5 \\
55.5 \\
47.9 \\
36.5 \\
\end{array}$ \\
\hline & Total ..... & 115,049 & ...... & 65. 9 & 755.6 & 719.7 & +4.0 & $723.7 i$ & 197.4 \\
\hline $\begin{array}{r}18 \\
18 \\
15-19 \\
19\end{array}$ & 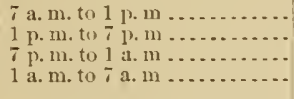 & $\begin{array}{l}25,762 \\
25,762 \\
29,5+0 \\
29,540\end{array}$ & $\begin{array}{l}.559 \\
.551 \\
.537 \\
.548\end{array}$ & $\begin{array}{l}16.1 \\
15.4 \\
15.9 \\
16.2\end{array}$ & $\begin{array}{l}220.5 \\
214.5 \\
206.2 \\
147.5\end{array}$ & $\begin{array}{l}204.7 \\
198.7 \\
190.3 \\
131.3\end{array}$ & $\begin{array}{r}+4.0 \\
+5.5 \\
-12.4 \\
+1.2 \\
\end{array}$ & $\begin{array}{l}20 \times .7 \\
204.2 \\
17.9 \\
132.5\end{array}$ & $\begin{array}{l}56.9 \\
55.7 \\
45.5 \\
36.1\end{array}$ \\
\hline & Total..... & 116,604 & -2. & 64.0 & 789.0 & 725.0 & -1.7 & 723.3 & $19 \% .2$ \\
\hline $\begin{array}{r}19 \\
19 \\
19-20 \\
20\end{array}$ & 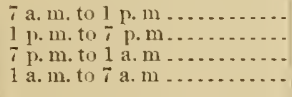 & $\begin{array}{l}27,205 \\
27,955 \\
29,540 \\
28,762\end{array}$ & $\begin{array}{l}.548 \\
.575 \\
.573 \\
.551\end{array}$ & $\begin{array}{l}14.9 \\
16.1 \\
16.4 \\
15.8\end{array}$ & $\begin{array}{l}209.5 \\
218.5 \\
2-20.1 \\
149.2\end{array}$ & $\begin{array}{l}194.6 \\
202.4 \\
203.2 \\
133.4\end{array}$ & $\begin{array}{r}+5.7 \\
+\quad 8.1 \\
-16.1 \\
+\quad 3.4\end{array}$ & $\begin{array}{l}200.3 \\
210.5 \\
187.1 \\
136.8\end{array}$ & $\begin{array}{l}54.6 \\
57.4 \\
51.0 \\
37.3\end{array}$ \\
\hline & Total & 113,495 & $\cdots$ & 63.7 & 797.3 & 733.6 & $\div 1.1$ & 734.7 & 200.3 \\
\hline $\begin{array}{l}20-21 \\
21-2 \cdot 2 \\
2 \cdot 2-23\end{array}$ & 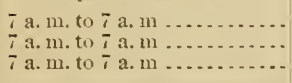 & $\begin{array}{l}112,717 \\
105,830 \\
111,162\end{array}$ & & $\begin{array}{l}64.3 \\
67.6 \\
66.4\end{array}$ & $\begin{array}{l}\$ 10.3 \\
8+3.3 \\
830.6\end{array}$ & $\begin{array}{l}776.0 \\
775.7 \\
764.2\end{array}$ & $\begin{array}{l}-2.3 \\
+4.8 \\
-0.2\end{array}$ & $\begin{array}{l}773.7 \\
7 \times 0.5 \\
764.0\end{array}$ & $\begin{array}{l}211.0 \\
212.5 \\
205.3\end{array}$ \\
\hline
\end{tabular}

TABLE LXV111. - Reeord of unter in ventilating air cmrent-Metubolism experiments . Vas. 26-28.

\begin{tabular}{|c|c|c|c|c|c|c|c|c|c|c|}
\hline \multirow[b]{2}{*}{ Date. } & \multirow[b]{2}{*}{ Period. } & \multirow[b]{2}{*}{$\begin{array}{l}\text { Ventilation. } \\
\text { Sumber oi } \\
\text { liters of air. }\end{array}$} & \multicolumn{2}{|c|}{$\begin{array}{c}\text { Water in ineom- } \\
\text { ing air. }\end{array}$} & \multicolumn{3}{|c|}{ Water in outgoing air. } & \multirow[b]{2}{*}{$\begin{array}{c}\text { Total ex- } \\
\text { cess water } \\
\text { in out- } \\
\text { going air. } \\
f-c .\end{array}$} & \multirow[b]{2}{*}{$\begin{array}{l}\text { Corsec- } \\
\text { tion for } \\
\text { water re- } \\
\text { maining } \\
\text { in ebam- } \\
\text { ber. }\end{array}$} & \multirow{2}{*}{$\begin{array}{l}\text { (i) } \\
\text { Total } \\
\text { water of } \\
\text { respira- } \\
\text { tion and } \\
\text { perspira- } \\
\text { tion, } \\
g+h .\end{array}$} \\
\hline & & & $\begin{array}{l}\text { Per } \\
\text { liter. }\end{array}$ & $\begin{array}{l}\text { (c) } \\
\text { Total, } \\
a \times b \text {. }\end{array}$ & $\begin{array}{c}(d) \\
\text { Amount } \\
\text { densed } \\
\text { in } \\
\text { freezers. }\end{array}$ & $\begin{array}{c}\text { (c) } \\
\text { Imount } \\
\text { not con- } \\
\text { densed in } \\
\text { freezers. }\end{array}$ & $\begin{array}{l}(f) \\
\text { Total, } \\
d+e\end{array}$ & & & \\
\hline Feb. $\begin{aligned} 1400 \\
15-15 \\
15-16 \\
16-17\end{aligned}$ & 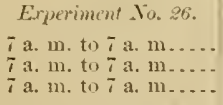 & $\begin{array}{l}\text { Liters. } \\
11+1,602 \\
115,158 \\
119,712\end{array}$ & $\begin{array}{c}\text { II } \\
\cdots \cdots \\
\cdots \cdots \\
\cdots \cdots\end{array}$ & $\begin{array}{r}\text { Grants. } \\
97.1 \\
101.8 \\
97.8\end{array}$ & $\begin{array}{l}\text { Grans. } \\
744.3 \\
734.3 \\
7 \geq 4.9\end{array}$ & $\begin{array}{l}\text { Grams. } \\
179.6 \\
175.4 \\
173.3\end{array}$ & $\begin{array}{l}\text { Grams. } \\
928,4 \\
909.7 \\
\$ 15.2\end{array}$ & $\begin{array}{l}\text { Grams } \\
831.8 \\
\text { i07.9 } \\
\text { sto.t }\end{array}$ & $\begin{array}{r}\text { Grams. } \\
-2.7 \\
-1.3 \\
-0.9\end{array}$ & $\begin{array}{l}\text { Grams. } \\
\$ 39.1 \\
\$ 06.6 \\
799.5\end{array}$ \\
\hline $\begin{array}{r}17 \\
17 \\
17-1 \text { i } \\
18\end{array}$ & 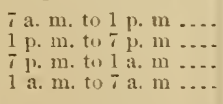 & $\begin{array}{l}29,5+0 \\
27,207 \\
24,5+0 \\
24,762\end{array}$ & $\begin{array}{l}x=0 \\
821 \\
8020 \\
820 \\
x-8\end{array}$ & $\begin{array}{l}24.2 \\
22.3 \\
24.5 \\
23.5\end{array}$ & $\begin{array}{l}183.9 \\
193.7 \\
184.7 \\
166.4\end{array}$ & $\begin{array}{l}42.5 \\
35.0 \\
45.2 \\
39.0\end{array}$ & $\begin{array}{l}226.4 \\
231.7 \\
2029.4 \\
2015.4\end{array}$ & $\begin{array}{l}202.2 \\
204.4 \\
205.4 \\
181.6\end{array}$ & $\begin{array}{r}-5.7 \\
+1.5 \\
-3.8 \\
-1.5\end{array}$ & $\begin{array}{l}207.9 \\
210.9 \\
201.6 \\
180.1\end{array}$ \\
\hline & Total & 115,049 & - . . & 94.8 & 728.7 & 164.7 & 693.4 & $79 x+6$ & -1.9 & 800.5 \\
\hline $\begin{array}{r}18 \\
18 \\
18-19 \\
19\end{array}$ & 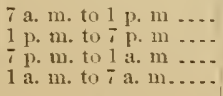 & $\begin{array}{l}24,762 \\
24,762 \\
29,540 \\
29,540\end{array}$ & $\begin{array}{l}.817 \\
800 \\
817 \\
.800\end{array}$ & $\begin{array}{l}23.5 \\
23.0 \\
24.2 \\
23.6\end{array}$ & $\begin{array}{l}194.5 \\
194.5 \\
185.5 \\
172.0\end{array}$ & $\begin{array}{l}43.6 \\
41.0 \\
43.8 \\
39.4\end{array}$ & $\begin{array}{l}235.1 \\
235.5 \\
224.3 \\
211.4\end{array}$ & $\begin{array}{l}214.6 \\
212.5 \\
20.5 .1 \\
1 \times 7.8\end{array}$ & $\begin{array}{l}+3.9 \\
+0.6 \\
-2.5 \\
-4.3\end{array}$ & $\begin{array}{l}215.5 \\
213.1 \\
202.6 \\
183.5\end{array}$ \\
\hline & Total ...... & 116.604 & ...... & 14.3 & $7+6.5$ & $367 .$. & 914.3 & $\therefore 0.0$ & -2.3 & sit. \\
\hline
\end{tabular}


TABLE LIY'III.-Record of nater in ventilating air current-Metabolism experiments Nos. 26-28-Continued.

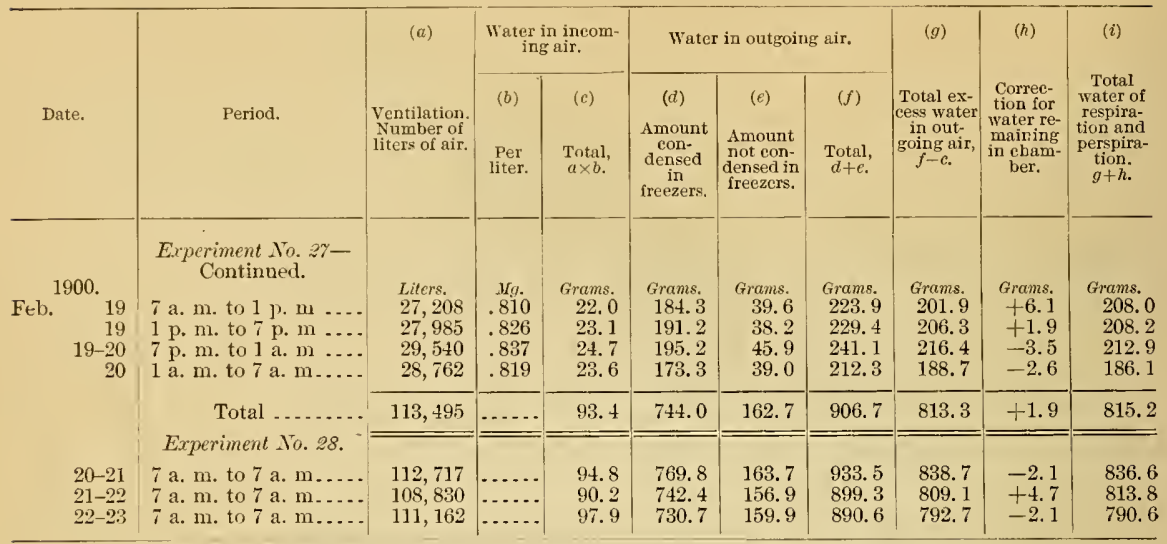

The heat carried away by the water current and the latent heat of vaporization of water in this series of experiments are shown in Table LXIX. As in the previous tables, the data are summarized for experiments Nos. 26 and 28 and given in detail for experiment No. 27, in which alcohol formed a part of the diet.

TABLE LXIX.-Summary of calorimetric measurements-Metabolism experiments Nos. 26-28.

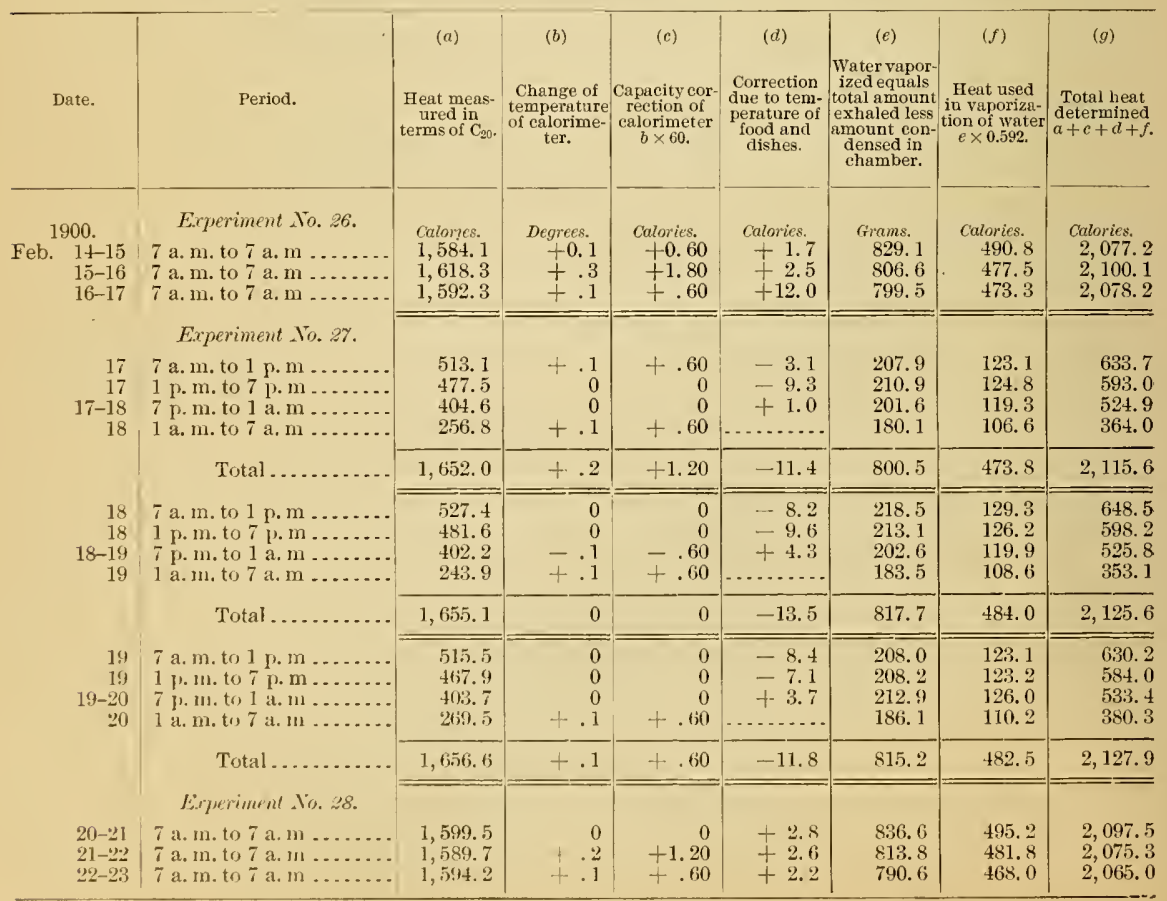


The determinations of alcohol in urine and freezer water and of reducing material reckoned as alcohol in the air current were made in the nsual mamer. and the results are given in Table LXX. It will be observed that there wis an elimination of redneing material equivalent to an arerage of 0.32 gram of alcohol per day on the 6 dars of experiments Nos. 26 and 28 . This amount has been deducted from the values obtained in experiment No, $2-5$. and the difference is taken as a measure of the alcohol excreted moxidized. It will likewise be observed that there is here no indication whatever of any lag in the elimination of alcohol from the body as was apparently indicated by the results ohtained in experiments Nos. 18-20.

TABLe LXX.-Aleohol ingested and excreted-Metubolism experiment No. 27.

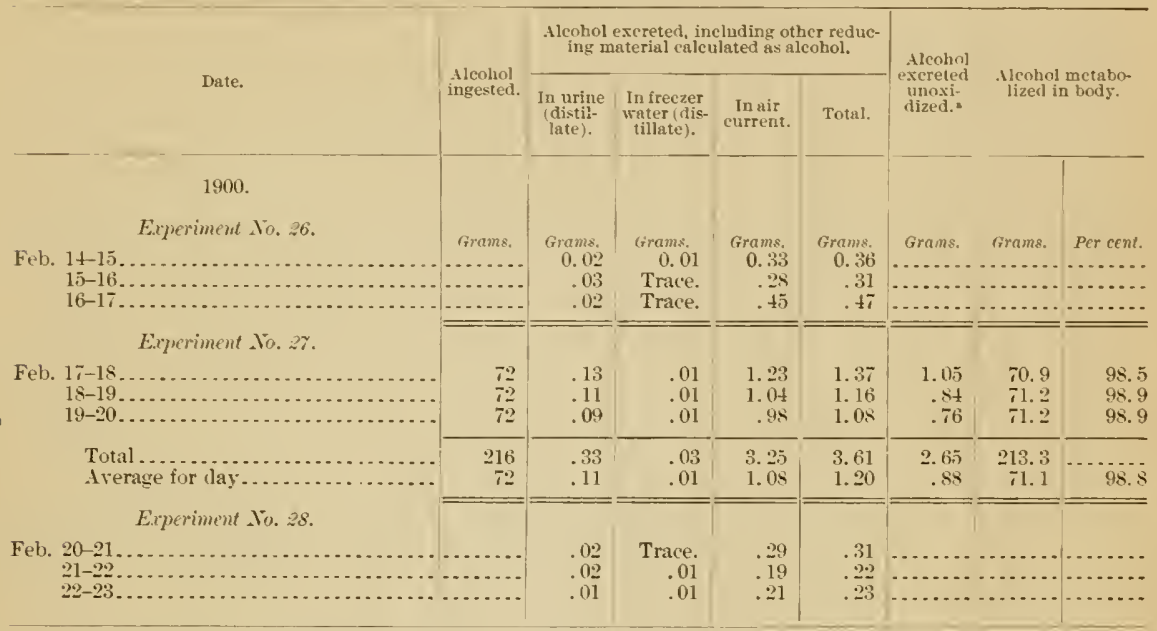

"Equals total reducing material excreted less 0.32 grams of reducing material not alcohol, the arerage for the day's on which no alcohol was consumed.

Bulance uf income and antgon of matter am energy.-Tables LXXI to LXXIV summarize the income and ontgo of nitrogen, carbon. hỵdrogen, and energy according to the plan adopted in previous experiments.

TABLE LXXI. - Income and outyo of nitrogen and carbon-Metabolism experiments . Tos. 26-28.

\begin{tabular}{|c|c|c|c|c|c|c|c|c|c|c|}
\hline \multirow[b]{2}{*}{ Date aral period. } & \multicolumn{4}{|c|}{ Nitrogen. } & \multicolumn{6}{|c|}{ Carbun. } \\
\hline & $\begin{array}{c}\text { (a) } \\
\text { In food. }\end{array}$ & $\begin{array}{c}\text { (b) } \\
\text { In feces. }\end{array}$ & $\begin{array}{c}\text { (c) } \\
\text { In urine. }\end{array}$ & $\begin{array}{c}\text { (d) } \\
\text { Gain }(+) \\
\operatorname{orloss}(-1) \\
a-(b+c)\end{array}$ & $\begin{array}{c}\text { (e) } \\
\text { In food. }\end{array}$ & $\begin{array}{c}(j) \\
\text { In feres. }\end{array}$ & $\begin{array}{c}(g) \\
\text { In urine. }\end{array}$ & $\begin{array}{l}\quad(h) \\
\text { In respir- } \\
\text { atory } \\
\text { products. }\end{array}$ & $\begin{array}{l}\quad(i) \\
\text { In aleohol } \\
\text { eliminat- } \\
\text { ed. }\end{array}$ & $\begin{array}{c}(k) \\
\text { Gain }(+) \\
\text { orlos }(-) \\
c-(f+g \\
+h+i) .\end{array}$ \\
\hline $\begin{array}{c}1900 . \\
\text { Experiment No. ¿ó. } \\
\text { Feb. } 14-15,7 \text { a.m. to } 7 \text { a.m. } \\
15-16, \text { a.m. to } 7 \text { a.m. } \\
16-17,7 \text { a.m.to } 7 \text { a.m. }\end{array}$ & $\begin{array}{r}\text { Grams. } \\
15.9 \\
15.9 \\
15.9\end{array}$ & $\begin{array}{r}\text { Grams. } \\
1.1 \\
1.1 \\
1.1\end{array}$ & $\begin{array}{l}\text { Grams. } \\
16.6 \\
15.1 \\
14.4\end{array}$ & $\begin{array}{r}\text { Grams. } \\
-1.8 \\
-3 \\
-.4\end{array}$ & $\begin{array}{l}\text { Grams. } \\
233.2 \\
233.2 \\
233.2\end{array}$ & $\begin{array}{r}\text { Groms. } \\
9.4 \\
9.5 \\
9.4\end{array}$ & $\begin{array}{l}\text { Grams. } \\
11.9 \\
10.8 \\
10.4\end{array}$ & $\begin{array}{l}\text { (irems. } \\
194.9 \\
195.4 \\
194.9\end{array}$ & $\begin{array}{c}\text { Grams. } \\
\ldots \\
\ldots\end{array}$ & $\begin{array}{l}\text { Grams. } \\
+17.0 \\
+14.5 \\
+18.5\end{array}$ \\
\hline $\begin{array}{l}\text { Total .............. } \\
\text { Average jer day ... }\end{array}$ & $\begin{array}{l}47.7 \\
15.9\end{array}$ & $\begin{array}{l}3.3 \\
1.1\end{array}$ & $\begin{array}{l}46.1 \\
15.4\end{array}$ & $\begin{array}{l}-1.7 \\
-.6\end{array}$ & $\begin{array}{l}699.6 \\
233.2\end{array}$ & $\begin{array}{r}28.3 \\
9.4\end{array}$ & $\begin{array}{l}33.1 \\
11.0\end{array}$ & $\begin{array}{l}5 \times 5.2 \\
196.1\end{array}$ & (....... & $\begin{array}{l}+50.0 \\
+16.7\end{array}$ \\
\hline
\end{tabular}


TABLE LXXI.-Income and outyo of nitrogen and carbon-Metabolism experiments Nos. 26-2S-Continued.

\begin{tabular}{|c|c|c|c|c|c|c|c|c|c|c|}
\hline \multirow[b]{2}{*}{ Date and period. } & \multicolumn{4}{|c|}{ Nitrogen. } & \multicolumn{6}{|c|}{ Carbon. } \\
\hline & In food. & $\begin{array}{c}\text { (b) } \\
\text { In feces. }\end{array}$ & In urine. & $\mid \begin{array}{c}(a) \\
\operatorname{Gain}(+) \\
\operatorname{or} \operatorname{loss}(-)) \\
a-(b+c)\end{array}$ & (e) & $\begin{array}{c}(f) \\
\text { In feces. }\end{array}$ & In urine. & $\begin{array}{l}(h) \\
\text { In respir- } \\
\text { atory } \\
\text { prodncts. }\end{array}$ & $\begin{array}{l}\text { (i) } \\
\text { In alcohol } \\
\text { eliminat- } \\
\text { ed. }\end{array}$ & $\begin{array}{c}(k) \\
\text { Gain }(+) \\
\text { or } \operatorname{los}(-) \\
e-(f+g \\
+h+i)\end{array}$ \\
\hline $\begin{array}{l}1900 . \\
\text { Experiment to } 27 . \\
17-18,7 \text { a. m. to } 7 \text { a. m. } \\
18-19,7 \text { a. } 11 \text {. to } 7 \text { a. m. } \\
19-20,7 \text { a. m. to } 7 \text { a. } m .\end{array}$ & $\begin{array}{r}\text { Grams. } \\
15.8 \\
15.7 \\
15.8\end{array}$ & $\begin{array}{r}\text { Grams. } \\
1.1 \\
1.1 \\
1.1\end{array}$ & $\begin{array}{r}\text { Grams. } \\
14.6 \\
15.5 \\
16.8\end{array}$ & $\begin{array}{l}\text { Grams. } \\
+\quad .1 \\
-.9 \\
-2.1\end{array}$ & $\begin{array}{l}\text { Grams. } \\
229.5 \\
229.5 \\
229.5\end{array}$ & $\begin{array}{r}\text { Grams. } \\
8.9 \\
9.0 \\
8.9\end{array}$ & $\begin{array}{l}\text { Grams. } \\
10.5 \\
11.1 \\
12.0\end{array}$ & $\begin{array}{l}\text { Grams } \\
197.4 \\
197.2 \\
200.3\end{array}$ & $\begin{array}{r}\text { Grams. } \\
0.5 \\
0.4 \\
0.4\end{array}$ & $\begin{array}{l}\text { Grams. } \\
+12.2 \\
+11.8 \\
+7.9\end{array}$ \\
\hline $\begin{array}{l}\text { Total . . . . . . . . . } \\
\text { Average per day ... }\end{array}$ & $\begin{array}{l}47.3 \\
15.8\end{array}$ & $\begin{array}{l}3.3 \\
1.1\end{array}$ & $\begin{array}{l}46.9 \\
15.7\end{array}$ & $\begin{array}{l}-2.9 \\
-1.0 \\
\end{array}$ & $\begin{array}{l}688.5 \\
229.5\end{array}$ & $\begin{array}{r}26.8 \\
8.9\end{array}$ & $\begin{array}{l}33.6 \\
11.2\end{array}$ & $\begin{array}{l}594.9 \\
198.3\end{array}$ & $\begin{array}{r}1.3 \\
.5\end{array}$ & $\begin{array}{r}+31.9 \\
+10.6 \\
\end{array}$ \\
\hline $\begin{array}{l}\text { Experiment } \mathrm{No} .28 \text {. } \\
20-21,7 \text { a. m. to } 7 \text { a. m. } \\
21-22,7 \text { a. m. to } 7 \text { a. m. } \\
22-23,7 \text { a. m. to } 7 \text { a. m. }\end{array}$ & $\begin{array}{l}15.8 \\
15.7 \\
15.8\end{array}$ & $\begin{array}{l}1.2 \\
1.3 \\
1.2\end{array}$ & $\begin{array}{l}15.9 \\
15.2 \\
14.7\end{array}$ & $\begin{array}{r}-1.3 \\
-.8 \\
-.1\end{array}$ & $\begin{array}{l}245.8 \\
245.8 \\
245.8\end{array}$ & $\begin{array}{l}10.0 \\
10.0 \\
10.0\end{array}$ & $\begin{array}{l}11.4 \\
10.9 \\
10.5\end{array}$ & $\begin{array}{l}211.0 \\
212.8 \\
208.3\end{array}$ & (1) & $\begin{array}{r}+13.4 \\
+12.1 \\
+17.0\end{array}$ \\
\hline $\begin{array}{l}\text { Total ........... } \\
\text { Average per day ... }\end{array}$ & $\begin{array}{l}47.3 \\
15.8\end{array}$ & $\begin{array}{l}3.7 \\
1.2\end{array}$ & $\begin{array}{l}45.8 \\
15.3\end{array}$ & $\begin{array}{l}-2.2 \\
-.7\end{array}$ & $\begin{array}{l}737.4 \\
245.8\end{array}$ & $\begin{array}{l}30.0 \\
10.0\end{array}$ & $\begin{array}{l}32.8 \\
10.9\end{array}$ & $\begin{array}{l}632.1 \\
210.7\end{array}$ & - $\ldots \ldots$ & $\begin{array}{l}+42.5 \\
+14.2\end{array}$ \\
\hline
\end{tabular}

TABLE LXXII.-Income and outgo of water and hydrogen-Metabolism experiments Nos. 26-28.

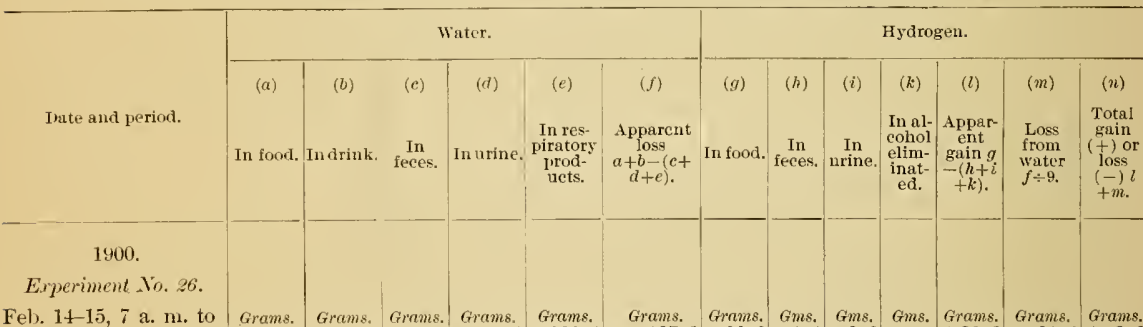

Feb. $14-15,7$ a. m. to Grams. Grams, Grams. Grams. Grams. Grams. Grams. Gms. Gms. Gms. Grams. Grams. Grams.

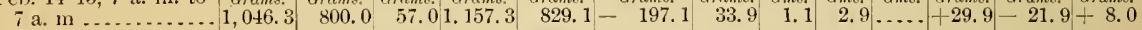
Feb. 15-16, 7 a. m. to

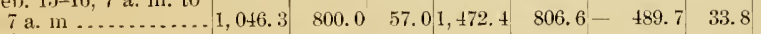

Feb. $16-17,7$ a. 11 . to 7 a. $\mathrm{m}$.............. 1,046. \begin{tabular}{|c|c|c|c|c|}
$1,046.3$ & 800.0 & $57.01,289.0$ & $799.5-299.2$ & 33.9 \\
\hline $3,188.0$ & &
\end{tabular}

Total ........ $\overline{3,138.9} \overline{2,400.0} \overline{171.0} \overline{3,918.7} \overline{2,435.2} \overline{986.0} \overline{101.6} \overline{3.4} \overline{8.0} \overline{\ldots \ldots} \overline{+90.2} \overline{-109.5} \overline{-19.3}$

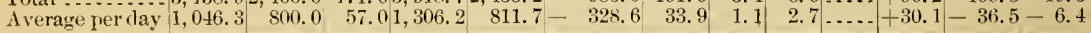
Experiment io. $2 \%$.

Fel). 17-1s; 7 a. m. to

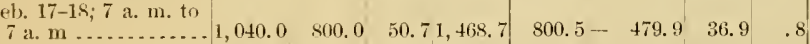

Fel. $18-19,7$ a. m. to

\begin{tabular}{ll|l|l|l}
7 a. m............ $1,040.0$ & 800.0 & $50.71,381.1$ & $817.7-409.5$ & 36.9
\end{tabular}

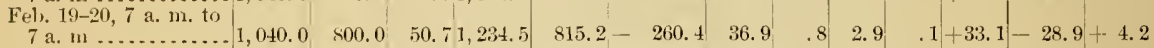

$1.2 \quad 2.6 \ldots+30.0-54.4-24.4$

Total ....... $\overline{3,120.02,400.0} \overline{152.1} \overline{4,084.2} \overline{2,433.4-1,149.8} \overline{110.7} \overline{2.4} \overline{8.1} \overline{.3} \overline{+99.9} \overline{-127.7} \overline{-27.8}$

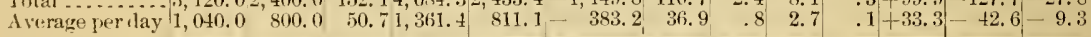

Expromert $1 \% 28$.

Fel., $20-21,7$ a. m. to

7 a. $11 \ldots \ldots \ldots \ldots .1,040.0 \quad 800.0 \quad 51.71,113.2 \quad 836.6-161.5 \quad 35.8 \quad 1.3 \quad 2.8 \ldots \ldots+31.7-17.4+13.8$

F(b), $21-22,7$ a. in. to

7а. 11 .......... 1,040.0 800.0 $51.81,238.0 \quad 813.8-263.6 \quad 35.8 \quad 1.4 \quad 2.6 \ldots+31.8-29.3+2.5$

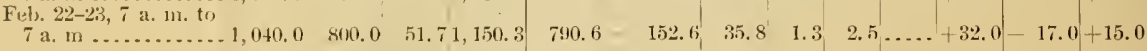

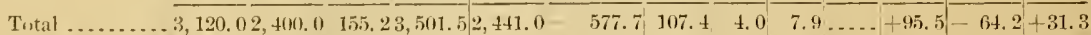

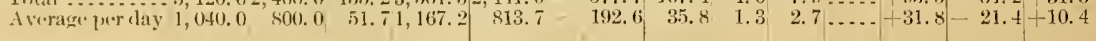




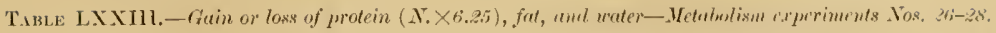

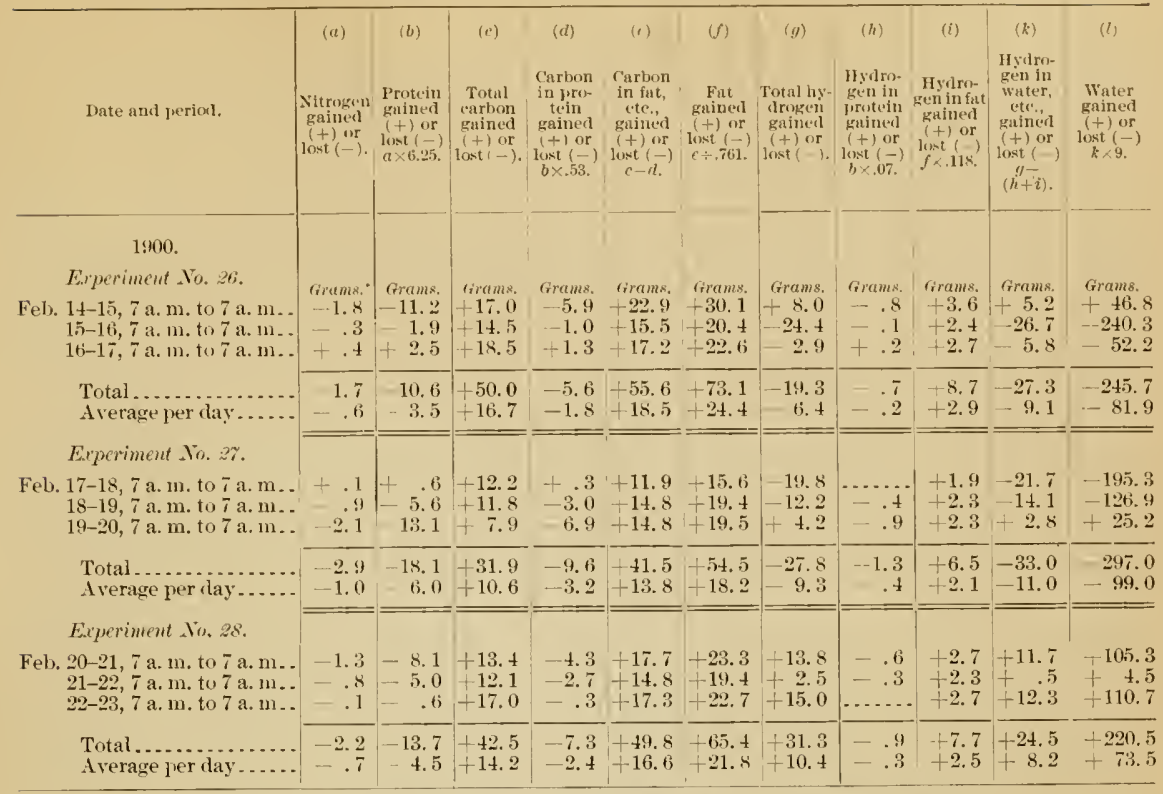

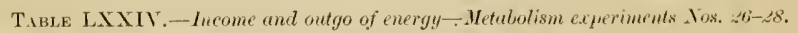

\begin{tabular}{|c|c|c|c|c|c|c|c|c|c|c|}
\hline \multirow[b]{2}{*}{ Date and period. } & \multirow[b]{2}{*}{$\begin{array}{l}\text { Heat of } \\
\text { eombus- } \\
\text { tion of } \\
\text { food } \\
\text { eaten. }\end{array}$} & \multirow[b]{2}{*}{$\begin{array}{l}\text { Heat of } \\
\text { combus- } \\
\text { tion of } \\
\text { feces. }\end{array}$} & \multirow[b]{2}{*}{$\begin{array}{l}\text { Heat of } \\
\text { eombus- } \\
\text { tion of } \\
\text { urine. }\end{array}$} & \multirow{2}{*}{$\begin{array}{c}(m) \\
\text { Heat of } \\
\text { combus- } \\
\text { tion of } \\
\text { alcohol } \\
\text { elimi- } \\
\text { nated. }\end{array}$} & \multirow{2}{*}{$\begin{array}{c}(d) \\
\text { Estimated } \\
\text { heat of } \\
\text { combus- } \\
\text { tion of } \\
\text { protein } \\
\text { gained } \\
(+) \text { or } \\
\text { lost }(-) .\end{array}$} & \multirow{2}{*}{$\begin{array}{c}(e) \\
\text { Estimated } \\
\text { heat of } \\
\text { combus- } \\
\text { tion of fint } \\
\text { gnined } \\
(+) \text { or } \\
\text { lost }(-)\end{array}$} & \multirow{2}{*}{$\begin{array}{c}(f) \\
\text { Estimated } \\
\text { enerrgy of } \\
\text { material } \\
\text { oxidized } \\
\text { in the } \\
\text { body. } \\
a-(b+c+ \\
m+d+c .)\end{array}$} & \multirow[b]{2}{*}{$\begin{array}{l}\text { Heat de- } \\
\text { termined. }\end{array}$} & \multicolumn{2}{|c|}{$\begin{array}{l}\text { Heat determined } \\
\text { greater }(+) \text { or less } \\
(-) \text { than estimated, }\end{array}$} \\
\hline & & & & & & & & & $\begin{array}{c}(h) \\
f-g .\end{array}$ & $\begin{array}{l}(i) \\
h \div f\end{array}$ \\
\hline $\begin{array}{c}1900 . \\
\text { Experiment Vo. } 26 . \\
\text { Feb. } 14-15,7 \text { a.m. to } 7 \text { a.m. } \\
15-16,7 \text { a.m. to } 7 \text { a. m. } \\
16-17,7 \text { a.m. to } 7 \text { a. m. }\end{array}$ & $\begin{array}{r}\text { Culories. } \\
2,490 \\
2,490 \\
2,490\end{array}$ & $\begin{array}{r}\text { Calories. } \\
106 \\
106 \\
106\end{array}$ & $\begin{array}{r}\text { Calorics. } \\
125 \\
125 \\
135\end{array}$ & $\begin{array}{c}\text { Calorics. } \\
\ldots . . . \\
\ldots \ldots \\
\ldots .\end{array}$ & $\begin{array}{r}\text { Cutories. } \\
-\quad 64 \\
-\quad 11 \\
+\quad 14 \\
\end{array}$ & $\begin{array}{r}\text { Calaries, } \\
+287 \\
+195 \\
+216 \\
\end{array}$ & $\begin{array}{r}\text { Calories. } \\
2,036 \\
2,075 \\
2,019\end{array}$ & $\begin{array}{c}\text { Crlarics. } \\
2,077 \\
2,100 \\
2,078\end{array}$ & $\begin{array}{r}\text { Calories. } \\
+\quad+1 \\
+\quad 25 \\
+\quad 59 \\
\end{array}$ & $\begin{array}{r}\text { Per cent. } \\
+2.0 \\
+1.2 \\
+\mathbf{2} .9\end{array}$ \\
\hline $\begin{array}{l}\text { Total ............ } \\
\text { Average per rlay } . . .\end{array}$ & $\begin{array}{l}7,470 \\
2,490\end{array}$ & $\begin{array}{l}318 \\
106 \\
\end{array}$ & $\begin{array}{l}385 \\
128 \\
\end{array}$ & ( $\cdots \cdots$ & $\begin{array}{r}-61 \\
-\quad 20 \\
\end{array}$ & $\begin{array}{r}+698 \\
+233 \\
\end{array}$ & $\begin{array}{l}6,130 \\
2,043 \\
\end{array}$ & $\begin{array}{l}6,255 \\
2,085 \\
\end{array}$ & $\begin{array}{r}+125 \\
+\quad 42 \\
\end{array}$ & $\begin{array}{r}2.0 \\
\end{array}$ \\
\hline $\begin{array}{l}\text { Experiment No. } 2 \% \text {. } \\
\text { Feb. } 17-18,7 \text { a. m. to } 7 \text { a. m. } \\
18-19,7 \text { a. m. to } 7 \text { a. m. } \\
19-20,7 \text { a. m. to } 7 \text { a. m. }\end{array}$ & $\begin{array}{l}2,491 \\
2,491 \\
2,491\end{array}$ & $\begin{array}{l}97 \\
97 \\
97\end{array}$ & $\begin{array}{l}111 \\
121 \\
140\end{array}$ & $\begin{array}{l}7 \\
6 \\
5\end{array}$ & $\begin{array}{r}+3 \\
-\quad 32 \\
-\quad 75\end{array}$ & $\begin{array}{r}+149 \\
+185 \\
+186\end{array}$ & $\begin{array}{l}2,124 \\
2,114 \\
2,138\end{array}$ & $\begin{array}{l}2,116 \\
2,126 \\
2,128\end{array}$ & $\begin{array}{r}8 \\
+\quad 12 \\
-\quad 10\end{array}$ & $\begin{array}{r}-.4 \\
+\quad .6 \\
-.5\end{array}$ \\
\hline $\begin{array}{l}\text { Total ............. } \\
\text { Average per day ... }\end{array}$ & $\begin{array}{l}7,473 \\
2,+91\end{array}$ & $\begin{array}{r}291 \\
97 \\
\end{array}$ & $\begin{array}{l}372 \\
124 \\
\end{array}$ & $\begin{array}{r}18 \\
6 \\
\end{array}$ & $\begin{array}{r}-104 \\
-35 \\
\end{array}$ & $\begin{array}{r}+520 \\
+174 \\
\end{array}$ & $\begin{array}{l}6,376 \\
2,125\end{array}$ & $\begin{array}{l}6,370 \\
2,123 \\
\end{array}$ & $\begin{array}{r}6 \\
-\quad 6 \\
-\quad 2 \\
\end{array}$ & -.1 \\
\hline $\begin{array}{l}\text { Erperiment To. } 28 . \\
\text { Feb. } 20-21,7 \text { a. m. to } 7 \text { a. m. } \\
21-22,7 \text { a. } m \text {. to } 7 \text { a. } m \text { - } \\
22-23,7 \text { a. m. to } 7 \text { a.m. }\end{array}$ & $\begin{array}{l}2,489 \\
2,489 \\
2,489\end{array}$ & $\begin{array}{l}112 \\
112 \\
112\end{array}$ & $\begin{array}{l}\cdot \\
119 \\
133 \\
132\end{array}$ & (n. & $\begin{array}{r}47 \\
-\quad 29 \\
-\quad 3\end{array}$ & $\begin{array}{r}+222 \\
+185 \\
+217 \\
\end{array}$ & $\begin{array}{l}2,083 \\
2,088 \\
2,031\end{array}$ & $\begin{array}{l}2,097 \\
2,075 \\
2,065\end{array}$ & $\begin{array}{r}+14 \\
-13 \\
+34\end{array}$ & $\begin{array}{r}+.7 \\
-.6 \\
+1.7 \\
\end{array}$ \\
\hline $\begin{array}{l}\text { Total ............... } \\
\text { Average per day ... }\end{array}$ & $\begin{array}{l}7,467 \\
2,489\end{array}$ & $\begin{array}{l}336 \\
112\end{array}$ & $\begin{array}{l}384 \\
128\end{array}$ & (n. & $\begin{array}{r}79 \\
-\quad 26\end{array}$ & $\begin{array}{r}+624 \\
+208\end{array}$ & $\begin{array}{l}6,202 \\
2,067\end{array}$ & $\begin{array}{l}6,237 \\
2,079\end{array}$ & $\begin{array}{l}+35 \\
+\quad 12\end{array}$ & \\
\hline
\end{tabular}




\section{EXPERIMENTS NOS. 29-31-WORK. NO. 30 WITH ALCOHOL DIET.}

Subject.-J. F. S., who served as the subject of the previous series of rest experimeuts Nos. 26-28. His weight with underclothing was about 64.5 kilograms (142 pounds).

Occupation during experiment. - Work, 8 hours a day, upon a stationary bicycle arranged as an ergometer, as described on page 237.

Duration.- This experiment was the second of a series of 3 , each of which continued 3 days. The preliminary period continued $t$ days, beginning with breakfast March 12, 1900. On the evening of the fourth day, March 15, the subject entered the calorimeter. The first of the 3 series of experiments, No. 29, began at 7 a. m. March 16, and continued until 7 a. m. March 19, when experiment No. 30 began and continued until 7 a. m. March 22, and in turn was followed by experiment No. 31, which continned until 7 a. m. March 25. The subject therefore remained in the respiration chamber 9 days and 10 nights.

Diet.-The object of this series of experiments was to study the relative replacing power of isodynamic quantities of sugar, alcohol, and fat, when the subject was at active exereise. There was a basal lation, as in the prerions series, which was practically the same in the 3 experiments, the only difference being that due to slight rariations in the composition of the milk consumed. It furnished, approximately, 100 grams of protein and from 2,949 to 2,984 calories of energy per day in the different periods. To this ration was added, in experiment No. 29, 128 grams of cane sugar per day, furnishing 507 calories of energy. In experiment No. 30 the supplemental ration consisted of 72 grams of absolute alcohol per day, furnishing 509 calories of energy. In experiment No. 31 the supplemental ration consisted of 63.5 grams of butter per day, furnishing 1 gram of protein and 511 calories of energy.

To 795.5 grams of water sweetened with 25 grams of sugar were added 79.5 grams of 90.6 per cent commercial alcohol containing 72 grams absolute alcohol. This alcohol mixture was taken with and between meals in experiment No. 30 as in previous experiments. The sugar in experiment No. 29 was likewise taken with and between meals, but the butter in experiment No. 31 was consumed with the rest of the food in approximately equal portions at breakfast, dinner, and supper. The same amount of water was given in the drink on each day of the experiment and amounted to 1,250 grams per day. In experiment No. 30, 803 grams of this water was furnished by the alcohol mixture. The kinds and quantities of food served at each meal and the quantities of drink at different periods of the day were as follows:

Diet in metabolism experiments Nos, 29-91.

FOOD-BASAL RATION.

\begin{tabular}{|c|c|c|c|c|}
\hline & Breakfast. & Dinner. & Supper. & Total. \\
\hline 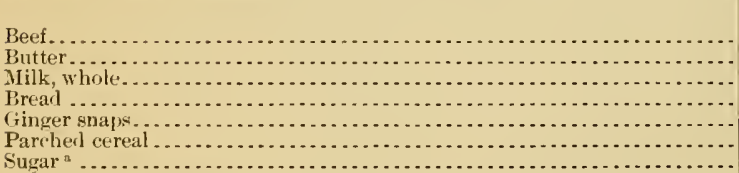 & $\begin{array}{l}\text { Grams. } \\
12 \\
300 \\
75 \\
25 \\
37.5 \\
12.5\end{array}$ & $\begin{array}{r}\text { Groms. } \\
58 \\
23 \\
300 \\
150 \\
25 \\
-. . .\end{array}$ & $\begin{array}{c}\text { Grams. } \\
12 \\
300 \\
75 \\
25 \\
37.5 \\
12.5\end{array}$ & $\begin{array}{r}\text { Grams. } \\
58 \\
47 \\
900 \\
300 \\
75 \\
75 \\
25\end{array}$ \\
\hline
\end{tabular}

" Gaten on farched cereal in experiments Nos. 29 aml 31; adderl to water and alcohol in experiment No. 30.

FOOD-SUPPLEMENTAL RATION.

Erperiment No. 29, Wurch 16-18. - 128 grams of cane sugar daily in the form of loaf sugar, taken with and between meals. This amount also supplemented the basal ration during the preliminary experiment March 12-15.

Esperiment 15. 30, Aferch 19-21.-72 grams absolute alcohol taily. This required 79.5 grams of 90.57 per cent alcohol, which was made up to 900 grams with the addlition of 25 grams sugar and the rest water.

Erperiment No. 31, March 22-24.-The additional energy during this experiment was furnished by 63.5 grams butter. 
Diet in metabolism experiments Los. 29-31.

DRINK.

\begin{tabular}{|c|c|c|c|c|}
\hline & $\begin{array}{c}\text { Experiment } \\
\text { No.29. }\end{array}$ & \multicolumn{2}{|c|}{ Experiment No. 30.} & $\begin{array}{l}\text { Experiment } \\
\text { No.3i. }\end{array}$ \\
\hline & Water. & $\begin{array}{l}\text { Aicohol and } \\
\text { sweetened } \\
\text { water. }\end{array}$ & Water. & Water. \\
\hline 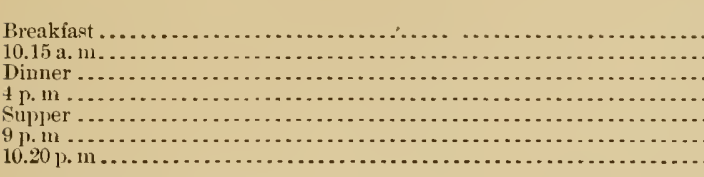 & $\begin{array}{r}\text { Grams. } \\
150 \\
200 \\
200 \\
200 \\
150 \\
200 \\
150\end{array}$ & $\begin{array}{r}\operatorname{Grams} \\
175 \\
100 \\
175 \\
100 \\
175 \\
100 \\
75\end{array}$ & $\begin{array}{r}\text { Grams. } \\
75 \\
75 \\
75 \\
75 \\
75 \\
72\end{array}$ & $\begin{array}{r}\text { Grams } \\
150 \\
200 \\
200 \\
200 \\
150 \\
200 \\
150\end{array}$ \\
\hline Total.. & 1,250 & ${ }^{2} 900$ & 447 & 1,250 \\
\hline
\end{tabular}

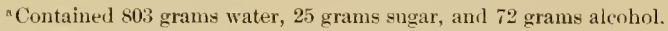

Daily routine. - The general routine of the series of experiments is indicated in the following schedule:

Daily programme-Metabolism experiments Nos. 29-31.

$6.50 \mathrm{a} \mathrm{m} . . . .$. Take pulse and temperature.

7 a. $\mathrm{m}$......... Pass urine, weigh self dressed, collect drip and weigh absorbers.

7.30 a. m ...... Breakfast. Drink 150 grams water.

8.15 a. m....... Begin work.

10.15 a. 11 ..... Stol? work. Drink 200 grams water.

10.30 a. m...... Begin work.

$12.30 \mathrm{p} . \mathrm{m}$...... Stop work.

$12.50 \mathrm{p} . \mathrm{m}$...... Take pulse and temperature.

1 p. m........ Pass urine, collect drip and weigh absorbers.

1.25 p. $\mathrm{m}$...... Dinner. Irink 200 grams water.

2 p. m......... Begin work. 4p. m....... Stop work. Drink 200 grams water.

4.15 r. $\mathrm{m}$...... Begin work.

$6.15 \mathrm{j} . \mathrm{m}$...... Stop work. Change underclothing.

6.20 p. m ..... . Supper. Drink 150 grams water.

$6.50 \mathrm{j.m} \ldots . .$. Take pulse and temperature.

7 p. m........ Pass urine, weigh self dressed, collect drip and weigh alsorbers.

9 p. m....... . Drink 200 grams water.

$10 \mathrm{p} . \mathrm{m} . . . . . .$. Take pulse and temperature.

10.10 p. m .... Arrange bed.

$10.20 \mathrm{p} . \mathrm{m}$.... Drink 150 grams water.

10.30 p. $\mathrm{m}$..... . Retire.

1 a. m ....... . Pass urine.

Table LXXV summarizes the nore important statisties in the diary kept by the subject. The pulse late was observed during periods of both work and rest. The observations of body temperature could not he made as frequently as in the previous series of (rest) experiments, but were frequent enough to aftord basis of comparison between the different experiments of this series.

Amount of work done.-The total number of miles registered by the eyclometer on different days of the series of experiments and the heat equivalent of the work done each day are shown in Table LXXVI. As has already been pointed out, the amount of work done could hardly have been as large as would be required to propel a bicycle the number of miles recorded by the cyelometer. It will be ohserved that there was but little difference in the average amounts of work done in different days in the different experiments of this series. 
TABLe LXXY.-Summary of the diany-Metabolism experiments Nos. 29-31.

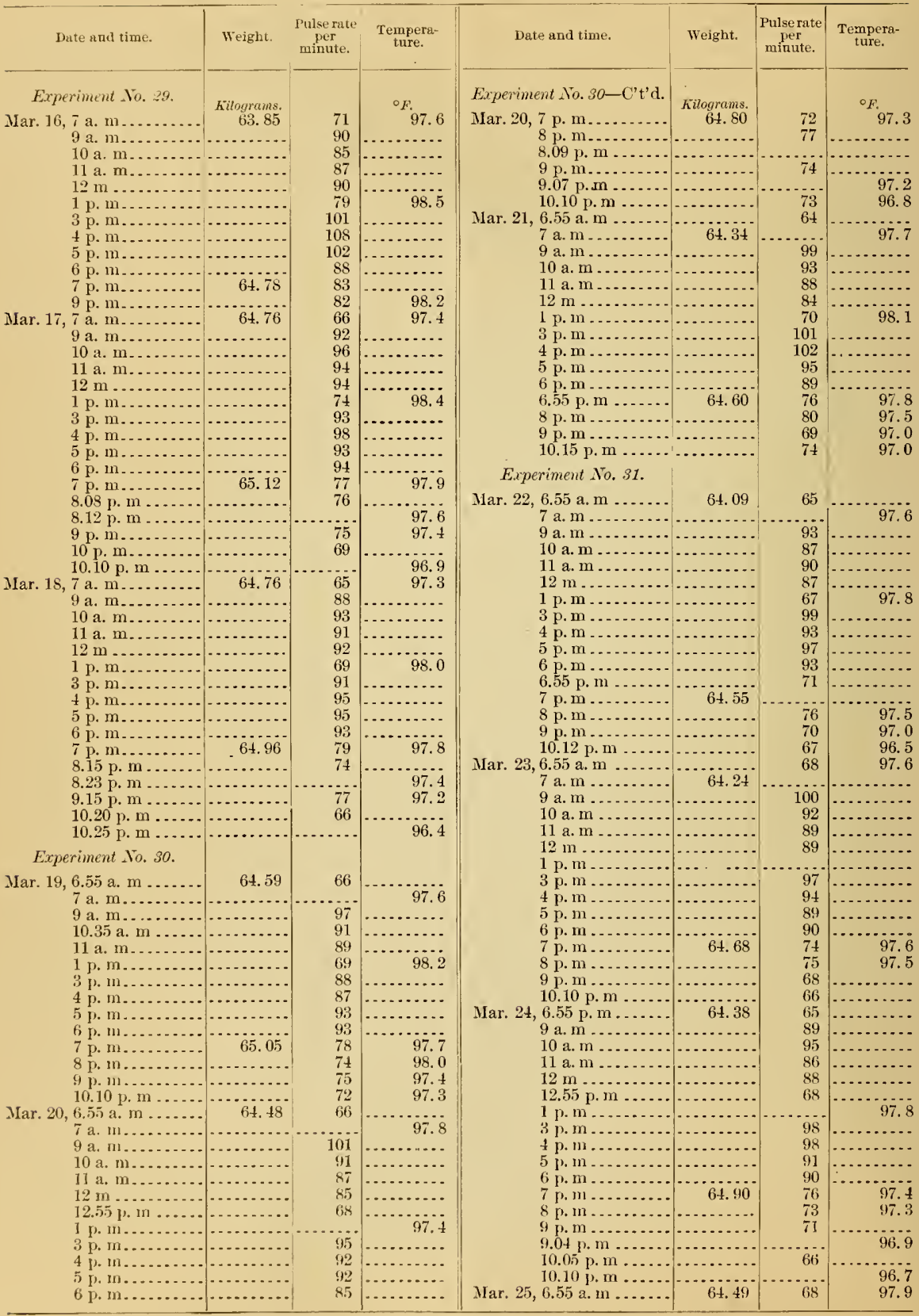


TABLE LXXVI.-Record of mork done-Metubolism experiments Nos. 29-81.

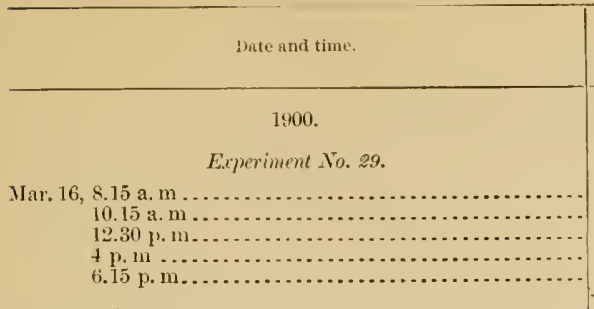

Total

IIar. $17,10.15$ a. $\mathrm{m}$

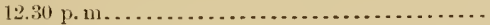

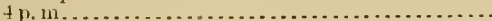

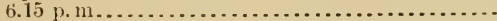

Total

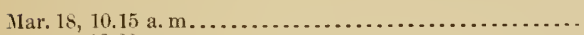

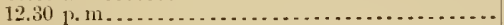

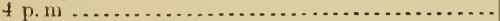
6.15 p. m.

Total

Experiment \o. 80.

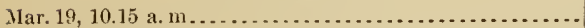

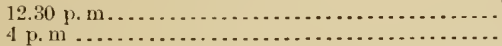
6.15 p. $\mathrm{m}$

Total

Mar. $20,10.15$ a. $m$ $12.30 \mathrm{p} .1$ $6.15 \mathrm{p} . \mathrm{m}$

Total

Mar. 21, 10.15 a. m 12.30 p. m 4 p. m...

Total

\section{Experiment No. 31.}

$\operatorname{Mar} .22,10.15$ a. $\mathrm{m}$ 12.30 p. $\mathrm{m}$. 4 p. $\mathrm{m} . \mathrm{p} . \mathrm{m}$

Total

Mar, 23, 10.15 a.m 12.30 p. $\mathrm{m}$ $+\mathrm{p}, \mathrm{m} . .$.
6.15 p. $\mathrm{m}$.

Total

Mar. $24,10.15$ a. $m$

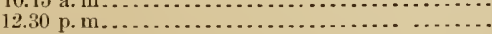
$+\mathrm{p} . \mathrm{m}$.. $6.15 \mathrm{p} . \mathrm{m}$

Total .

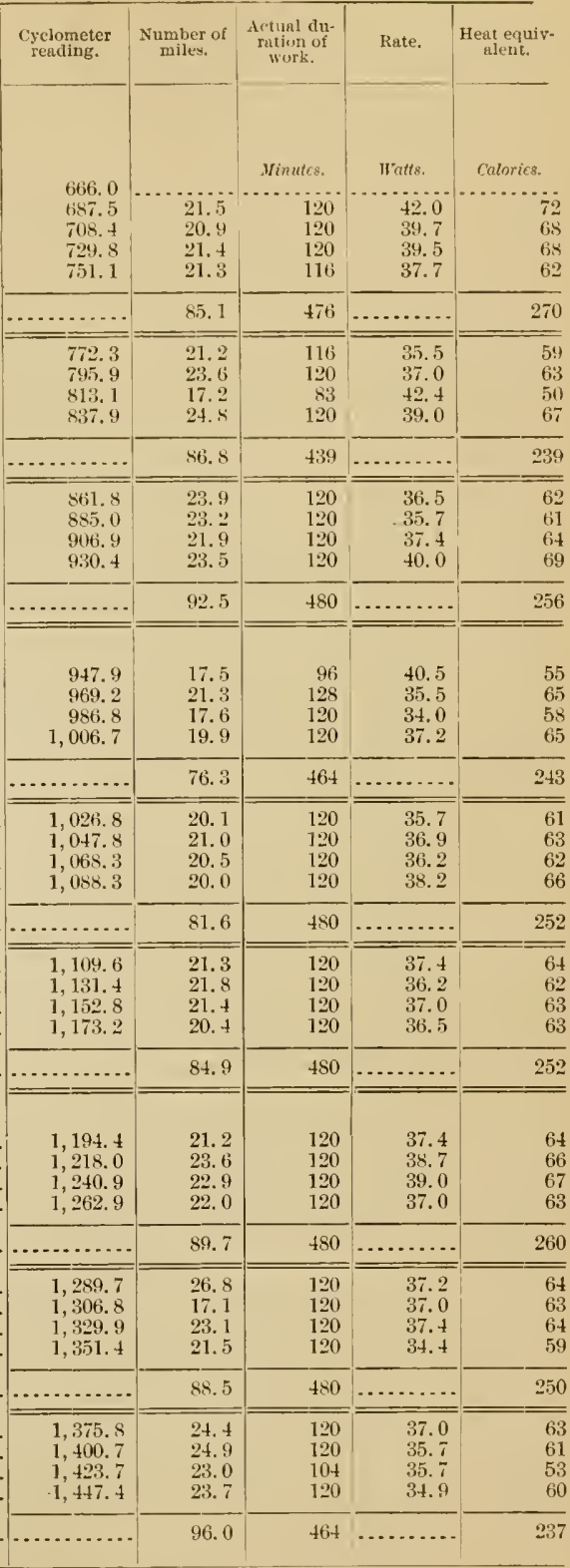

Vol. s-No. 6- -9 
Mhtrild stutisties of income and. ontyo. The quantities of nutrients in the basal ration which was the same except for the slight diflerences in the composition of the milk already mentioned, and the quantities in the supplemental rations in the different experiments of this series, are shown in Table LXXVII. The outgo of matter and energy in the feces during the snecessive experiments of this series is shown in Table LXXVIII.

T.nzLE LXXYI.- Weight, composition, and heat of combustion of foorls-Mitabolism experiments Niss. 22-31.

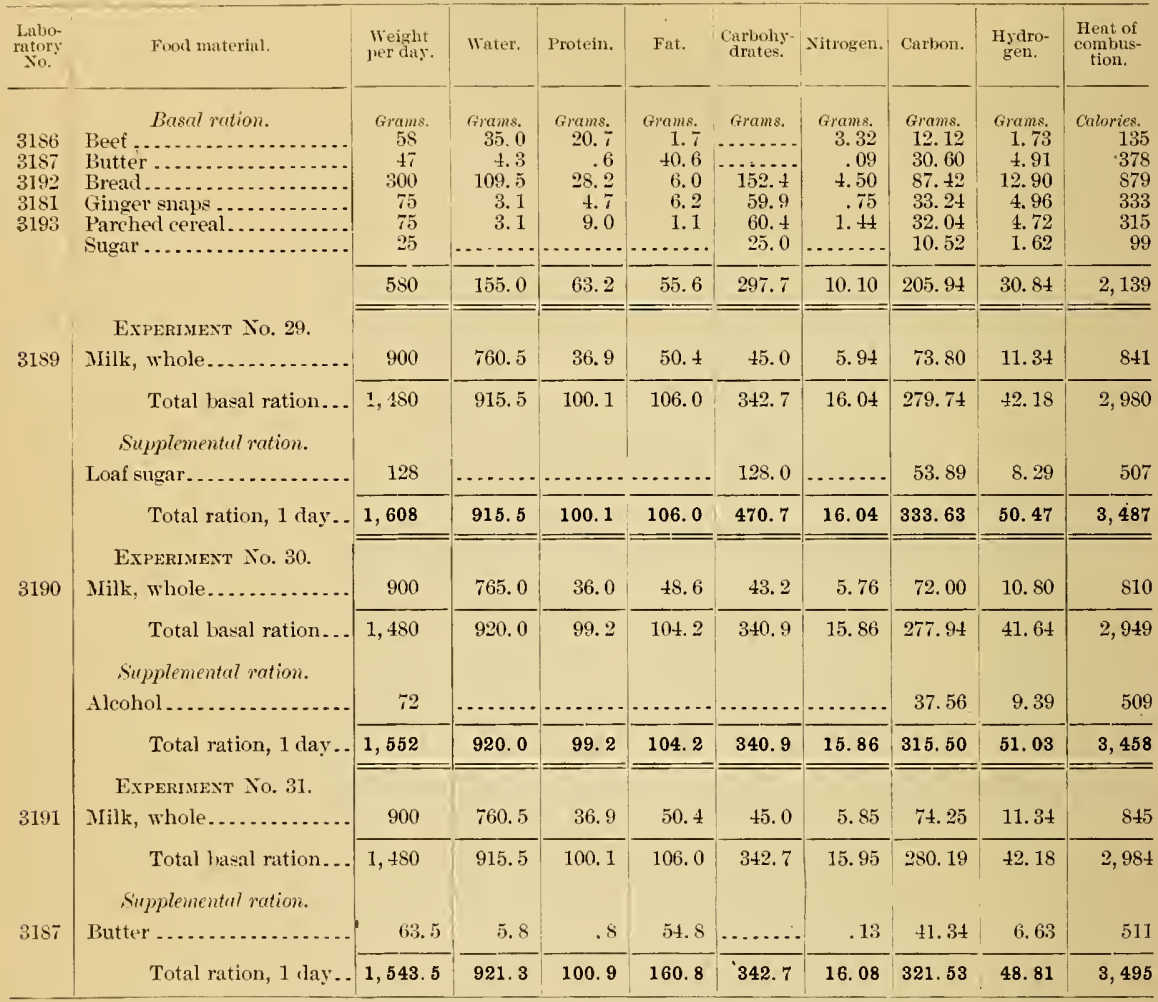

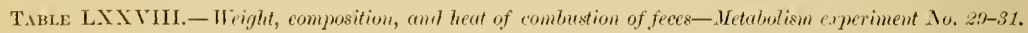

\begin{tabular}{|c|c|c|c|c|c|c|c|c|c|c|}
\hline $\begin{array}{l}\text { labo: } \\
\text { ratory } \\
\text { Sio. }\end{array}$ & & Weight. & Water. & l'rotein. & Fat. & $\begin{array}{l}\text { Carbohy- } \\
\text { drates. }\end{array}$ & Nitrogen. & Carbon. & $\begin{array}{c}\text { Hydro- } \\
\text { gen. }\end{array}$ & $\begin{array}{l}\text { Heat of } \\
\text { combus- } \\
\text { tion. }\end{array}$ \\
\hline \multirow[t]{3}{*}{3195} & \multirow{3}{*}{$\begin{array}{l}\text { Experiment Wo. } 89 . \\
\text { Feres for } 3 \text { days .......... } \\
\text { Average per day.... } \\
\text { E.rperiment Wo. } 30 .\end{array}$} & $\begin{array}{l}\text { firams } \\
177.0\end{array}$ & $\begin{array}{c}\text { frams. } \\
123.7\end{array}$ & $\begin{array}{r}\text { Grams. } \\
15.9\end{array}$ & $\begin{array}{r}\text { firame. } \\
9.0\end{array}$ & $\begin{array}{c}\text { Grem.s. } \\
18.2\end{array}$ & $\begin{array}{r}\text { Grams. } \\
2.55\end{array}$ & $\begin{array}{l}\text { Grams, } \\
25.01\end{array}$ & $\begin{array}{r}\text { Grams. } \\
3.6\end{array}$ & $\begin{array}{r}\text { Calorics } \\
279\end{array}$ \\
\hline & & 59.0 & 41.2 & 5.3 & 3.0 & 6.1 & .85 & 8.34 & 1. 2 & 93 \\
\hline & & 142.7 & 101.6 & 12.7 & 6.4 & 14.0 & 2.04 & 19.31 & 2.7 & 212 \\
\hline \multirow{3}{*}{$319 t$} & Average per day.... & 47.6 & $33 . \overline{9}$ & 4.3 & 2.1 & $4 . \overline{7}$ & .68 & 6.44 & .9 & 71 \\
\hline & $\begin{array}{l}\text { E.ryeriment No. } \$ 1 . \\
\text { Feres for } 3 \text { days ........... }\end{array}$ & 160.1 & 108. I & 15. 2 & 8.2 & 18.1 & 2.43 & 24.32 & 3.4 & 272 \\
\hline & Average per day.... & 53.4 & 36.0 & 5.1 & 2.7 & 6.0 & .81 & 8. 11 & 1.1 & 91 \\
\hline
\end{tabular}


The amount and composition of the mine in this experiment is shown in Tables LXXIX and LXXX. The statistis: are shown for 6-hom periods in experiment No. 30, in which alcohol formed a part of the diet, and for day periods in experiments Nos. 29 and and 31 without aleolrol. The heat of combustion of the urine was determined in the composite sample for each day, but the curbon and hyllogen were deterumed only in a composite for the total a days of this serie: of experiments.

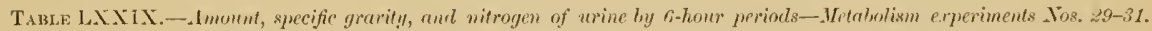

\begin{tabular}{|c|c|c|c|c|c|}
\hline Date. & Period. & Amount. & $\begin{array}{l}\text { Specifie } \\
\text { gravity. }\end{array}$ & Nitrog & \\
\hline \multirow[t]{2}{*}{$\begin{array}{r}1900 \\
\text { Mar. } 16-17 \\
17-18 \\
18-19\end{array}$} & \multirow{2}{*}{ 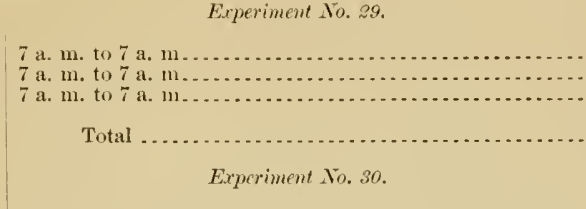 } & $\begin{array}{l}\text { frams. } \\
694.9 \\
777.2 \\
890.8\end{array}$ & $\begin{array}{l}1.034 \\
1.031 \\
1.030 \\
\end{array}$ & $\begin{array}{r}\text { Per cent. } \\
2.19 \\
2.07 \\
1.79 \\
\end{array}$ & $\begin{array}{l}\text { Grams. } \\
15.24 \\
16.11 \\
15.97\end{array}$ \\
\hline & & ...... & . & - & 47.32 \\
\hline $\begin{array}{r}19 \\
19 \\
19-20 \\
20\end{array}$ & 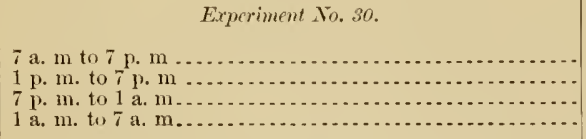 & $\begin{array}{l}247.0 \\
358.3 \\
196.8 \\
165.2\end{array}$ & $\begin{array}{l}1.029 \\
1.026 \\
1.031 \\
1.031\end{array}$ & $\begin{array}{l}1.71 \\
1.35 \\
2.02 \\
2.18\end{array}$ & $\begin{array}{l}4.22 \\
4.84 \\
\text { 3. } 98 \\
\text { 3. } 60\end{array}$ \\
\hline \multirow{2}{*}{$\begin{array}{r}19-20 \\
20\end{array}$} & Total ... & 967.3 & 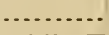 & $\ldots$ & 16.64 \\
\hline & Total by composite & 967.3 & 1.029 & 1.74 & 16.83 \\
\hline $\begin{array}{r}20 \\
20 \\
20-21 \\
21\end{array}$ & 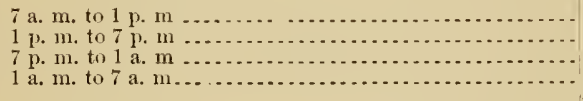 & $\begin{array}{l}309.5 \\
320.7 \\
254.6 \\
171.9\end{array}$ & $\begin{array}{l}1.027 \\
1.027 \\
1.025 \\
1.029\end{array}$ & $\begin{array}{l}1.47 \\
1.55 \\
1.80 \\
2.15\end{array}$ & $\begin{array}{l}4.55 \\
4.97 \\
4.58 \\
3.70\end{array}$ \\
\hline \multirow{2}{*}{$\begin{array}{r}20-21 \\
21\end{array}$} & Total. & $1,056.7$ & ....... & ...... & 17.80 \\
\hline & Total by composite & $1,056.7$ & 1.027 & 1.69 & 17.86 \\
\hline \multirow[t]{3}{*}{$\begin{array}{r}21-22 \\
22\end{array}$} & 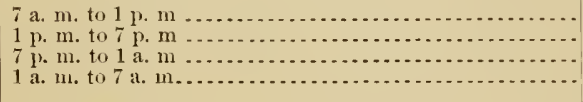 & $\begin{array}{l}355.3 \\
409.5 \\
217.5 \\
154.2 \\
\end{array}$ & $\begin{array}{l}1.021 \\
1.020 \\
1.026 \\
1.028\end{array}$ & $\begin{array}{l}1.28 \\
1.18 \\
1.89 \\
2.19\end{array}$ & $\begin{array}{l}4.55 \\
4.83 \\
4.11 \\
3.38 \\
\end{array}$ \\
\hline & Total ...... & $1,136.5$ & ....... & . & 16.87 \\
\hline & Total by composite ........... & $1,136.5$ & 1.023 & 1.47 & 16.70 \\
\hline $\begin{array}{l}22-23 \\
23-24 \\
24-25\end{array}$ & 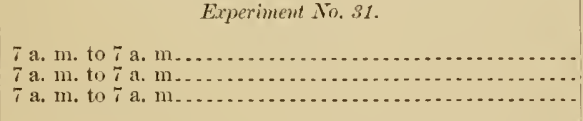 & $\begin{array}{l}812.3 \\
790.5 \\
880.0 \\
\end{array}$ & $\begin{array}{l}1.030 \\
1.030 \\
1.030 \\
\end{array}$ & $\begin{array}{l}1.98 \\
1.93 \\
1.71\end{array}$ & $\begin{array}{l}16.05 \\
15.24 \\
15.02 \\
\end{array}$ \\
\hline $24-25$ & Total ... & & & & 46.31 \\
\hline
\end{tabular}




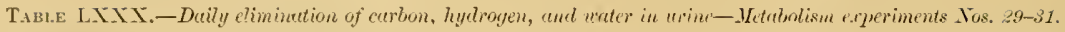

\begin{tabular}{|c|c|c|c|c|c|c|c|c|c|}
\hline \multirow{2}{*}{ Date. } & \multirow[b]{2}{*}{ Amonnt. } & \multirow{2}{*}{\multicolumn{2}{|c|}{ Carbon. }} & \multirow{2}{*}{\multicolumn{2}{|c|}{ Hydrogen. }} & \multirow{2}{*}{\multicolumn{2}{|c|}{ Water. }} & \multicolumn{2}{|c|}{ Heat of combustion. } \\
\hline & & & & & & & & Per gram. & Total. \\
\hline 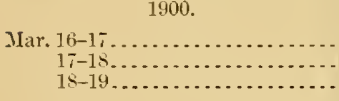 & $\begin{array}{l}\text { Grams. } \\
694.9 \\
777.2 \\
890.8\end{array}$ & \begin{tabular}{l} 
Pei cent. \\
$-\ldots \ldots$ \\
\hdashline$\ldots$ \\
$\cdots$
\end{tabular} & $\begin{array}{l}\text { Grums. } \\
10.78 \\
11.39 \\
11.29\end{array}$ & 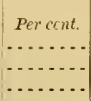 & $\begin{array}{l}\text { Grams. } \\
2.86 \\
3.03 \\
3.00\end{array}$ & $\begin{array}{l}\text { Per eent. } \\
\cdots \ldots \\
\cdots \\
\cdots\end{array}$ & $\begin{array}{l}\text { Grams. } \\
641.0 \\
720.3 \\
834.3\end{array}$ & $\begin{array}{r}\text { Calories. } \\
0.193 \\
.173 \\
.150\end{array}$ & $\begin{array}{r}\text { Culorice. } \\
134 \\
134 \\
134\end{array}$ \\
\hline Total.. & $2,362.9$ & $\ldots \ldots \ldots$ & 33.46 & ( . . n & 8.89 & - & $2,195.6$ & 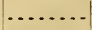 & 402 \\
\hline $\begin{array}{l}19-20 \ldots \ldots \ldots \\
20-21 \ldots \ldots \ldots \\
21-22 \ldots \ldots \ldots \ldots\end{array}$ & $\begin{array}{r}967.3 \\
1,056.7 \\
1,136.5\end{array}$ & 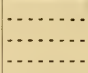 & $\begin{array}{l}11.76 \\
12.59 \\
11.93\end{array}$ & $\begin{array}{l} \\
\cdots\end{array}$ & $\begin{array}{l}\text { 3. } 13 \\
\text { 3. } 34 \\
\text { 3. } 17\end{array}$ & $\begin{array}{l}\ldots \\
\cdots \\
\cdots\end{array}$ & $\begin{array}{r}908.5 \\
993.8 \\
1,076.8\end{array}$ & $\begin{array}{l}.141 \\
.134 \\
.125\end{array}$ & $\begin{array}{l}136 \\
142 \\
142\end{array}$ \\
\hline Total . . . . . . . . . . . . & $3,160.5$ & . . . . . & 36.28 & . . . . . & 9.64 & -. & $2,979.1$ & (2) & 420 \\
\hline $\begin{array}{l}22-23 \\
23-24 \ldots \ldots \\
24-25 \ldots \ldots\end{array}$ & $\begin{array}{l}812.8 \\
790.5 \\
880.0\end{array}$ & $\mid \begin{array}{l}(1, \ldots \\
\cdots \ldots\end{array}$ & $\begin{array}{l}11.35 \\
10.78 \\
10.62\end{array}$ & $\begin{array}{l}\cdots \\
\cdots \\
\cdots \\
\cdots\end{array}$ & $\begin{array}{l}3.01 \\
2.86 \\
2.82\end{array}$ & $\mid \begin{array}{l}\ldots \ldots \\
\ldots \ldots \ldots \\
\ldots \ldots \ldots\end{array}$ & $\begin{array}{l}755.6 \\
736.6 \\
826.9\end{array}$ & $\begin{array}{l}.162 \\
.163 \\
.145\end{array}$ & $\begin{array}{l}132 \\
129 \\
128\end{array}$ \\
\hline Total ... & $2,482.8$ & ...... & 32.75 & $\ldots .$. & 8.69 & - & $2,319.1$ & - & 389 \\
\hline Total 9 clays ........... & $8,006.2$ & 1. 28 & 102.49 & 0.34 & 27.22 & ....... & 7,4938 & $\cdots$ & 1,211 \\
\hline
\end{tabular}

The quantities of carbon dioxid and water in the ventilating air current are given in Tables LXXXI to LXXXIII. These statisties are given in detail for experiment No. 30 in which alcohol was used, and summarized for the other two experiments of the series.

TABLE LXXX1.- Comparison of residual amounts of curbon dioxid and water in the chamber at the beginning and end of each perioil, and the rorresponding gain or loss-Metabolism experiment . To. 30.

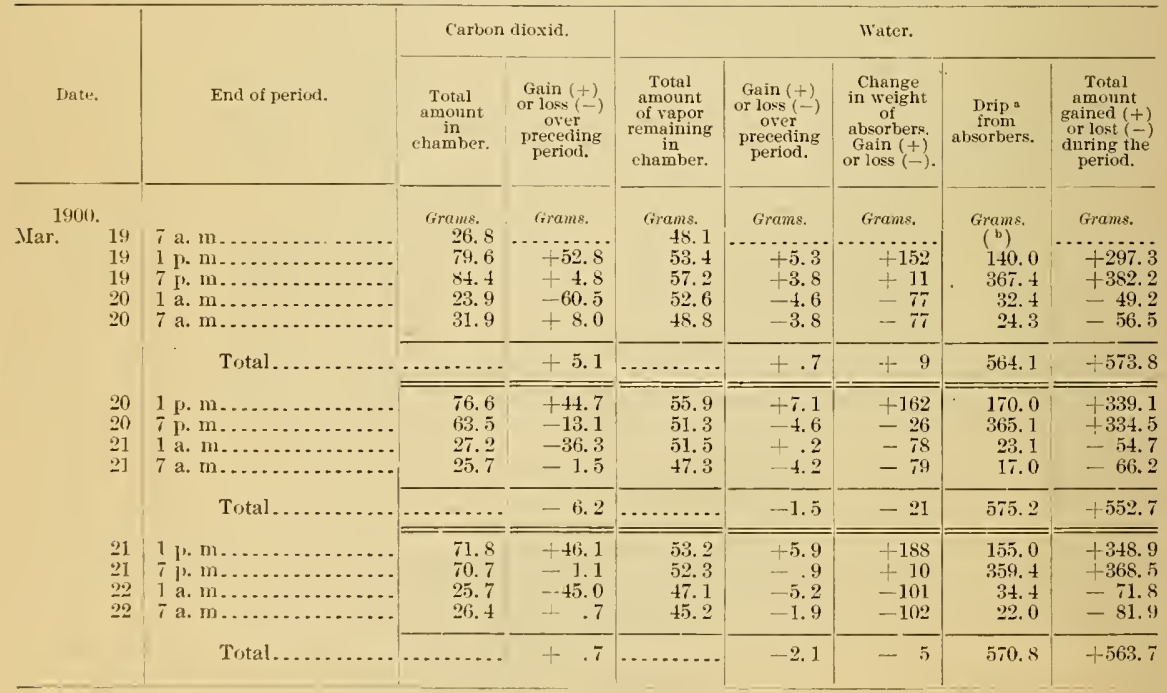

"Ineluding alsos the perspiration in mulerclothes.

- The rrip, was collenterl and weipherl but rnce a day. The volume was roughly observerl at 1 p. m., $7 \mathrm{p}$. m. aml $7 \mathrm{a} . \mathrm{m}$, and this volume taken as a rough approximation to the actual wejght of ilrip, for the ilifferent periods The small amount of irip olserverl at 7 a. m. was divided equally between the two night periods. 


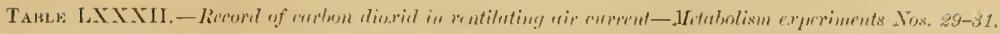

\begin{tabular}{|c|c|c|c|c|c|c|c|c|c|}
\hline \multirow{3}{*}{ Date. } & \multirow{3}{*}{ leteriot. } & \multirow[b]{3}{*}{$\begin{array}{l}\text { Ventila- } \\
\text { tiont Num- } \\
\text { ber of liters } \\
\text { of air. }\end{array}$} & \multicolumn{6}{|c|}{ farbon clisexis. } & \multirow{3}{*}{$\begin{array}{l}\text { (h) } \\
\text { Total } \\
\text { weighit of } \\
\text { carbon } \\
\text { exhaled, } \\
g \times \frac{3}{\pi} \text {. }\end{array}$} \\
\hline & & & \multicolumn{2}{|c|}{ In inceming air. } & \multirow[b]{2}{*}{$\begin{array}{l}\text { In wutgo- } \\
\text { ing sir. }\end{array}$} & & & (y) & \\
\hline & & & l'er litur. & $\begin{array}{l}|c| \\
\text { Tutal, } \\
a \quad b .\end{array}$ & & $\begin{array}{l}\text { Total ex- } \\
\text { ress in out- } \\
\text { goimg air, } \\
d=c \text {. }\end{array}$ & $\begin{array}{l}\text { Corree- } \\
\text { tion for } \\
\text { smumit } \\
\text { remain- } \\
\text { ing fin } \\
\text { chamber. }\end{array}$ & $\begin{array}{c}\text { Corrected } \\
\text { ammant ex- } \\
\text { haled by } \\
\text { subject, } \\
e+f .\end{array}$ & \\
\hline $\begin{array}{l}1900 . \\
\text { r. } 16-17 \\
17-18 \\
18-19\end{array}$ & 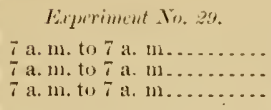 & $\begin{array}{c}\text { Liters } \\
110,3 \times 6 \\
110,385 \\
105, \times 31\end{array}$ & $\begin{array}{c}x_{g} \\
\ldots \ldots \\
\ldots \ldots \\
\ldots \ldots \\
\ldots \ldots\end{array}$ & $\begin{array}{l}\text { tiramk. } \\
\text { bio. } 2 \\
\text { (ii. } 5 \\
61.4\end{array}$ & $\begin{array}{l}\text { frams. } \\
1,306.7 \\
1,2 \pi 2.7 \\
1,315.2\end{array}$ & $\begin{array}{l}\text { trams. } \\
1,241.5 \\
1,187.2 \\
1,253.8\end{array}$ & $\begin{array}{l}\text { Grane } \\
+\quad 0.2 \\
-\quad 1.9 \\
+\quad 3.0\end{array}$ & $\begin{array}{l}\text { firrms. } \\
1,2+1.7 \\
1,185.3 \\
1,256.8\end{array}$ & $\begin{array}{r}\text { frrams. } \\
338.7 \\
323.3 \\
342.7\end{array}$ \\
\hline $\begin{array}{r}19 \\
19 \\
19-20 \\
20\end{array}$ & 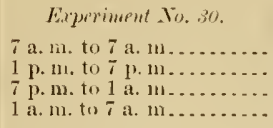 & $\begin{array}{l}25,653 \\
25,653 \\
27,208 \\
27,208\end{array}$ & $\begin{array}{l}0.575 \\
.587 \\
.577 \\
.573\end{array}$ & $\begin{array}{l}14.7 \\
15.1 \\
15.7 \\
15.6\end{array}$ & $\begin{array}{l}389.2 \\
442.2 \\
254.6 \\
151.6\end{array}$ & $\begin{array}{l}374.4 \\
427.2 \\
235.9 \\
136.0\end{array}$ & $\begin{array}{r}+52.8 \\
+\quad 4.8 \\
-60.5 \\
+\quad 8.0\end{array}$ & $\begin{array}{l}427.2 \\
432.0 \\
178.4 \\
144.0\end{array}$ & $\begin{array}{r}116.5 \\
117.8 \\
48.7 \\
39.3\end{array}$ \\
\hline & Total .............. & 105,722 & ...... & b1. 1 & $1,23 \pi .6$ & $1,176.5$ & +5.1 & $1,181.6$ & 322.3 \\
\hline $\begin{array}{r}20 \\
20 \\
20-21 \\
21\end{array}$ & 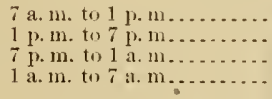 & $\begin{array}{l}25,1353 \\
27,208 \\
27,208 \\
27,205\end{array}$ & $\begin{array}{l}.576 \\
.582 \\
.563 \\
.578\end{array}$ & $\begin{array}{l}14.8 \\
15.8 \\
15.3 \\
15.7\end{array}$ & $\begin{array}{l}376.0 \\
439.5 \\
247.9 \\
149.6\end{array}$ & $\begin{array}{l}362.2 \\
423.7 \\
232.6 \\
133.9\end{array}$ & $\begin{array}{r}+44.7 \\
-13.1 \\
-36.3 \\
-1.5\end{array}$ & $\begin{array}{l}406.4 \\
410.6 \\
196.3 \\
1.22 .4\end{array}$ & $\begin{array}{r}111.0 \\
112.0 \\
53.5 \\
36.1\end{array}$ \\
\hline & Total ............. & $107,27 \pi$ & $\ldots$. & 61.6 & $1,214.0$ & $1,152.4$ & -6.2 & $1,14 t i .2$ & 312.6 \\
\hline $\begin{array}{r}21 \\
21 \\
21-22 \\
22\end{array}$ & 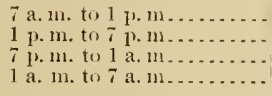 & $\begin{array}{l}26,430 \\
26,430 \\
27,985 \\
27,985\end{array}$ & $\begin{array}{l}.5 \times 7 \\
.5 \times 1 \\
.569 \\
.575\end{array}$ & $\begin{array}{l}15.5 \\
15.3 \\
15.9 \\
16.1\end{array}$ & $\begin{array}{l}389.2 \\
445.5 \\
232.5 \\
14 \times .6\end{array}$ & $\begin{array}{l}373.7 \\
+30.2 \\
216.6 \\
132.5\end{array}$ & $\begin{array}{r}+46.1 \\
-1.1 \\
-45.0 \\
0.7\end{array}$ & $\begin{array}{l}419.8 \\
429.1 \\
171.6 \\
138.2\end{array}$ & $\begin{array}{r}114.5 \\
117.0 \\
46.8 \\
36.3\end{array}$ \\
\hline & Tutal ................ & 108,830 & & ti2. 8 & $1,215.8$ & $1,153.0$ & +0.7 & $1,153.7$ & 314.6 \\
\hline $\begin{array}{l}22-23 \\
23-24 \\
24-25\end{array}$ & 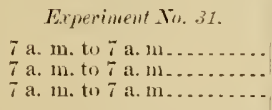 & $\begin{array}{l}106,497 \\
10 \mathrm{x}, 051 \\
108,830\end{array}$ & & $\begin{array}{l}61.7 \\
61.8 \\
62.3\end{array}$ & $\begin{array}{l}1,210.2 \\
1,223.6 \\
1,2 \cdot 4.5\end{array}$ & $\begin{array}{l}1,148.5 \\
1,161.8 \\
1,162.2\end{array}$ & $\begin{array}{r}0.7 \\
-\quad 1.0 \\
+\quad 2.9\end{array}$ & $\begin{array}{l}1,147.8 \\
1,160.8 \\
1,165.1\end{array}$ & $\begin{array}{l}313.1 \\
316.6 \\
317.8\end{array}$ \\
\hline
\end{tabular}

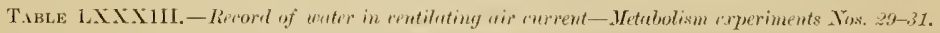

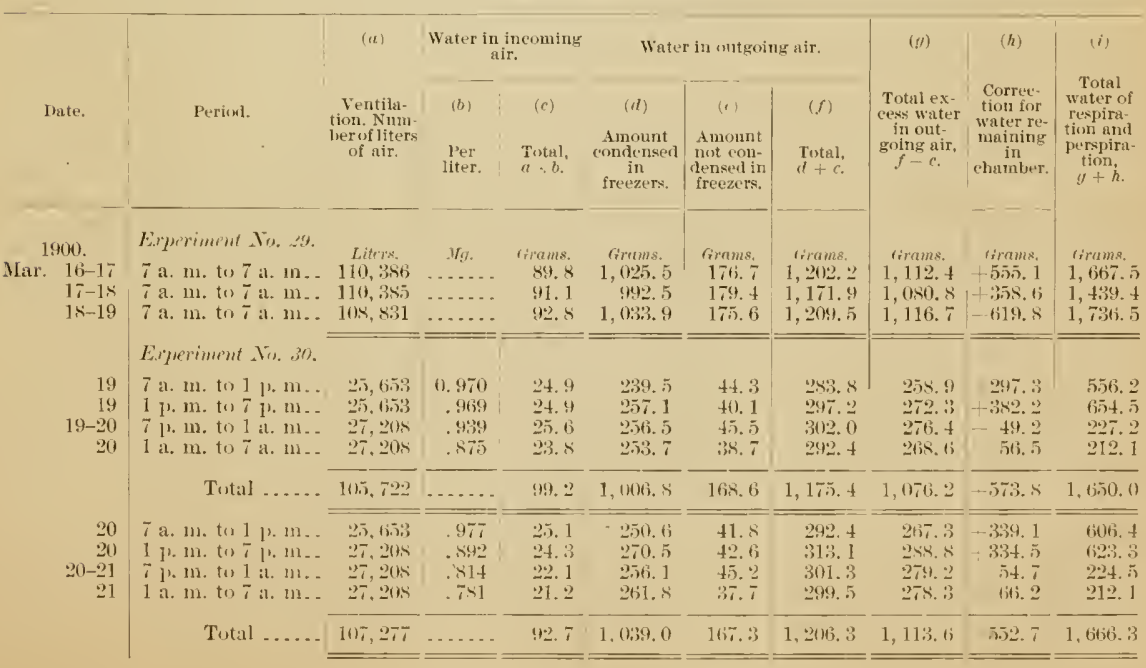


TABLE LXXXIII.-Recond of water in wentilating aiv current-Jetabolism experiments Jos. 29-31-Continued.

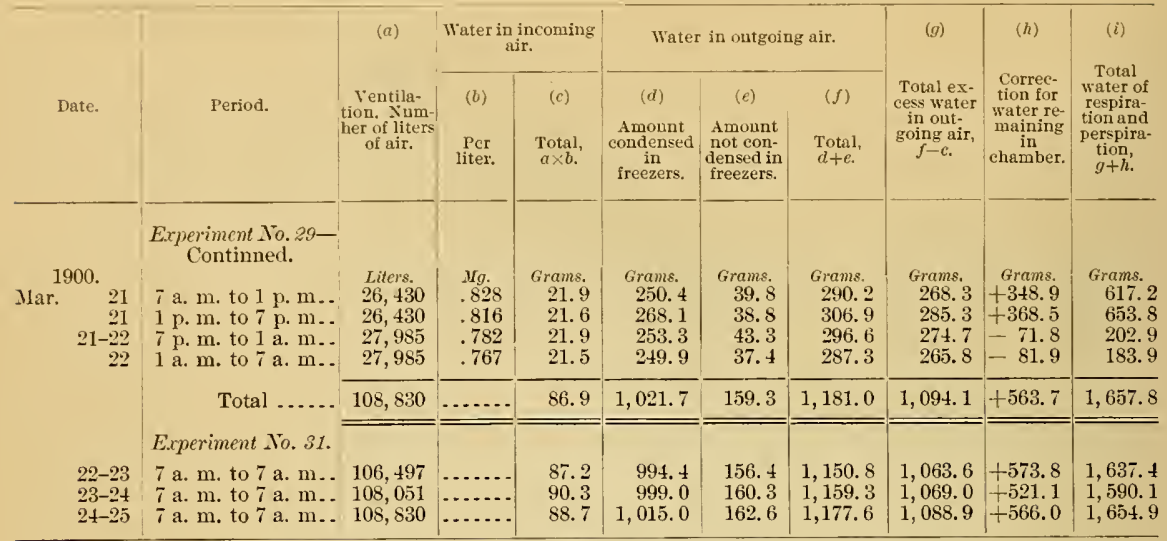

Table LXXXIV summarizes the calorimetric measurements in experiments Nos. 29 and 31 , and gives the details of these measurements in 6-hour periods during experiment No. 30 .

TABLE LXXXIV.-Summary of calorimetric measurements-Metabolism experiments Nos. 29-31.

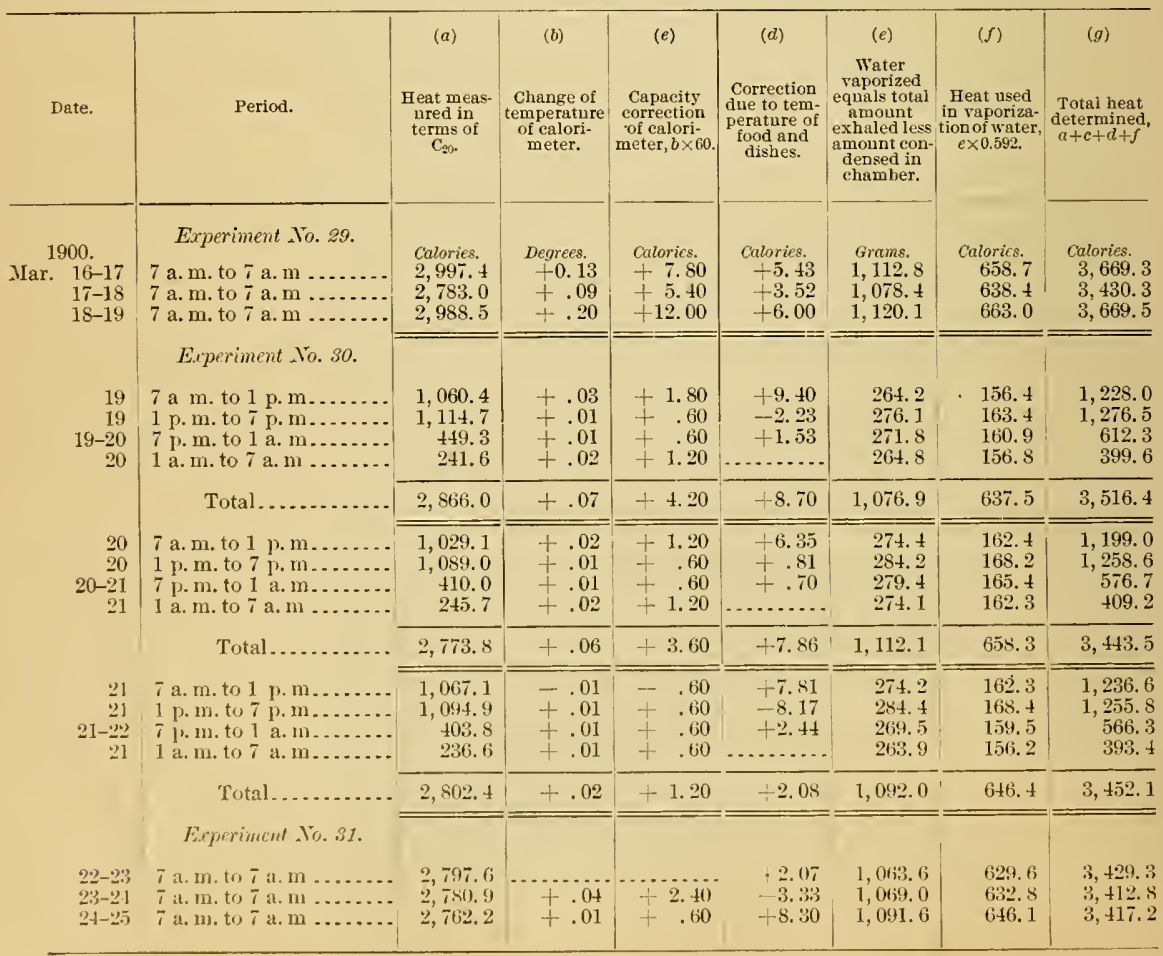


The alcohol. or reducing material equiralent to alcohol. was determined in the nrine and freezer water of each tay of experiment .50 .31 , and on the 3 days of the preceding and following experiments. Nos. $2 ! 1$ and 31 , respectively. The anount of reducing material in the air current on each dar of the 9 dars of this -eries of experiment- was also determined. Table LXXXV -ummarize the-e deterninations. The determinations of the reducing material in the urine on the first day of experiment No. 2: was lo-t. wo that we can only estimate the total reducing material on that dar. It wa- howerer. probably not far ditterent from the second and third day of this experiment. The arerage elimination of reducing material per day from all sources in experiment. No. 2 ? and 31 amounted to the equiralent of 0.32 gram of alcohol. In the third from the last column of "Table LXXXY' is giren the total outgro of alcohol in experiment No. 30 , which amounts to 1.76 gram per day. This value is obtained by subtracting from the 1.09 grams of total alcohol and reducing material equivalent to alcohol the $11.33 \mathrm{gram}$ of reducing material determined during the experiment- in which alcohol did not form a part of the diet. The total alcohol metabolized in the bodr was " $"$.". per cent of that ingested.

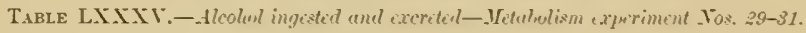

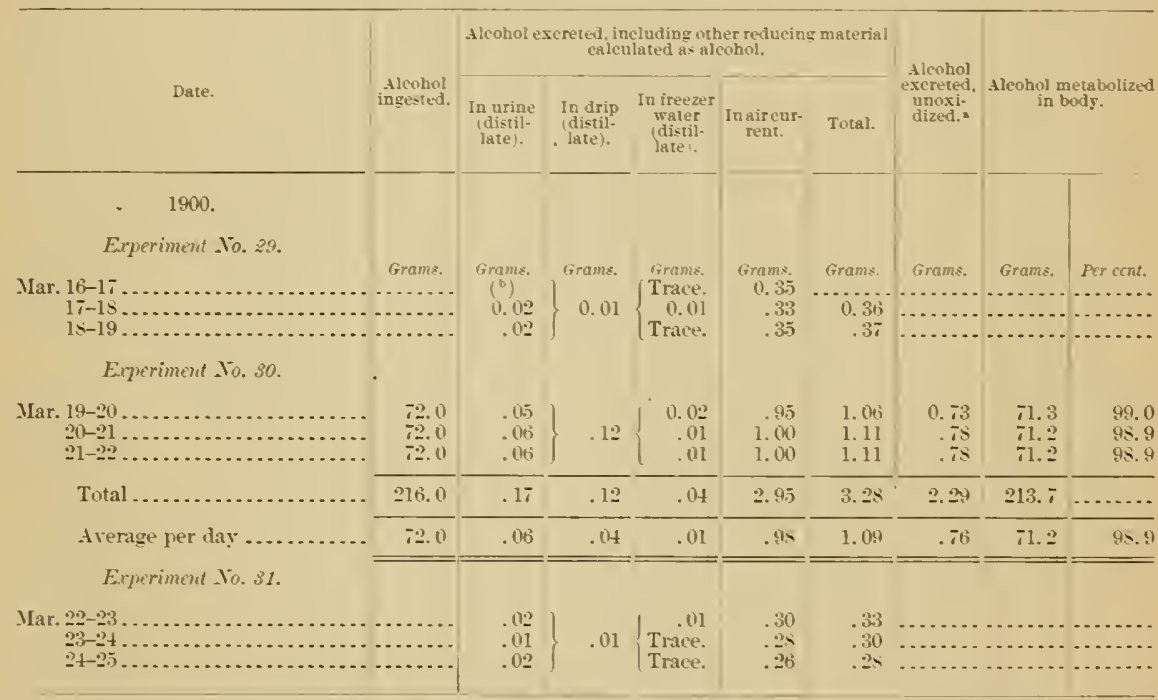

"Equals total reduciug material excreted les: 0.33 gram of reducing material not alcohol, the average for the days on which no alcohol was consumed.

'Tot delermined. 
Bulance of income and outgo of nutter and cnergy. - The income and outgo of nitrogen, carhon, hydrogen, and energy in the different experiments of this series are shown in Tables LXXXY to LXXXIX.

TABLE LXXXYL.-Income and ontgo of nitrogen and carbon-Metabolism experiments No8. 29-S1.

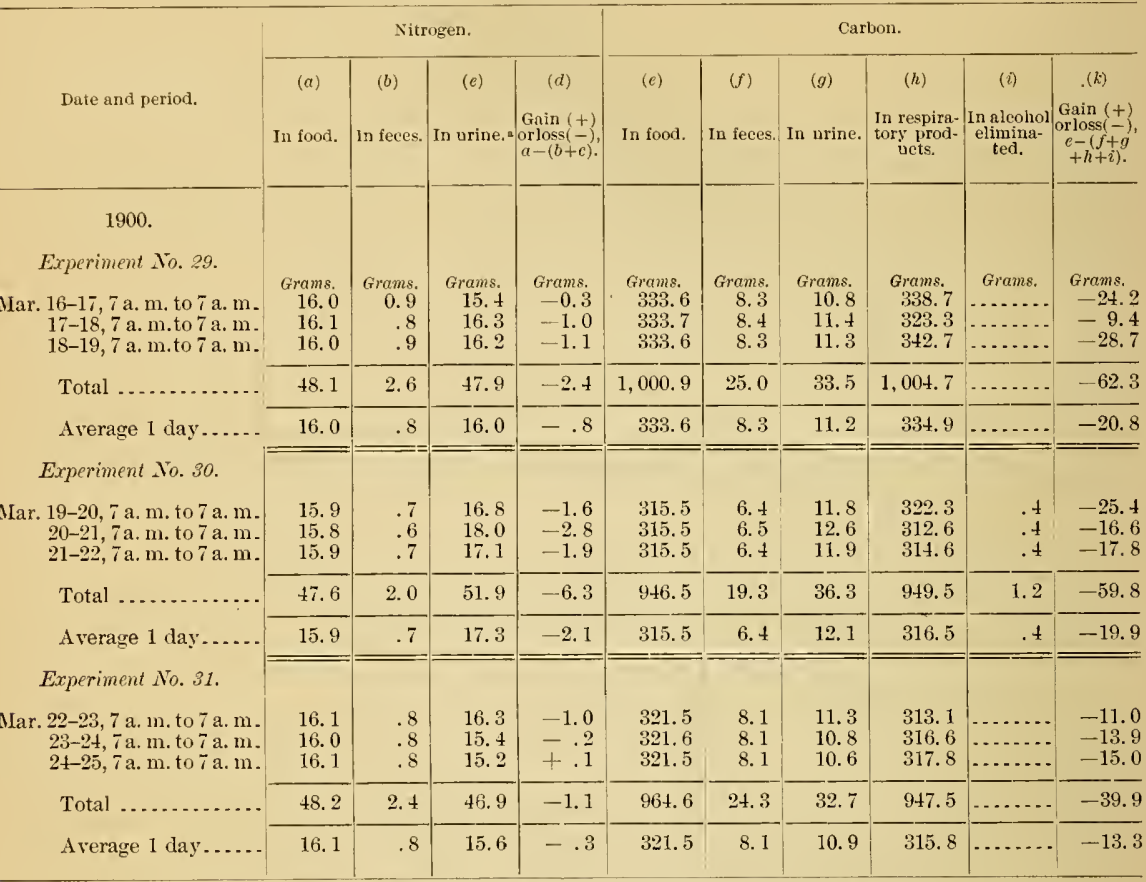

" Yitrogen in perspiration, 0.2 gram per day, is included in this column.

TABLE LXXXVII.-Income and outgo of water and hydrogen-Metabolism experiments Hos. 29-31.

\section{Water.}

Date and period.

1900.

Eryeriment lis. 39.

Mar. $16-17,7$ a. m. (1) $7 \mathrm{a} . \mathrm{m}$

$17-18,7$ a. 11 . (6) 7 a. 111

$15-1 !+7$ a. $\mathrm{m}$. (1) 7 a. 11

Trotal ..........
Firams. Grams, Grams. Grams. Girams. Girams, frrams. $\begin{array}{lllll}975.51,250.0 & 41.2 & 641.01,667.5 & 184.2 & 50.5\end{array}$ $\begin{array}{lllll}915.51,250.0 & 41.8 & 720.81,439.4 \quad 35.5 & 50.5\end{array}$ $915.51,250.0 \quad+1.2 \quad 83+31,736.5 \quad 4+6.5 \quad 50.5$

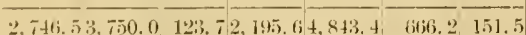
(1)5.51,250.0 41.2 $731,91,614.5 \quad 222.1 \quad 50.5$
Hydrogen.

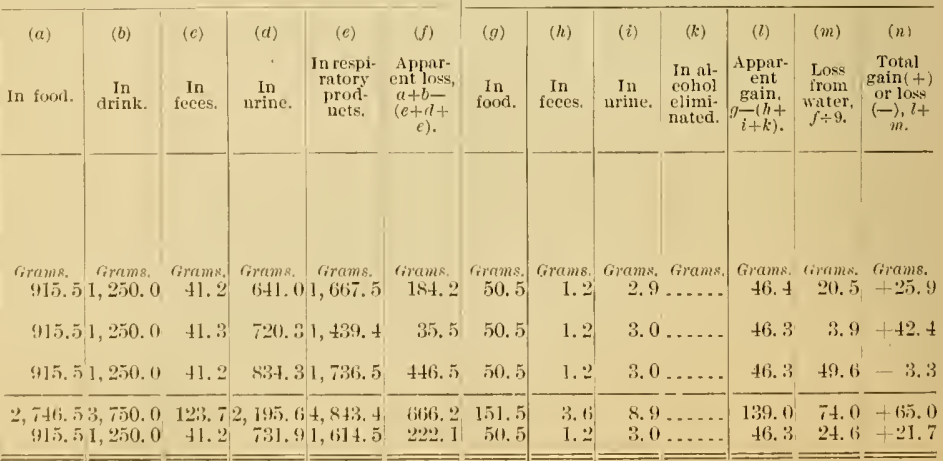




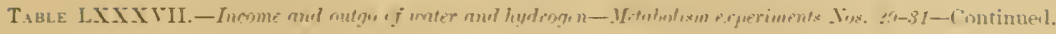

\begin{tabular}{|c|c|c|c|c|c|c|c|c|c|c|c|c|c|}
\hline \multirow{3}{*}{ Inate sad leriod. } & \multicolumn{6}{|c|}{ Water. } & \multicolumn{7}{|c|}{ Hỵdrugers. } \\
\hline & $a$ & b & $1 \cdot$ & $d$ & i, & $j$ & $a$ & h & $i$ & $k$ & I & $m$ & " \\
\hline & In fond. & $\underset{\text { drink. }}{\text { In }}$ & in & $\begin{array}{c}\text { In } \\
\text { urine. }\end{array}$ & $\begin{array}{c}\text { In reppi- } \\
\text { ratory- } \\
\text { proul- } \\
\text { wets. }\end{array}$ & $\begin{array}{c}\text { Appar- } \\
\text { entlom- } \\
a-b- \\
c-d+ \\
e .\end{array}$ & In & $\begin{array}{c}\text { In } \\
\text { fece- }\end{array}$ & $\begin{array}{c}\text { In } \\
\text { nrine. }\end{array}$ & $\begin{array}{l}\text { In al- } \\
\text { cohol } \\
\text { elimi- } \\
\text { nated. }\end{array}$ & $\begin{array}{c}\text { Apper- } \\
\text { ent } \\
\text { gain. } \\
g-h- \\
i=k .\end{array}$ & $\underset{\substack{\text { Lnss } \\
\text { from } \\
\text { water. } \\
j \div 9}}{ }$ & $\begin{array}{c}\text { Totsl } \\
\text { gain - } \\
\text { or low } \\
-.1- \\
\text { mi. }\end{array}$ \\
\hline \multicolumn{14}{|l|}{$19 \operatorname{cin}}$. \\
\hline Enperiment sis. so. & & & & & & & & & & & & & \\
\hline \multirow{3}{*}{ 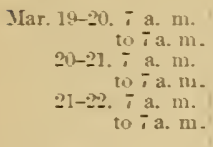 } & \multicolumn{2}{|c|}{$\begin{array}{l}\text { Grains. Gra } \\
92-0.01,250.0\end{array}$} & $\begin{array}{l}\text { Gmins: } \\
33.9\end{array}$ & \multicolumn{2}{|c|}{$\begin{array}{l}\text { fimms. frmms. } \\
908.51,650.0\end{array}$} & $\begin{array}{c}\text { timame } \\
4 \geq 2.4\end{array}$ & $\begin{array}{l}\text { Simemiz. } \\
51.0\end{array}$ & frams. & $\begin{array}{l}\text { Grame. } \\
3.1\end{array}$ & $\begin{array}{l}\text { Grams: } \\
0.1\end{array}$ & $\begin{array}{l}\text { Grame. } \\
\text { th. }\end{array}$ & $\begin{array}{r}\text { Grams. } \\
\text { t6. } 9\end{array}$ & $\begin{array}{l}\text { Grams. } \\
9 . . . .\end{array}$ \\
\hline & 920.0 & 1. 250.0 & 33. & 993. & $1.6 \operatorname{tin} 6.3$ & 523.9 & 51.0 & 0.9 & 3.3 & .1 & th. 7 & 5s.? & -11.5 \\
\hline & 920.0 & 1. 250.0 & 33.91 & 1.076 .5 & $61.25 \% .8$ & 594.5 & 51.0 & 0.9 & 3. 2 & 1 & the $=$ & 66.5 & $5-19.7$ \\
\hline $\begin{array}{l}\text { Total ......... } \\
\text { Aterage l day.. }\end{array}$ & $\begin{array}{r}\because .750 .0 \\
920.0\end{array}$ & $\begin{array}{l}\text { 3. }-550.0 \\
\text { 1. } 250.0\end{array}$ & $\begin{array}{r}101.6 \\
33.4\end{array}$ & $=9.979 .1$ & $\begin{array}{l}\text { 1. } 14.97 .1 \\
\text { o. } 1.57 .0\end{array}$ & 1.541 .8 & $\begin{array}{r}153.0 \\
51.0\end{array}$ & $\begin{array}{l}2.7 \\
0.9\end{array}$ & $\begin{array}{l}9 . \\
3.2\end{array}$ & .3 & $\begin{array}{r}140.4 \\
46 .\end{array}$ & $\begin{array}{r}171.6 \\
5 \% .2\end{array}$ & $\begin{array}{l}-31.2 \\
-10.4\end{array}$ \\
\hline Experimend . & & & & & & & & & & & & & \\
\hline Mar $23 .-2$ a m. & 921 & 1. $2=0.0$ & $3 \hbar .0$ & $7.25 .+1$ & i 1. 6331.4 & 25.7 & a. & 1.1 & 3. & & 44.7 & 28.6 & $5 \rightarrow 1$ ti. 1 \\
\hline to $7 \mathrm{a}, \mathrm{m}$. & 921.3 & I. 250.0 & 36.1 & $-3+3 t .6$ & 81.590 .1 & 191.5 & $4 s, n$ & 1.2 & 2.5 & & 44.7 & 21.3 & $3-23.4$ \\
\hline (1) 7 a. m. & 921.3 & $1,250.0$ & 3ti. 1$)$ & $\therefore=6.9$ & 91. Aist.9 & 34 ถ่. 5 & t.. & 1. 1 & 2. & ... & $4+9$ & 35.5 & $5-6.4$ \\
\hline $\begin{array}{l}\text { Total .......... } \\
\text { Average } 1 \text { day.. }\end{array}$ & $\begin{array}{r}2.763 .9 \\
921.3\end{array}$ & $\begin{array}{l}3.750 .0 \\
1,250.0\end{array}$ & $\begin{array}{r}105.1 \\
36.0\end{array}$ & 2.319 .1 & $\begin{array}{l}14.59-2.4 \\
1.62-5.5\end{array}$ & $\begin{array}{r}795.7 \\
265.2\end{array}$ & $\begin{array}{r}1+5.4 \\
40.8\end{array}$ & $\begin{array}{l}3.4 \\
1.1\end{array}$ & $\begin{array}{l}3.7 \\
2.8\end{array}$ & .. & $\begin{array}{r}134.3 \\
4.9\end{array}$ & $\begin{array}{l}8.4 \\
29.5\end{array}$ & $\begin{array}{l}4-45.9 \\
5-15.3\end{array}$ \\
\hline
\end{tabular}

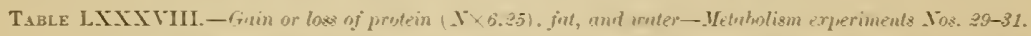

\begin{tabular}{|c|c|c|c|c|c|c|c|c|c|c|c|}
\hline & $(a)$ & $b$ & (c & $|n|$ & $\epsilon$ & $j$ & (9) & ih & (i & (k) & (l) \\
\hline Date and period. & $\begin{array}{c}\text { Nitmgen } \\
\text { gainend } \\
1-0 \mathrm{nr} \\
\text { lost -. }\end{array}$ & 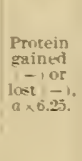 & $\begin{array}{c}\text { Total } \\
\text { carbon } \\
\text { gained } \\
1-1,0 \text {. } \\
\text { lost - }\end{array}$ & $\begin{array}{l}\text { Carbon } \\
\text { in pro } \\
\text { tein } \\
\text { gained } \\
-1 \text { or } \\
\text { - ost } \\
b \times .53\end{array}$ & $\begin{array}{c}\text { Carbon } \\
\text { in fat, } \\
\text { etc.. } \\
\text { gained } \\
\text { ine or } \\
\text { lost, } \\
c-d .\end{array}$ & $\begin{array}{c}\text { Fat } \\
\text { gained } \\
1 \rightarrow \text { or } \\
\text { lost }-1-1 . \\
\epsilon \rightarrow 061 .\end{array}$ & $\begin{array}{l}\text { Toral } \\
\text { hydro- } \\
\text { gen } \\
\text { gained } \\
-1-\text { or } \\
\text { lowit }\end{array}$ & $\begin{array}{c}\text { Hrdro- } \\
\text { gen in } \\
\text { protein } \\
\text { gained } \\
\text { ind or } \\
\text { lost :-1. } \\
b \times .0 \bar{t} \text {. }\end{array}$ & 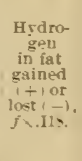 & $\begin{array}{l}\text { Hydro- } \\
\text { gen in } \\
\text { water. } \\
\text { etc., } \\
\text { gained } \\
(-1) \text { or } \\
\text { inst } \\
(-), g- \\
(h+1) .\end{array}$ & $\begin{array}{c}\text { Water } \\
\text { gained } \\
1-1 \text { or } \\
\text { loot },-1, \\
k \times 9 .\end{array}$ \\
\hline
\end{tabular}

1900.

Experiment 15. 29.

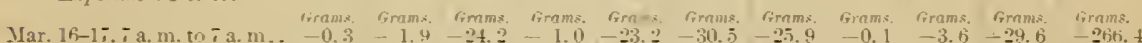

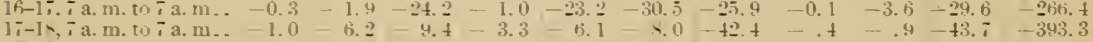
$15-19,7$ a.m.to 7 a.m. $-1.1-6 . \overline{9}-2.7-3.7-25.0-32.9-3.3-.5-3.9+1.1-9.9$

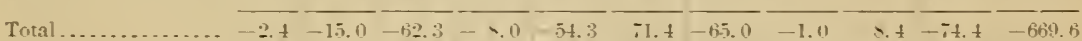

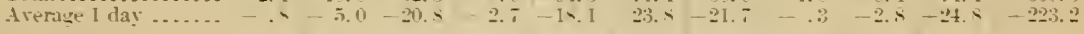

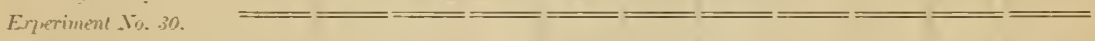

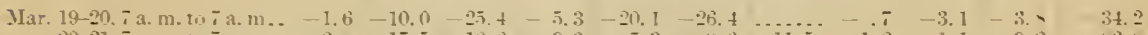

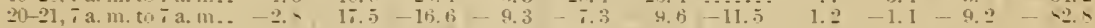

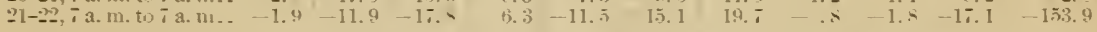

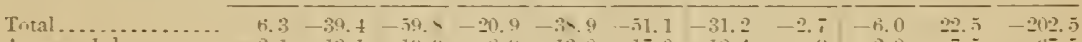

Average I lag...... $2.1-13.1-19.4-6.4-13.0-17.0-10.4-.9-2.0-7.5 \quad 6-5$

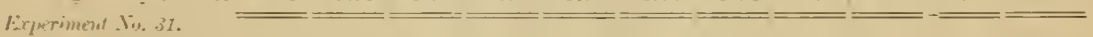

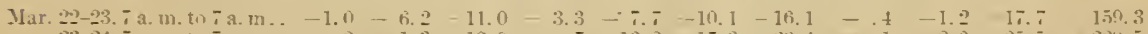

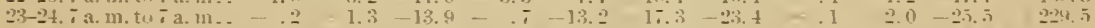

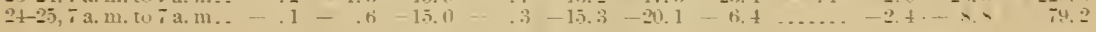

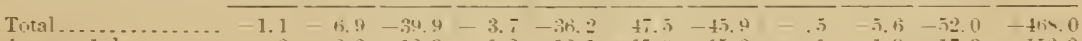
Average 1 day...... ... $3-2.3-13.3-1.2-12 . \overline{1} 15.9-15.3 \quad 1-1.9-17.3-156.0$ 


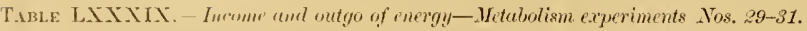

\begin{tabular}{|c|c|c|c|c|c|c|c|c|c|c|}
\hline \multirow[b]{2}{*}{ Date und period. } & \multirow[b]{2}{*}{$\begin{array}{c}\text { Heat of } \\
\text { combustion } \\
\text { of food } \\
\text { eaten. }\end{array}$} & \multirow[b]{2}{*}{$\begin{array}{l}\text { Heat of } \\
\text { combus- } \\
\text { tion of } \\
\text { feces. }\end{array}$} & \multirow[b]{2}{*}{$\begin{array}{l}\text { Heat of } \\
\text { combus- } \\
\text { tion of } \\
\text { urine. }\end{array}$} & \multirow{2}{*}{$\begin{array}{l}(m) \\
\text { Heat of } \\
\text { eombns- } \\
\text { tion of } \\
\text { aleohol } \\
\text { elimi- } \\
\text { nated. }\end{array}$} & \multirow{2}{*}{$\begin{array}{l}\quad(d) \\
\text { Estimated } \\
\text { leat of } \\
\text { combus- } \\
\text { tion of } \\
\text { protein } \\
\text { gained } \\
\text { (+) or } \\
\text { lost }(-) \text {. }\end{array}$} & \multirow{2}{*}{$\begin{array}{l}\text { Estimated } \\
\text { heat of } \\
\text { combus- } \\
\text { tion of } \\
\text { fat gained } \\
(+) \text { or } \\
\text { lost }(-)\end{array}$} & \multirow{2}{*}{$\begin{array}{l}(f) \\
\text { Estimated } \\
\text { energy of } \\
\text { material } \\
\text { oxidized } \\
\text { in the } \\
\text { body, } \\
a-(b+c+ \\
m+d+e)\end{array}$} & \multirow{2}{*}{$\begin{array}{l}(g) \\
\text { Heat } \\
\text { deter- } \\
\text { mined. }\end{array}$} & \multicolumn{2}{|c|}{$\begin{array}{l}\text { Heat determined } \\
\text { greater }(+) \text { or less } \\
(-) \text { than estimated. }\end{array}$} \\
\hline & & & & & & & & & $\begin{array}{c}(h) \\
f-g\end{array}$ & $\begin{array}{l}(i) \\
h \div f\end{array}$ \\
\hline $\begin{array}{c}1900 . \\
\text { Eeperimut To. } 29 . \\
\text { Mar. 16-17, 7a.m. to 7a.m. } \\
\text { 17-18, 7a.m. to 7a.m } \\
18-19,7 \text { a.m. to } 7 \text { a.m. }\end{array}$ & $\begin{array}{r}\text { Calories. } \\
3,487 \\
3,487 \\
3,487\end{array}$ & $\begin{array}{r}\text { Calories. } \\
93 \\
93 \\
93\end{array}$ & $\begin{array}{r}\text { Calorics. } \\
134 \\
134 \\
134\end{array}$ & $\begin{array}{l}\text { Calonies. } \\
\ldots . . . \\
\ldots . . . \\
\ldots . . . \\
\end{array}$ & $\begin{array}{c}\text { Calories. } \\
-\quad 11 \\
-\quad 35 \\
-\quad 39\end{array}$ & $\begin{array}{r}\text { Calories. } \\
-\quad 291 \\
-\quad 76 \\
-\quad 314\end{array}$ & $\begin{array}{r}\text { Calonics. } \\
3,562 \\
3,371 \\
3,613\end{array}$ & $\begin{array}{r}\text { Calonies. } \\
3,669 \\
3,430 \\
3,669\end{array}$ & $\begin{array}{r}\text { Calories. } \\
+\quad 107 \\
+\quad 59 \\
+\quad 56\end{array}$ & $\begin{array}{l}\text { Calories. } \\
+\quad 3.0 \\
+\quad 1.7 \\
+\quad 1.5\end{array}$ \\
\hline Total ........... & $\begin{array}{r}10,461 \\
3,487 \\
\end{array}$ & $\begin{array}{r}279 \\
93 \\
\end{array}$ & $\begin{array}{l}402 \\
134\end{array}$ & (...... & $\begin{array}{r}-\quad 85 \\
-\quad 28 \\
\end{array}$ & $\begin{array}{l}-681 \\
-\quad 227 \\
\end{array}$ & $\begin{array}{r}10,546 \\
3,515 \\
\end{array}$ & $\begin{array}{r}10,768 \\
3,589 \\
\end{array}$ & $\begin{array}{r}+222 \\
+\quad 71 \\
\end{array}$ & $\begin{array}{r}2.1 \\
+\quad 2\end{array}$ \\
\hline $\begin{array}{l}\text { Experiment No. } 30 . \\
\text { [ar. 19-20, 7a.m. to } 7 \text { a.m. } \\
\text { 20-21, 7a.m. to } 7 \text { a.m. } \\
\text { 21-22. 7a. m. to } 7 \text { a.m. }\end{array}$ & $\begin{array}{l}3,458 \\
3,458 \\
3,458\end{array}$ & $\begin{array}{l}71 \\
70 \\
71\end{array}$ & $\begin{array}{l}136 \\
142 \\
142\end{array}$ & $\begin{array}{l}5 \\
5 \\
6\end{array}$ & $\begin{array}{l}57 \\
-\quad 99 \\
-\quad 67\end{array}$ & $\begin{array}{r}-252 \\
-\quad 92 \\
-\quad 144\end{array}$ & $\begin{array}{l}3,555 \\
3,432 \\
3,450\end{array}$ & $\begin{array}{l}3,516 \\
3,443 \\
3,452\end{array}$ & $\begin{array}{r}-\quad 39 \\
+\quad 11 \\
+\quad 2\end{array}$ & $\begin{array}{r}-1.1 \\
+\quad .3 \\
+\quad .1\end{array}$ \\
\hline $\begin{array}{l}\text { Total ............ } \\
\text { Average } 1 \text { rlay .... }\end{array}$ & $\begin{array}{r}10,374 \\
3,458\end{array}$ & $\begin{array}{r}212 \\
71 \\
\end{array}$ & $\begin{array}{l}420 \\
140\end{array}$ & $\begin{array}{r}16 \\
5 \\
\end{array}$ & $\begin{array}{r}223 \\
-\quad 7 t \\
\end{array}$ & $\begin{array}{r}488 \\
-163\end{array}$ & $\begin{array}{r}10 \\
3,\end{array}$ & $\begin{array}{r}10,411 \\
3,470\end{array}$ & $\begin{array}{r}-\quad 26 \\
-\quad 9\end{array}$ & $-\quad .3$ \\
\hline $\begin{array}{l}\text { Experiment No. } 31 \text {. } \\
\begin{array}{l}\text { Iar. } 22-23,7 \text { a.m. to } 7 \text { a.m. } \\
23-24,7 \text { a.m. to } 7 \text { a.m. } \\
2+-25,7 \text { a.m. to } 7 \text { a.m. }\end{array}\end{array}$ & $\begin{array}{l}3,495 \\
3,495 \\
3,495\end{array}$ & $\begin{array}{l}91 \\
90 \\
91\end{array}$ & $\begin{array}{l}132 \\
129 \\
128\end{array}$ & ( & $\begin{array}{r}35 \\
-\quad 7 \\
+\quad 3\end{array}$ & $\begin{array}{r}96 \\
-\quad 165 \\
-\quad 192\end{array}$ & $\begin{array}{l}3,403 \\
3,448 \\
3,465\end{array}$ & $\begin{array}{l}3,429 \\
3,413 \\
3,417\end{array}$ & $\begin{array}{l}+\quad 26 \\
-\quad 35 \\
-\quad 48\end{array}$ & $\begin{array}{r}+\quad .8 \\
-\quad 1.0 \\
-\quad 1.4\end{array}$ \\
\hline $\begin{array}{l}\text { Total ............. } \\
\text { Average } 1 \text { rlay .... }\end{array}$ & $\begin{array}{r}10,485 \\
3,495\end{array}$ & $\begin{array}{r}272 \\
91\end{array}$ & $\begin{array}{l}389 \\
129\end{array}$ & $\cdots$ & $\begin{array}{r}-\quad 39 \\
-\quad 13\end{array}$ & $\begin{array}{l}-453 \\
-\quad 151\end{array}$ & $\begin{array}{r}10,316 \\
3,439\end{array}$ & $\begin{array}{r}10,259 \\
3,420\end{array}$ & $\begin{array}{l}57 \\
-\quad 19\end{array}$ & -6 \\
\hline
\end{tabular}

EXPERIMENTS NOS. 32-34-WORK. NO. 33 WITH ALCOHOL DIET.

Smlject.-J. F. S., the same as in experiments of the two previous series, Nos. 26-31. His weight with underclothing was about $66.5 \mathrm{kilograms}$ ( $145 \frac{1}{2}$ pounds).

Jccupation dreing erperiment. - Work, s hours a day, upon a stationary bicyele, as in the previous series of experiments.

Duretion.-This experiment was the second of a series of 3 , each of which continued 3 days. A preliminary period of $t$ days preceded the first. The series was intended to be as nearly as possible a repetition of the previous series, Nos. 29-31, with the exception that the order in which the supplemental materials were added to the basal ration was butter, alcohol, sugar, while in the prerious series the order was sugar, butter, alcohol. The preliminary period began with breaktast A pril 16, 1sm, and the subject entered the respiration chamber on the evening of April 19. The first experiment of the series, No. 32, began at 7 a. m. April 20: the second. No. 33, at 7 a. 23. I pril 23, and the third, No. 34, at $7 \mathrm{a} . \mathrm{m}$. April 26 . The subject thus spent 9 days and 11) niglits within the respiration chamber.

Dict.- Is hats already been indirated, this series was a duplicate in reverse order of the previons series. Ther was a basal ration differing slightly in the different experiments on account of diflerences in the composition of the milk. This ration furnished approximately 100 gram of protrin and z,ast calories of energy, or practically the sane as in the previous series. To thi- hasal ration were adderl: In No. 32, 63.5 grams of butter per day, furnishing 1 gram of

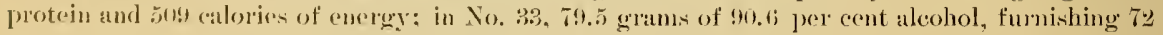
grams of alwolute aloolol and sob calories of energy per day, and in No. 34, 12s grams of cane stgar, furnisling sut aslories of mergy. The total ration therefore in this series of experiments furui-horl 10 grams of protein and 3.t!m (alories of energy per day. The alcohol was taken in fi doses. an usual. and the sllgar was also taken at frepuent intervals, int the butter was cousuned 
in ahont equal portions at breakfast, dimmer, and supper. The total amount of water in the drink on each day of the series of experiments amounted to 1.250 grams. The kinds and quantities of fool served at each meal and the cuantities of drink at diflerent periods of the day were as follows:

Wiet in metubolisw eryerimots Nos. 323-34.

FOOD-BASAL FATION

\begin{tabular}{|c|c|c|c|c|}
\hline & Breakfust. & binner. & Supler. & Total. \\
\hline Beef & $\begin{array}{l}\text { Grams. } \\
\text { G........ }\end{array}$ & $\begin{array}{r}\text { Grams. } \\
58\end{array}$ & $\begin{array}{c}\text { Grams. } \\
\ldots . . . . . .\end{array}$ & $\begin{array}{l}\text { Grams. } \\
58,8\end{array}$ \\
\hline Butter ................................... & 9.0 & 17 & 9.0 & 35 \\
\hline 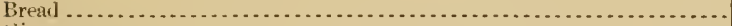 & 75.0 & 150 & 75.0 & 300 \\
\hline finger snaps , . . . . . . . . . . . . . . . . . . . . & 25.0 & 25 & 25.0 & 75 \\
\hline 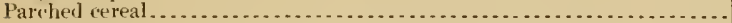 & 37.5 & - & 37.5 & 75 \\
\hline 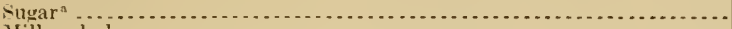 & 17.5 & $\cdots$. & 17.5 & 35 \\
\hline 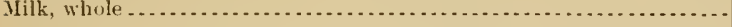 & 340.0 & 340 & 340.0 & 1,020 \\
\hline
\end{tabular}

${ }^{2}$ Eaten om parched cereal in experiments Nos. 32 and 34; mostly added to water and alcohol in experiment No. 33.

FOOD-SUPPLEMENTAL RATION.

Experiment So. 32, I pril 20-22.-Sixty-two grams butter added to basal ration. This amount also supplemented the ration during the prelininary period.

Experiment Yo. $33, .1$ pril $23-25$. - Seventy-t wo grams absolute alcohol daily. This was supplied in 79.5 grams of 90.57 per cent alcohol, which was made up to 900 grams with the addition of 25 grams sugar and the rest water.

Experiment .o. 34, 4 pril $26-28$. - The basal ration was increased by the addition of 128 grams of cane sugar.

DRINK.

\begin{tabular}{|c|c|c|c|c|c|}
\hline & \multirow{2}{*}{ Time. } & \multirow{2}{*}{$\begin{array}{c}\begin{array}{c}\text { Experiment } \\
\text { No.32. }\end{array} \\
\text { Water. }\end{array}$} & \multicolumn{2}{|c|}{ Experiment No. 33 . } & \multirow{2}{*}{$\begin{array}{c}\text { Experiment } \\
\text { No. } 34 . \\
\text { Water. }\end{array}$} \\
\hline & & & $\begin{array}{c}\text { Aleohol and } \\
\text { sweetened } \\
\text { water." }\end{array}$ & Water. & \\
\hline $\begin{array}{l}\text { Breakfast . } \\
10.15 \text { a. . . } \\
\text { Dinner.... } \\
4 \text { p. m..... } \\
\text { Suppper... } \\
9 \text { p. m .... } \\
10.20 \text { p. m. }\end{array}$ & 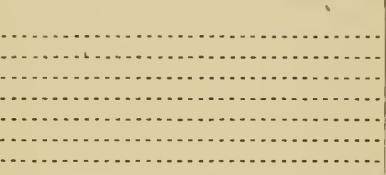 & $\begin{array}{r}\text { Grams. } \\
150 \\
200 \\
200 \\
200 \\
150 \\
200 \\
150\end{array}$ & $\begin{array}{r}175 \\
100 \\
175 \\
100 \\
175 \\
100 \\
75\end{array}$ & $\begin{array}{r}\text { trams }_{4} \\
75 \\
75 \\
75 \\
75 \\
75 \\
72 \\
72 \\
\ldots . . .\end{array}$ & $\begin{array}{r}150 \\
200 \\
200 \\
200 \\
150 \\
200 \\
150\end{array}$ \\
\hline Total & & 1,250 & 900 & 447 & 1,250 \\
\hline
\end{tabular}

"Contained 403 grams water, 25 grams sugar, and 72 grans aleohol.

Daily antire. - The general plan of the series of experinents was identical with that of the previous series, and is shown in the following schedule:

Intily programme. - Wetubolism experiments Liss. 32-34.

6.50 a. m ....... Take pulse and temperature.

Ta. m......... Pass urine, weigh self dressed, collect lrip, and weigh absorber:

7.30 a. $m$...... Breakfast, llrink 150 grams watex.

8.15 a. 11 ....... Begin work.

$10.15 \mathrm{a}, \mathrm{m}$...... Stop Work, llink 200 grams water.

10.30 a. $\mathrm{m}$...... Begin work.

12.30 p. 11 ...... Stop work.

$12.50 \mathrm{l} . \mathrm{m} \ldots .$. . Take pulse and temperature.

1 p. w......... Pass urine, collect drip, and weigh absorber:

1.25 \%. m ...... Dinner, irink 200 grrams water.

? p. m......... Begin work.
4 p. m...... . Stop work, tlrink 200 grams water.

4.15 p. . . .... . Begin work.

6.15 p. m ...... Ston work, change underchothing.

6.20 p. m ..... Supper, drink 150 grams water.

6.50 \%. $\mathrm{m}$...... Take pulse and temperature.

7 w........ Pans urine, weigh self dressed, collect drip, and weigh absorbers.

9 p. m........ Drink 200 grams water.

10 \%. m....... Take pulse and temperature.

$10.10 \mathrm{p} . \mathrm{m} \ldots . . .$. Arrange bed.

10.20 1. m . . . . Drink 150 grams water.

10.30 1. 111..... Retire.

1 a. $111 . . . . . . .$. Pass nrine. 
The more important statistics in the diary kept by the subject are -ummarized in Table XC. Frequent determinations of both pulse rate and body temperature were taken.

TABLE XC._Sirmmary of diary-Metabolism enperiments .Wos. 32-34.

\begin{tabular}{|c|c|c|c|c|c|c|c|}
\hline Date and rime. & $\begin{array}{c}\text { Weight } \\
\text { with } \\
\text { clothes. }\end{array}$ & $\begin{array}{l}\text { Pulserate } \\
\text { per } \\
\text { minute. }\end{array}$ & $\begin{array}{l}\text { Temper- } \\
\text { ature. }\end{array}$ & Date and time. & $\begin{array}{l}\text { Weight } \\
\text { with } \\
\text { clorhes. }\end{array}$ & $\begin{array}{c}\text { Pulse rate } \\
\text { per } \\
\text { minute. }\end{array}$ & $\begin{array}{l}\text { Temper- } \\
\text { ature. }\end{array}$ \\
\hline 1900. & & & & 1900. & & & \\
\hline Experiment Is. & Killograms. & & ${ }^{\circ} F$. & Experiment No. 3.3-C" $\mathrm{t}^{\prime} \mathrm{d}$. & Külograms. & & F. \\
\hline $\begin{array}{r}\text { Apr. } 20,6.55 \mathrm{a} . \mathrm{m} \\
7 \mathrm{a} . \mathrm{m} . . .\end{array}$ & …..... & 66 & 97. & Apr. $23,2.05$ p. m......... & & $\begin{array}{r}97 \\
100\end{array}$ & \\
\hline $\begin{array}{l}\text { a.m. } \\
9 \text { a.m. }\end{array}$ & & $\ddot{s i}$ & $\begin{array}{r}91.8 \\
\ldots . . .\end{array}$ & $\begin{array}{l}3 \text { p.m... } \\
\text { tp.m... }\end{array}$ & & $\begin{array}{l}100 \\
102\end{array}$ & \\
\hline 10 a.m. & ... & 83 & & бp.m... & & 102 & \\
\hline $11 \mathrm{a}$ & $\cdots$ & 85 & (n.... & $6 \mathrm{p}$ & $6=$ & 97 & $0^{-}-$ \\
\hline $\begin{array}{l}12 \mathrm{~m} \ldots \ldots \\
12.55 \mathrm{p} . \mathrm{m} .\end{array}$ & & 65 & -.... & sp.m.m.......... & 65.74 & 74 & 97.7 \\
\hline 1 p.m.... & & & 97.7 & $9 \mathrm{p.m} . \mathrm{s.}$ & & 75 & 97.2 \\
\hline 2.05 & $\cdots$ & 93 & $\cdots$. & 10.10 & & 72 & 97.0 \\
\hline $\begin{array}{l}3 \mathrm{p} \cdot \mathrm{m} . \\
4 \mathrm{p} \cdot \mathrm{m} .\end{array}$ & & 80 & $\cdots \cdot$ & $\begin{array}{r}\text { Apr. } 24,6.5 \% \text { a.m } \\
\text {; a.m }-. .\end{array}$ & 65.27 & & 97.8 \\
\hline $5 \mathrm{p.m}$ & $\cdots$ & 83 & (n. & y a.m.... & & 109 & \\
\hline $6 \mathrm{p.m}$ & & 84 & $\ldots$ & 10 a. $\mathrm{m} .$. & & 102 & \\
\hline ; p. 1 & 66.95 & 72 & $9 \% .8$ & 11 & & 96 & \\
\hline S p. & (n....... & 69 & $9 \bar{i} . \bar{i}$ & $12 \mathrm{~m} . .$. & & 95 & \\
\hline $\begin{array}{l}9 \mathrm{p} . \mathrm{m} \ldots . . . \\
10 \mathrm{pm}\end{array}$ & (n........ & 64 & 97.1 & 1 p.m.... & $\cdots$ & 72 & $9 \div .9$ \\
\hline pr. $21,6.55$ a. $\mathrm{m} . .$. & $\cdots$ & $\begin{array}{l}62 \\
64\end{array}$ & 96.6 & $2.07 \mathrm{pem}$. & & $\begin{array}{r}98 \\
10^{2}\end{array}$ & -. \\
\hline Apr.-1, 7 a.m.... & 66.36 & $\begin{array}{l}0 . \\
\cdots\end{array}$ & $97 . \bar{s}$ & $\begin{array}{l}3 \text { p.m.... } \\
\text { 4 p.m... }\end{array}$ & & 108 & $\begin{array}{l}\cdots \\
\cdots\end{array}$ \\
\hline 9 a.m.... & ... & 91 & $\cdots$ & 5 p.m... & & 104 & - \\
\hline 10 a. & $\cdots$ & 88 & -.... & 6 p.m... & & 100 & \\
\hline 11 a.m... & $\cdots \cdot$ & 89 & n......... & $7 \mathrm{p} . \mathrm{m}-$ & 65.69 & 28 & $9 \overline{7} . \overline{1}$ \\
\hline $\begin{array}{l}12 \mathrm{~m} \ldots \ldots \\
1 \mathrm{p} . \mathrm{m} \ldots . .\end{array}$ & $\cdots$ & $\begin{array}{l}90 \\
67\end{array}$ & 98.0 & $\begin{array}{l}8 \text { p.m } \\
9 \text { p. m } \ldots\end{array}$ & & $\frac{\pi}{75}$ & 97.6 \\
\hline 2.15 p. 111 & ( & 94 & ..... & 9.04 p.m. & & & $9 \div .1$ \\
\hline $3 \mathrm{p} . \mathrm{m} \ldots .$. & ...... & 96 & …. & $10.10 \mathrm{p.m}$. & & 71 & . \\
\hline & $\cdots$ & 97 & $\cdots$ & $\begin{array}{r}10.15 \mathrm{p} \cdot \mathrm{m} . \\
\text { Apr. } 25,6.55 \mathrm{a} . \mathrm{m} .\end{array}$ & - & 69 & 96.7 \\
\hline $\begin{array}{l}5 \mathrm{p} . \mathrm{m}_{\ldots} . . . \\
6 \mathrm{p} \cdot \mathrm{m}_{-. . .}\end{array}$ & & 85 & $\cdots$ & $\begin{array}{r}\text { Apr. } 25,6.55 \text { a.m... } \\
7 \text { a.m .... }\end{array}$ & 65.13 & & 97.7 \\
\hline $7 \mathrm{p} . \mathrm{m} \ldots . .$. & 66.27 & it & 97.9 & 9 a.m ... & & 109 & \\
\hline 8.0 & $\cdots$ & 73 & & 10 a.m .. & & 102 & \\
\hline $8.15 \mathrm{I}$ & & & $9 \overline{2} .5$ & 11 a. $\mathrm{m} \ldots$ & & 101 & \\
\hline $9 \mathrm{p} \cdot 1$ & ... & 67 & $9 \pi .1$ & $12 \mathrm{~m} \ldots .$. & -. & 100 & \\
\hline $\begin{array}{l}10.05 \mathrm{p} \\
10.12 \mathrm{p}\end{array}$ & $\cdots+$ & 66 & 966 & ${ }_{9}^{1} \mathrm{p} . \mathrm{m} \ldots$ & (n) & 102 & $9 \overline{7} .9$ \\
\hline $\begin{array}{l}10.12 \mathrm{p} \\
2.5 .5 \mathrm{a} .1\end{array}$ & & 68 & 96.6 & $\begin{array}{l}2.05 \mathrm{p} . \mathrm{m} . . \\
3 \mathrm{p.m} . . .\end{array}$ & & $\begin{array}{l}102 \\
112\end{array}$ & -. \\
\hline ia.m. & 65.83 & & 97.7 & $4 \mathrm{pm} . \mathrm{m}$ & $\ldots .$. & 107 & \\
\hline $9:$ & (....... & 101 & $\cdots$ & $5 \mathrm{p} . \mathrm{m} \ldots$ & .. & 104 & $\cdots \cdots$ \\
\hline 10 & ....... & 96 & $\cdots$ & 6 p. & & 105 & \\
\hline $11=$ & & 92. & $\cdots$ & $7 \mathrm{p} . \mathrm{m} \ldots \ldots$ & 65.47 & 76 & \\
\hline $12 \mathrm{~m} .$. & $\cdots$ & $9 s$ & & s p.m & ....... & $i 6$ & 97.8 \\
\hline $1 \mathrm{p} . \mathrm{In}_{2}-$ & ...... & 68 & 97.7 & 9 p.m.......... & …... & 78 & $9 \overline{7} \cdot 6$ \\
\hline 2.05 & & 100 & -.. & $10.10 \mathrm{p} . \mathrm{m} \ldots \ldots$ & ….... & 75 & 97.2 \\
\hline $3 p . m \ldots$ & (n.... & $\begin{array}{l}103 \\
104\end{array}$ & -. & Enperinmel Sir. 34. & & & \\
\hline $\begin{array}{l}4 \\
5 \text { p.m.......... }\end{array}$ & (n... & $\begin{array}{l}104 \\
102\end{array}$ & & Liperment - W. ne & & & \\
\hline $6 \mathrm{i}$, & & 100 & & $A p r, 26,6.55$ a. $m .$. & & $6 \mathrm{~s}$ & \\
\hline 31.1 & 65.59 & 79 & 97.7 & $7 \mathrm{a}, \mathrm{m} \ldots$ & 64.94 & & 97.7 \\
\hline ..... & . & it & 97.5 & $9 \mathrm{a} . \mathrm{m} \ldots$ & & 106 & \\
\hline 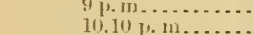 & & 61 & 97.3 & a. $111, \ldots \ldots . .$. & $\cdots$ & 102 & - \\
\hline 10. 10 p. 111. & & & 96.9 & $\begin{array}{l}11 \mathrm{a}, 11 \ldots \ldots \ldots \\
12 \mathrm{~m} \ldots \ldots\end{array}$ & $\ldots$ & 96 & \\
\hline Erporiment to , & & & & $1 \mathrm{p}, \mathrm{m} \ldots \ldots \ldots$ & & 66 & 97.7 \\
\hline, 15 & & & & $2.05[1,211 \ldots \ldots$ & ...... & 98 & $\cdots$ \\
\hline & (65). 21 & a... & $9 \%$ & $\begin{array}{l}31,111 \ldots \ldots \ldots \\
4 \text { p. } 11, \ldots \ldots \ldots \\
\end{array}$ & (n..... & 97 & $\because$ \\
\hline & ....... & 102 & $\cdots$ & 5 p. & $\cdots \cdots$ & $9 x$ & - \\
\hline 4 & & 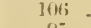 & & 6 [1. $111 . . . \ldots . .$. & $\cdots \cdots$ & $y_{i}$ & \\
\hline 14 & ... & 9.5 & $\cdots$ & ;р.11........... & 6i.5. 44 & $\because$ & 97.7 \\
\hline 11 a & & 435 & $\cdots$ & sp. 1n .......... & ....... & it & 4.6 \\
\hline $1211 \ldots \ldots$ & (n... & 7) & $(15,0)$ & 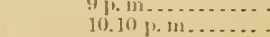 & $\cdots \cdots$ & 6 & 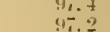 \\
\hline 1.57 p. D....... & …... & 73 & & Apr. $27,6.55$ a. $13 . . . .$. & & (15) & \\
\hline
\end{tabular}




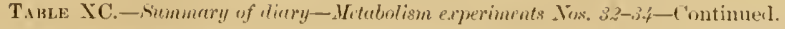

\begin{tabular}{|c|c|c|c|c|c|c|c|}
\hline lhate and time. & $\begin{array}{l}\text { Wcight } \\
\text { with } \\
\text { elothes. }\end{array}$ & $\begin{array}{l}\text { 1'ulse rate } \\
\text { jer } \\
\text { minute. }\end{array}$ & $\begin{array}{l}\text { Temper- } \\
\text { uture. }\end{array}$ & Date autl time. & $\begin{array}{l}\text { Wuight } \\
\text { with } \\
\text { elothes. }\end{array}$ & $\begin{array}{c}\text { P'ulserute } \\
\text { per } \\
\text { minute. }\end{array}$ & $\begin{array}{l}\text { Templet- } \\
\text { ature. }\end{array}$ \\
\hline 1900. & & & & 1900. & & & \\
\hline Experiment No. 34-C't'd. & & & & Expuriment No. 34-C't'il. & & & \\
\hline$\mu r^{2}, i, 7$ a.m $\ldots \ldots \ldots$ & $\begin{array}{l}\text { Kilograns. } \\
\text { 6ั. } 09\end{array}$ & & ${ }^{F} \cdot 6$ & A Ir. $2 k, 4$ a. m.... & $\begin{array}{l}\text { Kilograme. } \\
\text {............ }\end{array}$ & 104 & \\
\hline 9 a.m............ & ......... & $10 ;$ & $\ldots \ldots \ldots$ & $10 \mathrm{a} . \mathrm{m}$ & (........... & 98 & $\cdots$ \\
\hline ........ & ........... & 98 & $\ldots \ldots \ldots$ & II a.m......... & $\ldots$ & 90 & ......... \\
\hline ....... & ........ & 100 & ........ & $12112 \ldots \ldots \ldots$. & $\ldots .$. & 93 & . . . . . \\
\hline $12 \mathrm{~m} \ldots \ldots \ldots$ & $\ldots \ldots \ldots$ & $6 i$ & …...... & 1 l.m....... & $\ldots$ & 66 & 97.8 \\
\hline ........ & 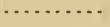 & 71 & 48.3 & 2.05 P. $111 \ldots$ & $\cdots \cdots$ & 96 & .......... \\
\hline 2.0511 .11 & $\ldots \ldots \ldots$ & 100 & .... & 3 p. $11 . . . . .$. & & 97 & $\ldots \ldots$ \\
\hline 3 r.11... & $\ldots \ldots \ldots$ & 29 & ......... & ${ }^{4} \mathrm{j} . \mathrm{m} \ldots . .$. & ..... & 102 & $\ldots \ldots \ldots$ \\
\hline$\pm \mathrm{p}, \mathrm{m} \ldots \ldots \ldots$ & . . . . . . . . & 94 & ......... & 5 p.111........ & . . . . . & 99 & ........ \\
\hline $5 \mathrm{p} . \mathrm{m} \ldots \ldots . . .$. & $\ldots \ldots \ldots$ & 100 & $\ldots \ldots . . . .$. & fip.m......... & …....... & 97 & 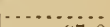 \\
\hline . . . n & - n & $9 \overline{7}$ & . . . . & $7 \mathrm{I} . \mathrm{m} \ldots . . . . .$. & tiล̄. 37 & 73 & 97.0 \\
\hline$\ldots \ldots$ & 63.34 & 73 & 97. & $8 \mathrm{j}, \mathrm{m} \ldots . . .$. & 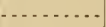 & 75 & 97.5 \\
\hline$\cdots$ & ........ & 73 & 47 & 91 & & 67 & 97.4 \\
\hline 9 [. 11 & $\ldots \ldots \ldots$ & 71 & 97.5 & $10.10_{1}$. & $\ldots$ & tit) & 97.3 \\
\hline $10 \mathrm{p} . \mathrm{m}$. & ........... & 68 & 97.3 & Apr. $29,6.5 \overline{\text { a }}$ a. m... & $\cdots . .$. & 69 & . \\
\hline Apr. $28,6.55$ a. m. & ……… & 67 & 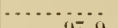 & 7 a.m...... & 64.92 & $\cdots$ & 97.7 \\
\hline † a. m... & 64.98 & $\cdots$ & $4-$ & & & & \\
\hline
\end{tabular}

Amonnt of mork drme.-The total number of miles registered by the eyclometer and the heat equivalent of the work done each day are shown in Table XCI.

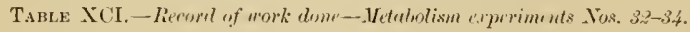

\begin{tabular}{|c|c|c|c|c|c|}
\hline Dote and time. & $\begin{array}{l}\text { cyelometer } \\
\text { rearling. }\end{array}$ & $\begin{array}{l}\text { Number } \\
\text { of } \\
\text { miles. }\end{array}$ & $\begin{array}{l}\text { Actual } \\
\text { duration } \\
\text { of work. }\end{array}$ & Rate. & $\begin{array}{c}\text { Heat } \\
\text { ("quivalent. }\end{array}$ \\
\hline 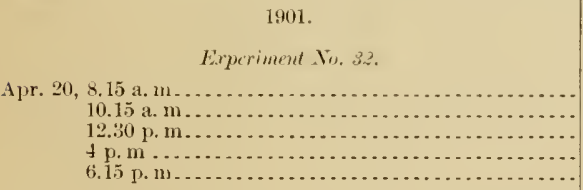 & $\begin{array}{l}1,510.4 \\
1,527.2 \\
1,5+1.5 \\
1,562.8 \\
1,579.1\end{array}$ & $\begin{array}{l}16.8 \\
19.3 \\
16.3 \\
16.3\end{array}$ & $\begin{array}{l}\text { Minutrs. } \\
120 \\
120 \\
120 \\
120\end{array}$ & $\begin{array}{l}\text { Watts. } \\
18.8 \\
21.0 \\
16.7 \\
17.4\end{array}$ & $\begin{array}{r}\text { Calorite. } \\
32 \\
36 \\
29 \\
30\end{array}$ \\
\hline . & (n......... & 68.7 & 480 & …........ & 127 \\
\hline 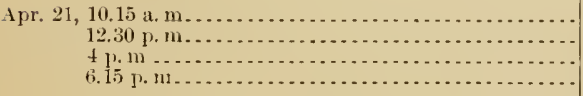 & $\begin{array}{l}1,599.2 \\
1,626.0 \\
1,654.0 \\
1,681.7\end{array}$ & $\begin{array}{l}20.1 \\
26.8 \\
28.0 \\
27.7\end{array}$ & $\begin{array}{l}120 \\
120 \\
120 \\
120\end{array}$ & $\begin{array}{l}21.0 \\
25.5 \\
30.5 \\
29.6\end{array}$ & $\begin{array}{l}36 \\
44 \\
52 \\
51\end{array}$ \\
\hline Total .. & - ......... & 102.6 & 480 & -.. $\quad \ldots . .$. & 183 \\
\hline 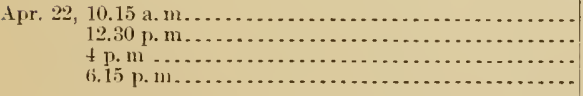 & $\begin{array}{l}1,711.6 \\
1,7 \pm 4.6 \\
1,774.5 \\
1,806.1\end{array}$ & $\begin{array}{l}29.4 \\
33.0 \\
29.9 \\
31.6\end{array}$ & $\begin{array}{l}120 \\
120 \\
120 \\
120\end{array}$ & $\begin{array}{l}36.2 \\
+7.4 \\
35.1 \\
40.0\end{array}$ & $\begin{array}{l}62 \\
81 \\
65 \\
69\end{array}$ \\
\hline Total ............. & & 124.4 & $4 \times 0$ & ..... & 277 \\
\hline 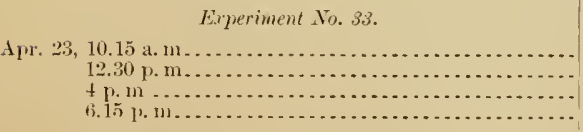 & $\begin{array}{r}1,825.3 \\
1,854.1 \\
1,880.8 \\
1,908.2\end{array}$ & $\begin{array}{l}19.2 \\
28.8 \\
26.7 \\
27.4\end{array}$ & $\begin{array}{l}120 \\
120 \\
120 \\
120\end{array}$ & $\begin{array}{l}20.6 \\
23.9 \\
26.6 \\
27.5\end{array}$ & $\begin{array}{l}35 \\
41 \\
+65 \\
+7\end{array}$ \\
\hline Total & 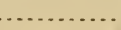 & 102.1 & $4 \times()$ & $\ldots$ & 169 \\
\hline
\end{tabular}


TABLE XCI.-Record of work done-Metabolism experiments $\lambda$ Kos. 82-34-Continued.

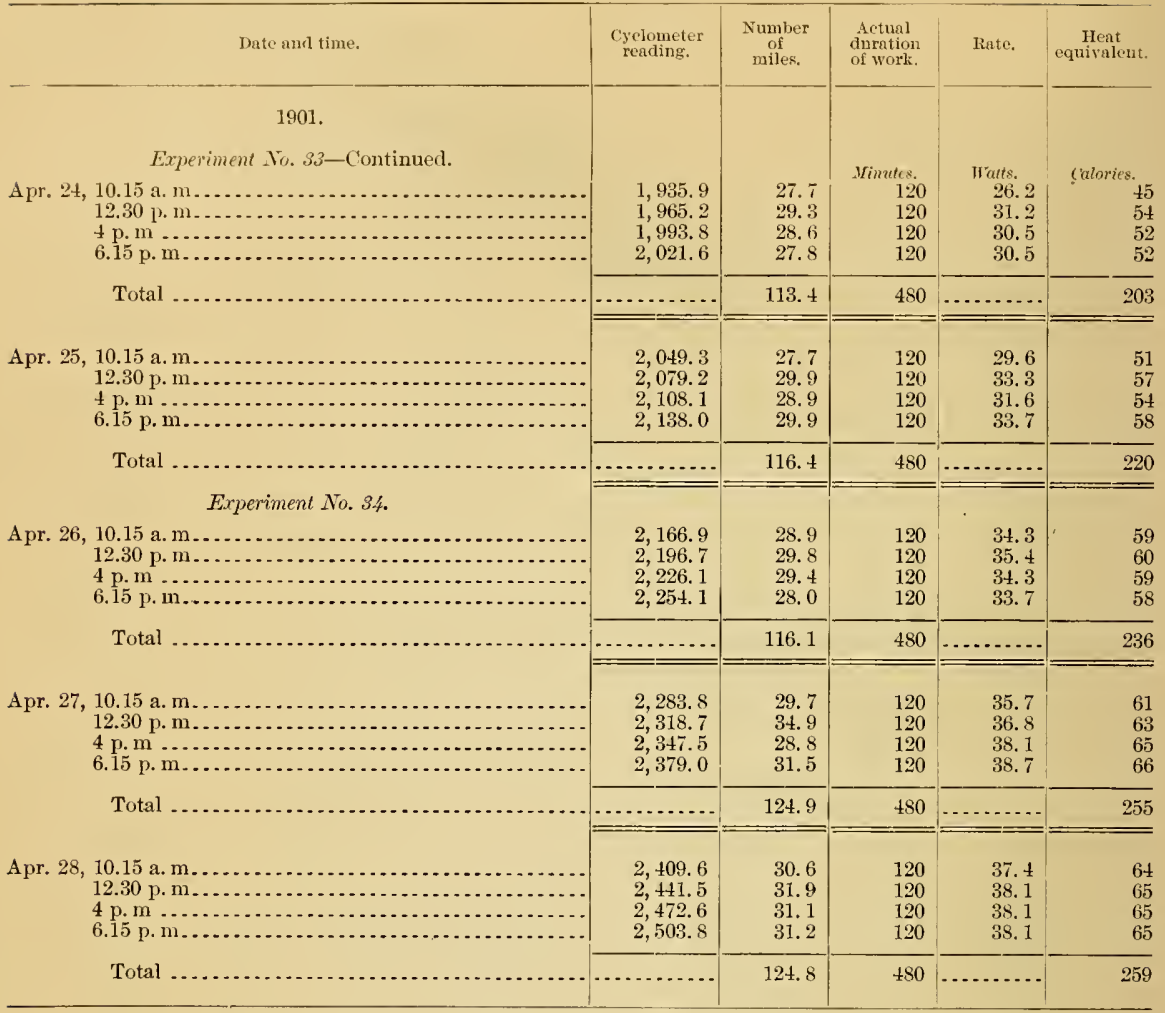

Detailed statistics of income and outgo. - The quantities of nutrients in the basal ration and the quantities in the smpplemental rations for the different experiments are shown in Table XCII. The outgo of matter and energy in the feces during the different experiments is shown in Table XCIII.

TABLE XC11.- Weight, composition, and heut of combustion of foorls-Metabolism experiments Nos. 38-34.

\begin{tabular}{|c|c|c|c|c|c|c|c|c|c|c|}
\hline $\begin{array}{c}\text { Labora- } \\
\text { tory } \\
\text { No. }\end{array}$ & Food material. & $\begin{array}{l}\text { Weight } \\
\text { per day. }\end{array}$ & Water. & Protein. & Fat. & $\begin{array}{c}\text { Carbohy- } \\
\text { drates. }\end{array}$ & Nitrogen. & f'arbon. & $\begin{array}{c}\text { Hyolro- } \\
\text { gen. }\end{array}$ & $\begin{array}{c}\text { Heat of } \\
\text { combus- } \\
\text { tion. }\end{array}$ \\
\hline $\begin{array}{l}3205 \\
3206 \\
3204 \\
3207 \\
3193\end{array}$ & 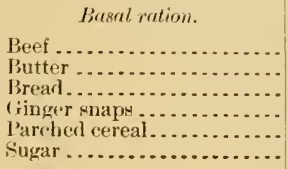 & $\begin{array}{r}\text { fircems. } \\
58 \\
35 \\
300 \\
75 \\
75 \\
35\end{array}$ & $\begin{array}{r}\text { Grams. } \\
37.4 \\
2.9 \\
113.4 \\
2.8 \\
3.1 \\
\end{array}$ & $\begin{array}{r}\text { Grams. } \\
18.6 \\
.4 \\
25.8 \\
4.1 \\
9.0 \\
\ldots . . .\end{array}$ & $\begin{array}{r}\text { Gramis. } \\
1.6 \\
30.7 \\
7.5 \\
5.4 \\
1.1 \\
\ldots . . .\end{array}$ & \begin{tabular}{|r} 
frams. \\
0.2. \\
149.4 \\
61.2 \\
60.4 \\
35.0
\end{tabular} & $\begin{array}{r}\text { Grams. } \\
2.98 \\
.07 \\
4.14 \\
.60 \\
1.44\end{array}$ & $\begin{array}{l}\text { Grams. } \\
10.76 \\
22.95 \\
84.81 \\
32.90 \\
32.04 \\
14.74\end{array}$ & $\begin{array}{r}\text { Grams. } \\
1.54 \\
3.63 \\
12.90 \\
5.40 \\
4.73 \\
2.27\end{array}$ & $\begin{array}{r}\text { Culorics. } \\
120 \\
287 \\
861 \\
333 \\
.315 \\
139\end{array}$ \\
\hline & & 578 & 159.6 & 57.9 & 46.3 & 306.0 & 9.29 & 198.20 & 30.47 & 2,055 \\
\hline
\end{tabular}




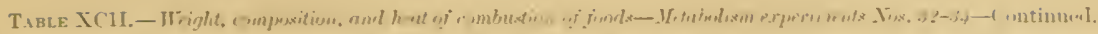

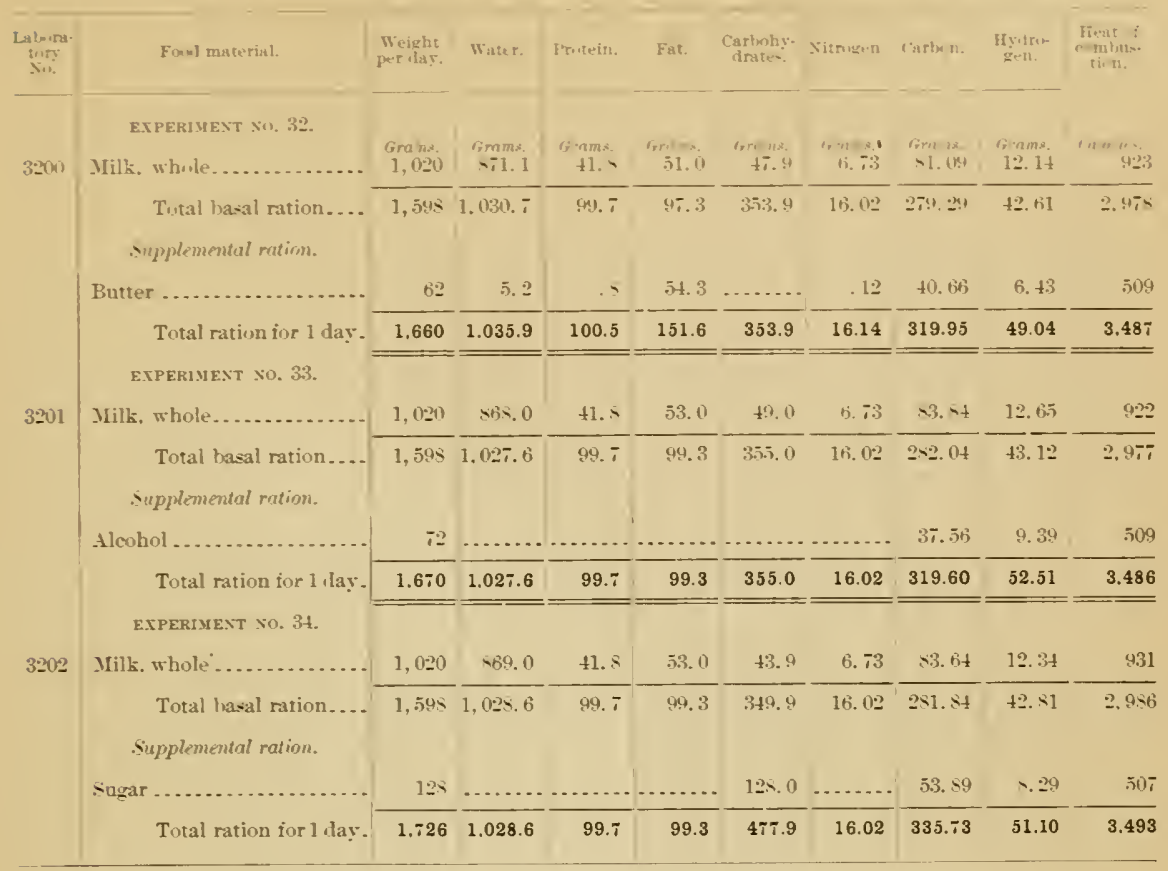

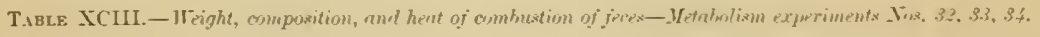

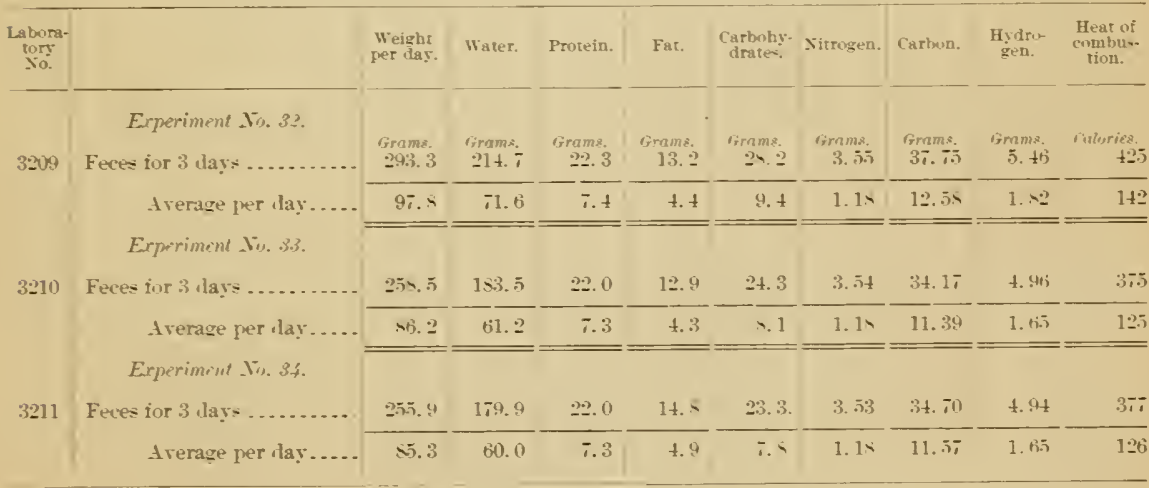


Table XCIV shows the quantity of urine eliminated on different days, and the quantity of urine and nitrogen in the urine for each 6 -hour period of experiment No. 33 . The heat of combustion of the urine was determined in the composite sample for each day and the carbon and hydrogen in the composite for the total 9 days of the series.

T.1BLE XCIV.-Amounts, specific gratity, and nitrogen of urine-Vetubolism experiments Nos. 32-34.

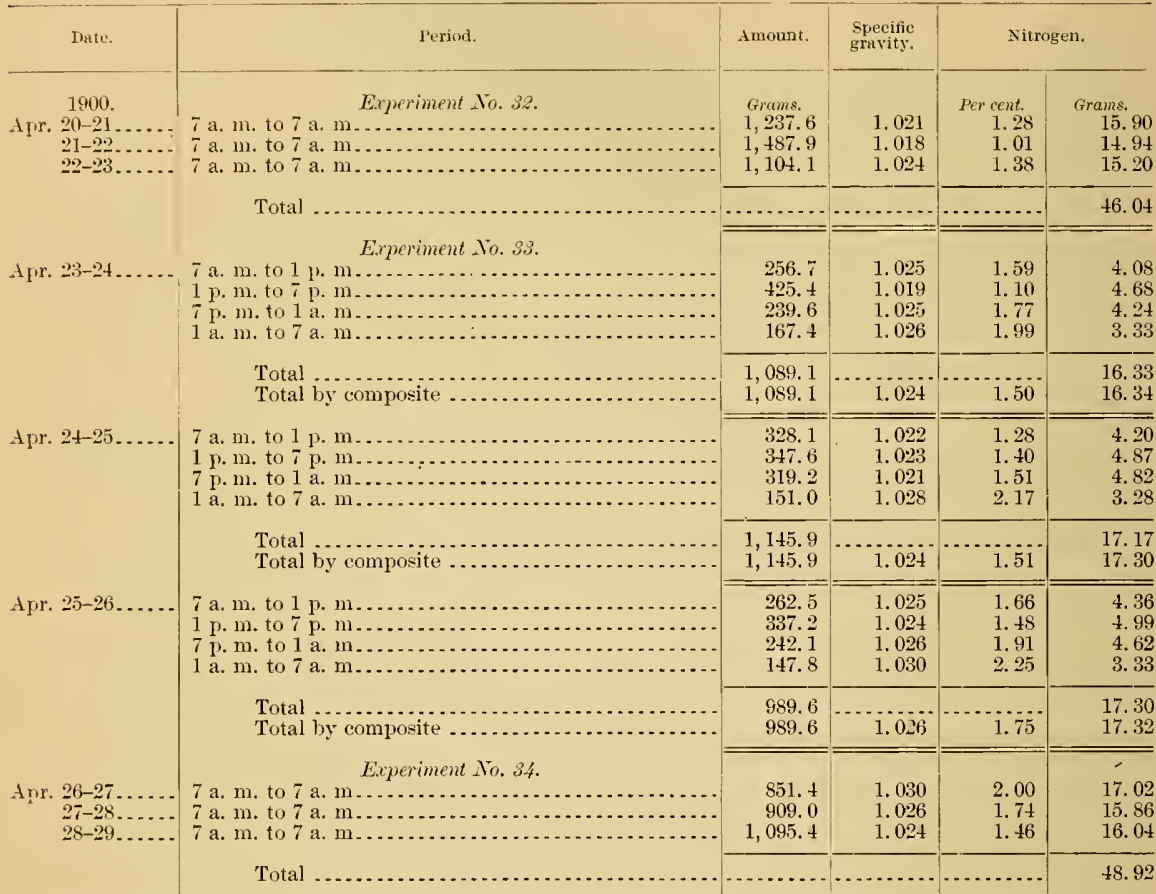

TABLE XCV.-Duily eliminution of curbon, hystrogen, and uater in urine-Metubolism experiments Nos. 32-34.

\begin{tabular}{|c|c|c|c|c|c|c|c|c|c|}
\hline \multirow{2}{*}{$\begin{array}{c}\text { Date. } \\
1900 .\end{array}$} & \multirow{2}{*}{ Amount. } & \multirow{2}{*}{\multicolumn{2}{|c|}{ Carbon. }} & \multirow{2}{*}{\multicolumn{2}{|c|}{ Hydrogen. }} & \multirow{2}{*}{\multicolumn{2}{|c|}{ Water. }} & \multicolumn{2}{|c|}{ Heat of combustion. } \\
\hline & & & & & & & & Per gram. & Total. \\
\hline $\begin{array}{c}1900 . \\
\text { A jur. } 20-21 \ldots \ldots \ldots \\
21-22 \ldots \ldots \\
22-23 \ldots \ldots\end{array}$ & $\begin{array}{l}\text { Groms. } \\
1,237.6 \\
1,487.9 \\
1,104.1\end{array}$ & $\begin{array}{l}\text { Pcr cent. } \\
\ldots \ldots \\
\cdots \\
\cdots\end{array}$ & $\begin{array}{r}\text { firamis. } \\
11.35 \\
10.67 \\
10.85\end{array}$ & 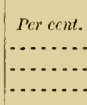 & $\begin{array}{l}\text { Grams. } \\
3.13 \\
2.95 \\
3.00\end{array}$ & \begin{tabular}{l} 
Per cent. \\
$\ldots \ldots$ \\
\hdashline$\ldots$ \\
\hdashline$\ldots$
\end{tabular} & $\begin{array}{l}\text { Grams. } \\
1,179.7 \\
1,433.4 \\
1,048.7\end{array}$ & $\begin{array}{r}\text { Calories. } \\
0.104 \\
.076 \\
.105\end{array}$ & $\begin{array}{r}\text { Calorics. } \\
129 \\
113 \\
116\end{array}$ \\
\hline Total. & $\cdots$ & ........ & 32.87 & & 9.08 & & & 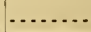 & 358 \\
\hline $\begin{array}{l}23-24 \\
24-25 \\
25-26 \ldots \ldots\end{array}$ & $\begin{array}{r}1,089.1 \\
1,145.9 \\
989.6\end{array}$ & 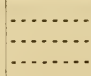 & $\begin{array}{l}11.66 \\
12.26 \\
12.35\end{array}$ & (n..... & $\begin{array}{l}3.22 \\
3.38 \\
3.41\end{array}$ & & $\begin{array}{r}1,029.6 \\
1,083.3 \\
926.6\end{array}$ & $\begin{array}{l}.115 \\
.113 \\
.134\end{array}$ & $\begin{array}{l}125 \\
129 \\
133\end{array}$ \\
\hline Total . & ....... & $\ldots$ & 36.27 & .. & 10.01 & & . . . . . & ........ & 387 \\
\hline $\begin{array}{l}24 i-27 \ldots \ldots \\
27-28 \ldots \ldots \\
28-29+\ldots\end{array}$ & $\begin{array}{r}85 \mathrm{I} .4 \\
909.0 \\
1,095.4\end{array}$ & ... & $\begin{array}{l}12.15 \\
11.32 \\
11.45\end{array}$ & & $\begin{array}{l}3.36 \\
3.13 \\
3.16\end{array}$ & & $\begin{array}{r}789.4 \\
851.2 \\
1,036.9\end{array}$ & $\begin{array}{l}.154 \\
.137 \\
.112\end{array}$ & $\begin{array}{l}131 \\
125 \\
123\end{array}$ \\
\hline $\begin{array}{l}\text { Total ....... } \\
\text { Total g dayy }\end{array}$ & $9,910.0$ & 1.05 & $\begin{array}{r}34.92 \\
104.06\end{array}$ & .29 & $\begin{array}{r}9.65 \\
24.74\end{array}$ & 94.64 & & $(.112)$ & $\begin{array}{r}379 \\
1,124\end{array}$ \\
\hline
\end{tabular}


Tables XC'V to Xe'VIII show the results of earon dioxid and water in the ventilating atr enrent. These statisties an given in detail for experiment No. 33, in whirh aleolol formed a part of the diet, and summarized for the other 2 experiments of the series. Similar statistics of the heat measurements are given in Table XCIX.

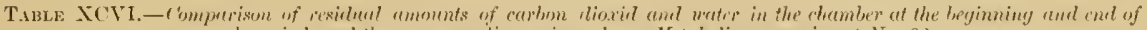

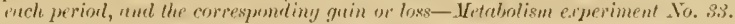

\begin{tabular}{|c|c|c|c|c|c|c|c|c|c|}
\hline \multirow{2}{*}{\multicolumn{2}{|c|}{ Inte. }} & \multirow[b]{2}{*}{ End of periot. } & \multicolumn{2}{|c|}{ f'nrixu dioxjel. } & \multicolumn{5}{|c|}{ Witer. } \\
\hline & & & $\begin{array}{l}\text { Total } \\
\text { umsunt in } \\
\text { chamber. }\end{array}$ & $\begin{array}{c}\text { fiain }(+) \text { or } \\
\text { losis }(-) \text { over } \\
\text { preceding } \\
\text { jeriud. }\end{array}$ & $\begin{array}{c}\text { Total } \\
\text { gmount of } \\
\text { vapor re- } \\
\text { numing in } \\
\text { r'hamber. }\end{array}$ & $\begin{array}{l}\text { Gain }(+) \text { or } \\
\text { losk }(-) \text { over } \\
\text { preceding } \\
\text { period. }\end{array}$ & $\begin{array}{l}\text { Change in } \\
\text { weight of } \\
\text { nbsorters. } \\
\text { finin (t) or } \\
\text { loss (-). }\end{array}$ & $\begin{array}{l}\text { Drip from } \\
\text { absorbers. }\end{array}$ & $\begin{array}{l}\text { Total } \\
\text { gmount } \\
\text { gained }(+) \\
\text { or lost } \\
\text { during the } \\
\text { period. }\end{array}$ \\
\hline \multirow{17}{*}{${ }^{1}{ }^{1}$} & \multirow{7}{*}{$\begin{array}{l}23 \\
23 \\
23 \\
24 \\
24\end{array}$} & \multirow{6}{*}{ 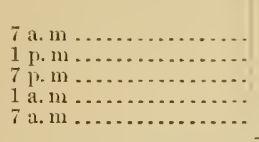 } & \multirow{6}{*}{$\begin{array}{l}\text { (irtus. } \\
27.0 \\
\times 2.8 \\
80.2 \\
29.5 \\
28.5\end{array}$} & \multirow{6}{*}{$\begin{array}{r}\text { Homs. } \\
+5.5 .8 \\
-2.6 \\
-50.7 \\
-1.0\end{array}$} & \multirow{6}{*}{ 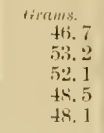 } & \multirow{6}{*}{$\begin{array}{r}\text { firtums. } \\
+6.5 \\
-1.1 \\
-3.6 \\
-.4\end{array}$} & \multirow{6}{*}{$\begin{array}{r}\text { frrams. } \\
147 \\
-\quad 9 \\
-74 \\
-73\end{array}$} & \multirow{6}{*}{$\begin{array}{r}171.7 \\
424.9 \\
31.0 \\
31.0\end{array}$} & \multirow{6}{*}{$\begin{array}{l}\text { firms } \\
+325.2 \\
+414.8 \\
-46.6 \\
-\quad 42.4\end{array}$} \\
\hline & & & & & & & & & \\
\hline & & & & & & & & & \\
\hline & & & & & & & & & \\
\hline & & & & & & & & & \\
\hline & & & & & & & & & \\
\hline & & Total .. & .... & +1.5 & . $\ldots \ldots \ldots$. & +1.4 & -9 & 658.6 & +651.0 \\
\hline & \multirow{5}{*}{$\begin{array}{l}24 \\
24 \\
25 \\
25\end{array}$} & $1 \mathrm{p}, \mathrm{m} \ldots \ldots \ldots \ldots$ & S4. 4 & -55.9 & 54.5 & +6.4 & \multirow{4}{*}{$\begin{array}{r}+172 \\
-24 \\
-76 \\
76\end{array}$} & \multirow{4}{*}{$\begin{array}{r}263.4 \\
434.3 \\
19.0 \\
19.0\end{array}$} & \multirow{4}{*}{$\begin{array}{r}+441.8 \\
+404.1 \\
-60.5 \\
-59.4\end{array}$} \\
\hline & & 7 j, & $80 . \mathrm{s}$ & -3 & & -2.2 & & & \\
\hline & & $1 \mathrm{n}, \mathrm{m} \ldots \ldots \ldots$ & 29.9 & -51.9 & 48.8 & -3.5 & & & \\
\hline & & $7 \mathrm{a}, \mathrm{m} \ldots \ldots \ldots \ldots$ & 27.0 & -1.9 & 46.4 & -2.4 & & & \\
\hline & & Total. & ..... & -1.5 & $\ldots . .$. & -1.7 & $-x$ & 735.7 & +726.0 \\
\hline & \multirow{5}{*}{$\begin{array}{l}25 \\
25 \\
26 \\
26\end{array}$} & \multirow{5}{*}{ 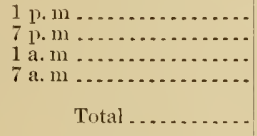 } & 85.7 & +58.7 & 54.7 & +8.3 & +186 & 241.0 & +415.3 \\
\hline & & & 85.7 & & 53.0 & -1.7 & -4 & $\$ 71.0$ & +465.3 \\
\hline & & & 27.6 & -58.1 & 49. 8 & -3.2 & -82 & 24.0 & -61.2 \\
\hline & & & 26.0 & -1.6 & 46.0 & -3.8 & -82 & 24.0 & -61.8 \\
\hline & & & $\ldots$ & -1.0 & & -.4 & -2 & 760.0 & +757.6 \\
\hline
\end{tabular}

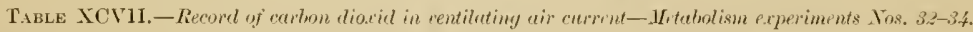

\begin{tabular}{|c|c|c|c|c|c|c|c|c|c|}
\hline \multirow{3}{*}{ Date. } & \multirow{3}{*}{ Period. } & \multirow[b]{3}{*}{$\begin{array}{l}\text { Ventilation. } \\
\text { Sumber of } \\
\text { liters of air. }\end{array}$} & \multicolumn{6}{|c|}{ Carbon dioxid. } & \multirow{3}{*}{$\begin{array}{l}\text { Totul } \\
\text { weight } \\
\text { of car- } \\
\text { bon } \\
\text { exhaled, } \\
g \times{ }_{11}^{3} \text {. }\end{array}$} \\
\hline & & & \multicolumn{2}{|c|}{ In ineoming air. } & \multirow{2}{*}{$\begin{array}{c}\text { In outgoing } \\
\text { air. }\end{array}$} & \multirow[b]{2}{*}{$\begin{array}{c}\text { Total excess } \\
\text { in outgoing } \\
\text { air. } \\
d-c\end{array}$} & \multirow{2}{*}{$\begin{array}{l}(f) \\
\text { Corree- } \\
\text { tion for } \\
\text { umotant } \\
\text { remain- } \\
\text { ing in } \\
\text { chamber. }\end{array}$} & \multirow{2}{*}{$\begin{array}{c}(g) \\
\text { Correcter } \\
\text { amount } \\
\text { exhiled } \\
\text { by subjeet, } \\
c+f .\end{array}$} & \\
\hline & & & $\begin{array}{l}\text { (b) } \\
\text { Per liter. }\end{array}$ & $\begin{array}{l}\text { Total, } \\
\qquad<\approx b\end{array}$ & & & & & \\
\hline $\begin{array}{c}1900 . \\
\text { A pr. } \quad 20-21 \\
21-22 \\
22-23\end{array}$ & 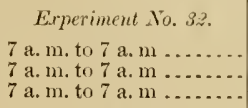 & $\begin{array}{l}\text { Liters } \\
107,275 \\
105,542 \\
106,320\end{array}$ & $\begin{array}{c}\text { My. } \\
\ldots \ldots \\
\cdots \\
\cdots \\
\cdots\end{array}$ & $\begin{array}{l}\text { Grams } \\
66.1 \\
66.2 \\
63.4\end{array}$ & $\begin{array}{l}\text { frrms. } \\
1,145.8 \\
1,273.4 \\
1,359.1\end{array}$ & $\begin{array}{l}\text { froms. } \\
1,079.7 \\
1,207.2 \\
1,295.7\end{array}$ & $\begin{array}{l}\text { Grang. } \\
+\quad .6 \\
+\quad 2.8 \\
-\quad 3.4\end{array}$ & $\begin{array}{l}\text { frrans. } \\
1,080.3 \\
1,210.0 \\
1,292.3\end{array}$ & $\begin{array}{l}\text { Grams. } \\
294.6 \\
399.9 \\
352.4\end{array}$ \\
\hline $23-24$ & 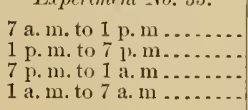 & $\begin{array}{l}25,952 \\
25,175 \\
26,430 \\
26,430\end{array}$ & $\begin{array}{r}0.583 \\
.593 \\
.609 \\
.600\end{array}$ & $\begin{array}{l}15.1 \\
14.9 \\
16.1 \\
15.9\end{array}$ & $\begin{array}{l}383.8 \\
462.9 \\
258.9 \\
158.5\end{array}$ & $\begin{array}{l}368.7 \\
448.0 \\
242.8 \\
142.6\end{array}$ & $\begin{array}{r}+55.8 \\
-2.6 \\
-50.7 \\
-\quad 1.0\end{array}$ & $\begin{array}{l}424.5 \\
445.4 \\
192.1 \\
1+1.6\end{array}$ & $\begin{array}{r}115.8 \\
121.5 \\
52.3 \\
38.6\end{array}$ \\
\hline & Total ....... & 103,987 & ......... & 62.0 & $1,264.1$ & $:, 202.1$ & +1.5 & $1,203.6$ & 328.2 \\
\hline $24-25$ & 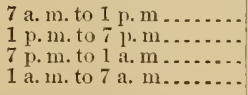 & $\begin{array}{l}25.175 \\
26,730 \\
27,204 \\
27,208\end{array}$ & $\begin{array}{l}.598 \\
.558 \\
.581 \\
.642\end{array}$ & $\begin{array}{l}15.1 \\
14.9 \\
15.8 \\
17.5\end{array}$ & $\begin{array}{l}406.6 \\
477.6 \\
248.7 \\
154.1\end{array}$ & $\begin{array}{l}391.5 \\
462.7 \\
232.9 \\
136.6\end{array}$ & $\begin{array}{r}+5.9 .9 \\
-3.6 \\
-51.9 \\
-\quad 1.9\end{array}$ & $\begin{array}{l}447.4 \\
459.1 \\
181.0 \\
134.7\end{array}$ & $\begin{array}{r}122.0 \\
125.2 \\
49.4 \\
36.7\end{array}$ \\
\hline & Total... & 106,321 & ......... & 63.3 & $1,2 S 7,0$ & $1,223.7$ & -1.5 & $1,222.2$ & 333.3 \\
\hline
\end{tabular}

${ }^{a}$ Absorbers not weighed between $i \mathrm{p}$. m. and $i$ a. m. The change in weight during this time is divided equally between the two periods.

Vol. S-No. 6 


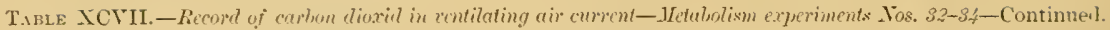

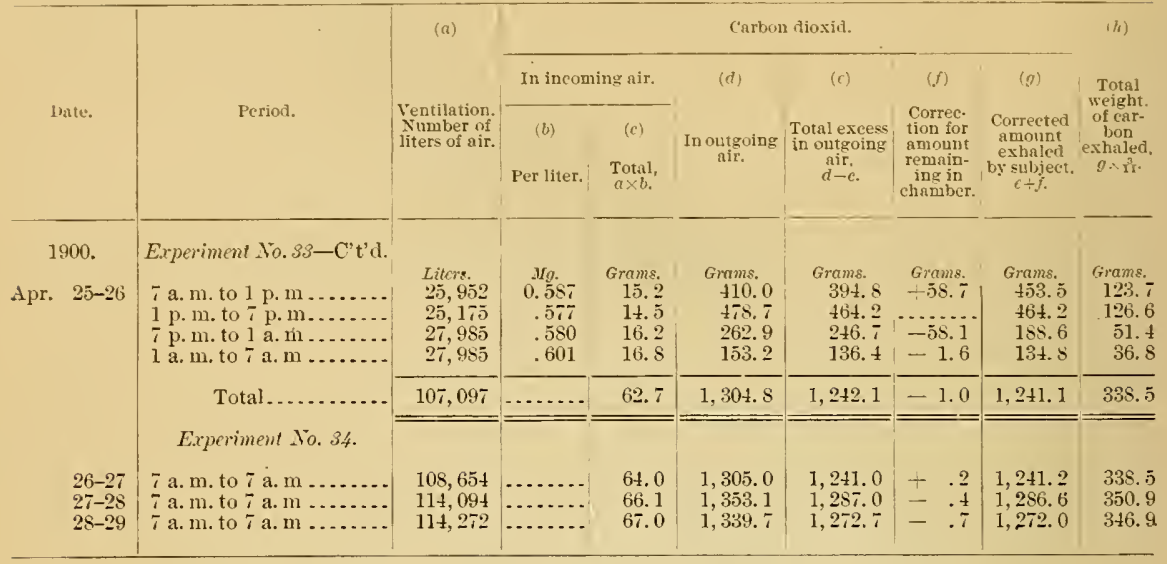

TABLE XCVIII.-Record of uater in ventilating air current-Metabolism experiments Tos. 32-34.

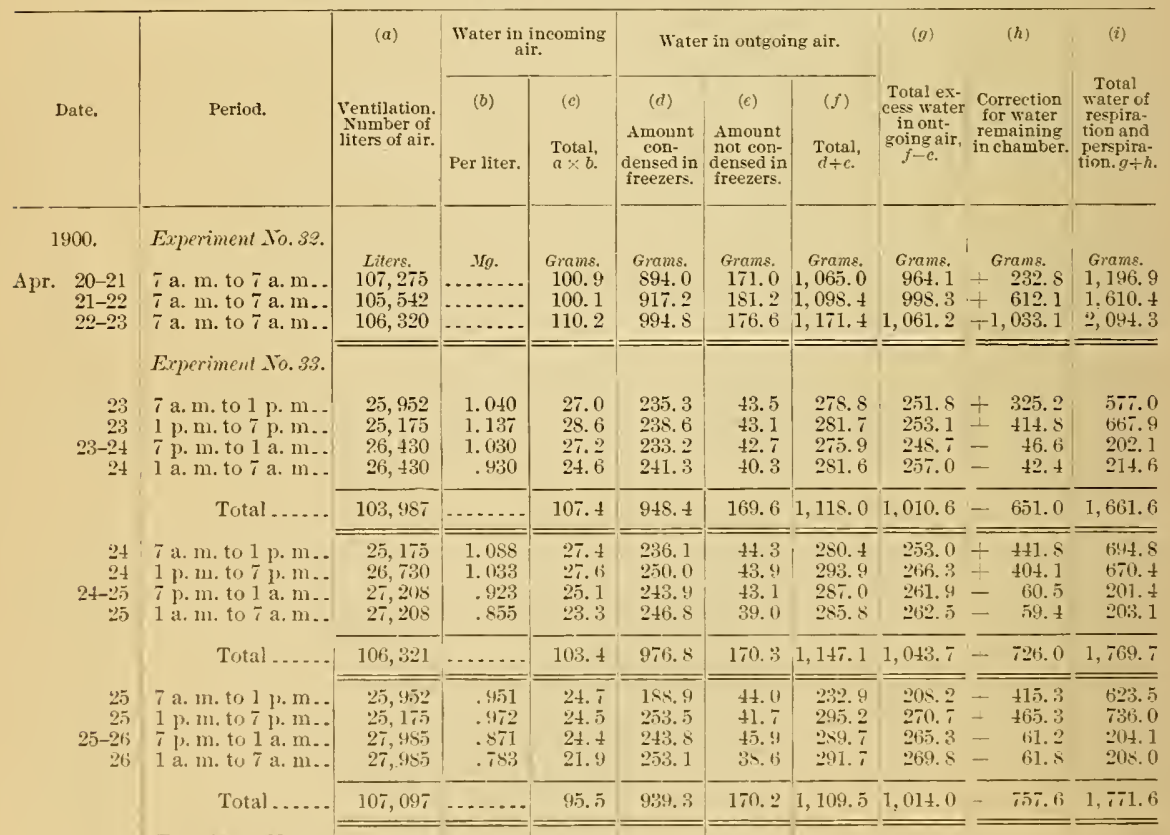

Eryeriment No. 3.4.

$26-27 \quad 7$ a. m. to 7 a.m... $108,654 \ldots . .$. $27-2$, ia.m. to 7 a.m... $114,094 \ldots . . . .$. $28-29$ 7 a. 13. to 7 a.m.. $114,272 \ldots . .$.
45.6945 .9 $100.51,026.2$ $105.11,021.8$
$166.61,162.51,066.9+709.91,775.5$ $173.81,200.01,099.5 \rightarrow 724.8 \quad 1,824.3$ $180.51,20.2 .31,097.2+710 . \pm 1,807.6$ 


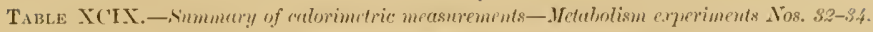

\begin{tabular}{|c|c|c|c|c|c|c|c|c|}
\hline Date. & P'crionl. & $\begin{array}{l}\text { Heat meas- } \\
\text { ured in } \\
\text { terms of Cgr. }\end{array}$ & $\begin{array}{l}\text { (b) } \\
\text { Change of } \\
\text { temperature } \\
\text { of ealorime. } \\
\text { ter. }\end{array}$ & $\begin{array}{l}\text { Cuparity cor- } \\
\text { rectiou of } \\
\text { ealorimeter } \\
b \times 60\end{array}$ & $\begin{array}{l}\text { (d) } \\
\text { Correction } \\
\text { due to tem- } \\
\text { perature of } \\
\text { fooil and } \\
\text { dishes. }\end{array}$ & $\begin{array}{l}\text { (e) } \\
\text { Water vap- } \\
\text { orizeil equals } \\
\text { total fmoms } \\
\text { exhaled less } \\
\text { amount con- } \\
\text { densed in } \\
\text { ehamber. }\end{array}$ & $\begin{array}{l}(f) \\
\text { Heat used in } \\
\text { vmporizution } \\
\text { of water, } \\
\text { ex0.592. }\end{array}$ & $\begin{array}{l}\text { Total heat } \\
\text { detcrmined, } \\
a+c+d+f\end{array}$ \\
\hline 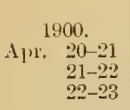 & 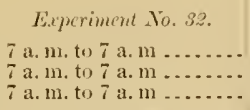 & $\begin{array}{l}\text { Calorics. } \\
2,665.3 \\
2,454.4 \\
3,275.2\end{array}$ & $\begin{array}{c}\text { Degrecs. } \\
+0.32 \\
+.07 \\
\ldots . . .\end{array}$ & $\begin{array}{r}\text { Culoris. } \\
+19.2 \\
+\quad 4.2 \\
.+. . . .\end{array}$ & $\begin{array}{l}\text { Calorir. } \\
-6.0 \\
-6.8 \\
-12.4\end{array}$ & $\begin{array}{l}\text { frums. } \\
968.2 \\
1,004.6 \\
1,054.5\end{array}$ & $\begin{array}{l}\text { cutorie. } \\
573.2 \\
594.7 \\
626.7\end{array}$ & $\begin{array}{l}\text { Catoriss. } \\
3,252.7 \\
3,551.5 \\
3,889.5\end{array}$ \\
\hline $23-24$ & 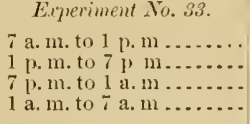 & $\begin{array}{r}1,058.6 \\
1,207.6 \\
455.7 \\
269.3\end{array}$ & $\begin{array}{r}+.07 \\
+.01 \\
+.01 \\
+.01\end{array}$ & $\begin{array}{l}+4.2 \\
+0.6 \\
+0.6 \\
+\quad 0.6\end{array}$ & $\begin{array}{r}-3.3 \\
-14.4 \\
+1.2 \\
\ldots\end{array}$ & $\begin{array}{l}258.3 \\
252.0 \\
245.1 \\
256.6\end{array}$ & $\begin{array}{l}152.9 \\
1+9.2 \\
145.1 \\
151.9\end{array}$ & $\begin{array}{r}1,242.4 \\
1,343.0 \\
602.0 \\
421.8\end{array}$ \\
\hline & Total.......... & $3,021.2$ & +.09 & +5.4 & -16.5 & $1,012,0$ & 599.1 & $3,609.2$ \\
\hline $2+-25$ & 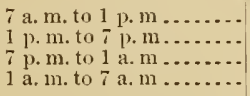 & $\begin{array}{r}1,153.8 \\
1,189.9 \\
437.1 \\
248.4\end{array}$ & $\begin{array}{c}-.04 \\
-.02 \\
+.01\end{array}$ & $\begin{array}{c}-2.4 \\
-1.2 \\
+0.6\end{array} \mid$ & $\begin{array}{l}-5.1 \\
-15.3 \\
+1.4 \\
\end{array}$ & $\begin{array}{l}259.4 \\
264.1 \\
258.4 \\
260.1\end{array}$ & $\begin{array}{l}153.5 \\
156.3 \\
153.0 \\
154.0\end{array}$ & $\begin{array}{r}1,299.8 \\
1,329.7 \\
591.5 \\
403.0\end{array}$ \\
\hline & Total.............. & $3,029.2$ & -.05 & -3.0 & -19.0 & $1,042.0$ & 616.8 & 4.0 \\
\hline $25-26$ & 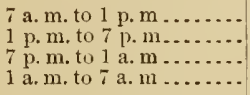 & $\begin{array}{r}1,180.4 \\
1,226.8 \\
429.2 \\
239.9\end{array}$ & $\begin{array}{c}-.04 \\
\cdots \ldots . .01 \\
+.01\end{array}$ & $\begin{array}{c}-2.4 \\
\ldots \ldots \\
+0.6\end{array}$ & $\begin{array}{c}-2.5 \\
-10.4 \\
+2.3 \\
\ldots \ldots .\end{array}$ & $\begin{array}{l}216.5 \\
269.0 \\
262.1 \\
266.0\end{array}$ & $\begin{array}{l}128.2 \\
159.2 \\
155.2 \\
157.5\end{array}$ & $\begin{array}{r}1,303.7 \\
1,375.6 \\
586.7 \\
398.0\end{array}$ \\
\hline & Total . - & $3,076.3$ & -.03 & -1.8 & -10.6 & $1,013.6$ & 600.1 & $3,664.0$ \\
\hline $\begin{array}{l}26-27 \\
27-28 \\
28-29\end{array}$ & 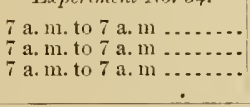 & $\begin{array}{l}2,948.7 \\
2,989.9 \\
2,924.1\end{array}$ & $\begin{array}{l}-.07 \\
-.11 \\
-.01\end{array}$ & $\begin{array}{r}-4.2 \\
-6.6 \\
-0.6\end{array}$ & $\begin{array}{r}-7.7 \\
-0.7 \\
-11.4\end{array}$ & $\begin{array}{l}1,067.1 \\
1,098.3 \\
1,095.7\end{array}$ & $\begin{array}{l}631.7 \\
650.2 \\
6+8.6\end{array}$ & $\begin{array}{l}3,568.5 \\
3,632.8 \\
3,560.7\end{array}$ \\
\hline
\end{tabular}

"Including 4.8 calories during each day period generated by the electric current nsed to magnetize the fields of the dynamo.

The alcohol, or reducing material equivalent to alcohol, given off from the body in different ways was determined in the usual mamer, and the result appear in Table C. The usual correction is made for the total anount of reducing material in the urine, drip, freezer water, and air eurrent, as found in experiments Nos. 32 and $3 t$, in which alcohol did not form a part of the diet. It will be obverved that about one-third of the total redueing material in experiment No. 33 must be considered as due to other compounds than the unoxidized alcohol. As in the previous series of experiments, there was no indication of a lag in the elimination of unoxidized alcohol.

TABLE C.-Heohol ingested and excreted-Mefaholism experiments Nos. 32-34.

\begin{tabular}{|c|c|c|c|c|c|c|c|c|}
\hline \multirow{2}{*}{ Date. } & \multirow{2}{*}{$\begin{array}{l}\text { Aleohol } \\
\text { ingested. }\end{array}$} & \multicolumn{5}{|c|}{$\begin{array}{c}\text { Alcohol excreted, inclurling other reducing } \\
\text { material ealculated ns alcohol. }\end{array}$} & \multirow{2}{*}{$\begin{array}{l}\text { Aleohol } \\
\text { exereted } \\
\text { unoxi- } \\
\text { dized." }\end{array}$} & \multirow{2}{*}{$\begin{array}{l}\text { Aleohol metabolized } \\
\text { in body. }\end{array}$} \\
\hline & & $\begin{array}{l}\text { In urine } \\
\text { (dis- } \\
\text { tillate). }\end{array}$ & $\begin{array}{l}\text { In (inip } \\
\text { d dis- } \\
\text { tillate). }\end{array}$ & $\begin{array}{l}\text { In freezer } \\
\text { water } \\
\text { (dis- } \\
\text { :illate). }\end{array}$ & $\begin{array}{l}\text { In air } \\
\text { eurrent. }\end{array}$ & Total. & & \\
\hline 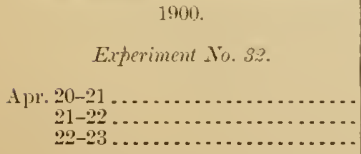 & 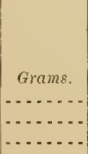 & $\begin{array}{r}\text { Grams. } \\
0.02 \\
.01 \\
.03\end{array}$ & $\left\{\begin{array}{r}\text { Grams. } \\
0.02\end{array}\right.$ & $\begin{array}{r}\text { Grams. } \\
0.01 \\
\text { Trace. } \\
.01\end{array}$ & $\begin{array}{r}\text { Grams. } \\
0.41 \\
.30 \\
.20\end{array}$ & $\begin{array}{r}\text { Grams. } \\
0.44 \\
.32 \\
.25\end{array}$ & \begin{tabular}{|l}
\multicolumn{2}{|c}{ Grams. } \\
$\ldots \ldots \ldots$ \\
$\ldots \ldots$ \\
$\ldots \ldots$
\end{tabular} & \begin{tabular}{|c} 
Grams. Per cent. \\
$\ldots \ldots .$. \\
\\
\hdashline
\end{tabular} \\
\hline
\end{tabular}

a Equals total reducing material excreted less 0.32 gram of reducing material not alcohol, the average for the days on which no alcohol was consumed. 
TABLE C.-Alcohol ingesterl and excreted-Mitabolism experiments . Nos. 32-34-Continued.

\begin{tabular}{|c|c|c|c|c|c|c|c|c|c|}
\hline \multirow{2}{*}{ Date. } & \multirow{2}{*}{$\begin{array}{l}\text { Aleohol } \\
\text { ingested. }\end{array}$} & \multicolumn{5}{|c|}{$\begin{array}{l}\text { Alcohol exereted, including other reducing } \\
\text { material calculated as aleohol. }\end{array}$} & \multirow{2}{*}{$\begin{array}{l}\text { Alcolsol } \\
\text { exereted } \\
\text { unoxi- } \\
\text { dized." }\end{array}$} & \multirow{2}{*}{\multicolumn{2}{|c|}{$\begin{array}{l}\text { Alcohol metabolized } \\
\text { in body. }\end{array}$}} \\
\hline & & $\begin{array}{l}\text { In urine } \\
\text { (dis- } \\
\text { tillate). }\end{array}$ & $\begin{array}{l}\text { In drip } \\
\text { (dis- } \\
\text { tillate). }\end{array}$ & $\begin{array}{c}\text { In freezer } \\
\text { water } \\
\text { (dis- } \\
\text { tillate). }\end{array}$ & $\begin{array}{l}\text { In air } \\
\text { current. }\end{array}$ & Total. & & & \\
\hline 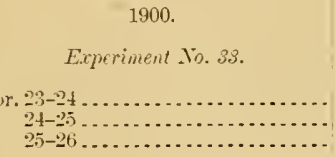 & $\begin{array}{r}\text { Grams. } \\
72.0 \\
72.0 \\
72.0\end{array}$ & $\begin{array}{r}\text { Grams. } \\
0.05 \\
.06 \\
.05\end{array}$ & $\left\{\begin{array}{l}\text { Grams. } \\
0.22\end{array}\right.$ & $\left\{\begin{array}{r}\text { Grams. } \\
0.01 \\
.02 \\
.02\end{array}\right.$ & $\begin{array}{r}\text { Grams. } \\
0.85 \\
.92 \\
.93\end{array}$ & $\begin{array}{r}\text { Grams. } \\
1.02 \\
1.07 \\
1.07\end{array}$ & $\begin{array}{r}\text { Grames. } \\
0.70 \\
.75 \\
.75\end{array}$ & $\begin{array}{r}\text { Grams. } \\
71.3 \\
71.3 \\
71.2\end{array}$ & $\begin{array}{r}\text { Per ecnt. } \\
99.0 \\
99.0 \\
98.9\end{array}$ \\
\hline $\begin{array}{l}\text { Total ... . . . . . . . . . . . . . . } \\
\text { Average, } 1 \text { tay . . . . . . . }\end{array}$ & $\begin{array}{r}216.0 \\
72.0\end{array}$ & $\begin{array}{l}.16 \\
.05\end{array}$ & .22 & $\begin{array}{l}.05 \\
.01\end{array}$ & $\begin{array}{r}2.73 \\
.91 \\
\end{array}$ & $\begin{array}{l}3.16 \\
1.05\end{array}$ & $\begin{array}{r}2.20 \\
.73\end{array}$ & $\begin{array}{r}213.8 \\
71.3\end{array}$ & 99.0 \\
\hline 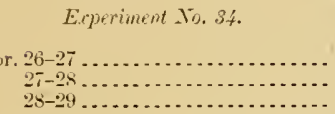 & (n) & .04 & .04 & $\begin{array}{l}.01 \\
.01 \\
.01\end{array}$ & $\begin{array}{l}.32 \\
.26 \\
.20\end{array}$ & $\begin{array}{l}.37 \\
.30 \\
.24\end{array}$ & (n) & (n) & (n) \\
\hline
\end{tabular}

"Equals total reducing naterial excreted less 0.32 gram of reducing material not alcohol, the average for the days on which no alcohol was consumed.

Balance of income and outgo of matter and energy.-From the preceding statisties are computed the income and outgo of nitrogen, carbon, hydrogen, and energy on the different dars of each of this series of experiments. The results of these computations are shown in Tables CI-CIV.

TABLE CI.-Income and outgo of nitrogen and carbon-Metabolism experiments Nos. 32-34.

\begin{tabular}{|c|c|c|c|c|c|c|c|c|c|c|}
\hline \multirow[b]{2}{*}{ Date and period. } & \multicolumn{4}{|c|}{ Nitrogen. } & \multicolumn{6}{|c|}{ Carboll. } \\
\hline & $\begin{array}{c}\text { (a) } \\
\text { In food. }\end{array}$ & $\begin{array}{c}\text { (b) } \\
\text { In feces. }\end{array}$ & In urine ${ }^{\mathrm{n}}$ & $\begin{array}{l}(d) \\
\text { Gain }(+) \\
\text { or loss } \\
\left(-\frac{)}{(b+a-}\right) \\
(b+c)\end{array}$ & $\begin{array}{c}\text { (e) } \\
\text { In food. }\end{array}$ & $\begin{array}{c}(f) \\
\text { In feces. }\end{array}$ & $\begin{array}{c}(g) \\
\text { In wrine. }\end{array}$ & $\begin{array}{c}(h) \\
\text { In respi- } \\
\text { ratory } \\
\text { products. }\end{array}$ & $\begin{array}{c}\text { In alcohol } \\
\text { elimi- } \\
\text { nated. }\end{array}$ & $\begin{array}{l}(k) \\
\text { Gain }(+) \\
\text { or loss } \\
(-), e-(f \\
+g+h+i) .\end{array}$ \\
\hline $\begin{array}{c}1900 . \\
\text { Experiment No. } 32 . \\
\text { Apr. } 20-21, \text { ia. m. to 7a.m. } \\
21-2-7 \text { a. m. to } 7 \text { a.m. } \\
22-23,7 \text { a. m. to } 7 \text { a.m. }\end{array}$ & $\begin{array}{r}\text { Grams. } \\
16.1 \\
16.2 \\
16.1\end{array}$ & $\begin{array}{r}\text { Grams. } \\
1.2 \\
1.2 \\
1.2\end{array}$ & $\begin{array}{r}G r a m 8 . \\
16.3 \\
15.3 \\
15.6\end{array}$ & $\begin{array}{r}\text { Grams. } \\
-1.4 \\
-.3 \\
-.7\end{array}$ & $\begin{array}{r}\text { Grams. } \\
320.0 \\
320.0 \\
320.0\end{array}$ & $\begin{array}{r}\text { Grams. } \\
12.6 \\
12.6 \\
12.6\end{array}$ & $\begin{array}{r}\text { Grams. } \\
11.3 \\
10.7 \\
10.9\end{array}$ & $\begin{array}{c}\text { Gramis. } \\
294.6 \\
329.9 \\
352.4\end{array}$ & \begin{tabular}{c} 
Grams. \\
\hdashline$\ldots$ \\
\hdashline$\ldots$ \\
\hdashline$\ldots$ \\
$\ldots$
\end{tabular} & $\begin{array}{r}\text { Grams. } \\
+\quad 1.5 \\
-\quad 33.2 \\
-\quad 55.9\end{array}$ \\
\hline $\begin{array}{l}\text { Total ........... } \\
\text { Average, } 1 \text { day .... }\end{array}$ & $\begin{array}{l}48.4 \\
16.1\end{array}$ & $\begin{array}{l}3.6 \\
1.2\end{array}$ & $\begin{array}{l}47.2 \\
15.7\end{array}$ & $\begin{array}{r}-2.4 \\
-\quad .8\end{array}$ & $\begin{array}{l}960.0 \\
320.0\end{array}$ & $\begin{array}{l}37.8 \\
12.6\end{array}$ & $\begin{array}{l}32.9 \\
11.0\end{array}$ & $\begin{array}{l}976.9 \\
325.6\end{array}$ & $\mid \cdots \ldots$. & $\begin{array}{l}-87.6 \\
-29.2 \\
\end{array}$ \\
\hline $\begin{array}{c}\text { Experimut To. } 83 . \\
\text { Apr. } 23-24,7 \text { a.m. to } 7 \text { a. m. } \\
24-25,7 \text { a. m. to } 7 \text { a.m. } \\
25-26,7 \text { a.m. to } 7 \text { a.m. }\end{array}$ & $\begin{array}{l}16.0 \\
16.0 \\
16.0\end{array}$ & $\begin{array}{l}1.2 \\
1.2 \\
1.2\end{array}$ & $\begin{array}{l}16.7 \\
17.6 \\
17.7\end{array}$ & $\begin{array}{r}-1.9 \\
-2.8 \\
-2.9\end{array}$ & $\begin{array}{l}319.6 \\
319.6 \\
319.6\end{array}$ & $\begin{array}{l}11.4 \\
11.4 \\
11.4\end{array}$ & $\begin{array}{l}11.7 \\
12.3 \\
12.3\end{array}$ & $\begin{array}{l}328.2 \\
333.3 \\
338.5\end{array}$ & $\begin{array}{r}0.3 \\
.4 \\
.4\end{array}$ & $\begin{array}{r}-32.0 \\
-37.8 \\
-\quad 43.0\end{array}$ \\
\hline $\begin{array}{l}\text { Total .......... } \\
\text { Average, i day ... }\end{array}$ & $\begin{array}{l}48.0 \\
16.0\end{array}$ & $\begin{array}{l}3.6 \\
1.2\end{array}$ & $\begin{array}{l}52.0 \\
17.3\end{array}$ & $\begin{array}{r}-7.6 \\
-2.5 \\
\end{array}$ & $\begin{array}{l}958.8 \\
319.6 \\
\end{array}$ & $\begin{array}{l}34.2 \\
11.4\end{array}$ & $\begin{array}{l}36.3 \\
12.1\end{array}$ & $\begin{array}{r}1,000.0 \\
333.3 \\
\end{array}$ & $\begin{array}{r}1.1 \\
.4 \\
\end{array}$ & $\begin{array}{r}-112.8 \\
-37.6 \\
\end{array}$ \\
\hline 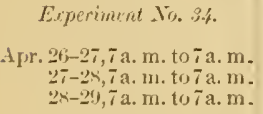 & $\begin{array}{l}16.0 \\
16.0 \\
16.0\end{array}$ & $\begin{array}{l}1.2 \\
1.2 \\
1.2\end{array}$ & $\begin{array}{l}17.4 \\
16.3 \\
16.4\end{array}$ & $\begin{array}{r}2.6 \\
-1.5 \\
-1.6\end{array}$ & $\begin{array}{l}335.7 \\
335.8 \\
335.7\end{array}$ & $\begin{array}{l}11.6 \\
11.5 \\
11.6\end{array}$ & $\begin{array}{l}12.2 \\
11.3 \\
11.4\end{array}$ & $\begin{array}{l}338.5 \\
350.9 \\
346.9\end{array}$ & 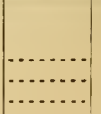 & $\begin{array}{r}-26.6 \\
-37.9 \\
-34.2\end{array}$ \\
\hline $\begin{array}{l}\text { Trital .......... } \\
\text { Average, i day ... }\end{array}$ & $\begin{array}{l}4 \times .0 \\
16.0\end{array}$ & $\begin{array}{l}3.6 \\
1.2\end{array}$ & $\begin{array}{l}50.1 \\
16.7\end{array}$ & $\begin{array}{l}-5.7 \\
-1.9\end{array}$ & $\begin{array}{r}1,007.2 \\
335.7\end{array}$ & $\begin{array}{l}34.7 \\
11.6\end{array}$ & $\begin{array}{l}34.9 \\
11.6\end{array}$ & $\begin{array}{r}1,036.3 \\
345.4\end{array}$ & $\cdots$ & $\begin{array}{r}-98.7 \\
-\quad 32.9\end{array}$ \\
\hline
\end{tabular}




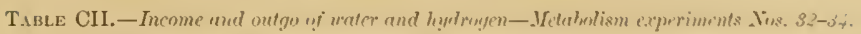

\begin{tabular}{|c|c|c|c|c|c|c|c|c|c|c|c|c|c|}
\hline \multirow[b]{2}{*}{ Date and period. } & \multicolumn{6}{|c|}{ Water. } & \multicolumn{7}{|c|}{ IIytrogen } \\
\hline & In fourl. & $\begin{array}{c}\text { (b) } \\
\ln \\
\text { drink. }\end{array}$ & $\begin{array}{c}\text { (c) } \\
\text { int } \\
\text { fece's. }\end{array}$ & III wrine. & $\begin{array}{c}\text { ICI } \\
\text { Inres- } \\
\text { piratory } \\
\text { prodi- } \\
\text { uets. }\end{array}$ & 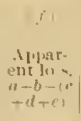 & $\begin{array}{l}\text { In } \\
\text { Inot. }\end{array}$ & $\begin{array}{l}\text { hil } \\
\text { in } \\
\text { leces. }\end{array}$ & $\begin{array}{c}\text { I } \\
\text { In } \\
\text { urine. }\end{array}$ & $\begin{array}{c}k \\
\text { In nleo- } \\
\text { hol. } \\
\text { elimi- } \\
\text { mated. }\end{array}$ & $\begin{array}{c}I \\
\text { Ippar- } \\
\text { ent } \\
\text { gain. } \\
g=h+i \\
+k .\end{array}$ & $\begin{array}{c}|n| \\
\text { Lows } \\
\text { irum } \\
\text { water, } \\
f \neq y\end{array}$ & $\begin{array}{c}\text { Total } \\
\text { gain } \\
+\infty \text { or } \\
\operatorname{lom}-1 \\
l-m .\end{array}$ \\
\hline 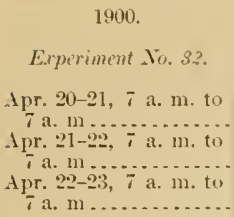 & $\begin{array}{l}\text { Grams. } \\
1.035 .9 \\
1,035.9 \\
1.035 .9\end{array}$ & $\begin{array}{l}\text { Grame. } \\
\text { 1. } 250 \\
1.250 \\
1,250\end{array}$ & $\begin{array}{l}71.6 \\
71.5 \\
71.6\end{array}$ & $\begin{array}{l}\text { froms. } \\
1,179.7\end{array}$ & $\begin{array}{l}\text { Groms. } \\
1.196 .9 \\
+1,610.4 \\
12,094.3\end{array}$ & $\begin{array}{l}\text { Grome. } \\
162.3 \\
\times 2.4 \\
\text { 4.25. } 7\end{array}$ & $\begin{array}{l}\text { frams. } \\
49.0 \\
49.0 \\
49.0\end{array}$ & $\begin{array}{l}\text { fims } \\
1 . \\
1.2\end{array}$ & $\begin{array}{l}\text { rims: } \\
3.1 \\
3.0 \\
3.0\end{array}$ & $\begin{array}{l}\text { Gramin. } \\
\ldots \ldots \\
\ldots \ldots\end{array}$ & $\begin{array}{l}\text { lirreuns. } \\
-\quad 44.1 \\
+\quad 44.2 \\
+\quad 44.2\end{array}$ & $\begin{array}{l}\text { G) } \begin{array}{l}-15.0 \\
-92.2 \\
-103.2\end{array}\end{array}$ & $\begin{array}{l}\text { Grams. } \\
+\quad 66.1 \\
+4.0 \\
-59.0\end{array}$ \\
\hline $\begin{array}{l}\text { Total .......... } \\
\text { Averave, } 1 \text { day .. }\end{array}$ & $\begin{array}{l}3.107 .7 \\
1.035 .9\end{array}$ & $\begin{array}{l}3.750 \\
1,250\end{array}$ & $\begin{array}{r}214.7 \\
71.6\end{array}$ & $\begin{array}{l}3.6031 .8 \\
31,220.6\end{array}$ & $\begin{array}{l}4,901.6 \\
1,633.5\end{array}$ & $\begin{array}{r}1,9 \geq 0.4 \\
640.1\end{array}$ & $\begin{array}{r}147.0 \\
49.0\end{array}$ & 5. 4 & $\begin{array}{l}4.1 \\
3.0\end{array}$ & ..... & $\begin{array}{r}-132.5 \\
-\quad 44.2\end{array}$ & $\begin{array}{r}-213.4 \\
-71.1\end{array}$ & $\begin{array}{r}80.9 \\
-26.9\end{array}$ \\
\hline 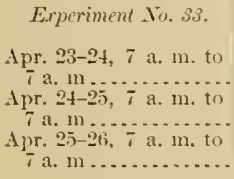 & $\begin{array}{l}1,02 \div .6 \\
1,027.6 \\
1,02 \div .6\end{array}$ & $\begin{array}{l}1,250 \\
1,250 \\
1,250\end{array}$ & $\begin{array}{l}61.2 \\
61.1 \\
\text { 61. } 2\end{array}$ & $\begin{array}{l}21,029.6 \\
1,083.3 \\
? \quad 926.6\end{array}$ & $\begin{array}{l}1,661.6 \\
31.769 .7 \\
31,771.6\end{array}$ & $\begin{array}{l}474 . \\
636.5 \\
451 .\end{array}$ & $\begin{array}{l}52.5 \\
52.5 \\
52.5\end{array}$ & $\begin{array}{l}1.6 \\
1.7 \\
1.6\end{array}$ & $\begin{array}{l}3.2 \\
3.4 \\
3.4\end{array}$ & $\begin{array}{l}.1 \\
.1\end{array}$ & $\begin{array}{r}-47.6 \\
-47.3 \\
-\quad 4.4\end{array}$ & $\begin{array}{r}-52.5 \\
70.5 \\
-53.5\end{array}$ & $\begin{array}{r}-5.2 \\
-23.4 \\
-0.1\end{array}$ \\
\hline $\begin{array}{l}\text { Total. ... ...... } \\
\text { Average, } 1 \text { day .. }\end{array}$ & $\begin{array}{l}3,0 \times 2.8 \\
1,0 \geq 1.6\end{array}$ & $\begin{array}{l}3,750 \\
1,250\end{array}$ & $\begin{array}{r}183.5 \\
61.2\end{array}$ & $\begin{array}{l}3,039.5 \\
1.013 .2\end{array}$ & $\begin{array}{l}5,202.9 \\
21.734 .3\end{array}$ & $\begin{array}{r}1,593.1 \\
531.0\end{array}$ & $\begin{array}{r}1.5 .5 \\
5: 2.5\end{array}$ & $\begin{array}{l}4.9 \\
1.6\end{array}$ & $\begin{array}{r}10.0 \\
3.4\end{array}$ & & $\begin{array}{r}-142.3 \\
47.4\end{array}$ & $\begin{array}{r}17.0 \\
-\quad 59.0\end{array}$ & $\begin{array}{l}-34.7 \\
-11.6\end{array}$ \\
\hline 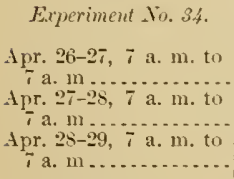 & $\begin{array}{l}1,028,6 \\
1,028,6 \\
1,025.6\end{array}$ & $\begin{array}{l}1,250 \\
1,250 \\
1,250\end{array}$ & $\begin{array}{l}60.0 \\
59.9 \\
60.0\end{array}$ & $\begin{array}{r}789.4 \\
\text { i51.2 } \\
1,036.9\end{array}$ & $\begin{array}{l}41,76.8 \\
21,84.3 \\
1,807.6\end{array}$ & $\left\{\begin{array}{l}346.6 \\
456 . \\
625.4\end{array}\right.$ & $\begin{array}{l}51.1 \\
51.1 \\
51.1\end{array}$ & $\begin{array}{l}1.7 \\
1.6 \\
1.7\end{array}$ & $\begin{array}{l}3.4 \\
3.1 \\
3.2\end{array}$ & $\ldots$ & $\begin{array}{r}-40.0 \\
-\quad 46.4 \\
-\quad 40.2\end{array}$ & $\begin{array}{r}-38.5 \\
-50.5 \\
-69.5\end{array}$ & $\begin{array}{r}-7.5 \\
4.4 \\
-23.3\end{array}$ \\
\hline $\begin{array}{l}\text { Total.......... } \\
\text { Average, I day .. }\end{array}$ & $\begin{array}{l}3,0 \times 5.8 \\
1,025.6\end{array}$ & $\begin{array}{l}3,-50 \\
1,250\end{array}$ & $\begin{array}{r}179.9 \\
60.0\end{array}$ & $\begin{array}{r}+2,67 \pi .5 \\
890.5\end{array}$ & $\begin{array}{l}5.5,40 \overline{1} \\
51,502.5\end{array}$ & $\begin{array}{r}1,4.99 .3 \\
4,6.4\end{array}$ & $\begin{array}{r}153.3 \\
51.1\end{array}$ & $\begin{array}{l}5.0 \\
1.7\end{array}$ & $\begin{array}{l}9.7 \\
3.2\end{array}$ & $\ldots$ & $\begin{array}{r}135.6 \\
46.2\end{array}$ & $\begin{array}{r}15 x .2 \\
52.9\end{array}$ & -20.2 \\
\hline
\end{tabular}




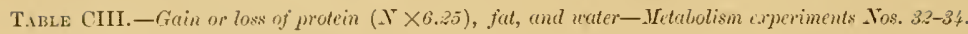

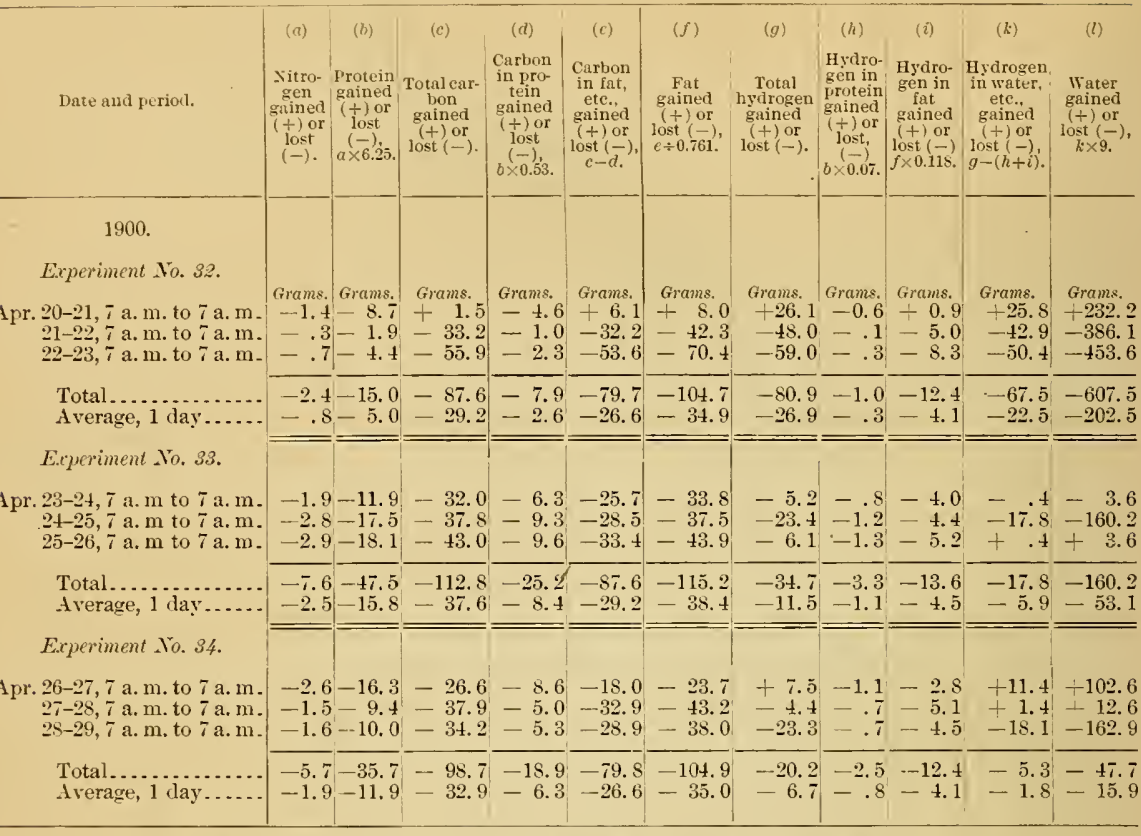

TABLE CIV.-Income and outgo of energy-Metabolism experiments Wos. 32-34.

\begin{tabular}{|c|c|c|c|c|c|c|c|c|c|c|}
\hline \multirow{3}{*}{ Date and period. } & \multirow{3}{*}{$\begin{array}{l}\text { Heat of } \\
\text { combustion } \\
\text { of food } \\
\text { eaten. }\end{array}$} & \multirow{3}{*}{$\begin{array}{l}\text { Heat of } \\
\text { combus- } \\
\text { tion of } \\
\text { feces. }\end{array}$} & \multirow{3}{*}{$\begin{array}{l}\text { Heat of } \\
\text { combus- } \\
\text { tinn of } \\
\text { urine. }\end{array}$} & \multirow{3}{*}{$\begin{array}{l}\text { (ni) } \\
\text { Heat of } \\
\text { combus- } \\
\text { tion of } \\
\text { aleohol } \\
\text { elimi- } \\
\text { nated. }\end{array}$} & \multirow{3}{*}{$\begin{array}{c}(d) \\
\text { Estimated } \\
\text { heat of } \\
\text { combus- } \\
\text { tion of } \\
\text { protein } \\
\text { gained } \\
\text { ( }+) \text { or } \\
\text { lost }(-) .\end{array}$} & \multirow{3}{*}{$\begin{array}{c}(c) \\
\text { Estimated } \\
\text { heat of } \\
\text { eombus- } \\
\text { tion of } \\
\text { fat } \\
\text { gained } \\
(+) \text { or } \\
\text { lost }(-) \text {. }\end{array}$} & \multirow{3}{*}{$\begin{array}{c}(f) \\
\text { Estimated } \\
\text { energy of } \\
\text { material } \\
\text { oxidized } \\
\text { in the } \\
\text { bodis. } \\
a-(b+c+ \\
m+d+e) .\end{array}$} & \multirow{3}{*}{$\begin{array}{l}(g) \\
\text { Heat } \\
\text { deter- } \\
\text { mined. }\end{array}$} & \multirow{2}{*}{\multicolumn{2}{|c|}{$\begin{array}{l}\text { Heat determined } \\
\text { greater }(+) \text { or } \\
\text { less }(-) \text { thanl } \\
\text { estimated. }\end{array}$}} \\
\hline & & & & & & & & & & \\
\hline & & & & & & & & & $\begin{array}{l}(h) \\
f-g\end{array}$ & $\begin{array}{l}(i) \\
h \div f .\end{array}$ \\
\hline & & & & & & & & & & \\
\hline $\begin{array}{l}\text { Experiment No. } 82 . \\
\text { r. } 20-21,7 \text { a.m. to } 7 \text { a.m. } \\
21-22,7 \text { a.m. to } 7 \text { a.m.- } \\
22-23,7 \text { a.m. to } 7 \text { a.m. }\end{array}$ & $\begin{array}{r}\text { Calorics. } \\
3,487 \\
3,487 \\
3,487\end{array}$ & $\begin{array}{r}\text { Calorics. } \\
142 \\
141 \\
142\end{array}$ & $\begin{array}{r}\text { Culorics. } \\
129 \\
113 \\
116\end{array}$ & $\begin{array}{l}\text { Calories. } \\
\ldots \ldots \ldots \\
\ldots \ldots \\
\ldots \ldots \ldots\end{array}$ & $\begin{array}{r}\text { Calorics. } \\
-\quad 35 \\
+\quad 3 \\
-\quad 11\end{array}$ & $\begin{array}{r}\text { Calorics } \\
+\quad 77 \\
-\quad 404 \\
-\quad 672 \\
\end{array}$ & $\begin{array}{r}\text { Calorics. } \\
3,174 \\
3,634 \\
3,912\end{array}$ & $\begin{array}{r}\text { Calorics. } \\
3,253 \\
3,551 \\
3,890\end{array}$ & $\begin{array}{l}\text { Calorics. } \\
+\quad 79 \\
-\quad 83 \\
-\quad 22\end{array}$ & $\begin{aligned} \text { Per cent. } \\
+2.5 \\
-2.3 \\
-.5\end{aligned}$ \\
\hline $\begin{array}{l}\text { Total ............ } \\
\text { Average, } 1 \text { day ... }\end{array}$ & $\begin{array}{r}10,+61 \\
3, \pm \leqslant 7\end{array}$ & $\begin{array}{l}425 \\
142\end{array}$ & $\begin{array}{l}358 \\
119\end{array}$ & & $\begin{array}{l}43 \\
-14\end{array}$ & $\begin{array}{r}999 \\
-\quad 333\end{array}$ & $\begin{array}{r}10,720 \\
3,573\end{array}$ & $\begin{array}{r}10,694 \\
3,565\end{array}$ & $\begin{array}{r}-26 \\
-\quad 8\end{array}$ & -2 \\
\hline $\begin{array}{l}\text { E.periment To. } 33 . \\
\text { r. } 23-24, \text { 7a.m. to } 7 \text { a.m. } \\
24-25,7 \text { a.m. to } 7 \text { a.m. } \\
25-26,7 \text { a.m. to } 7 \text { a.m. }\end{array}$ & $\begin{array}{l}3,486 \\
3,486 \\
3,486 \\
\end{array}$ & $\begin{array}{l}125 \\
125 \\
125\end{array}$ & $\begin{array}{l}125 \\
129 \\
133\end{array}$ & $\begin{array}{l}5 \\
5 \\
5\end{array}$ & $\begin{array}{l}-54 \\
-\quad 86 \\
-\quad 90\end{array}$ & $\begin{array}{r}-322 \\
-\quad 357 \\
-\quad 419\end{array}$ & $\begin{array}{l}3,607 \\
3,670 \\
3,732\end{array}$ & $\begin{array}{l}3,609 \\
3,6 \geq 4 \\
3,664\end{array}$ & $\begin{array}{l}+\quad 2 \\
-46 \\
-68\end{array}$ & $\begin{array}{r}.0 \\
-1.3 \\
-1.8\end{array}$ \\
\hline $\begin{array}{l}\text { Total ............ } \\
\text { Average, } 1 \text { ray ... }\end{array}$ & $\begin{array}{r}10,458 \\
3,486\end{array}$ & $\begin{array}{l}375 \\
125\end{array}$ & $\begin{array}{l}387 \\
129\end{array}$ & $\begin{array}{r}15 \\
5\end{array}$ & $\begin{array}{r}-230 \\
-\quad 76\end{array}$ & $\begin{array}{r}-1,098 \\
-\quad 366\end{array}$ & $\begin{array}{r}11,009 \\
3,669\end{array}$ & $\begin{array}{r}10,897 \\
3,632\end{array}$ & $\begin{array}{l}-112 \\
-37\end{array}$ & -1.0 \\
\hline 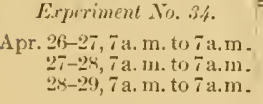 & $\begin{array}{l}3,493 \\
3,493 \\
3,493\end{array}$ & $\begin{array}{l}126 \\
125 \\
126\end{array}$ & $\begin{array}{l}131 \\
125 \\
123\end{array}$ & & $\begin{array}{r}79 \\
-\quad 40 \\
-\quad 43\end{array}$ & $\begin{array}{r}226 \\
-\quad 413 \\
-\quad 363\end{array}$ & $\begin{array}{l}3,5+1 \\
3,696 \\
3,650\end{array}$ & $\begin{array}{l}3,568 \\
3,633 \\
3,561\end{array}$ & $\begin{array}{l}+2 \vec{r} \\
-63 \\
-89\end{array}$ & $\begin{array}{l}+.7 \\
-1.7 \\
-2.4\end{array}$ \\
\hline $\begin{array}{l}\text { Total ... } \\
\text { Average, } 1 \text { day ..... }\end{array}$ & $\begin{array}{r}10,47 !) \\
3,49: 3\end{array}$ & $\begin{array}{l}377 \\
126\end{array}$ & $\begin{array}{l}379 \\
126\end{array}$ & & $\begin{array}{r}-162 \\
-54\end{array}$ & $\begin{array}{l}-1,002 \\
-\quad 3: 34\end{array}$ & $\begin{array}{l}10,8 \times 7 \\
: 3,629\end{array}$ & $\begin{array}{r}10,762 \\
3,587\end{array}$ & $\begin{array}{r}-125 \\
-42\end{array}$ & -1.1 \\
\hline
\end{tabular}




\section{STATISTICAL DETAILS OF DIGESTION EXPERIMENTS.}

A- bas aldeady heen explained. atch metabolim experiment or series of experiments was preceded hy a digestion experiment and each metaholism experinent includes a digestion experinent The result of those digestion experiments in which alcohol formed a part of the diet are detailed berewith. Those of the corresponding experiments without alcohol are given in comection with the description of the latter, as etsewhere published." The results of the digestion experiment with and withont aleohol are summarized beyond.

The weights of the different food materials. as shown in the first column of Tables CV-CVIII, together with the figures for percentage, composition, and heat of combustion, as shown in Tables I-III above. suttice for the computations of the nutrients and energy in the food and feces. In computing the protein from the nitrogen, the factor 6.25 has been used for all animal foods and 5. Tl for the regetible foods used in the experiments. ${ }^{\circ}$ The total organic matter as shown in the tables is the sum of the organic constituents-protein, fat, carbohydrates, and aleohol.

DETAILS OF DIGESTIUN EXPERIMENT XO, 41 .

This was prelininary to metabolism experiment No. 7 , hegan with hreakfast June 3,1897 , and continued 5 days. The diet was the same in kind and practically the same in the relative amounts of the different ingredients as in the following metabolism experiment. The subject was E. O., the laboratory assistant who served in a large number of the experiments here recorded. His weight at the begrinning of the experiment was not recorded: at the end it was without clothing. bt. 7 kilograms (147 pounds). He was oceupied in bis nsual duties about the labolatory. but did a- little muscular work as practicable, in order that the conditions of exerese should not ditter greatly from those in the following rest experiment in the respiration apparatus. The result $s$ of the experiment are sbown in Table CV.

\section{DETAILS OF DIGESTION EXPERIMENT NO. 42.}

This experiment followed immediately after No. 41 and formed a part of metaholism experi-

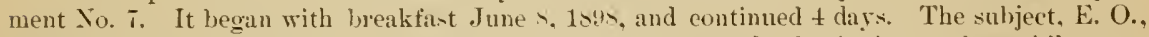
weighed without clothing 66.7 kilograns (147 pounels) at the beginning and bit kilograms (1 $155 \frac{1}{2}$ pounds) at the end of the study. The subject had as little muscular activity ats was practicable during the experiment. The details are given in Table ('VI.

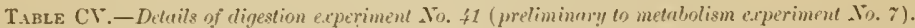

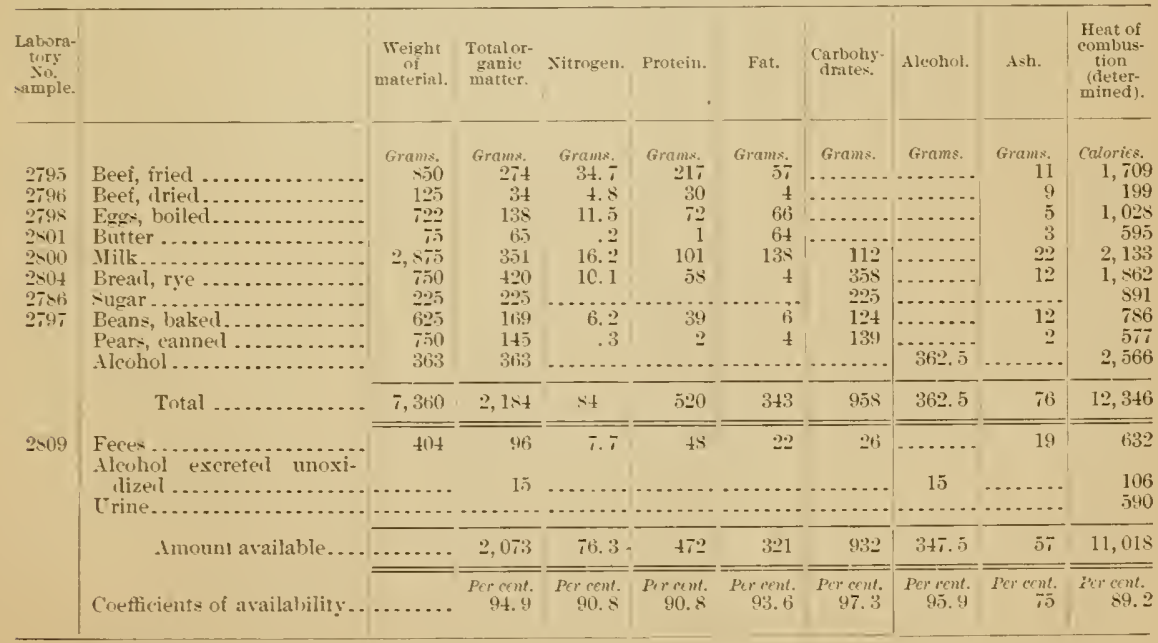




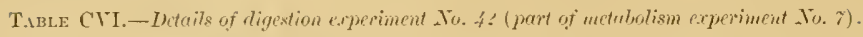

\begin{tabular}{|c|c|c|c|c|c|c|c|c|c|c|}
\hline $\begin{array}{l}\text { Labora- } \\
\text { tory } \\
\text { >o. } \\
\text { sample. }\end{array}$ & & $\begin{array}{c}\text { Weight } \\
\text { of } \\
\text { material. }\end{array}$ & $\begin{array}{l}\text { Totalor- } \\
\text { ganii } \\
\text { natter. }\end{array}$ & Nitrogen. & Protein. & Fat. & $\begin{array}{l}\text { Carbohy- } \\
\text { drates. }\end{array}$ & Aleohol. & Ash. & $\begin{array}{l}\text { Heat of } \\
\text { combus- } \\
\text { tion } \\
\text { (deter- } \\
\text { mined). }\end{array}$ \\
\hline $\begin{array}{l}2795 \\
2796 \\
2798 \\
2801 \\
2800 \\
2804 \\
2786 \\
2797\end{array}$ & 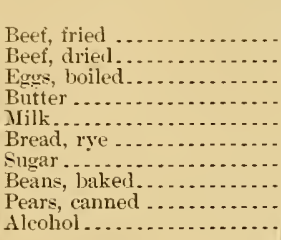 & $\begin{array}{r}\text { Grams. } \\
675 \\
100 \\
564 \\
60 \\
2,300 \\
600 \\
180 \\
500 \\
600 \\
290\end{array}$ & $\begin{array}{l}\text { frcums. } \\
217 \\
27 \\
108 \\
52 \\
281 \\
336 \\
180 \\
135 \\
116 \\
290\end{array}$ & 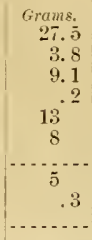 & $\begin{array}{r}\text { Grams. } \\
172 \\
24 \\
57 \\
1 \\
81 \\
46 \\
\ldots . \\
31 \\
2\end{array}$ & $\begin{array}{r}\text { Grams. } \\
45 \\
3 \\
51 \\
51 \\
510 \\
4 \\
4 \\
5 \\
3\end{array}$ & 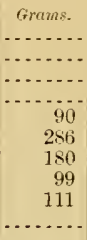 & 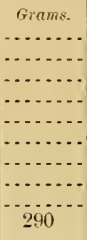 & $\begin{array}{r}\text { Grams. } \\
9 \\
7 \\
4 \\
2 \\
18 \\
10 \\
10 \\
10 \\
1\end{array}$ & $\begin{array}{r}\text { Calorirs. } \\
1,357 \\
160 \\
803 \\
476 \\
1,707 \\
1,490 \\
713 \\
628 \\
461 \\
2,050\end{array}$ \\
\hline & Total & 5,869 & 1,742 & 66.9 & 414 & 272 & 766 & 290 & 61 & 9,845 \\
\hline \multirow[t]{3}{*}{2810} & 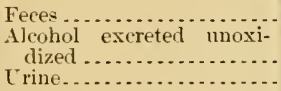 & 198 & $\begin{array}{c}47 \\
11.9 \\
-. .2\end{array}$ & 3.5 & 22 & 10 & 15 & $\begin{array}{r}11.9 \\
\end{array}$ & 10 & $\begin{array}{r}303 \\
84 \\
490\end{array}$ \\
\hline & Amount arailable. & ..... & $1,683.1$ & 63.4 & 392 & 262 & 751 & 278.1 & 51 & 8,968 \\
\hline & Coefficients of availability.. & & $\begin{array}{r}\text { Per cent. } \\
96.6\end{array}$ & $\begin{array}{l}\text { Per cent. } \\
94.8\end{array}$ & $\begin{array}{r}\text { Pereent. } \\
94.7\end{array}$ & $\begin{array}{r}\text { Per ernt. } \\
96.3\end{array}$ & $\begin{array}{l}\text { Per cent. } \\
98.1\end{array}$ & $\begin{array}{r}\text { Per cent. } \\
9 \overline{5} .9\end{array}$ & $\begin{array}{r}\text { Per ernt. } \\
83.6\end{array}$ & $\begin{array}{r}\text { Per ecent. } \\
91.1\end{array}$ \\
\hline
\end{tabular}

DETAILS OF DIGESTION EXPERIMENT NO. 4\%.

This experiment began with breakfast February 11. 1898, and continued $t$ days. The diet was the same in kind and practically the same in amount as in metabolism experiment No. 10, which immediately followed and of which this experiment formed the preliminary period. The subject,

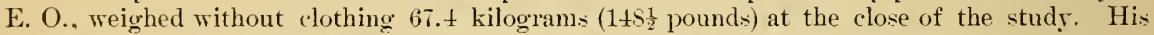
weight at the beginning was not recorded. He was engaged about the lahoratory in his usual occupation, but aroided muscular exertion so far as practicable. Table CVII gives the details.

DETAILS OF DIGESTION EXPERIMENT No. 48.

This experiment, which forned a part of metabolisn experiment Yo. 10. began with breakfast February 15, 1898, and continued $t$ days. The subject. E. O.. weighed without clothing 67.4 kilograms at the beginning and 67.6 kilograms ( 149 pounds) at the end of the experimental period. Table CVIII gives detailed results.

Table CTII.-Ditails of digestion experiment to. f7 (preliminary to metabolism experiment to. 10).

\begin{tabular}{|c|c|c|c|c|c|c|c|c|c|c|}
\hline $\begin{array}{l}\text { Lah. } \\
\text { No. } \\
\text { sample. }\end{array}$ & & $\begin{array}{l}\text { Weight } \\
\text { of } \\
\text { material. }\end{array}$ & $\begin{array}{c}\text { Total } \\
\text { organie } \\
\text { matter. }\end{array}$ & Nitrogen. & Protein. & Fat. & $\begin{array}{l}\text { Carbohy" } \\
\text { drates: }\end{array}$ & Aleohol. & Ash. & $\begin{array}{l}\text { Heat of } \\
\text { combus. } \\
\text { tion } \\
\text { (deter- } \\
\text { mined). }\end{array}$ \\
\hline 2839 & Beef & $\begin{array}{c}\text { frams. } \\
1,080\end{array}$ & $\begin{array}{c}\text { Grems. } \\
329.0\end{array}$ & $\begin{array}{l}\text { Grams, } \\
\text { 16. } 9\end{array}$ & $\begin{array}{r}\text { Grams. } \\
293\end{array}$ & $\begin{array}{r}\text { Grums. } \\
36\end{array}$ & $\begin{array}{c}\text { Grams. } \\
\ldots . . .\end{array}$ & $\begin{array}{c}\text { Grams. } \\
\text {. . . . }\end{array}$ & $\begin{array}{r}\text { Grams. } \\
21\end{array}$ & $\begin{array}{c}\text { Catories. } \\
1,961\end{array}$ \\
\hline 2843 & Putter & 60 & $5: 3.0$ & 然 & $\ldots$. & 53 & 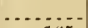 & & 1 & 479 \\
\hline 2845 & Milk, skimmerl .. & 3,000 & 261.0 & 14.9 & 93 & 3 & 16.5 & ... & 24 & 1,206 \\
\hline $28+4$ & Bread .......... & 500 & 288.0 & 6.7 & 38 & 1 & 249 & $\ldots \ldots \ldots$ & 7 & 1,277 \\
\hline 2842 & Maize breakfast food....... & 200 & 187.0 & 3.8 & 2 & 16 & $14 s$ & ... & 3 & 887 \\
\hline $2 x+0$ & Wheat breakfa.t food ..... . . & 200 & 182.0 & 3. & 20 & 3 & 159 & .... & 4 & 810 \\
\hline \multirow[t]{4}{*}{2841} & (inger snaps............. & 240 & 223.0 & 2.2 & 13 & 15 & 195 & $\cdots$ & $\bar{i}$ & 1,019 \\
\hline & Sugar . . . . . . . . . . . & 280 & 280.0 & $\ldots$. & & ... & 280 & & & 1, 109 \\
\hline & Alcuhol ..................... & 290 & 290.0 & & & & $\cdots$ & 290.0 & - & 2,050 \\
\hline & Total & 5,850 & $2,093,0$ & $7 x .0$ & 480 & 127 & 1,196 & 290.0 & 67 & 10,798 \\
\hline \multirow[t]{5}{*}{2847} & Feres $\ldots . . . \ldots \ldots \ldots \ldots$ & 267 & 59.0 & 4.0 & 25 & 10 & 24 & $\ldots$ & 12 & 360 \\
\hline & $\stackrel{A}{C}$ & & & -. & $\ldots \ldots$ & & $\cdots$ & $4 . \frac{1}{4}$ & .. & 31 \\
\hline & & & & & & & & & & mon \\
\hline & Amount available... & ....... & $2,029.6$ & $i+.0$ & 455 & $11 \overline{1}$ & 1,172 & $2 \times 5.6$ & 5.5 & $9, \$ 38$ \\
\hline & Coefficients of availability .. & & $\begin{array}{r}\text { Perernt. } \\
97.0\end{array}$ & $\begin{array}{r}\text { Ierernt. } \\
94.9\end{array}$ & $\begin{array}{r}\text { Per crnt. } \\
94.8\end{array}$ & $\begin{array}{r}\text { Per ecnt. } \\
92.1\end{array}$ & $\begin{array}{r}\text { Per cent. } \\
98.0\end{array}$ & $\begin{array}{l}P e r \text { rent. } \\
98.5\end{array}$ & $\begin{array}{l}\text { Per wnt. } \\
\quad 82.1\end{array}$ & $\begin{array}{r}\text { Per erut. } \\
91.1\end{array}$ \\
\hline
\end{tabular}




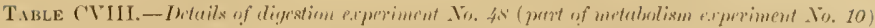

\begin{tabular}{|c|c|c|c|c|c|c|c|c|c|c|}
\hline $\begin{array}{l}\text { Luh. } \\
\text { Nin, } \\
\text { sample. }\end{array}$ & & $\begin{array}{l}\text { Weight } \\
\text { of } \\
\text { moterial. }\end{array}$ & $\begin{array}{l}\text { Total } \\
\text { organi. } \\
\text { matter. }\end{array}$ & Nitrogen. & l'rotein. & Fut. & $\begin{array}{l}\text { Corlobly- } \\
\text { drates. }\end{array}$ & Alorihot. & Antr. & 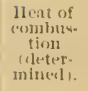 \\
\hline $25 ; 39$ & Beet' . & $\begin{array}{l}\text { trrams. } \\
1,0 \times 0\end{array}$ & $\begin{array}{l}\text { Graws } \\
32 \geq 0.0\end{array}$ & $\begin{array}{l}\text { Grams. } \\
\quad+6.9\end{array}$ & $\begin{array}{l}\text { (ircems } \\
\quad 293\end{array}$ & $\begin{array}{r}\text { Gramis } \\
3 t ;\end{array}$ & $\begin{array}{l}\text { Groths. } \\
\text { G...... }\end{array}$ & $\begin{array}{l}\text { Grmms. } \\
\text {........ }\end{array}$ & $\begin{array}{r}\text { firums } \\
21\end{array}$ & $\begin{array}{l}\text { crelorics. } \\
\text { 1, } ! \text { 1 }\end{array}$ \\
\hline 2843 & Butter & 60 & $5: 3.0$ & . & 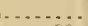 & 5.3 & - & & 1 & 479 \\
\hline $2 x+6$ & Milk, skimmet . . . . . . . . . & 3,000 & 264.0 & 15.8 & 99 & 3 & 162 & & 24 & 1,242 \\
\hline $2 \times 4 t$ & Breal. ........ & 500 & $2 S$ & b. $T$ & 3. & 1 & $2+9$ & ... & 7 & 1,27 \\
\hline $28+2$ & Maize lireakfant food...... . & 2 & 14 & 3. & 2 & 16 & 144 & - & 3 & 857 \\
\hline 2840 & Wheat breakfast fond .... . . & 20 & $1 \times 2.0$ & 3.5 & 2 & 3 & 159 & .. & \pm & 810 \\
\hline \multirow[t]{4}{*}{$28+1$} & 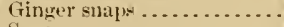 & 240 & $2: \cdots 0$ & 2.2 & 13 & 15 & 195 & ........ & 7 & 1,019 \\
\hline & $\ldots \ldots \ldots \ldots \ldots$ & $2 \mathrm{NO}$ & 2.50 .0 & $\cdots$. & ... & … & 280 & $\ldots . .$. & $\ldots \ldots$. & 1,109 \\
\hline & Aleohol . . . . . . . . . . . . . . . . & 290 & 290.0 & $\cdots$ & & & $\cdots \cdots$ & 290.0 & $\ldots \ldots$ & 2,050 \\
\hline & Total & 5,850 & $2,09+1,0$ & 78.9 & 486 & $12 \overline{7}$ & 1,193 & 290.0 & 67 & $10, \times 34$ \\
\hline \multirow[t]{4}{*}{$28+8$} & Feces $\ldots \ldots \ldots$ & 351 & (5i. 0 & 5,4 & 34 & 15 & 36 & & 17 & $50 \%$ \\
\hline & Urine................... & & & $\cdots$ & & $\ldots$ & 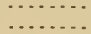 & & & 565 \\
\hline & Amount availal, & & $2,006,6$ & 73.5 & 452 & 112 & 1,157 & $2 \times 5.6$ & 50 & 9.731 \\
\hline & Coeffirients of availahility. & & $\begin{array}{l}\text { Per cent. } \\
95.7\end{array}$ & $\begin{array}{r}\text { Perfont. } \\
93.1\end{array}$ & $\begin{array}{r}\text { Per cent. } \\
93.01\end{array}$ & $\begin{array}{r}\text { Per cent. } \\
88.2\end{array}$ & $\begin{array}{r}\text { Per remt. } \\
97.11\end{array}$ & $\begin{array}{r}\text { Per rent. } \\
9 \text { K. } 5\end{array}$ & $\begin{array}{r}\text { Per ernt. } \\
7 t .6\end{array}$ & $\begin{array}{r}\text { Percent. } \\
89.8\end{array}$ \\
\hline
\end{tabular}

DETAILS OF DIGEKTION EXPERIMENT NO. 51.

This study was preliminary to metabolism experiment No. 12. with the same kinds and amounts of the different food materials. The subjeet, E. O.. was engaged in his usual laboratory work, but in addition took considerable muscular exercise on the bicycle and otherwise, in order to make the conditions of muscular activity not greatly different from those in the following metabolism experiment. The study began with breakfast April s. 1s9s, and continued $t$ dars. The subject weighed, without elothing, 70.5 kilograms (155.4 pounds) at the beginning and 70.1 kilograms (15t.5 pounds) at the end of the study.

DETALS OF DIGESTION EXPERIMENT NO. 5:.

This experiment, which formed a part of metabolism experiment No. 12, began with breakfast April 12. 1sas, and continued + days. The subject, E. O., weighed, without elothing, 70.4 kilograms (156.3 pounds) at the beginning and 70.3 kilograms (155 pounds) at the end of the study. He worked 8 hours a day upon a stationaly bicycle within the chamber of the calorimeter.

TaBLE CIX. - Details of digestion experiment No. 51 (preliminury to metaholism experiment No. 12).

\begin{tabular}{|c|c|c|c|c|c|c|c|c|c|c|}
\hline $\begin{array}{c}\text { Lab. } \\
\text { No. } \\
\text { sample. }\end{array}$ & & $\begin{array}{c}\text { Weight } \\
\text { of } \\
\text { material. }\end{array}$ & $\begin{array}{l}\text { Total } \\
\text { organie } \\
\text { matter. }\end{array}$ & Nitrogen. & Protein. & Fat. & $\begin{array}{l}\text { Carbohy- } \\
\text { drates. }\end{array}$ & Aleohol. & Ash. & $\begin{array}{c}\text { Heat of } \\
\text { combus- } \\
\text { tion } \\
\text { (deter- } \\
\text { mined). }\end{array}$ \\
\hline 2860 & 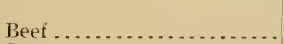 & $\begin{array}{r}\text { Grams. } \\
700\end{array}$ & $\begin{array}{l}\text { Grams. } \\
2: 31.0\end{array}$ & $\begin{array}{l}\text { Grams. } \\
30.7\end{array}$ & $\begin{array}{l}\text { Grams. } \\
192\end{array}$ & $\begin{array}{r}\text { Grams, } \\
39\end{array}$ & $\begin{array}{l}\text { frams. } \\
\ldots \ldots \ldots\end{array}$ & $\begin{array}{l}\text { Grams. } \\
\text { G. }\end{array}$ & $\begin{array}{r}\text { Grams. } \\
18\end{array}$ & $\begin{array}{l}\text { Calories. } \\
1,+00\end{array}$ \\
\hline 2861 & Butter ..................... & 380 & 330.0 & .3 & 2 & 328 & $\cdots$ & & 8 & 3,004 \\
\hline $2 \pi \cdot 5 t^{3}$ & Milk.. & 3,600 & 482.0 & 19.0 & 119 & 180 & 183 & & 25 & 3,114 \\
\hline 2859 & Brearl & 1,200 & 702.0 & 18. 1 & 103 & 12 & 587 & ... & 13 & 3,196 \\
\hline $2+12$ & Maize breakfast form ....... & 240 & 224.0 & 4.5 & 27 & 20 & 177 & $\ldots$ & + & 1,065 \\
\hline \multirow[t]{4}{*}{2858} & Ieviled ham ............ & 200 & 110.0 & 5.9 & 37 & 73 & & & 8 & $\times 73$ \\
\hline & 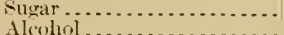 & 280 & 280.81 & .... & & .... & 280 & & & 1,109 \\
\hline & Then & & 2010 & 70 & & & 1 . & 290.0 & & 2,000 \\
\hline & Total ................. & 6,890 & $2,6+9.0$ & 78.5 & 480 & 652 & 1,227 & 290.0 & 76 & $15 \bar{x}, 811$ \\
\hline \multirow[t]{4}{*}{2862} & Feces ............................ & 495 & 120.0 & 7. 2 & 45 & $3 \mathrm{~s}$ & 37 & & 27 & 791 \\
\hline & $\begin{array}{l}\text { Almohotexcreted unoxilized } \\
\text { Urine.................... }\end{array}$ & & .... & & & & & & & 542 \\
\hline & Amount arailable. & & $2,523.0$ & 71.3 & 435 & 614 & 1,190 & $24+0$ & 49 & $1+4,434$ \\
\hline & Coefficients of arailability.. & $\ldots .$. & $\begin{array}{r}\text { Per cent. } \\
95.2\end{array}$ & $\begin{array}{r}\text { Per mont. } \\
\quad 90.8\end{array}$ & $\begin{array}{r}\text { Per rent. } \\
90.6\end{array}$ & $\begin{array}{l}\text { Pererut. } \\
94.2\end{array}$ & $\begin{array}{l}\text { Percent. } \\
\quad 97.0\end{array}$ & $\begin{array}{r}\text { Per rent. } \\
\quad 97.9\end{array}$ & $\begin{array}{l}P c r \text { rent. } \\
\quad 6 \pm .5\end{array}$ & $\begin{array}{l}\text { Per etent. } \\
\quad 91.3\end{array}$ \\
\hline
\end{tabular}


TaвqE C.-Details of digestion eqperiment No. 52 (part of metabolism experiment No. 12).

\begin{tabular}{|c|c|c|c|c|c|c|c|c|c|c|}
\hline $\begin{array}{c}\text { Lab. } \\
\text { >o. } \\
\text { sample. }\end{array}$ & & $\begin{array}{c}\text { Weight } \\
\text { of } \\
\text { material. }\end{array}$ & $\begin{array}{l}\text { Total } \\
\text { organic } \\
\text { matter. }\end{array}$ & Nitrogen. & Protein. & Fat. & $\begin{array}{l}\text { Carbohy- } \\
\text { drates. }\end{array}$ & Alcohol. & Ash. & $\begin{array}{l}\text { Heat of } \\
\text { combus- } \\
\text { tion - } \\
\text { (deter- } \\
\text { mined). }\end{array}$ \\
\hline $\begin{array}{l}2466 \\
2 \times 61 \\
2457 \\
2 \times 59 \\
2842 \\
2858\end{array}$ & 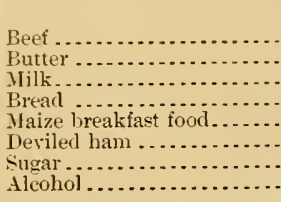 & $\begin{array}{r}\text { Grams. } \\
700 \\
380 \\
3,600 \\
1,200 \\
240 \\
200 \\
280 \\
290\end{array}$ & $\begin{array}{l}\text { Grams. } \\
231.0 \\
330.0 \\
425.0 \\
702.0 \\
224.0 \\
110.0 \\
280.0 \\
290.0\end{array}$ & $\begin{aligned} \text { Grams. } \\
30.7 \\
0.3 \\
17.9 \\
18.1 \\
4.5 \\
5.9\end{aligned}$ & $\begin{array}{r}\text { Grams. } \\
192 \\
2 \\
112 \\
103 \\
27 \\
37\end{array}$ & $\begin{array}{r}\text { Grams. } \\
39 \\
328 \\
162 \\
12 \\
20 \\
73\end{array}$ & $\begin{array}{r}\text { Grams. } \\
\cdots \\
158 \\
587 \\
177 \\
280\end{array}$ & $\begin{array}{l}\text { Grams. } \\
\ldots \\
\\
\\
\\
290 . \\
\end{array}$ & $\begin{array}{r}\text { Grams. } \\
18 \\
8 \\
25 \\
13 \\
4 \\
8\end{array}$ & $\begin{array}{r}\text { Calories. } \\
1,+00 \\
3,004 \\
2,873 \\
3,196 \\
1,065 \\
873 \\
1,109 \\
2,050 \\
\end{array}$ \\
\hline \multirow{4}{*}{2863} & Total & 6,890 & $2,592.0$ & 77.4 & 473 & 634 & 1,195 & 290.0 & 76 & 15,570 \\
\hline & $\begin{array}{l}\text { Feces } \\
\text { Alcohol excreted unoxidized } \\
\text { Urine............................ }\end{array}$ & 370 & $\begin{array}{r}79.0 \\
6.0 \\
\end{array}$ & 5.0 & 31 & 26 & 22 & 6.0 & $\begin{array}{c}16 \\
\cdots\end{array}$ & $\begin{array}{r}545 \\
42 \\
553\end{array}$ \\
\hline & Amount available & (n....... & $2,507.0$ & 72.4 & 442 & 608 & 1,173 & 284.0 & 60 & 14,430 \\
\hline & Coeffieients of availability.. & & $\begin{array}{r}\text { Per cent. } \\
96.7\end{array}$ & $\begin{array}{r}\text { Per cent. } \\
93.5\end{array}$ & $\begin{array}{r}\text { Per cent. } \\
93.4\end{array}$ & $\begin{array}{r}\text { Per cent. } \\
\quad 95.9\end{array}$ & $\begin{array}{r}\text { Per cent. } \\
\quad 98.2\end{array}$ & $\begin{array}{r}\text { Per cent. } \\
97.9\end{array}$ & $\begin{array}{r}\text { Per cent. } \\
78.9\end{array}$ & $\begin{array}{r}\text { Per cent. } \\
92.7\end{array}$ \\
\hline
\end{tabular}

\section{DETAILS OR DIGESTION EXPERIMENT NO. SO.}

This experiment formed the preliminary period to the series of metabolism experiments Nos. 15-17. It began with breakfast January 12,1899 , and continued 4 days. The subject, E. O., as in prerious experiments here reported, was engaged in very light work about the laboratory. His weight at the end of the study, withont elothing, was 70.9 kilograms (156 pounds). The alcohol during this period was taken in the form of commercial alcohol in sweetened coffee infusion, as in metabolism experiment No. 15. In metabolism experiment No. 16 the alcohol was taken in the form of whisky, and in No. 17 in the form of brandy.

\section{DETAILS OF DIGESTION EXPERIMENT No. 81 .}

This experiment, which formed a part of the series of metabolism experiments Nos. 15, 16, and 17 , hegan with breakfast January 16, 1899, and continued 6 days. The subject, E. O., weighed, without clothing, 70.9 kilograms at the beginning and 70.1 kilograms (154.5 pounds) at the end of the experiment.

TABLE CXI.-Datails of digestion experimen No. so (preliminary to metabolism experiment No. 15).

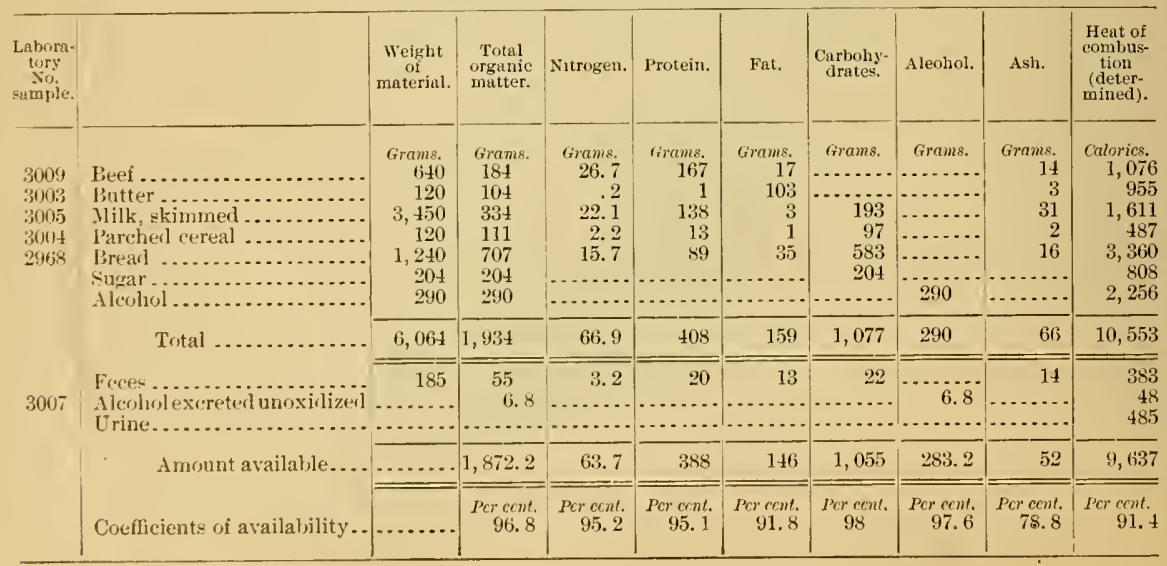




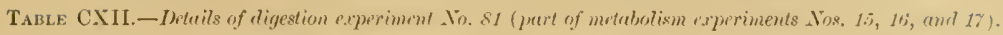

\begin{tabular}{|c|c|c|c|c|c|c|c|c|c|c|}
\hline $\begin{array}{c}\text { Labora. } \\
\text { tury } \\
\text { No } \\
\text { amijus. }\end{array}$ & & $\begin{array}{c}\text { Weight } \\
\text { of } \\
\text { material. }\end{array}$ & $\begin{array}{l}\text { Total } \\
\text { organic } \\
\text { mutter. }\end{array}$ & Nitrogen. & l'rotein. & Fut. & $\begin{array}{l}\text { Carbohy:- } \\
\text { drates. }\end{array}$ & Aleohol. & $A+h$, & $\begin{array}{l}\text { leent vi } \\
\text { cumbus. } \\
\text { tims } \\
\text { (deter- } \\
\text { minedi). }\end{array}$ \\
\hline 3009 & Beef & $\begin{array}{r}\text { Grems. } \\
960\end{array}$ & $\begin{array}{l}\text { Grams. } \\
275\end{array}$ & $\begin{array}{l}\text { Grams. } \\
\text { t0. } 0\end{array}$ & $\begin{array}{l}\text { Grams. } \\
250\end{array}$ & Groms. & Grtms. & Grams. & Grams: & ralorice, \\
\hline 3003 & Butter ...... & 180 & 157 & .3 & 2 & 155 & 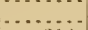 & ....... & -5 & 1,433 \\
\hline 3006 & Milk, skimmerl .......... & 5,700 & 553 & 37.5 & 234 & 6 & 313 & $\ldots$ & 46 & 2,667 \\
\hline 3004 & Parched cereal ........... & 180 & 166 & 3.2 & 18 & 1 & 147 & $\ldots \ldots$ & 3 & 730 \\
\hline \multirow[t]{2}{*}{2968} & Brearl .. & 1,860 & 1,060 & 23.5 & 134 & 52 & 874 & $\ldots \ldots$ & 24 & 5,040 \\
\hline & 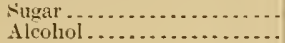 & $\begin{array}{l}3+2 \\
435\end{array}$ & $\begin{array}{l}3+2 \\
435\end{array}$ & ........ & $\ldots$ & $\ldots$ & 342 & 43.5 & . & $\begin{array}{l}1,354 \\
3,075\end{array}$ \\
\hline \multirow{6}{*}{3008} & Total ............... & 9,657 & 2,988 & 104.5 & 638 & 239 & 1,676 & 435 & 99 & 15,914 \\
\hline & \multirow{4}{*}{ 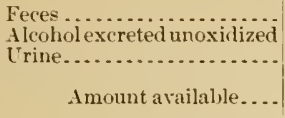 } & 316 & 76 & 5 & 31 & 18 & 27 & & 24 & 529 \\
\hline & & & 10.3 & & & & & 10.3 & $\ldots$ & 73 \\
\hline & & & & & & & & - & & 759 \\
\hline & & & $2,901.7$ & 99.5 & 607 & 221 & 1,649 & 424.7 & 75 & 14,553 \\
\hline & Coefticients of availability.. & & $\begin{array}{l}\text { Per cent. } \\
97.1\end{array}$ & $\begin{array}{l}\text { Per cent. } \\
95,2\end{array}$ & $\begin{array}{r}\text { Per cent. } \\
95.2\end{array}$ & $\begin{array}{l}\text { Per cent. } \\
\quad 92.5\end{array}$ & $\begin{array}{r}\text { Percent. } \\
98.4\end{array}$ & $\begin{array}{l}P e \mathrm{CCnt}_{0} \\
9 \% .6\end{array}$ & $\begin{array}{l}\text { Per cent. } \\
75.8\end{array}$ & $\begin{array}{l}\text { Per cent. } \\
\quad 91.5\end{array}$ \\
\hline
\end{tabular}

1)ETAILS OF DIGESTION EXPERIMENT NO. $\$ 2$.

This experiment was preliminary to and formed a part of metabolism experiments Nos. 15-21. The subject was A. W. S., a physicist. He was engaged in the investigations of which this experiment forms a part. The study began with breakfast February 2, 1899, and continued $t$ days outside the apparatus. During the following 9 days, beginning with February 6 , the subject was inside the rexpiration chanber. It was the intention to subdivide the 13 days covered by this digestion experiment into three scparate experiments, comprising the 4 preliminary days prevons to the time when the subject entered the respiration calorimeter; the 6 days in the calorimeter in which alcohol formed a part of the diet, either as commercial alcohol, whisky, or brandr: and the 3 days of experiment No. 21 in which alcohol was omitted from the diet. Unfortumately no satisfactory separation of the feces was obtained hetween the preliminary period and the end of the experiment No. 21 . The whole time is therefore included in one digestion experiment. The body weight of the subject at the beginning of the period was 72.4 kilograms, and at the end 72.7 kilograns (160.3 pounds). During the preliminary days very little muscular work was done, and during the sojomn in the apparatus practically no exercise was taken. The kinds and daily amounts of foods were the same during the $t$ preliminary days, and the 6 days of metabolism experiments Nos. 18-20, except that alcohol was taken in the form of commereial ethyl alcohol in the preliminary period and in No. 1s, whisky in No. 19, brandy in No. 20. In experiment No. $\because 1$ the alcohol was omitted from the diet. 


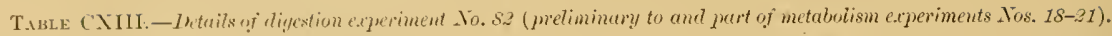

\begin{tabular}{|c|c|c|c|c|c|c|c|c|c|c|}
\hline $\begin{array}{l}\text { Iabora- } \\
\text { tury } \\
\text { fon. } \\
\text { samples. }\end{array}$ & & $\begin{array}{l}\text { Weight of } \\
\text { material. }\end{array}$ & $\begin{array}{l}\text { Total or } \\
\text { ganic } \\
\text { matter. }\end{array}$ & Nitrogen. & Protein. & Fut. & $\begin{array}{l}\text { Carbo- } \\
\text { hydrates. }\end{array}$ & Alcohol. & Asl. & $\begin{array}{l}\text { Heat of } \\
\text { combus- } \\
\text { tion } \\
\text { (deter- } \\
\text { mined). }\end{array}$ \\
\hline $\begin{array}{l}3022-2 \\
3021 \\
30223-1 \\
3004 \\
2968\end{array}$ & 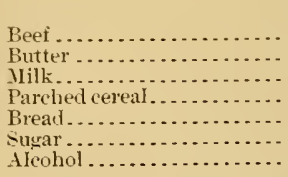 & $\begin{array}{r}\text { frams. } \\
2,0 \times 0 \\
390 \\
9,750 \\
390 \\
4,030 \\
585 \\
725 \\
\end{array}$ & $\begin{array}{r}\text { Grams. } \\
634 \\
341 \\
1,232 \\
360 \\
2,297 \\
585 \\
725\end{array}$ & \begin{tabular}{r} 
Grams. \\
92.9 \\
.7 \\
49.6 \\
7.2 \\
50.9 \\
\hdashline \\
\end{tabular} & $\begin{array}{r}\text { Grams. } \\
581 \\
4 \\
310 \\
41 \\
290 \\
2 . . \\
\end{array}$ & $\begin{array}{r}\text { Grams. } \\
53 \\
337 \\
430 \\
2 \\
113 \\
- \\
\end{array}$ & $\begin{array}{r}\text { Grams. } \\
\ldots . . \\
492 \\
317 \\
1,894 \\
585 \\
\ldots . .\end{array}$ & 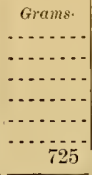 & $\begin{array}{r}\text { Grams. } \\
43 \\
10 \\
78 \\
6 \\
52\end{array}$ & $\begin{array}{r}\text { calories. } \\
3,500 \\
3,148 \\
7,658 \\
1,582 \\
10,921 \\
2,317 \\
5,331\end{array}$ \\
\hline & Total ................ & 17.950 & 6,174 & 201.3 & 1,226 & 935 & 3,288 & 725 & 189 & 34,757 \\
\hline \multirow[t]{3}{*}{3033} & $\begin{array}{l}\text { Feces } \\
\text { Aleohol excreted unoxidized } \\
\text { Crine } \ldots . . . . . . . . . . . .\end{array}$ & 832 & $\begin{array}{r}188 \\
24.5 \\
\ldots\end{array}$ & $\begin{array}{c}13.5 \\
\cdots \ldots . . \\
\ldots \ldots . \\
\end{array}$ & $\begin{array}{r}\mid 84 \\
\ldots \ldots \\
\ldots . . . \\
\end{array}$ & $\begin{array}{r}52 \\
\ldots . . .2\end{array}$ & $\begin{array}{r}52 \\
\quad \ldots \ldots \ldots \\
\cdots \ldots \ldots \\
\end{array}$ & $\begin{array}{c}24.5 \\
\ldots \ldots . .\end{array}$ & \begin{tabular}{|c|}
39 \\
$\cdots \ldots \ldots$ \\
\hdashline$\ldots . .$. \\
\end{tabular} & $\begin{array}{r}1,307 \\
173 \\
1,427 \\
\end{array}$ \\
\hline & Amount arailable.... & 17,118 & $5,961.5$ & 187.8 & 1,142 & 883 & 3,236 & 700.5 & 150 & 31,850 \\
\hline & Coefficients of availability .. & . & $\begin{array}{r}P(j \mathrm{crnt} \\
96.6\end{array}$ & $\begin{array}{r}\text { Pcr cent. } \\
93.8\end{array}$ & $\begin{array}{r}\text { Per cent. } \\
93.2\end{array}$ & $\begin{array}{r}\text { Per cent. } \\
94,4\end{array}$ & $\begin{array}{r}\text { Per rent. } \\
98.4\end{array}$ & $\begin{array}{r}\text { Percent. } \\
96.6\end{array}$ & $\begin{array}{r}\text { Per cent. } \\
79.4\end{array}$ & $\begin{array}{r}\text { Per cent. } \\
91.6\end{array}$ \\
\hline
\end{tabular}

DETAILS OF DIGESTION EXPERIHENT NO. 83.

This experiment began with breakfast March 9, 1899, and continued 4 days. It was preliminary to the series of metabolism experiments Nos. 2-24, and was made with the same subject. E. O.. who served in the majority of the digestion experiments here described. The diet during the first 3 days contained no alcohol. On the last day 72.5 grams of absolute alcohol were added in the form of commercial ethyl alcohol. The subject was engaged in his usual wrork about the laboratory and performed rery little manual labor. His weight, without clothing, was $72 .+$ kilograms (159.6 pounds) at the close of the experiment.

\section{DETAILS OF DIGESTION EXPERIMENT No. $8 t$.}

The experiment began with breakfast Iarch 13. 1899, and continued 6 days, forming a part of metabolism experiment Nos. 22 and 23 , details of which are given above. Alcohol formed a part of the diet on the first 3 days (netabolism experiment No. 22) while on the last 3 days (metabolism experiment No. 23) only the basal ration was eaten. The subject, E. O., weighed, without clothing, at the beginning of the experiment 72.4 kilograms and at the end $72.7 \mathrm{kilo-}$ grams (160.3 pounds). He had as little muscular activity during the series of experiments as was practicable.

T.13LE CX1V.-Detaits of rigestion experiment No. 88 (proliminary to metabolism experiment No. 22).

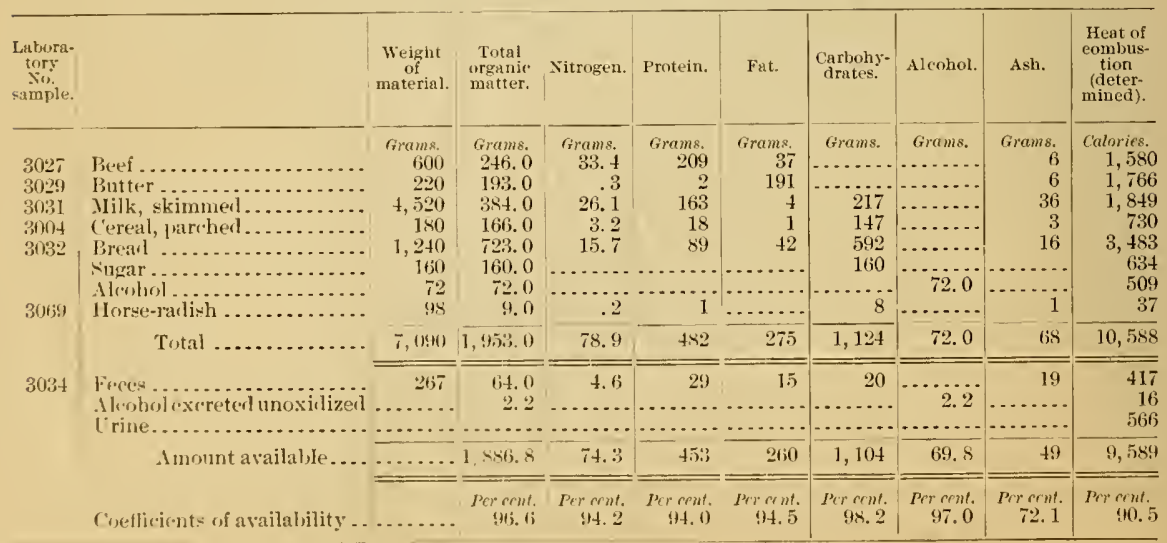




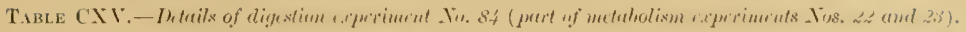

\begin{tabular}{|c|c|c|c|c|c|c|c|c|c|c|}
\hline \multicolumn{2}{|l|}{$\begin{array}{l}\text { Labora- } \\
\text { tory } \\
\text { tiri } \\
\text { sample. }\end{array}$} & \multirow{2}{*}{$\begin{array}{l}\text { Weight } \\
\text { if } \\
\text { matrint. } \\
\text { circtus. }\end{array}$} & \multirow{2}{*}{$\begin{array}{c}\text { Total } \\
\text { orguni. } \\
\text { matter. } \\
\begin{array}{c}\text { irams, } \\
364.0\end{array}\end{array}$} & \multirow{2}{*}{$\begin{array}{c}\text { Nitrogen. } \\
\text { Grams., }\end{array}$} & \multirow{2}{*}{ I'Totcin. } & \multirow{2}{*}{$\begin{array}{l}\text { Fat. } \\
\text { (irums. } \\
\text { is) }\end{array}$} & \multirow{2}{*}{$\begin{array}{c}\begin{array}{c}\text { Carbohy- } \\
\text { drates. }\end{array} \\
\text { fircems. }\end{array}$} & \multirow{2}{*}{$\frac{\text { Meohol. }}{\text { firams. }}$} & \multirow{2}{*}{$\begin{array}{l}\text { Ashi. } \\
\text { tirame, }\end{array}$} & \multirow{2}{*}{ 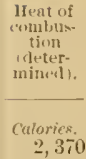 } \\
\hline $30 \div 7$ & Beef. & & & & & & & & & \\
\hline 30204 & Butter. & 330 & 290.0 &. $\bar{T}$ & + & $2 x+6$ & & .. & 8 & 2,644 \\
\hline $30 \div 31$ & Milk, skin & $(i, 7)$ & 57 & 39. & $\because 44$ & $\bar{t}$ & 325 & ... & $5+4$ & 2,773 \\
\hline 3004 & Cereal, parrherl........... & 270 & $\because-$ & 5 & 24 & 1 & 20 & $\ldots$ & 4 & 1,1095 \\
\hline \multirow[t]{2}{*}{3032} & Brearl ..................... & 1, sitio & $1,0 \times 4.0$ & 23.5 & 134 & 63 & 857 & - . & 24 & 5,225 \\
\hline & ol & $\begin{array}{l}2+11 \\
21+i\end{array}$ & $\begin{array}{l}= \pm 0.0 \\
: 16.0\end{array}$ & ...... & ... & - & 240 & $\cdots$ & & $\begin{aligned} 950 \\
1,5 \pm 16\end{aligned}$ \\
\hline \multirow[t]{2}{*}{$30 t i 9$} & Horse-ralish ............. & 40 & 8.0 & $\therefore$ & 1 & & $\bar{T}$ & ...... & 1 & 34 \\
\hline & Total & $10,6 \times 15$ & $3,03: 2.0$ & 118.6 & 725 & $41:$ & $1,67 !$ & 211 & 100 & $16,6 * 2$ \\
\hline \multirow[t]{4}{*}{3035} & Feces. & 426 & 100.0 & 6.7 & 42 & 22 & $3 t ;$ & & 30 & $6 \times 6$ \\
\hline & 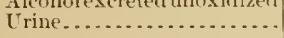 & . & & & & & & & & $\begin{array}{r}f 1 \\
654\end{array}$ \\
\hline & Imount available. & $\ldots . .$. & $2,925,4$ & 111.9 & 6983 & 3919 & $1,6+3$ & 209.4 & 70 & 15,035 \\
\hline & Coefficients of availability... & $\cdots$ & $\begin{array}{l}\text { Peritut. } \\
9 t i .5\end{array}$ & $\begin{array}{l}\text { Per cent. } \\
94.4\end{array}$ & $\begin{array}{r}\text { Prater. } \\
94.2\end{array}$ & $\begin{array}{l}\text { Perst. } \\
4.7\end{array}$ & Per & $\begin{array}{r}\text { Per erut. } \\
97.0\end{array}$ & $\begin{array}{r}\text { Peretst. } \\
70.0\end{array}$ & $\begin{array}{r}\text { Per crint. } \\
90 . \overline{5}\end{array}$ \\
\hline
\end{tabular}

DETAILA OF DIGETION EXIERIMEXT NU. 151.

This experiment formed a part of metabolism experiment No. 27 in series $26-28$. studying the comparitive effects of fat, aleohol, and sugar in the diet. The subject. J. F. S., was a chemist engaged in the investigation here reported. His reight, in underelothing, was tit. 1 kilograms at the begiming and 63.7 kilograms (140.4 pounds) at the end of the study. The experiment began with breakfast February 17, 190, and continued 3 days.

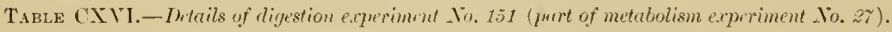

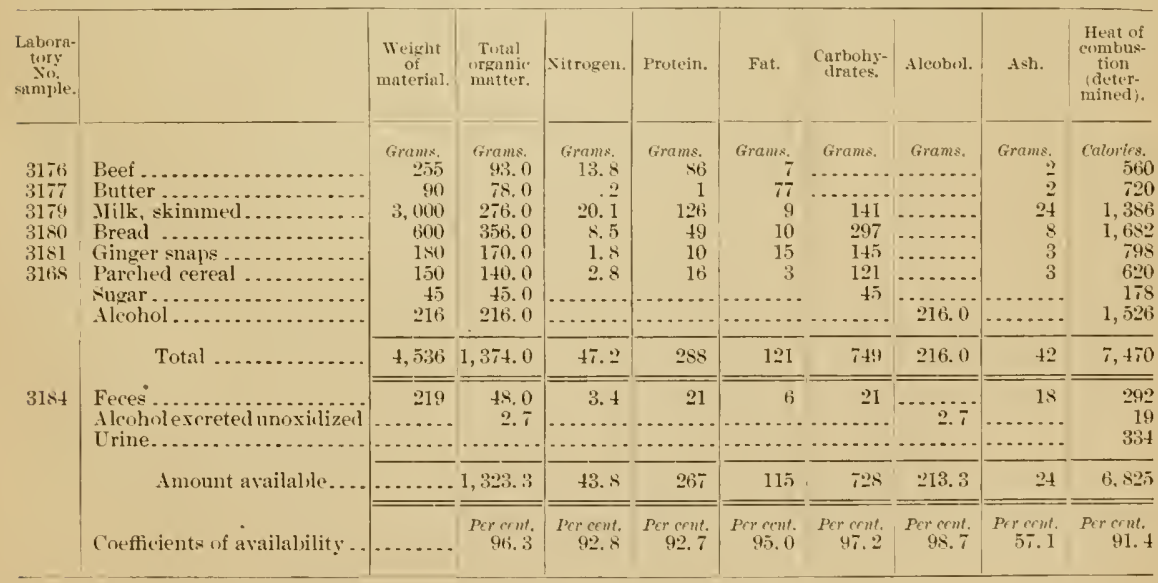

DETAILK OF DIGESTION EXPERIMENT NO. 1 กัก.

'This experiment formed a part of metabolism experiment No. 30, the seend of the series of experiments Nos. 29-31 for the purpose of studying the relative efferet of sugar, alcoherl, and fat in the diet during periods of work. It hegan with breakfast March 1!, 19n10, and continued 3 
days. The subject was J. F. S. His weight, in underclothing, was 64.6 kilograms at the beginning and tit.1 kilograms ( $1 \pm 1.3$ pounds) at the end of the experiment.

T.ABLE (XY11. Details of digestion experiment No. 155 (part of metabolism experiment No. 30).

\begin{tabular}{|c|c|c|c|c|c|c|c|c|c|c|}
\hline $\begin{array}{l}\text { Labora- } \\
\text { tury } \\
\text { ×o } \\
\text { sample. }\end{array}$ & & $\begin{array}{c}\text { Weight } \\
\text { of } \\
\text { material. }\end{array}$ & $\begin{array}{l}\text { Totul } \\
\text { organic } \\
\text { matter. }\end{array}$ & Sitrogen. & Protein. & Fat. & $\begin{array}{l}\text { Carbohy- } \\
\text { drates. }\end{array}$ & Aleohol. & Ash. & $\begin{array}{l}\text { Heat of } \\
\text { combus- } \\
\text { tion } \\
\text { (deter- } \\
\text { mined). }\end{array}$ \\
\hline $\begin{array}{l}3186 \\
3157 \\
3190 \\
3192 \\
3151 \\
3193\end{array}$ & 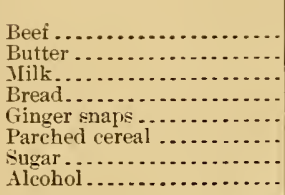 & $\begin{array}{r}\text { Grams. } \\
174 \\
141 \\
2,700 \\
900 \\
225 \\
225 \\
75 \\
216\end{array}$ & $\begin{array}{r}\text { Grams. } \\
67.0 \\
124.0 \\
384.0 \\
560.0 \\
213.0 \\
211.0 \\
75.0 \\
216.0\end{array}$ & $\begin{array}{r}\text { Grams. } \\
10.0 \\
17.3 \\
13.3 \\
2.5 \\
2.3 \\
4.3 \\
\end{array}$ & $\begin{array}{r}\text { Grams. } \\
62 \\
2 \\
108 \\
77 \\
13 \\
25\end{array}$ & $\begin{array}{r}\text { Grams. } \\
5 \\
122 \\
146 \\
18 \\
19 \\
3\end{array}$ & \begin{tabular}{|r} 
Grams. \\
\hdashline$\ldots . .$. \\
130 \\
465 \\
181 \\
183 \\
75 \\
$\cdots \ldots .$.
\end{tabular} & 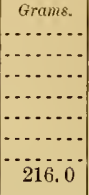 & $\begin{array}{r}\text { Grams. } \\
2 \\
5 \\
22 \\
12 \\
4 \\
5\end{array}$ & $\begin{array}{r}\text { Calorics. } \\
405 \\
1,135 \\
2,430 \\
2,637 \\
998 \\
945 \\
297 \\
1,526\end{array}$ \\
\hline & Total & 4,656 & $1,850.0$ & 47.7 & 287 & 313 & 1,034 & 216.0 & 50 & 10,373 \\
\hline \multirow[t]{3}{*}{3196} & 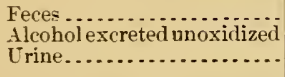 & $\begin{array}{r}143 \\
\ldots . .\end{array}$ & $\begin{array}{r}33.0 \\
2.3\end{array}$ & 2 & 13 & 6 & 14 & 2.3 & 8 & $\begin{array}{r}213 \\
16 \\
343\end{array}$ \\
\hline & Amount available.. & .... & $1,814.7$ & 45.7 & $27 t$ & 307 & 1,020 & 213.7 & 42 & 9,801 \\
\hline & Coefficients of arailability.. & & $\begin{array}{r}\text { Per cent. } \\
98.1\end{array}$ & $\begin{array}{r}\text { Per cent. } \\
95.8\end{array}$ & $\begin{array}{r}\text { Per cent. } \\
95.5\end{array}$ & $\begin{array}{r}\text { Per cent. } \\
98.1\end{array}$ & $\begin{array}{r}\text { Per cent. } \\
98.6\end{array}$ & $\begin{array}{r}\text { Per cent. } \\
98.9\end{array}$ & $\begin{array}{c}\text { Per cent. } \\
84\end{array}$ & $\begin{array}{r}\text { Per cent. } \\
94.5\end{array}$ \\
\hline
\end{tabular}

\section{DEXAILS OF DIGESTION EXPERIMENT NO. 159.}

This experiment, which hegan with breakfast, April 23, 1900, and continued 3 days, formed a part of the series of metabolism experiments Nos. 32-3t, studying the relative effect of fat, alcohol, and sugar in the diet during periods of work. The subject was the same as in the two preceling experiments here described. His weight, in underclothing, was 65.2 kilograms at the beginning and 64.9 kilograms ( $1+3.1$ pounds) at the end of the investigation.

TABLE CXYIII.-Detrils of digestion experiment No. 159 (part of metabolism experiment No. 38).

\begin{tabular}{|c|c|c|c|c|c|c|c|c|c|c|}
\hline $\begin{array}{c}\text { Lab. } \\
\text { So. } \\
\text { sumple. }\end{array}$ & & $\begin{array}{l}\text { Weight of } \\
\text { material. }\end{array}$ & $\begin{array}{c}\text { Total } \\
\text { organje } \\
\text { matter. }\end{array}$ & Xitrogen. & Protein. & Fat. & $\begin{array}{l}\text { Carbohy- } \\
\text { drutes. }\end{array}$ & Alcohol. & Ash. & $\begin{array}{l}\text { Heat of } \\
\text { combus- } \\
\text { tion } \\
\text { (deter- } \\
\text { nined). }\end{array}$ \\
\hline $\begin{array}{l}3205 \\
3206 \\
3201 \\
3204 \\
3207 \\
3199\end{array}$ & 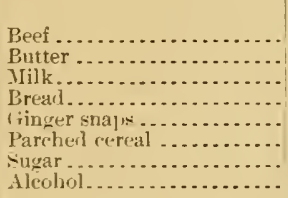 & $\begin{array}{r}\text { Grams } \\
174 \\
105 \\
3,060 \\
400 \\
225 \\
225 \\
105 \\
216\end{array}$ & $\begin{array}{r}\text { Grums. } \\
61.0 \\
93.0 \\
432.0 \\
548.0 \\
212.0 \\
211.0 \\
105.0 \\
216.0\end{array}$ & $\begin{array}{r}\text { Grams. } \\
8.9 \\
.2 \\
20.2 \\
12.4 \\
2.0 \\
4.3 \\
\ldots . .\end{array}$ & $\begin{array}{r}\text { Grams. } \\
56 \\
1 \\
126 \\
71 \\
11 \\
25\end{array}$ & $\begin{array}{r}\text { Grams. } \\
5 \\
92 \\
159 \\
23 \\
16 \\
3 \\
\\
\end{array}$ & \begin{tabular}{|r|} 
Grams. \\
$\ldots \ldots$ \\
$\ldots \ldots$ \\
147 \\
$45 \pm$ \\
185 \\
183 \\
105 \\
$\ldots \ldots$
\end{tabular} & 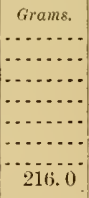 & $\begin{array}{r}\text { Grams. } \\
2 \\
3 \\
24 \\
12 \\
5 \\
5 \\
\ldots . . .\end{array}$ & $\begin{array}{r}\text { Calorieg. } \\
361 \\
862 \\
2,766 \\
2,582 \\
998 \\
945 \\
416 \\
1,526\end{array}$ \\
\hline & Total & 5,010 & $1,478,0$ & 48.0 & 290 & 298 & 1,074 & 216.0 & 51 & 10,456 \\
\hline & 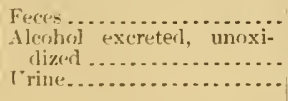 & 259 & $\begin{array}{r}59.0 \\
2.2 \\
-\ldots . .\end{array}$ & 3.5 & 22 & 13 & 24 & $\begin{array}{c}-2.2 \\
2.2 \\
\cdots \\
\cdots\end{array}$ & 16 & $\begin{array}{r}375 \\
165 \\
335\end{array}$ \\
\hline & Amonnt available.... & $\ldots \ldots$ & $1, x 16.8$ & 44.5 & 268 & 285 & $1,(0.50$ & 213.5 & 35 & 9,730 \\
\hline & Coefficienty of availahility... & & $\begin{array}{r}\text { Perermt. } \\
96.7\end{array}$ & $\begin{array}{r}\text { Per rout. } \\
92.7\end{array}$ & $\begin{array}{r}\operatorname{Per} \text { cent. } \\
92.4\end{array}$ & $\begin{array}{r}\text { Per crut. } \\
\quad 95.6\end{array}$ & $\begin{array}{r}\text { Per cent. } \\
97.8\end{array}$ & $\begin{array}{r}\text { Per Crut. } \\
99.0\end{array}$ & $\begin{array}{r}\text { Per eent. } \\
68.6\end{array}$ & $\begin{array}{l}\text { Per } \mathrm{crnt} \\
\quad 03.1\end{array}$ \\
\hline
\end{tabular}




\section{TABULAR SUMMARIES OF RESULTS OF THE EXPERIMENTS.}

The following tables summarize the more important results of the experinents.

IXCOME AND OUTGO OF NITROGEN AND GAIN OR LOSS OF PROTEIN AND FAT.

The data which bear jmmediately upon the nitrogen and carbon balance, and the gains and losses of protein and fat, with and without alcohol in the ration, are brought together in Table CXIX. The method of grouping was explained above, page -

TABLE CXIX, - Income and outgo of nitrogen amd carton and gain or loss of protein and fat, in experiments with and withoul alcohol.

\begin{tabular}{|c|c|c|c|c|c|c|c|c|c|c|c|c|c|c|c|c|c|}
\hline \multirow[b]{2}{*}{$\begin{array}{l}\text { Classification, serial numbers, } \\
\text { and subjects of experi- } \\
\text { ments. }\end{array}$} & \multicolumn{5}{|c|}{ In daily food. } & \multicolumn{4}{|c|}{ Nitrogen. } & \multirow[b]{2}{*}{ 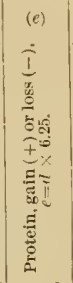 } & \multicolumn{6}{|c|}{ Carbon. } & \multirow[b]{2}{*}{ 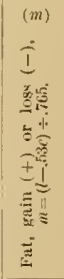 } \\
\hline & 氞 & 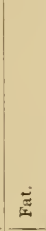 & 离 & $\frac{\overrightarrow{0}}{\frac{0}{\pi}}$ & है & $\underset{\Xi}{\Xi}$ & 递 & $\underset{\Xi}{\stackrel{\Xi}{\Xi}}$ & 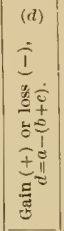 & & $(f)$ & 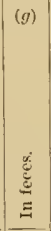 & $\stackrel{\Xi}{\Xi}$ & 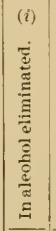 & 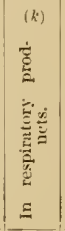 & 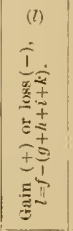 & \\
\hline $\begin{array}{l}\text { Experiments with and } \\
\text { without alcohol more } \\
\text { strictly comparable. }\end{array}$ & & & & & & & & & & & & & & & & & \\
\hline 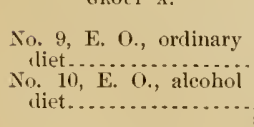 & $\begin{array}{r}\text { D. (7s } \\
+119 \\
+123\end{array}$ & Gins. & $\begin{array}{l}\text { Gim.. } \\
342 \\
297\end{array}$ & $\begin{array}{l}\text { (ims. } \\
72.5\end{array}$ & $\begin{array}{l}c a / s \\
2,717 \\
2,709\end{array}$ & $\begin{array}{l}\text { Cims. } \\
719.1 \\
19.8\end{array}$ & $\begin{array}{l}\text { tims. } \\
1.3 \\
1.4\end{array}$ & $\begin{array}{l}\text { fins. } \\
18.4 \\
19.5\end{array}$ & $\begin{array}{l}\text { Gms } \\
-0.6 \\
-1.1\end{array}$ & $\begin{array}{l}\operatorname{sim} s \\
-3.6 \\
-6.9\end{array}$ & $\begin{array}{l}\text { Gms. } \\
261.6 \\
253.3\end{array}$ & $\begin{array}{l}\text { Gms. } \\
13.4 \\
11.8\end{array}$ & 13.5 & Gms. & $\begin{array}{l}\text { fims. } \\
223.6 \\
214.9\end{array}$ & $\left\{\begin{array}{l}\text { fims. } \\
+12.0 \\
+12.6\end{array}\right.$ & $\begin{array}{l}\text { Gims. } \\
+18.2 \\
+21.2\end{array}$ \\
\hline
\end{tabular}

riROTP B.

No. 24, E. O., ordinary No. 22, E. O., alcohol diet. GROTPA $A-\mathrm{B}$.

Avernge, 9,24 , ordinary diet.................

GROUP C.

No. 26, J. F.s., ordinary diet $\ldots$ diet . . . . . . . . . . . . . Average, $26,28 \ldots \ldots . .$.

No. 27, J. F. S., alcohol diet...
$312469409 \ldots .3,06119.81 .318 .2+.3+1.7299 .710 .511 .4 \ldots .230 .9+46.5+59.7$ $31246927672.03,04419.8 \quad 1,118.5+.2+1.4279 .810 .311 .81 .2207 .8+4$ s. $7+62.7$ $712169375 \ldots .2,88919 .+1.318 .3-.2-1.0280 .711 .912 .2 \ldots .227 .3+29.3 \div 39.0$ $\begin{array}{ll}7 & 5128672.32,87719.4 \quad 1.314 .0-.5-2.8266 .611 .112 .7 \quad .8211 .4+30.6+42.0\end{array}$ $3100 \quad 95 \quad 247 \ldots 2,49015.9 \quad 1.115 .4-.6-3.5233 .29 .411 .0 \ldots 19 k .1+16.7+24.1$ 399 t0 $375 \ldots .2,48915.8 \quad 1.215 .3 \quad .7-4.5245 .810 .010 .9 \ldots .210 .7+14.2+21.8$ $69968311 \ldots 2,49015.91 .215 .3-.6-4.0239 .59 .711 .0 \ldots 203.4+15.4+23.1$

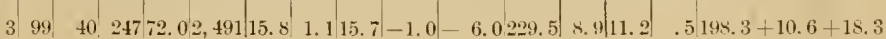


T.unL CIIX. - Ineome and outgo of nitrogen and carbon and gain or Inss of protein and fat, etc.-Continued.

Classification, serial numbers, and subjects of experiments.
Experiments with and rithout alcohol more striatly comparableContinuerl.

Rext EAPERIMEXTsContinuerl.

(iRot'Ps . $1-C^{\prime}$.

Arerage, 9, 24, 26-2s, orlinary diet .........

Arerage, 10, 22, 27, alcohol cliet

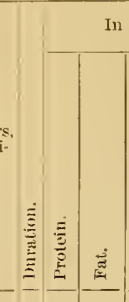

In daily food.

\section{Work Experiunexts.}

(iROLP J),

No. 11, F. O., ordinary diet................

No. 12 , E. 0. alcohol diet.

(iROLP E.

No. 29, J. F. S., ordinary diet ............... Xo. 31, J. F. S., ordinary diet............... Average, 24, 31 ....... diet.................

GROLP F.

Jo. 32, J. F. S., orlinary diet........... diet............... Average, $32,34 \ldots . . .$.

Tr. 33, J. F. .', alcohol diet

\begin{tabular}{l|l|l|l|l|l|l}
3101 & 152 & $354 \ldots 3,48716.1$ & 1.2 & $15.7 \ldots .8-5.0320 .012 .611 .0 \ldots 325.6-29.2-34.9$
\end{tabular} $3100 \quad 99478 \ldots 3,49316.0$ 1.2 $16.7-1.9-11.9335 .711 .611 .6 \ldots \ldots+35.4-32.9-35.0$ $6100126416 \ldots .3,49016.0$ 1.2 $26.2-1.4-8.5327 .812 .111 .3 \ldots \ldots 35.5-31.1-35.0$ $3100 \quad 9935572,03,48616.0 \quad 1.217 .3-2.5-15.8319 .611 .412 .1$

\begin{tabular}{|c|c|c|c|}
\hline \multicolumn{3}{|c|}{ arbon, } & $(m)$ \\
\hline (i) & (k) & (l) & 1 \\
\hline 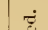 & $\frac{1}{2}$ & $\dot{i}$ & 8.80 \\
\hline$\stackrel{\Xi}{\Xi}$ & 总 & $\frac{1}{2}$ & $\cong *$ \\
\hline 吾 & 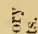 & $\stackrel{+}{+}$ & $\mp^{\text {\% }}$ \\
\hline$\frac{\overrightarrow{0}}{3}$ & U. & 5 & \pm \\
\hline$\stackrel{g}{\mathscr{g}}$ & $\bar{z}$ & \pm 1 & 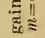 \\
\hline$\stackrel{\Xi}{\equiv}$ & $\Xi$ & $\vec{\Xi}$ & 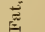 \\
\hline
\end{tabular}

$4124129+85 \ldots .3,86219.82 .218 .1-.5-3.0373 .520 .212 .7$ $372.6-32.0-39.7$ $+12115929672.43,89119.31 .318 .2-.2-1.0344 .812 .112 .3$
D. Gs. Fms. Gms. Gms. Cals. Gms. Gms. Gns. Fms, Fms. Gms. Gms. Gms. Gms. Gms. Gms. Gms. $1311469354 \ldots 2,756.18 .31 .317 .3-0.3-2.0266 .911 .211 .8 \ldots 219.3+24.6+33.7$ $101154727372.22,74818.51 .217 .9-.6-3.8254 .210 .312 .20 .7207 .0+24.0+34.1$ $\begin{array}{lllll}3100 & 106 \quad 471 \ldots .+3,48716.0 \quad .816 .0-.8-5.0333 .6 & 8.311 .2 \ldots 334.9-20.8-23.8\end{array}$

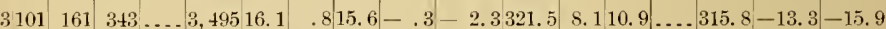
$6100134+07 \ldots 3,49116.0 \quad .815 .8-.6-3.7327 .68 .211 .1 \ldots \ldots 25.4-17.1-19.9$

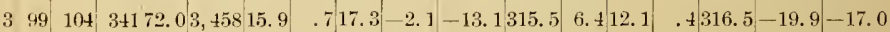

(iROT'PS E-F.

A verage, $29+31,32+34$, ordinary diet ....... $12100130412 \ldots . .3,49016.0 \quad 1.016 .0 \ldots 1.0-6.1327 .710 .211 .2 \ldots 330.4-24.1-27.5$ Average, 30,33 , alcohol lict.

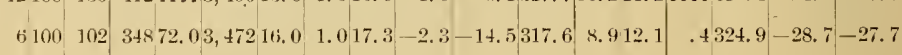

(iROL']' It IT.

Average, $11,29+31,32$

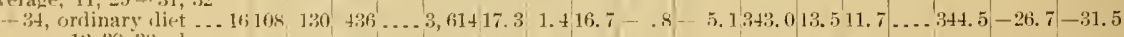
Average, $12,30,33.3$, alc(3) hol diet .......... 10 $107 \quad 2133172.23,61117.1$ 1.117.6-1.6-10.0326.6.10.012.2 .5331.5.27.5,-29.2 


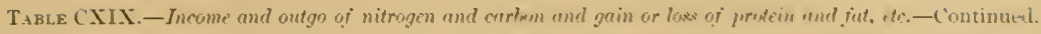

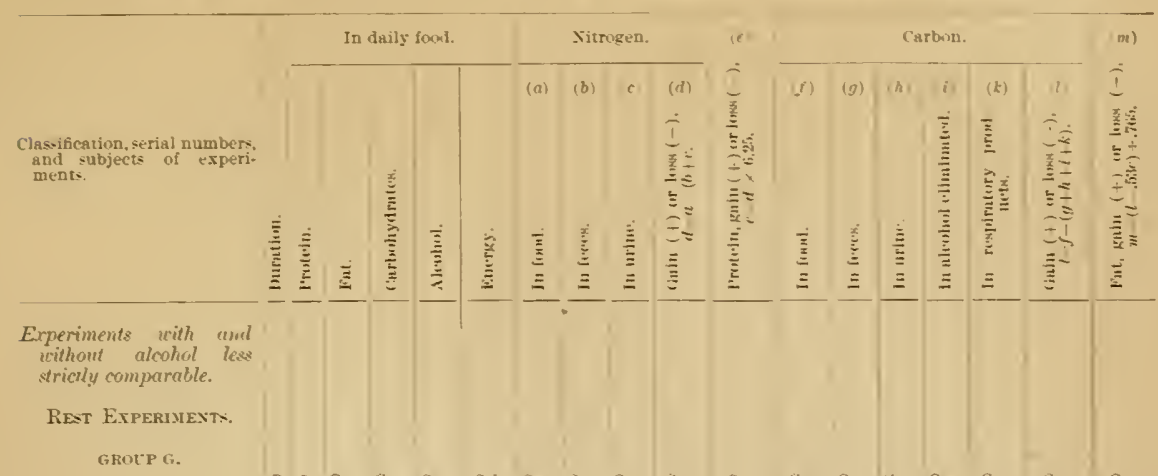

Yo. 13 , E. 0., ordinary diet.................... diet................. +94

Average, $13,14 \ldots . . . . .7105$

No. T, E.O., alcohol diet. $\$ 104$

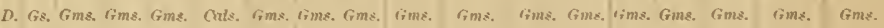
GROLP H.

No. 5. E. O.. ordinary

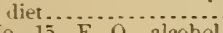
10. 15, E. O., alcohol diet................... alcohol diet................ 2109 So. 17, E. O., alcohol diet................. 2109

Arerage. $15,16,17 \ldots . . .6109$ $+11995276 \ldots .2,65719.1$ 1.71..1-.7-4.2245.913.511.6...231.7-8.2-7.8

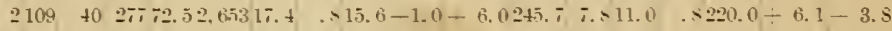
40 $40.7 .2 .52 .65317 .4 .815 .6-1.0-6.0245 .7 \div .811 .0 .8214 .5-11.6-11.0$ t0 $27.2 .52 .65317 .4 \quad 315.6-1.1-6.4245 .7 \% .811 .0 \quad .921 \% .6-8.4-6.6$ (GROTP I.

Io. 21. A. W, S., ordinary diet.............. diet....................... diet .................

Yo. 20, A. Tr.... alcohol diet ................. Arerage. $15,19,20 \ldots \ldots$. 6 \% $\$ 3290 \ldots .2,51315.1 \quad .916 .2-2.0-12.4239 .0 \quad 7,412.2 \ldots .207 .3-12.1-24.4$ 66 $280 \ldots . .55016 .91 .017 .5-1.9-12.0242 .49 .313 .6 \ldots 206.3-13.2-25.7$ 65 $19172.52,46216.7 .917 .7-1.9-12.0215 .66 .713 .31 .5214 .5-17.4-14.3$ GROTP G-I.

Average, $13-14,5,21$, nr.linary diet .......... $1+10$ i

Arerage, 7.15 to $17.1 \mathrm{~s}$ to 20 , alcohol diet.... 1610.3

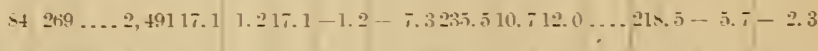
$6023972.52,63016.5 \quad .916 .1-.5-3.0289 .17 .211 .31 .3215 .4 \rightarrow 3.3-6.5$ GROTPS I-I.

Average, $9,24,26-2 x$. 11. $24-31,32+34,13$ -14. 5, 21, urdinary diet............ $30,33,7,15$ to $1 \div, 18$

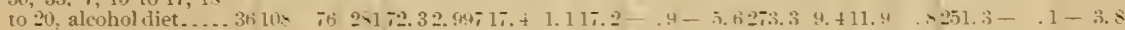

Vol. s- 


\section{INCOME AND OUTGO OF MATERIAL AND EXERGY.}

Table CXX compares the arailable protein and energy, the gain or loss of body protein and body fat, and the energy of material oxidized in the body and that measured as heat and muscular work in the rarious groups of experiments with and without alcohol. The arailable protein is the difference between the protein in the food and that in the fees, while the arailable energy represents the energy of the food less the energy of the feces and (dry matter of) nrine. The energy of the material oxidized in the body represents what may be called the net income, while the energy measured as heat and muscular work may be called the net outgo.

TABLE CXX. - Material and energy supplied and metabolized in experiments with and without alcolool.

[Quantities per day.]

Classifidation, serial numbers, and subjeet of
experiments.

Experiments with and without alcohol more strictly comparable.

REst ExperineNTS.

GROUP A.

No. 9, E. O., ordinary diet

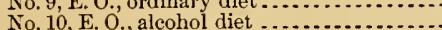

GROUP B.

No. 24, E. O., ordinary diet

No. 22, E. O., alcohol diet

$$
\text { GROLPS A AND B. }
$$

Average 9,24, E. O., ordinary diet

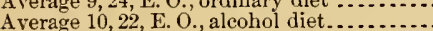

GROUP C.

No. 26, J. F.S., ordinary diet

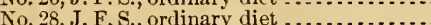

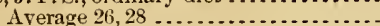

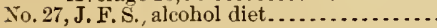

$$
\text { GROLPS A, B, AND C. }
$$

Average $9,24,26+28$, ordinary diet ....... Average $10,22,27$, alcohol diet ...........

WORK ExpenMENTs.

GROUP D.

No. 11, E. O., ordinary diet

To. 12, F, 0 , alcolol iliet ................

\section{(iROCP E.}

No. 29, J. F. S., ordinary diet
No. 31, J. F. S., ordinary dliet

$$
\text { A verage } 24,31
$$

No. 30, J. F.S., alcohol diet

\section{GROTP $F$.}

No. 32, J. F. . . , ordinary dictt

\$o. 34, J. F. S., orlinary diet . .................

\begin{tabular}{|c|c|c|c|c|c|c|c|}
\hline \multirow{2}{*}{$\begin{array}{c}\text { Available } \\
\text { protein. }\end{array}$} & \multirow{2}{*}{$\begin{array}{l}\text { Available } \\
\text { energy. }\end{array}$} & \multicolumn{2}{|c|}{$\begin{array}{l}\text { Gain }(+) \text { or loss }(-\overrightarrow{)}) \\
\text { of body material. }\end{array}$} & \multirow{2}{*}{$\begin{array}{c}\text { Energy of } \\
\text { material } \\
\text { oxidized } \\
\text { in the } \\
\text { body. }\end{array}$} & \multicolumn{3}{|c|}{ Energy measured as- } \\
\hline & & Protein. & Fat. & & Heat. & $\begin{array}{c}\text { IIuseular } \\
\text { work. }\end{array}$ & Total. \\
\hline $\begin{array}{r}\text { Grams. } \\
112 \\
115\end{array}$ & $\begin{array}{r}\text { Calories. } \\
2,426 \\
2,427\end{array}$ & $\begin{array}{l}\text { Grams. } \\
-\quad 3.6 \\
-6.9\end{array}$ & $\begin{array}{l}\text { Grams. } \\
+18.2 \\
+21.2\end{array}$ & $\begin{array}{c}\text { Calories. } \\
2,277 \\
2,268\end{array}$ & $\begin{array}{r}\text { Calories. } \\
2,309 \\
2,283\end{array}$ & $\begin{array}{c}\text { Calories. } \\
\ldots \ldots \\
\ldots \ldots \\
\end{array}$ & $\begin{array}{r}\text { Calories. } \\
2,309 \\
2,283\end{array}$ \\
\hline $\begin{array}{l}115 \\
117\end{array}$ & $\begin{array}{l}2,809 \\
2,777\end{array}$ & $\begin{array}{r}1.7 \\
+\quad 1.4\end{array}$ & $\begin{array}{r}+59.7 \\
+62.7\end{array}$ & $\begin{array}{l}2,238 \\
2,180\end{array}$ & $\begin{array}{l}2,272 \\
2,258\end{array}$ & $\begin{array}{l}\ldots \ldots \\
\cdots \\
\cdots\end{array}$ & $\begin{array}{l}2,272 \\
2,258\end{array}$ \\
\hline $\begin{array}{l}114 \\
116\end{array}$ & $\begin{array}{l}2,618 \\
2,602\end{array}$ & $\begin{array}{r}-1.0 \\
-2.8\end{array}$ & $\begin{array}{r}+39.0 \\
+42.0\end{array}$ & $\begin{array}{l}2,258 \\
2,224\end{array}$ & $\begin{array}{l}2,291 \\
2,270\end{array}$ & $\ldots .$. & $\begin{array}{l}2,291 \\
2,270\end{array}$ \\
\hline $\begin{array}{l}93 \\
91 \\
92 \\
92\end{array}$ & $\begin{array}{l}2,256 \\
2,249 \\
2,253 \\
2,264\end{array}$ & $\begin{array}{r}3.5 \\
-4.5 \\
-4.0 \\
-6.0\end{array}$ & $\begin{array}{r}+24.4 \\
+21.8 \\
+23.1 \\
+18.2\end{array}$ & $\begin{array}{l}2,043 \\
2,067 \\
2,055 \\
2,125\end{array}$ & $\begin{array}{l}2,085 \\
2,079 \\
2,082 \\
2,123\end{array}$ & \begin{tabular}{|c|}
$\ldots$ \\
$\ldots \ldots$ \\
\hdashline$\ldots \ldots$ \\
\hdashline$\ldots \ldots$
\end{tabular} & $\begin{array}{l}2,085 \\
2,079 \\
2,082 \\
2,123\end{array}$ \\
\hline $\begin{array}{l}106 \\
108\end{array}$ & $\begin{array}{l}2,496 \\
2,459\end{array}$ & $\begin{array}{r}2.0 \\
-3.8\end{array}$ & $\begin{array}{l}+33.7 \\
+34.1\end{array}$ & $\begin{array}{l}2,190 \\
2,191\end{array}$ & $\frac{2,221}{2,221}$ & & $\begin{array}{l}2,221 \\
2,221\end{array}$ \\
\hline $\begin{array}{l}110 \\
113\end{array}$ & $\begin{array}{l}3,510 \\
3,614\end{array}$ & $\begin{array}{r}3.0 \\
-\quad 1.0\end{array}$ & $\begin{array}{l}-39.7 \\
-32.2\end{array}$ & $\begin{array}{l}3,901 \\
3,922\end{array}$ & $\begin{array}{l}3,746 \\
3,727\end{array}$ & $\begin{array}{l}186 \\
200\end{array}$ & $\begin{array}{l}3,932 \\
3,927\end{array}$ \\
\hline $\begin{array}{l}95 \\
96 \\
96 \\
95\end{array}$ & $\begin{array}{l}3,260 \\
3,275 \\
3,268 \\
3,242\end{array}$ & $\begin{array}{l}-5.0 \\
-2.3 \\
-3.7 \\
-13.1\end{array}$ & $\begin{array}{l}-23.8 \\
-15.9 \\
-19.9 \\
-17.0\end{array}$ & $\begin{array}{l}3,515 \\
3,439 \\
3,477 \\
3,479\end{array}$ & $\begin{array}{l}3,334 \\
3,171 \\
3,253 \\
3,321\end{array}$ & $\begin{array}{l}255 \\
249 \\
252 \\
249\end{array}$ & $\begin{array}{l}3,589 \\
3,420 \\
3,505 \\
3,470\end{array}$ \\
\hline $\begin{array}{l}98 \\
92 \\
93 \\
92\end{array}$ & $\begin{array}{l}3,226 \\
3,241 \\
3,234 \\
3,227\end{array}$ & $\begin{array}{r}5.0 \\
-11.9 \\
-8.5 \\
-15.8\end{array}$ & $\begin{array}{r}-34.9 \\
-35.0 \\
-35.0 \\
-38.4\end{array}$ & $\begin{array}{l}3,573 \\
3,629 \\
3,601 \\
3,669\end{array}$ & $\begin{array}{l}3,369 \\
3,337 \\
3,353 \\
3,435\end{array}$ & $\begin{array}{l}196 \\
250 \\
223 \\
197\end{array}$ & $\begin{array}{l}3,565 \\
3,587 \\
3,576 \\
3,632\end{array}$ \\
\hline
\end{tabular}
Average 32, 34

No. 33, J. F. S., alcohol diet. 


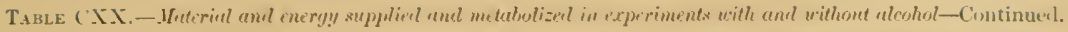

Classification, serial tumbers, and subject of

Expreriments with und rithoul alcuhel wore strictly cumpurable-Continued.

RET EXPERINexts-Continuel.

(iROIPS E AND F

Average $29-31,32+34$, ordinary liet ......

Arerage 30,33 , alcohol diet

GROTPS D, E, AND F.

Average $11,29-31,32-34$, ordinary diet ... Average $12,30,33$, alcohol diet ...........

GROTPS A TO F.

Average $9,24,26+28,11,29--31,32-34$,

ordinary diet ......................

Average $10,22,27,12,30,33$, alcohol diet ....

Experiments with and without alcohol less strictly comparable.

Rest Experiuexts.

GROLP G.

సo. 13, E. O., ordinary diet

ro. $14, \mathrm{E}, 0$, orlinary diet

Average $13,14^{\circ}$

Yo., , E. O., alcohol diet

GROTP II.

So, 5. E. O., ordinary diet

No. 15 , E. O., alcohol diet

To. 16 , E. O., alcohol diet Average $15,16,17$

\section{GROLP I.}

Yo. 21, A. II. S., ordinary diet

Yo. 18 , IT 5 , aleohol diet.

Yo. 19 A. Wr.

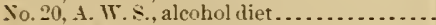

Average $18,19,20$

GROTPS G, F, AND I.

Arerage $13-14,5,21$, ordinary diet ......... Arerage 7,15 to 17,18 to 20 , alcohol diet ...

$$
\text { GROTPS A TO I. }
$$

Arerage $9,24,26-25,11,29+31,32+34$, $13-14,5,21$, ordinary diet $\ldots \ldots \ldots \ldots \ldots$. Arerage $10,22.27,12,30,33,7,15$ to 17,18 to 20 , alcohol diet.......................

\begin{tabular}{|c|c|c|c|c|c|c|c|}
\hline \multirow{2}{*}{$\begin{array}{l}\text { Arailable } \\
\text { protein. }\end{array}$} & \multirow{2}{*}{$\begin{array}{l}\text { Arailable } \\
\text { energy. }\end{array}$} & \multicolumn{2}{|c|}{$\begin{array}{l}\text { Gain }(+ \text { or lows }(-) \\
\text { of bexly malerial. }\end{array}$} & \multirow{2}{*}{$\begin{array}{l}\text { Energy of } \\
\text { material } \\
\text { oxidlized } \\
\text { in the } \\
\text { body. }\end{array}$} & \multicolumn{3}{|c|}{ Energy medsures] aw } \\
\hline & & Protein. & Fut. & & Ileat. & $\begin{array}{l}\text { Muscular } \\
\text { work. }\end{array}$ & Total. \\
\hline $\begin{array}{r}\text { Grams. } \\
95 \\
94\end{array}$ & $\begin{array}{c}\text { Calorics. } \\
3,251 \\
3,235\end{array}$ & $\begin{array}{r}\text { Grams. } \\
-\quad 6.1 \\
-14.5\end{array}$ & $\begin{array}{l}\text { Grams. } \\
-27.5 \\
-27.7\end{array}$ & $\begin{array}{r}\text { Calorics. } \\
3,539 \\
3,574\end{array}$ & $\begin{array}{r}\text { Calorics. } \\
3,303 \\
3,328\end{array}$ & $\begin{array}{c}\text { Calorics, } \\
238 \\
223\end{array}$ & $\begin{array}{l}\text { Calories. } \\
\qquad \begin{array}{r}3,5 \pm 1 \\
3,551\end{array}\end{array}$ \\
\hline 100 & 3,337 & -5.1 & -31.5 & 3,660 & 3,451 & 220 & 3,671 \\
\hline 100 & 3,361 & -10.0 & -29.2 & 3,690 & 3,461 & 215 & 3,676 \\
\hline 103 & 2,917 & -3.5 & +1.1 & 2,925 & 2,836 & 110 & 2,946 \\
\hline 104 & 2,925 & -6.9 & +2.4 & 2,941 & $2,8+1$ & 108 & 2,949 \\
\hline 110 & 2,298 & -11.7 & +26.9 & 2,112 & 2,151 &. & 2,151 \\
\hline 89 & 2,289 & -12.4 & +24.4 & 2,131 & 2,193 & ......... & 2,193 \\
\hline 100 & 2,294 & $-1 \geq .0$ & +25.7 & 2,121 & 2,172 & ......... & 2,172 \\
\hline 99 & 2,230 & -12.0 & $-1+.3$ & 2,434 & 2,394 & $\therefore \ldots$ & 2,394 \\
\hline 109 & 2,384 & -4.2 & $-7 . s$ & 2,482 & 2,379 & & 2,379 \\
\hline $10 t$ & 2,426 & +6.0 & +3.8 & 2,357 & 2,362 & $\ldots$. & 2,362 \\
\hline 104 & 2,424 & +7.2 & +5.0 & 2,336 & 2,332 & $\ldots$ & 2,332 \\
\hline 104 & $2,+27$ & +6.0 & +11.0 & 2,289 & 2,276 & . & 2,276 \\
\hline 104 & 2,426 & +6.4 & +6.6 & 2,327 & 2,323 & ...... & $-2,323$ \\
\hline 90 & $2,03 \mathrm{~s}$ & -5.6 & -24.9 & 2,304 & 2,279 & $\ldots$ & 2,279 \\
\hline 90 & 2,532 & -12.2 & +25.1 & 2,367 & 2,488 & $\ldots$ & 2,488 \\
\hline 90 & 2,550 & .0 & +35.1 & 2,220 & 2,279 & |...... & 2,279 \\
\hline $\begin{array}{l}90 \\
90\end{array}$ & 2,549 & $\begin{array}{r}2.2 \\
-\quad 33\end{array}$ & +21.1 & $\begin{array}{l}2,339 \\
2,309\end{array}$ & 2,303 & $\ldots$ & 2,303 \\
\hline & & & & & & - & \\
\hline 100 & 2,239 & -7.3 & -2.3 & 2,302 & $2,27 i$ & .. & 2,277 \\
\hline 98 & 2,400 & -3.0 & +6.5 & 2,356 & $2,35 \mathrm{~s}$ & $\ldots$. & 2,358 \\
\hline 102 & 2,691 & -4.8 & -.1 & 2,717 & 2,650 & 73 & $2,7 \geq 23$ \\
\hline 102 & 2,750 & -7.1 & +3.8 & $2, i+6$ & $2,6 \times 0$ & 72 & 2,752 \\
\hline
\end{tabular}


PROPORTIONS OF ALCOHOL OXIDIZED AND LNOXIDIZED.

In the experiments in which alcohol formed part of the diet the urine, drip, and freezer waters and outgoing air current were examined for the presence of alcohol, or the products of incomplete oxidation of alcohol, aceording to the method discussed on page 258. The determinations were made by the amount of reduction of a standard stlphuric-acid solution of chromic acid. The materials thus found were called reducing materials. and the total amounts were calculated as alcohol.

In 6 of the later experiments in which alcohol did not form part of the diet the same tests were made in the excretory and respiratory products as indicated above, and considerable quantities of reducing material were found. These were likewise calculated as alcohol. The arerage daily amount eliminated in each of these experiments and the arerage of the results of alt 6 are shown in Table CXXI.

T.вLe CXXI.-Avcrage daily elimination of reducing material by lungs and kidneys in experiments in which alcohol did not form a part of the diet.

[Quantities expressed in alcohol equivalent.]

\begin{tabular}{|c|c|c|c|}
\hline & \multicolumn{3}{|c|}{$\begin{array}{l}\text { Reducing material excreted, calcu- } \\
\text { lated as alcohol. }\end{array}$} \\
\hline Experiment No. & In urine. & \begin{tabular}{|c|} 
In \\
respiratory \\
produets.
\end{tabular} & Total. \\
\hline 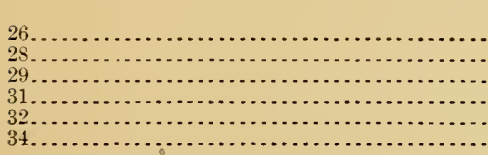 & $\begin{array}{r}\text { Grams. } \\
0.02 \\
.02 \\
.01 \\
.02 \\
.02 \\
.03\end{array}$ & $\begin{array}{r}\text { Grams. } \\
0.36 \\
.24 \\
.35 \\
.28 \\
.32 \\
.28\end{array}$ & $\begin{array}{r}\text { Grams. } \\
0.38 \\
.26 \\
.36 \\
.30 \\
.34 \\
.31\end{array}$ \\
\hline Average of all ............ & .02 & .30 & .32 \\
\hline
\end{tabular}

In the average of all 6 experiments the reducing material determined was found equivalent to 0.32 of a gram of alcohol per day. Accordingly, from the total amount of reducing material determined in the alcohol experiments. 0.3 gram was subtracted in estimating the amount of alcohol excreted nnoxidized. This is shown in Table CXXII, which summarizes the data for the excretion of unoxidized alcohol in the different experiments. The figures in column $d$ show the total amount of reducing material, calculated as alcohol, which was found in the distillates from the urine and the water condensed in the chamber and the freezers, and more especially in the air current. From each of the values in column $d 0.3$ gram is subtracted. as explained abore, to obtain the values in column $e$, which represent the amount of alcohol excreted unoxidized. The difference between the alcohol ingested, column $a$, and that excreted, column $e$, represents the amount actually metabolized, column $f$. The latter amount divided by the amount ingested shows the per cent metabolized, column $a$.

It will be noticed that the ralues for alcohol metabolized in the body in experiments 7 to 22 are slightly larger in Table CXXII than they are in the tables giving the details of these experiments on preceding pages. This is due to the fact that in the detail tables the total amount of reducing material. as found in the experiments, was taken as the measure of the alcohol excreted in the experiment: specitied, whereas in the summary table the arerage amount of reducing material found has been dedueted from the total redueing material in all the experiments alike. 


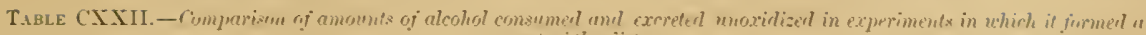
furt withe ilit.

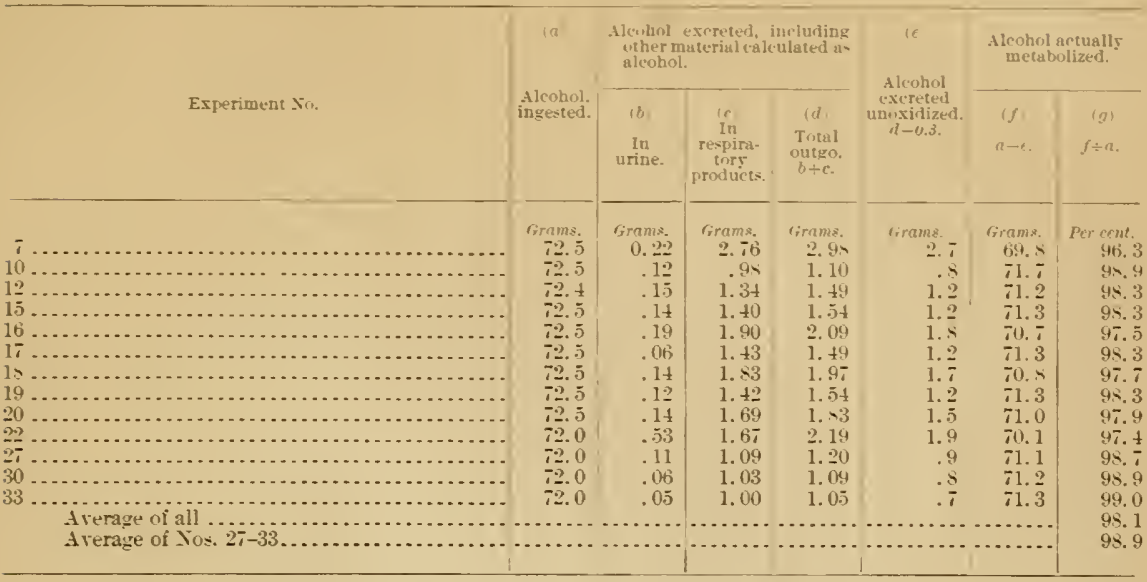

\section{TAPIATIOSS L DAILY EXCRETION OF SITROGEX.}

In the course of these experiments it has been found rery difticult to ohtain a uniform excretion of nitrogen in the urine from day to day. eren with uniform conditions of food, rest. and work. In studring the effect of alcohol upon nitrogen metabolism these rariations should be considered. Table CXXII shows the daily nitrogen content in the mine in experiment: with and without alcohol. It also shoms the elimination of nitrogen on the days of the preliminary period which alwars preceded an experiment in the calorimeter, and during which the subject had rery nearly the same diet as in the following experimental period. In many cases the amount of nitrogen in the urine raried greatly from dis to das, this rariation being especially uarked in the preliminary period. This may posibly he due in part to differences in amounts of external muscular work performed on different dars, but the general results of experiments on the effects of muscular activity upon nitrogen metabolism imply that when the work is not serere and the supply of energy is sutticient the ontput of nitrogen is not greatly increased. It seems more probable that the canse may he in part psychic. We have had occasion to note an increase of nitrogen excretion after mental excitement, and not infrequently such inerease has occurred on the day before or the dar after the subject entered the respiration chamber for an experinent. This was e-pecially the case with $\mathrm{E}$. $\mathrm{O}$.. with whom there was a notable increase in the excretion of nitrogen on the day lefore entering the chamber in experiments 5.6 . $7,12.13$, and 14 , and on the day after in experiment-10,11.15. and 20 . Something of the same kind appears with A. W. S. in experiment 1 . with the exception that the increase was observed on the second dar of the preliminary period. continued for a fer dars. and. with the exception of a slight rise on the day after entering the calorimeter. greatly decreased in amount during experiments 18 to 20 . With .T. F. S.. on the other hand. there was as a rule comparatively little difference in the nitrogen eliminated on different dars of the preliminary period. and a rery slight, although regular. increa-e on the day following his entrance into the calorimeter.

The figures in the la-t four column- of the table shom the arerage elimination of nitrogen during different periods with and without alcohol as part of the diet. The pronounced difference in some experiments betmeen the elimination of nitrogen in the preliminury period and the calorimeter period is of interest as indicating that the-e unexplaned rariation are much greater than ans which may be hrought about by the addition of alcohol to the diet. This is one of the facts which lead w- to he-itate to attribute to the alcobol ans definite and uniform effect upon the metaboli-m of nitrogen. 
One thing has impressed us, not only in these experiments but in others, the results of which we have studied. It is that the daily nitrogen balanee is a much less reliable indication of the effects of diet. or of drugs, or of muscular work, or of medical treatment than is conmonly supposed."

TABLE CXXIII.-Comparison of daily elimination of nitrogen in the urine when alcohol did and did not form a part of the diet.

[Figures in bold face indicate days in which alcohol formed a part of the diet.]

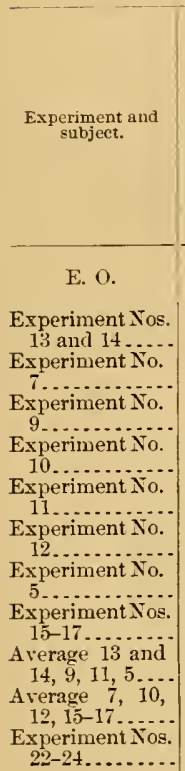

A. W. S.

Experiment Nos. Experiment Nos. $18-21 \ldots . . . .$.

J. F. s.

Experiment $\mathrm{Nos}$. $26-28 \ldots . . . . . .$.
Experiment 29-31......... $32-34 . . . \ldots .$. Average 26-34..

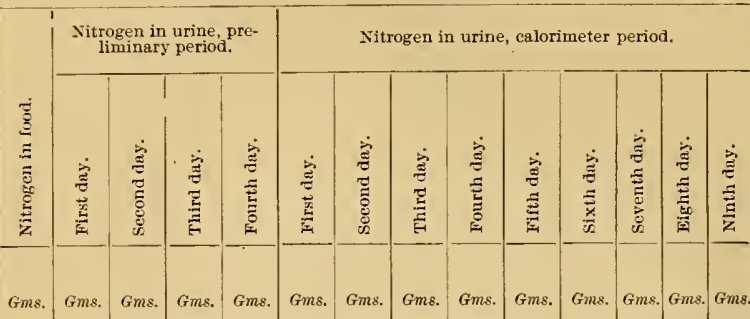
$\begin{array}{lllll} & 16.9 & 15.3 & 16.0 & 17.2\end{array}$

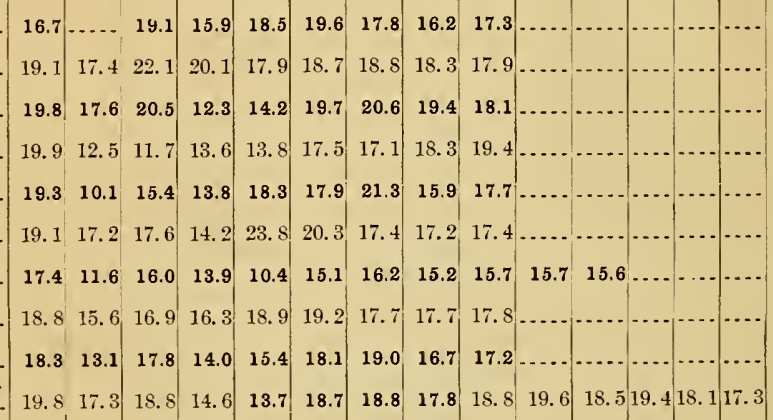
\begin{tabular}{ll|l|l|l}
19.8 & 17.3 & 18.8 & 14.6 & $\mathbf{1 3 . 7}$
\end{tabular}

$\begin{array}{lll}20.2 & 17.4 & 16.9\end{array}$

$\begin{array}{llll}9.6 & 17.8 & 16.2\end{array}$

\begin{tabular}{r|r|r|r|r|r|r|r|}
\hline 16.7 & $\cdots .$. & 19.1 & 15.9 & 18.5 & 19.6 & 17.8 & 16.2 \\
\hline 19.1 & 17.4 & 22.1 & 20.1 & 17.9 & 18.7 & 18.8 & 18.3 \\
19.8 & 17.6 & 20.5 & 12.3 & 14.2 & 19.7 & 20.6 & 19.4 \\
\hline 19.9 & 12.5 & 11.7 & 13.6 & 13.8 & 17.5 & 17.1 & 18.3 \\
\hline 19.3 & 10.1 & 15.4 & 13.8 & 18.3 & 17.9 & 21.3 & 15.9 \\
\hline 19.1 & 17.2 & 17.6 & 14.2 & 23.8 & 20.3 & 17.4 & 17.2 \\
\hline 17.4 & 11.6 & 16.0 & 13.9 & 10.4 & 15.1 & 16.2 & 15.2 \\
\hline 18.8 & 15.6 & 16.9 & 16.3 & 18.9 & 19.2 & 17.7 & 17.7 \\
\hline 18.3 & 13.1 & 17.8 & 14.0 & 15.4 & 18.1 & 19.0 & 16.7 \\
\hline 19.8 & 17.3 & 18.8 & 14.6 & 13.7 & 18.7 & 18.8 & 17.8 \\
\hline
\end{tabular}

16.5

17.3

17.9

18.1

12.91

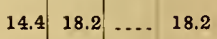

$\begin{array}{lll}18.2 & 18.1 & 18.1 \ldots . .\end{array}$

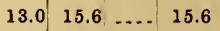

16. $918.118 .1 \ldots .$.

\begin{tabular}{l|l|l|l}
15.4 & 17.7 & $\ldots$ & 17.8
\end{tabular}

\begin{tabular}{l|l|l|l}
16.1 & 18.5 & 18.6 & 18.4
\end{tabular}

\begin{tabular}{l|l|l|l|l|l|l|l|l|l|l|l|l}
15.3 & 15.0 & 15.6 & 14.3 & 14.4 & 14.6 & 14.1 & 13.1 & 13.7 & 12.6 & 11.912 .4 & 13.1 & 11.7
\end{tabular} 14. $8 \quad 13.013 .0 \ldots .$.

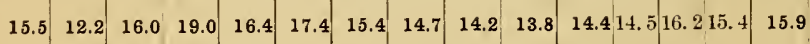
15.0 15.0 \begin{tabular}{ll|l|l|l|l|l|l|l|l|l|l|l|l|l|l|l}
15.9 & 16.6 & 15.9 & 15.7 & 16.0 & 16.6 & 15.1 & 14.4 & 14.6 & 15.5 & 16.8 & 15.9 & 15.214 .7 & 16.0 & 15.4 & 15.3 & 15.6
\end{tabular} \begin{tabular}{l|l|l|l|l|l|l|l|l|l|l|l|l|l|l|l|l}
16.0 & 13.9 & 15.5 & 15.0 & 14.8 & 15.4 & 16.3 & 16.2 & 16.8 & 18.0 & 17.1 & 16.3 & 15.415 .2 & 14.8 & 16.3 & 15.8 & 17.3
\end{tabular} $\begin{array}{llllllllllllllllllll}16.1 & 15.0 & 15.5 & 15.6 & 15.1 & 16.3 & 15.3 & 15.6 & 16.7 & 17.6 & 17.7 & 17.4 & 16.3 & 16.4 & 15.3 & 16.6 & 16.2 & 17.3\end{array}$

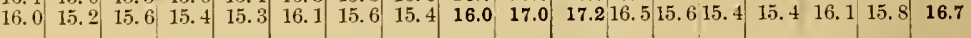

- JIy own confidence in the results of the experiments of a few days' duration as indications of the influence of any such ageneies upon nitrogen metabolism was much shaken by the experience of Dr. C. F. LAxGwortmr and myelf in collating and comparing the results of experiments on these subjects in the course of the preparation by ourselves of Bulletin 45 of the Office of Experiment Stations of the United States Dejrartment of Agrienlture, A Digest of Jetabolism Experiments in which the Balance of Income and Outgo was observed. The tables of this volume inclufe summaries of 2,299 experiments with men and 1,362 with animals, in which the nitrogen balance was studied. The very clear impression left upon my own mind is that a not inconsiderable share of the conclusions reacherl by the authors of this very large anount of painstaking inquiry must be held suhject to revision in the light of inquiries in which the experimental periods will be longer and the determinations more detailed.-W. O. A. 
A

Table CXXIV compares the coethicients of arailability of protein. fat. carbohydrates. and energy iu experiment sin which alcohol did and did not form a part of the diet. These experiment: are compared according as the ordinary diet and alcohol diet were more or less comparable. and aceording to the rharacter of the experiment, whether rest or work.

TABLE CXIIS.-Cuefficients of arailability of nutrients and energy in diet with and without alcohol.

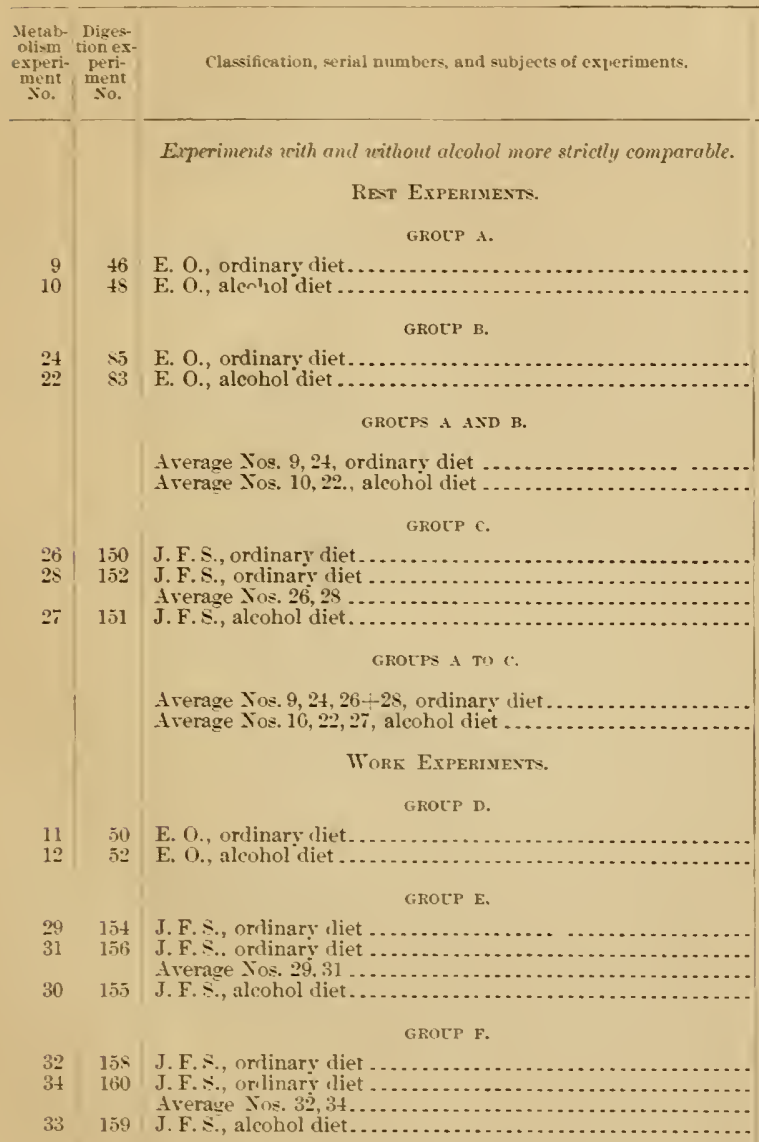

GROTPS E AXD F.

Arerage Nos. $29,31,32,34$, ordinary diet Average Ios. 30,33 , alcohol diet

\section{GROTPS D TO $\mathrm{F}$.}

Average $11,29-31,32-34$, ordinary diet Average $12,30,33$, alcoliol diet

\section{GROCPS A TO F.}

Average Tos. 9, 11, 24, 26-28, $29-31,32+34$, ordinary diet . . A rerage Nos. 10, 1?,2:2, 27, 30, 33, alcohol diet

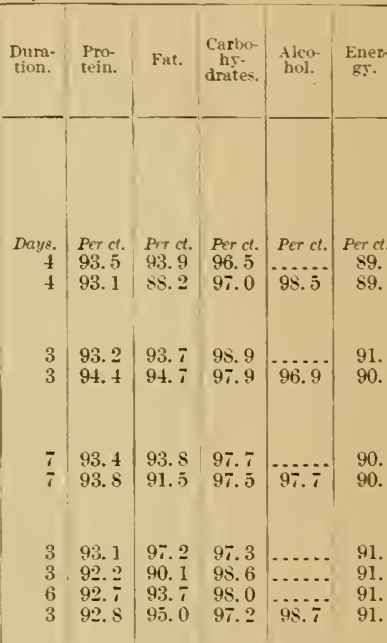

13 10 0,93

93. 1 93. 4

93. 92.6

9.8 97.498 .0

90.5 90.6
97. 2

95.3

97.

งร. 1
9. 7

$98 . \frac{2}{5}$

98.
3$$
3
$$$$
6
$$$$
3 .
$$

92.8

9.2. 7
97.

95.0

96.2

95.6
97. 4

9s. 4

97. 9

97.599 .0
6.

3.8 94.3 96.

9.. 2

95.2

990

92. 1

44.0

98.0

95.2

98.6
95.

96.
92.7

93.4

93.5

93.5 
T.ubLe CXXIV.-Coefficients of artilability of nutrients and energy in diet with and without alcohol-Continued.

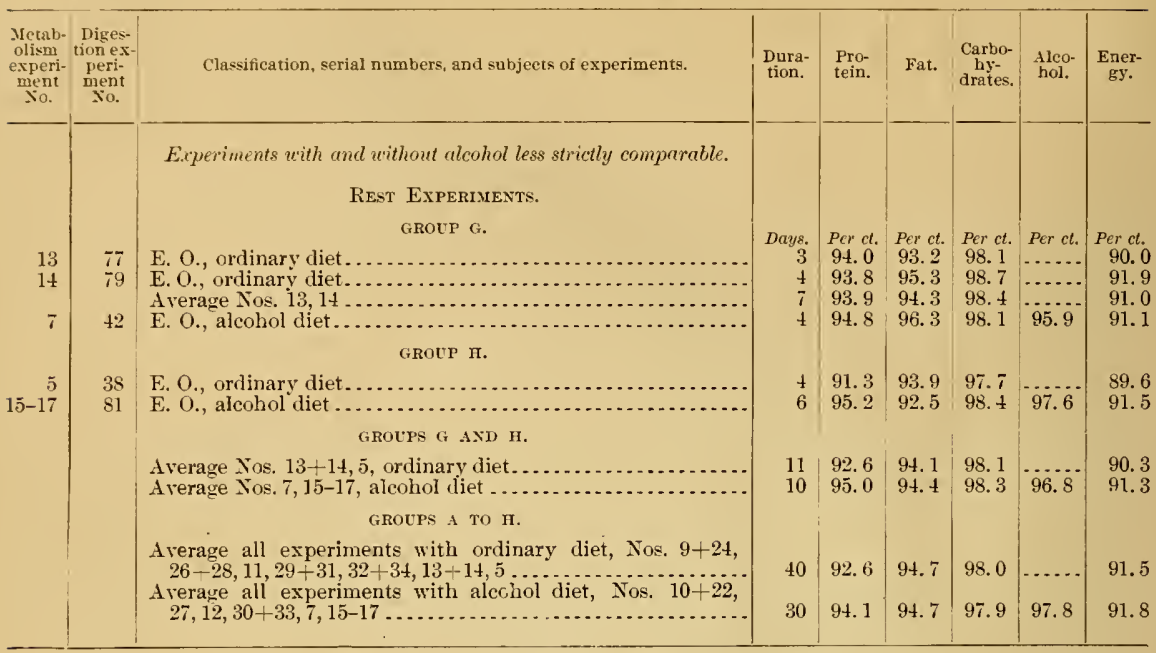

Table CXXV summarizes the results of experiments with the same subject and the same diet before and after entering the calorimeter and averages the results for all the experiments.

TABLE CXXV.-Comparison of gains or losses of nitrogen, and of coefficients of availability in the preliminary periods outside the calorimeter and the experimental periods inside.

[Quantities per day.]

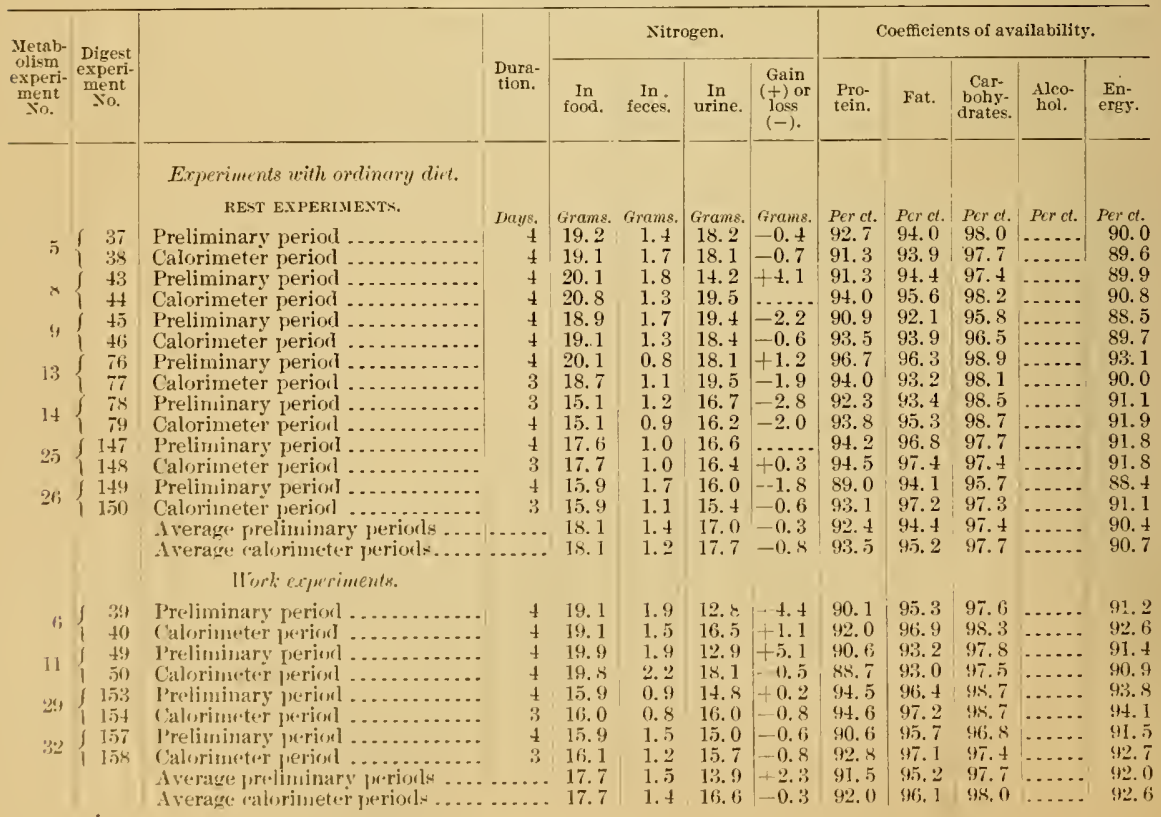




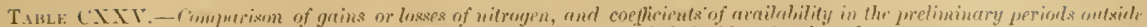

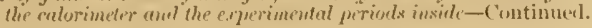

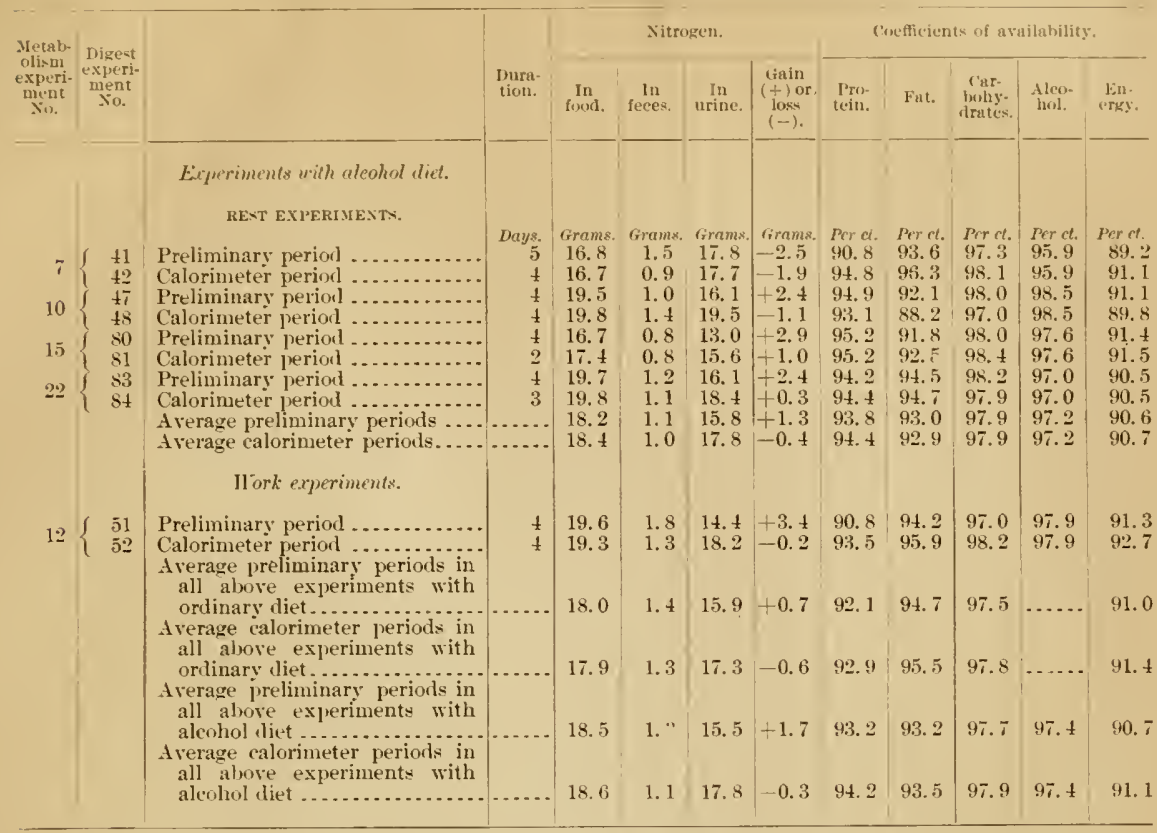

The figures for the arailability of alcohol in the preliminary period are based upon the an-wuption that the excretion of unoxidized alcohol was the same during the preliminary period an during the following period when the subject was within the chamber of the respiration calorimeter. It will be observed that while the diet was practically the same in the preliminary as in the alorimeter period, the eofficients of arailahility are quite ditferent. Sometimes the subject appeited to digest the food more thoroughly during the preliminary period and sometime- more thoroughly during the period spent within the respiration chumber. In both the rest and work experiment without alcohol the avilability of the mutrients and energy of the dirot was slightly los in the preliminary period than in the subsequent experiment in which the -1 hlject was within the respiration chamber. In the rest experiments in which aleohol formed a part of the diet there was no pronouned difference in the coeflieients in the two cases. hut in the one instance in which there was prelininary and alorimeter period with work the coethicient: of arailathility in the folmer period were noticeably lesis than in the latter.

Taking all the experiments into ronsideration it would seen that there was, as a rule, a quite noticealle ditference in the proportion of the food which were actually made arailable for wne in the body in the preliminary as eompared with the calorimeter periols. a ditference which was not noticably affected by the presence or absence of alcolol in the diet.

Vol. s-Xo. i-- -1:2 






\section{COLUMBIA UNIVERSITY LIBRARY}

This book is due on the date indicated below, or at the expiration of a definite period after the date of borrowing, as provided by the rules of the Library or by special arrangement with the Librarian in charge.

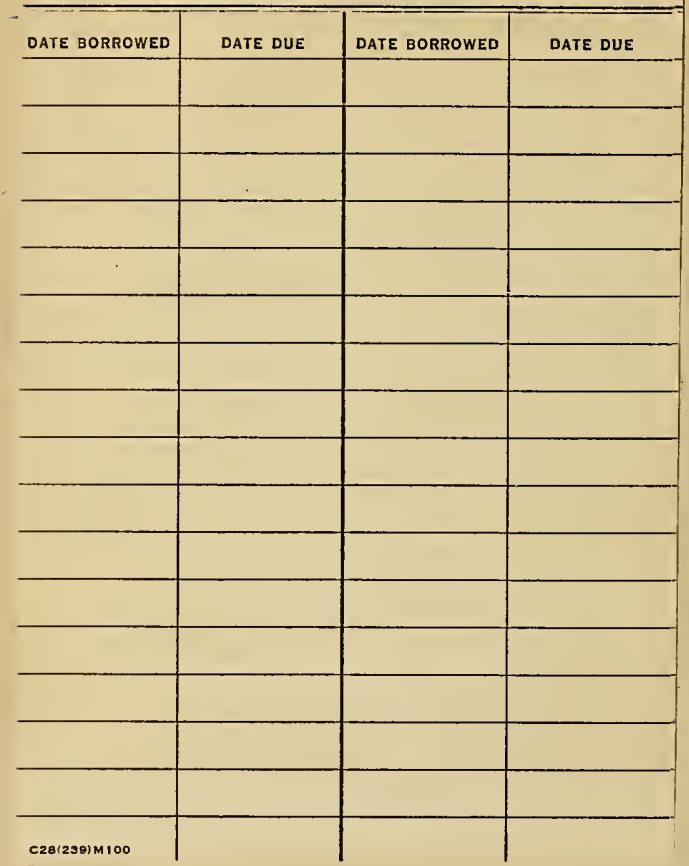




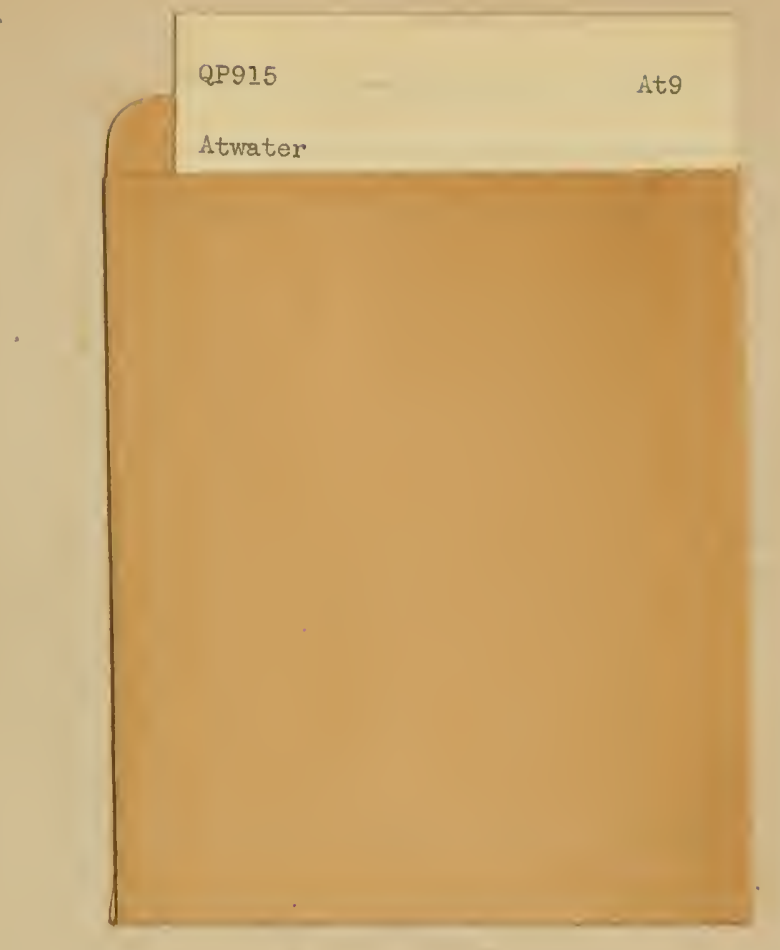


